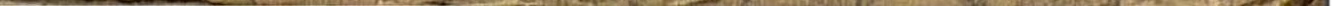



DEPARTMENT OF THE INTERIOR

UNITED STATES GEOLOGICAL SURVEY

GEORGE OTIS SMITH, DIRECTOR

BULLetin 587

\section{GEOLOGY AND MINERAL RESOURCES}

OF

\section{KENAI PENINSULA, ALASKA}

G. C. MARTIN, B. L. JOHNSON

AND U. S. GRANT

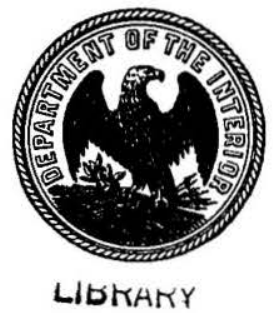

TEXAS TECHNOLOGICAL COLLEGE LUBBOCK, TEXAS

WASHINGTON

GOVERNMENT PRINTING OFFICE 



\section{CONTENTS.}

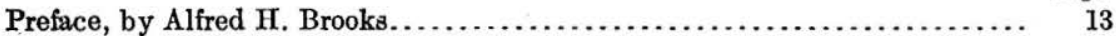

General features of Kenai Peninsula, by G. C. Martin................... 21

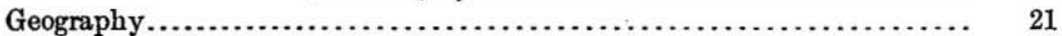

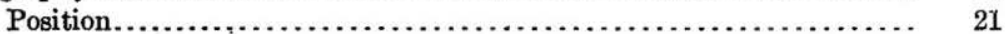

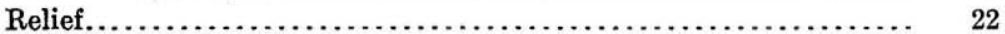

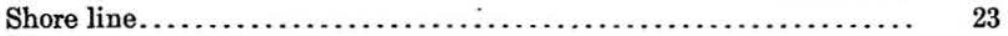

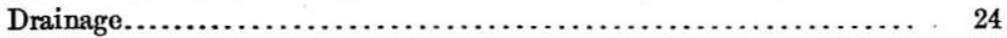

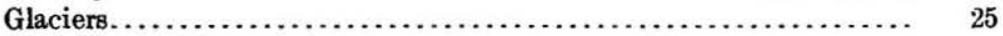

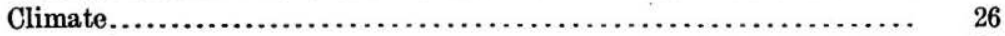

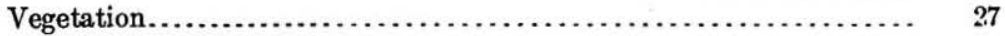

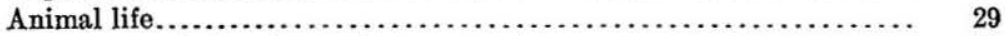

Settlements, industries, and transportation.............. 30

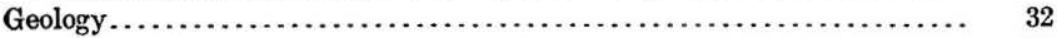

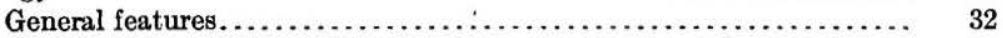

Stratigraphic and lithologic features...................... 33

Metamorphic rocks of uncertain age..................... 33

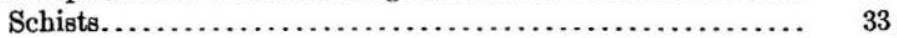

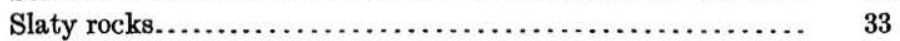

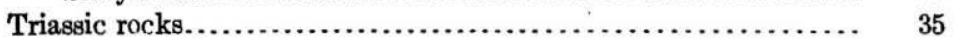

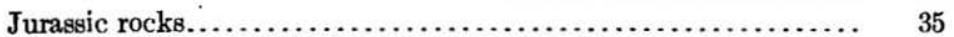

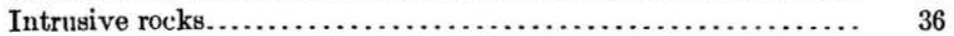

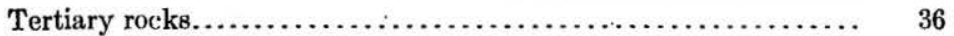

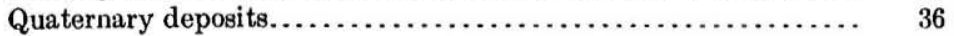

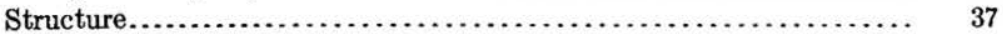

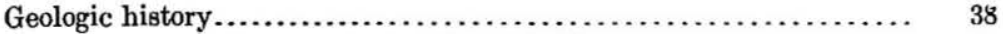

The western part of Kenai Peninsula, by G. G. Martin.............. 41

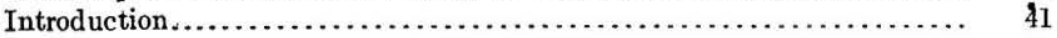

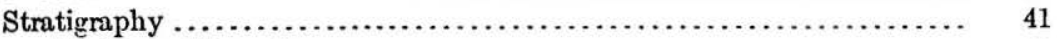

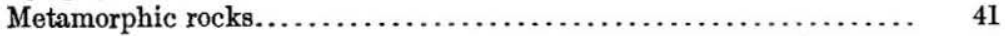

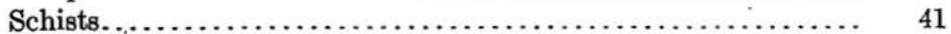

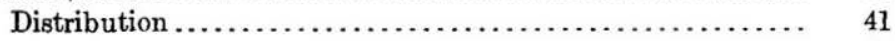

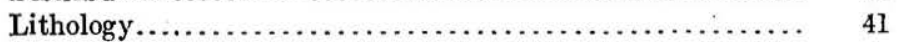

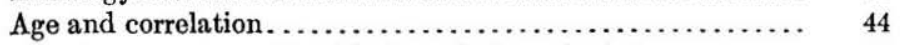

Slates and graywackes of the Kachemak Bay district......... 44

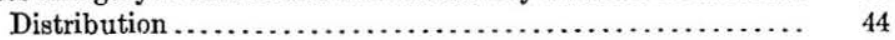

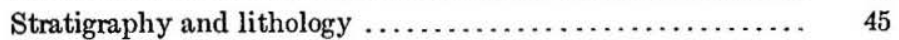

Age and correlation. ............................ 49

Slates and graywackes of the Kenai Valley ............... 50

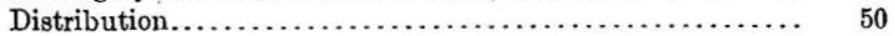

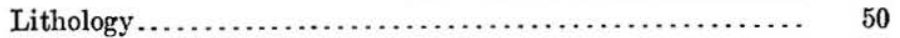

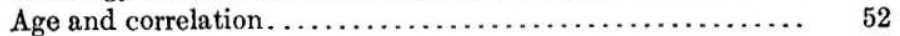

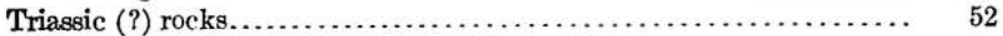

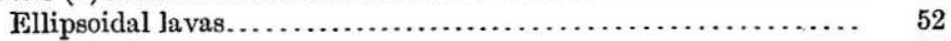

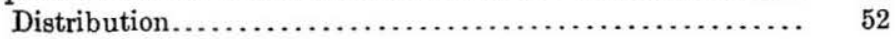

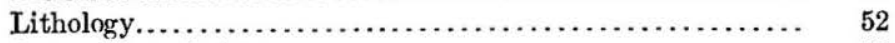

Age and correlation........................... 55 
The western part of Kenai Peninsula-Cintinued.

Stratigraphy-Continued. Page.

Upper Triassic rocks....................................... 55

Limestone and tuff................................... $\quad 55$

Distribution.................................... 55

Lithology $\ldots \ldots \ldots \ldots \ldots \ldots \ldots \ldots \ldots \ldots \ldots \ldots \ldots \ldots \ldots \ldots \ldots \ldots \ldots \ldots \ldots \ldots, \quad 55$

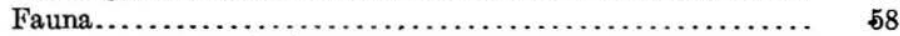

Age and correlation.................................. 59

Chert.............................................. 60

Distribution................................... $\quad 60$

Stratigraphic relations.............................. $\quad 60$

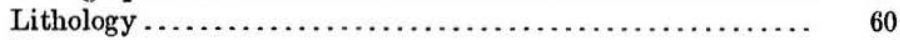

Fauna............................................... 61

Age and correlation................................... 61

Lower Jurassic rocks....................................... 63

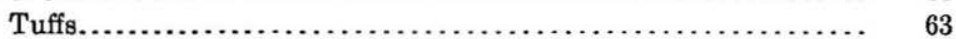

Distribution.................................... 63

Lithology........................................ 63

Fauna.......................................... 65

Age and correlation................................ 67

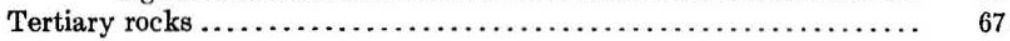

Kenai formation..................................... 67

Distribution.................................. $\quad 67$

General features................................. $\quad 68$

Local sections................................ $\quad 68$

Section between Anchor Point and Homer Spit....... 68

Section on north shore of Kachemak Bay............ 74

Section from Anchor Point to Clam Gulch........... 79

Isolated areas south of Kachemak Bay .............. $\quad 82$

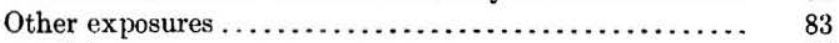

Flora and fauna.................................... 85

Correlation of the Kenai flora, by Arthur Hollick........... 88

Quaternary deposits...................................... 89

Glacial and terrace gravels............................ $\quad 89$

Distribution and character.......................... 89

Conditions of deposition.......................... 94

Recent alluvial deposits............................. $\quad 97$

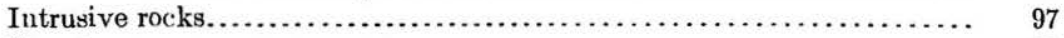

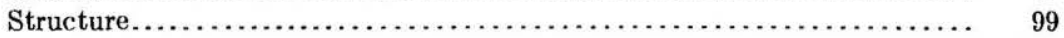

Mineral resources......................................... 104

Coal.................................................. 104

Distribution.................................... 104

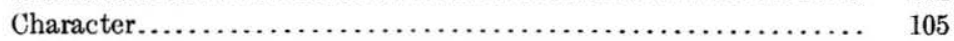

Mining development................................... 107

Placer deposits............................................ 110

Limestone....................................... 111

The central and northern parts of Kenai Peninsula, by Bertrand L. Johnson... 113

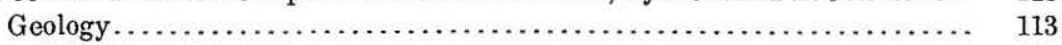

Metamorphic: rocks..................................... 113

General features................................... 113

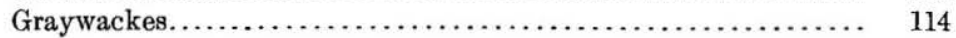

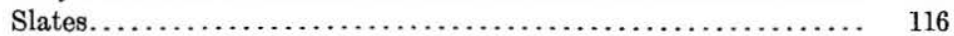

Quartzites........................................... 116

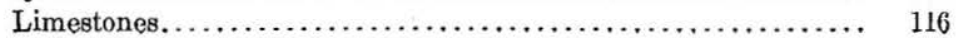


The central and northern parts of Kenai Peninsula-Continued.

Geology-Continued.

Metamorphic rocks-Continued. Page.

Conglomerates..................................... $\quad 117$

Greenstones and cherts.............................. 117

Structure........................................... 118

Age................................................. 118

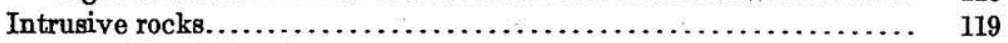

Unconsolidated deposits $\ldots \ldots \ldots \ldots \ldots \ldots \ldots \ldots \ldots \ldots \ldots \ldots \ldots \ldots, 120$

General features................................ 120

Glacial deposits................................. 121

Bench deposits................................... 121

Recent gravels................................... 123

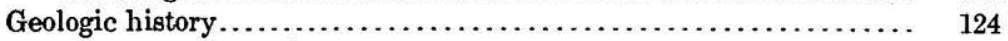

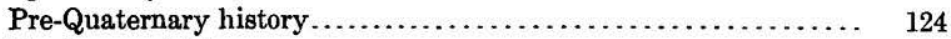

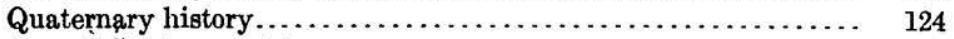

Preg!lacial conditions........................... 124

Glacial conditions............................. 125

Beginning of glaciation and advance of the ice......... 125

Maximum extent of the ice..................... 125

Retreat of the ice........................... 126

Results of glaciation......................... 126

Postglacial erosion ............................... 127

Mineral resources........................................... 128

Area and deposits considered ............................ 128

Lode depasits....................................... 129

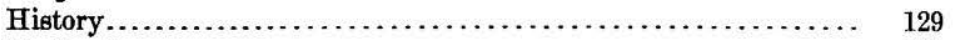

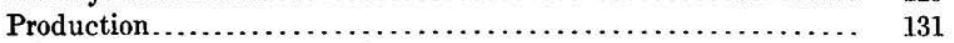

Mineralogy of the ore deposits........................ 131

Notes on the more important minerals of the ore deposits....... 133

Gold ...................................... 133

Silver.......................................... 134

Copper...................................... 134

Tellurides.................................... 134

Arsenopyrite................................... 135

Sphalerite ................................... 135

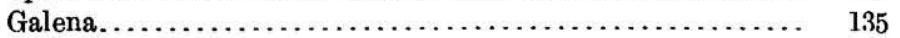

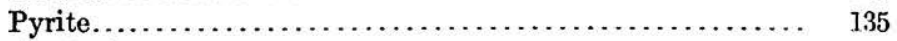

Pyrrhotite.................................... 136

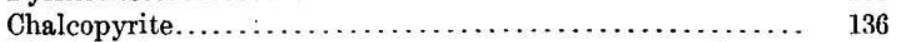

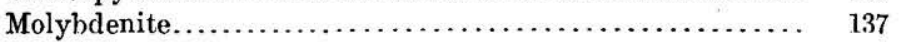

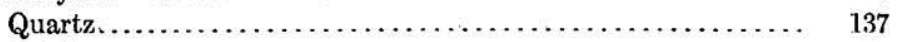

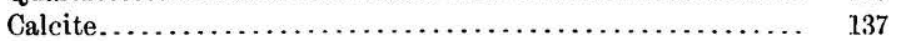

Gold lodes....................................... 137

Types of deposits.............................. 137

Veins ........................................ 137

Stringer lodes.................................. 140

Mineralized acidic dikes.......................... $\quad 140$

Detailed descriptions of mines and prospects............ 142

Resurrection Bay Mining Co.'s prospect............. 142

Tozier-Lane Northern Light Group................ 142

Mile Four Mining Co ......................... 144

Brewer Alaska Syndicate property .................. 144

Kennedy-Pullen-Davis property.................. 145 
The central and northern parts of Kenai Peninsula-Continued.

Mineral resources-Continued.

Lode deposits-Continued.

Gold lodes-Continued.

Detailed descriptions of mines and prospects-Continued. Page.

Primrose Mining Co............................ 146

Lower Porcupine Creek prospects .................. 147

Graystone ledge No. $1 \ldots \ldots \ldots \ldots \ldots \ldots \ldots \ldots \ldots . \quad 147$

Homestake ledge.......................... 147

Porcupine ledge........................... 148

Prospects near miles 17 and 18, A laska Northern Railway. $\quad 148$

Lakeside claim........................... 148

Brown Bear claim......................... 148

Devil Club ledge.......................... 148

Seward Bonanza Gold Mines Co.................. 149

California-Alaska Mining Co..................... 151

Skeen-Lechner Mining Co........................ 154

Kenai-Alaska Gold Co........................ 157

Fairman-Madson prospects ...................... 163

Devil Creek prospects.......................... 163

Imhoff-Weidlich-Saulsbury prospects ................. 164

The J. C. Gilpatrick property........................ 164

Prospects on mineralized dike between Summit and

Colorado creeks............................ 167

Prospects on mineralized dikes between Colorado and

Fresno creeks............................ 167

Prospects on mineralized dike north of Fresno Creek.... 168

Seward Gold Co............................ 169

Palmer Creek prospects......................... 171

Bear Creek prospects.......................... 172

Sawmill Creek prospects......................... 172

Barnes property .............................. 173

Treasure Box claim .............................. 176

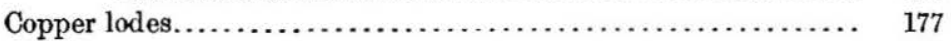

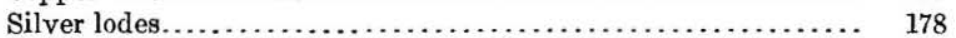

Antimony lodes....................................... 179

Conclusions....................................... 179

Gold placers............................................ 181

General features................................. 181

History $\ldots \ldots \ldots \ldots \ldots \ldots \ldots \ldots \ldots \ldots \ldots \ldots \ldots \ldots \ldots \ldots \ldots \ldots \ldots \ldots \ldots \ldots \ldots, 181$

Production...................................... 183

Fineness of the placer gold............................ 184

Source of the placer gold ............................. 185

Placer-mining methods................................ 186

Classification ....................................... 187

Detailed descriptions of creeks....................... 187

General features................................ 187

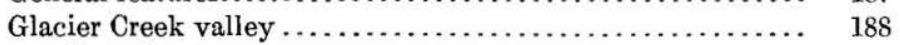

Crow Creek.................................. 188

California Creek................................ 192

Winner Creek............................... 192

Resurrection Creek valley ......................... 193

Resurrection Creek.......................... 193 
The central and northern parts of Kenai Peninsula-Continued.

Mineral resources-Continued.

Gold placers-Continued.

Detailed descriptions of creeks-Continued.

Resurrection Creek valley-Continued. Page.

Palmer Creek............................... $\quad 195$

Bear Creek.................................. 196

Kenai River valley ............................ 197

Kenai River.............................. 197

Cooper Creek................................. 199

Quartz Creek................................. 201

Falls Creek................................... 202

Sixmile Creek valley ................................ 202

Sixmile Creek ................................. 202

Canyon Creek............................... 203

Mills Creek................................ 204

East Fork................................. 205

Silvertip Creek............................. 206

Granite Creek................................ 206

Gulch Creek............................... 206

Lynx Creek............................... 207

The southeastern coast of Kenai Peninsula, by U. S. Grant................ 209

Geography.......................................... 209

General features of the geology ............................. 210

Details of the geology .................................... 211

Metamorphic rocks.................................. 211

Highly folded graywacke and slate east of Nuka Island Passage. . 211

General features................................ 211

Special localities.............................. 212

Passage Canal, Blackstone and Cochrane bays ........ 212

Port Nellie Juan to Port Bainbridge................ 213

Cape Puget to Day Harbor...................... 215

Resurrection Bay......................... 217

Aialik Bay .............................. 218

Harris Bay to Pye Islands........................ 219

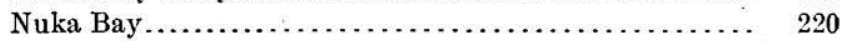

Age and correlation........................... 222

Greenstones of Day Harbor and Resurrection Bay............ 223

Tuffs, graywackes, and slates of Resurrection Bay ............ 225

Slightly altered slate, graywacke, and conglomerate......... 227

Graywacke and slate, with chert, limestone, and volcanic material . $\quad 227$

Unmetamorphosed sedimentary rocks....................... 227

Upper Triassic limestone and tuff..................... 227

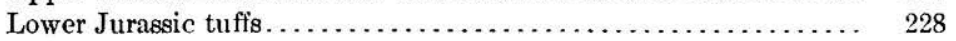

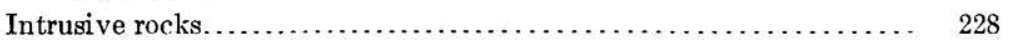

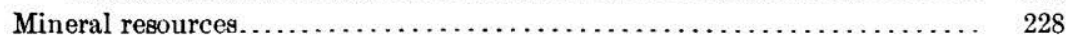

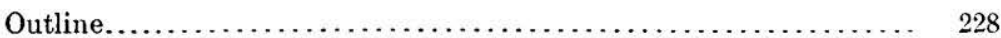

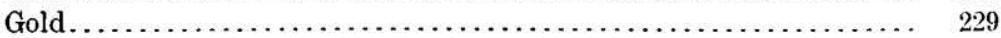

Two Arm Bay . . . . . . . .

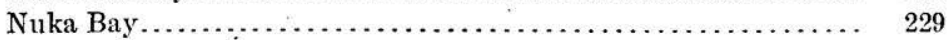

Port Dick.................................... $\quad 230$

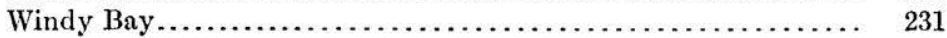


The southeastern coast of Kenai Peninsula-Continued.

Mineral resources-Continued.

Gold-Continued. Page.

Port Chatham ...................................... $\quad 232$

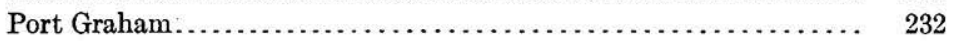

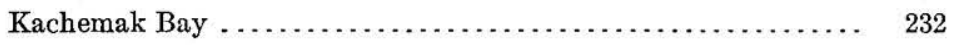

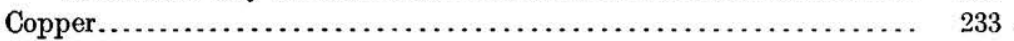

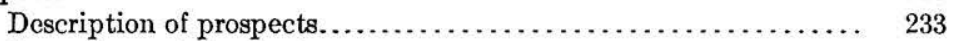

Summary and conclusions............................ 236

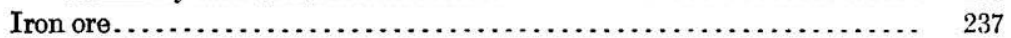

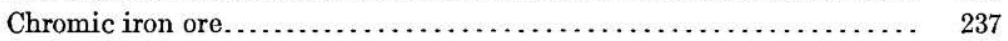

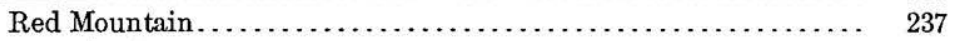

Port Chatham ....................................... 238

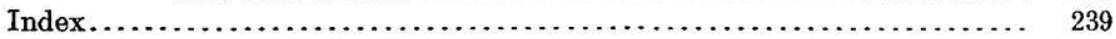

\section{ILLUSTRATIONS.}

Plate I. Map of central Alaska ............................... Page. 20

II. Topographic reconnaissance map of Kenai Peninsula......... In pocket.

III. Geologic reconnaissance map of Kenai Peninsula.............. In pocket.

IV. Topographic map of Moose Pass and vicinity............... In pocket.

V. $A$, View of Seward; $B$, Site of Russian coal mine at Port Graham. 22

VI. $A$, View at headwaters of Henry and Slate creeks, looking west; $B$, View at headwaters of Donaldson and Frenchy creeks, look- 24

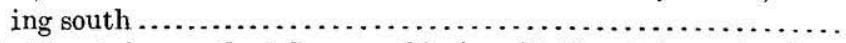

VII. $A$, Mountains south of Spencer Glacier; $B$, Mountains at headwaters of Placer River................................ $\quad 26$

VIII. $A$, Tustumena Glacier; $B$, Spencer Glacier................. 28

IX. $A$, Trail Glacier; $B$, Bartlett Glacier..................... 29

$\mathrm{X}$. Timber on Alaska Northern Railway near Snow River summit... $\quad 30$

XI. Map showing distribution of timber..................... 32

XII. $A$, Grass, bushes, and light timber in high valley near Summit Lake; $B$, Light scattered and burned timber with new undergrowth near mouth of John Creek....................... $\quad 34$

XIII. Timber at head of Resurrection Bay ...................... $\quad 36$

XIV. Mountains near Quartz Creek........................ 37

XV. $A$, Cherty slate cut by dike of hornblende andesite porphyry on south shore of Port Graham; $B$, Closely folded slate on west shore of Kenai Lake............................ 46

XVI. $A$, Ellipsoidal lava on east shore of Seldovia Bay; $B$, Lower Jurassic tuffs on north shore of Port Graham.....................

XVII. $A$, Contorted chert on east shore of Seldovia Bay near cannery; $B$, Chert on east shore of IIalibut Cove.....................

XVIII. Section of Kenai formation on east shore of Cook Inlet from Anchor Point to Mine Camp..............................

XIX. $A$, Kenai formation, with lignite beds, in cliff at Bluff Point; $B$, Kenai formation, with lignite beds, near Mine Camp......... 
Plate XX. Section of Kenai formation on north shore of Kachemak Bay.......

Page.

XXI. $A$, Kenai formation and Quaternary deposits, with shell bed, at mouth of Cottonwood Creek; $B$, Kenai formation, with lignite beds, overlain by Quaternary gravels, $9 \frac{1}{2}$ miles south of Anchor

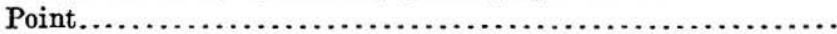

XXII. $A$, Braided drainage on the alluvial plain of Placer River; $B$, Alluvial plain of Resurrection River and Salmon Creek at the head of Resurrection Bay....................................

XXIII. $A$, Overturned anticline on east shore of Seldovia Bay; $B$, Folds in massive graywacke in railroad cut at Kern Creek............

XXIV. $A$, Polished surface of crumpled slate showing minute folding and development of joints and cleavage; $B$, Cleavage and bedding in slate and graywacke.

XXV. Quartz diorite intrusives in slaty rocks near headwaters of Crow Creek.

XXVI. $A$, Bench gravels on Resurrection Creek; $B$, Old gravel-filled channel of Gulch Creek.

XXVII. $A$, Alluvial fan of Victor Creek extending into Kenai Lake; $B$, Section of bench gravels on Cooper Creek....................

XXVIII. $A$, Cirques and small glaciers between Granite Creek and Placer River; $B$, Peak at head of south fork of Center Creek.

XXIX. $A$, Cirque at head of Block Creek; $B$, Hanging valleys east of Summit Lake.........................................

XXX. $A$, Mineralized diorite porphyry dike, Fresno Creek; $B$, Quartz vein parallel to joint planes in graywacke....................

XXXI. $A$, Gold-bearing quartz lode on Kennedy-Pullen-Davis property, Lost Creek; $B$, Fissure vein in No. 1 tunnel, Barnes property, Crow Creek..........................................

XXXII. $A$, Gold-bearing quartz vein on property of Seward Bonanza Gold Mines Co., near mile 20, Alaska Northern Railway; $B$, Nearer view of same vein

XXXIII. Panorama of small cirque, showing position of mine of Kenai Alaska Gold Co., Falls Creek. .

XXXIV. A, Pick and shovel work at "the forks" of East Fork and Canyon Creek; $B$, Gravels on rock bench, Canyon Creek...............

XXXV. $A$, Dredge on Kenai River below Cooper Creek; $B$, Ruble elevator, Cooper Creek

XXXVI. $A$, Deep cut following old channel on Nutter-Dawson property, Crow Creek; $B$, Wheel run by hydraulic giant for hoisting bowlders with a derrick, Lynx Creek.......................

XXXVII. $A$, Gravel-filled moraine-dammed basin, Crow Creek; $B$, Cooper Creek placer workings ................................

XXXVIII. $A$, Gravel flat at lower end of Lynx Creek; $B$, Forked tailrace for spreading tailings over Bench Creek flats at Lynx Creek......

Figure 1. Sketch showing relations of Tertiary to Jurassic rocks in cliffs $1 \frac{1}{2}$ miles northeast of Dangerous Cape.......................

2. Views showing relations of Tertiary to Jurassic rocks 2 to 3 miles southwest of Seldovia Bay. ............................

3. Diagrammatic sketch showing relations of stratified sands and till at Kenai

4. Section from head of Port Graham along south shore to a point near the wharf.

5. Sketch showing minor faulting in graywacke on north shore of

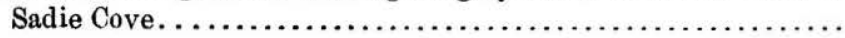


Figure 6. Ground plan showing structural details and relation of bedding to cleavage on west shore of Kenai Lake $2 \frac{1}{2}$ miles northwest of Porcupine Island.

7. Sketch showing overturned anticlines and faults in railroad cut at mile $22 \frac{1}{2}$, east shore of Kenai Lake.

Page.

8. Sketch showing overturned anticline in railroad cut at mile $22 \frac{3}{4}$, east shore of Kenai Lake..............................

9. Sketch showing close folding and faulting in banded slates on wagon road near headwaters of Bench Creek, 9 miles north of mile 34 .

10. $A$, Sketch showing flexure passing into double-fracture planes in railroad cut at mile $34 ; B$. Hypothetical extension of sketch, showing fractures passing into a fault......................

11. Contorted and faulted chert on south shore of Kachemak Bay near west end of Ismailof Island.

12. Fault in Kenai formation on north shore of Kachemak Bay threefourths of a mile northeast of Falls Creek...................

13. Sketch map showing location of Cook Inlet Coal Fields Co.'s operations.

14. Section of gravel bluff at mouth of Cooper Creek..................

15. Map showing the relation of the area described in this report to the Kenai and Knik recording districts....................

16. Diagram showing strike of gold quartz veins..................

17. Diagram showing dip of set of veins whose trend ranges from north to northwest......................................

18. Diagram showing dip of set of veins whose trend ranges from east to northeast. . .......................................

19. Topographic map of the Falls Creek district.................

20. Map showing location of workings of the California-Alaska Mining Co. and the Skeen-Lechner Mining Co., Falls Creek ............

21. Flow sheet of mill of California-Alaska Mining Co., Falls Creek....

22. $a$, Plan of upper level of workings of California-Alaska Mining Co., Falls Creek; $b$, Sketch of vein near entrance to tunnel.........

23. Plan of workings on upper vein of Skeen-Lechner Mining Co.'s property, Falls Creek................................

24. Vertical section along upper tunnel of Skeen-Lechner Mining Co.'s property, Falls Creek................................

25. Map showing claim locations of the Kenai-Alaska Gold Co., Falls

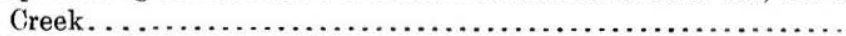

26. Plan of underground workings on Black Butte vein..............

27. Longitudinal section of Black Butte vein showing levels and stopes

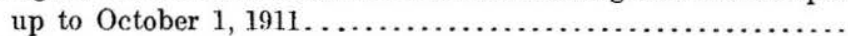

28. Diagram of mill treatment of gold quartz ore from the Black Butte vein

29. Vertical section along lower tunnel on Black Butte No. 2 claim, showing relation of dip of vein to slope of hillside...............

30. Plan of portion of vein in east end of lower level of Black Butte No. 2 claim.......................................

31. Sketch illustrating occurrence of quartz in Black Butte vein.......

32. Cross section of Black Butte vein in raise on Black Butte No. 2 claim..........................................

33. Sketch showing location of tunnels on the Gilpatrick claims between Slate and Summit creeks....................... 
FraURe 34. Geologic sketch plans of upper and lower tunnels on mineralized dike, Gilpatrick claim..............................

35. Plan and longitudinal section of workings on the Telluride No. 1 claim, Seward Gold Co., Groundhog Creek...................

36. Sketch showing relation of dikes and vein on property of Seward Gold Co., Groundhog Creek.......................... $\quad 170$

37. Cross section of vein in shaft, Seward Gold Co., Groundhog Creek. 171

38. Map showing location of mine workings on the Barnes property, Crow Creek ......................................

39. Plan of workings on north and south veins, Stella claim, Barnes property, Crow Creek..............................

40. Longitudinal section along plane of south vein, Stella claim, Barnes property, Crow Creek, looking north..................

41. Curve showing annual placer-gold production from Kenai Peninsula and the creeks tributary to Turnagain Arm from the north.

42. Sketch showing structure along shore westward from Cape Junken..

43. Sketch showing structure between Puget Bay and Cape Junken...

Page.

\section{INSERT.}

Correlation of formations in southern and southwestern Alaska 



\section{PREFACE.}

\section{By Alfred H. Brooks.}

Kenai Peninsula (see Pl. I) is a field that offers attractions to the prospective miner and settler. The climate being comparatively mild and the rainfall not excessive, the peninsula is more favorable to permanent settlement than many parts of the Temperate Zone that have large populations. The southern harbors of the peninsula are ice free throughout the year and are therefore at all times available for ocean service. Seward (Pl. V, $A$ ), the largest town on the peninsula, located on Resurrection Bay, is destined to become an important seaport, affording, as it does, an outlet for the mineral and other resources of the peninsula, which will be opened up by railways that have been partly constructed.

Kenai Peninsula contains auriferous lode-bearing areas of some promise, though deep mining has so far been done on only a small scale. Auriferous gravels are widely distributed in the northeastern part of the peninsula and have been mined in a small way for nearly 20 years. The future of placer mining on the peninsula depends on the exploitation of many large bodies of gravel carrying values too low to permit development by the simple methods thus far chiefly used. On the Cook Inlet side of the peninsula there are very large deposits of lignitic coal which, though now almost entirely unused, are a possible source of power (PI. I), and hydroelectric developments are also possible at several places on the peninsula.

Timber, though not abundant in the region as a whole, is sufficient for local use (Pl. XI). There are some small tracts of excellent timber, notably near Seward. The peninsula contains considerable agricultural and grazing land, the largest areas being on the Cook Inlet side of the divide.

Along the shores of this part of Alaska there are valuable fisheries, thus far only partly developed. Kenai Peninsula has long been a favorite hunting ground for the seeker of big game. The accessibility of the game by railway and boat makes it a particularly desirable field for the nonresident big-game hunter whose available time for sport is far too short to permit him to penetrate inland Alaska.

The purpose of this volume is to present a concise summary of what is known of the geography, geology, and mineral resources 
of Kenai. Peninsula. The results set forth are based on investigations made at different times by many observers. Some parts of the peninsula have been studied in considerable detail, others have been traversed only hastily, and information about the bedrock geology over considerable areas is almost entirely lacking. It is therefore evident that the data at hand will not permit a comprehensive discussion of the geologic sequence, structure, or mineral resources, so that the matter here presented consists of contributions to a knowledge of the geology and mineral resources of the peninsula rather than a well-balanced analysis of the many problems touched upon. The aim has been to let each of the three investigators present the facts and his conclusions about the areas with which he was personally familiar. No attempt has been made to introduce uniformity in the different sections of the report or to harmonize all the conclusions. The only departure from this policy is in Mr. Martin's introductory chapters, which cover, so far as the information permits, the entire peninsula. In this Mr. Martin has correlated, as far as possible, the data presented in greater detail in the sections that follow.

In spite of the incompleteness of this report, however, its publication is believed to be justified because it presents data on the geology and resources of a region concerning large parts of which little information has heretofore been available. It will at least pave the way for more exhaustive studies, which have been planned and will be carried out as soon as circumstances permit.

Although the geologic surveys of the peninsula are far from complete, the topographic surveys have been carried over nearly its entire area. The map here presented (Pl. II, in pocket) is the first cartographic representation of the varied features of its relief, and as such is a notable contribution to the geography of Alaska.

To Capt. James Cook, who made a voyage to Alaska in 1778, must be credited the first survey of the shore line of any part of Kenai Peninsula, yet undoubtedly the peninsula was known to the roving Russian fur trader before Cook's visit. When Cook made his voyage the Russians already had a permanent trading post on Kodiak Island and were invading the adjacent waters in their scarch for the valuable sea otter. To Cook's officers, Portlock and Dixon, but more especially to Vancouver, fell the task of surveying the shore line in greater detail. The work of these earlier navigators during the succeeding half century was amplified by surveys of various parts of the coast line. The surveys made by Russian naval officers and by employees of the Russian American Fur Trading Co. are especially noteworthy. That a fairly complete knowledge of the geography of the region was thus gained is made evident by the charts of the peninsula and the accompanying text, in Tebenkof's Atlas of Russian America, published in 1852. 
Meanwhile, fur-trading posts had been built at several places on the Cook Inlet shore of the peninsula. The excellent timber on Resurrection Bay (see Pl. XIII) was not overlooked by the Russians, who established a shipyard there. Here the first vessel built in Alaska was launched in 1795. Feeble attempts to establish other industries on the peninsula were also made by the Russians. In 1793 the first agricultural colony was settled, on the east shore of Cook Inlet. The descendants of these and other colonists who followed still hold these lands and are among the few evidences of the Russian occupation of Alaska. In 1848 the Russian-American company sent Peter Doroshin, a mining engineer, to their American colony to find gold. His search for placer gold was confined to Kenai Peninsula. The first gold mined in Alaska was taken from Kenai River basin by Doroshin in 1850 . The venture ${ }^{1}$ was not successful and was soon abandoned. Another mining venture by the Russians was the development of the coal at Port Graham. Here, in 1854, the first coal was won from any Alaskan field. (See Pl. V, A, p. 22.) Mining here continued in a small way to supply the Russian steamers, convict labor being used in part.

For many years after the transfer of Russian America to the United States the industrial conditions on Kenai Peninsula changed but little. In 1889 an ill-advised attempt was made to develop the lignitic coal at Kachemak Bay for export to the western coast of the United States. About 1890 gold was found in beach placers at Anchor Point, on Cook Inlet. In 1894 the gold placers of Bear and Palmer creeks were found. This led in the next two years to an influx of prospectors into a region which up to hat time had been known only to the fur trader. These prospectors swarmed over the peninsula and began mining in many places. In 1896 a gold-bearing quartz lode was found near Moose Pass, but this excited little interest.

The present industrial condition dates from. 1902, when a railway leading inland from Resurrection Bay (see Pl. I) was projected, the construction of which began in 1903. About this time the presence of high-grade coal in tho Matanuska Valley became known and the Fairbanks gold district was discovered. Both of these mineral districts are on the route of the proposed railway. A patent was obtained to the Seward town site and a settlement quickly sprang up. (See Pl. V, A.) The coal-land controversy, which delayed the opening of the Matanuska coal ficld, so discouraged the promoters of the railway enterprise that it has not yet been completed. This line, now called the Alaska Northern Railway, of which only 72 miles has been built, furnishes transportation to the northeastern part of the peninsula

1 Doroshin, Peter, Einige Beobachtungen und Bemerkungen über die Goldvorkommen in die Besitzungen der Russisch-Amerikanischen Compagnie: Archiv wiss. kunde Russland, vol. 25, pp. 229-237, 1866, 
and has been supplemented by a number of wagon roads, stimulating prospecting and resulting in marked advances in the mining industry. During the last few years lode-mining development has been specially active. Meanwhile, the salmon-fishing industry has made advances on the Cook Inlet side of the peninsula. Some homesteads have also been taken up in the region, and several sawmills have been built to meet the local demand for timber. On the whole, Kenai Peninsula is commercially fairly prosperous in spite of the fact that the hope that Seward may become the ocean terminal of a trans-Alaska railway has not yet been realized.

The charting of Alaska's shore line by the Coast and Geodetic Survey was among the first activities of our Government in the new Territory. Practically the entire coast line of the peninsula hus now been accurately charted. Though the earlier explorers recorded some random notes on the geology of the peninsula, the first systematic investigation was made in 1880 by William H. Dall, ${ }^{1}$ while he was a member of the Coast Survey. In 1895 Dall, in company with George F. Becker, heading the first expedition sent to Alaska by the Geological Survey, studied the geology of the west shore of the peninsula. ${ }^{2}$ These surveys were made along the coast line, the inland region being known only through the reports of prospectors.

Walter C. Mendenhall was the first geologist to traverse the peninsula. In 1898, as a member of an Army exploring expedition, he first crossed from Portage Bay, on Prince William Sound, to Turnagain Arm and later from Resurrection Bay to Turnagain Arm by way of Kenai Lake. These two journeys yielded not only geologic data, ${ }^{3}$ but also a topographic map that was very fair considering the conditions under which Mendenhall worked, for he traveled on foot with a pack on his back.

In 1899 the Harriman-Alaska expedition skirted the west shore of Kenai Peninsula and made lindings at Port Graham and Kachemak Bay. This gave opportunity to the geologists of the expedition, including Dall, Emerson, Palache, and Gilbert, to make observations on the bedrock ${ }^{4}$ and, more particularly, on the glaciers and physiography. ${ }^{5}$ About 1900 Kirsopp $^{6}$ made a detailed examination of some of the coal fields on the west side of Kenai Peninsula.

\footnotetext{
${ }^{1}$ Dall, W. H., and Harris, G. D., Correlation papers-Neocene: U. S. Geol. Survey Bull. 81, pp. 236237, 1892.

${ }^{2}$ Dall, W. H., Report on coal and lignite of Alaska: U. S. Geol. Survey Seventeenth Anu. Rept., pt. 1, pp. 763-906, 1896. Becker, G. F., Reconnaissance of the gold fields of southern $\Lambda$ laska: U. S. Geol. Survey Eighteenth Ann. Rept., pt. 3, pp. 7-86, 1898.

${ }^{3}$ Mendenhall, W. C., A reconnaissance from Resurrection Bay to the Tanana River, Alaska, in 1898: U. S. Geol. Survey Twentieth Ann. Rept., pt. 7, pp. 265-340, 1900.

4 Emerson, B. K., Gilbert, G. K., and Palache, Charles, The general geology of Alaska: Alaska, vol. 4, IIarriman Alaska Expedition, New York, 1904.

${ }^{5}$ Gilbert, G. K., Glaciers and glaciation: Alaska, vol. 3, Harriman Alaska Expedition, New York, 1904.

${ }^{6}$ Kirsopp, John, jr., Coal fields of Cook Inlet, Alaska, U. S. A., and the Pacific coast: Inst. Min. Eng. (England), Trans., vol. 21, 1903, pp. 536-559.
} 
The investigations above chronicled were chiefly either detailed examinations of a few small areas or the hasty notes of the rapid traveler. In 1904 systematic geologic and topographic surveys were begun. Two parties were detailed for this work. The one led by F. H. Moffit, with E. G. Hamilton as topographer, made a reconnaissance survey of the Sunrise placer district, in the northeastern part of the peninsula, spending about four months in this work. G. C. Martin had charge of the other party, which included R. W. Stone and T. W. Stanton and investigated the southwest part of the peninsula. Martin and Stanton devoted about two weeks to the general geologic problems, and Stone spent about a month in studying the coal measures near Kachemak Bay. Later Hamilton made some topographic surveys in the same region. The results of these two expeditions were a topographic map, a general report on the character of bedrock in placer-bearing areas, ${ }^{1}$ some detailed information about coal fields, ${ }^{1}$ and considerable data on the Mesozoic and Tertiary sequence. ${ }^{2}$

The surveys of adjacent provinces helped to elucidate the geology of Kenai Peninsula. Mendenhall and Schrader reconnoitered parts of Prince William Sound in $1898 .^{3}$ This work was supplemented two years later by Schrader and Spencer.4

In 1905 and 1908 Grant made more systematic surveys of Prince William Sound and did some work in the northeastern part of Kenai Peninsula. In 1909 he extended his work along the entire southern and eastern shores of Kenai Peninsula. The details in regard to Grant's field work are as follows:

In 1905 Grant, ${ }^{5}$ assisted by Sidney Paige, spent two days in a hurried reconnaissance of the eastern coast of Kenai Peninsula from a point north of Icy Bay northward to Passage Canal. The various indentations of the shore line were not studied at this date, although the passage between Culross Island and the mainland was traversed and recorded for the first time. Three years later Grant ${ }^{6}$ and Higgins spent part of the time between August 2 and 10 in a reconnaissance of the eastern shore of Kenai Peninsula from Port Bain-

1 Momit, F. II., and Stone, R. W., Mineral resources of Kenai Peninsula, Alaska: U. S. Geol. Survey Bull. 277, 1906.

2 Stanton, T. W., and Martin, G. C., The Mesozoic section on Cook Inlet, Alaska: Bull. Geol. Soc. America, vol. 16, pp. $391-410,1905$.

${ }^{3}$ Mendenhall, W. C., op. cit. Schrader, F. C., A reconnaissance of a part of Prince William Sound and the Copper River district, Alaska, in 1898: U. S. Geol. Survey Twentieth Ann. Rept., pt. 7, pp. 341-423, 1900.

i Schrader, F. C., and Spencer, A. C., The geology and mineral resources of a portion of the Copper River district, Alaska: U. S. Geol. Survey special pub., 1901.

$\checkmark$ Grant, U. S., Copper and other mineral resources of Prince William Sound: U. S. Geol. Survey Bull. 284, pp. 78-87, 1906 .

- Grant, U. S., and Higgins, D. F.,jr., Copper mining and prospecting on Prince William Sound, 190S:

U. S. Geol. Survey Bull. 379, pp. 87-96, 1909. Grant, U. S., Gold on Prince William Sound: Idem, p. 97. $48891^{\circ}-$ Bull. $587-15-2$ 
bridge north to Culross Passage. During this time they made a study of the general geology, of the mineral prospects, and of the tidewater glaciers, and mapped the shore line by rapid boat traverse. Later in the same season they made a trip to Seward and spent twe days in examining the copper and gold prospects on the east side of Resurrection Bay and near Seward. ${ }^{1}$

In 1909 Grant and Higgins completed the field work on Prince William Sound, and prepared a report on that region, which was published in $1910 .^{2}$ They devoted the field season of 1909 chiefly to Kenai Peninsula, and studied the shore line from Cape Puget, at the western entrance to Prince William Sound, to Nubble Point, on the southeastern shore of Kachemak Bay, Cook Inlet. They also spent a short time in Passage Canal, Blackstone Bay, and Cochrane Bay, on the eastern coast of the peninsula. The time devoted to the coast of the Kenai Peninsula included (1) July 3 to 6, (2) July 11 and 12, (3) July 20 to September 8. The work was, however, interrupted several times by heavy rains and by the difficulty in traveling in a small boat along the exposed coast of the peninsula. The field work on the southern coast of Kenai Peninsula from Resurrection Bay to Nubble Point included (1) a reconnaissance of the general geology, (2) a study of all the known mineral prospects, (3) a hurried investigation of the fronts of the tidewater glaciers, and (4) the preliminary mapping of the coast line where such work had not already been done by the Coast and Geodetic Survey, which has published detailed charts of Resurrection Bay, Port Chatham, Port Graham, and Seldovia Bay. The mapping, which was done almost entirely by Higgins, was based on a rough graphic triangulation with the traverse plane table and the sketching of the topography. The geographic locations were controlled by several triangulation stations of the Coast and Geodetic Survey, and occasional trips were made 1 mile to 7 miles back from the shore line. A preliminary report of the field work in 1909 has already been published, ${ }^{3}$ as has also an account of the glaciers. ${ }^{4}$

Valuable assistance in the field was rendered in 1905 by Sidney Paige, in 1908 by Carl Focht, and in 1909 by R. C. Jacobson. J. J. Bettles, of Valdez, whose knowledge of the coast and harbors of Kenai Peninsula was of much help in the field work, was with the Grant party each season.

1 (irant, U.S., and IIiggins, D. F., jr., Notes on geology and mineral prospects in the vieinity of Seward, Kienai L'eninsula: U. S. Geol. Survey J3ull. 379 , pp. $98-107,1909$.

2 Grant, U.S., and Jliggins, D. F., jr., Reconnaissance of the geology and mineral resources of Prince William Sound, Alaska: U. S. Geol. Survey Bull. 443,89 pp., 1910.

${ }^{3} \mathrm{Grant}$, U. S., and Iliggins, D. F., Preliminary report on the mineral resources of the southern purt of Kenai Peninsula: U. S. Geol. Survey Bull. 442, pp. 168-178, 1910.

4 Grant, U.S., and II iggins, D. F., Coastal glaciers of Prince William Sound and Kenai P'eninsula, Alaska: L. S. Geol. Survey Bull. 526, 1913. 
In 1906 W. W. Atwood, assisted by C. E. Weaver, devoted a month to an investigation of the coal fields of the Cook Inlet region, spending some time at Kachemak Bay and Port Graham. ${ }^{1}$ The region north of Kenai Peninsula had been investigated, as already stated, by Mendenhall in 1898. Areal geologic surveys of this province were made by Paige and Knopf ${ }^{2}$ in 1906 . The region lying west of Cook Inlet has been studied by Martin and Katz. ${ }^{3}$ The writer has also prepared a brief summary ${ }^{4}$ of the geology of the larger province of which Kenai Peninsula is a part.

Most of the investigations referred to above were confined to the shore line and did but little to elucidate the geography and geology of much of the interior. The industrial advancement in Kenai Peninsula made it important to extend the reconnaissance mapping over its entire area. To this task four parties were assigned in 1911, as follows:

R. H. Sargent, with a party of four men, began field work at Kachemak Bay on June 9 and carried a topographic reconnaissance survey northward to Turnagain $\Lambda \mathrm{rm}$. The work included the revision and original mapping of part of the Sunrise placer district, and later the survey of the drainage basin of Resurrection River near Seward. Surveys were continued until October 5 . All told, an area of 3,100 square miles was surveyed, besides which the mapping of some 660 square miles was revised. These surveys were made for publication on a scale of $1: 250,000$, with 200 -foot contours.

J. W. Bagley, who began work on Kenai Peninsula on July 25 and continued it, so far as the weather permitted, until October 13, made detailed topographic surveys (see $\mathrm{Pl} . \mathrm{IT}$, in pocket) of an area of 86 square miles (scale, $1: 62,500$ ) in the Moose Pass region (for when the work was planned the Moose Pass region seemed to aftord promise of early lode development) and also covered some 360 square miles by reconnaissance surveys, besides revising the mapping of an area of 170 square miles. These surveys were made by photo-topographic methods.

G. C. Martin, assisted by Hamon Lewis, carried a geologic reconnaissance northward from Port Graham to Kenai River, then eastward to the Alaska Northern Railway. In addition, Mr. Martin made some special geologic investigations in other parts of the peninsula. The Martin party was engaged in field work from June 23 to September

${ }^{1}$ Atwood, W. W., Mineral resources of southwestern Alaska: U. S. Geol. Survey 13ull. 379, pp. 116-126i, 1909.

2 Paige, Sidney, and Knopf, $A$ dolph, Geologic reconnaissance in the Matanuska and 'Talkeet na basins, Alaska: U.S. (ieol. Survey Bull. 327,1907 .

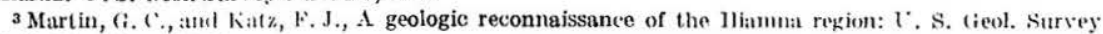
Bull, 485,312 pp., 1912.

4 Brooks, A. II., The Mount Mckinley region, Alaska: U. S. (ieol. Survey Prof. Paper 70, 1911. 
30 , during which time it mapped an area of 800 square miles on a scale of $1: 250,000$.

In view of the discovery and development of auriferous lodes in the northern half of Kenai Peninsula, a special investigation of these lodes was determined upon, and B. L. Johnson was assigned to the work. Mr. Johnson was engaged in field work near Seward from May 31 to October 26 . He made a more or less detailed examination of most of the important lodes and of many of the gold placers.

To summarize the results accomplished in Kenai Peninsula in 1911: Detailed topographic surveys were made of 86 square miles and topographic reconnaissance surveys of 3,520 square miles, and the mapping of 830 square miles was revised. About 800 square miles was covered by geologic reconnaissance surveys, and in addition most of the important lode and placer deposits were studied in some detail.

C. E. Giffin made a topographic reconnaissance of the Portage Glacier region in 1913. ${ }^{1}$ The results indicate that it is available as a railway route from Passage Canal, on Prince William Sound, to Turnagain Arm.

Ellsworth and Davenport ${ }^{2}$ made a reconnaissance of the water supply of the Kenai Peninsula in 1913.

In view of the delay in the preparation of Mr. Grant's final report on the southwestern part of the peninsula, based on the survey of 1909 (see p. 18), it seemed desirable to embody this in the same volume with reports on other parts of the peninsula by Messrs. Martin and Johnson. By this means all the data relating to the geology and mineral resources are brought together for convenient reference.

\footnotetext{
1 Mineral resources of Alaska, 1913: U. S. Geol. Survey Bull. 592, p. 50, Pl. II, 1914.

2 Ellsworth, C. E., and Davenport, R. W., Preliminary report on a water-power reconnaissance in south-central Alaska: U. S. Geol. Survey Bull, 592, pp. 180-188, 1914.
} 


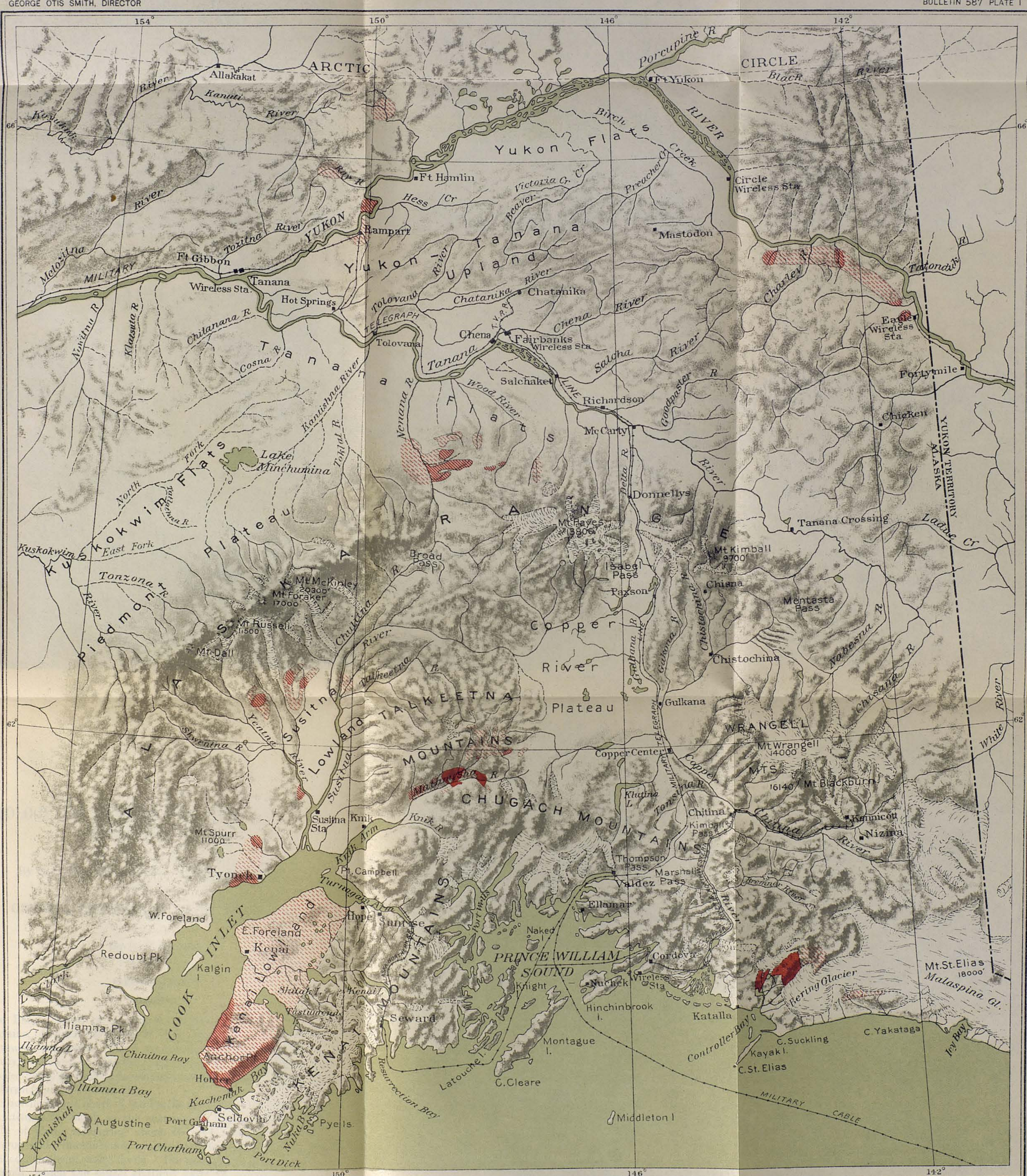

MAP OF CENTRAL ALASKA. SHOWING POSITION OF THE COAL FIELDS

Scale $\frac{1}{2,500,000}$

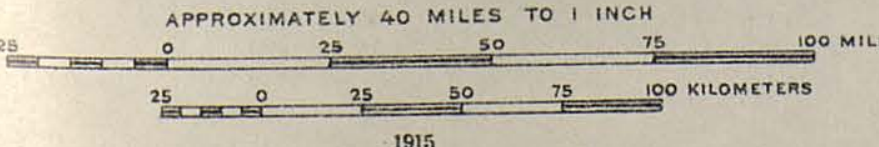

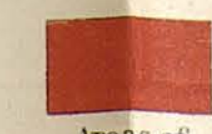

high-grai

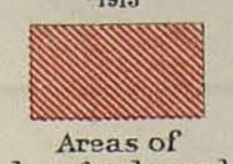

Areas of
low-grade coal
Areas probably containing some coal 



\title{
GEOLOGY AND MINERAL RESOURCES OF KENAI PENINSULA, ALASKA.
}

\author{
By G. C. Martin, B. L. Johinson, and U. S. Grant. \\ GENERAL FEATURES OF KENAI PENINSULA.
}

\author{
By G. C. Martin.
}

\section{GEOGRAPHY.}

POSITION.

The Pacific coast of Alaska is bordered throughout by high mountains, of which the Coast, St. Elias, Chugach, Kenai, and Aleutian ranges are parts. These mountains in most places descend abruptly to the sea, so that the coast is extremely bold, but it is also in places deeply embayed, presenting many long and deep fiords and an extremely sinuous shore line.

The northernmost point of the Pacific Ocean is near longitude $146^{\circ}$ west, latitude $60^{\circ}$ north, at the entrance to Prince William Sound, a body of water measuring about 60 by 90 miles, lying behind Montague and Hinchinbrook islands and consisting of the united expanded mouths of many fiords. The numerous islands, both large and small, which the sound contains make it an archipelago. It extends well into the heart of the coastal mountains and is one of the major indentations of the Alaskan coast.

Cook Inlet, which lies about 150 miles west of Prince William Sound, is an immense bay covering more than 10,000 square miles and extending over 200 miles inland. It differs from the other indentations of the Pacific coast of Alaska in heading well behind the coastal ranges and in having brond tributary valleys, which are drained by large rivers.

Kenai Peninsula lies between Prince William Sound and Cook Inlet (see Pl. I), and is almost separated from the rest of the continent by the waters of Passage Canal, or Portage Bay, as it is more generally called, and of Turnagain Arm, branches of Prince William Sound and of Cook Inlet, respectively, which head within about 9 
miles of each other. The position of Kenai Peninsula may be otherwise stated as lying between meridians $148^{\circ}$ and $152^{\circ}$ west longitude and parallels $59^{\circ}$ and $61^{\circ}$ north latitude. Its maximum dimensions are about 170 miles from northeast to southwest and 100 miles from northwest to southeast. Its area is about 9,400 square miles.

\section{RELIEF.}

- Kenai Peninsula includes two geographically dissimilar and sharply separated districts, the Kenai Mountains and the Kenai lowland. The former, embracing about 6,500 square miles, includes all the mountainous or eastern and southern parts of the peninsula; the latter comprises about 2,900 square miles in the western part of the peninsula bordering Cook Inlet north of Kachemak Bay. The boundary between these districts lies along an approximately straight line connecting the heads of Kachemak and Chickaloon bays, both of which are branches of Cook Inlet.

The Kenai Mountains have a general altitude of from 3,000 to 5,000 feet above sea level, the maximum being about 6,400 feet. These mountains constitute a rugged mass (see Pls. VI and VII) which is apparently without very orderly arrangement of form and drainage. The higher peaks are irregularly distributed, linear ridges are seemingly absent, the slopes are steep, and the drainage systems are irregular. (See Pls. II and IV, in pocket.) These mountains are composed dominantly of metamorphosed sedimentary rocks, which are broadly uniform but narrowly diverse in lithologic character, and which are structurally most intricate, the broad features of the structure being unknown. From these rocks the present land forms were carved by stream and glacial erosion at times and under conditions that have not been determined. The dominant factor in the production of the present land forms (see Pls. VI and XIV) was apparently glacial erosion (see pp. 37,96 ), which probably consisted chiefly of bergschrund attack and trough deepening by a coalescent group of alpine glaciers which, in general, tended to accentuate rather than to obliterate the preglacial relief. The southern and eastern parts of the mountains are now occupied by glaciers, which in each part consist of one great central ice mass from which many large valley tongues radiate and near which lie smaller separate glaciers.

Most of the Kenai lowland stands only 50 to 200 feet above sea level, although the ridge on the north shore of Kachemak Bay is over 2,000 feet high and the surface of the lowland slopes up to about the same altitude at the edge of the mountains between Tustumena and Skilak lakes.

The Kenai lowland (see Pl. I) has heretofore been called the Kenai Plateau, but the topographic surveys (see Pl. II) have shown that the 


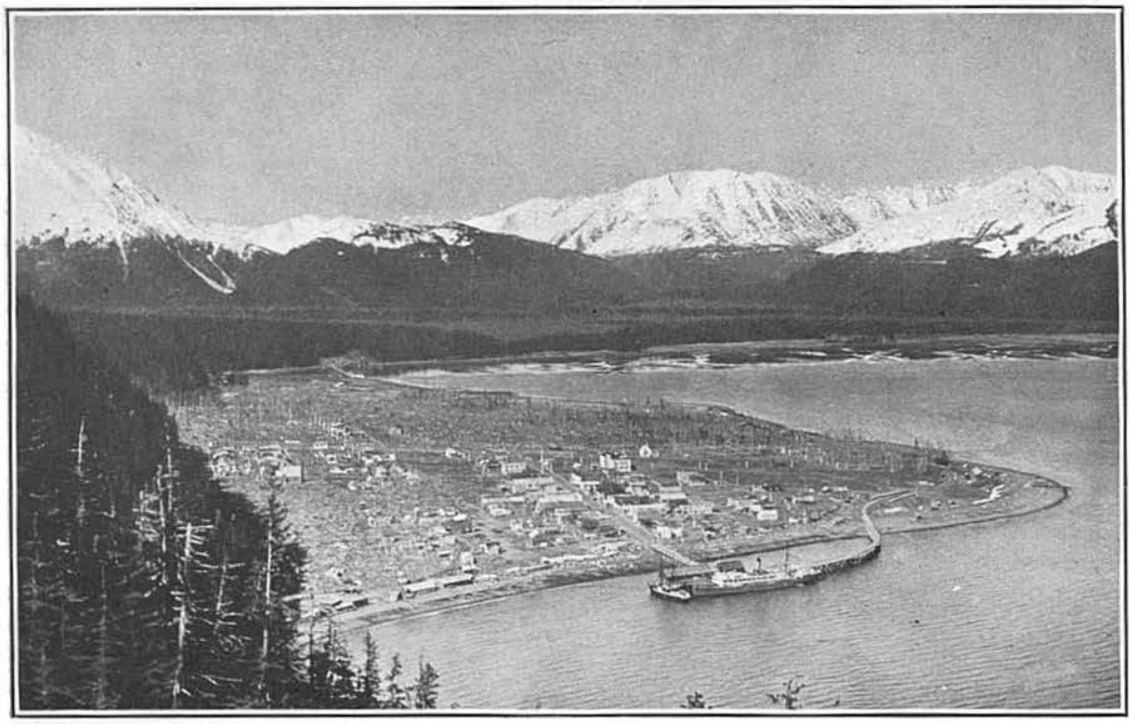

A. VIEW OF SEWARD.

Ocean terminus of the Alaska Northern Railway, situated on the delta of a small stream near the head of Resurrection Bay. Photograph by L. H. Pederson.

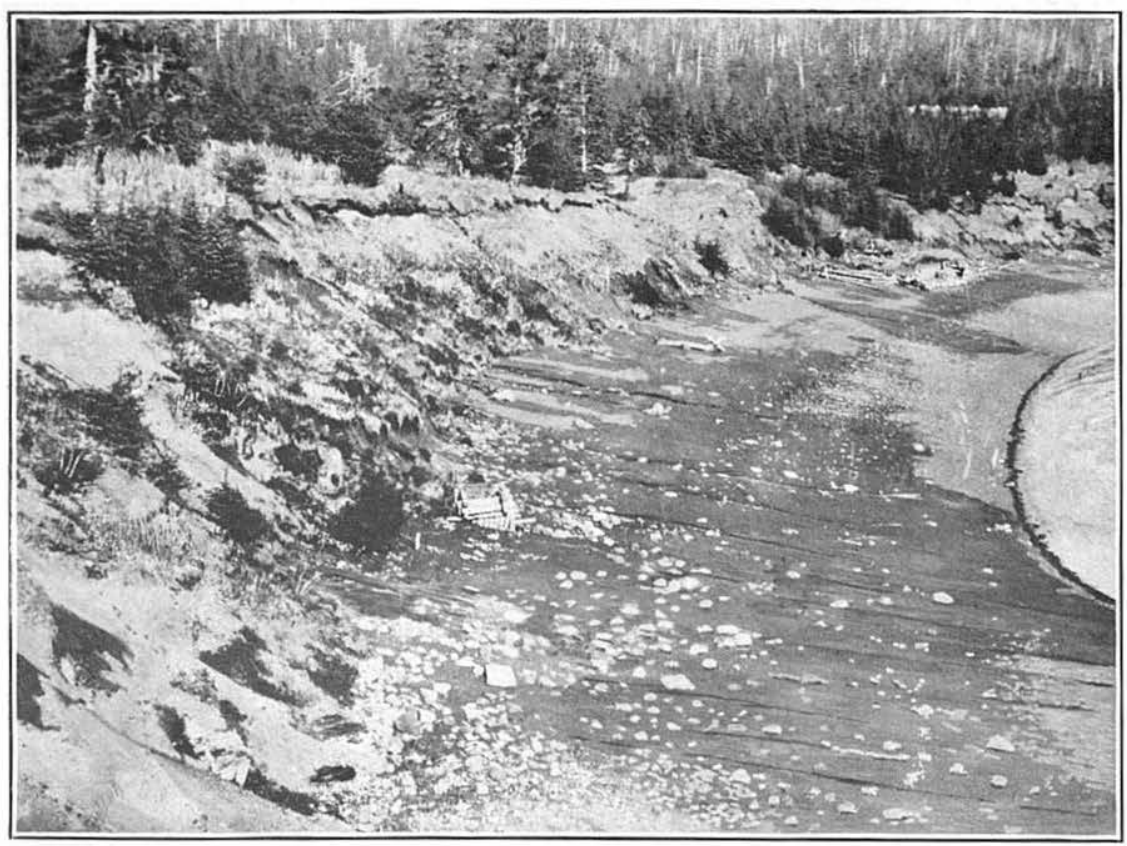

B. SITE OF RUSSIAN COAL MINE AT PORT GRAHAM.

Shows low terrace characteristic of the Cook Inlet forelands, capped by gravels and underlain by a local block of coal-bearing rocks, which outciop at the base of the bluff. The shaft and drift opened by the Russians in 1855 may be seen on the beach. 

name plateau is inappropriate because the area does not stand at the altitude of a plateau and is not tabular in form except in those parts of it which are near sea level. It is in most respects similar to the Susitna lowland, ${ }^{i}$ of which it is practically an extension and from which it is separated only by the waters of Cook Inlet.

The Kenai lowland is underlain by slightly consolidated Tertiary beds, which are gently flexed and but slightly and locally faulted and upon which rest glacial till and fluviatile or lacustrine terrace gravels. The entire lowland, except probably the higher ridges, has been overridden by an immense glacier which formerly filled much of the present Cook Inlet channel. The land forms were produced by the glacial sculpture of the Tertiary beds, by the deposition of glacial detritus at the margin of a large melting valley glacier and on the streams that drained it, by the cutting and building of benches and terraces in lakes that bordered the glacier and probably also in a large estuary, and by the vigorous but short-lived dissection of the Tertiary and Quaternary deposits by large streams that headed in waning glaciers and by the action of a large body of water that was subject to 20 to 100 foot tides and violent winds.

\section{SHORE IINE.}

The two geographic subprovinces of Kenai Peninsula present two distinctive types of shore line. The shore of the Kenai Mountains is intricately embayed and exhibits features that would be expected on a deeply. drowned coast where the rocks are resistant and have been greatly eroded by glaciers of the alpine type. The shore of the Kenai lowland, on the other hand, is smooth and fairly straight, as would be expected on a coast where the rocks are weak; where the glacial erosion has been accomplished by a large and probably sluggish glacier, and where deposition predominated over erosion, at least toward the close of the glacial action.

The following table gives an index to the character of the shore in the two parts of the peninsula:

Length of shore line in the several parts of Kenai Peninsula, in miles.

Prince William Sound. . . . . . . . . . . . . . . . . . . 320

Pacific Ocean. ............................... 580

$-1900$

South shore of Kachemak Bay . . . . . . . . . . . . 180

Cook Inlet lowland .......................... 190

Turnagain Arm........................ 30

1 Brooks, ^. H., The Mount. MeKinley region, Alaska: U. S. Geol. Survey Prof. Paper 70, pp. 43-44, 1911. 
DRATNAGE.

The drainage of Kenai Peninsula is strikingly asymmetric, the larger rivers all flowing to the north and west. The divide between the northward or westward flowing streams, which are tributary to Cook Inlet, and the streams that flow directly into the Pacific Ocean or into Prince William Sound lies near the Pacific coast. A notable example of this asymmetry is seen in Kenai River, which drains territory lying within 6 miles of the head of Resurrection Bay, yet in which water must flow 112 miles before it reaches tidewater at the mouth of Kenai River, and over 200 miles before it reaches the ocean at the mouth of Cook Inlet. The following table illustrates the asymmetry of the main divide, and also gives the area of each of the minor drainage basins:

Areas of drainaye basins in Kenai Peninsula, in square miles.

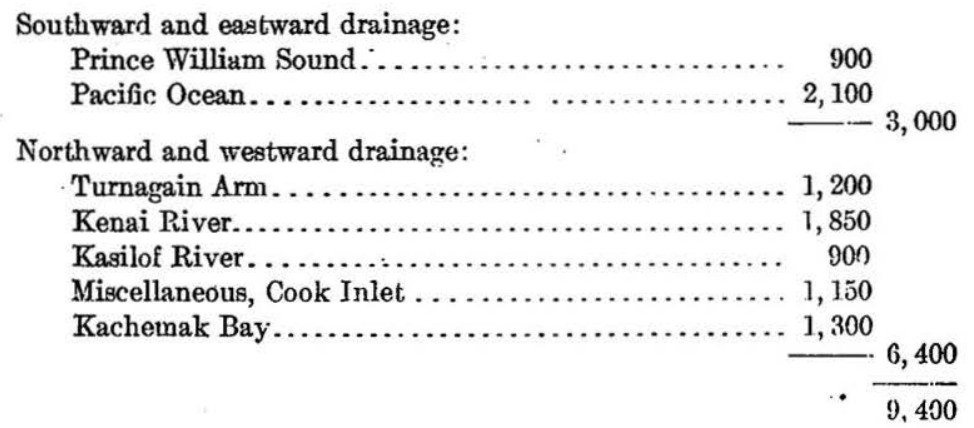

Kenai River, the largest stream in Kenai Peninsula, has its source in Kenai Lake, at an altitude of about 470 feet. It descends about 300 feet in a distance of about 15 miles to Skilak Lake, whence it flows across the lowlands to its mouth at the town of Kenai, on the east shore of Cook Inlet. It is a tidal stream in the lower 9 or 10 miles of its course, for which distance it is navigable by tugs and similar craft. Farther upstream it is too swift and shallow to be navigated by any of the vessels now on Cook Inlet, although fairly large river steamers, designed for such streams, could doubtless ascend it to the rapids just above Moose River, a distance of about 40 miles. Between these rapids and Skilak Lake and between Skilak and Kenai lakes it is so swift and shallow that it can be navigated only by canoes or poling boats, although dories have been dragged through.

The waters of this stream have their chicf ultimate source in Snow River, Trail Creek, and the smaller streams tributary to Kenai Lako. Most of these streams head in glaciers (see Pl. IX, $A$ ), which supply the sediment that keeps Kenai River turbid for its entire length. It receives two large tributaries, Killey River and Funny River, below Skilak Lake. 


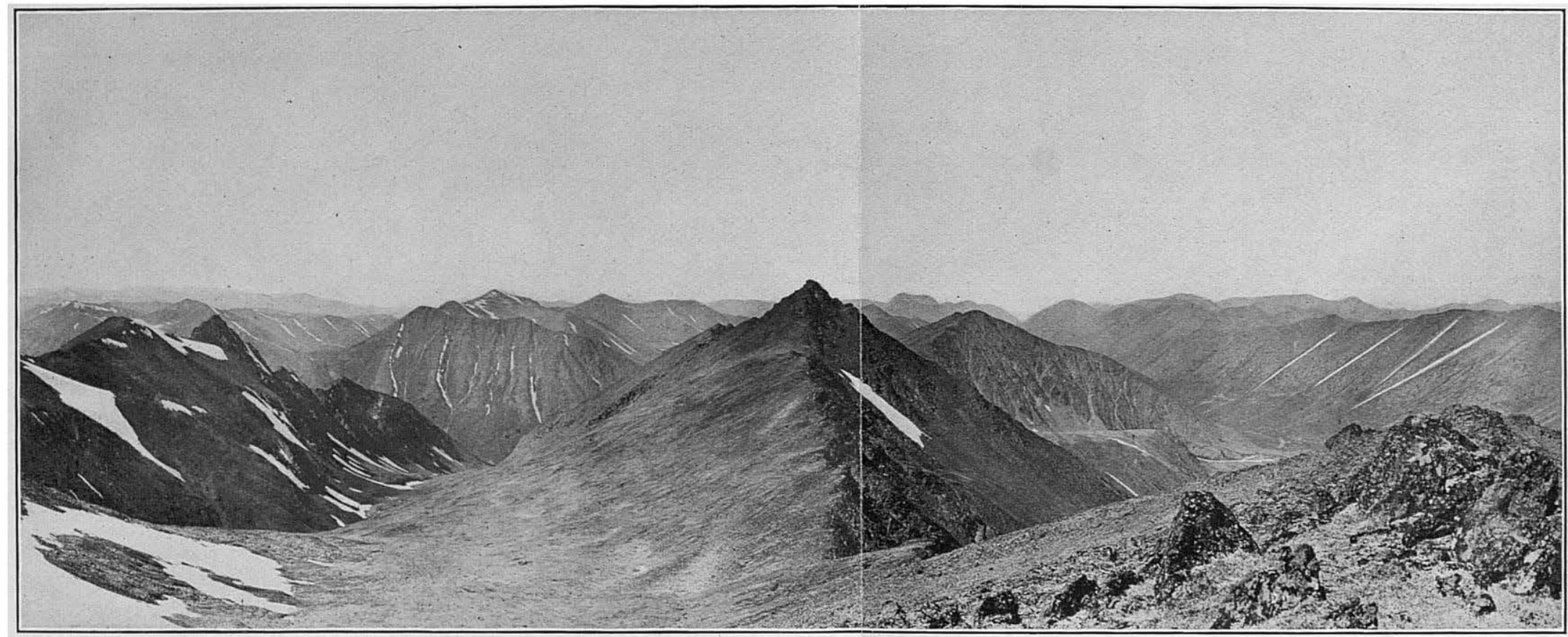

A. VIEW AT HEADWATERS OF HENRY AND SLATE CREEKS, LOOKING WEST.

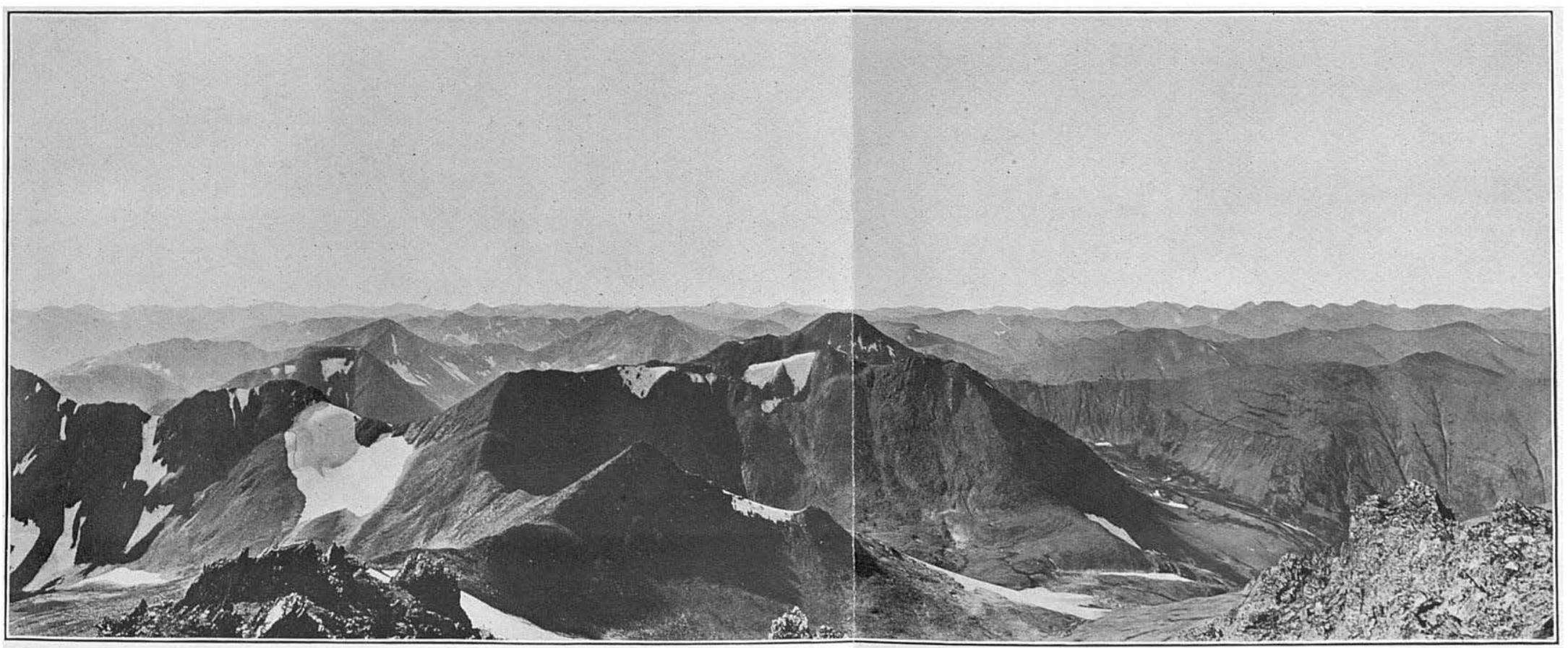

B. VIEW AT HEADWATERS OF DONALDSON AND FRENCHY CREEKS, LOOKING SOUTH.

Views typical of the upland features of the northwest part of the Kenai Mountains, from which the glaciers have disappeared. 

Kasilof River, which is the second stream of Kenai Peninsula in volume, has its source in Tustumena Lake at an elevation of about 90 feet and reaches Cook Inlet at Kasilof after a course of about 15 miles. It is tidal for the lower 5 miles of its course, where it can be navigated by cannery tugs and by the local Cook Inlet steamers. Canoes and poling boats can ascend to Tustumena Lake without difficulty, and launches can go up to the lake at the higher stages of the water.

The other large streams include Resurrection River, which is tributary to Resurrection Bay; Fox River, which discharges at the head of Kachemak Bay; and Placer River, Sixmile River, Resurrection Creek, Chickaloon River, and Big Indian River, which empty into Turnagain Arm. None of these are navigable for boats of any kind except Fox River, which can be ascended by canoes or poling boats for about 8 miles.

\section{GLACIERS.}

Glaciers occur throughout the greater part of the Kenai Mountains but are most extensively developed in the area south of the valleys of Resurrection River and Skilak Lake and east of the valleys tributary to Kachemak Bay and Tustumena Lake, and in the eastern part of the peninsula between the Alaska Northern Railway and Prince William Sound. (See Pl. VII and Pl. VIII, B, p. 28.) The mountain area north of the Kenai Valley and west of the valleys of Placer River and Trail Creek contains only very small glaciers. (See Pl. XXVIII, $A$, p. 126 , and Pl. XXIX, $A$, p. 128.)

The most extensive known glaciation in Kenai Peninsula is in the area south of the valleys of Resurrection River and Skilak Lake and east of the valloys tributary to Kachemak Bay and Tustumena Lake. The higher land in this area is covered by a large snow field from which large valley glaciers flow out in all directions. The main area of this snow field measures approximately 45 miles from northeast to southwest and 25 miles from northwest to southeast. A probable extension much narrower and less certainly continuous reaches about 20 miles farther southwest. Many of the glacial tongues that flow out from this snow field have long been known, but the extent and character of the snow field itself were first recognized by R. H. Sargent in the survey made for the topographic map which accompanies this report (Pl. II). This snow field consists of the neighboring and largely united upper ends of many valley glaciers, whose névé fields join in one broad snowy expanse, broken only by seattered sharp ridges and peaks. The general altitude of the snow field is from 4,000 to 6,000 feet.

The glacial flow from this snow field is not strictly radial, being dominantly to the northwest and southeast. The glaciers that flow out to the Pacific seaboard form the largest part of this system, including large named glaciers, which have been described in detail by 
Grant and Higgins. ${ }^{1}$ Bear, Northwestern, McCarty, and Yalik glaciers, all of which end practically at tide level, are the largest of the group.

The glaciers that flow out to the northwest include Skilak, Tustumena (Pl. VIII, A), Chernof, Dinglestadt, Kachemak, Dixon, Portlock, and Grewingk glaciers. Grewingk Glacier is the only one of these which has been heretofore described. ${ }^{2}$

The unsurveyed eastern part of Kenai Peninsula contains many large glaciers, and is probably occupied by an extensive snow field similar to that in the south-central part of the peninsula. The glaciers on the Pacific and Prince William Sound shores have been described by Grant and Higgins. ${ }^{3}$ This district is also the source of many glaciers which drain into the eastern tributaries of Kenai Lake and Placer River. Most of these are unnamed and undescribed, and only Spencer (Pl. XXVIII, $B$, p. 126, and Pl. XXIX, $B$, p. 128) and Bartlett (Pl. IX, $B$, p. 29) glaciers, in the valley of Placer River, and Trail Glacier (Pl. IX, $A$, p. 29), at the headwaters of Trail Creek, are well known.

The distribution of glaciers in Kenai Peninsula is governed primarily by the occurrence of areas above snow line large enough to serve as gathering grounds for glacial snow and ice. The glaciers that lie in districts whose average altitude is greatest are therefore largest and most numerous. (See Pl. II, in pocket.) Differences in precipitation (see p. 27) are probably sufficient to have a notable local effect on glaciation. Local differences in temperature are overbalanced by differences in precipitation, the mean temperature being lower on Turnagain Arm than on the Pacific seaboard.

\section{CLIMATE.}

The climate of Kenai Peninsula, like that of all the Pacific coast of Alaska, is characterized by cool summers and by winters that are rather mild for the latitude. The effect of the warm ocean currents is felt here as elsewhere along the coast. The precipitation differs in different parts of the district. The southern coast of the peninsula has abundant rainfall, although the precipitation there is by no means so great as it is farther east. The northern part of the Kenai Mountains has considerably less rain and is colder than the southern part. The lowlands bordering Cook Inlet are likewise considerably colder than the Pacific coast and have a very light rainfall. The following tables, compiled from the records of the United States Weather Bureau, show the temperature and precipitation in different parts of Kenai Peninsula and at neighboring localities:

1 Grant, U. S., and Higgins, D. F., Coastal glaciers of Prince William Sound and Kenai Peninsula, Alaska: U. S. Geol. Survey Bull. 526, pp. 56-67, 1913.

2 Becker, G. F., Reconnaissance of the gold fields of southern Alaska: U. S. Geol. Survey Eighteenth Ann. Rept., pt. 3, p. 60, 1595. Gilbert, G. K., Alaska, vol. 3, pp. 97-102, Iarriman Alaska Expedition, 1904.

8 Grant, U. S., and II iggins, D. F., op. cit., pp. 40-55. 


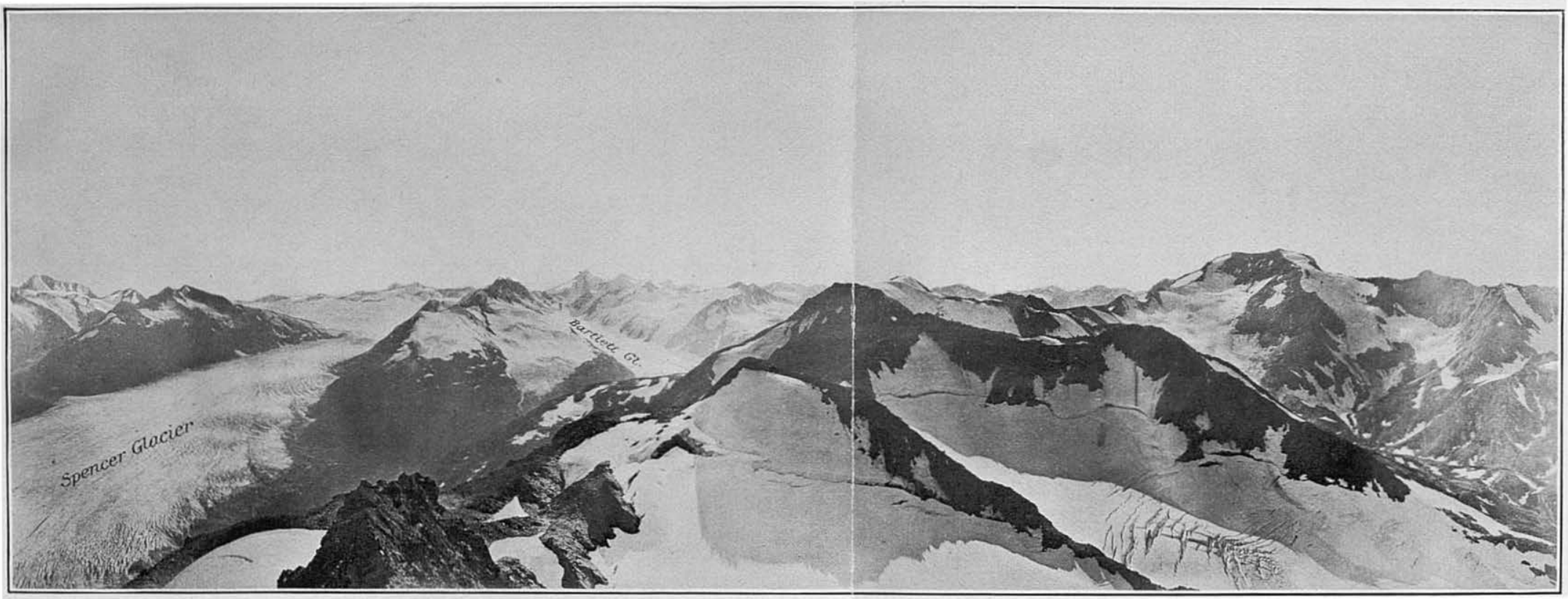

A. MOUNTAINS SOUTH OF SPENCER GLACIER.

View from 5,000-foot peak 13 miles west of end of Spencer Glacier, looking S. $15^{\circ}$ E. Shows character of the Kenai Mountains and of the more severe existing glaciation in the eastern part of the district. Photograph taken September 16, 1911.

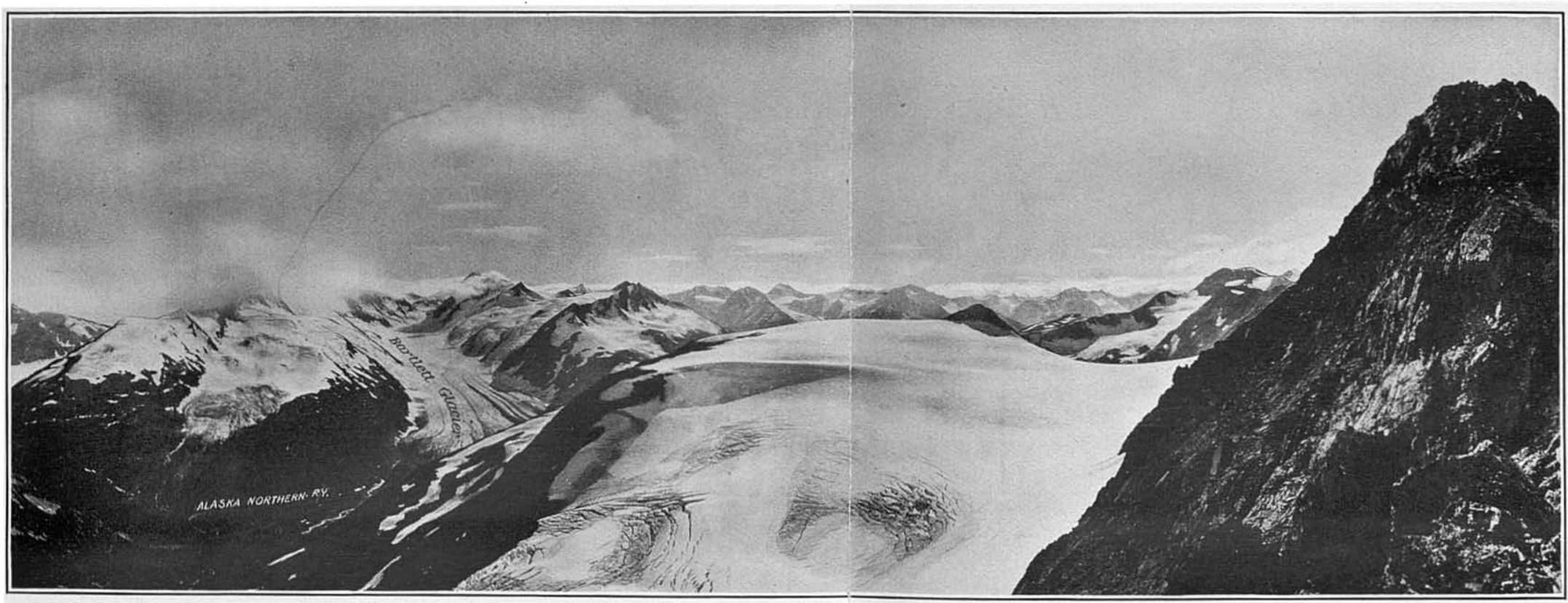

B. MOUNTAINS AT HEADWATERS OF PLACER RIVER.

View from point $2 \frac{1}{2}$ miles northwest of lower end of Bartlett Glacier, looking S. $15^{\circ}$ E. Photograph taken September $17,1911$. 

Average monthly temperature and precipitation at certain places on and near Kenai Peninsula. ${ }^{a}$

[The time given in years represents the length of the record.]

Temperature.

\begin{tabular}{|c|c|c|c|c|c|c|c|c|c|c|}
\hline \multirow{2}{*}{. } & \multicolumn{2}{|c|}{ Seward. } & \multicolumn{2}{|c|}{ Sunrise. } & \multicolumn{2}{|c|}{ Kenai. } & \multicolumn{2}{|c|}{ Tyonek. } & \multicolumn{2}{|c|}{$\begin{array}{l}\text { Kodiak and } \\
\text { Wood Island. }\end{array}$} \\
\hline & - F. & Years. & $\circ \mathrm{F}$. & Years. & ० $\mathrm{F}$. & Years. & $\circ \mathrm{F}$. & Years. & $\circ$ F. & Years. \\
\hline 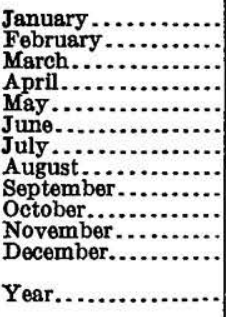 & $\begin{array}{l}16.34 \\
25.72 \\
30.85 \\
36.24 \\
43.80 \\
48.59 \\
54.00 \\
54.29 \\
48.62 \\
37.12 \\
30.40 \\
27.55 \\
37.79\end{array}$ & $\begin{array}{l}2 \\
3 \\
3 \\
3 \\
3 \\
3 \\
3 \\
3 \\
3 \\
2 \\
3 \\
3 \\
2\end{array}$ & $\begin{array}{r}8.70 \\
16.29 \\
24.47 \\
33.59 \\
43.71 \\
50.14 \\
53.34 \\
51.88 \\
43.98 \\
33.76 \\
22.31 \\
17.90 \\
33.34\end{array}$ & $\begin{array}{l}7 \\
7 \\
6 \\
7 \\
7 \\
6 \\
7 \\
7 \\
7 \\
8 \\
8\end{array}$ & $\begin{array}{r}9.70 \\
17.90 \\
25.29 \\
33.89 \\
43.15 \\
47.98 \\
52.84 \\
52.77 \\
46.90 \\
35.28 \\
21.34 \\
14.08 \\
33.43\end{array}$ & $\begin{array}{l}9 \\
9 \\
8 \\
7 \\
9 \\
9 \\
9 \\
9 \\
9 \\
9 \\
9 \\
9\end{array}$ & $\begin{array}{l}10.57 \\
18.73 \\
26.38 \\
34.70 \\
42.65 \\
52.42 \\
57.05 \\
55.57 \\
48.71 \\
33.50 \\
23.89 \\
18.00 \\
35.18\end{array}$ & $\begin{array}{r}10 \\
10 \\
8 \\
8 \\
6 \\
8 \\
7 \\
7 \\
8 \\
8 \\
9 \\
9\end{array}$ & $\begin{array}{l}28.92 \\
33.17 \\
34.60 \\
36.24 \\
43.52 \\
51.11 \\
53.14 \\
55.22 \\
49.61 \\
41.15 \\
34.50 \\
30.57 \\
40.98\end{array}$ & $\begin{array}{r}10 \\
10 \\
11 \\
10 \\
11 \\
11 \\
12 \\
10 \\
10 \\
10 \\
11 \\
9\end{array}$ \\
\hline \\
\hline. & \multicolumn{2}{|c|}{ Seward. } & \multicolumn{2}{|c|}{ Sunrise. } & \multicolumn{2}{|c|}{ Kenai. } & \multicolumn{2}{|c|}{ Tyonek. } & \multicolumn{2}{|c|}{$\begin{array}{l}\text { Kodiak and } \\
\text { Wood Island. }\end{array}$} \\
\hline & Inches. & Years. & Inches. & Years. & Inches. & Years. & Inches. & Years. & Inches. & Years. \\
\hline 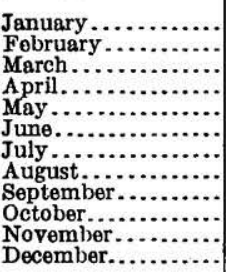 & \begin{tabular}{r|}
1.92 \\
5.14 \\
2.86 \\
2.53 \\
2.51 \\
2.48 \\
2.04 \\
4.17 \\
5.72 \\
8.12 \\
7.64 \\
12.59
\end{tabular} & $\begin{array}{l}2 \\
3 \\
3 \\
3 \\
3 \\
3 \\
3 \\
3 \\
2 \\
3 \\
3 \\
2\end{array}$ & $\begin{array}{l}2.69 \\
2.06 \\
2.07 \\
2.38 \\
1.61 \\
1.27 \\
2.11 \\
3.35 \\
2.95 \\
4.81 \\
4.18 \\
5.04\end{array}$ & $\begin{array}{l}7 \\
7 \\
6 \\
7 \\
7 \\
7 \\
7 \\
7 \\
7 \\
8 \\
8 \\
8\end{array}$ & $\begin{array}{r}0.80 \\
1.06 \\
.58 \\
.58 \\
2.47 \\
1.53 \\
2.40 \\
3.75 \\
3.71 \\
2.52 \\
1.10 \\
1.05\end{array}$ & $\begin{array}{l}8 \\
8 \\
8 \\
8 \\
8 \\
9 \\
9 \\
9 \\
9 \\
9 \\
9 \\
8\end{array}$ & $\begin{array}{r}1.65 \\
1.21 \\
.92 \\
1.18 \\
.83 \\
1.05 \\
2.78 \\
3.98 \\
3.81 \\
2.73 \\
1.19 \\
1.19\end{array}$ & $\begin{array}{r}10 \\
10 \\
8 \\
8 \\
7 \\
9 \\
7 \\
8 \\
8 \\
8 \\
9 \\
9\end{array}$ & $\begin{array}{l}3.23 \\
4.94 \\
3.37 \\
4.42 \\
5.07 \\
3.86 \\
3.75 \\
4.17 \\
4.46 \\
6.32 \\
5.72 \\
5.87\end{array}$ & $\begin{array}{r}11 \\
11 \\
10 \\
10 \\
11 \\
11 \\
10 \\
9 \\
10 \\
10 \\
11 \\
10\end{array}$ \\
\hline Year................ & 57.72 & $\ldots \ldots$ & 34.52 & $\ldots \ldots$ & 21.55 & ..... & 22.52 & ........... & 55.18 & ... \\
\hline
\end{tabular}

a Annual reports for the Alaska agricultural experiment stations, 1902 to 1910.

VEGETATION.

The vegetation of Kenai Peninsula (see map, Pl. XI) is controlled by the physiographic features and the climate. Within the Kenai Mountains are forested areas and barren uplands. The better growth of trees is restricted to the bottoms and lower slopes (see Pl. X, p. 30), timber line being at a general altitude of about 2,000 feet. Spruce grows in suitable places throughout the mountain valleys (see $\mathrm{Pl}$. XII, $A$, p. 34 , and $\mathrm{Pl}$. XXI, $B$, p. 74 ), but attains size and numbers sufficient to make fair timberland only in some of the valleys on the Pacific coast (see Pl. XIII, p. 36, and Pl. XXII, $B$, p. 74) and on Turnagain Arm, where many trees are 3 or 4 feet in diameter. Even here, as elsewhere in Alaska, it is of only fair quality. Forest fires are frequent (see Pl. XII, B, p. 34) in the parts of the peninsula which have little rainfall. Birch grows throughout the valleys of the drainage basin of Cook Inlet, but apparently not 
in the Pacific drainage area. The influence of greater precipitation is possibly shown in the absence of birch on the Pacific streams and in the size of the spruce and the density of the undergrowth of shrubs and moss.

\section{- The following quotation from Osgood ${ }^{1}$ describes the part of} Kenai Peninsula lying just south of Turnagain Arm:

The flora of the Cook Inlet region is quite different in its general character from that of the coast farther south, although many species are common to both regions. The difference is largely in the reduction of the number of coniferous trees in the Cook Inlet region and the corresponding increase in deciduous trees; but other features somewhat transitional between the heavy saturated forest of the southern coast and the treeless tundra of the north are numerous. The flora of the mountainous district about Turnagain Arm is, of course, different from that of the coastal plains of other parts of the inlet. The low country near Hope consists of a grassy tide flat, about 50 acres in extent, and a few miles of forest and occasional small swamps along the lower part of Rejerrection Creek. Balsam poplars, paper birches, alders, and willows abound near the streams, and spruces (Picea canadensis and Picea sitchensis) and hemlocks (Tsuga mertensiana) are common on the slopes and slightly elevated flats. A third species of spruce (Picea mariana) is found in the small peat bogs, where smaller Hudsonian plants, such as Labrador tea (Ledum), crowberry (Empetrum), and dwarf birch(Betula glandulosa) are in profusion. The hemlock is much the mest abundant of the large trees, but it is exceeded in individual size by the sprucesf- The conifers ascend the mountain slopes to about 2,000 feet, but above . that point rapidly disappear. Beyond this elevation are alder thickets, small patches. of dwarf willows and birches, and vast siretches of waving grass from 1 to 3 feet high. Still higher, the slopes and rounded backs of the ridges are cushioned with a mass of heather and heather-like shrubs, chiefly Empetrum nigrum. This extends up to an approximate altitude of 5,000 feet, above which there is very little or no plant growth. The whole country is characterized by the abundance of high grass; otherwise it is a typical Hudsonian-Alpine region.

The Kenai lowlands are covered with a growth which consists of mixtures of spruce, hemlock, birch, and poplar in groves between which lie open meadows or patches of small bushes. The spruce is only locally of fair size and quality, trees more than 2 feet in diameter being rare. The local canneries have used much of the more accessible timber as piling. White birch grows on the east coast of Cook Inlet at least as far south as Bear Cove.

Native grasses are abundant, especially in the Cook Inlet region, which contains broad areas of natural grassland. There is also a considerable aggregate area of patches of grassland in the mountain province, especially around timber line (Pl. XII, $A$, p. 34) and in the upper timberless parts of the valleys. There is no difficulty in finding good forage for horses during the summer in almost any part of the peninsula except along the rock-bound coast. Considerable hay is now being made in the peninsula, especially in the vicinity of Hope, Sunrise, and Seward. In the Sunrise country native hay in stacks brings from $\$ 10$ to $\$ 12$ a ton, and late in the winter occasionally goes

1 Osgood, W. H., Natural history of the Cook Inlet region, Alaska: North American Fauna, No. 21, p. 53,1901 . 


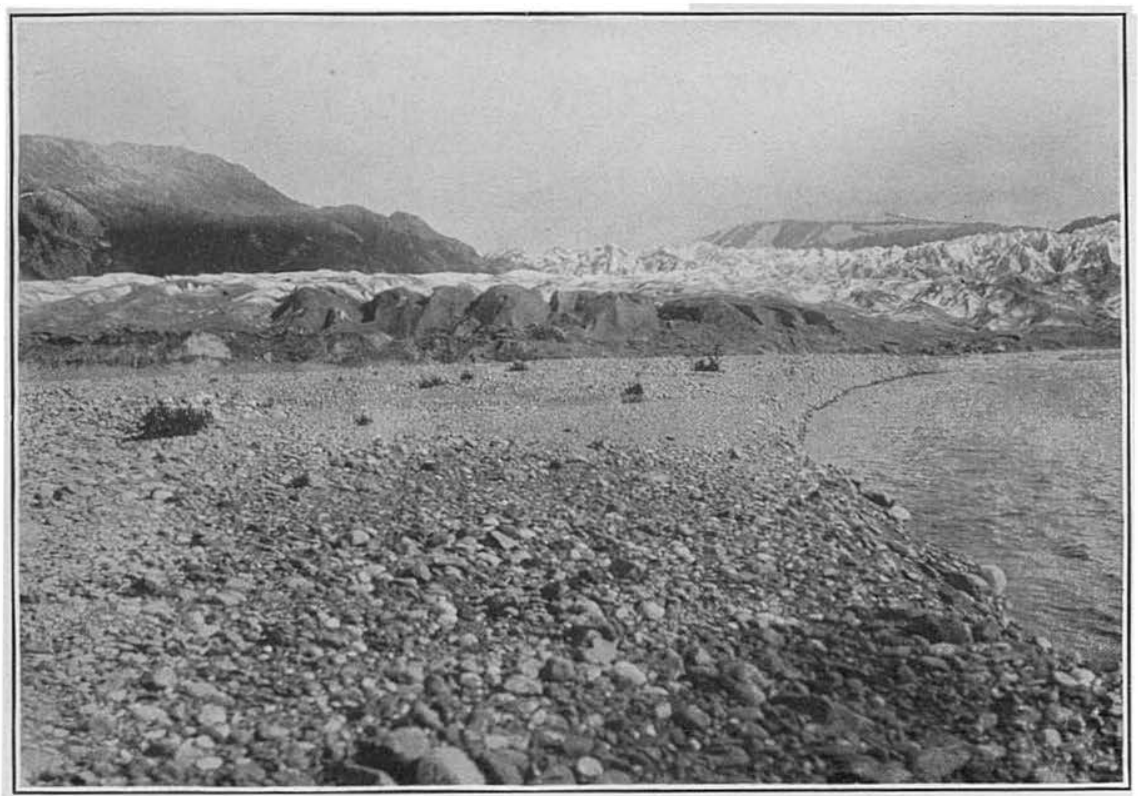

A. TUSTUMENA GLACIER.

Showing crevassed condition of lower end. Photograph taken August 13, 1911.

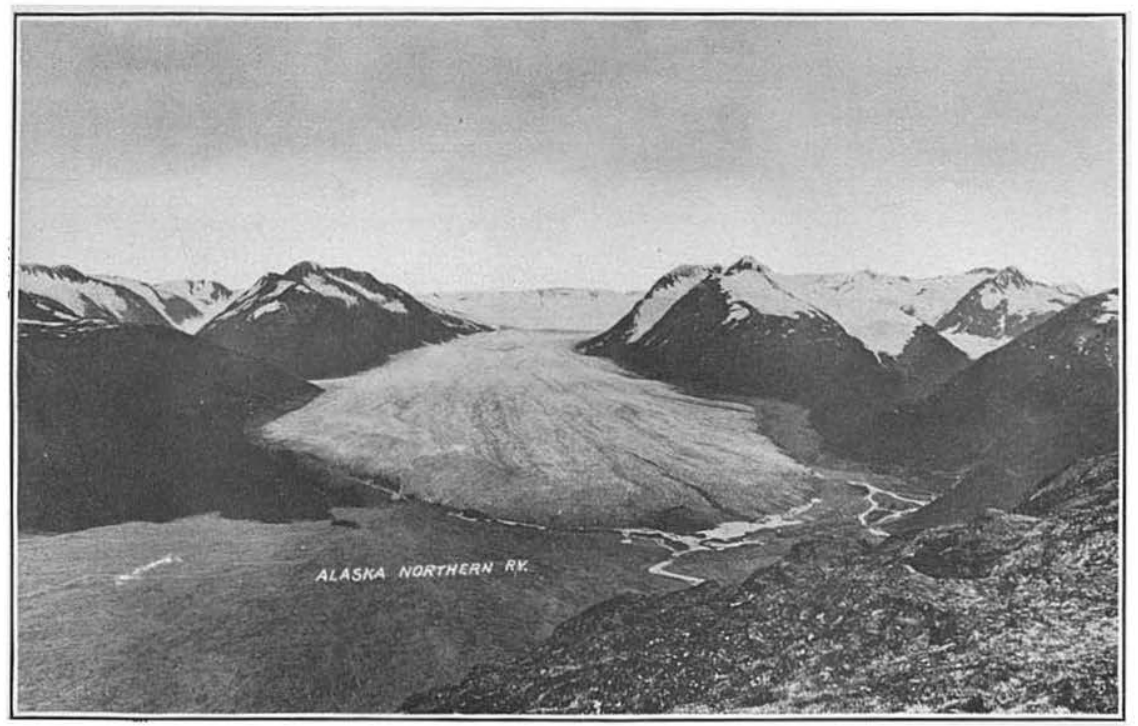

B. SPENCER GLACIER.

View from opposite mountain top, showing position of front of ice and of marginal drainage. The lower end of the same alluvial flat is shown in Plate XXII, A. Photograph take: September 20, 1911. 


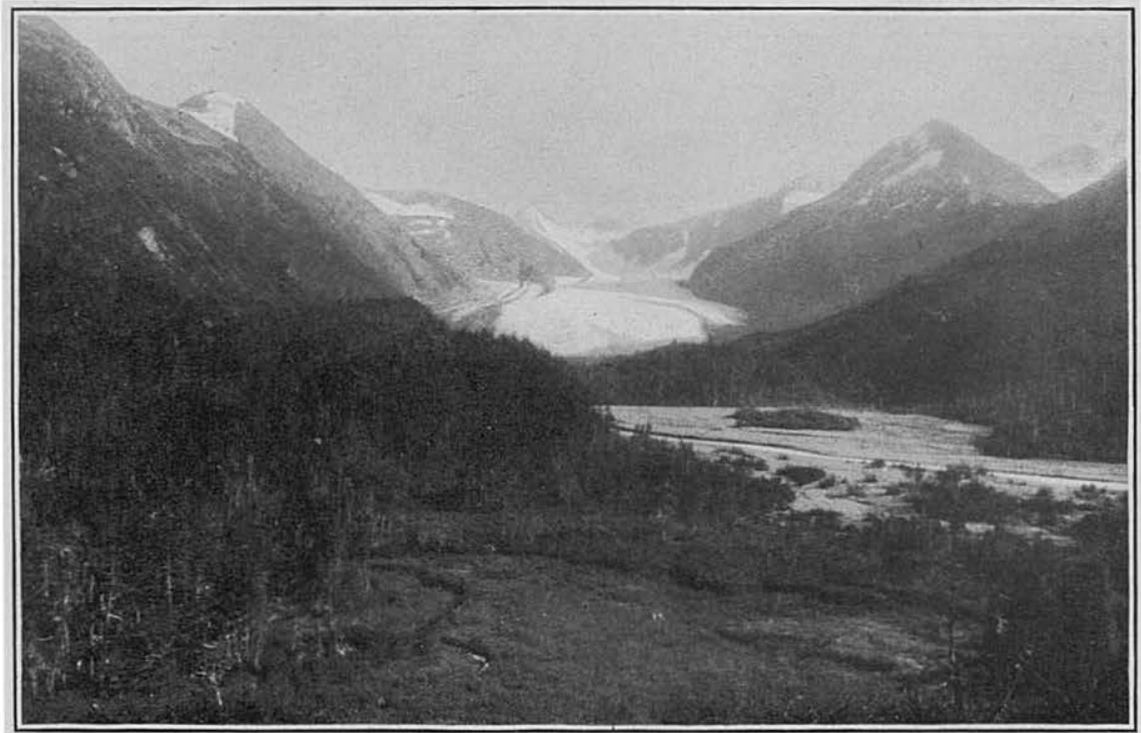

A. TRAIL GLACIER.

View from bridge No. 66, Alaska Northern Railway. Photograph taken September 21, 1911.

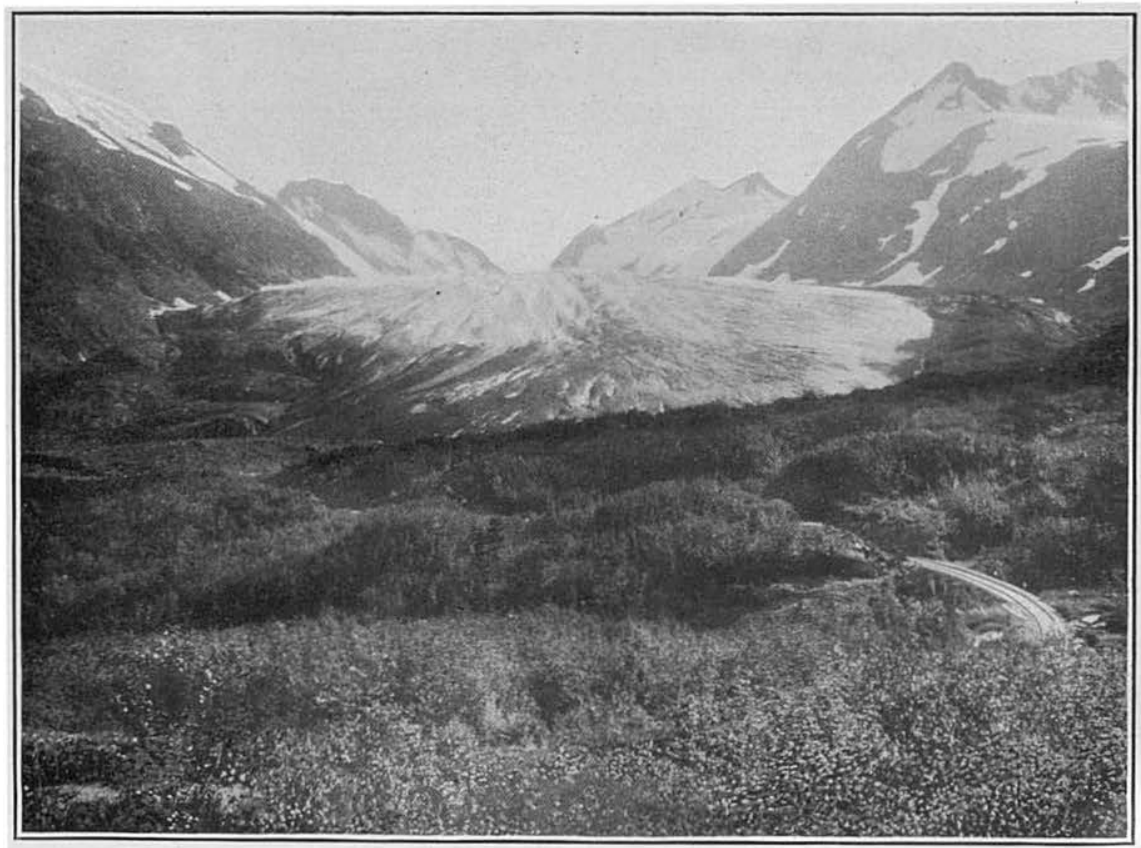

B. BARTLETT GLACIER.

View from milepost 48, Alaska Northern Railway, showing position of glacier front and the bare zones on each side of the glacier which indicate its position at a time of recent expansion. Photograph taken September $21,1911$. 
as high as $\$ 20$ a ton. Near Seward, Sunrise, Hope, and Kenai, where the conditions are most favorable for gardening, vegetables are raised in considerable quantities for local consumption. The wild fruits include cranberries, currants, blueberries, huckleberries, and a few salmonberries. An experiment station was established by the United States Department of Agriculture at Kenai in 1899 and maintained until 1908, when, on account of the isolation of the location, the work was transferred to Kodiak.

ANIMAL IIFE.

Kenai Peninsula is well and favorably known as a big-game country. Both the brown and the black bear are native to the peninsula, the black bear being by far the most abundant. Fur-bearing animals other than the bear include the lynx, ermine, mink, marten, and land otter. Foxes are scarce, wolverines are only occasionally seen, beavers are very rare, and wolves are practically extinct. Ground squirrels are fairly numerous and rabbits are beginning to reappear. Porcupines are abundant and form an easily obtainable food for the numerous dogs.

Moose are very abundant in the central and western parts of the peninsula. Mountain sheep are numerous, but mountain goats are rare. Caribou are very scarce. Grouse, ptarmigan, and shore birds, as well as waterfowl, such as ducks, geese, brant, swans, snipe, and curlew, are found in most parts of the peninsula. Trout are found in many of the mountain streams, and lake trout, whitefish, and a few grayling are reported in the large lakes. In summer salmon in great numbers run up most of the streams that flow into Resurrection Bay and Cook Inlet.

The fauna of the part of Kenai Peninsula that borders the upper part of Cook Inlet is described by Osgood ${ }^{1}$ as follows:

The mammals of the Cook Inlet region are essentially the same as those of the interior of Alaska. Nearly all the species of the Lower Yukon Valley are found among them, and none show any marked peculiarities not possessed in their interior habitat. With the exception of widely distributed species, such as the black bear, no species are common to the Cook Inlet region and the Sitkan region. Thus, while the mammals of Cook Inlet are not peculiar to the region, the mammal fauna, as a whole, is peculiar as contrasted with that of the coast farther south. Two new species, Microtus miurus and Sorex eximius, were found, but both are new, not only to Cook Inlet but to Alaska as well, and will undoubtedly be found in other parts of the Territory. Considering the latitude, both large and small mammals are numerous in species as well as individuals. Moose, bear, and mountain sheep are the principal big game, and although they have already been hunted to a considerable extent, it is probable that they are more abundant than in any equally accessible place in North America. Fur-bearing animals are well represented, but, as elsewhere in the North, have been much reduced in numbers. The smaller, less conspicuous mammals are such as are generally found throughout northern Alaska, and are well represented on account of the varied con-

1 Osgood, W. H., op. eit., pp. 56-57. 
ditions offered by the mountains of the Kenai Peninsula and the low country on the northwest side of the inlet. Our collection of mammals from Cook Inlet numbers 240 specimens, the majority of which, of course, are species of small size-such as shrews and mice-since we made no special effort to secure big game.

Birds were not found in great numbers. Owing to the lateness of the season at the time of our arrival in the inlet, those seen were permanent residents or fall stragglers, the summer residents being missed almost entirely. Land birds, with the exception of grouse, which were fairly common, were not numerous in species or individuals. Water birds, particularly hittoral or semipelagic forms; are noticeably uncommon, probably on account of the brackish water of the inlet and the comparative absence of marine invertebrates. Ducks and geese, however, and birds which feed in fresh water, are locally quite abundant. As in the case of the mammals, no birds are peculiar to the Cook Inlet region, but several interior species are found which do not occur on the Alaskan coast south of Cook Inlet.

The only other land vertebrate is a frog, collected by Heller at Tyonek.

Sea otter, which were formerly abundant along the south coast of the peninsula, are now practically extinct. There is a colony of sea lions on the Seal Rocks, south of Aialik Bay. Harbor seal are numerous along the coast and the beluga inhabits the waters of upper Cook Inlet.

\section{SETTLEMENTS, INDUSTRIES, AND TRANSPORTATION.}

The towns and villages of Kenai Peninsula include. Seward, which is at the head of Resurrection Bay (Pl. XIII, p. 36); Kenai, Kasilof, and Seldovia on Cook Inlet; and Sunrise and Hope on Turnagain Arm. Ninilchik, Alexandrovsk, and several other small native villages are on Cook Inlet. The population of Kenai Peninsula in the winter of 1910 was 1,692 . The summer population is considerably greater.

Seward, the largest and most important of these towns $(\mathrm{Pl} . \mathrm{V}, A)$, had a population of 534 in 1910. It is the ocean terminus of the Alaska Northern Railway and is reached by two steamship lines from Seattle, two steamers a week arriving during the summer of 1913 ; it is also the transfer point to the steamer running to the Alaska Peninsula and Bristol Bay.

Kenai, the second town in size, which had a population of 250 in 1910, stands at the mouth of Kenai River. It is reached only by boats plying on Cook Inlet.

Seldovia, which had a population of 173 in 1910, is reached by steamer from Seattle and Seward, and is the transfer point to the launches plying on Cook Inlet.

Sunrise and Hope are trading points for the local placer camps.

The principal industries of Kenai Peninsula are mining and fishing. Mining is restricted to the northern and central parts of the peninsula and fishing to Cook Inlet. There are salmon canneries at Kenai, Kasilof, Seldovia, and Port Graham.

Many of the small streams of the Kenai Mountains will furnish abundant water power for purely local use. These streams fluctuate 


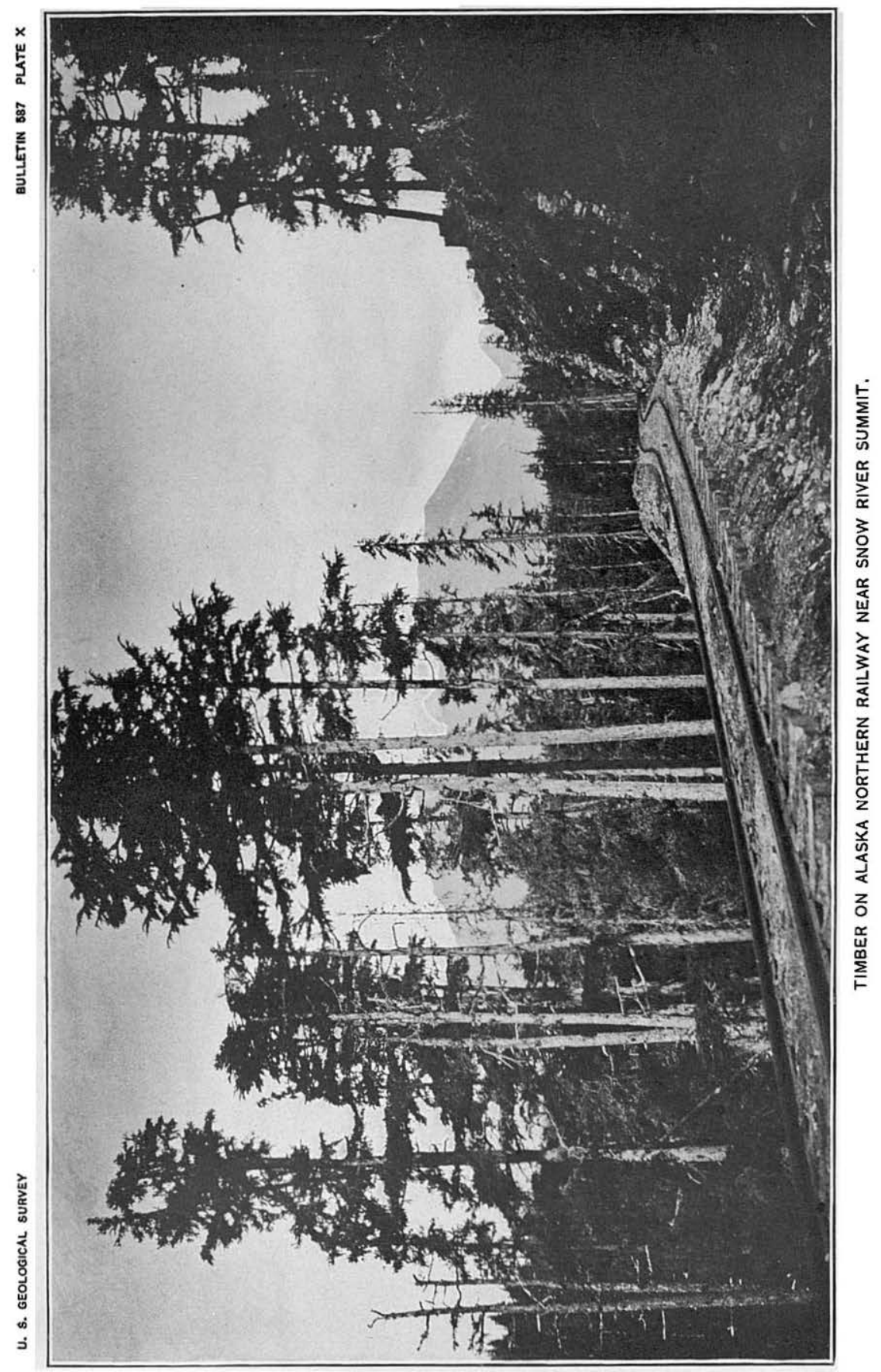



greatly with the melting of the snow and ice, and few, except the larger ones heading in lakes, can be depended on for a constant supply. The abundant precipitation in much of the mountainous district and the steep gradients of many of the streams promise well for small local powers. No large powers seem to be available except on Kenai River and some of its larger tributaries, where, owing to the probable great cost of installation and the probable small local demand, it is unlikely that there will be any development under existing economic conditions. A preliminary report on the water power of the eastern part of Kenai Peninsula, including stream measurements, has been published by the United States Geological Survey, ${ }^{1}$ and a more detailed discussion is being prepared.

Few power plants were in operation in 1911 in the Seward-Sunrise region. The Kenai Alaska Gold Co.'s stamp mill on Falls Creek was operated by a small steam engine with a wood-burning boiler. The California-Alaska Mining Co.'s stamp mill on Falls Creek was run by water power furnished by a Pelton water wheel. The town of Seward was furnished with electric light and power throughout the year by a 225-kilowatt Allis-Chalmers (Bullock) alternating-current generator, driven by a Pelton water wheel operating under an effective head of 360 feet. The local coal resources of this region have hitherto been unavailable. British Columbia (Nanaimo) coal, which is used in Seward, cost in 1911 about $\$ 10$ to $\$ 12$ a ton wholesale and about $\$ 17$ a ton retail.

The steamships of the Alaska Coast Co. and the Alaska Steamship Co. run regularly between Seattle and Seward throughout the year, navigation in Resurrection Bay never being interrupted byice. Seldovia and Port Graham are also regular ports of call throughout the year. Water transportation to ports on upper Cook Inlet, however, is possible only during the summer, for the upper part of the inlet is closed by ice for about five months. During the summer the steamers of the Alaska Coast Co. make regular trips to Knik Anchorage, serving points on upper Cook Inlet directly or by barge from Knik Anchorage, instead of transferring passengers and freight at Seldovia and Port Graham to the smaller boats plying on the inlet, as formerly. Ocean steamers can not enter Turnagain Arm, howover, and small gasoline boats, which can reach the settlements at high tide, must still be used between the ocenn-steamer terminus in Knik Anchorage and Kern Creek, Girdwood, Sunrise, Hope, and other minor ports on the upper part of Cook Inlet.

The Alaska Northern Railway Co. has built 71 miles of standardgage track from Seward (Pl. XIII, p. 36) to Kern Creek, on the north shore of Turnagain Arm. This line is in operation only during the

${ }^{1}$ Ellsworth, C. E., and Davenport, R. W., Preliminary report on a water-power reconnaissance in southcentral Alaska: U.S. Geol. Survey Bull. 592, pp. 180-188, 1914. 
summer and autumn, when gasoline passenger cars are run almost every day. Freight trains are run only occasionally.

Wagon roads have been built from Sunrise to mile 34 on the Alaska Northern Railway, from Hope up Resurrection Creek for several miles, and from Girdwood to the Nutter-Dawson placer camp on Crow Creek. Roads have also been built from the mouths of Bear and Lynx creeks to prospects near their heads. The Alaska Road Commission has cut good trails from Hope to Sunrise and from mile 29 on the Alaska Northern Railway through Moose Pass to Slate Creek. A winter trail extends from the end of the wagon road on Crow Creek by way of Crow Creek Pass and Eagle River to Knik Arm. A trail has also been laid out down Canyon Creek from Moose Pass to the Sunrise road.

In winter most of the supplies are carried by dog teams. In summer pack trains are run at irregular intervals from mile 34 on the Alaska Northern Railway to Hope and Sunrise and from mile 29 through Moose Pass to Mills Creek. The following rates, averaging approximately $\$ 0.0025$ per pound per mile, were charged in 1911:

Freighting charges in Seward-Sunrise region.

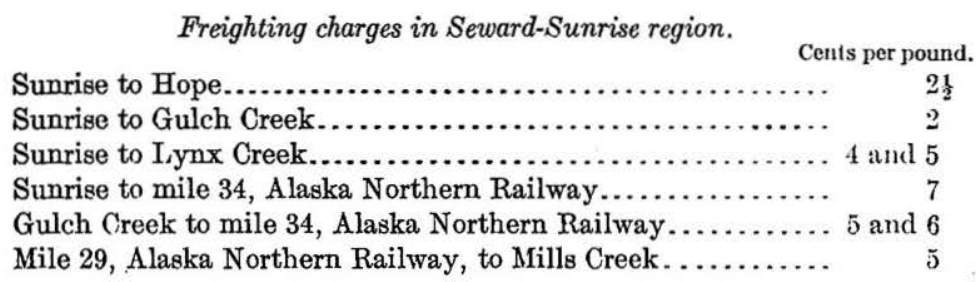

Water transportation on the peninsula is restricted at present to Kenai Lake, where several small gasoline launches are in operation. This lake is reported to freeze over about January 1 and to open up late in May. Kenai and Kasilof rivers are navigable for canoes throughout their courses, and launches can ascend both streams for considerable distances.' (See pp. 24-25.)

\section{GEOLOGY.}

\section{GENERAL FEATURES.}

The mountainous and the lowland districts of Kenai Peninsula are geologically unlike. (See PI. III, in pocket.) The mountains are composed of thoroughly indurated, slightly metamorphosed, and highly folded rocks of Mesozoic or earlier age which, though chiefly of sedimentary origin, include some intrusive masses. The lowlands are composed of slightly indurated and gently folded Tertiary beds. Quaternary deposits occur in both parts of the peninsula, but are much more widespread in the lowlands. The following table shows the general stratigraphic sequence and the correlation of the formations in southern and southwestern Alaska: 


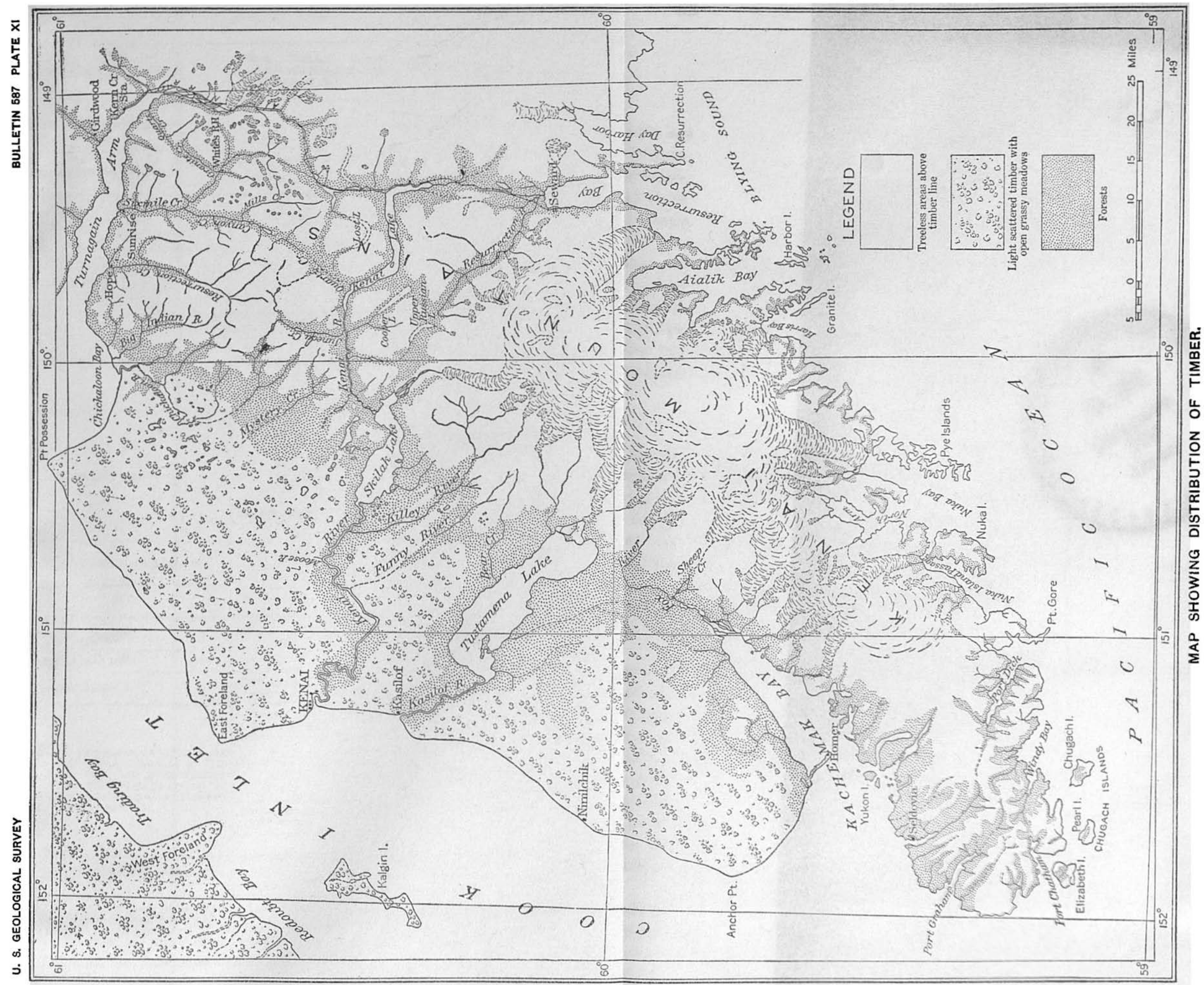


Correlation of formations in southern and southwestern Alaska.

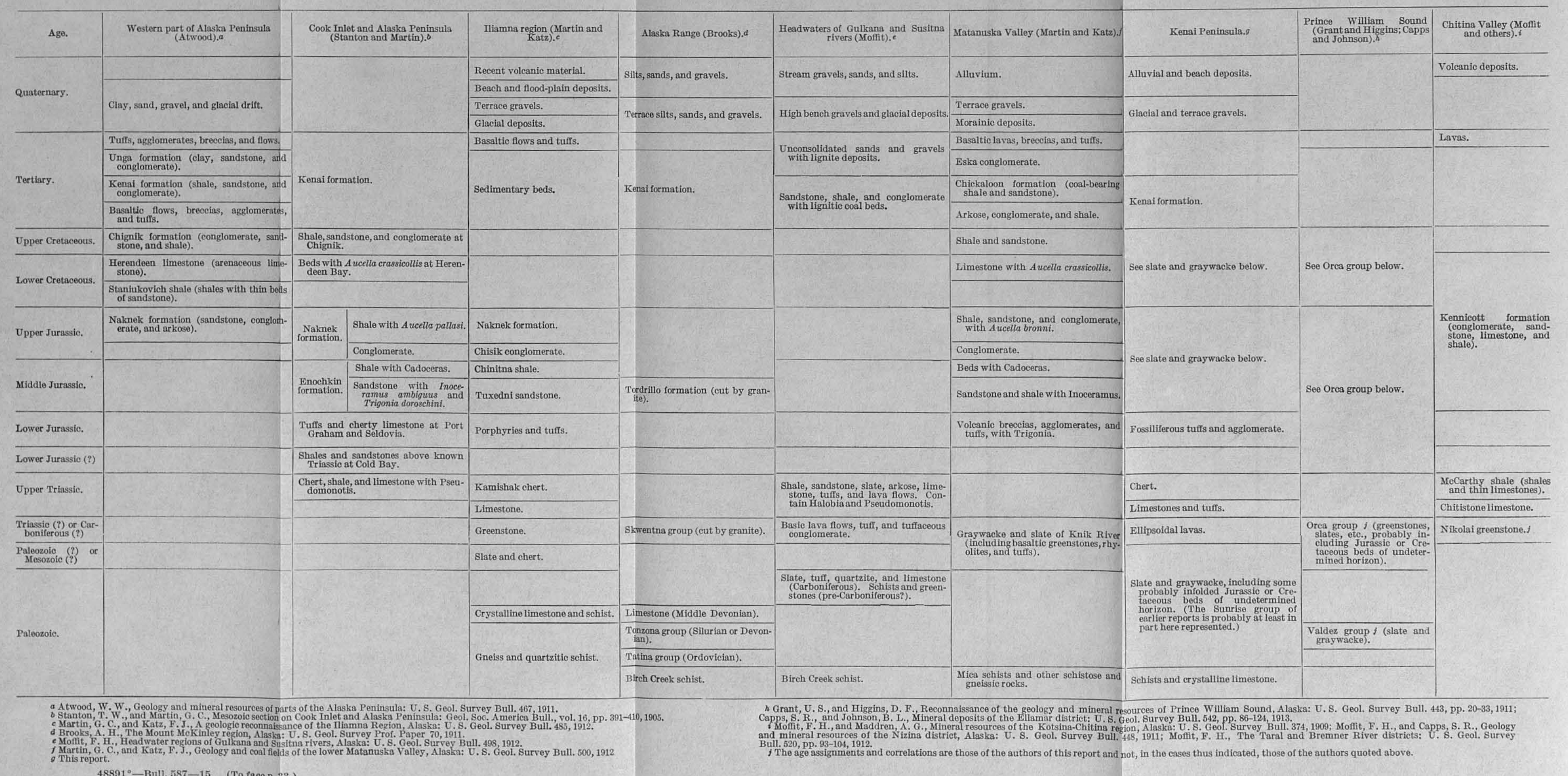




\begin{tabular}{|c|c|}
\hline Age. & 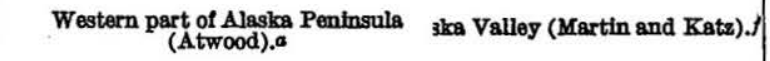 \\
\hline \multirow{4}{*}{ Quaternary. } & im. \\
\hline & \multirow{3}{*}{ Clay, sand, gravel, and glacial drift. } \\
\hline & \\
\hline & \\
\hline \multirow{4}{*}{ Tertiary. } & Tuffs, agglomerates, breccias, and flows, 3 lavas, breccias, and tuffs. \\
\hline & $\begin{array}{l}\text { Unga formation (clay, sandstone, andinglomerate. } \\
\text { conglomerate). }\end{array}$ \\
\hline & $\begin{array}{l}\text { Kenai formation (shale, sandstone, artoon formation (coal-bearing } \\
\text { conglomerate). }\end{array}$ \\
\hline & $\begin{array}{l}\text { Basaltic flows, breccias, agglomerate, conglomerate, and shale. } \\
\text { and tuffs. }\end{array}$ \\
\hline Upper Cretaceous. & $\begin{array}{l}\text { Chignilk formation (conglomerate, santind sandstone. } \\
\text { stone, and shale). }\end{array}$ \\
\hline \multirow{2}{*}{ Lower Cretaceous. } & $\begin{array}{l}\text { Herendeen limestone (arensceous linidone with Aucella crassicollis. } \\
\text { stone). }\end{array}$ \\
\hline & $\begin{array}{l}\text { Staniukovich shale (shales with thin bet } \\
\text { of sandstone). }\end{array}$ \\
\hline \multirow[t]{2}{*}{ Upper Jurassic. } & $\begin{array}{l}\text { Naknek formation (sandstone, conglontsandstone, and conglomerate, } \\
\text { erate, and arkose). }\end{array}$ \\
\hline & merate. \\
\hline \multirow{2}{*}{ Middle Jurassic. } & \multirow{2}{*}{$\because$} \\
\hline & \\
\hline Lower Jurassic. & $\begin{array}{l}\text { ic breccias, agglomerates, and } \\
\text { with Trigonia. }\end{array}$ \\
\hline Lower Jurassic (?) & $=$ \\
\hline Upper Triassic. & \\
\hline $\begin{array}{c}\text { Triassic (?) or Car- } \\
\text { boniferous (?) }\end{array}$ & \multirow{2}{*}{$\begin{array}{l}\text { acke and slate of Knik River } \\
\text {-ding basaltic greenstones, rhy- } \\
\text {, and tuffs). }\end{array}$} \\
\hline $\begin{array}{l}\text { Paleozoic (?) or } \\
\text { Mesozoic (?) }\end{array}$ & \\
\hline \multirow{2}{*}{ Paleozoic. } & \multirow[b]{2}{*}{ s } \\
\hline & \\
\hline $\begin{array}{l}\text { a Atwood, W } \\
\text { b Stanton, T. } \\
\text { c Martin, G. } \\
\text { d Brooks, A. } \\
\text { e Moffit, F. } \\
\text { f Martin, G. } \\
\text { o This report }\end{array}$ & 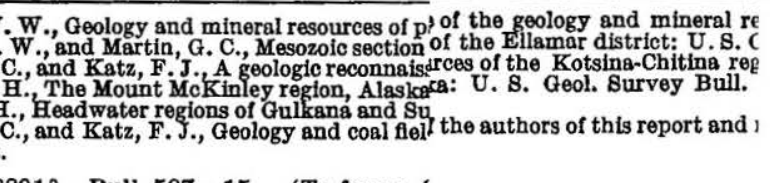 \\
\hline
\end{tabular}

48891 ${ }^{\circ}$-Bull. 587-15. (To face p. $\varepsilon$ 
STRATIGRAPHIC AND IITHOLOGIC FEATURES.

METAMORPHIC ROCKS OF UNCERTAIN AGE.

SCHISTS.

The most highly metamorphosed rocks on Kenai Peninsula are some schists that were observed on Seldovia Bay and Port Graham, including quartzitic sericite schists, quartzite, crystalline limestone, and greenish schists, of probably volcanic origin. The age of these rocks has not yet been firmly established. They are much more altered than the Triassic rocks with which they are associated, and the character of the metamorphism is apparently regional and not local. This greater alteration indicates that the rocks are far older than the less altered Triassic rocks. If, however, this determination is accepted it becomes necessary to assume theories concerning the structure which are so complex that it is desirable to consider the possibility that these rocks are the local metamorphosed equivalents of the Triassic limestones, cherts, and volcanic rocks.

\section{SLATY ROCKS.}

Slates and graywackes compose the greater part of the Kenai Mountains, the only other known rocks they contain being intrusive masses, which are most abundant on the southern and eastern coasts, the greenstones near Resurrection Bay, the volcanic beds interstratified with the slate and graywacke in the western part of the peninsula, and the Mesozoic and other sediments that compose the foothills along the southern shore of Kachemak Bay.

These rocks have been mapped as a unit in the northern and central parts and along the western front of the Kenai Mountains, but on the southern coast of the peninsula Grant has recognized (pp. 211-227) four formations, each composed partly of slates and graywackes, but differing in degree of metamorphism and to some extent in composition. The writer believes that most or all of these formations extend into other parts of the Kenai Mountains where the rocks were mapped as a unit, not because of their lithologic homogeneity, but because the ficld work was not sufficiently detailed to justify the mapping of the subdivisions. The slaty rocks of Kenai Peninsula are not a lithologic unit of uniform stratigraphic character, but constitute a stratigraphic and structural complex containing rocks of moderately diverse lithologic character and probably of widely differing ages.

The slate and graywacke of Seldovia Bay underlie the ellipsoidal basalts, which in turn apparently lie beneath the presumably Upper Triassic cherts (pp. 52-55). They are consequently either Paleozoic or early Triassic. The slates and graywackes in the vicinity of Turnagain $\Lambda \mathrm{rm}$ (pp. 118-119) contain fossils which are apparently $4889 \tau^{\circ}-$ Bull, $587-15-3$ 
either Jurassic or Cretaceous. This locality is within the type district of the. Sunrise group as described by Mendenhall ${ }^{1}$ and by Moffit, ${ }^{2}$ which has been generally regarded as the probable equivalent ${ }^{3}$ of the Valdez group and has been generally assigned ${ }^{4}$ to the Paleozoic. The slaty rocks on the south coast of the peninsula include slates and graywackes consisting of two probably unconformable members (pp. 211-223), occurring from Day Harbor to Nuka Island Passage, regarded by Grant as the equivalent of the Sunrise group; slate and graywacke in relatively small volume associated with greenstones (pp. 225-226), occurring on Day Harbor and the east shore of Resurrection Bay, regarded by Grant as the equivalent of the Orca group of Prince William Sound; slate, graywacke, and conglomerate (p. 227) less altered than the rocks regarded by Grant as equivalent to the Sunrise group, occurring on the forelands from Nuka Island Passage to Chugach Bay; and graywacke and slate, associated with cherts, limestones, and basic igneous rocks (p. 227), occurring on the bays from Nuka Island Passage to Port Chatham, and apparently the direct areal extension of the slate and graywacke of Port Graham and Seldovia Bay (pp. 44-49).

The evidence of the age of these slaty rocks indicates that the type area of the Sunrise group contains beds that are middle or late Mesozoic, possibly as young as Upper Cretaceous, whereas the slates of the southern part of the district are probably Paleozoic, certainly not being younger than Triassic. The data now available afford no grounds for separating these rocks, either cartographically or by description, so that the term Sunrise group can not be used at present for a lesser, aggregate than all the slaty rocks of the Kenai Peninsula. The Sunrise group, in such a usage of the term, therefore doubtless includes beds which are equivalent to the Valdez group of Prince William Sound. The correlation of the Sunrise and Valdez as exact equivalents is, however, of very doubtful validity. As the rocks of the type district of the Sunrise group are probably high rather than low in the stratigraphic sequence of rocks in the Kenai Mountains, and as the Valdez group is generally regarded as including the older rather than the younger slaty rocks of Prince William Sound, it seems probable that if the slates of the Kenai Mountains and of Prince William Sound are in general equivalent, as they are supposed to be, then the rocks of the type area of the Sunrise group on Turnagain Arm and vicinity are probably more nearly equivalent'to the slates

\footnotetext{
1 Mendenhall, W. C., A reconnaissance from Resurrection Bay to the Tanana River, Alaska, in 1898 U. S. Geol. Survey Twentioth Ann. Rept., pt. 7, pp. 305-307, 1900.

2 Moffit, F. H., Gold fields of the Turnagain Arm region: U. S. Geol. Survey Bull. 277, pp. 17-19, 1906.

3 Paige, Sidney, and Knopf, Adolph, Geologic reconnaissance in the Matanuska and Talkectna basins, Alaska: U. S. Geol. Survey Bull. 327, pp. 15-16, 1907.

1 Grant, U. S., and Higgins, D. F., Reconnaissance of the geology and mineral resources of Prince William Sound, Alaska: U. S. Geol. Survey Bull. 443, p. 24, 1911.
} 


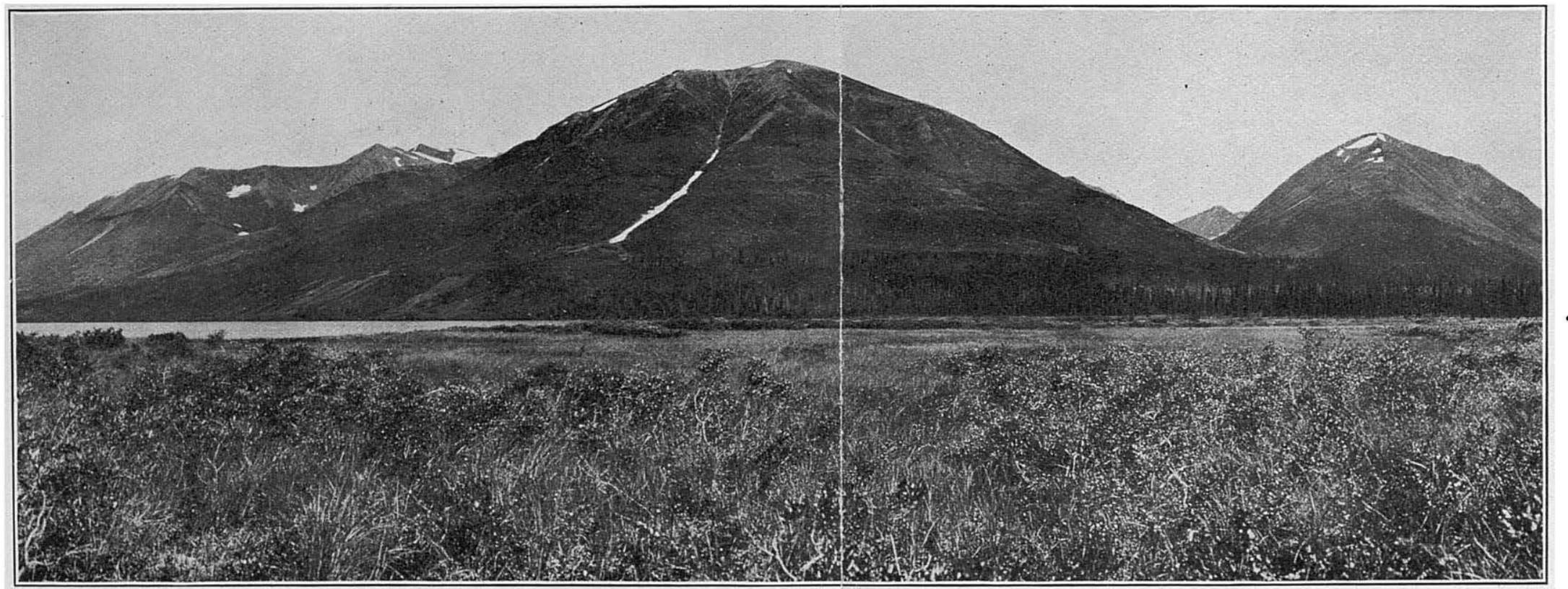

A. GRASS, BUSHES, AND LIGHT TIMBER IN HIGH VALLEY NEAR SUMMIT LAKE.

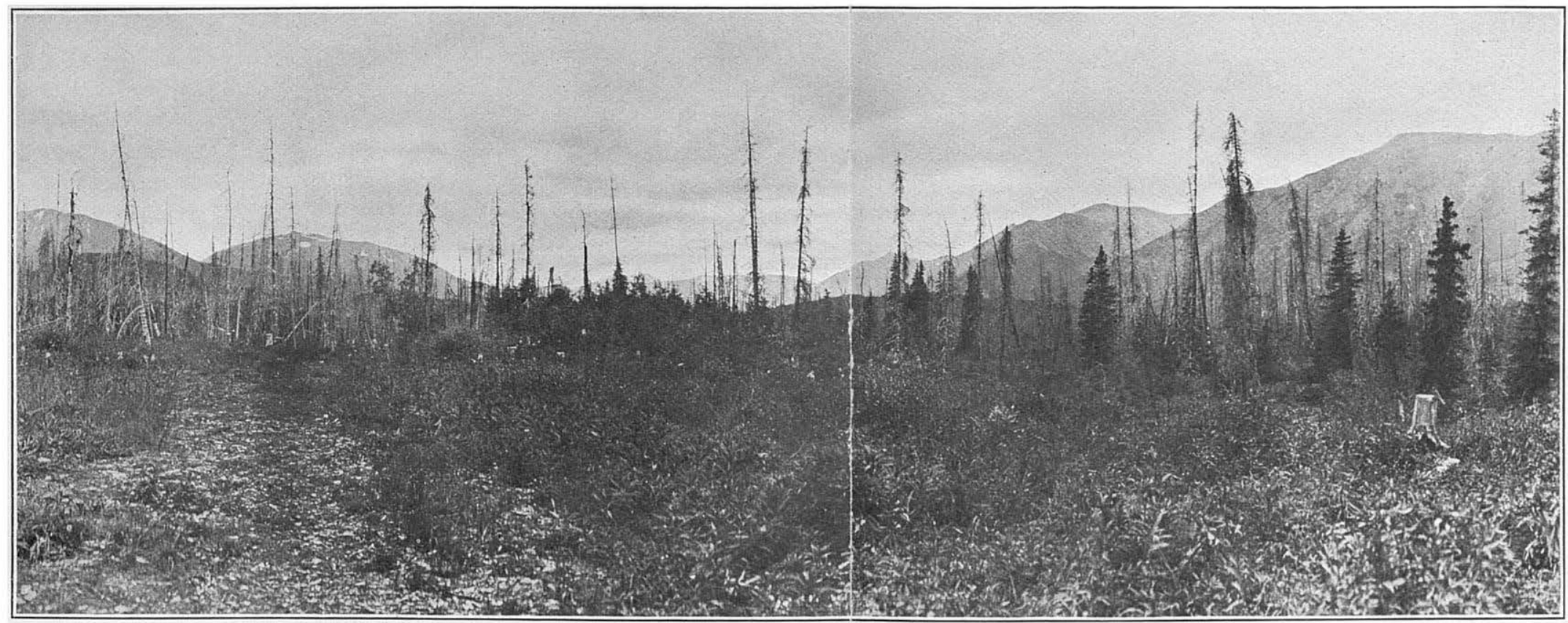

B. LIGHT SCATTERED AND BURNED TIMBER WITH NEW JNDERGROWTH NEAR MOUTH OF JOHN CREEK. 

of the Orca group than to those of the Valdez group. The equivalent of the Valdez group is probably to be sought in the unfossiliferous pre-Triassic slates south of Kachemak Bay or in the more altered lower member of the slates on the coast from Resurrection Bay to Nuka Island rather than in the fossiliferous Jurassic or Cretaceous slates in the vicinity of Turnagain Arm. It should be noted that the fossils which were obtained at Nuka Bay (p. 222), from the upper. member of the slates and graywackes that extend from Resurrection Bay to Nuka Island are identical with the fossils collected by the writer on Kenai Lake (p. 52), and that these fossils occur on Prince William Sound ${ }^{1}$ in the Orca and not in the Valdez group.

TRIASSIC ROCKS.

The only rocks of Kenai Peninsula that are definitely known to be of Triassic age are the fossiliferous limestones and tuffs of Port Graham (pp. 55-59). These beds contain highly characteristic Upper Triassic marine fossils, which fix their stratigraphic position with certainty.

The contorted cherts of the south shore of Kachemak Bay, described on pages 60-63, are also probably of Upper Triassic age.

The ellipsoidal lavas of the same district (pp. 52-55) underlie the cherts and overlie the slate and graywacke on Seldovia Bay. They bear a strong resemblance to the Nikolai greenstone of the Chitina Valley, not only in their general lithologic character but in their stratigraphic relations to the Triassic sedimentary rocks. They probably belong either in the Triassic or in the uppermost Paleozoic. These rocks are in some respects not unlike the ellipsoidal greenstones of Day Harbor and Resurrection Bay (pp. 223-225), and of the Orca group of Prince William Sound, which Grant believes to be equivalent. If ellipsoidal lavas of Seldovia can be correlated with the greenstones of the Orca group the age of part of the Prince William Sound sequence will be more definitely established.

\section{JURASSIC ROCKS.}

The coarse stratified tuffs and agglomerates that occur on the shore of Cook Inlet from Point Bede to Seldovia Bay are the only rocks of certain Jurassic age on the Kenai Peninsula. These beds carry a marine fauna by means of which they have been referred to the Lower Jurassic.

The possible Jurassic age of part of the slates of the Turnagain Arm district has already been discussed (pp. 33-34). 
INTRUSIVE ROOKS.

Intrusive rocks are abundant in various parts of Kenai Peninsula. They are most numerous in the slates and graywackes, but a few were observed in the Triassic and Jurassic rocks. There are none in the Tertiary beds.

The most extensive of the intrusive rocks are the granitic masses, -which are greatest and most abundant in the slates on the southern and eastern coasts. The largest masses occur in the vicinity of Aialik Bay and Pye Islands. An unmapped area of granite occurs at the headwaters of Benjamin Creek, near Skilak Lake.

Small acidic dikes are numerous in all the slaty rocks along the southern shore of the peninsula. They also occur in the slate and graywacke between Kenai Lake and Turnagain Arm and in the Crow Creek district. Small dikes of several kinds cut the slates and the Mesozoic rocks on the south shore of Kachemak Bay.

Masses of peridotite intrude the slate and graywacke at Red Mountain, southeast of Seldovia, and on the north shore of Port Chatham, and diabase and gabbro occur near Point Bede and Grewingk Glacier.

TERTIARY ROCKS.

The only Tertiary beds of Kenai Peninsula are those of the Kenai formation, which is areally restricted to the Kenai lowland and to the southern shore of Kachemak Bay. This formation is about 2,000 feet thick, is composed of slightly consolidated sands and clays with many lignite beds, and is apparently wholly of nonmarine origin. Its fossil plants fix its age as Eocene.

\section{QUATERNARY DEPOSITS.}

The Quaternary daposits of Kenai Peninsula consist of extensive beds of glacial and terrace gravels, which cover practically all the Kenai lowland; of local deposits of high gravels, occurring in the Kenai Mountains; and of the recent alluvial and shore deposits, which are best developed as flood plains on the glacial streams and as deltas in the lake and tidal waters.

The distribution and character of the older gravels show that they were connected in origin with the glaciers that once occupied the region. At the time of maximum glaciation the Kenai Mountains were the site of an extensive system of alpine glaciers. These were largely coalescent and covered most of the mountain area except the higher peaks and ridges, but apparently did not submerge and override the entire mountain mass. The important fact to be noted is that these glaciers behaved as individual alpine glaciers and not as a continental ice mass. Throughout their entire existence their flow was 


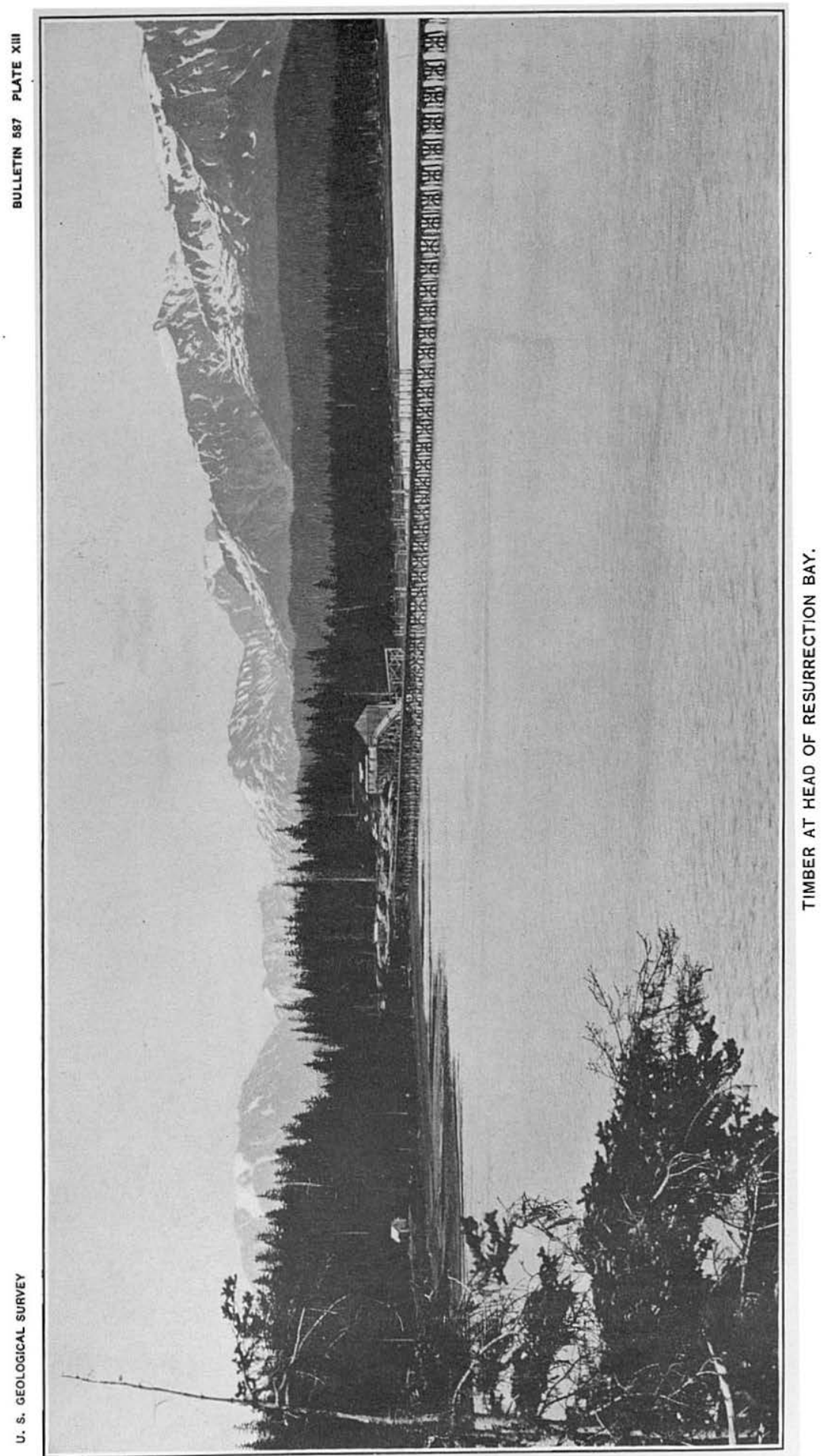




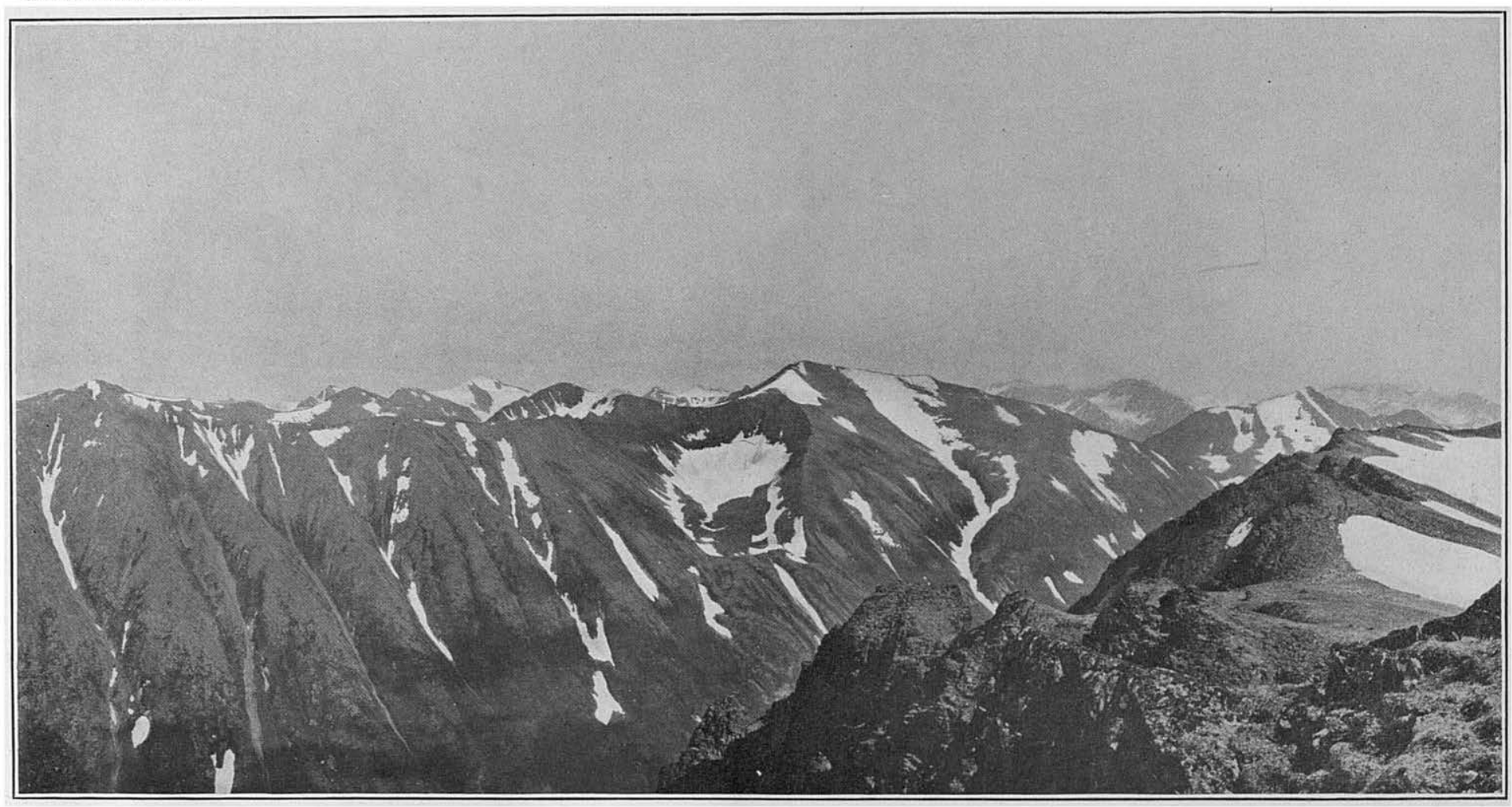

MOUNTAINS NEAR QUARTZ CREEK.

View from peak north of head of John Creek, looking eastward across valley of Quartz Creek. Photograph taken August 8, 1911. 
directed by the valleys in which they originated and their erosive effects (Pl. XTV, p. 37) continued to consist verylargely of bergschrund attack combined with accentuated deepening of the main glacial channels. They etched rather than polished the preglacial land. (Soe Pls. XXVIII and XXIX, pp. 126, 128.) Until the glaciers began to melt away the Kenai Mountains were the site of glacial erosion and not of glacial deposition. During the same period the Cook Inlet basin was occupied by a great valley glacier, fluvial in form, provincial in magnitude. It received tributaries not only from the Kenai Mountains, but from all the mountain masses that now encircle the Cook Inlet-Susitna basin. The main lower stem of this glacial stream lay across the Kenai lowland. It was doubtless a sluggish and heavily waste-laden mass, and deposited a tremendous volume of sediment, so that the Kenai lowland presented a marked contrast to the Kenai Mountains. The lowland was a district of glacial deposition; the mountains a district of glacial erosion. The Quaternary deposits of the Kenai lowland consist of a thick sheet of till interstratified with local beds of water-laid sands and gravels and overlain by a cover of stratified and terraced sands and gravels. The Quaternary deposits of the Kenai Mountains are comparatively insignificant in volume and are closely related in distribution and composition to the local land form and rock character.

\section{STRUCTURE.}

The Kenai Peninsula consists of two very distinct structural provinces, the Kenai Mountains and the Kenai lowland. The Kenai Mountains are structurally complex, the rocks being everywhere closely folded and the argillaceous beds having a slaty cleavage. The Kenai lowland is structurally simple, its characteristic structural features being broad, gentle folds. The structural relations of the rocks along the boundary between these two provinces are not known for the rocks are not there exposed.

The structure shows no distinct regional variation in character within the Kenai Mountains but apparently varies in complexity with the age of the rocks. There is a progressive change from schists that are both highly metamorphosed and closely and intricately flexed (Pl. XXIII, $A$, p. 98), through slaty rocks that show various degrees of metamorphism and of complex folding (Pl. XXIII, $B$, p. 98; Pl. XXIV, $A$, p. 99), Triassic rocks that are sharply folded (Pls. XVI, $A$, and XVII, pp. 52,60) but not metamorphosed, and Jurassic tuffs that are involved only in monoclinal dips and normal faults (Pl. XVI, $B$, p. 52), to Tertiary outliers which, though faulted (fig. 12, p. 104), are nearly horizontal (Pls. XVIII, XIX, XX, XXI) and but poorly indurated. 


\section{GEOLOGIC HISTORY.}

The rocks of Kenai Peninsula contain no legible record of the events of Paleozoic time. The sediments that now form the schists were probably deposited, consolidated, and partly altered before the end of the Paleozoic era, but there is no evidence as to the exact period or the detail of the events. Part of the sediments that formed the slates and graywackes are believed to have been deposited in Paleozoic time, probably late Paleozoic. The character of the graywacke indicates that its constituents were derived from a near-by land mass on which vigorous erosion was in progress, and that granites and quartzites were among the rocks that supplied the detritus. The local absence of the characteristic Paleozoic strata which occur in other parts of Alaska may mean either that these beds were not deposited here or that they were eroded away before the end of the Paleozoic era. The Carboniferous period was a time of widespread limestone-forming seas over most of the present area of Alaska, but the Carboniferous limestones were apparently not preserved in the Kenai Peninsula.

The beginning of Mesozoic time in the area that is now Alaska was marked by wide areas of land and by general volcanic activity. The ellipsoidal lavas of the Kachemak Bay district, probably together with the greenstones of Resurrection Bay, are believed to have been poured out at this time. The seas were widespread during much of Upper Triassic time, when the limestones at Port Graham were laid down. Volcanic activity continued during part of the Upper Triassic, but the volcanic material which then reached this area was tuffaceous detritus rather than lava.

Early Jurassic time was likewise a period of local volcanic activity, coarse tuffs and agglomerates having been deposited at the present west end of Kenai Peninsula.' The presence of marine fossils in these tuffs shows that the sea then extended into this area although most of Alaska was probably land.

There is no local record of the profound and widespread submergence in middle and late Jurassic time. The apparent local absence of rocks that date from this period is puzzling and confusing. There is a great development of marine Middle and Upper Jurassic sediments on the west coast of Cook Inlet and in many other near-by districts. The apparent absence of these beds in Kenai Peninsula may mean that this was a land area at that time, that some peculiar action of post-Jurassic erosion removed all trace of them, or that they are represented in the slaty rocks of the Kenai Mountains. The writer believes that a combination of the second and third hypotheses represents the probable truth. If the Middle and Upper Jurassic shales and sandstones were laid down upon a floor composed of the 
partly folded and possibly partly altered shales and sandstones that now compose the bulk of the slates and graywackes of the Kenai Mountains, if subsequent erosion removed a large part of the Jurassic sediments, and if a renewed period of mountain folding incorporated the residue into the present mass of the Kenai Mountains, the resulting conditions would be closely akin to those that we now recognize.

The intrusion of the granitic masses probably took place in Jurassic time, which is the date of the intrusion of the similar rocks ${ }^{1}$ on the west shore of Cook Inlet, as well as in most other parts of Alaska.

The record of Cretaccous sedimentation is also locally absent. It seems probable that during at least part of Cretaceous time this region stood above the seal, the folding of its rocks had been largely accomplished, and the major features of the present land forms were being outlined by subaerial erosive agents.

$\Lambda$ the beginning of Tertiary time this district, and probably all of Alaska, stood above the sea. The writer believes that the present Cook Inlet depression was then in existence. During Eocene time this depression was being filled by the nonmarine deposits that now constitute the Kenai formation. It is uncertain whether this sedimentation took place in river or in lake waters. The sea was certainly excluded and deposition was probably slow and was accompanied by slow crustal subsidence, aggregating 2,000 feet. Broad swampy surfaces frequently spreal at the general water level, vegetation flourished upon them, and thus the formation of the existing lignite beds was begun. The local climate was warm, possibly being even subtropical, for the plants that grew at localities not far from this include eycads and poilms.

The Miocene submergence which brought part of the present Alaskan coastal belt beneath the sea left no record in the Kenai Peninsula and cook Inlet districts.

$\Lambda$ the end of 'Tertiary time the present mountain belts existed and probably had something like their present form. Subsequent changes were probably more largely erosional than diastrophic and altered the details rather than the bread essential features of the land forms.

The Kenai Mountains, like all the mountains of southern Alaska, were occupied by glaciers in early Quaternary time. It is impossible to affirm the exact date of the maximum glacial extension. It may or may not have been contemporaneous with one of the Pleistocene glaciations of other farts of the world. The fact that much of Alaska has not been reeently glaciated shows that the Pleistocene glaciation was either controlled or modified by causes that were not world-wide. The aclditional fact that on at least part of the Alaskan coast the exist-

\footnotetext{
1 Martin. G. C, and Kat\%, F, J., A geologie reconnaissance of the Hliamna region, Alaska: L. S. Geol. Survey Bull. + si; pp. $7 i-7 i, 1912$.
} 
ing glacial conditions ${ }^{1}$ are little less severe than any of which there is local record suggests that the maximum Alaskan glaciation may have been due to other causes than those which operated in eastern North America and in Europe in Pleistocene time, and that the maximum glaciation in Alaska may not have been contemporaneous with any of the well-recognized Pleistocene glaciations, or may even have been post-Pleistocene.

However this may be, it is certain that the glaciers of the Kenai Peninsula once extended far beyond their present limits. At that time the entire area of the Kenai Mountains was occupied by a system of through glaciers. All the broad, high areas were covered by snow fields such as that which now occupies the area north and west of Aialik Bay. Only isolated ridges and peaks protruded through the ice and snow. The valley glaciers which flowed out from this highland area extended into the present site of Prince William Sound, into a belt now occupied by ocean waters south of the peninsula, and united with an immense valley glacier which came down the Cook Inlet valley. The conditions that existed during the maximum glacial occupation are described in detail elsewhere (pp. 36-37, 94-97). It was during the retreat of the glaciers from their maximum extension that the local land forms received their latest profound alteration. The subsequent erosion has been comparatively slight and has not changed the land forms except in local and insignificant details.

1 Martin, G. C., Geology and mineral resources of the Controller Bay region, Alaska: U. S. Geol. Survey Bull. 335, pp. 50-51, 64-65, 1908. Tarr, R. S., Glaciers and glaciation of Alaska: Science, vol. 35, pp. 257258, 1912. 


\title{
THE WESTERN PART OF KENAI PENINSULA.
}

\author{
By G. C. Martin.
}

\section{INTRODUCTION.}

The area here to be described comprises the Kenai lowland and the .west, front of the Kenai Mountains, including the.valley of Kenai River, portions of the region with which the writer is personally most familiar. Similar accounts of the northern and central parts of the Kenai Mountains and of the southern coast are given later by Mr. Johnson and Mr. Grant.

\section{STRATIGRAPHY.}

\section{METAMORPHIC ROCKS.}

SCHISTS.

DISTRIBUTION.

The most highly. metamorphosed and possibly the oldest rocks known on Kenai Peninsula are schists of several types, which occur in the vicinity of Seldovia Bay and Port Graham. (See Pl. III.) These rocks lie in a narrow belt that crosses Seldovia Bay near its entrance and probably extends continuously across the hills to Port Graham on the northern shore of which the rocks are exposed. The exposures on the east shore of Seldovia Bay extend from Watch Point to the entrance of the bay, a distance of about 2 miles, probably being interrupted at the head of the cove just inside the bay by an area of cherts and lavas.

LITHOLOGY.

The metamorphic rocks of this area constitute a heterogeneous assemblage whose members have little in common except their degree of metamorphism and their intimate structural association. Among the lithologic types are micaceous quartzite, crystalline limestone, and green schists of possibly several kinds.

The rocks that outcrop at Watch Point consist of highly micaceous, somewhat crumpled quartz schist, a banded greenish schistose rock in which the harder (quartzitic) bands have been fractured and drawn out into lens-shaped fragments surrounded by more schistose material.

Red Bluff, about half a mile north of Watch Point, consists of crumpled micaceous quartzite which is richly pyritiferous and in 
places highly iron-stained by the oxidation of the pyrite. This rock extends northward as far as Gray Cliff. At the south end of Red Bluff there is green hornblende schist which contains quartzitic bands and is much contorted. These two associated rocks may be the metamorphosed equivalents of the Triassic cherts and volcanic rocks.

Gray Cliff, which is about three-quarters of a mile north of Watch Point, is composed of crystalline limestone which is gray to white, massive, banded, well crystallized, and fairly pure. The bedding is about vertical, although intricate folding is shown in many minor, closely appressed folds, and the general strike is about N. $30^{\circ} \mathrm{E}$. (mag.). The limestone makes the entire promontory at Gray Cliff.

South of the limestone is green schist whose foliation is parallel to that of the limestone and which contains interbedded bands, 6 to 12 inches thick, of limestone, and also garnetiferous bands. The green schist also contains and passes southeastward into quartzite schist which makes the cliff across the cove to the south. The quartzitic schist is finely laminated and micaceous and contains garnetiferous bands. It is most intricately crumpled, closely appressed isoclinal folds (Pl. XXIII, $A$, p. 98) appearing almost everywhere.

The stratigraphic succession in the bluffs northeast of the limestone exposure in Gray Cliff is a repetition of that between Gray Cliff and Red Bluff. The limestone is succeeded by quartzites and green schists interbanded with thin limestone beds, and these by chloritic schist and quartzite. A specimen of the more quartzitic phase of the green schist at this locality was examined under the microscope and proved to be a horneblende-epidote-albite schist containing feldspar (albite) augen, much larger than the other constituents, which include epidote, hornblende, quartz, sericite, apatite, and calcite.

The exposures are then interrupted by a long stretch of sandy beach, behind which lie lagoons and marshes. The next exposures are at the small point about half a mile northeast of Gray Cliff, which is composed of chert banded with slaty material and of a sheared breccia consisting of hard brecciated bands with intervening soft bands showing flowage. This breccia resembles a conglomerate with a schistose matrix. These rocks are apparently intruded by a green rock which is massive, fairly well crystallized, shows no sign of bedding, weathers green with white specks like an even-grained igneous rock, and apparently contains inclusions of chert. It cuts across the chert bands and the schistosity at several places in a way that suggests intrusion, but the contacts may be faults. The chert is much contorted and fractured, the thin intervening shale bands being schistose. There is no sericitic development as in the quartzite at Red Bluff, which may also be a metamorphosed chert. 
About a third of a mile farther north (half a mile south of Seldovia Point) the cliffs for about 200 feet contain exposures of contorted banded chert, which is locally iron stained. These are followed, after a rather sharp contact of indeterminate character, by green schist like that at Watch Point and near Gray Cliff. This mass of schist includes a 10-foot bed of gray crystalline limestone like that at Gray Cliff. The contacts of the limestone with the schist on each side of it are parallel to each other and to the foliation of both the schist and the limestone.

A specimen (No. 78) from a locality near the limestone just described was determined under the microscope as a glaucophane epidote schist, which is apparently the product of the metamorphism of basic igneous rocks or sedimentary rocks of similar composition. The presence of glaucophane indicates a high soda content of the original rock.

The schist extends northward along the shore to Seldovia Point, at which locality a specimen (11 Mn 79) was taken which, when examined under the microscope, proved to be a quartz-mica schist, composed of quartz, sericite, and green biotite, and containing veinlets of crystalline quartz which are coarser than the quartz in the body of the rock and of later origin than the mica.

The cliffs from Seldovia Point eastward present good exposures of quartzite with some sericite schist, standing about vertical and striking N. $25^{\circ}-40^{\circ} \mathrm{E}$. (mag.). Only about 25 feet of the thickness of the quartzite is exposed, as the contact with the green schist lies parallel to the cliff face. A green, thoroughly crystalline but not schistose rock, which somewhat resembles the green schist, lies on the outer side of the belt of quartzite. The observed field relations suggest an intrusive rather than a fault contact between this rock and the quartzite.

The schists were observed at several places on the south shore of Seldovia Bay, where outcrops of quartzite and green schist were seen. Numerous large bowlders of crystalline limestone were found at the north end of the schist belt, but this rock was not found in place. The exposures are not as continuous here as on the east shore of the bay and the relations of the various kinds of rock to each other could not be determined. The contacts of these rocks with the Jurassic tuffs that lie north of the schists and with the cherts south of them were not observed.

These schistose rocks are exposed on Port Graham in a single outcrop on the north shore, about $2 \frac{1}{4}$ miles below the head of the bay. The rock is a highly micaceous quartzite of somewhat coarser grain than any seen on Seldovia Bay. The contacts with the neighboring Triassic rocks are not exposed. 


\section{AGE AND CORRELATION.}

No direct evidence of the age of these rocks has been obtained. They are so much more metamorphosed than any of the rocks with which they are in contact and evidence of any metamorphic gradation into the surrounding rocks is so entirely lacking that they seem to be far older than these neighboring rocks, which include not only the fossiliferous Lower Jurassic and Upper Triassic formations but the still older cherts and lavas. The schists are also far more meta_ morphosed than the slates and graywackes at the head of Seldovia Bay and of Port Graham. The degree of metamorphism therefore indicates that they probably lie well down in the Paleozoic.

The possibility that these rocks are the locally metamorphosed representatives of the Triassic limestone and the probably Triassic chert and lava must be considered. The evidence in favor of this interpretation is that these schists include such types, and only such types, as would be produced by the metamorphism of these neighboring rocks, and the simplest theory of the local structure is that which is based on this interpretation. The evidence against this interpretation is that the schists are of the sort that would be produced by regional rather than by local metamorphism, and that neither the agents nor the gradation phases of local metamorphism have been recognized. It is consequently safest to conclude that these schists are probably Paleozoic, but this conclusion is purely tentative.

These rocks strongly resemble some of the quartzites and crystalline limestones and associated schistose greenstones of Lake Clark ${ }^{1}$ and also some quartzitic and ferromagnesian schists and crystalline limestone on the northwest shore of Kodiak Island, just southwest of Uyak. The rocks on Kodiak Island ${ }^{2}$ are not only lithologically similar to those at Seldovia but have similar geographic relations to a belt of slates and graywackes which presumably should be correlated with those of the Kenai Peninsula, and are also associated with presumably Triassic cherts and lavas.

\section{SLATES AND GRAYWACKES OF THE KACHEMAK BAY DISTRICT.}

\section{DISTRIBUTION.}

The mountains of the western end of Kenai Peninsula are apparently made up very largely of slates and graywackes. These rocks were observed at the heads of Port Graham and of Seldovia Bay, on Jakolof and Tutka bays and Sadie Cove, and in the hills back of Aurora. The exposures seen at these points are believed to be all part of one general and continuous belt (see Pl. III), the northwest

\footnotetext{
1 Martin, G. C., and Katz, F. J., A geologic reconnaissance of the Hiamna region, Alaska: U. S. Geol. Survey Bull. 485 , pp. $31,33,40,1912$.

2 Martin, G. C., The mineral deposits of Kodiak and the neighboring islands: U. S. Geol. Survey Bull. 542, p. 128, 1913.
} 
boundary of which runs parallel to the general direction of the south shore of Kachemak Bay, and which covers a tract of undetermined dimensions in the west end of Kenai Peninsula. It is believed to be a part of the area of slates and graywackes described by Mr. Grant on page 227 .

STRATIGRAPHY AND IITHOLOGY.

These rocks are well exposed on the east shore and near the head of Seldovia Bay where, beneath the possibly Triassic scoriaceous and ellipsoidal lavas, which are described on pages 52-55, the following section was measured:

\section{Section of slaty rocks on east shore of Seldovia Bay.}

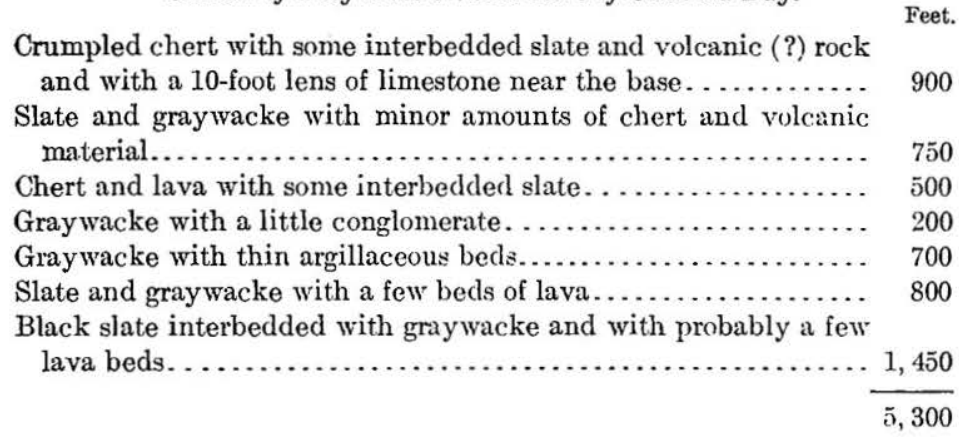

The lower 1,450 feet of the section is composed chiefly of massive green to gray fine-grained rock interbedded with black slate. Some of the interbanding is on a fine scale and is gradational, and the massive beds that are thus banded seem in all other respects like the rock in which the banding is not so apparent. The series appears to be essentially sedimentary, although it may include tuffaceous material. The gray-greenish rock resembles some of the lavas on the other shore of the bay (locality 30) but is markedly different in the weathered surface, as it breaks into angular blocks and does not show the rounded or ellipsoidal forms of the other. Possibly some of this rock is volcanic.

The slates and associated beds forming the next 800 feet of the section are interstratified with several chert beds. The graywacke members contain small elongated fragments of black slate.

The graywacke and slate, 700 feet thick, lying next above, consist of 2-foot beds of massive graywacke interstratified with thin beds of black slate. This graywacke contains small slate fragments and is otherwise similar to that described lower in the section. There are no reasons for believing that any of its constituents are tuffaceous. A thin section of the graywacke (11 Mn 104) examined under the microscope showed the presence of quart\% grains, some of them rounded and some angular. The remaining constituents are completely altered to muscovite and other secondary products. The 
upper beds are in general thinner and contain a larger proportion of beds of slate.

The graywacke and conglomerate, which come next higher in the section and aggregate 200 feet in thickness, contain beds more massive than those just below and possibly contain tuffaceous material.

The exposures of this formation on the west shore of Seldovia Bay are less complete than those on the east shore but reveal substantially the same sequence. They include fine-grained graywacke interstratified with thin beds of black slaty rock, a green, dense schistose rock which is similar in character to the younger (Triassic ?) lavas except in schistosity, and interstratified chert and slate. The exposures are not so complete as on the east shore of the bay, and the stratigraphic relation of the several outcrops was not determined.

The exposures on both shores of Port Graham for about $1 \frac{1}{4}$ miles from the head of the bay consist of rocks that probably all constitute one series of alternating volcanic beds, slates, graywackes, and cherts, the latter probably including a considerable amount of impure cherty limestone in thin and possibly local beds. (See fig. 4, p. 100.) Calcite veins are abundant on the fracture planes in the rocks of each kind. These rocks stand at high angles but appear to have a general northwestward dip. It is probably safe to assume that the older members of the series are those nearest the head of the bay, but the possibility of overturns and local structural repetitions must be borne in mind.

Slate and graywacke, with a subordinate amount of chert, predominate from the head of the bay to a point on the south shore about half a mile below the mouth of the river. At this point volcanic rocks occur, apparently overlying the slates, graywackes, and cherts, but constituting a member of the same general assemblage with them. These volcanic rocks seem considerably altered, most exposures being of greenish rock which is much shattered, and slickensided on irregular faces. The rock breaks up into very irregular masses and small chips and powder. No trace of bedding or flow structure is discernible in most places, although what is regarded as probably flow structure appears plainly on some of the weathered surfaces. A highly characteristic mottling shows on fresh fractures at many places, the rock apparently having been shattered into a multitude of minute light-green fragments, between which and through which run dark reticulating narrow bands, most of them only narrow cracks, though some are an eighth of an inch or more wide. These rocks extend for about 150 feet along the shore, in which distance the greenish volcanics predominate, although cherts that have indeterminate relations to them were also seen. They are then succeeded, farther northwest along the shore, by slate and graywacke, the slates standing at a high angle and apparently overlying the volcanic rocks. These beds extend along the shore as far as the cove about a mile 


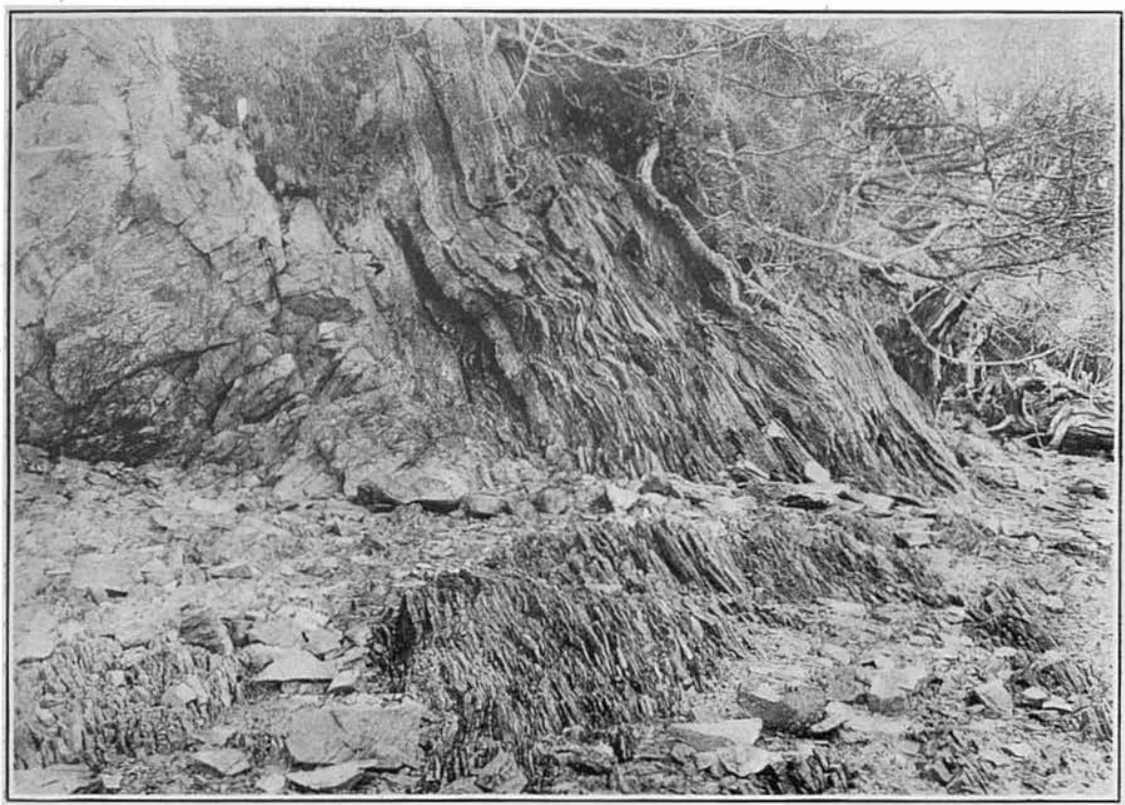

A. CHERTY SLATE CUT BY DIKE OF HORNBLENDE ANDESITE PORPHYRY ON SOUTH SHORE OF PORT GRAHAM.

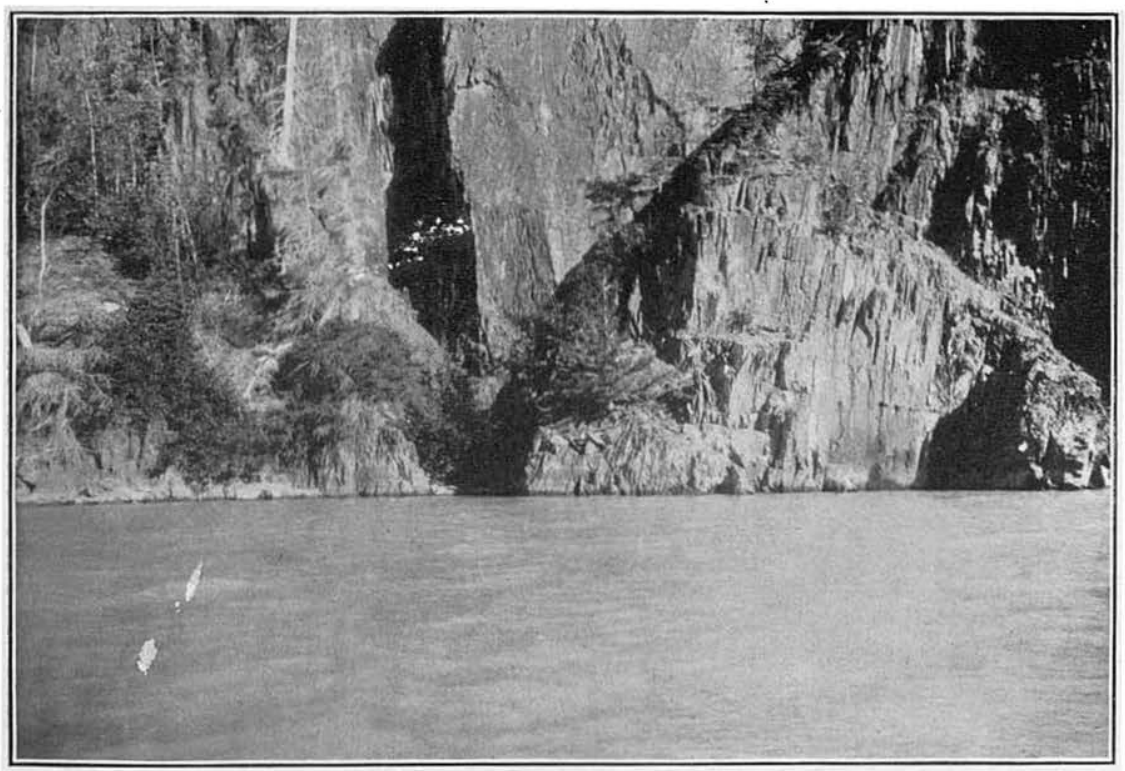

B. Closely folded SLATE ON WEST SHoRE OF KENAI LAKE. 

and a quarter below the head of the bay and include (PI. XV; $A$ ), in addition to the dominant slate and graywacke, a considerable volume of cherty beds. They are limited on the northwest by a mass of presumably much younger lavas, which will be described later (see p. 53). The character of the local contact of the slaty rocks with the lavas was not determined.

The exposures on the northeast shore of Port Graham show massive graywacke at the head of the bay. Greenish volcanic rocks and cherts occur on the small islands and neighboring peninsulas and are suggestive of the Triassic lavas and cherts rather than of the volcanic rocks and cherts seen on the southwest shore of the bay. Farther north there is more graywacke, which is a tough, light olive-green rock interbanded with layers of black slaty material. Most of these slaty layers are very thin, but a few noted are 1 inch or 2 inches thick. Curved bedding is a rather characteristic feature of these slaty rocks.

It should be noted that these rocks and those on the opposite side of the bay (Pl. XV, $A$ ) are intruded by hornblende andesite porphyry. Dikes were not observed in the younger rocks of this district.

These rocks are exposed also on Jakolof Bay. The lower beds, which are exposed at the head of the bay, are mostly of graywacke and slate. Chert becomes more and more abundant upward in the sequence until at the mouth of the bay and on the neighboring shore of Kahsitnah Bay it dominates over the graywacke and slate. The exposures near the mouth of the bay contain some fine-grained volcanic material. The cliffs just east of the mouth of the bay are composed of massively bedded graywacke and some conglomerate. The rocks in this vicinity are cut by dikes.

The chert in this section differs from the presumably Triassic chert described on pages $60-63$ in being interstratified with slate and graywacke and in being more altered. These older cherts are not merely crumpled and contorted, like the younger cherts, but are crushed, sheared, and thoroughly shattered.

The southeast end of Yukon Island contains a small area of the older mashed cherty and volcanic beds which should not be confused with the less-altered and younger cherts and lavas which make up the rest of the island.

Most of the rocks at the head of Tutka Bay consist of very massive graywacke. A specimen (11 Mn 155) from 1.4 miles below the head of the bay on the west shore was examined under the microscope and found to consist of angular fragments of quartz, orthoclase, acidic andesine, chert, quartzite, glassy igneous material, and magnetite. It contains also secondary muscovite, epidote, and calcite. Slate and chert occur on the lower shores of the bay, but the chert does 
not appear in great amount except near the entrance. The bedding is obscure, both on account of the massive character of the beds and because of the deformation. There is some uncertainty regarding which is the upper and which the lower part of the sequence. Presumably the rocks at the head of the bay are the older.

The rocks on Sadie Cove include massive graywacke above the bend, and cherts, slates, and volcanic beds below it. Porphyritic dikes, the largest 200 feet wide, were noted. The general dip appears to be down the bay, which accords with the apparent general structure of the entire district. Close examination of an exposure on the east shore near the head of the bay reveals an actual local southeast dip where the apparent dip is to the northwest. (See fig. 5, p. 101.) The conditions at this exposure are described in detail in the discussion on structure (p. 101) and are here referred to only in connection with their bearing on the question of the relative ages of the members of the formation.

The rocks exposed along the mountain front from Grewingk Glacier to Aurora include graywacke, chert, and igneous rocks of several kinds.

At the north end of the front of Grewingk Glacier a sheared Dasic igneous, probably intrusive rock is exposed. The river coming from Grewingk Glacier breaks through a low ridge in a narrow canyon in which are exposures of graywacke and chert. The rocks exposed on the bay south of Aurora are mostly igneous, including both sheared basic rocks and several kinds of light-colored dikes. Some chert is present, but it is decidedly subordinate in amount.

The canyon southeast of Aurora contains exposures of steeply dipping graywacke cut by porphyritic dikes.

The rocks at the head of Bear Cove are dark fine-grained massive rocks, in which no bedding could be recognized and which are probably chiefly igneous, although they may include some graywacke. The rocks on the lower part of the bay are contorted cherts and associated volcanics. They probably belong to the Triassic (?) cherts, but they may belong in the older cherty series. These cherts extend northwestward along the coast as far as the delta of the glacial river next above Bear Cove. Some graywacke occurs in the eastern exposures, which suggests that the cherts may be those of the slate and graywacke series.

The rocks exposed in the cliffs for about a quarter of a mile southwest of the edge of the mud flats above Halibut Cove are graywacke and chert. The graywacke ranges from fine grained to conglomeratic and has no discernible bedding. Veins in the graywacke are much contorted and fractured. The banded chert has in places been fractured and drawn out until it looks like a conglomerate of chert pebbles. 
AGE AND CORRELATION.

There is no direct and positive evidence as to the age of these slates and graywackes. The exposures on Seldovia Bay, described on pages 45,53 , and 55 , indicate that the slates and graywackes underlie the ellipsoidal basalt, which is apparently beneath the presumably Upper Triassic cherts. This evidence suggests that the age of the slates is either Paleozoic or early Triassic, probably the former.

On the other hand, the slates and graywackes of Kachemak Bay and vicinity are lithologically very similar to the slates and graywackes of Kenai Lake and of the district north of Turnagain Arm, which have yielded fossils. The fossils from Kenai Lake (see p. 52) are identical in character with some of those from Kodiak Island, the Orca group of Prince William Sound, and the Yakutat group of Yakutat Bay, which have been assigned ${ }^{1}$ to the Lower Jurassic. The fossils from localities north of Turnagain Arm (see p. 118) are apparently either Jurassic or Cretaceous, possibly. as young as Upper Cretaceous. The lithologic similarity of the slates at the north and south ends of Kenai Peninsula makes it easy to believe that they are of the same age, yet it is impossible to believe that the slates at the head of Seldovia Bay and Port Graham are younger than the much less altered Upper Triassic and Lower Jurassic rocks, which they apparently underlio and with which they are practically in contact.

The only safe conclusion therefore is that if the slates at the north end of Kenai Peninsula are Jurassic or Cretaceous, as the fossils seem to indicate, they are not identical with the slates at the south end of the peninsula. The slates and graywackes of Kenai Peninsula should accordingly not be regarded as a stratigraphic unit but as constituting an undifferentiated complex containing rocks of fairly uniform lithologic character but of widely differing ages.

The slates and grnywackes of Prince William Sound have been divided into two groups, the younger or Orca group being possibly Mesozoic and the older or Valdez group being probably Paleozoic. The siate and graywacke of the northern and central parts of Kenai Peninsula have been named the Sunriso group, which has been generally regarded as the equivalent of the Valdez group. The writer believes that if the Sunrise group is to include all the slaty rocks of Kenai Peninsula, it must be regarded as the equivalent of the combined Orea and Valdez. The rocks of the type area of the Sunrise group on Turnagain $\Lambda \mathrm{rm}$ and vicinity are probably more nearly equivalent to the Orca than to the Valdez, but the equivalents of the Valdez rocks should be sought in the unfossiliferous pre-Triassic slates south of Kachemak Bay rather than in the fossiliferous Jurassic or Cretaceous slates in the vicinity of Turnagain Arm.

1 Tlrich, E. O., Fossils and age of the Yakutat formation: Alaska, vol. 4, pp. 125-146, 1Jarriman Alaska Expedition, 1904.

$48 S 91^{\circ}-$ К 


\section{SLATES AND GRAYWACKES OF THE KENAI VALLEY.}

DISTRIBUTION.

Slatẻ and graywacke with associated cherty and igneous beds are the only consolidated rocks that the writer has seen in place in the Kenai Valley, and are believed to be the only rocks in the valley above Caribou Islands in Skilak Lake. They probably constitute the entire mass of this part of the Kenai Mountains (see Pl. III), except on the headwaters of Killey River, where there are granitic rocks and limestone.

These slates and graywackes are probably areally continuous with rocks of similar lithologic character which extend throughout the west front and the greater part of the area of the Kenai Mountains.

\section{LITHOLOGY.}

The rocks observed by the writer along the west front of the Kenai Mountains near Tustumena and Skilak lakes consist of graywacke and a subordinate amount of slate. These rocks are regarded as an undifferentiated complex, possibly equivalent to part of the rocks on the south shore of Kachemak Bay, already described, and probably identical with at least part of the similar slates and graywackes that make up the larger portion of the central and northern parts of the Kenai Mountains.

The westernmost exposures on the south shore of Skilak Lake include massive graywacke that exhibits very little trace of bedding. Some exposures show abundant angular and subrounded fragments of dark material, probably chert. Other exposures contain beds of chert very much like that of the older cherty rocks at the heads of Port Graham and Seldovia Bay. These chert beds are individually lenticular, probably as the result of the folding and squeezing which they have undergone. The largest individual beds are 2 or 3 inches thick, and few are continuous for more than a foot or two along the bedding. The dip is steep, being in most places almost vertical, and the beds are not contorted, probably because the folding has passed beyond that stage. Rocks of this general character extend from the westernmost exposures as far east as the mouth of Cottonwood Creek. A few thin beds of limestone were observed, the thickest measuring about 18 inches. Between Cottonwood Creek and the mouth of the stream draining Skilak Glacier the rocks are chiefly massive graywacke, although thin-bedded and slaty graywacke were also seen. One outcrop is of a rock of conglomeratic aspect, which was regarded as possibly a disjointed chert. Graywacke also forms the hills at the head of Cottonwood Creek.

The rocks that outcrop on the north shore of the lake from the valley of upper Kenai River westward to the limit of the high hills, consist chiefly of graywacke and slate but include also some appar- 
ently igneous red and green rocks, which are intimately but obscurely associated with the graywacke and slate.

The rocks on the east shore of the lake between the valley of upper Kenai River and that of the stream draining Skilak Glacier include some finely laminated gray slate and some masses that seem to be igneous, in addition to slaty graywacke like that seen on the north shore. In one exposure the slate appeared to underlie the graywacke, but this relation can not be regarded as fully established because of the difficulty of recognizing the true bedding and because of the possibility that the beds are inverted. A 10-foot dike of porphyry was intruded parallel to the cleavage (bedding?) of the slate.

A specimen of graywacke (11 Mn 298) from the east shore of Tustumena Lake was examined under the microscope and found to consist of angular fragments of quartz and chert, much altered fragments of basic plagioclase, and secondary quartz, calcite, and pyrite.

Exposures on Kenai River between Kenai and Skilak lakes are mostly confined to the canyons 2 to 5 miles above Skilak Lake. The rock in the lower canyon is graywacke, that at the second canyon is graywacke and some conglomerate, and that in the fourth and fifth canyons is slate. The few scattered outcrops between these canyons and the mouth of Russian River and the exposures on Russian River are of graywacke.

The rocks on Kenai Lake consist entirely of slate and graywacke. Those exposed at the lower end of the lake, below Porcupine Island, are thinly interbedded graywacke and slate in about equal amounts. A belt of massive graywacke, trending northeast and southwest and about three-quarters of a mile wide, crosses the lake near Porcupine Island. A similar belt of about the same width, trending north and south, crosses the lake about 3 miles farther east. The rocks between these two belts of graywacke are slate (Pl. XV, $B, \mathrm{p} .46)$ and some thin-bedded graywacke. Another belt of massive graywacke crosses the lake just west of the valley of Trail Creek and forms the hills west of Trail Lakes and of the southern arm of Kenai Lake. The rocks on either side of this belt of graywacke are slates.

There is no evidence as to whether the rocks on Kenai Lake are in anything like the original stratigraphic sequence. The three parallel belts of graywacke may represent three stratigraphic horizons or they may be repeated by folding or faulting. They show no distinctive lithologic fentures and their structure is so complex and obscure that it is not possible to determine whether the beds may or may not be structurally repeated; nor is there any evidence as to which are the lower and which the higher beds.

An outcrop on the north shore of Kenai Lake near the outlet consists of evenly bedled slaty rocks containing a large proportion 
of siliceous bands, the largest 2 inches thick. (Pl. XXIV, $B$, p. 99). The siliceous beds (11 Mn 359) consist of strained quartz, sericite, and carbonaceous material. A few grains of acidic plagioclase twinned according to the albite law were noted. The finer-grained beds (11 Mn 359a) between the siliceous layers contain quartz and muscovite, the grains having a maximum diameter of 0.015 millimeter, in a matrix of argillaceous and carbonaceous material. Cleavage is well developed in the argillaceous but not in the siliceous beds.

\section{AGE AND CORRELATION.}

The only fossils that have been found in the slaty rocks of the Kenai Valley were collected by the writer on the shore of Kenai Lake. The following discussion of their identity and age has been furnished by T. W. Stanton:

Lot No. 7240. Sunrise group, south shore of Kenai Lake, N. $42^{\circ}$ W. of outer end of Porcupine Island.

This lot contains slender tuoes which seem to be referable to the worm Terebellina palachei Ulrich, which is known only in the Yakutat group, supposed to be of Jurassic age, though its position in the Alaskan section has not been definitely determined.

It should be noted that this fossil is identical with that collected by Grant from the slates at Nuka Bay. (See p. 222.) The question of the age of these slates relative to that of the probably pre-Triassic slates on the south shore of Kachemak Bay has been discussed on page 49.

\section{TRIASSIC (P) ROCKS.}

\section{ELLIPSOIDAL LAVAS.}

DISTRIBUTION.

Ellipsoidal lavas are widely distributed along the shores of Kenai Peninsula that border on Kachemak Bay and Cook Inlet. Exposures are abundant along a probably discontinuous series of belts extending from Port Graham at least as far northeastward as Aurora, the best exposures being on Port Graham, Seldovia Bay, Hesketh and Yukon islands, and Halibut Cove. Only the larger areas are represented on the map (Pl. III), but many smaller areas are included in the contorted cherts, with which these rocks are very intimately associated.

\section{LITHOLOGY.}

These beds consist predominantly of green scoriaceous and ellipsoidal lavas. (See Pl. XVI, A.) At a few places, notably on Hesketh and Yukon islands, their color is dark red rather than green. They include tuffaceous beds, but only in small volume. The exposures on the east shore of Seldovia Bay indicate a thickness of approximately 3,000 feet, assuming no repetition by faulting.

The lavas are exposed on the south shore of Port Graham about $1 \frac{1}{2}$ miles above the wharf (see fig. 4, p. 100), where they consist of fine- 


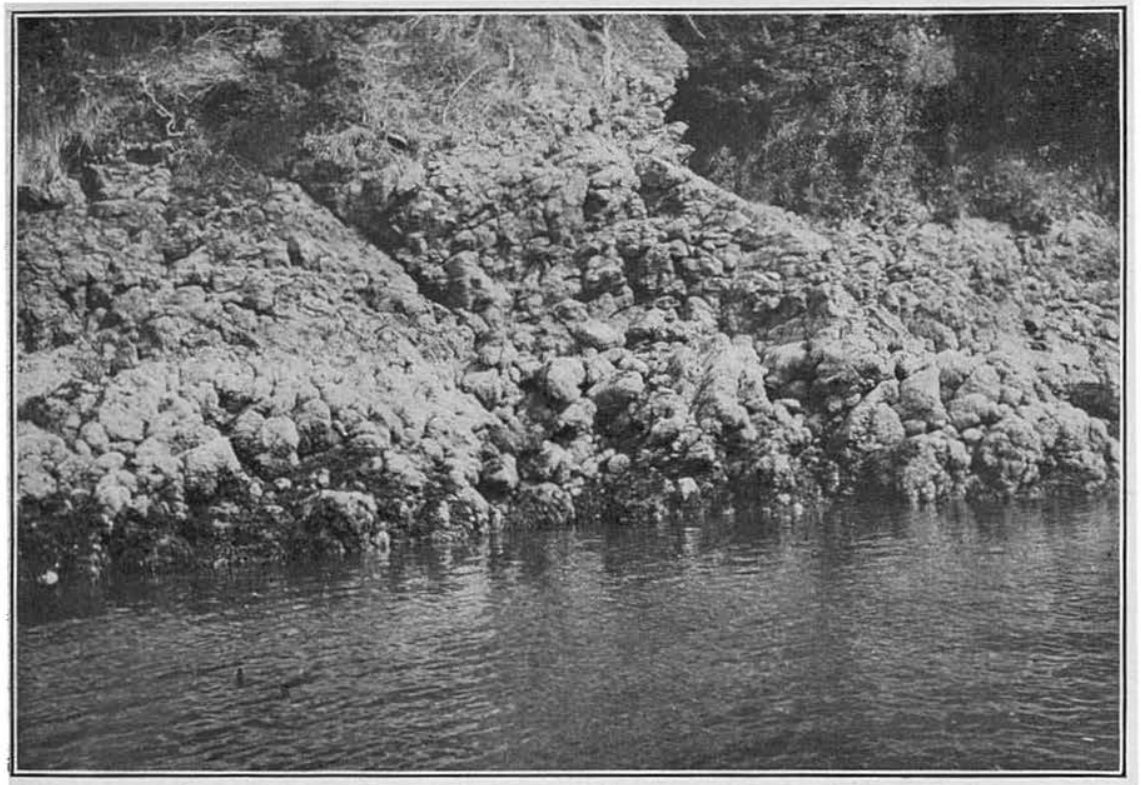

A. ELLIPSOIDAL LAVA ON EAST SHORE OF SELDOVIA BAY.

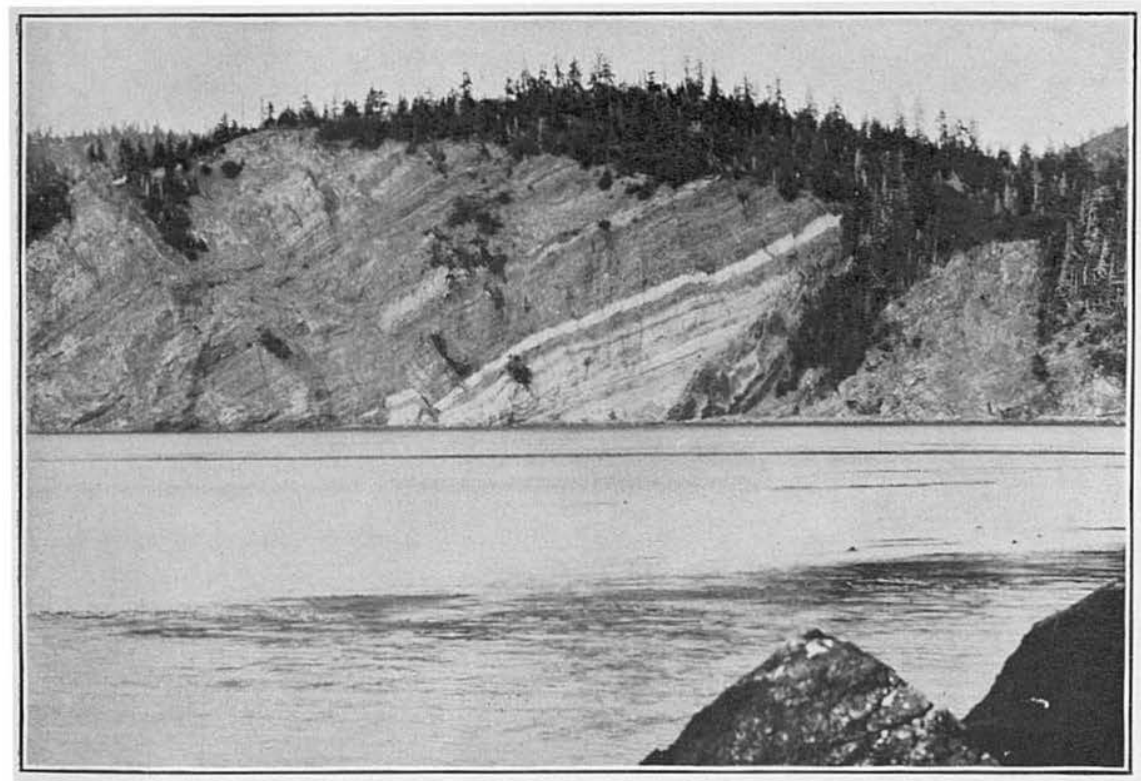

B. LOWER JURASSIC TUFFS ON NORTH SHORE OF PORT GRAHAM.

Note smal! normal fault at lower end of white stratum. 

grained red and green rocks lying west of the slates and graywackes (which they probably overlie), and east of and presumably beneath a mass of cherts. The contacts with the adjacent rocks are not exposed.

The cliffs on the north shore of Port Graham from a point $1 \frac{1}{2}$ miles to a point 2 miles below the head of the bay are composed of red and green basalt. Ellipsoidal structure and flow surfaces are well developed. Several masses of chert, each 40 or 50 feet thick, occur within the main mass of lava. These bands of chert stand about vertical and strike at right angles to the shore. They appear to be interbedded with the lava.

Exposures of lava occur along the southwest shore of Seldovia Bay for nearly a mile, beginning at a point $1 \frac{1}{2}$ miles below the head of the bay. The rock is a dark ellipsoidal basalt which lies north of an area of slate and graywacke and south of an area of contorted chert. The relations at the contacts were not determined.

The lavas are well displayed in the cliffs on the east shore of Seldovia Bay, the exposures beginning at a point almost 2 miles below the head of the bay and extending as far north as the end of the cape just above the cannery. The rocks are greenish ellipsoidal (Pl. XVI, $A$ ) and scoriaceous basalts, which here and there contain veins and irregular masses of epidote. A little chert is interbedded with the lava.

The thickness of these rocks, as computed from the width of the belt and the average dip, is about 3,000 feet. They apparently conformably overlie the slates and graywackes already described, but the actual contact was not observed. They are overlain by the contorted cherts, which will be described below, the contact apparently being a sedimentary one.

Several masses of lava occur within the general area of chert that extends from a place near the cannery to Watch Point. Evidence is lacking as to whether these masses are interbedded with the chert or are structurally repeated masses of the lava that underlies the chert.

The shore from the cape $2 \frac{1}{2}$ miles northeast of Seldovia Point to Nubble Point contains several outcrops of ellipsoidal basalt. Exposures of chert also occur along this shore, but the local relations of the lava to the chert were not determined.

Hesketh Island is apparently composed entirely of lava and chert, occurring in parallel repeated belts, each having a north-northeast trend. Three such belts of lava, 400,600, and 1,600 feet in width, were observed. The lavas are dark ellipsoidal basalts, apparently not containing any interbedded material of either tuffaceous or detrital origin. The contact of the lava and chert was clearly exposed and accessible for close study at only one place, where it is evident that the chert overlies the lava on a fault contact, the fault being approxi- 
mately parallel to the general bedding of the chert. The other masses of lava may or may not be in this relation to the chert.

The northwest shore of Yukon Island is made up largely of lava. There are also masses of chert on this island, but the local relations of the lava and chert were not determined.

The cape and two small neighboring islands, three-quarters of a mile southeast of Cohen Island, are occupied by ellipsoidal reddish lavas in a belt about a quarter of a mile wide, lying between parallel areas of chert.

The rock at the entrance of the lagoon about $2 \frac{1}{2}$ miles east of Cohen Island is also composed of volcanic rocks and some chert. The low hill between this lagoon and the base of the long sandspit which shelters Chinaput Bay is made up of volcanic rocks, which appear to have been originally ellipsoidal lavas, but which are now somewhat sheared. Gull Island also is composed of ellipsoidal and amygdaloidal basalt. Another area of ellipsoidal basalt lies just west of Ismailof Island.

The rocks on the shores of the head of Halibut Cove are practically all volcanic. Ellipsoidal lavas are the most abundant rocks, though some tuffaceous beds are probably present. A few light-colored dikes were observed. Basalts also make up the low rocky hill and the small island near the wharf at Aurora.

The lava from the west shore of Port Graham (11 Mn 8b) when examined under the microscope proved to be an altered diabase containing plagioclase in laths and other phenocrysts which are altered to calcite and other secondary products, in a groundmass of glassy, devitrified, and secondary interstitial material including magnetite and secondary pyrite and chlorite. A specimen from the west shore of Seldovia Bay (11 Mn 93) consists of a mass of plagioclase laths, too much altered for determination, in a matrix of partially devitrified glass and secondary calcite and chlorite. The rock appears to be a glassy diabase. A specimen from Yukon Island (11 Mn 124) is a partially devitrified glass of basaltic (?) composition, whose groundmass is too fine-grained and glassy for the determination of any of its component minerals. The rock shows good flow structure and considerable secondary quartz and chlorite in veins.

Moffit ${ }^{1}$ described these lavas as follows:

Specimens obtained at a number of localities from Seldovia to Yukon Island have been examined and show a coarse green diabase with long lath-shaped plagioclase feldspars and crystals of pale-green pyroxene and brown hornblende. The pyroxene and some serpentinous material, apparently an altered glass, make up the larger part of the filling between the feldspars. Long needle-like apatites are numerous, while biotite is less so. Ilmenite, largely altered to leucoxene, is found in all sections. Secondary calcite is often present. Dark patches of fine-grained rock are sometimes seen in the field exposures, which proved to consist of small scattered olivine crystals,

1 Moffit, F. H., Gold fields of the Turnagain Arm region: U. S. Geol. Survey Bull. 277, p. 23, 1906. 
somewhat altered, in a felty groundmass of fine lath-shaped feldspars. An opaque ore, probably magnetite, is disseminated through the rock, and its decomposition products, giving the section a reddish cast, show the advanced alteration.

\section{AGE AND CORRELATION.}

The stratigraphic relations of the lavas to the underlying and overlying rocks are most clearly shown on Seldovia Bay. The excellent exposures on the east shore of the bay show that the lavas are underlain by slate, graywacke, crumpled chert, and some volcanic rocks. These beds, aggregating over 5,000 feet in thickness, have already been described. Their dip places them beneath the lavas, but there is no conclusive evidence as to whether or not the contact is unconformable. The lavas are, however, considerably less altered than the volcanic members of the slate and graywacke series and it is consequently assumed that they are considerably younger.

The ellipsoidal lavas are overlain by Upper Triassic (?) cherts and there is no evidence as to the presence or absence of a stratigraphic break between them. Most of the contacts are not exposed in detail or are faults. The lavas are comparatively unaltered and appear to be not very much older than the cherts. They may reasonably be assigned to the Triassic or, at the earliest, to the latest Paleozoic. They appear to correspond closely in stratigraphic position and in lithologic character to the Nikolai greenstone ${ }^{1}$ of the Chitina district.

\section{UPPER TRIASSIC ROCKS.}

\section{LIMESTONE AND TUFF.}

DISTRIBUTION.

The Upper Triassic limestone of Kenai Peninsula is known only in the vicinity of Port Graham and Dog Salmon Bay, the exposures in these two localities being parts of one continuous belt. (See Pl. III.) The exposures in the vicinity of Dog Salmon Bay are at the south end of the belt, which extends northward, forming the shores of Port Graham for $2 \frac{1}{2}$ to 3 miles on each side of the bay, or from the vicinity of Passage Island to a point within about 2 miles of the head of the bay, and terminates in the hills between Port Graham and Seldovia Bay.

\section{LITHOLOGY.}

The Upper Triassic limestone includes considerable amounts of chert and fine-grained volcanic material, mostly tuffaceous. The thickness of these beds and their stratigraphic relations to the beds that underlie and overlie them are not certainly known.

${ }^{1}$ Moffit, F. II., and Capps, S. R., Geology and mineral resources of the Nizina district, Alaska: U. S. Gecl. Survey Bull. 4t8, pp. $60-633,1911$. 
The exposures on the north shore of Port Graham consist of limestone, both cherty and noncherty; rather massive black chert, and volcanic rocks including tuffs, tuffaceous conglomerates, and breccias. The exposures are fairly continuous, but folding and faulting and the small concealed intervals at critical points made it impossible to measure a complete stratigraphic section, or even to estimate the total thickness of the beds represented in an exposure. The descriptions of these beds will consequently consist of a record of the field observations made at each exposure examined from east to west.

The easternmost known Triassic beds exposed are black impure limestone banded with conglomeratic material composed of quartz grains but including some dark, dense pebbles. These beds have been much shattered and filled with minute calcite veins, the pebbles having been faulted and crushed. The rocks are exposed for about 1,400 feet along the shore, but no estimate of their thickness could be made. Mr. Grant collected Halobia cf. H. superba from the south end of this exposure (lot 6380, p. 59). The next outcrop, which is separated from the limestone by a concealed interval, consists of rather massive chert interbedded with strata which appear to consist of igneous material lying in a recumbent fold. Normal faulting has also taken place at this point. A little farther down the shore is dark impure limestone, part of which is cherty. Several thin conglomerates are interbedded with the limestone. One of these, exposed near the southern end of the outcrop, has a thickness of 4 or 5 feet and contains pebbles of chert and of fine-grained igneous rock, the largest about 3 inches in diameter, though most of them are smaller. The rock next exposed is likewise impure cherty limestone with a mass of greenish finely crystalline rock lying parallel to its bedding. There is some doubt as to whether the green rock is a volcanic bed or a sill. A concealed interval follows, beyond which lies gently folded massive chert, cut by many small dikes. The next exposure consists of fine granular rock, parts of which look like coarse sand, but many of the grains have crystal or cleavage faces. The rock contains many inclusions, the largest several feet long, of black cherty-looking rock. A specimen (11 Mn 41) of the tuffaceous material of this bed was examined under the microscope and found to consist chiefly of feldspar, including both orthoclase and plagioclase (the latter in part acidic), in angular to partly rounded grains, much of it altered to kaolin, calcite, and other secondary products. A few pieces of calcite of uncertain origin and a few grains of altered pyrite were also observed. The matrix is composed of chloritic and shaly material. This rock is overlain by nearly horizontal bedded cherty rocks. After a short concealed interval, there comes a small exposure of massive black chert, which dips northward at a low angle. The next exposure, which is continuous along the shore for 
over 1,500 feet, reveals gently undulating beds of massive black cherty rock interbedded with a considerable volume of tuff, tuffaceous conglomerate, and volcanic breccia. Just west of this is an exposure of a black massive rock which appears to be a siliceous shale. The next rocks exposed are greenish tuffs interbedded with more of the siliceous shale. The tuffaceous beds grade upward into dark, massive limestone, of which about 150 feet is exposed, and which is faulted against a volcanic agglomerate of Lower Jurassic age. A thin section (11 Mn 63) of the more tuffaceous beds near the base of the limestone was examined under the microscope and found to contain plagioclase in more or less rounded grains which are altered to kaolin, calcite, etc., fragments of calcite and shale, grains of detrital quartz, and a few grains of magnetite, all in a chloritic and shaly matrix.

The beds exposed on the south shore of Port Graham seem to correspond to part of those seen on the north shore, but include also beds that were not recognized across the bay.

The massive Halobia-bearing limestone, which outcrops at the east end of the Triassic limestones and tuffs on the north shore of Port Graham, does not seem to be represented on the south shore, unless by a single small outcrop of gray shattered limestone, 10 feet thick, about a mile southeast of the wharf. Associated with the limestone are beds of slate, chert, and a sheared greenish rock, probably of volcanic origin. These rocks lie just north of a belt of lavas and occupy the same relative position as the schists (p. 43) seen on the opposite shore. It is not known whether they belong in the Triassic formation or are the equivalents of the crystalline limestone, quartzite, and green schist of Seldovia Bay. The rocks in the peninsula, three-quarters of a mile above the wharf, are concealed by till and other Quaternary deposits. The rocks exposed from this place to a point about a third of a mile above the wharf are tuffaceous and cherty beds which are so intricately folded and faulted that no estimate of their thickness was made.

An exposure about a third of a mile above the wharf consists of well-bedded chert interstratified with tuffaceous beds. About 100 yards farther down the shore, and presumably lower in the sequence, is massively bedded fine-grained tuff containing lenticular masses of chert and underlain by 10 feet or more of dark, fine-grained, evenly bedded, flinty limestone. This is apparently the locality from which Mr. Grant obtained Halobia (lot 6383, p. 59).

It is estimated that about 550 feet of these rocks, dipping southwestward, are exposed between the locality about a third of a mile above the wharf and a locality a quarter of a mile below it. Two of these exposures, a short distance above the wharf, have yielded Upper Triassic fossils (lots 6381 and 6383, p. 59). The sequence is interrupted by a fault about a quarter of a mile below the wharf. West 
of the fault are greenish volcanic beds, which overlie about 150 feet of cherty limestone interbedded with some volcanic material. A thin section (11 Mn 55) of one of the tuffaceous layers interbedded with the limestone shows that it consists chiefly of orthoclase and plagioclase in angular to rounded grains much altered to calcite, kaolin, and other secondary products. Grains of calcite, fragments of chert and shale, and some quartz were also seen. The lower beds of this member consist of strata, 6 inches to 2 feet thick, of black, impure cherty limestone, containing abundant but poorly preserved impressions of Halobia cf. H. superba (lots 6382 and 6573, p. 59). Still lower in the section are other strata of impure cherty limestone, interbedded with thin layers of shale and black vesicular lavas. Farther down in the stratigraphic sequence the beds become sandy and well bedded until, at a distance of 450 feet beneath the Halobia-bearing bed, black argillaceous sandstones predominate. About 80 feet lower is a bed of black, vesicular agglomerate, apparently interbedded with black sedimentary rocks which carry abundant but very poorly preserved-fossils. For the next mile the exposures are few and the lack of outcrops and the variable strikes and dips prevented the measurement of a stratigraphic section. The exposures noted are of limestone, two of which (lots 7234, 7235, p. 59) yielded Pseudomonotis subcircularis, indicating a higher horizon in the Upper Triassic than that of the Halobia-bearing beds up the bay. An exposure nearly south of the east end of Passage Island contains 200 or 300 feet of massively bedded, brown, impure limestone, apparently overlain by about 40 feet of a granular rock. Coarse tuff and agglomerate of Lower Jurassic age lie immediately west of this exposure. The stratigraphic and structural relations of the Triassic and Jurassic rocks at this point were not determined.

FAUNA.

The fossiliferous localities in this formation have already been noted in the descriptions of the exposures. The fossils that have been identified consist essentially of two species, Halobia cf. H. superba Mojsisovics and Pseudomonotis subcircularis Gabb. Of these, Halobia has been found only in the eastern part and Pseudomonotis only in the western part of the area. The structural observations within the area of this formation are not sufficient to warrant any definite statement as to the stratigraphic relations of the beds carrying Halobia to those carrying Pseudomonotis. If, however, the general structure of the area occupied by this formation is of the same character as the structure of the province of which it is a part, the easternmost beds should be lower than the western, a conclusion that is in harmony with the known stratigraphic occurrence of these species 
in other regions, where, in general, species of Halobia and Pseudomonotis related to those occurring here are characteristic of definite horizons, that bearing the Pseudomonotis being the younger.

The following fossils were identified by T. W. Stanton in material collected by U. S. Grant:

6380 (G662). North side of Port Graham. Lat. $59^{\circ} 21^{\prime} 8^{\prime \prime}$; long. $151^{\circ} 48^{\prime}$ : Halobia sp. related to $H$. superba Mojsisovics. Triassic.

6381 (G663). South side of Port Graham. Lat. 59 20 42'; long. $151^{\circ} 49^{\prime} 45^{\prime \prime}$ : Halobia sp., same as 6380 . Triassic.

6382 (G673). South side of Port Graham. Lat. 59 $21^{\prime} 2^{\prime \prime}$; long. $151^{\circ} 50^{\prime} 24^{\prime \prime}$ : Halobia sp., same as 6380 . Triassic.

6383 (G710). South side of Port Graham. Lat. $59^{\circ} 20^{\prime} 46^{\prime \prime}$; long. $150^{\circ} 49^{\prime} 57^{\prime \prime}$ : Astrocœnia? sp. Probably Jurassic or Triassic.

The following reports were also made by T. W. Stanton on material collected by G. C. Martin:

6573. West shore of Port Graham about a quarter of a mile northwest of the wharf (same locality as 6382): The only species in the lot is a Halobia related to H. superba Mojsisovics, which is a characteristic Upper Triassic form. The same species was obtained by Grant in this neighborhood last year.

7234. Station 61, west shore of Port Graham: Pseudomonotis subcircularis (Gabb). Upper Triassic.

7235. Station 53, west shore of Port Graham: Pseudomonotis subcircularis (Gabb). Upper T'riasic.

7452. Port Graham, southwest shore, 1 mile below the wharf: The single specimen is a small pelecypod, which does not show the hinge characters and consequently can not be definitely referred to a genus, though it may be a Nucula. The age of the rocks can not be determined from this fossil, though it is probably Triassic, like that of the overlying rocks, the age of which has been determined by other collections.

\section{AGE AND CORRELATION.}

The fossils identified, as indicated above, show that this formation is of Upper Triassic age. The species of Halobia, which has been recognized at three localities, is identical with a form from the Upper Triassic of California and is probably the same as Halobia superba Mojsisovics of the European Triassic rocks. It has been recognized at many widely separated localities in Alaska, notably in the Chitistone limestone of the Chitina Valley. It is a highly characteristic member of the fauna of the Hosselkus. limestone of California. The other identified species, Pseudomonotis subcircularis Gabb, is a wellknown Upper Triassic horizon marker, being characteristic of the highest known faunal zone of the Upper Triassic of California, and is closely related to species occupying the same relative stratigraphic position in other parts of the world. Its terrane is above that of the Halobia. This species has been recognized at many widely separated Alaskan localities, especially those in the MeCarthy shale of the Chitina Valley, in the Kamishak chert of the west coast of Cook Inlet, and in the Upper Triassic rocks of the Alaska Peninsula. 


\section{CHERT.}

\section{DISTRIBUTION.}

Contorted chert occurs on Kenai Peninsula at many places along the shores of Kachemak Bay and Cook Inlet. The best exposures are on Bear Cove, Halibut Cove, Chinaput Bay, Eldred Passage, Seldovia Bay, and Port Graham. The areas represented as chert on the geologic map (Pl. III, in pocket) include numerous small undifferentiated masses of ellipsoidal lavas, the two kinds of rock being so intimately and complexly associated as not in all places to permit an accurate cartographic separation of the smaller areas of lava.

\section{STRATIGRAPHIC RELATIONS.}

The cherts are everywhere intensely deformed, minute crumpling being universal (Pl. XVII) and faulting being common, so that it is impossible to make even the roughest estimate of the thickness of the formation, nor can the upper and the lower part be determined in any local section. At the exposure on the east shore of Seldovia Bay just above the cannery the cherts apparently rest upon ellipsoidal lavas. This contact is assumed to be the base of the formation, but there may be a fault or an overturn at this point. Within the area of the cherts at the town of Seldovia there are masses of ellipsoidal lava which are identical in character with the lava exposed farther up the bay and which appear to underlie the chert. These masses may be either interbedded or structurally included. Interbedding is suggested by the apparent interbedding of thin strata of lava and chert on the north shore of Port Graham. At other places, notably on Hesketh Island, there are wider alternate bands of chert and lava which suggest structural repetition. The safest assumption, probably, is that each condition exists in one or another part of the district, that the main masses of both the chert and the lava contain thin-bedded strata of the other, and that masses of each kind of rock have been included by folding and faulting within the main area of the other.

The rocks exposed on the northeast shore of Halibut Cove consist chiefly of banded chert, with which is associated some basalt. These rocks are cut by light-colored dikes. The contacts of the dikes with the chert are sharp and straight, contrasting strongly with the crumpled bedding of the chert (PI. XVII, $B$ ) and showing that the dikes were intruded after the cherts were folded.

IITHOLOGY.

The cherts are thin-bedded and even-bedded rocks (Pl. XVII), consisting of hard siliceous layers from half an inch to 2 inches thick, separated by thin films of softer material. The hard siliceous layers are of fairly uniform appearance except as they vary in color. They 


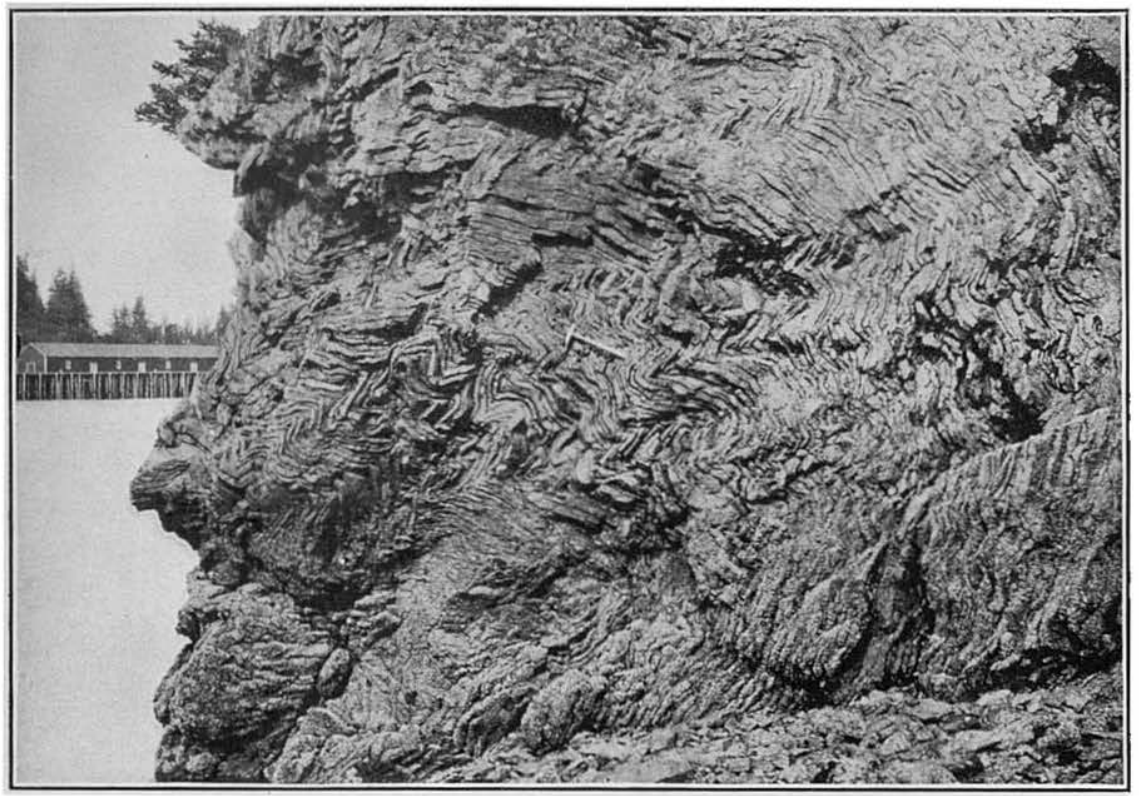

A. CONTORTED CHERT ON EAST SHORE OF SELDOVIA BAY NEAR CANNERY.

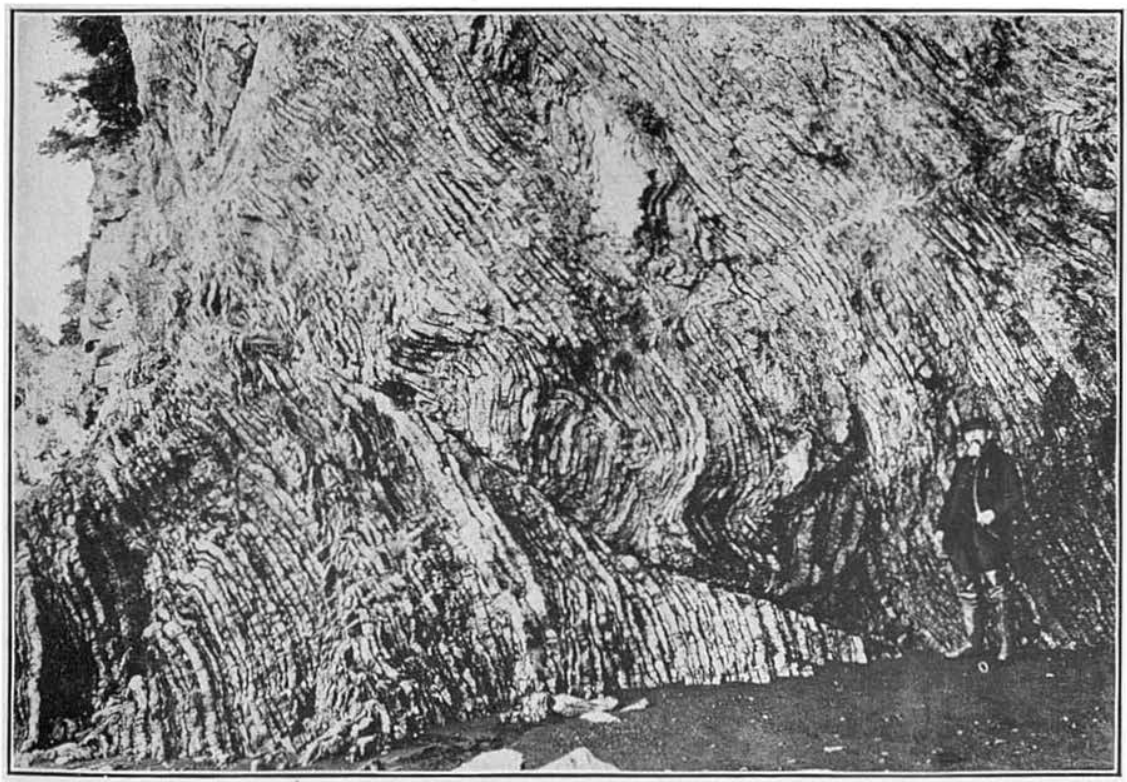

b. CHERT ON EAST SHORE OF HALIBUT COVE. 

are of very fine grain, being uniformly of almost glassy texture and not containing any recognizable detrital fragments. The character of the material between the hard siliceous beds was not definitely determined, but is probably shaly. The color of the chert at most places is green, gray, or black. Brown or red cherts were noted at a few places, and are believed to owe their color to the infiltration of iron minerals.

The cherts are cut by a multitude of minute veins that run at various angles to the bedding and appear on the bedding surfaces as a network of thin slightly raised ridges.

The cherts show in thin section a fine-grained siliceous groundmass containing no indication of detrital grains, but contain numerous rounded forms which suggest the simpler Radiolaria. The rock is cut by a multitude of fine veins, most of which are completely filled with secondary quartz. Some of the veins are not entirely filled, and in one section calcite is associated with the vein quartz. The secondary quartz in the veins is of much coarser grain than any of the siliceous material of the body of the rock.

FAUNA.

The only fossils that have been recognized in these rocks are poorly preserved Radiolaria. The radiolarian remains appear in the thin section as clear, round spots that contrast slightly with the body of the rock, which is more stained and clouded. They vary in abundance from bed to bed, some layers being made up chiefly of them. They are less distinct under crossed nicols, where they can be recognized only by a yellowish shell separating a crystallographic unit within from the cryptocrystalline aggregate without. Some protuberances, probably the stumps of broken spines, and some pores were seen. No details of the lattice shells could be made out. Most of the forms apparently belong to the Sphæroidea, although the thin sections contain many elongated forms. The remains are so poorly preserved that it is not possible to recognize more than a few genera with even approximate certainty.

\section{AGE AND CORRELATION.}

These cherts have yielded no determinable fossils, consequently wheir age must be determined by their relations to neighboring fossiliferous horizons and by their lithologic similarity to rocks of known age in other districts.

It is practically certain that the cherts are younger than and overlie the ellipsoidal lavas just described, and it is also certain that they are older than the much less folded and less altered Lower Jurassic tuffs. 
Their relation to the Upper Triassic limestones and tuffs, which will be described below, is the critical problem in the determination of their age. The exposures on Port Graham suggest but do not prove that the Upper Triassic limestones and tuffs immediately underlie the Lower Jurassic tuffs, and that the cherts occur beneath the Upper Triassic rocks. The exposures on Seldovia Bay likewise suggest but do not prove that the cherts immediately overlie the ellipsoidal lavas, and are consequently not above the Upper Triassic limestones and tuffs. The Upper Triassic limestones and tuffs have not been recognized on Seldovia Bay, the geographic position in which they would be expected (that between the cherts and the Lower Jurassic tuffs), being occupied by crystalline schists.

These cherts bear a strong lithologic resemblance to the Kamishak chert $^{1}$ of the west coast of Cook Inlet, which contains characteristic Upper Triassic fossils and has been generally regarded as the approximate equivalent of the chert of Seldovia Bay. The Kamishak chert is associated with limestone beds ${ }^{1}$ which also carry Upper Triassic fossils. The fauna of this limestone includes at least one of the species (Halobia cf. H. superba) that occur in the Upper Triassic limestones and tuffs of Port Graham. (See p. 59.) The Halobiabearing limestone of the west coast of Cook Inlet, although not cartographically separated from the Kamishak chert, was regarded as probably distinct from and older than it. It is probably, at least in part, the equivalent of the Chitistone limestone, which likewise carries Halobia cf. H. superba and which is overlain by thin-bedded limestones and shales whose fauna, which includes Pseudomonotis subcircularis, suggests an approximate equivalence with the Kamishak chert.

If the cherts of Kenai Peninsula are to be correlated with the Kamishak chert, and if the Upper Triassic limestones and tuffs of Port Graham are to be correlated with the limestones associated with the Kamishak chert, then the cherts of Kenai Peninsula should be considered as probably overlying the Upper Triassic limestones and tuffs of Port Graham. If this conclusion is adopted the apparently conformable contacts between the chert and the underlying lavas at the Seldovia cannery and between the Lower Jurassic tuff's and the Upper Triassic limestones and tuffs on Port Graham must be regarded as faults, of which the one at the Seldovia cannery has cut out the limestones and tuffs, and the one on Port Graham has cut out the cherts. This interpretation offers the simplest and most satisfactory solution of the broader problems, but considering only the local conditions and problems and ignoring the broader question of the correlation of these rocks with the rocks of other districts, it

1 Martin, G. C., and Katz, F. J., A geologic reconnaissance of the Iliamna region, Alaska: U. S. Geol. Survey Bull. 485, pp. 47-50, 1912. 
would be simpler to assume that the limestones and tuffs overlie the cherts.

Another possibility is that the limestones and tuff's and the cherts are local phases of the same stratigraphic unit. In this connection it should be noted that the Upper Triassic limestones and tuffs of Port Graham contain chert beds, and that much of the limestone is decidedly cherty. On the other hand, it should be noted that the cherts are uniformly associated with lavas and not tuffs, and the limestone with tuffs and not lavas. The lavas associated with the cherts are apparently diabase or basalt, whereas the tuffs associated with the limestone are free from femic minerals and were apparently derived from a rather acidic magma. On the whole, it seems highly improbable that the cherts are a local facies of the limestone. This interpretation has little or nothing in its favor except that it affords a possible escape from the difficulties involved in the other hypotheses. Whatever be the position of the cherts relative to that of the limestones and tuffs it is probably safe to assume that they are of Upper Triassic age.

\section{LOWER JURASSIC ROCKS.}

TUFFs.

DISTRIBUTION.

The Lower Jurassic tuffs occur along the western shore of Kenai Peninsula from Point Bede to Seldovia Bay. Their eastern boundary extends from near Point Bede in a fairly straight line to the west shore of Seldovia Bay, about a mile and a half inside the entrance. (See Pl. III.) The rocks in contact with them along this line are the Upper Triassic limestones and tuffs at Port Graham and Point Bede and the crystalline schists at Seldovia Bay. They extend along the strike into the waters of Cook Inlet and Kachemak Bay. No rocks comparable with them in lithologic character or stratigraphic position have been recognized in other parts of Kenai Peninsula.

\section{LITHOLOGY.}

These rocks consist of tuffs and volcanic agglomerates of indeterminate thickness, with which are interbedded thin strata of sandstone, shale, and limestone. The presence of marine shells indicates the marine deposition of part of the series. The absence of any sharp break in the sequence or of anything that indicates a considerable change in the character of the sedimentation suggests that the entire series may have been laid down in marine waters.

No stratigraphic section has been measured and the thickness of the beds therefore can not be stated. The only data on which an estimate of thickness can be based are the width of the belt occupied by these rocks and the amount of dip. The dip is apparently monoclinal and is northwestward, ranging from $10^{\circ}$ to $80^{\circ}$. Assuming 
an average dip of $30^{\circ}$, the thickness of the series would be about 8,000 feet. This is probably much in excess of the true thickness, for the beds are broken by normal faults. (See Pl. XVI, B.) The amount of movement on these faults could not be determined in any place, so it was impossible to surmise the aggregate amount of repetition by faulting. It is safe, however, to assume a thickness of at least 1,000 feet, though the beds probably measure 2,000 or 3,000 feet.

The base and top of this series have not been recognized. Upper Triassic rocks, which probably immediately underlie these Lower Jurassic beds, lie east of them on the shores of Port Graham, but the observed contacts appear to be faults, so the nature of the initial deposition is not known. The next younger rocks here are Tertiary, some of their contacts with the Lower Jurassic rocks being unconformities and others being faults. The local absence of the Middle and Upper Jurassic rocks, which occur in great thickness on the west shore of Cook Inlet and in other neighboring districts, suggests erosion in Middle Jurassic time or later, which may have removed a large part of the original volume of rock and possibly a large part of the original thickness of the Lower Jurassic series.

The contact of the Lower Jurassic tuffs with the Upper Triassic limestone is exposed on the north shore of Port Graham about 2 miles above its entrance. This contact is a fault. The tuffs extend from this point to the end of the small peninsula near Passage Island and are also exposed across the small bay north of this peninsula, but at that place the contact with the Triassic limestone is not exposed.

The high cliffs at this point show continuous exposure of northwestward dipping sedimentary and volcanic beds. In the lower part of the outcrop is a prominent bed which from a distance appears white and which is shown in Plate XVI, $B$. This bed is a greenish tuff, its white color, which is so striking as seen from points across the bay, being due to weathering. The rocks both above and below this stratum are well bedded and are dominantly tuffaceous. Some large bowlders, many of which were seen on the beach and which must have come from this place, yielded the marine shells in the collection marked lot No. 2983 (p. 65). Several dikes and faults were seen in this bluff, but the dip is monoclinal throughout the exposure (Pl. XVI, $B$, p. 52). Around the point north of the cliffs there are other exposures of this same series of rocks, in which the volcanic beds predominate over the others. The change from sedimentary to volcanic material is gradual, the rock finally becoming practically all coarse agglomerate and breccia, which from a distance shows a very rude stratification parallel to that in the higher cliffs. The last pronounced bedding appears at a point about $1 \frac{1}{4}$ miles east of the coal mine. From this point to the contact with the Tertiary rocks the bedding can be seen 
only from out on the water, and the agglomerate becomes very coarse, some of its constituent masses being as much as 4 or 5 feet across. Bodies of limestone were seen here and there, but their relations to the tuffs could not be determined. Possibly they are faulted in with the tuffs.

These tuffs include rocks that show considerable variation in composition, but the significance of this variation has not been determined. The light-colored bed described on page 64, which apparently lies near the base of these rocks, is a rhyolite tuff composed (11 Mn 64) of orthoclase, quartz, a little acidic plagioclase, and small amounts of iron oxide, together with a large amount of secondary calcite. The coarser tuffs and agglomerates near the entrance to Port Graham, which lie higher in the series, appear to be of andesitic composition, a specimen from Russian Cape (11 Mn 50) being composed of oligoclase, a little orthoclase, and some ferromagnesian minerals altered to epidote and chlorite. The thin section contained some quartz, which is probably of detrital origin. The fossiliferous tuffs on the west shore of Seldovia Bay near the entrance contain beds that were recognized under the microscope as quartz keratophyre tuff (11 Mn 83), consisting of primary albite, secondary albite that was probably derived from a soda-rich orthoclase, and quartz, in a glassy to cryptocrystalline, largely fragmental groundmass which contains secondary sericite. These rocks are interbedded with fossiliferous beds of similar composition, some of them finely conglomeratic. A specimen (11 Mn 82) taken from one of these beds was examined under the microscope and found to contain grains of fine-grained to glassy igneous rock, rounded individual grains of albite, fragments of quartzite, and a few grains of quartz, all embedded in a matrix of calcite and chlorite. Albite not only forms rounded grains of the rock but is a constituent of the fragments of the igneous rock from which it was derived, in which it appears both as phenocrysts and in the groundmass.

FAUNA.

These tuffs contain abundant marine fossils, of which the following were collected and identified by T. W. Stanton:

Locality 904 (2977).-West side of Seldovia Bay, opposite village, one-fourth mile southeast of locality 905 .

Trigonia sp. a. This abundant form be-
longs to the section Glabræ.

Locality 905 (2978).-Point Naskowhak at entrance to Seldovia Bay.

Pentacrinus.

Trigonia sp. a.

Trigonia sp. b.

Myophoria? sp.
Cardinia? sp. b.

Pecten sp. a.

Pinna cf. P. expansa Hyatt.

Fragments of an undetermined ammonite.

$48591^{\circ}-$ Bull. $587-15-5$ 
Locality 906 (2979).- Three-fourths of a mile west of locality 905.

Cardinia sp.

Trigonia? sp. a?

Pleurotomaria (?)

Ammonite. Fragmentary imprint.

Locality 907 A (2980).- Shore of Cook Inlet, 2 miles west of Seldovia Bay.

Cardinia sp. a.

Pecten sp. b.

Gryphæa sp.

Perna ??

Pzeudomelania? sp:

Locality 907 B (2981).-Same locality as 907 A, but 200 feet higher.

Trigonia sp. a?

Trigonia ?

Pinna cf. P. expansa Hyatt.

Pecten sp. b.

Pecten sp. c.

Astrocœnia?

Arietites? sp.

Only one fragmentary specimen of form last named, which certainly belongs either to Arietites or to a closely related genus of ammonites.

Locality 908 (2982). -Shore of Cook Inlet, 3 miles west of Seldovia Bay.

Pecten sp. b.

I Pecten sp. d.

Locality 909 (2983).-Port Graham $1_{\frac{1}{2}}$ miles southeast of coal mine.

Trigonia? Fragmentary imprints.

Pecten sp. a.

Ostrea or Gryphæa.

Fossils were collected by U. S. Grant at the localities indicated below and were identified by T. W. Stanton:

Locality G682 (6384).-East shore of Cook Inlet, about one-third of the distance from Point Naskowhak (which is at the south entrance to Seldovia Bay) to Dangerous Cape.

Montlivaultia? sp.

Gryphæa sp.

Pecten (two undescribed species).

Pleuromya sp.

Anatina (Cercomya) sp.

Natica? sp.

These fossils are Jurassic and belong to the fauna that Martin and Stanton found in this neighborhood in 1904 and tentatively referred to the Lower Jurassic. ${ }^{2}$

Locality G684 (6385).-East shore of Cook Inlet, 1 mile southwest of Point Naskowhak.

Ostrea sp.

| Cardinia? sp.

Jurassic. Probably from the same formation as 6384 .

The following lists were also furnished by T. W. Stanton, the material having been collected by G. C. Martin:

Locality 7236.-Station 115, 3 miles southwest of Point Naskowhak.

Anomia? sp.

Pecten sp. Small, ribbed form.

Pecten sp. Large, smooth form.
Natica? sp.

Lower Jurassic, like the fauna collected from the tuffs near Seldovia in 1904.

Locality 7237.-About 23 miles southwest of Point Naskowhak.

Undetermined coral.

Lower Jurassic?

1 Geol. Soc. America Bull., vol. 16, pp. 396, 397, 1905. 
AGE AND CORRELATION.

\section{Mr. Stanton says of these fossils collected on and west of Seldovia} Bay:

The evidence can not be considered final on account of the imperfect state of preservation, the small number of species, and the lack of definitely characteristic forms, but so far as I can judge from the present collections and from the field relations of the beds containing them it seems most probable that all of these small lots belong to one general fauna and that the age of the beds is Lower Jurassic. The fossils are certainly Mesozoic, and the collections include no species in common with the Middle and Upper Jurassic faunas, which are so well developed in thick formations on the west side of Cook Inlet and on the Alaska Peninsula, and contain several types that are apparently older than any found in those faunas. On the other hand, the only evidence suggesting the Triassic age is the presence of shells doubtfully referred to Myophoria from superficial characters, and this evidence is overbalanced by the Jurassic affinities of the other species.

Volcanic beds that are lithologically similar to these and that also were deposited, at least partly, in marine waters have been recognized at several localities in the Matanuska Valley. ${ }^{1}$ The fauna of the beds here under discussion, though not specifically identical with that of the supposed Lower Jurassic tuffs of the Matanuska Valley, is of the same general character and contains several species in common with it. No Lower Jurassic beds have been recognized with certainty in other parts of Alaska, although the rocks at several localities have been tentatively correlated with these rocks because of their lithologic similarity and their stratigraphic relations.

\section{TERTIARY ROCKS.}

\section{KENAI FORMATION.}

\section{DISTRIBUTION.}

The Kenai formation probably underlies the entire Kenai lowland and also occurs in six small detached areas on the south shore of Kachemak Bay. (See Pl. III.) It outcrops continuously in the bluffs along the north shore of Kachemak Bay and for several miles northeast of the head of the bay in the cliffs on the western wall of the valley of Fox River. It is also exposed almost continuously in the cliffs on the eastern shore of Cook Inlet from Homer Spit nearly to Anchor Point and from the mouth of Anchor Point River to Clam Gulch, about $10 \frac{1}{2}$ miles south of Kasilof. Other exposures were seen in the banks of Kasilof River 8 miles above its mouth and (probably) on the shore of Tustumena Lake. It is also reported to outcrop at two places on the shore of Cook Inlet between Kenai and Point Possession. It is the only pre-Quaternary formation that has been

1 Martin, G. C., and Katz, F. J., Geology and coal fields of the lower Matanuska Valley, Alaska: U. S. Geol. Survey Bull. 500, pp. 17-10, 29-32, 1912. 
observed in the Kenai lowland and it probably underlies the Quaternary deposits throughout that district.

The best known of the areas on the southern shore of Kachemak Bay is the one on the eastern shore of Port Graham, which contains the coal beds discovered by Portlock ${ }^{1}$ in 1786 and mined (Pl. V, B, p. 22) by the Russians 58 years ago. (See pp. 107-108.) Four smaller areas occur on the shore between Port Graham and Seldovia Bay and another lies just east of Seldovia Point.

GENERAL FEATURES.

The Kenai formation is probably about 1,800 or 2,000 feet thick. Two measured sections (see pp. 77, 79-81) contain about 1,880 and 1,700 feet of beds, and neither the top nor the bottom is exposed. These sections undoubtedly overlap and are possibly complete duplicates, but the beds in one can not with certainty be correlated with those in the other.

The rocks of the Kenai formation consist of partly indurated sands and clays, probably of about equal volume, the individual beds being generally not more than 20 or 30 feet thick, though a few measure more than 100 feet, interbedded with a few inconspicuous conglomerates and with many beds of lignite. The rocks are in general sufficiently indurated to stand up readily in almost vertical cliffs several hundred feet high, yet they may be easily cut with the point of a pick or knife. A few beds are more thoroughly indurated but they apparently owe their greater consolidation to the growth of concretions or to other local cementation.

The argillaceous beds are mostly gray or blue, though rarely white, soft, plastic when wet, and have imperfectly developed shaly fracture.

Most of the sandy beds are composed of fairly well sorted and clean-washed white quartz sand, and contain not very abundant ferromagnesian grains. Some beds are feldspathic.

The coal beds are numerous, but most of them are of only moderate thickness. The measured stratigraphic sections show that 3 to 5 per cent of the total thickness of rock consists of coal beds 3 to 7 feet thick.

Neither the base nor the top of the formation has been observed. It apparently contains no beds of marine origin.

LOCAL SECTIONS.

SECTION BETWEEN ANCHOR POINT AND HOMER SPIT.

The exposures of Tertiary rocks in the cliffs between Anchor Point and Homer Spit are not continuous, being interrupted by landslides and deposits of Quaternary gravels. The general dip is southeast- 

ward, so that the outcrops nearest Anchor Point reveal the lowest Tertiary beds in this part of the section. (See Pl. XVIII.) It is impossible to describe the entire section with certainty, for there is no evidence as to the amount of dip or the presence of faults in the stretches in which the Tertiary beds are concealed. The exposures observed will be described and their probable stratigraphic relations will be considered. From the data thus presented an approximately complete section of the rocks can be compiled.

The only deposits exposed in the first $2 \frac{3}{4}$ miles southeast of Anchor Point are Quaternary gravels and a few small scattered outcrops (?) of lignite at the base of the cliff or far out on the beach at very low tide. A 2 -foot bed of lignite is exposed at the mouth of a creek $2 \frac{3}{4}$ miles south of Anchor Point, at an elevation of about 10 feet. The fossils (lot 4129) described on page 85 came from this locality. The dip at this point, or at least the component showing in the cliff face, is about $2^{\circ} \mathrm{SE}$, which carries the coal below tide within a short distance. What was regarded as the same coal was seen far out on the beach a quarter of a mile farther southeast. In the next quarter of a mile several gentle folds cause a repetition of either this bed or of one near its horizon. An anticline 4 miles south of Anchor Point has maximum dips of $6^{\circ}$ on each flank for short distances, beyond which the dips flatten to very low angles. Half a mile farther south the following section was measured:

Section of shore cliffs about $4 \frac{1}{2}$ miles southeast of Anchor Point.

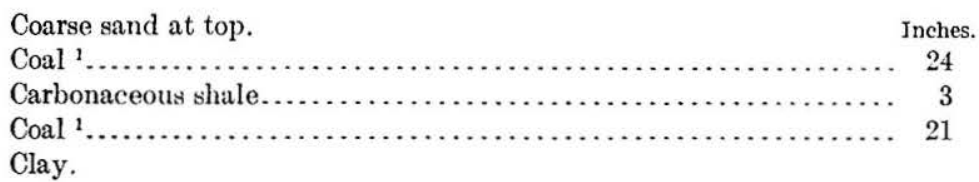

The bed that overlies the coal consists of white sand with a stratum of 2-inch pebbles at its base. It rests unconformably upon the coal and is probably Quaternary. This sand forms the lower part of the cliff for the next half mile, to the mouth of the next creek, where there are exposures of clay, dark sands, and coal beds that dip gently southward. A short distance farther south the following section was measured:

Section of shore cliffs about 5 miles southeast of Anchor Point.

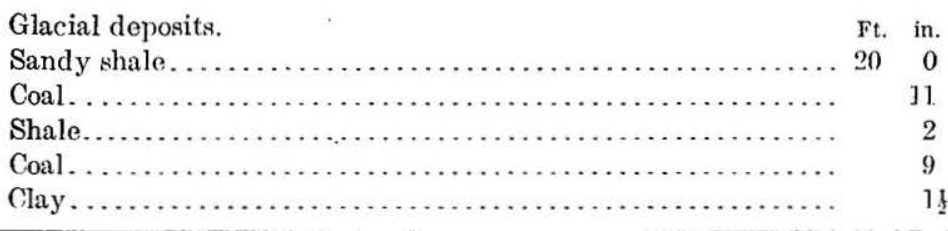

Incluted in sample No. $+432, \mathrm{pp}$. 106-107. 


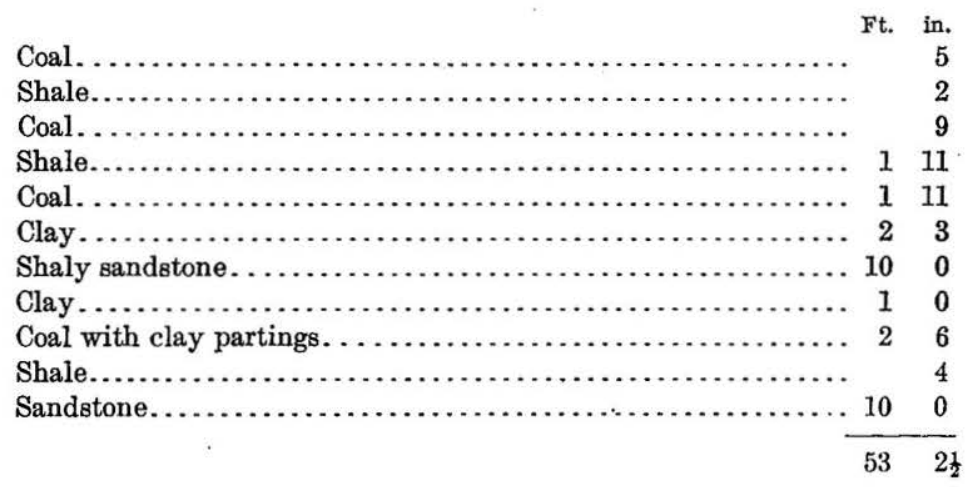

The dip is southward at a low angle, the beds exposed in the above section passing below the beach in about half a mile. The exposures are then obscured by landslides for about a quarter of a mile, the next outcrop showing the following section:

Section about $5 \frac{3}{6}$ miles southeast of Anchor Point.

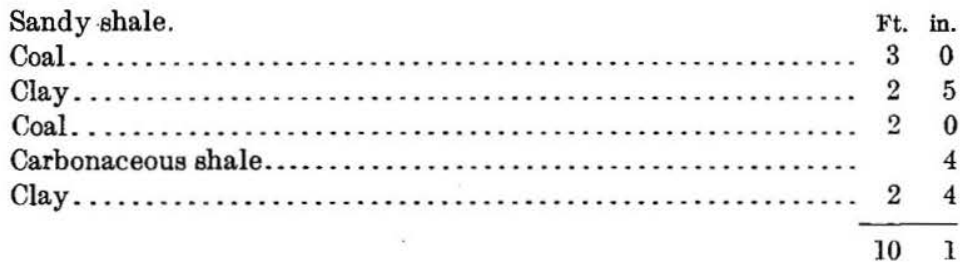

The following section, exposed farther southeast, is regarded as immediately overlying the preceding:

Section about 6 miles southeast of Anchor Point.

Glacial deposits.

Ft. in.

Sand and clay with large sandstone nodules. . . . . . . . $20 \quad 0$

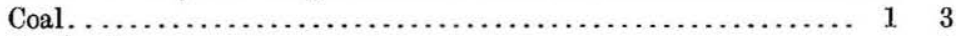

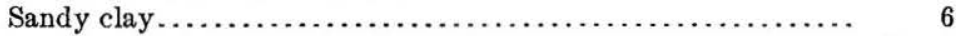

Thin alternating beds of coal and clay ................. 30

Sandy clay ........................................ 6

Coal and clay in alternating beds up to 4 inches thick........ $3 \quad 0$

339

The following section represents beds which probably immediately overlie those of the section just described:

Section about $6 \frac{1}{2}$ miles southeast of Anchor Point.

Ft. in.

Lignite and shale in thin alternating beds. ............. $4 \quad 0$

Sandstone with concretionary masses................... $10 \quad 0$

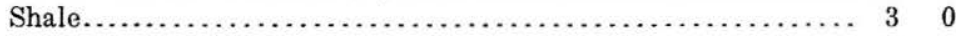

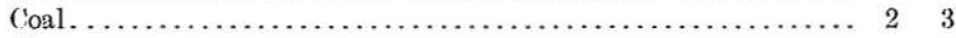

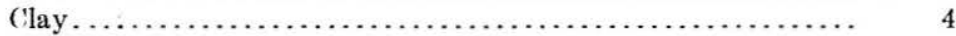


Ft. in.

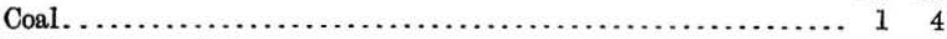

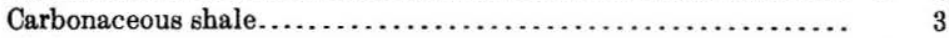

Shale................................ 50

Shale with lignite bands. . . . . . . . . . . . . . . . $3 \ldots \ldots \ldots . \ldots$

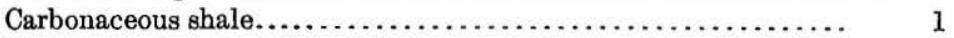

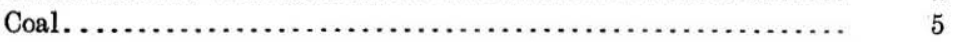

Quaternary deposits and landslides conceal the rocks for some distance southeast of this point. The next exposures show the following section:

Section about $7 \frac{1}{3}$ miles southeast of Anchor Point.

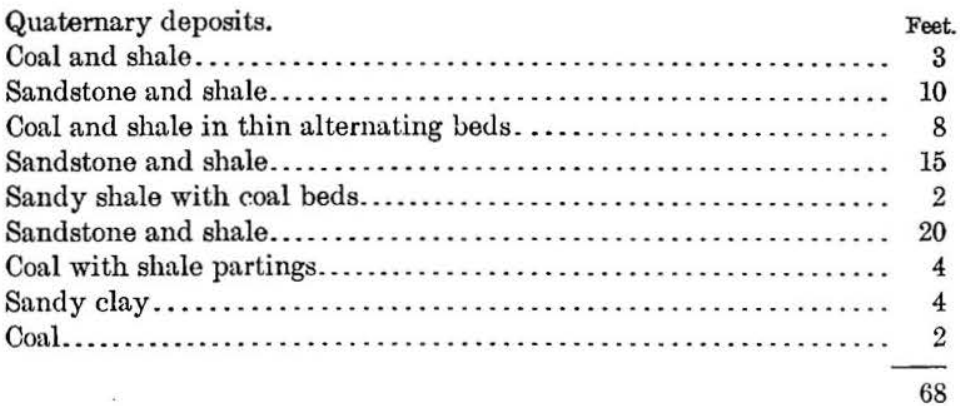

The following section (see Pl. XXI, $B$, p. 74), which was measured a little farther southeast, immediately follows in stratigraphic sequence:

Section about $8 \frac{1}{2}$ miles southeast of Anchor Point.

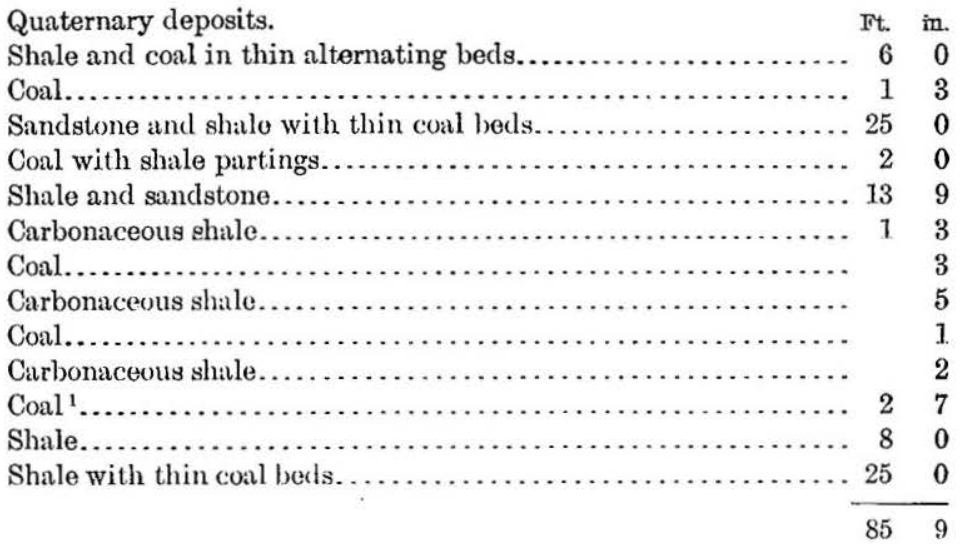

The next 100 feet of strata contains eight or ten thin coul beds separated by shales. 
The following section, measured at Bluff Point (PI. XIX, $A$ ), overlies these beds, a very small, if any, interval lying between and the rocks being practically horizontal:

Section of part of Kenai formation at Bluff Point.

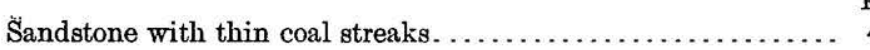

Massive cross-bedded sandstone ....................... 20

Massive sandstone................................... 15

Areriaceous shale .................................. 15

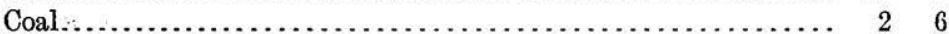

Bluish clay shale.................................. 150

Coal............................................. 5

Carbonaceous clay shale............................. 13

Coal................................................. 18

Clay shale...................................... $30 \quad 0$

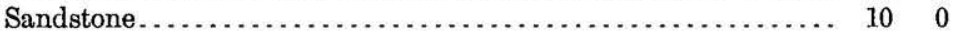

Coal.......................................... $2 \quad 6$

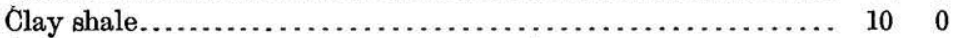

Coal .............................................. 10

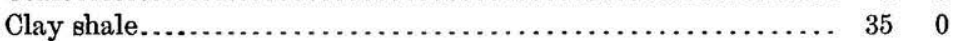

Sandstone......................................... $20 \quad 0$

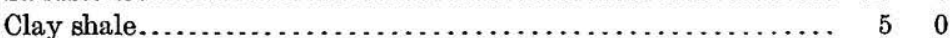

Coal, Cooper bed (section below):

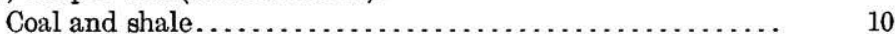

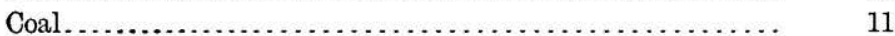

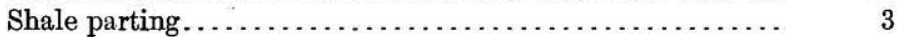

Coal........................................ 9

Shale parting.................................. 1

Coal......................................... 3

Shale parting.................................. 2

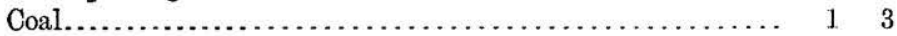

Clay shale with sandstone lens..................... $40 \quad 0$

Coal................................................

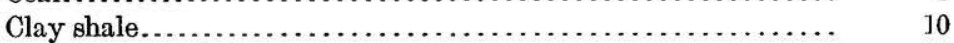

Carbonaceous shale.................................. 10

Coal............................................ ${ }_{2} \quad 6$

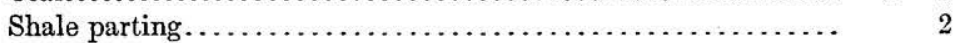

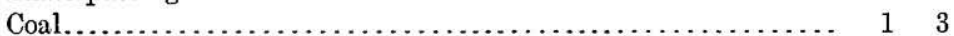

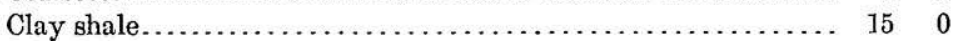

Bony coal......................................... 6

Clay shale....................................... 10

Sandstone....................................... 50

Coal.......................................... 7

Clay shale...................................... 20

Coal......................................... 9

Clay shale.......................................... 13

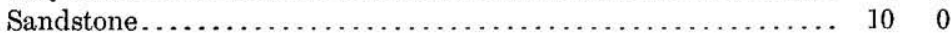

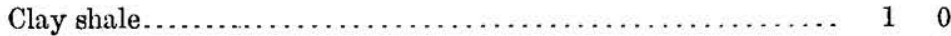

Coal............................................... 3

Clay shale........................................ $2 \quad 0$

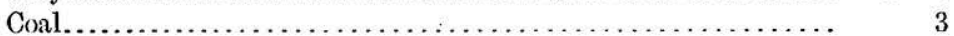




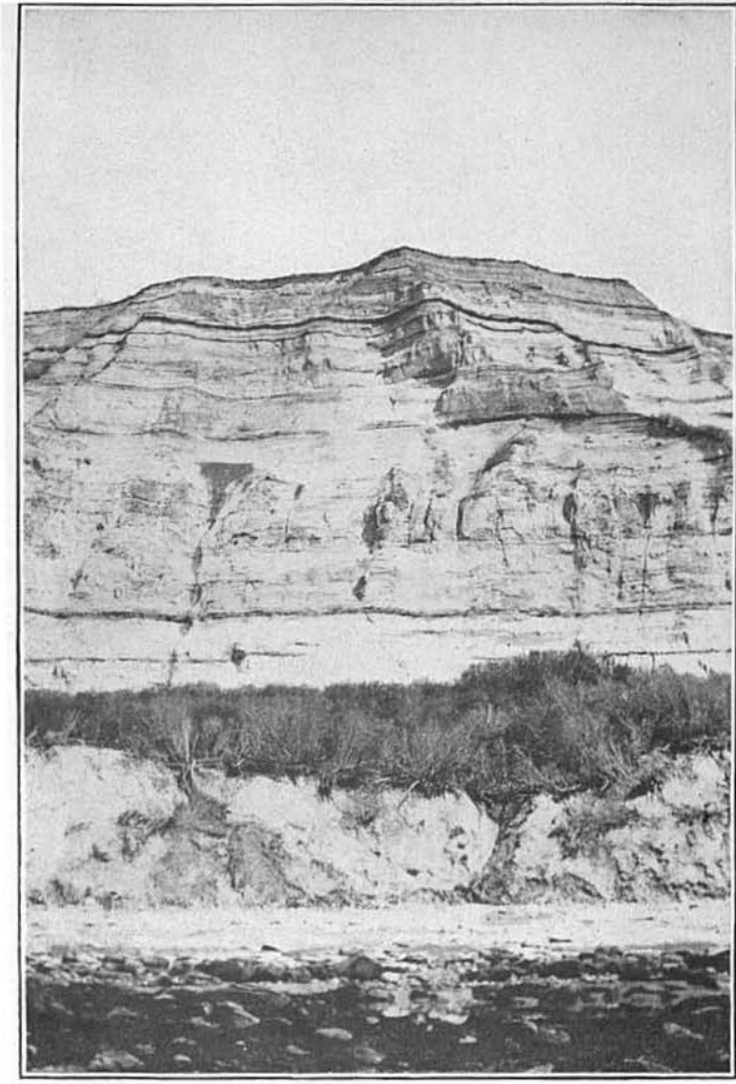

A. KENAI FORMATION, WITH LIGNITE BEDS, IN CLIFF AT BLUFF POINT.

The low, brush-covered deposits in the foreground are the result of a landslide. Photograph by A. G. Jaffa.

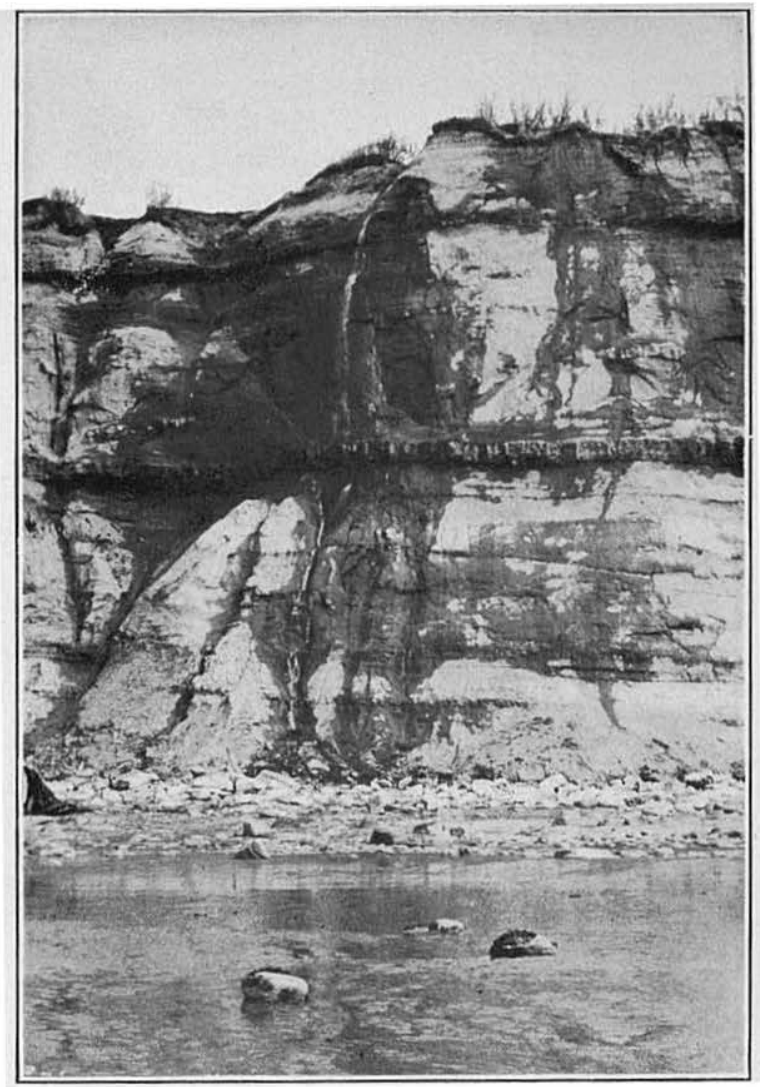

B. KENAI FORMATION, WITH LIGNITE BEDS, NEAR MINE CAMP. Photograph by A. G. Jaffa. 



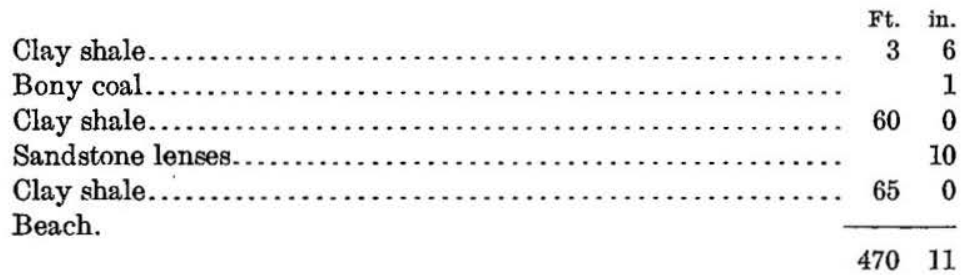

The fossil leaves of lot 5821 (p. 86) were collected from blocks of talus material at the base of this exposure. It is not known which bed or beds they came from.

The following section, exposed at Mine Camp, is practically a duplicate of the Bluff Point section. Minor differences in detail may be noted.

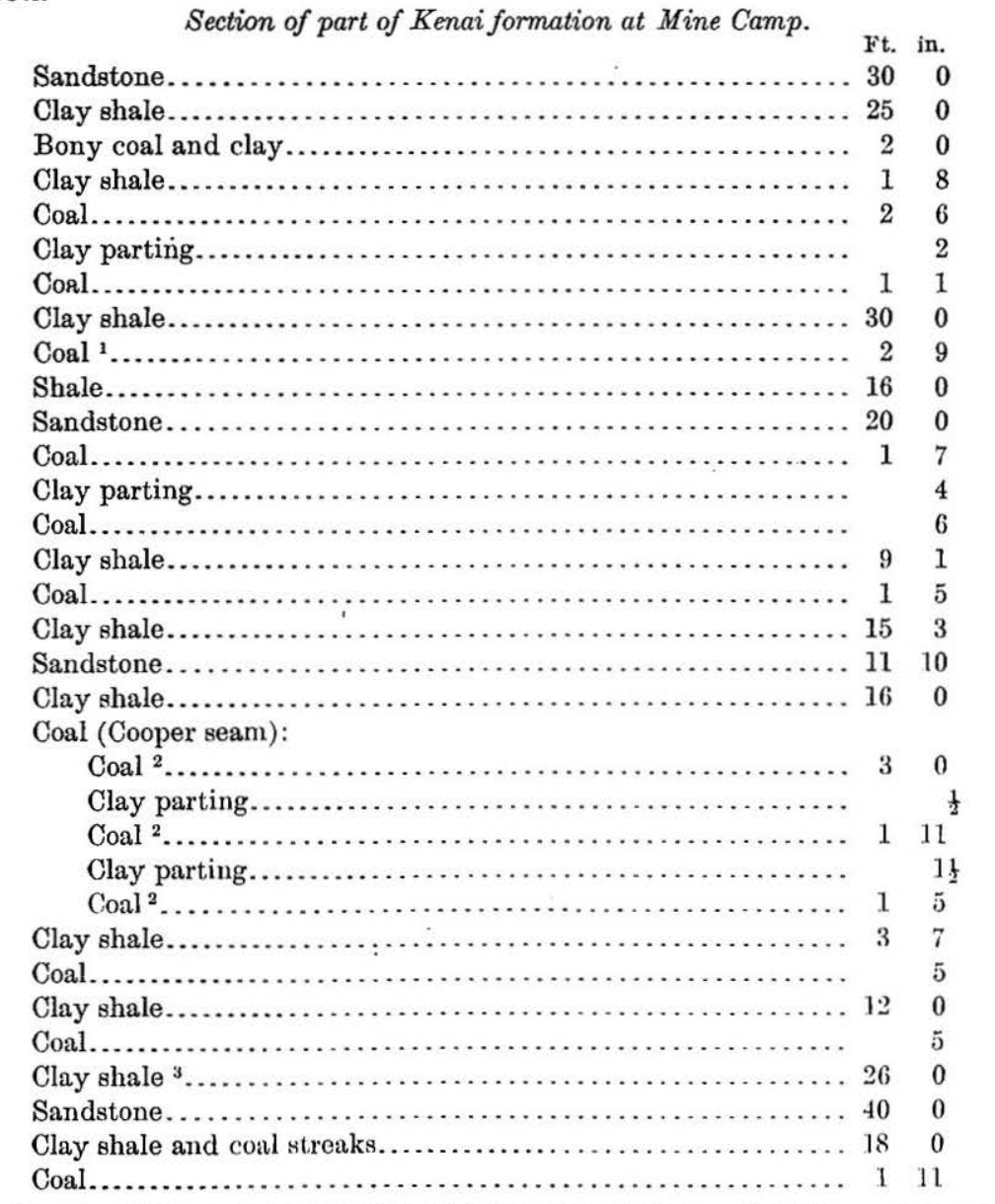

I Included in sample No. 3, p. 106. 3 The fossils in lot $5 \times 20$ (p. sti) (tame from this hor izon. 2 Included in simple No. 4 , p. 106. 


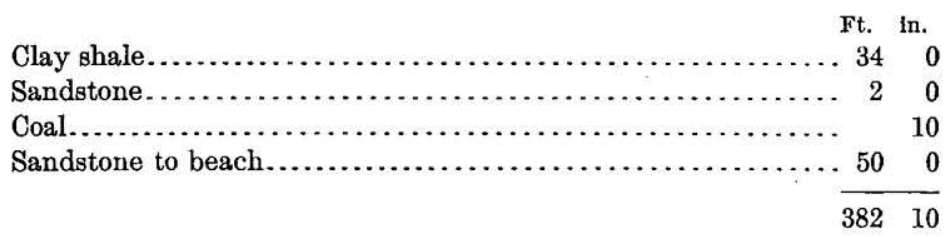

The sections recorded above aggregate about 855 feet of strata (4t per cent coal), no allowance being made for concealed beds. As the places where the beds are concealed are near outcrops in which the rocks are practically horizontal, the missing strata are probably not very thick. It is quite as probable that the apparent thickness is reduced by reversed dips in these intervals as it is that there is any appreciable increase.

Other beds of coal lying lower than those given in the section on page 72 are found below high tide at the point near Coal Creek. One outcrops about 350 feet from the base of the point and appears to be about 6 feet thick. Its upper bench is at least 15 inches and a lower one is 30 inches thick. The strike of this bed across the beach is $\mathrm{N} .58^{\circ} \mathrm{W}$. and the dip is north. The interval between this coal and the base of the section given above (p. 73) seems to be occupied by sandstone. Outcropping parallel with it and 130 feet farther offshore is another bed, which is 4 feet 5 inches thick and strikes N. $80^{\circ}$ W. Still farther offshore and exposed only at very low tide is a 1 -foot bed.

The section from Anchor Point to Homer Spit certainly lies beneath at least the larger part of the Kachemak Bay section, which is described below. No exact correlation of the beds in the two sections is possible, but the upper part of the Cook Inlet section is probably in general the equivalent of the lower part of the Kachemak Bay section. The Bradley coal, east of Homer Spit, is possibly the equivalent of the Cooper coal of the Mine Camp section, or at least it can not be far from the stratigraphic place of the Cooper coal.

SECTION ON NORTH SHORE OF KACHEMAK BAY.

The Kenai formation is exposed almost continuously in the cliffs on the northwest shore of Kachemak Bay. The rocks dip gently in a general northerly direction (see Pl. XX), so that the highest beds outcrop at the head of the bay and the lowest near the base of Homer Spit. The total thickness of the beds exposed is about 1,250 feet.

The lowest exposures observed are about $2 \frac{1}{2}$ miles east of the spit, where several coal beds outcrop on the beach. The following section was measured at this point by W. W. Atwood: 

Section of part of Kenai formation $2 \frac{1}{2}$ miles east of Homer Spit.

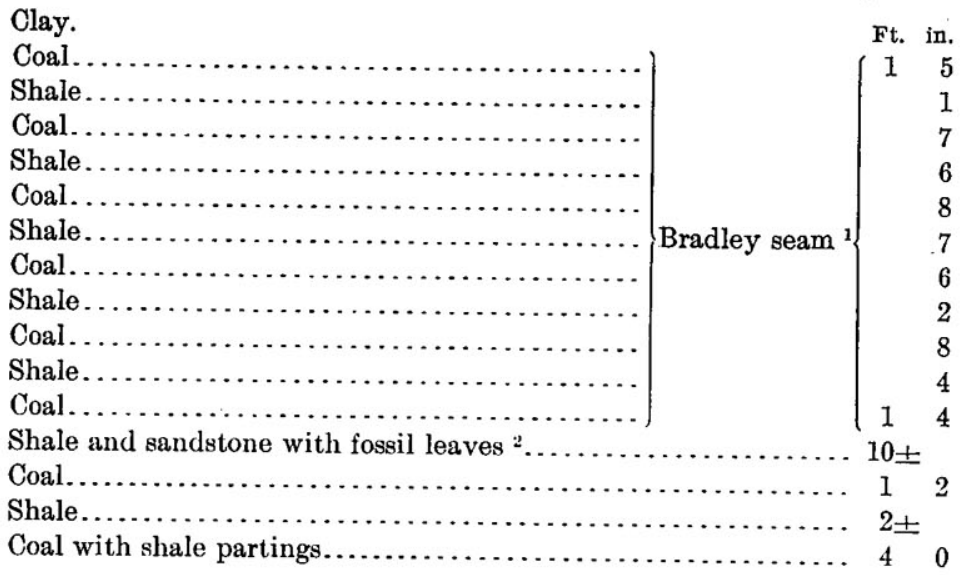

The dip at this place is $6^{\circ}-13^{\circ} \mathrm{NW}$. and the strike is N. $64^{\circ} \mathrm{E}$., which carries the outcrop across the shallow bight and into the low foreland just east of Fritz Creek, from which point higher and higher beds are exposed up the shore of the bay.

The following section, measured by Kirsopp,${ }^{3}$ includes the exposures between Fritz and McNeil creeks:

Section of part of Kenai formation on north shore of Kachemak Bay.

Coal (Curtis seam) Feet.

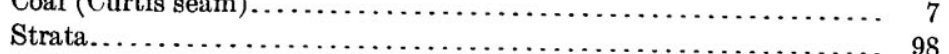

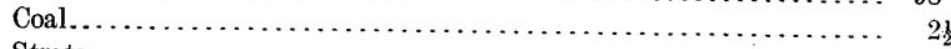

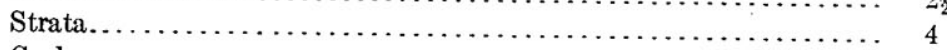

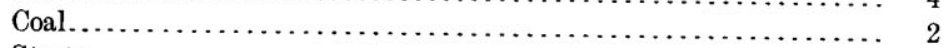

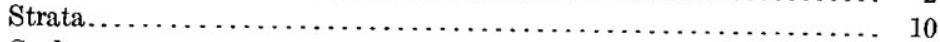

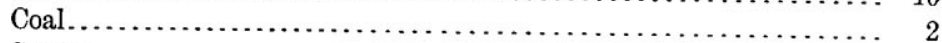

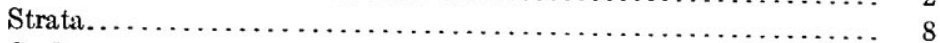

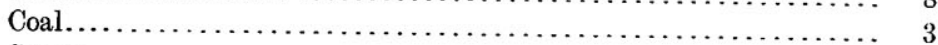

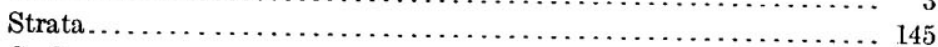

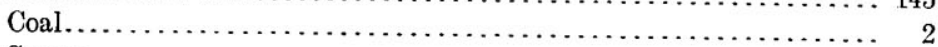

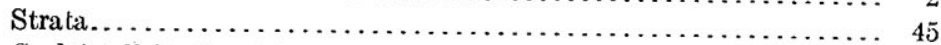

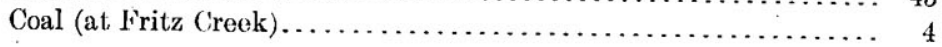

$332 \frac{1}{2}$

${ }^{1}$ Coal included in sample No. 4457 (pp. 106-107). Shale partings excluded from sample.

2 The fossils in lot 4131 (p. 86) came from this bed.

${ }^{3}$ Kirsopp, John, jr., The coal fields of Cook Inlet, Alaska, U. S. A., and the Pacific coast: Inst. Min. Eng. (England) Trans., vol. 21, p. 526, 1903. 
The beds exposed on and near McNeil Creek are represented in the following section, which was measured by R. W. Stone:

Section of part of Kenai formation at McNeil Creek.

Top of bluff.

Clay shale (estimated)

Ft. in.

Coal (estimated)

200

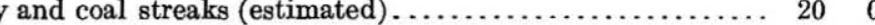

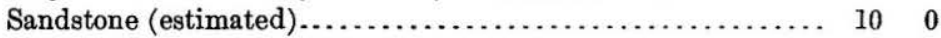

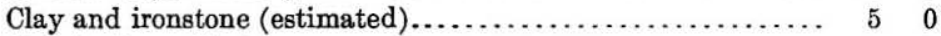

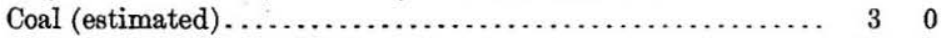

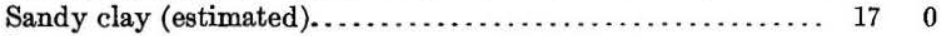

Ironstone.......................................... 3

Coal. ......................................... $2 \quad 6$

Clay, coal streaks, and sandstone nodules............... $25 \quad 0$

Coal . . . . . . . . .

Clay shale.......................................... 6

Coal.......................................... 2

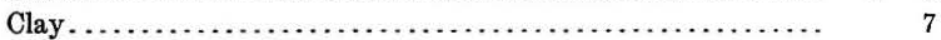

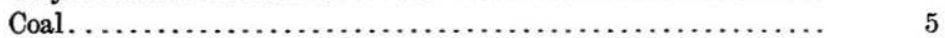

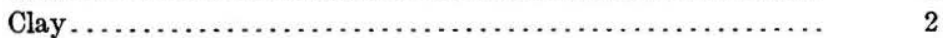

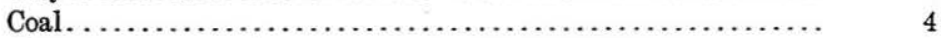

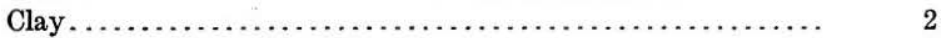

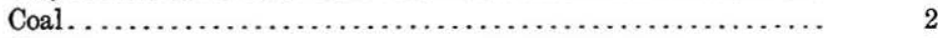

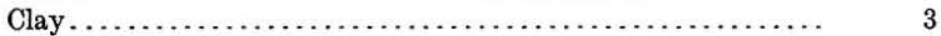

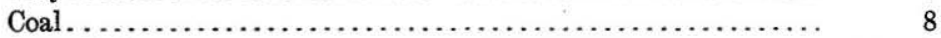

Clay shale...................................... 14

Coal. ....................................... 7

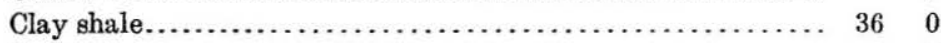

Coal ........................................... 6

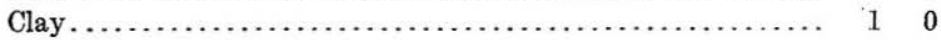

Coal ............................................. 34

Clay shale........................................... $26 \quad 0$

Coal ............................................ 10

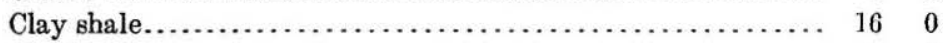

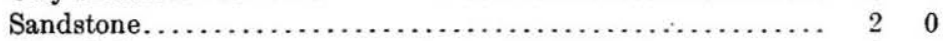

Clay shale.......................................... 8 o

Coal. ............................................ 8

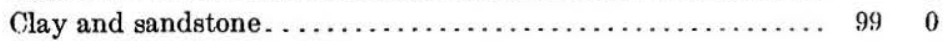

Coal ............................................. 18

Shale. . . . . . . . . . . . . . .

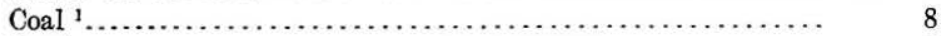

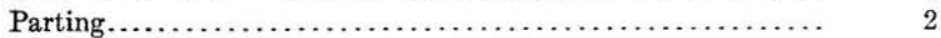

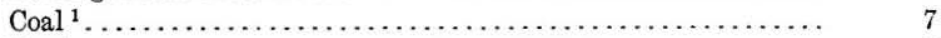

Parting. . . . . . . . .

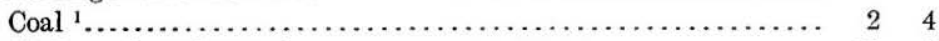

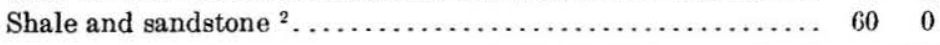

1 Included in sample No. 9, p. 106.

${ }^{2}$ Lower vart, exposed in cliffs west of ereek; thickness estimated. 


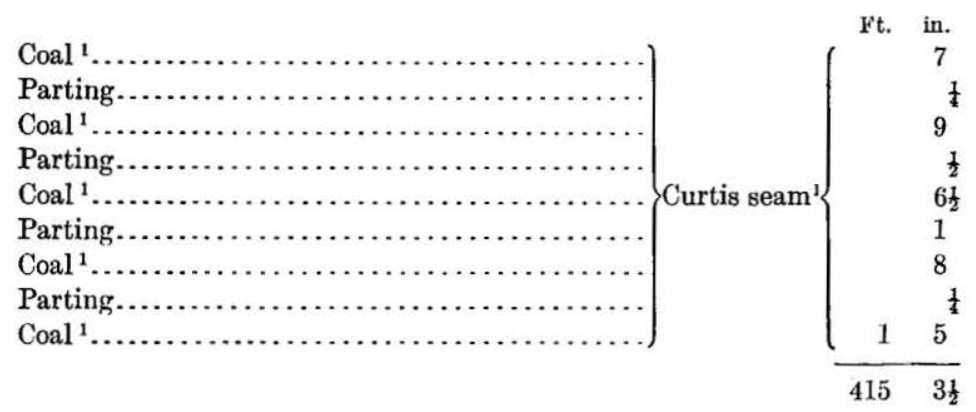

The sections on Cottonwood and Eastland creeks were not measured in detail. The coal bed represented in the following section outcrops in the bed of Eastland Creek at an elevation of about 250 feet:

Section of coal in Eastland Canyon, Kachemak Bay.

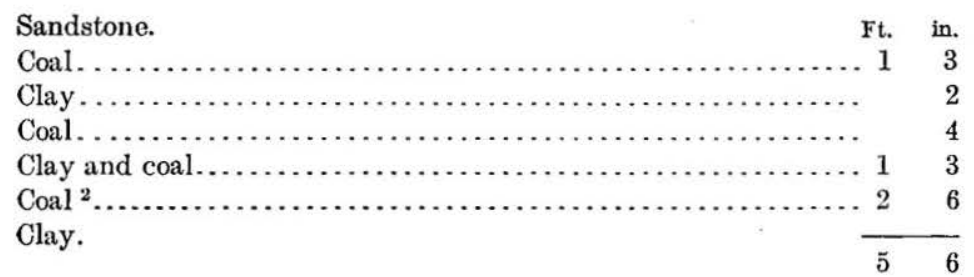

A higher coal bed, 3 feet 2 inches thick, is exposed on the same creek at an elevation of 360 feet above sea level.

From McNeil Creek to Falls Creek the exposures are practically continuous and show that the beds dip gently northward and descend toward the head of the bay at a slope less than the true dip. The coal bed, which is 180 feet above sea level or 215 feet above the base of the local section at McNeil Creek, descends to about 50 feet above sea level at Cottonwood Creek. (See Pl. XX, p. 74.) From Cottonwood Creek to Eastland Creek the beds descend about 70 feet, and between Eastland and Falls creeks they go down about 50 feet more. This brings the highest coal in the McNeil Creek section to a level about 80 feet above the base of the following section, which was measured by R. W. Stone at Falls Creek:

Section of part of Kenai formation at Falls Creek.

\begin{tabular}{|c|c|c|}
\hline & Ft. & in. \\
\hline 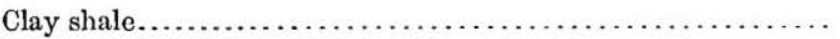 & 15 & 0 \\
\hline 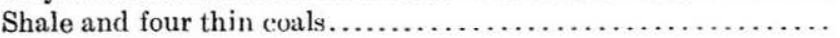 & 15 & 0 \\
\hline 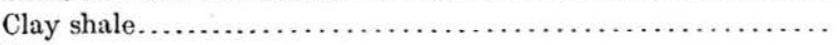 & 20 & 0 \\
\hline 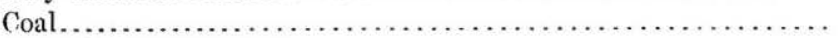 & 1 & 0 \\
\hline 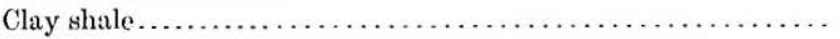 & 50 & 0 \\
\hline 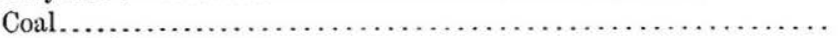 & 4 & 0 \\
\hline 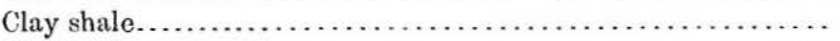 & 15. & 0 \\
\hline
\end{tabular}




\begin{tabular}{|c|c|c|}
\hline & & \\
\hline 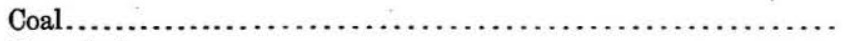 & 1 & $\mathbf{0}$ \\
\hline 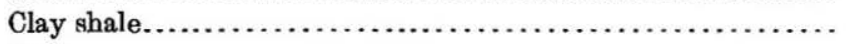 & 8 & 0 \\
\hline 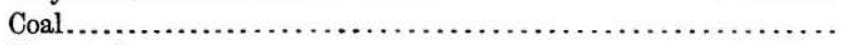 & 1 & 0 \\
\hline 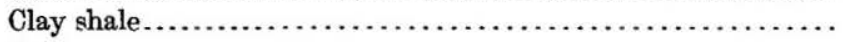 & 90 & 0 \\
\hline 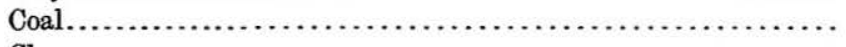 & 1 & 6 \\
\hline 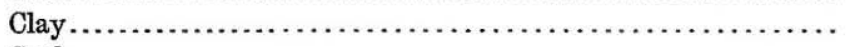 & & 5 \\
\hline 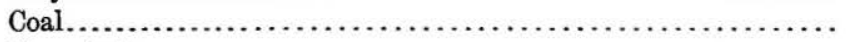 & 2 & 6 \\
\hline 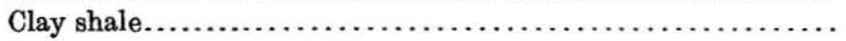 & 12 & 0 \\
\hline 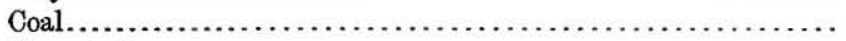 & 1 & 0 \\
\hline 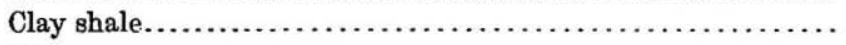 & 3 & 0 \\
\hline 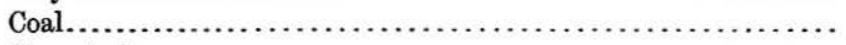 & & 6 \\
\hline 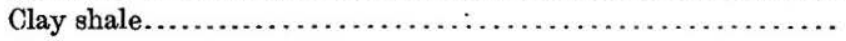 & 45 & 0 \\
\hline 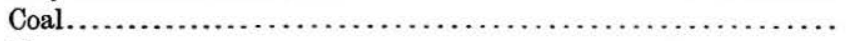 & & 8 \\
\hline 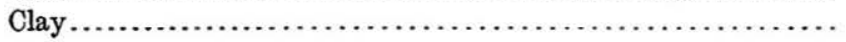 & & 4 \\
\hline 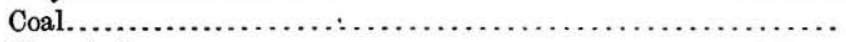 & 3 & 0 \\
\hline 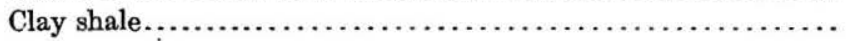 & 2 & 0 \\
\hline 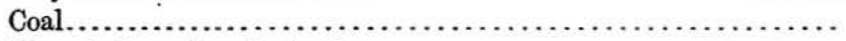 & 1 & 6 \\
\hline Clay shale and coal streaks $\ldots \ldots \ldots \ldots \ldots \ldots \ldots \ldots \ldots \ldots \ldots \ldots$ & 65 & 0 \\
\hline 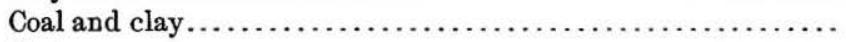 & 3 & 0 \\
\hline 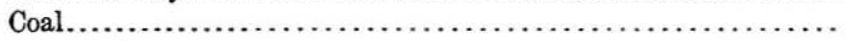 & 3 & 0 \\
\hline 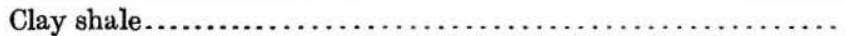 & 1 & 0 \\
\hline 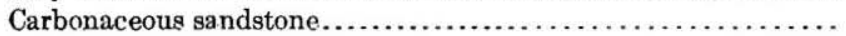 & 2 & 0 \\
\hline 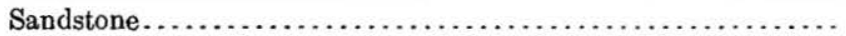 & 10 & 0 \\
\hline 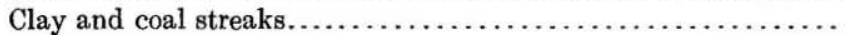 & 10 & 0 \\
\hline 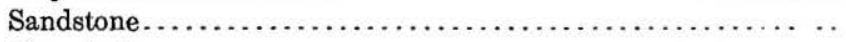 & 15 & 0 \\
\hline 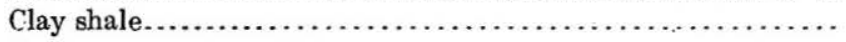 & 10 & \\
\hline$\ldots \ldots \ldots \ldots \ldots \ldots \ldots \ldots \ldots \ldots \ldots \ldots \ldots \ldots \ldots \ldots \ldots \ldots$ & 1 & \\
\hline Clay shale and coal streaks $\ldots \ldots \ldots \ldots \ldots \ldots \ldots \ldots \ldots \ldots \ldots$ & 20 & \\
\hline 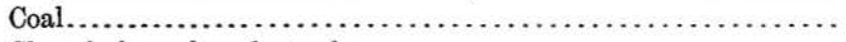 & 1 & \\
\hline 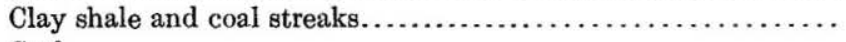 & 25 & 0 \\
\hline 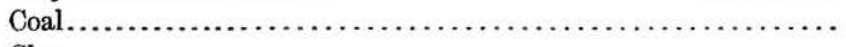 & & 6 \\
\hline n.m. & & 6 \\
\hline 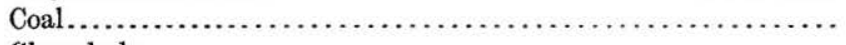 & 2 & 0 \\
\hline 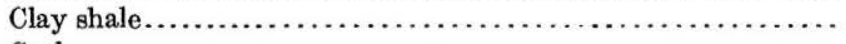 & 8 & 0 \\
\hline 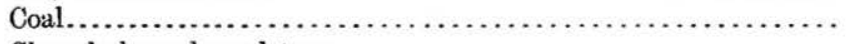 & 2 & 0 \\
\hline 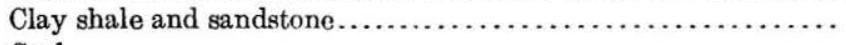 & 30 & 0 \\
\hline 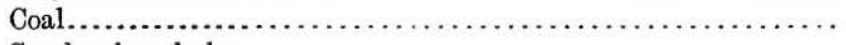 & 2 & 0 \\
\hline 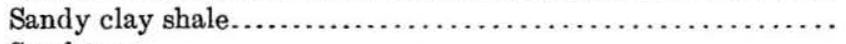 & 15 & 0 \\
\hline 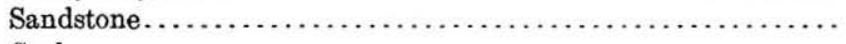 & 10 & 0 \\
\hline Coal & 1 & 0 \\
\hline 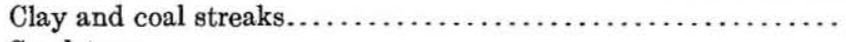 & 5 & 0 \\
\hline 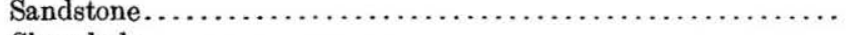 & 25 & 0 \\
\hline 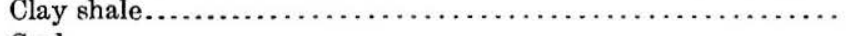 & 2 & 0 \\
\hline 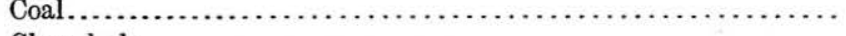 & 2 & 0 \\
\hline 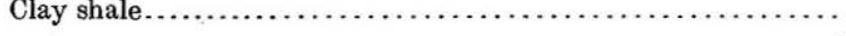 & 20 & 0 \\
\hline & & \\
\hline
\end{tabular}

From Falls Creek to the head of the bay the strata dip at a low angle to the north. Clay beds baked hard and red by burning coal beds color the upper part of the bluff for some distance.

The coal-bearing formation outcrops in the bluffs west of Fox River for at least 5 or 6 miles beyond the head of the bay, and a 3 -foot bed 
of coal is reported 15 miles northeast of the bay, 200 feet above sea level.

The entire section on Kachemak Bay thus aggregates about 1,250 feet ( 5 per cent being coal). If the Bradley coal and the Cooper coal are identical the section from Anchor Point to the head of Kachemak Bay contains about 1,880 feet of strata, 4.7 per cent being coal. This is the most complete section of the Kenai formation yet measured and probably shows very nearly the true thickness of the formation. It is certainly safe to assume that the section from the creek $2 \frac{3}{4}$ miles south of Anchor Point to the top of the bluff at Falls Creek does not contain more than 2,000 feet of strata.

SECTION FROM ANCHOR POINT TO CLAM GULCH.

The exposures of the Kenai rocks in the cliffs of Cook Inlet north of Anchor Point are in places very complete, but for several long stretches the rocks are concealed so that it is impossible to describe the entire section or to determine its relation to the section south of Anchor Point.

There are no outcrops of Tertiary rocks between Anchor Point and the mouth of the river, $2 \frac{1}{3}$ miles north of Cape Starichkof, the only deposits here observed consisting of till and the overlying stratified gravels. Throughout most of this distance a belt of low land that lies between the bluffs and the shore protects the bluffs from the waves and permits the accumulation of landslide material over the entire face of the bluff. It is uncertain whether the bluff is composed entirely of Quaternary deposits or whether its lower part consists of Tertiary beds mantled by landslide material. Fresh exposures both north and south of this point show that the Tertiary beds are absent at many places in the bluffs for considerable distances, and they may be absent here.

At the mouth of the river, $2 \frac{1}{3}$ miles north of Cape Starichkof, Tertiary clay forms the lower fourth or third of the bluff and is overlain by stratified gravel. The exposures are practically continuous for several miles north of this point, and the dip is uniformly northward. The bedding becomes distinct about two-thirds of a mile north of the mouth of the river, or 3 miles north of Cape Starichkof, the locality at which is found the base of the local section given below.

Section of Kenai formation on the east shore of Cook Inlet from a point 3 miles south of Ninilchik to a point 3 miles north of Cape Starichkof.

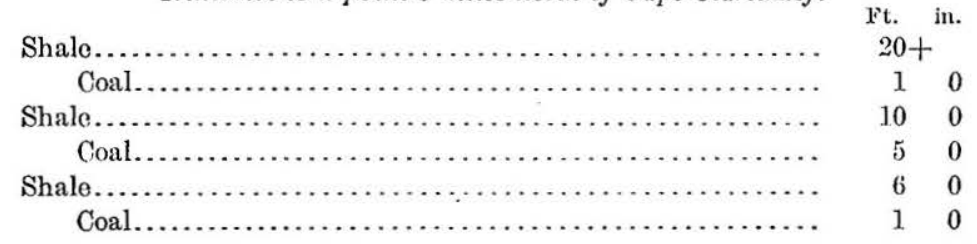




\begin{tabular}{|c|c|c|}
\hline Shale...... & $\begin{array}{r}\text { Ft. } \\
40\end{array}$ & \\
\hline 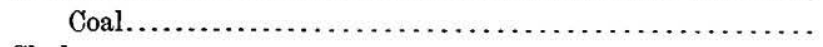 & 2 & 0 \\
\hline 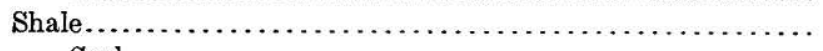 & 8 & 0 \\
\hline 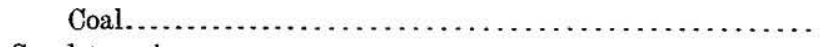 & 2 & 0 \\
\hline 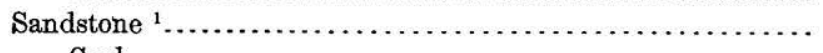 & 40 & 0 \\
\hline 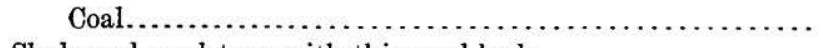 & & 6 \\
\hline Shale and sandstone with thin coal beds.................... & 50 & 0 \\
\hline 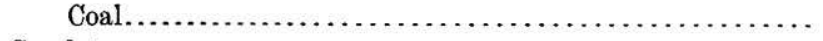 & 1 & 0 \\
\hline 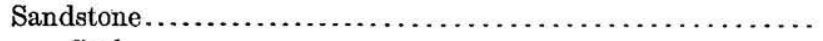 & 40 & 0 \\
\hline 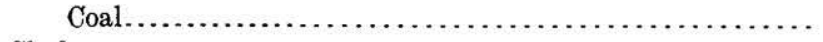 & 1 & 0 \\
\hline 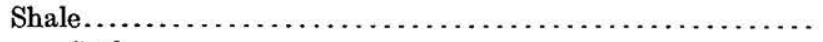 & 10 & 0 \\
\hline 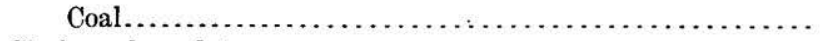 & 2 & 0 \\
\hline 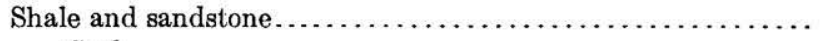 & $100 \pm$ & \\
\hline 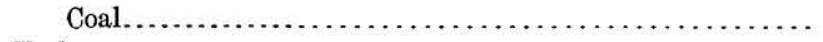 & 1 & 0 \\
\hline 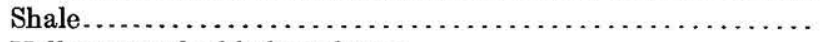 & 40 & 0 \\
\hline Yellow cross-bedded sandstone $\ldots \ldots \ldots \ldots \ldots \ldots \ldots \ldots \ldots$ & 100 & 0 \\
\hline 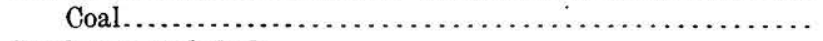 & 1 & 0 \\
\hline 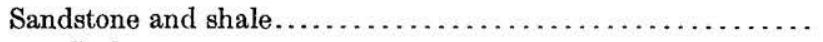 & 30 & 0 \\
\hline 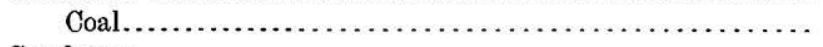 & 5 & 0 \\
\hline 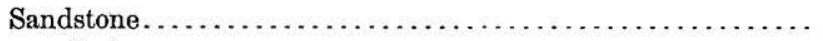 & 50 & 0 \\
\hline 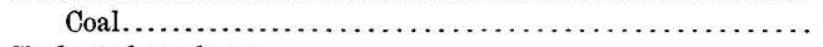 & 4 & 6 \\
\hline 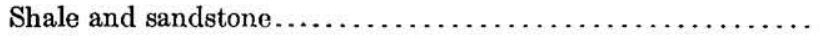 & 40 & 0 \\
\hline${ }_{n}$ & 40 & 0 \\
\hline${ }^{\prime} \ldots \ldots \ldots \ldots \ldots \ldots \ldots \ldots \ldots \ldots \ldots \ldots \ldots \ldots$ & 4 & 0 \\
\hline n.m. & 15 & 0 \\
\hline n.m. & & 6 \\
\hline n.w. & 2 & 0 \\
\hline n.m. & 1 & 0 \\
\hline 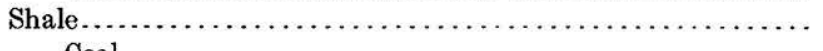 & 10 & 0 \\
\hline (n, & & 3 \\
\hline 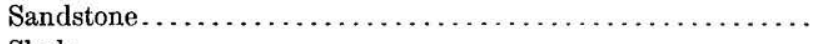 & 20 & 0 \\
\hline 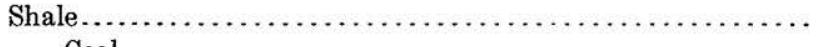 & 30 & 0 \\
\hline 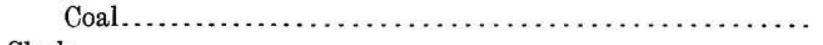 & & 6 \\
\hline n.m. & 25 & 0 \\
\hline 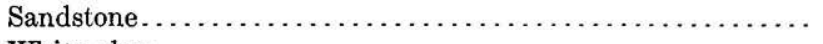 & 25 & 0 \\
\hline 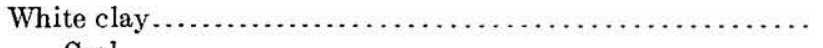 & 6 & 0 \\
\hline 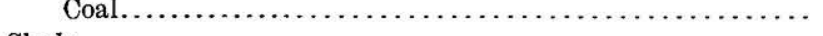 & & 6 \\
\hline 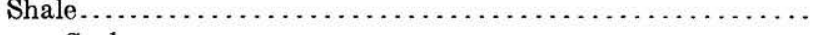 & 35 & 0 \\
\hline 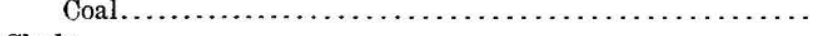 & 2 & 0 \\
\hline 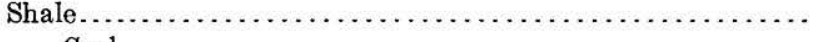 & 60 & 0 \\
\hline 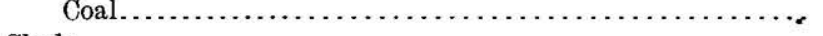 & 1 & 0 \\
\hline 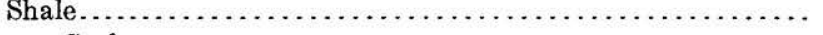 & 20 & 0 \\
\hline 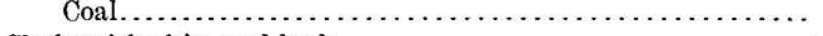 & 1 & 6 \\
\hline Shale with thin coal beds.................................. & 20 & 0 \\
\hline Coal........................................ & 3 & 0 \\
\hline 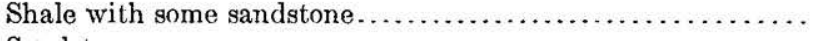 & 50 & 0 \\
\hline 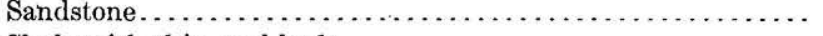 & 50 & 0 \\
\hline Shale with thin coal beds.................................... & 5 & 0 \\
\hline 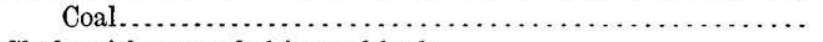 & 4 & 0 \\
\hline 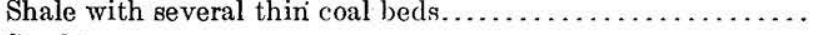 & 60 & 0 \\
\hline 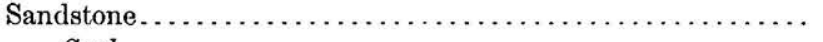 & 50 & 0 \\
\hline & & 6 \\
\hline
\end{tabular}

${ }^{1}$ At the base of this sandstone is an unconformity which cuts out the underlying coal and 20 feet or more of the shale beneath it. 


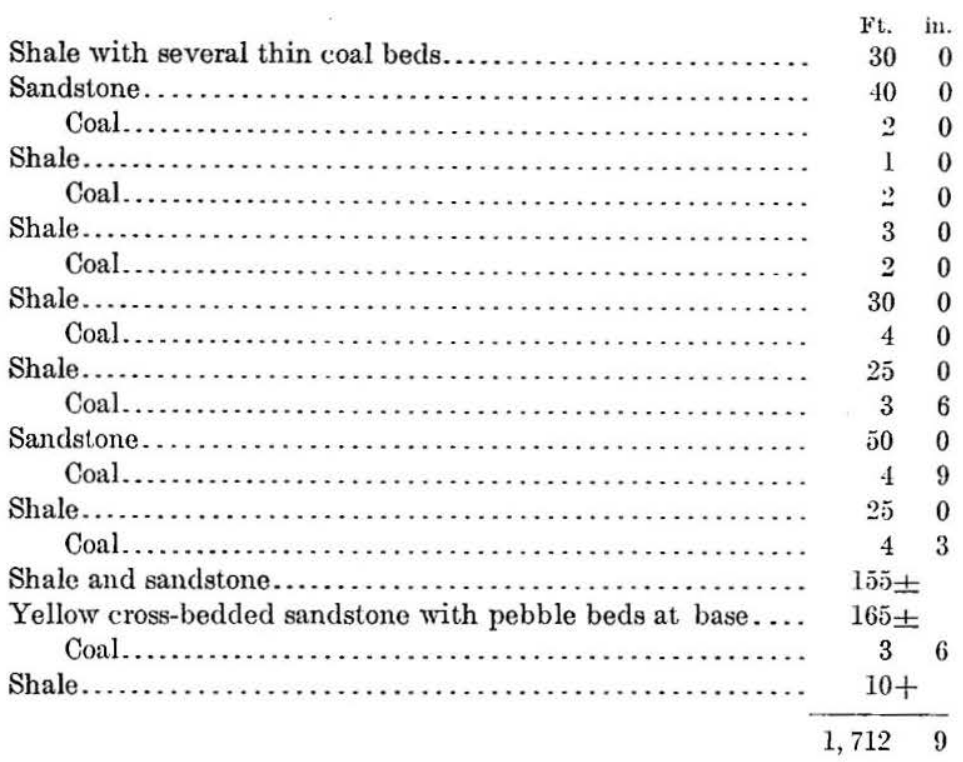

The uppermost beds in this section pass below sea level on a $2^{\circ}$ dip at a point about 3 miles south of Ninilchik. The bluffs from this point to the mouth of the creek $1 \frac{1}{2}$ miles south of Ninilchik are composed entirely of Quaternary gravel. The Tertiary beds are again exposed at the mouth of the creek, where they are horizontal and consist of clay and two or three thin coal beds. There is no evidence as to the relations of the beds on either side of this concealed interval. About a mile farther north, or just south of the mouth of the creek at Ninilchik, is an exposure of nearly horizontal sandstone. The exposure in the bluffs north of Ninilchik consists of 100 feet or more of clays and sands and several coal beds 2 or 3 feet thick. The dip is about $2^{\circ}$ south, which should carry these beds beneath the sandstone south of the town. These exposures are continuous for about 2 miles north of the town, the dip being $2^{\circ}-4^{\circ} \mathrm{S}$., which would make the thickness between 350 and 700 feet. There is an anticline 2 miles north of Ninilchik, on the north flank of which the dip is about $5^{\circ}$ for about 100 feet. The rocks are then concealed by a slide for 400 or 500 feet. North of this the rocks dip $5^{\circ} \mathrm{S}$. for a few hundred feet, then dip gently southward for about a mile, or to the cape about $3 \frac{1}{2}$ miles north of Ninilchik. Just north of this cape the dip changes from gently $\left(1^{\circ}-2^{\circ}\right)$ south to approximately horizontal, continuing thus for about a mile. For several miles farther north the beds undulate gently, the dip being probably everywhere under $1^{\circ}$ and being reversed several times. The exposures of Tertiary beds are apparently continuous as far north as it point half a mile north of Clam Gulch, where they dip northward $48591^{\circ}-$ Bull. $587-15-6$ 
at angles of $5^{\circ}-10^{\circ}$ and pass beneath the Tertiary gravels that form all the bluffs from this point to Kenai.

The Tertiary beds of the section described above, from Ninilchik to Clam Gulch, are probably largely, if not wholly, equivalent to those of the section between Ninilchik and Cape Starichkof. From Clam Gulch to Ninilchik the general dip is southward, and from Cape Starichkof to Cape Ninilchik it is northward. The sections consequently occur on the opposite sides of a syncline and presumably are approximately equivalent. The beds north of Ninilchik are not completely exposed and were not studied in detail, so that the individual strata can not be correlated with those south of Ninilchik. The data at hand afford no means of computing the thickness of the section north of Ninilchik, but it probably does not exceed 1,000 feet and is possibly only 500 or 600 feet. It doubtless contains no beds that are not represented in the section south of Ninilchik, and it is probably the general equivalent of the upper half of that section.

ISOLATED AREAS SOUTH OF KACHEMAK BAY.

The Kenai formation occupies about a quarter of a mile of the northeast shore of Port Graham, at the small embayment known as Coal Cove, which is just inside Dangerous Cape. This mass of Tertiary rocks lies between two areas of Lower Jurassic tuffs. It is uncertain whether it occupies an eroded basin in the older rocks or is a fault block. The exposures are few (see Pl. V, B, p. 22) and show neither a complete section of the Tertiary beds nor the nature of the contacts with the Jurassic rocks. The beds exposed in the scanty outcrops consist of sandstone, shale, and lignite. A section of the beds outcropping at this locality has been published by Heer ${ }^{1}$ from observations by Furuhjelm. The locality was visited by Stone and the writer in 1904. According to Stone: ${ }^{2}$

Two outcrops of coal were seen, one on the beach between tides and the other at high-tide mark, near the west end of the gravel beach. A tunnel (Pl. V, B, p. 22) driven on the coal at the latter outcrop is now caved and inaccessible. At the mouth of the tunnel there is between 8 and 9 feet of coal, some of which is good and some bony. Clay underlies the bed, and the roof is shaly sandstone. On top of the bluff, a short distance back from the beach and about in line with this tunnel, is the mouth of a large shaft. Its dump is small and shows no coal, from which it appears that sinking ended at no great depth. On the beach at the end of a log crib is the framework of a 6 by 10 foot shaft (Pl. V, $B$, p. 22), in one corner of which are hollow upright logs, which may have been pump columns. A Russian miner, who lived for many years at Seldovia and died there in May, 1904, at the age of about 95, said that he worked in this shaft. As he remembered it, the shaft was 180 feet deep and passed through five seams of coal, the first of which was about 5 feet thick, the three succeeding ones smaller, and the fifth, at the bottom of the shaft, about 9 foet thick.

\footnotetext{
1 Heer, Oswald, Flora fossilis Alaskana: Kongl. Svenska Vetenskaps- $\mathrm{A}$ kademiens IIandlingar, Tand 8, No. 4, pp. 4-5, 1859.

${ }^{2}$ Stone, R. W., Coal fields of the Kachemak Bay region: U. S. Geol. Survey Bull. 277, p. 67, 1906.
} 
A small mass of Tertiary rocks is exposed in the cliffs about $1 \frac{1}{2}$ miles northeast of Dangerous Cape. The beds are horizontal and lie in an eroded basin in the Jurassic tuffs, as shown in the accompanying sketch (fig. 1). This outcrop may be the northeast end of the mass of Tertiary rocks at the coal mine on Port Graham. The fossil leaves in lot 5671 (p. 87) came from this exposure.

Another small area of Tertiary rocks is exposed on the shore between Port Graham and Seldovia Bay at a point from 2 to 3 miles southwest of the entrance to the bay. The Tertiary beds consist of horizontal, locally indurated sands and gravels. The contacts with the Lower Jurassic tuffs that adjoin the Tertiary rocks at each end of the exposure are faults, as is shown in the accompanying sketch (fig. 2). It.is not known whether these contacts are on the same or opposite sides of the Tertiary mass, so it can not be affirmed that this is certainly a fault block, as the exposures seem at first sight to indicate. It may be that the Tertiary beds here rest upon the Jurassic rocks along one side of the mass and that only the other side is faulted. The fossil leaves in lot 6061 (p. 87) were collected

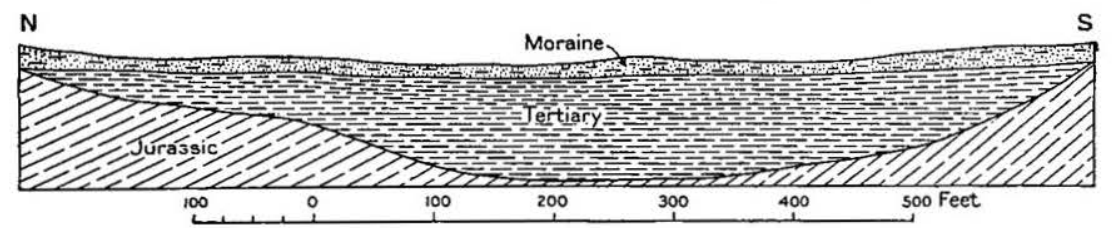

FIGURE 1.-Sketch showing relations of Tertiary to Jurassic rocks in cliffs $1 \frac{1}{2}$ miles northeast of Dangerous Cape.

from a bed of yellow sandstone interbedded with indurated gravels about midway of this exposure.

The Tertiary rocks at the locality east of Seldovia Point consist of gravel, thin beds and lenses of incoherent sandstone, and very soft shale, dipping nearly eastward at an angle of about $5^{\circ}$. They contain poorly preserved fragmentary and indeterminate plant impressions, consisting mostly of sticks and stems. These beds rest upon soft, much decomposed greenish rocks, which have no observable bedding or grain. They are probably the ancient decomposition products of schistose rocks like those at Seldovia Point. The local base of the Tertiary at this point should not be assumed, without further evidence, to be the basal bed of the Kenai formation. These beds may be the equivalent of beds that lie high in the Kenai formation or even higher than the Kenai.

\section{OTHER EXPOSURES.}

An exposure on the north bank of Kasilof River 8 miles above its mouth shows the top of a nearly horizontal bed of lignite. A thickness of 6 to 12 inches showed above the water. The river was high at the time the locality was visited and the base of the bed could not 

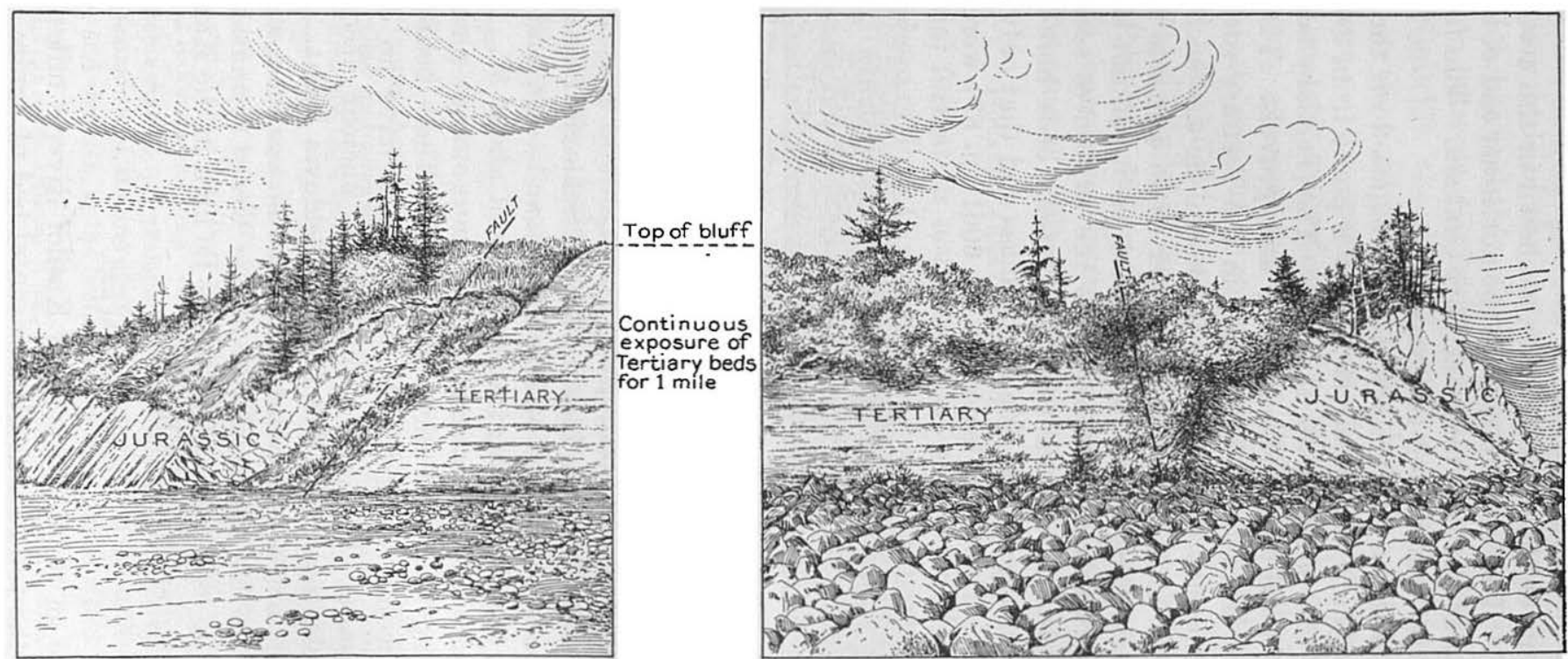

FIGURE 2.-Views showing relations of Tertiary to Jurassic rocks 2 to 3 miles southwest of Seldovia Bay. 
be seen. Soft clay shale like that of the Kenai formation of the shores of Cook Inlet is exposed at the base of the bluffs on the bends next below this.

It is reported that lignite is exposed at the base of the cliffs on the shore of Cook Inlet between Kenai and East Foreland and also in the vicinity of Point Possession.

The bluff at Point Possession consists of poorly exposed Quaternary beds. The base of the bluff is covered with sand, gravel, and soil, which make it impossible to tell whether the Quaternary deposits extend down to sea level or whether Tertiary beds compose the lower part of the bluff. About a foot below the surface of the beach is a stratum of sand containing abundant rounded pieces of lignite in sufficient amount to have been mined for local use. The abundance of the lignite at this locality indicates that the bed from which it was derived is not far distant, and it is probably at the base of the bluff.

The bluffs on the south shore of Tustumena Lake, just east of Nikolai Creek, are composed of horizontal, well-bedded, slightly indurated sand. The material is much more like the less indurated sandstone of the Kenai formation than it is like any Quaternary deposits seen on the shore of Cook Inlet. The other beds exposed on this shore of the lake, except the metamorphic rocks at its head, are of Quaternary age. Possibly some of the exposures of sand noted on the western half of the north shore are also Tertiary, but they were not observed closely enough to make certain that they are not Quaternary.

\section{FLORA AND FAUNA.}

Although a large number of species of fossil plants have been recorded from beds that are supposed to be the equivalents of the Kenai formation in various parts of Alaska, the list from the Kenai formation of the type district is rather small. The chief reason for this is probably the fact that the Tertiary rocks of the Kenai lowland are but slightly consolidated and that consequently the leaves are not well preserved and are difficult to extract and transport in good condition.

The following fossils were found near the base of the section from Anchor Point to Homer Spit, described on pages 68-74, and represent the lowest local horizon from which fossils have been obtained in this formation:

Lot 4129. Entrance to Troublesome Gulch, north side of Kachemak Bay. Collected by $\Lambda$ twood and Weaver, 1908; identified by Arthur Hollick.

Taxodium tinajorum Heer.

Salix reana Heer?

Betula prisca Ettingshausen.

Alnus kefersteini Heer.

Juglans acuminata Alex. Braun.

Juglans strozziana Gaudin.
Ulmus sorbifolia Unger.

Ulmus quadrans Goeppert.

Quercus dalli Lesquereux.

Laurus salicifolia Lesquereux?

Andromeda grayana Heer.

Diospyros lancifolia Lesquereux. 
The following were obtained from talus at the base of the Bluff Point exposure. They came from undetermined beds in the upper half of the section from Anchor Point to Homer Spit:

Lot 5821. Bluff Point, about $1 \frac{1}{2}$ miles west of Cook Inlet Coal Fields Co.'s mines. Collected by T. W. Stanton, 1904; identified by Arthur Hollick.

Salix varians Goeppert.

Salix angusta Alex. Braun.

Corylus macquarrii (Forbes) Heer.

Corylus americana fossilis Newberry.

Alnus alaskana Newberry.

Alnus corylifolia Lesquereux.

Alnus serrata Newberry.

Betula prisca Ettingshausen.
Betula brongniartii Ettingshausen.
Carpinites macrophyllus Goeppert.
Ulmus appendiculata Heer.
Ulmus braunii Heer.
Laurus primigenia Unger?
Viburnum nordenskioldii Heer?

The following species were obtained from a bed about 580 feet above the base of the section from Anchor Point to Homer Spit, as described on page 73 :

Lot No. 5820. Seven miles west of Homer, 30 feet below Cooper coal. Collected by T. W. Stanton, 1904; identified by Arthur Hollick.

Salix varians Goeppert.

| Prunus hartungi Heer.

According to Dall and Harris ${ }^{1}$ the plants from the Tertiary of Cook Inlet described by Lesquereux ${ }^{2}$ came from the 7-foot coal bed ("Bradley seam") inside Homer Spit. The horizon is probably not far from that of the preceding list. The following species were recognized by Lesquereux from this locality:

Alnus corylifolia n. sp.

Carpinus grandis Unger.

Fagus deucalionis Unger.

Quercus dallii n. sp.

Salix reana Heer.

Ulmus sorbifolia Goeppert.

Diospyros anceps Heer.

Vaccinium reticulatum Alex. Braun. Cornus orbifera Heer.

The following were obtained from a locality at about the same horizon (see p. 75):

Lot 4131 (locality 2). Near mouth of Fritz Creek, from concretionary masses. Collected by W. W. Atwood, 1906.

Taxodium tinajorum Heer.

Corylus macquarrii (Forbes) Heer.

Salix sp.

Ulmus sorbifolia Goeppert.

Vaccinium friesii Heer.

Andromeda grayana Heer.

The following were collected by R. W. Stone at or near the same locality and were identified by Arthur Hollick:

Lot 5822. Kachemak Bay, shore east of Bradley Creek. Collected by R. W. Stone, 1904.

Andromeda protogæa Unger.

| Laurus primigenia Unger.

The following represent the highest local horizon at which plants are known to have been obtained. They were collected from beds

1 Dall, W. H., and Harris, G. D., Correlation papers-Neocene: U. S. Geol. Survey Bull. 84, p. 237, 1892.

2 Lesquereux, Leo: U. S. Nat. Mus. l'roc., vol. 5, pp. 443-449, $18 \times 2$. 
at least as high as the uppermost 160 feet of the section at McNeil Creek (see p. 76):

Lot 6062. North shore of Kachemak Bay, near Eastland Creek. Collected by G. C. Martin, 1911; identified by Arthur Hollick.

Alnus or Corylus sp. | Juglans strozziana Gaudin.

The following were collected from the small detached Tertiary areas south of Kachemak Bay. Their position in the formation is not determinable.

No. G680 (5671). East shore of Cook Inlet, $1 \frac{1}{2}$ miles northeast of Dangerous Cape. Collected by U. S. Grant (see p. 83); determined by F. H. Knowlton.

Taxodium distichum miocenum Heer.

?Corylus macquariii (Forbes) Heer.

Populus sp.?

This material is very fragmentary and contains no perfect leaves-in fact, none with margin preserved. Age apparently Kenai.

No. G712 (5670). East shore Cook Inlet, three-fourths of a mile east of Seldovia Point. Collected by U. S. Grant (see p. 83); determined by F. H. Knowlton.

Consists of three or four fragments of dicotyledonous leaves but nothing determinable.

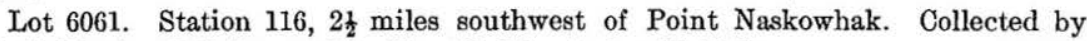
G. C. Martin, 1911 (see p. 83); identified by Arthur Hollick.

Taxodium distichum miocenum Heer.

Ulmus plurinervia Unger.

Castanea castaneæfolia (Unger) Heer.

Fagus antipcfi Heer?

Lot 3518. On beach at Coal Bay, Port Graham. Collected by G. C. Martin, 1904; identified by Arthur Hollick.

Betula prisca Ettingshausen.

The only fossils other than plants which have been found in the Kenai formation of this district are fresh-water mollusks. A small collection of poorly preserved material, obtained by the writer on the north shore of Kachemak Bay near McNeil (reek, was reported on by W. H. Dall as follows:

The Tertiary shells from the north shore of Kachemak Bay appear to be Unio athlios C. Mayer, described from the Kenai leaf beds in Heer's monograph Flora fossilis Alaskana.

Dall also says ${ }^{1}$ of the older collections from Port Graham:

The plants are all terrestrial or fresh-water species. One of the most common is a species of Trapa represented by many fruits. With them are found Unio (Margaritana) onariotis Mayer, a species probably related to Margaritana margaritifera L.; Amicola abavia Mayer; and Melania (Goniobasis?) furuhjelmi Nayer, together with elytra of a beetle described by Heer under the name of Chrysomelites alaskianus. Among the plants are both Conifera and broad-leaved trees, the total number of species amounting to forty-four. The deposit appears to have been formed at the bottom of a lake. The leaf-bearing strota crop out below the level of the sea and are accessible only at extreme low water. 
$\mathrm{He}$ also says, ${ }^{1}$ regarding the beds at Kasilof, that an Anodon ( $A$. athlios Mayer) was found at this locality in making Furuhjelm's collection.

CORRELATION OF THE KENAI FLORA.

By ARTHUR HOLLICK.

The flora of the Kenai formation included in the collections from localities at and near Kachemak Bay, as identified by Lesquereux, Knowlton, and the writer, is represented by about 50 species, all of which are enumerated in the appended list. It consists chiefly of species that belong to well-known Tertiary horizons in the Old World and to the so-called "Arctic Miocene" of the north circumpolar region, the latter now generally recognized as Eocene in age. Inasmuch, however, as about one-third of the species identified have never been recorded from the United States and as only a few of the others are characteristic of any well-defined geologic formation, it is difficult to correlate the beds in which they occur in Alaska with any formation in the States. For example, Alnus serrata Newberry, Corylus americana fossilis Newberry, Corylus macquarrii (Forbes) Heer, Betula prisca Ettingshausen, Viburnum nordenskioldi Heer, and Taxodium distichum miocenum Heer, occur in the Fort Union formation, but only the first three may be regarded as typical of that formation. Carpinus grandis Unger, Ulmus braunii Heer, Salix angusta Alex. Braun, and Vaccinium reticulatum Alex. Braun are recorded from strata in the United States that are recognized as Oligocene or Miocene in age, but all of them are associated in Alaska and elsewhere in the far North with species characteristic of the "Arctic Miocene" or Eocene.

Possibly when the flora of the Kenai formation from other Alaskan localities has been completely identified and determined a more exact or restricted correlation may be made, but from an analysis of the flora from the type section alone we would hardly be justified in restricting it to any narrower limit than is included in the term upper Eocene.

\section{Fossil plants of the Kenai formation.}

1. Alnus alaskana Newberry.

2. Alnus corylifolia Lesquereux.

3. Alnus kefersteini Heer.

4. Alnus serrata Newberry.

5. Andromeda grayana Heer.

6. Andromeda protogæa Unger.

7. Betula brongniartii Ettingshausen.

8. Betula prisca Ettingshausen.

9. Carpinites macrophyllus Goeppert.

10. Carpinus grandis Unger.

11. Castanea castaneæfolia (Unger) Heer.

12. Cornus orbifera Heer.
13. Corylus americana fossilis Newberry.

14. Corylus macquarrii (Forbes) Heer.

15. Diospyros anceps Heer.

16. Diospyros lancifolia Lesquereux.

17. Fagus antipofi Heer.

18. Fagus deucalionis Unger.

19. Juglans acuminata $\Lambda$ lex. Braun.

20. Juglans strozziana Gaudin.

21. Laurus primigenia Unger?

22. Laurus salicifolia Lesquereux?

23. Prunus hartungi Heer.

24. Quercus dalli Lesquereux. 
25. Rhamnus brevifolius Alex. Braun.

26. Salix abbreviata Goeppert.

27. Salix angusta Alex. Braun.

28. Salix lingulata Goeppert.

29. Salix reana Heer.

30. Salix varians Goeppert.

31. Taxodium distichum miocenum Heer.

32. Taxodium tinajorum Heer.
33. Ulmus appendiculata Heer.

34. Ulmus braunii Heer.

35. Ulmus plurinervia Unger.

36. Ulmus quadrana Goeppert.

37. Ulmus sorbifolia Unger.

38. Vaccinium friesii Heer.

39. Vaccinium reticulatum Alex. Braun.

40. Viburnum nordenskiöldi Heer?

In addition to the above there are several undescribed species of the genera Rhamnus, Diospyros or Nyssa, Vaccinium, and Salix and possibly four other species of genera not yet determined.

QUATERNARY DEPOSITS.

GLACIAL AND TERRACE GRAVELS.

DISTRIBUTION AND CHARACTER.

Quaternary gravels cover the greater part of the Kenai lowland (see Pl. III), the only known exposures of other deposits being in cliffs and stream beds. These gravels consist partly of strictly glacial deposits, such as till and other morainic material, and partly of water-laid sands and gravels, which are largely if not wholly of glacial derivation but which were deposited in their present position by waters that were not necessarily of strictly glacial origin.

These deposits cover all the Kenai lowland except probably an area in the hills north of Kachemak Bay. The eastern boundary of the gravel-covered area is practically coincident with the western front of the Kenai Mountains, but the altitude to which the gravels rise against the mountain front varies from place to place, as will be described below.

A close inspection of the map (Pl. II) will show that the 800-foot contour on the north side of the valley of Little Indian Creek, where it leaves the mountains, indicates a sharp ridge pointing into the valley. A similar feature oceurs at the same eleration and in the same relative position in the valley of Big Indian River. These and other topographic features are believed to represent fragments of the lateral moraine of the former Cook Inlet glacier at a time when it covered the northern part of the Kenai lowland and may be considered as marking the local eastern edge of the gravel sheet of the Kenai lowland.

The eastern limit of the gravels on Skilak Lake is at a place where the high hills leave the shore about 7 miles above the outlet. The vertical limit of the gravels in the Skilak Valley was not determined accurately, but is probably on the 1,000 to 1,200 foot bench, 4 miles south and southeast of Caribou Island. 
The gravels and terraces are well developed on the shores of the Tustumena Lake. Stratified gravels form the bluffs of the north wall of the gorge of Indian Creek to an altitude of at least 800 feet above the lake, and up to this height there are well-developed benches, one of them forming the site of Lake Emma, which lies $2 \frac{1}{2}$ miles east of the mouth of Indian Creek. The benches probably extend higher than this, and the gravels certainly do, but the benches were not so distinctly marked as at lower altitudes. Probably both the benches and the gravels, certainly the gravels, extend up to an altitude of 1,000 feet.

The 2,800-foot hill east of Lake Emma is composed of massive graywacke and has been thoroughly glaciated, exhibiting abundant glacially eroded surfaces to its very summit, and near the summit lie perched bowlders. Transported material, however, is very scarce above timber line, which locally is at an altitude of about 1,500 feet, and stratified gravels certainly do not occur above timber line on this hill.

A view from the summit of this hill showed that the surface of the Cook Inlet lowland rises eastward with a gentle and fairly uniform slope, which seems to start below or on the terraces and to reach an altitude of 2,500 or 2,800 feet along the mountain front. This surface was not examined close at hand, so it is impossible to state how high the gravels rise on it.

The cliff on the north shore of Kachemak Bay, $1 \frac{1}{2}$ miles southwest of McNeil Creek, is capped by about 40 feet of gravel, the top of which stands at an elevation of about 200 feet. The cliffs at places northeast of this point have no gravel capping, a fact which indicates that the terraces are locally absent and that, if the highland area north of Kachemak Bay was overridden by a glacier, no great amount of glacial detritus was deposited.

The character of the Quaternary gravels is well shown by the exposures in the cliffs on the east shore of Cook Inlet, a typical section of which is as follows:

Section of cliff on cast shore of Cook Inlet.

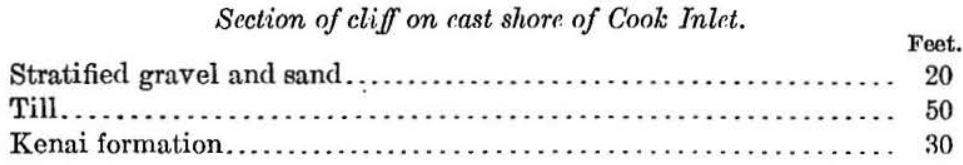

The upper half of the bluff $9 \frac{1}{2}$ miles south of Anchor Point, shown on Plate XXI, $B$, consists of till underlain by the Kenai formation and probably overlain by a thin capping of stratified gravels, above which lies a bed of peat.

The following sketch (fig. 3) shows the general character of the outcrops in the vicinity of Kenai, where the Tertiary beds are not exposed. The difference between the underlying nonstratified glacial 
deposits and the overlying stratified deposits was recognized by Moffit, ${ }^{1}$ who describes the occurrence as follows:

At Kenai the bluff on which the town was built is between 75 and 100 feet high. A bluish-black silt containing some gravel forms the lower two-thirds of the bluff and is overlain by sands and gravels. This upper third is often firmly cemented with iron oxide and resembles a weathered ferruginous sandstone. The contact of silts and sands is distinctly shown by the outline of the bluff, for the silts stand at a higher angle than the sands (fig. 3), by the difference in color, and by a line of springs whose waters have streaked the silts with iron stains. It is evident that the ground water seeps down through sands and gravels to the less porous silts and then follows the contact until it finally emerges insprings. Granite forms a large proportion of the beach gravel and also furnishes most of the numerous bowldersstrewn along the shore. These angular bowlders or blocks reach diameters as great as 8 to 10 feet and are evidently not all derived from the same source, since they represent a variety of granites. Similar granites are found in the valley of the Sushitna but

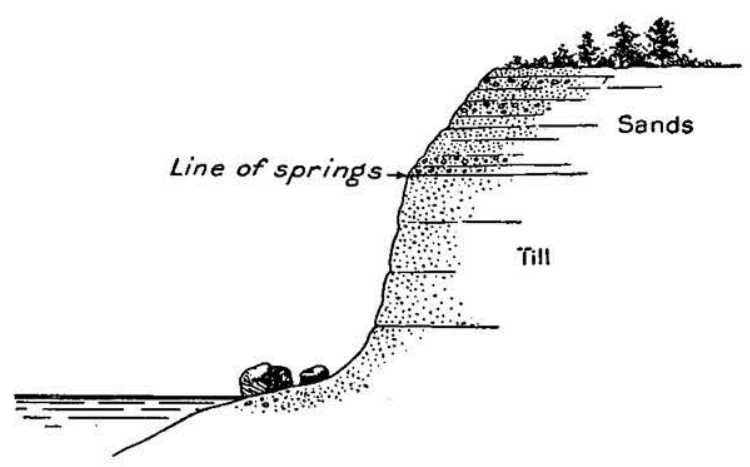

Figure 3.-Diagrammatic sketch showing relations of stratified sands and till at Kenai. (After Moffit.) are not known in the Kenai Mountains. It is therefore probable that their source must be sought somewhere to the north rather than on the peninsula.

The strictly glacial deposits which, as in the section given above, are usually found at the base of the bluffs, are not exclusively morainic, but are locally interbedded with stratified sands and gravels, as is shown in the following sections:

Section of Quaternary deposits about $2 \frac{3}{2}$ miles south of Anchor Point.

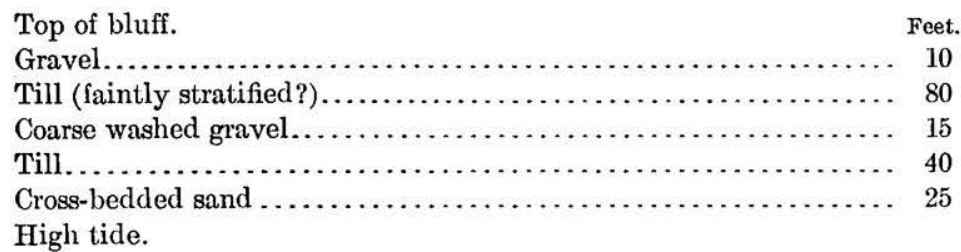

Section of Quaternary deposits $3 \frac{2}{5}$ miles northwest of Homer.

Till .............................................. 60

Stratified gravel.................................... 50

The conditions represented in these two sections are exceptional. In most places the stratified gravels overlie the till and should be regarded as outwash deposits formed after the retreat of the ice.

\footnotetext{
${ }^{1}$ Momit, F. II., Gold fields of the Turnagain Arm region: U. S. Geol. Survey Bull. 277, p. 27,1896
} 
Kasilof River flows between terraced banks which are composed mainly of stratified gravel. A few exposures of till were noted.

The deposits exposed along Kenai River below Skilak Lake consist entirely of till, gravel, and sand. Most of them are terrace sands and gravels, which at many places overlie the glacial deposits. The terraces are well developed and extend up to a general elevation of about 40 feet above the river. Higher terraces probably lie farther back from the river but were not observed from its banks.

Kenai River from the second to the fifth mile above Skilak Lake flows in a winding course over a bed of large bowlders, passing alternately through straight, open reaches and sharp bends. On one or both banks of the bends there are exposures of rock. There are five such rocky bends, of which the first, fourth, and fifth, counted from below, are canyons with rocky walls. In this stretch the river has left its former westerly course and has cut across a gravel-floored pass, for at the upper canyon abandoned channels about 100 feet above the present river level were seen on the west side of the stream.

At the mouth of Cottonwood Creek on the north shore of Kachemak Bay there are some interesting features which were not observed elsewhere. The view given in Plate XXI, $A$, shows the general conditions at this point. The mouth of Cottonwood Creek is at the right among the trees. The horizontal beds at the left of the picture are the shales of the Kenai formation. The burned bed about 30 feet above high-tide level is the remains of a bed of lignite $3 \frac{1}{2}$ feet thick, which is burned for 500 feet along the bluff from Cottonwood Creek. The oblique line that truncates the Kenai beds from the upper left corner to the lower right corner of the picture is the west wall of the older valley of Cottonwood Creek. This older valley is now partly filled with deposits, the exposure shown in the picture exhibiting the following section:

Section of Quaternary deposits at mouth of Cottonwood Creek.

Soil................................................. Feet. 1

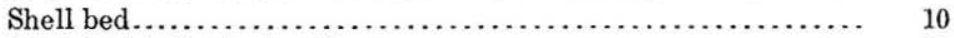

Gravel with lignite bowlders........................... 20

Pebbles of burned clay extend from the intersection of the burned bed with the wall of the older valley of Cottonwood Creek down the surface of this wall into the lower part of the gravel bed.

The horizontal shell bed on top of the gravel is about 10 feet thick and contains a goodly variety of marine species. A small collection of shells was made from this bed by the writer and has been reported on by W. H. Dall as follows:

The Pleistocene fossils from this locality are all species now found in the region, as follows: Chrysodomus liratus Martyn, Cardium corbis Martyn, Serripes grönlandicus Gmelin, Mytilus californianus Conrad, Spisula alaskana Dall, Mya japonica Jay. 


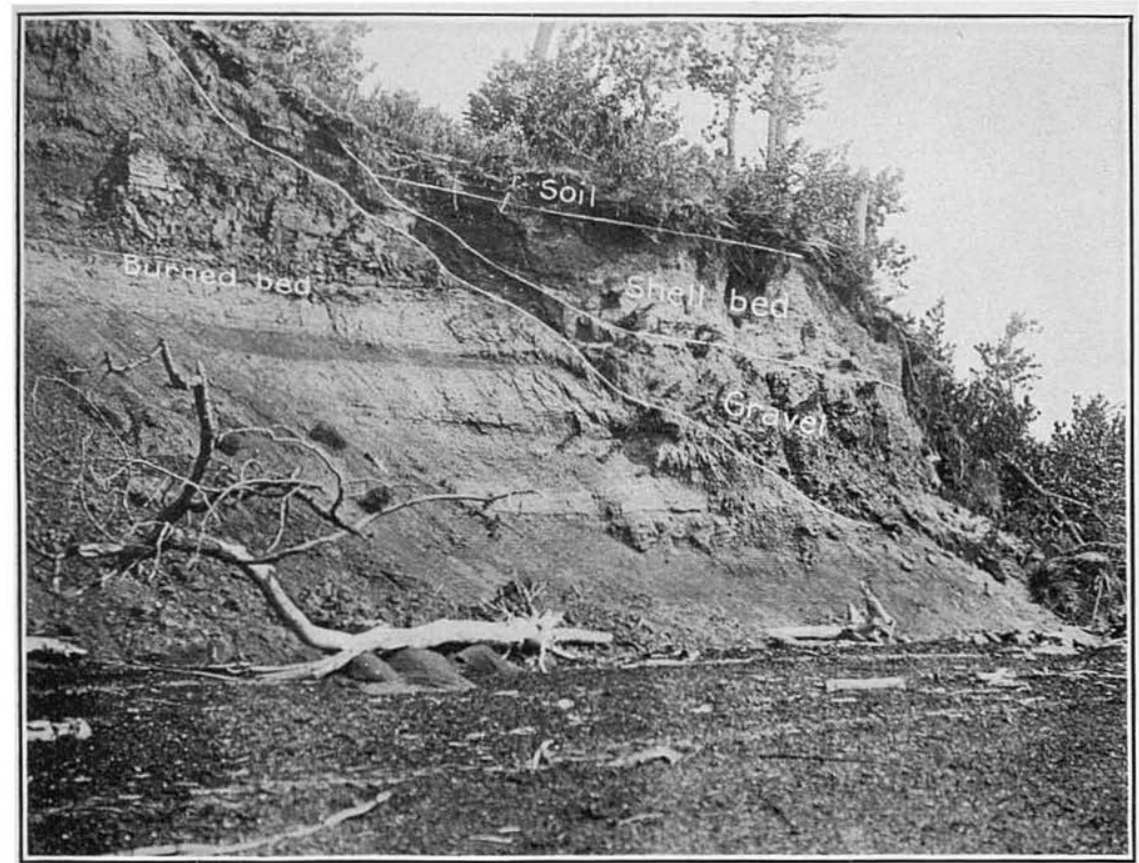

A. KENAI FORMATION AND QUATERNARY DEPOSITS, WITH SHELL BED, AT MOUTH OF COTTONWOOD CREEK.

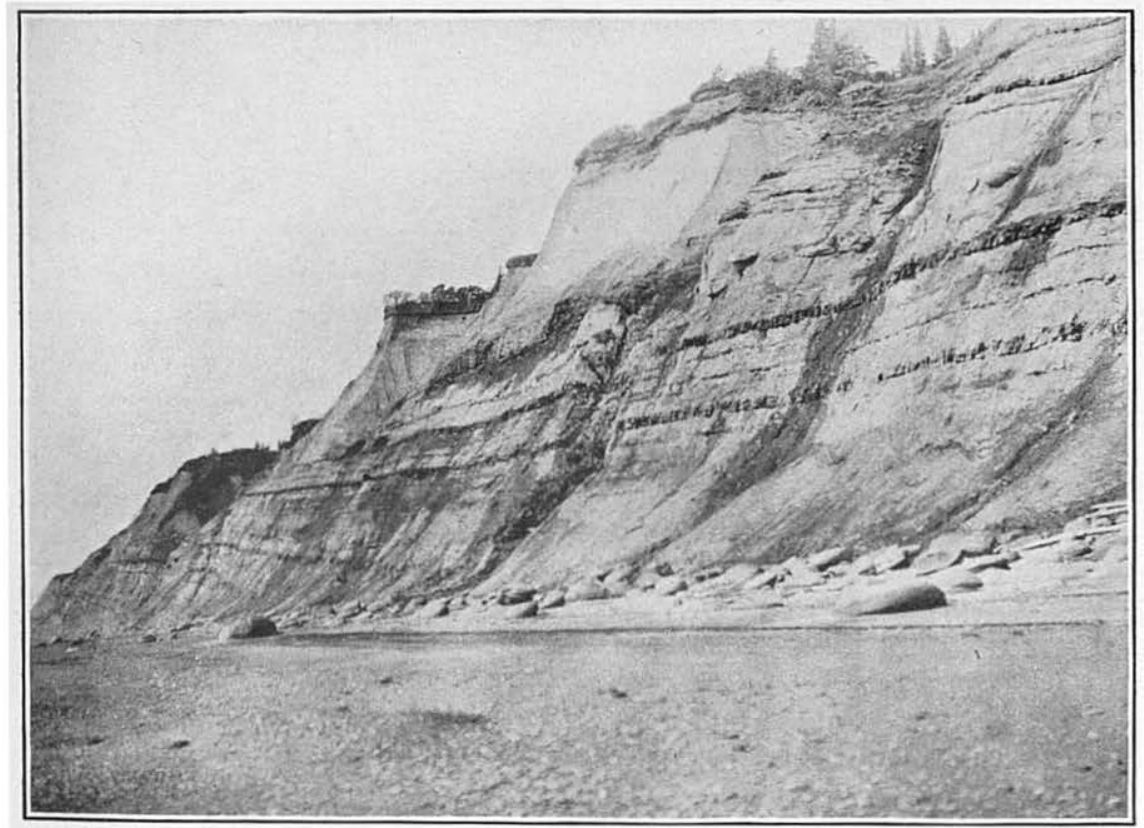

B. KENAI FORMATION, WITH LIGNITE BEDS, OVERLAIN BY QUATERNARY GRAVELS 9! MILES SOUTH OF ANCHOR POINT, 


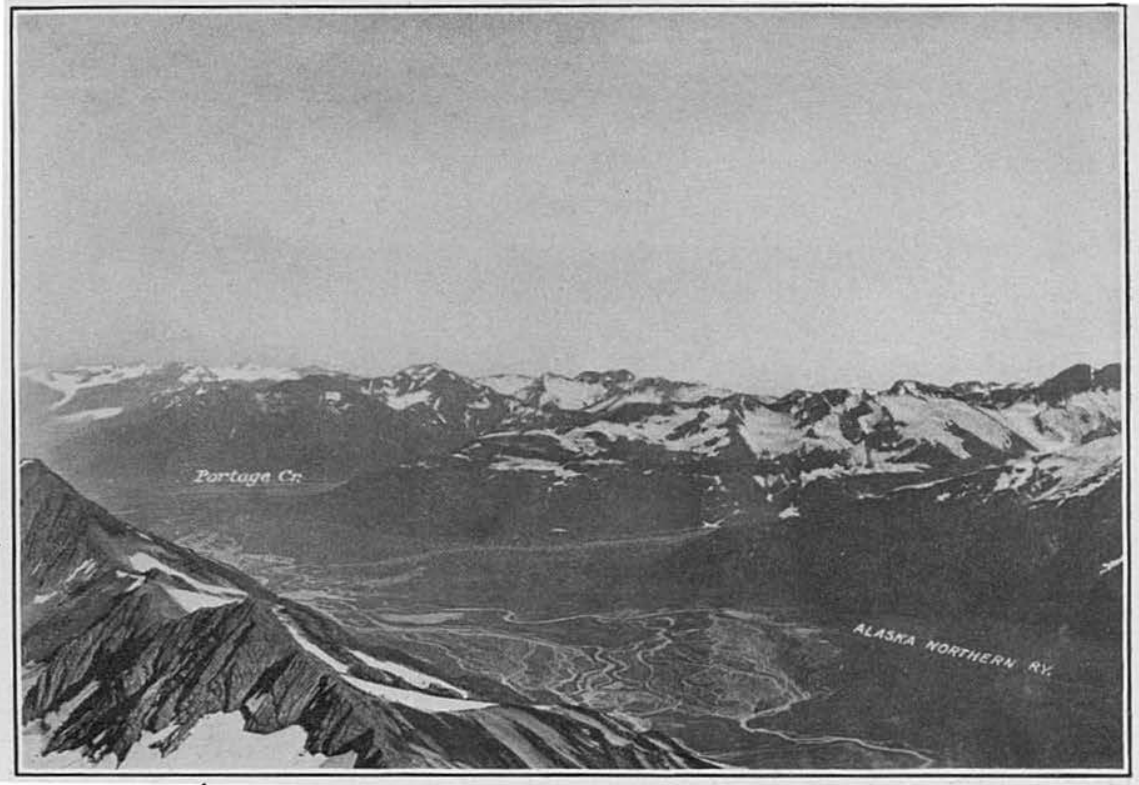

A. BRAIDED DRAINAGE ON THE ALLUVIAL PLAIN OF PLACER RIVER.

This stream is actively aggrading, and its flood plain therefore has little timber and is in many places bare of vegetation.

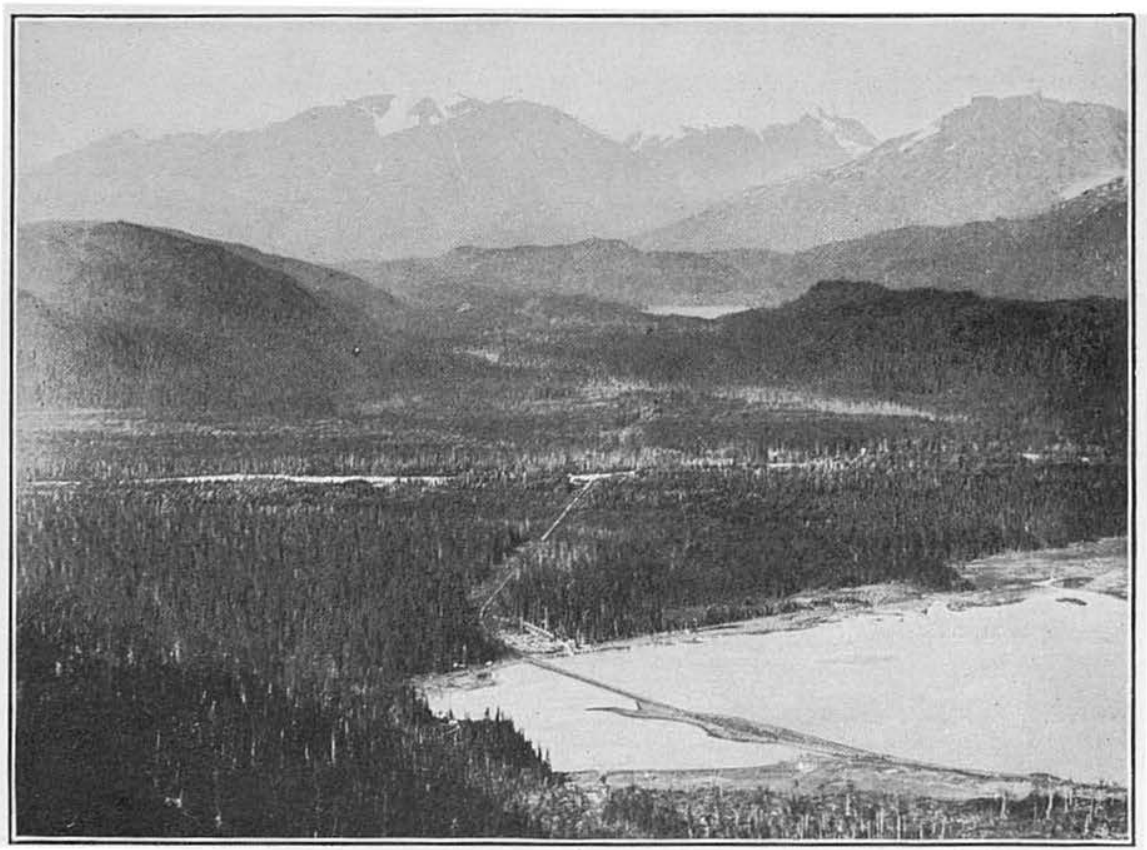

B. ALLUVIAL PLAIN OF RESURRECTION RIVER AND SALMON CREEK AT THE HEAD OF RESURRECTION BAY.

A dense growth of spruce covers the flats and the lower mountain slopes. 
The shell bed is overlain by a considerable thickness of soil, in which large cottonwood trees are growing. The size of these trees indicates the age of the deposits beneath them, and their upright position shows that there has probably been no recent violent slumping of the ground on which they stand.

The origin of the shell bed is uncertain. It may be either a natural deposit or a kitchen midden. The natural origin is suggested by its position, its thickness, its apparently natural occurrence in what appears to be an elevated terrace, and by its apparent antiquity, which is indicated by the presence of a well-developed soil and of old trees on top of it. On the other hand, the possibility that it is a kitchen midden is suggested by the fact that the only identified species are edible, by the complex series of events which its natural origin seems to imply, by the presence of a human bone that is possibly interbedded with the shells, and by the presence of burned clay at the base of the gravels that underlie it. The available evidence points more strongly toward the kitchen midden origin of the shell bed, but this origin can not be proved without further field investigation.

What was regarded in the field as a fossil bone was also obtained at this locality, on which the following report was submitted by A. Hrdlička:

The bone submitted for examination is an ordinary and, according to all indications, a very recent human fibula. The bone has lost scarcely any organic matter and, on the whole, is such as one would expect to recover from a burial 10 to 20 years old. There is absolutely no possibility that it is even a few centuries old, not to say Pleistocene.

This appears to show that the bone is not fossil. In this case it only remains to offer a possible explanation of its occurrence. It was found loosely embedded in the shell bed, about halfway up its face. The thickness of the shell bed, the presence of a considerable accumulation of soil on top of it, and the size of the living and dead trees show that the shell bed was deposited many years ago. If the bone is only a few years old it could not havo been deposited contemporaneously with the shells. The depth beneath the soil at which the bone lay when it was found, the apparently undisturbed condition of the shells and soil that overlay the bone, the apparent absence of other bones, and the fact that deep burial is not a local custom all make it highly improbable that the bone was intentionally buried where it was found. It is possible that the bone came into the position in which it was found by falling from the surface of the ground into a crack opened by the caving of the face of the bluff. The interval that elapsed between the time when the bone fell into the crack and the time when the present face of the bluft dereloped along that crack was long enough to allow the material in which the 
bone was embedded to adhere more or less firmly to the unbroken face of the shell bed. The occurrence of the bone can thus be regarded as accidental and as having no bearing on the age or the conditions of deposition of the shell bed. It must, however, be remembered that decay is slow in the climate of Alaska, and the bone should therefore be compared with bones of northern extinct mammals of known antiquity rather than with human bones preserved in other climates.

The most important feature to be noted at this locality is the relation of the burned lignite bed to the Quaternary deposits. Many years, and possibly many hundred years, have elapsed, and many geologic events have taken place since the lignite was burned. The relative date of the burning of the lignite bed is shown approximately below:

1. Deposition of the Kenai formation (Eocene).

2. Uplift of the Kenai formation to a height above its present altitude.

3. Maximum local glaciation (late Pleistocene or post-Pleistocene).

4. Cutting of the valley of Cottonwood Creek.

5. Burning of the lignite bed.

6. Partial filling of the valley with stream wash, in which fragments of burned clay were incorporated.

7. Submergence to a level at least 30 feet below present high tide followed by deposition of the shell bed in marine waters, and uplift in one or more stages to present position, or-

7. Human habitation and accumulation of the shells in their present position on a terrace.

8. Growth of the cottonwood trees.

The burning of the lignite bed probably occurred at least several centuries ago and may have closely followed the retreat of the former Cook Inlet Glacier. This was possibly prior to the local human occupation. As thunderstorms are rare in this district it is difficult to determine the cause of the burning. Spontaneous combustion is a possible cause, but burning coal beds are generally if not absolutely restricted to regions and times of human habitation or to regions of frequent and violent thunderstorms. It may be necessary to assume either that the climatic conditions have changed and that there were thunderstorms when the lignite bed was burned, or that man lived on Kachemak Bay not only when the shell bed was being formed but at an earlier time, when the valley of Cottonwood Creek was first cut, an event which, even if it closely followed the retreat of the Cook Inlet Glacier, may not have occurred until long after the close of Pleistocene time.

\section{CONDITIONS OF DEPOSITION.}

The Quaternary deposits of the Kenai lowland are chiefly if not wholly of glacial origin and were evidently laid down at about the time of the maximum glaciation of the district. They consist of a 
basal and, in general, thick sheet of till (Pl. XXI, $B$, p. 92), in most places overlain by stratified sands and gravels whose surface is well terraced. These deposits extend throughout the greater part of the Kenai lowland and are strikingly different from the glacial deposits of the Kenai Mountains. The glacial deposits of the mountains are very thin and irregular and are closely related in volume and character to the local topographic and lithologic features. They are the characteristic products of a system of local actively eroding alpine glaciers. The glacial deposits of the lowland are such as would be laid down near the lower end of a large stagnant ice mass whose load had been derived from many sources and had been carried far, finely ground, and deposited not only by the melting away of the glacier itself but by the action of streams that were bringing large amounts of glacial detritus from more or less distant points.

At its maximum extension the Cook Inlet Glacier apparently covered the entire floor of the Cook Inlet Valley from the Kenai Mountains on the east to the Chigmit Mountains on the west except, probably, an area north of Kachemak Bay. It received many large tributaries from the Kenai Mountains, which were then occupied by an extensive system of partly coalescent alpine glaciers. The presence of these tributaries, which flowed out from the highlands with various but mostly high grades, obscures the geologic record of the position of the margin of the main Cook Inlet Glacier, but it evidently stood across the valleys draining into Chickaloon Bay at an altitude of at least 900 or 1,000 feet. The gravels on the mountain front between Skilak and Tustumena lakes, which stand at an elevation above 1,000 feet, may have been derived from the large glacial tributaries that came down these valleys and consequently do not prove that the Cook Inlet Glacier ever stood so high in this place.

The gravels north of Bluff Point and near McNeil Creek lie at an elevation of about 240 feet, and this may have been the local vertical limit of the ice. If this level is correct there was an extensive area in the hills north of Kachemak Bay and southeast of Tustumena Lake which the glacier did not override.

The crests of the sharp ridges (see Pl. II) that lie parallel to the north shore of Kachemak Bay at the mouths of Falls and Fox creeks, part of which are about 600 feet high and which consist of poorly consolidated, almost horizontal Tertiary beds, perhaps mark the lateral margin of the Kachemak Bay tributary glacier. These ridges were probably formed along streams that became intrenched on the lateral margin of the glacier. The Kachemak Glacier probably joined the Cook Inlet Glacier near the present mouth of Kachemak Bay.

No evidence is available as to the extreme southern position reached by the front of the ice. The glacier may never have reached the present mouth of Cook Inlet, or it may have passed down through 
Shelikof Strait, or it may have divided near Barren Islands, one tongue overriding Portlock Bank. It need not necessarily be assumed, even if it reached the farthest limit suggested, that the glacier terminated in the sea, for both Portlock Bank and Shelikof Strait carry in general less than 100 fathoms of water, and there are many reasons to suspect that vertical movements much exceeding this amount may have occurred in various parts of southern Alaska since the time of maximum glaciation. ${ }^{1}$

The stratified and well-terraced gravels and sands that overlie the till in the exposures on the east shore of Cook Inlet are mainly outwash deposits laid down during the melting back of the Cook Inlet Glacier. Some of the higher gravels, such as those near the head of Tustumena Lake, may have been deposited in marginal lakes formed by the temporary damming of tributary valleys by the main ice sheet or on the margin of the main glacier and above a tributary glacier. The terraces probably do not mark former marine or estuarine strand lines, for the terrace deposits so well exposed on the east shore of Cook Inlet do not contain marine fossils. The material is, moreover, so coarse that it must have been deposited either in running water or at the very mouths of swiftly flowing streams.

A rather long halt during the melting back of the ice is believed to be indicated by the southeast course of Kenai River for 10 miles below Moose River. (See Pl. II.) This course of the river was probably established by marginal drainage along the side of the Cook Inlet Glacier. It is significant that this course of the river is parallel to and nearly in line with the lower end of Tustumena Lake, the water of which is held in by a mass of coarse morainic material that occurs some distance below its outlet. During such halts as this large quantities of outwash material were deposited over the lowlands between the margin of the ice and the base of the mountains. A still later halt is probably marked by the notable constriction in Cook Inlet between East and West forelands.

The fact that the bottom of Cook Inlet is almost flat and the water very shallow suggests that the present bottom of Cook Inlet was at sea level at the time the ice melted away, for it is otherwise difficult to understand why Cook Inlet was not completely filled with outwash material.

The origin of the high-lying gravels of the mountains is easily understood and calls for little detailed comment. The mountain valleys were filled by actively eroding alpine glaciers. Many of these were tributary to the Cook Inlet Glacier; others discharged eastward into Prince William Sound or southward into the sea. The mountains were thus, in general, the site of glacial erosion and not of glacial deposition, so that glacial deposits were not laid down in the moun-

1 Knopf, Adolph, The Eagle River region, southeastern Alaska: U. S. Geol. Survey Bull. 502, p. 13, 1912. 
tains until the glaciers had waned to comparatively insignificant proportions. During their later halts the glaciers built moraines and formed deposits of various kinds. These deposits, however, are small and their features show that they are of essentially local origin.

\section{RECENT ALLUVIAL DEPOSITS.}

The recent alluvial deposits include the flood plain and delta deposits of such streams as are doing constructive work, the outwash from glaciers, and the beach deposits now forming on the shores of Cook Inlet and of the larger lakes. (See Pl. III; in pocket.)

River deposits have been formed (see PI. XXII, p. 93) in notable amount only near the mouths of large streams which discharge into tidal or lacustrine waters. Most of the streams of this district have steep grades and are actively cutting down their beds so that their areas of deposition are confined practically to their deltas.

Under ordinary conditions beach deposits would form very rapidly on the shores of Cook Inlet. All the larger streams are bringing down tremendous loads of sediment, and the material in the cliffs, which consists chiefly of unconsolidated Quaternary deposits and very slightly consolidated Tertiary sands and clays, is an easy prey to the waves. The insignificance of the volume of shore deposits is evidently due to the great range of the tides. Deposition is certainly going on rapidly in Cook Inlet, but the bulk of it occurs below low tide and therefore makes no contribution to the beaches, spits, and other features of the shore line.

\section{INTRUSIVE ROCKS.}

Small dikes formed of several kinds of rock are numerous in the area south of Kachemak Bay. (See Pl. III.) Most of them occur in the slates and graywackes, but a few were observed in the Triassic limestone and tuff and in the Jurassic tuffs. No dikes were noted in the cherts except at Halibut Cove, or in the ellipsoidal lavas. None occur in the Tertiary rocks.

A dike of hornblende-andesite porphyry cuts the slate and graywacke and associated chert on the south shore of Port Graham, a mile below the head of the bay. (See Pl. XV, A, p. 46.) This rock (11 Mn 14) is of holocrystalline porphyritic texture and is composed of much altered acidic labradorite, somewhat leached hornblende, and a little iron oxide. A 50-foot dike of identical rock outcrops on the north shore of the bay directly opposite this locality.

Many small dikes cut the slate and graywacke on the shore between Jakolof and Tutka bays. One of these (11 Mn 131) was identified as a hornblende diabase, composed of labradorite laths in a groundmass consisting of basaltic hornblende, augite, quartz, $48891^{\circ}-$ Bull. $587-15-7$ 
chlorite, and brown glass. Light-colored dikes of the same general appearance were seen also on the shore of Tutka Bay.

A dike of rhyolite porphyry about 200 feet wide is intruded into the graywacke on the south shore of Sadie Cove, near its entrance. This is the largest dike noted in the district. A thin section of this rock (11 Mn 164a) shows a holocrystalline porphyritic texture and very fine grain. Orthoclase occurs both as phenocrysts and in the groundmass, being in part altered to muscovite and kaolin. The other constituents include subordinate amounts of plagioclase, which is largely altered to calcite, and some muscovite, which is in part secondary. A large amount of material that is apparently identical in character with this rhyolite porphyry lies in the bed of the creek three-quarters of a mile inside the entrance of the cove. It appears to have come from an outcrop at an elevation of about 1,500 feet.

The outcrops on the shores of the small bay 3 miles north of Grewingk Glacier include many dikes, which are apparently rhyolitic. The intruded rocks include some chert but are mainly indeterminate basic rocks which are somewhat sheared.

A dike of andesite porphyry, 20 feet wide, cuts the graywacke that is exposed in the canyon a mile south of Aurora, or about 4 miles north of Grewingk Glacier. When examined under the microscope this rock (11 Mn 214) proved to be of holocrystalline porphyritic texture and to be composed of plagioclase (andesine to acidic labradorite in zonal growths), quartz (which is not plentiful), a few grains of orthoclase, biotite (which is largely altered to chlorite), and some magnetite and apatite.

An outcrop of gabbro, a rock that has not been noted elsewhere in this region, was described by Becker ${ }^{1}$ from near Grewingk Glacier as follows:

A gabbro occurs at the southerly bounding wall of the Grewingk Glacier, on Kachemak Bay. The structure is granular, and the ferromagnesian silicates are olivine and augite. The former predominates, but is largely converted into serpentine. The feldspars in this rock are so clouded with decomposition products as not to be capable of identification. Doubtless fresher specimens might have been collected in the neighborhood. These were taken at the glacier wall on account of the relations of the glacier to the disintegration of the mass.

The Triassic cherts are notably free from dikes at most localities, although several intrusive masses were seen at Halibut Cove. Emerson $^{2}$ says of them:

The series is cut by a group of conspicuous light-colored porphyry dikes, standing nearly vertical, parallel, and $20,10,50$, and 60 feet in width, respectively. Under the microscope these dikes proved to be much altered dacite porphyries, showing phenocrysts of embayed quartz, acid plagioclase, much altered to calcite and kaolin,

1 Becker, G. F., Reconnaissance of the gold fields of southern Alaska, with some notes on general geology: U.S. Geol. Survey Eighteenth Ann. Rept., pt. 3, p. 47, 1898.

2 Emerson, B. K., General geology: Alaska, vol. 4, p. 26, Harriman Alaska Expedition, 1904. 


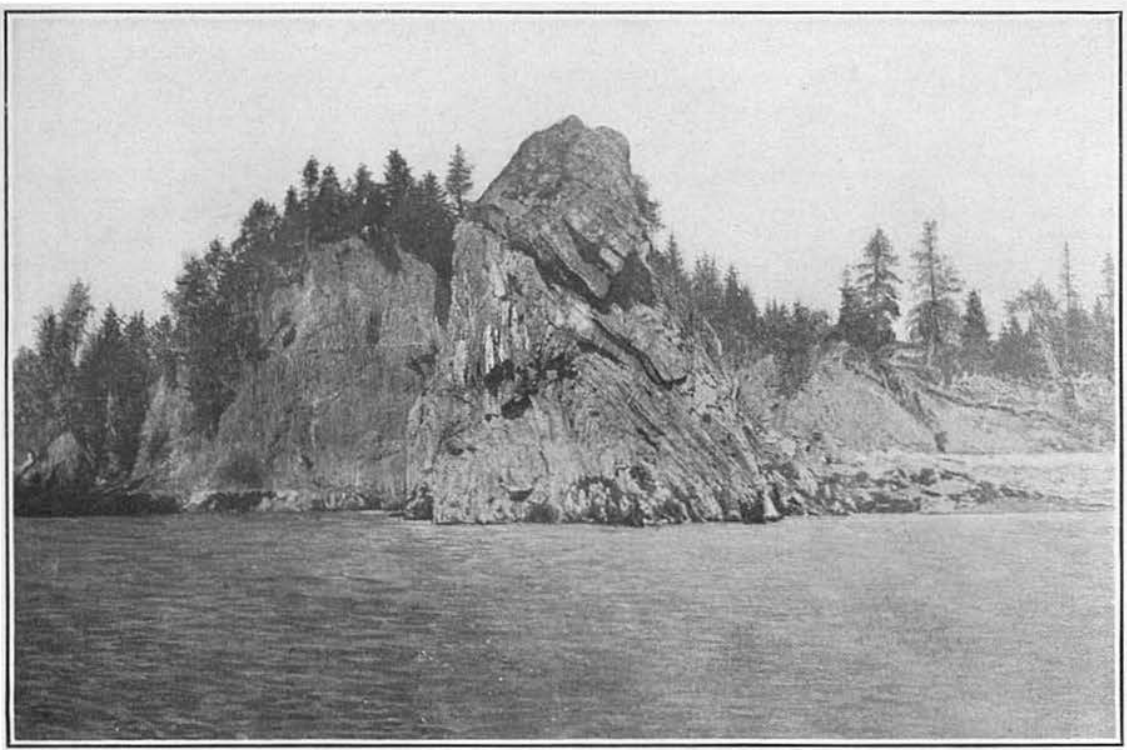

A. OVERTURNED ANTICLINE ON EAST SHORE OF SELDOVIA BAY.

The strata involved in the fold are of quartzitic schist.

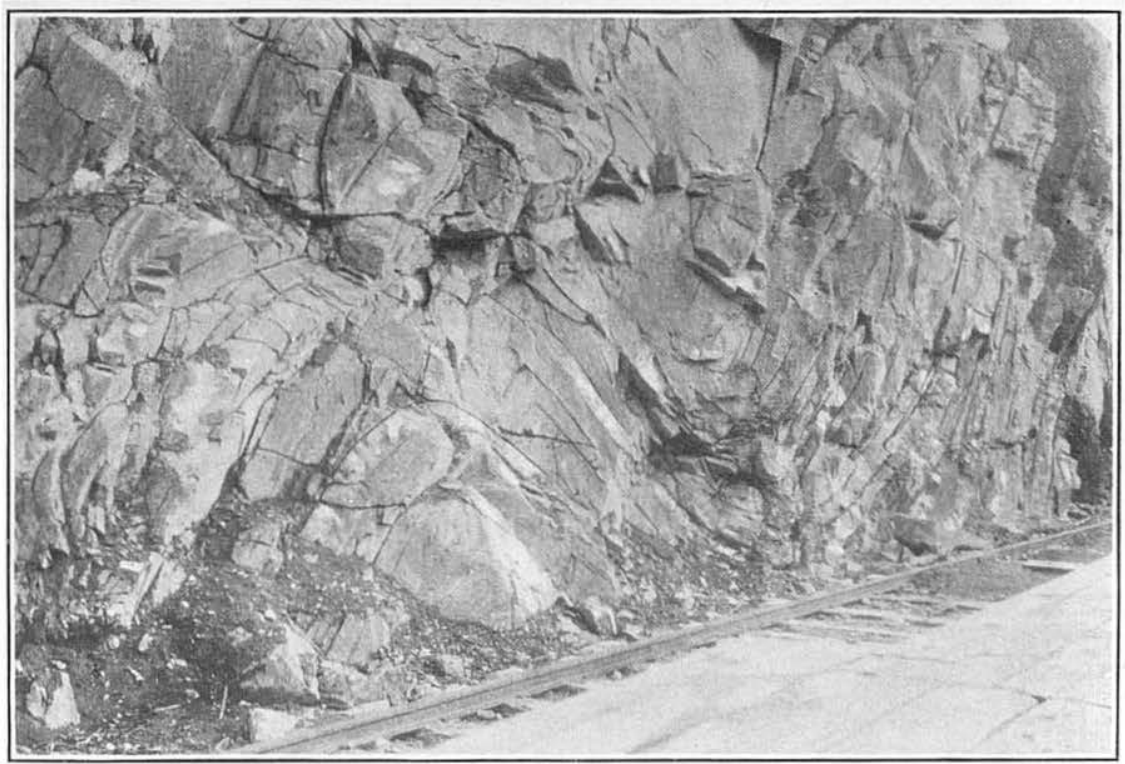

13. FOLDS IN MASSIVE GRAYWACKE IN RAILROAD CUT AT KERN CREEK. 


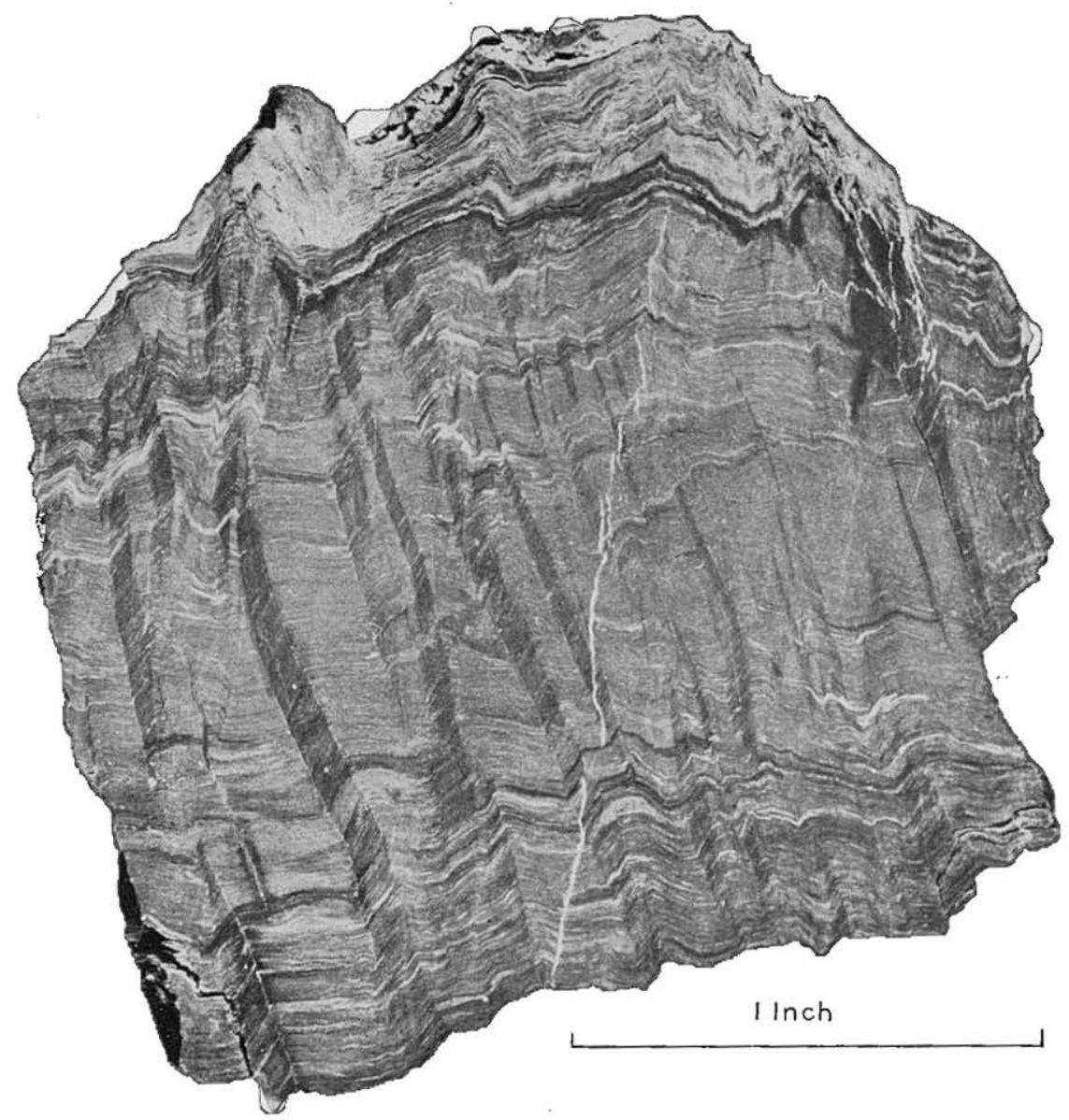

A. POLISHED SURFACE OF CRUMPLED SLATE SHOWING MINUTE FOLDING AND DEVELOPMENT OF JOINTS AND CLEAVAGE.

The strong contrasts in shade were brought out by treating the polished surface with chemicals. Specimen from railroad cut 46.84 miles from Seward.

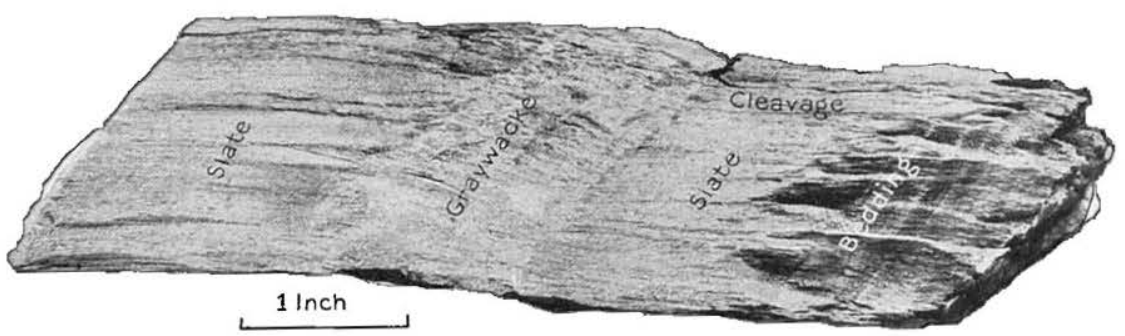

B. CLEAVAG $\subseteq$ AND BEDDING IN SLATE AND GRAYWACKE. Specimen from outlet of Kenai Lake. 
and occasional orthoclase in a granular to granophyric groundmass of quartz and feldspar. Chlorite is sparingly present throughout the rock, but the bisilicate from which it was derived could not be determined. The dikes are quite coarsely porphyritic near their centers, but toward the contact with the cherts become almost aphanitic. The cherts are whitened for a few inches from the contact but not otherwise altered.

A rock that outcrops on the southern shore of Port Graham at the contact of the Jurassic and Triassic beds, but of indeterminate field relations (see p. 58), may be either an intrusive mass or a flow. It appears to overlie the Upper Triassic limestone but may be a dike intruded along the contact of the Upper Triassic and Lower Jurassic beds. When examined under the microscope this rock (11 Mn 51B) proved to be a quartz gabbro porphyrite of granoporphyritic texture. The recognizable constituents include labradorite, augite, and quartz, with some secondary pyrite and chlorite.

Several small dikes of undetermined petrographic character were observed in the Upper Triassic limestone and tuff and in the Lower Jurassic tuffs in the vicinity of Port Graham and Seldovia Bay.

Moffit has described ${ }^{1}$ the dikes cutting the Lower Jurassic tuffs near Seldovia as follows:

Diabase dikes.-A small diabase dike, about 3 feet thick, was found cutting Jurassic tuffs at a point 2 miles west of the entrance to Seldovia Bay. It is fine grained, grayish green in color, and is made up of lath-shaped plagioclase feldspars, the interspaces being filled chiefly with green chloritic material. Small, nearly colorless crystals of pyroxene are also present, as is considerable magnetite. Occasional small spherulitic feldspar aggregates are seen scattered on the surface of a hand specimen.

Rhyolite dikes.-Only one small dike of rhyolitic rock was observed, about 2 inches thick, and this also occurred in the same formation. The hand specimen shows a dark, cryptocrystalline, almost glassy groundmass, thickly strewn with small angular fragments of quartz and feldspar. Under the microscope both quartz and feldspar are seen occasionally to have their crystal forms well developed. Orthoclase and acid plagioclase are present but somewhat altered.

\section{STRUCTURE.}

Kenai Peninsula consists of two distinct structural provinces, the boundary between them being coincident with the boundary between the Kenai Mountains and the Kenai lowlands. The structure of the Kenai Mountains is highly complex, the rocks being everywhere intricately folded. The structure of the Kenai lowland is simple, the rocks being in most places nearly horizontal. The structural relations of the rocks along the boundary between these two provinces are not known.

The rocks of the Kenai Mountains, all of which have been involved in complex folding, include the crystalline schists of Seldovia Bay, the various slates and graywackes, the presumably Triassic lavas

${ }^{1}$ Moffit, F. H., Gold fields of the Turnagain Arm region: U. S. Geol. Survey Bull. 277, p. 24, 1906. 


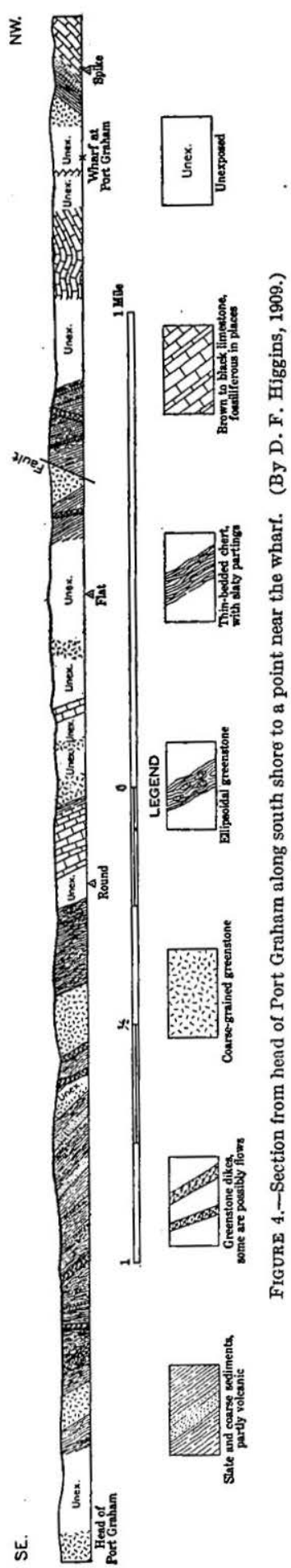

and cherts, the Upper Triassic limestones and tuffs, the Lower Jurassic tuffs, and a small and unimportant part of the Tertiary beds. The complexity of the structure varies approximately with the age of the rocks, the crystalline schists being highly metamorphosed and flexed in closely appressed isoclinal folds (see PI. XXIII $A$, p. 98) of several orders of magnitude. The slates and graywackes are less metamorphosed, having been nowhere altered beyond the development of slaty cleavage, but are very highly and complexly folded. (See Pl. XXIV, $A$, p. 99.) The character of the folding varies from place to place and possibly varies with the age of the different slates but is in general considerably less complex than that of the schists. (See Pl. XXIII, B.) The Triassic (?) lavas and cherts show no indication of the development of secondary structure analogous to cleavage or schistosity but are everywhere highly folded. The thin-bedded strata, such as the cherts, are minutely crumpled. (See Pl.XVII,p.60.) The Upper Triassic limestones and tuffs are more gently folded than the chert and lava, show no minute crumpling, and are entirely unmetamorphosed. The Lower Jurassic tuffs are steeply but not complexly folded, monoclinal dips and normal faults being their characteristic structural features (see $\mathrm{Pl}$. $\mathrm{XVI}, B$, p. 52), and are not altered. The Tertiary beds that occur within the area of the older rocks of the mountains are apparently involved in no structural disturbances other than faulting and are but poorly indurated. No marked geographic variation in structural complexity other than that dependent primarily upon the age of the rocks has been noted within the province.

It is not possible to describe the structure of the Kenai Mountains in a detailed systematic manner, but certain structural details which have been noted are worthy of description. 
The general dip of the slates and graywackes south of Kachemak Bay is apparently to the northwest. The dip is certainly in this direction on the upper half of Seldovia Bay, where the section recorded on page 45 was measured, and on Jakolof Bay. The same dip seems to prevail, although the evidence is not so clear on Port Graham (see

N.

$\mathrm{S}$.

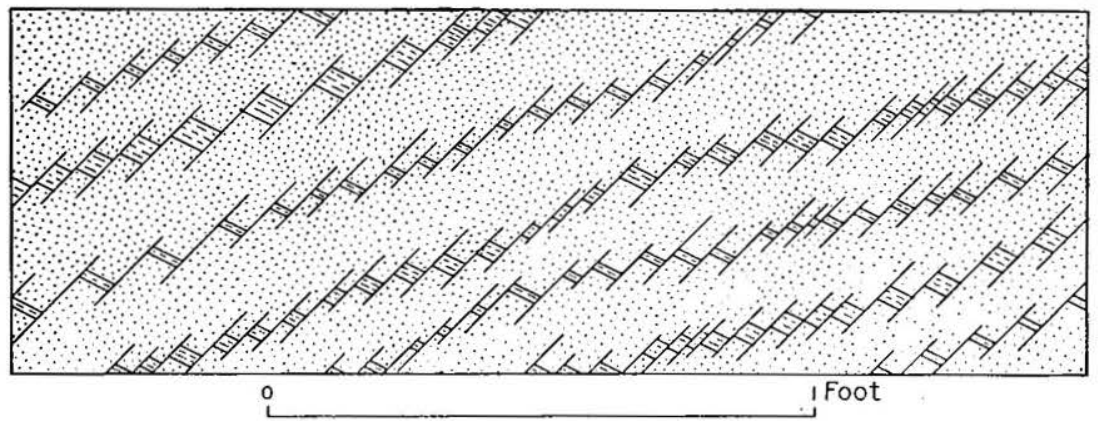

FIGURE 5.-Sketeh showing minor faulting in graywacke on north shore of Sadie Cove.

fig. 4), Tutka Bay, and Sadie Cove. This apparent northwest dip is in harmony with the general sequence of older formations toward the southeast and younger ones toward the northwest, and is parallel to the undoubted northwest dip of the Lower Jurassic rocks and to the presumably general northwest dip of the Upper Triassic rocks of Port Graham.

The uncertainty of structural generalization based on single outcrops or on poor exposures is shown by the accompanying sketch (fig. 5), which was drawn from an outcrop near the head of Sadie Cove. The actual dip at this point is $25^{\circ}$ S., but the beds are cut by a. multitude of minute parallel faults, each normal, having a hade of $45^{\circ} \mathrm{N}$. and a downthrow of 1 inch

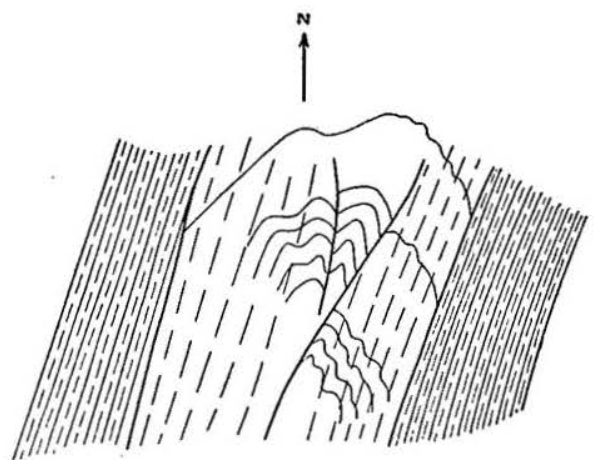

0

Foot

Figure 6.-Ground plan showing struetural details and relation of bedding (fine, solid lines) to cleavage (dash lines) on west shore of Kenai Lake $2 \frac{1}{2}$ miles northwest of Porcupine Island. (Faults are indicated by heavy solid lines.) or less to the north. One effect of the faulting is to produce parallel lines of displaced fragments of the harder beds, which make the rock appear to dip $20^{\circ} \mathrm{N}$. Another effect is to decrease the apparent thickness, the beds represented in the sketch having an apparent thickness of 1.14 feet, wherens the actual thickness is 2.31 feet. 
An exposure on the west shore of Kenai Lake exhibits a detail of the crumpling in the midst of an oitcrop in which the general bedding and cleavage are parallel. (See fig. 6.) This outcrop is probably typical of the general structure in the vicinity of Kenai Lake. This structure is believed to be characterized by closely appressed isoclinal folds, in which much of the minor crumpling has been flattened out and obliterated by the final pressure and obscured by the

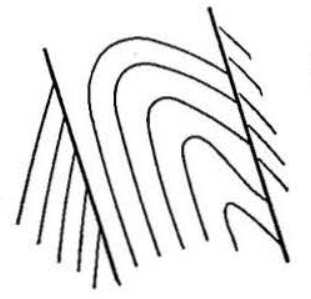

w.

20 Feet

FIGURE 7.-Sketch showing overturned anticlines and fanlts in railroad cut at mile $22 \frac{1}{2}$, east shore of Kenai Lake.

development of the cleavage. (See $\mathrm{Pl} . \mathrm{XV}, B, \mathrm{p}$. 46.)

The accompanying sketches (figs. 7 and 8) show that the rocks on the east shore of Kenai Lake are involved in overE. turned folds and faults.

The apparently monoclinal structure of tho rocks of the Kenai Mountains is probably far less simple than it seems. If seen in a poorer exposure the close folding and faulting shown in figure 9 could easily be mistaken for simple monoclinal dip.

An outcrop in the railroad cut at mile 34 consists of thin alternating beds of graywacke and slate, with jointing well developed in the graywacke and cleavage in the slate. The bedding and cleavage are at most places coincident or at low angles with each other. The cleavage is best developed where parallel or nearly parallel with the bedding. The accompanying sketch (fig. 10) shows a gently inclined double fracture passing into a flexure and probably passing into a fault in the opposite direction, beyond the limits of the exposure.

Minute crumpling is a characteristic feature of the Triassic (?) cherts. The intricacy of this crumpling and the

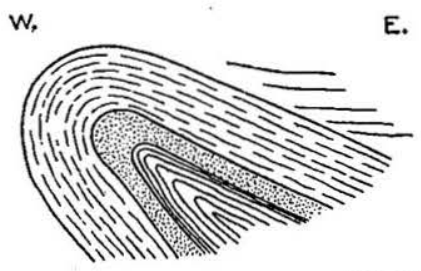

5 Feet

FIGURE 8.-Sketch showing overturned anticline in railroad cut at mile 223 , east shore of Kenai Lake. stratigraphic uniformity of the beds make it impossible to determine the major character of the folding. The nature of the minute crumpling is well illustrated on Plate XVII (p. 60). An apparently unusual feature of the structure of the cherts is the presence of nearly horizontal parallel fault planes that truncate the contorted folds, as shown in figure 11.

The structure of the Kenai lowland is very simple. Broad, gentle folds, in which the dips are in general from $1^{\circ}$ to $5^{\circ}$, are characteristic structural features. A few small normal faults were observed, one of which is shown in figure 12 , but there is no reason to believe that 


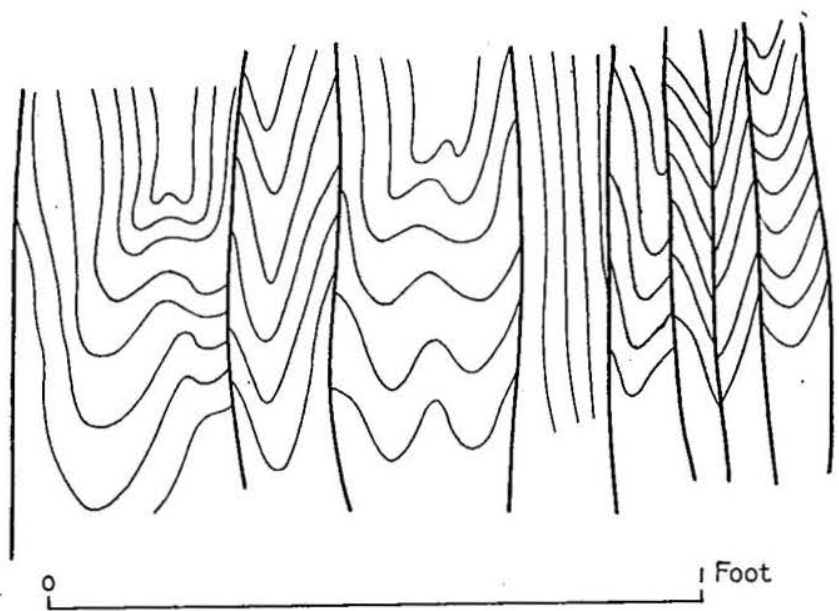

FraURE 9.-Sketch showing close folding and faulting in banded slates on wagon road near headwaters of Bench Creek, 9 miles north of mile 34 .

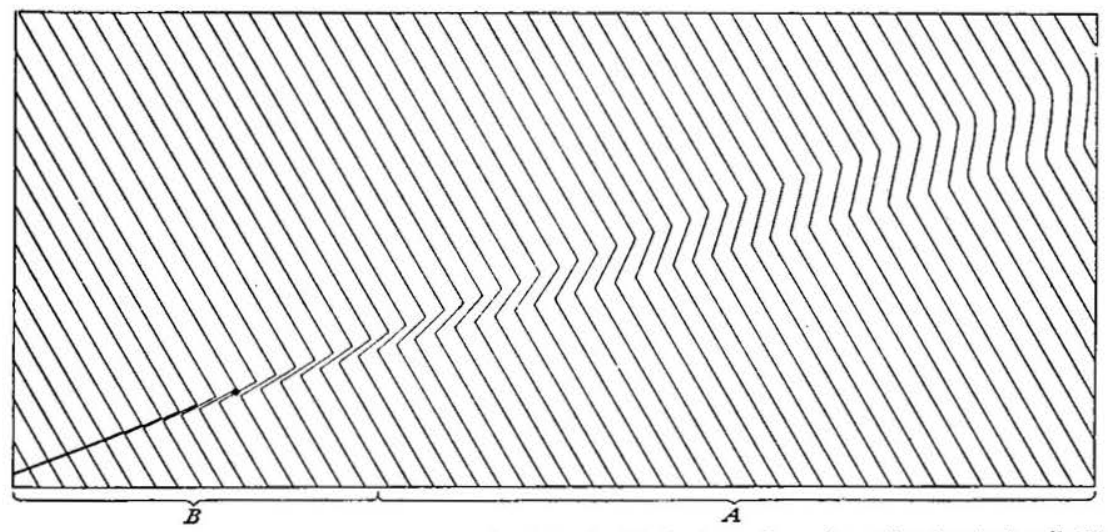

FIGURE 10.-A, Sketch showing flexure passing into double-fracture planes in railroad cut at mile 34 ; $B$, Hypothetical extension of sketch, showing fractures passing into a fault.
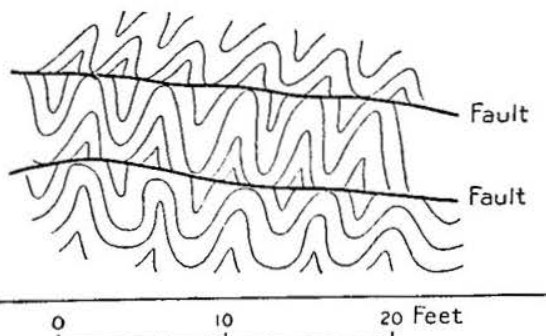

FIGURE 11.-Contorted and faulted chert on south shore of Kachemak Bay near west end of Ismailof Island. The thickness of the ch:ert beds is greatly exaggerated. 
faulting is an important element of the structure. The restriction of the exposures to the shore line makes it impossible to outline the broader structural features with certainty. The dip on the north shore of Kachemak Bay is northward (see Pl. XX, p. 74), the strike being in general east, but varying considerably and, because of the low dip, being difficult to read with accuracy. The general dip from Homer Spit to Anchor Point is eastward, but several small folds

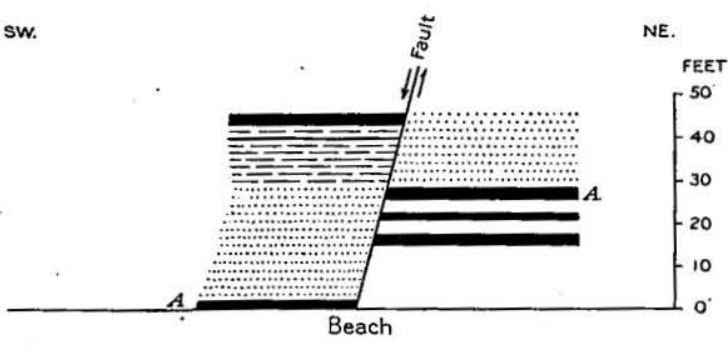

Figure 12.-Fault in Kenai formation on north shore of Kachemak Bay three-fourths of a mile northeast of Falls Creek. (p. 69) were noted (see Pl. XVIII, p. 68). The dip from the first exposures north of Anchor Point to the mouth of the creek $1 \frac{1}{2}$ miles south of Ninilchik is northward at angles ranging from $1^{\circ}$ to $9^{\circ}$ and probably av-

eraging a little less than $3^{\circ}$. The dip from Ninilchik to Clam Gulch is in general southward at angles of less than $2^{\circ}$, although several local reversals and steeper dips have been noted. (See p. 81.) The structure in the area north of Clam Gulch and east of the shore of Cook Inlet is entirely unknown, for there are practically no exposures of bedrock in this area.

\section{MINERAL RESOURCES.}

COAL.

\section{DISTRIBUTION.}

The coal deposits of Kenai Peninsula are restricted to beds of lignite in the Kenai formation. (See Pl. III.) The largest known area of coal land lies on the east shore of Cook Inlet north of Kachemak Bay and south of the Kasilof Valley. The entire Kenai lowland is probably underlain by the Kenai formation and may be coal bearing, but there are no known exposures of pre-Quaternary rocks back from the shore except the single outcrop on Kasilof River, described on page 83. The cliffs on the shore of Cook Inlet north of Clam Gulch contain only Quaternary deposits except as reported at two localities between Kenai and Point Possession. There is consequently no positive evidence either that the Kenai formation actually does underlie the lowland area north of Kasilof River or that the coal beds persist into this area. It is also doubtful whether the coal beds, if present, are near enough to the surface to be workable.

The small detached area of the Kenai formation on the north shore of Port Graham is coal bearing ( $\mathrm{Pl}$. V, $B, \mathrm{p} .22$ ), and coal has also been 
reported in several of the similar areas along the shore between Port Graham and Nubble Point.

The section from Anchor Point to Homer Spit, described on pages 68-74 (see section, Pl. XVIII, p. 68), contains 855 feet of strata in which there are eight lignite beds from 3 to $4 \frac{1}{2}$ feet thick, aggregating 26 feet of lignite. The uppermost 230 feet of this section probably overlaps on the section from Homer Spit to the head of Kachemak Bay, which, as given on pages 74-79, contains 1,252 feet of strata. (See section, Pl. XX, p. 74.) This section contains fourteen beds of lignite from 3 to 7 feet thick, aggregating 62 feet of lignite. The entire section from Anchor Point to the head of Kachemak Bay thus includes 1,880 feet of strata, containing 88 feet of lignite in beds 3 to 7 feet thick. The exposures north of Anchor Point include the section from a point 3 miles north of Cape Starichkof to a point 3 miles south of Ninilchik, given on pages 79-81, which is 1,712 feet thick and contains eleven beds of lignite from 3 to 5 feet thick, aggregating $45 \frac{1}{2}$ feet of lignite. Detailed sections of the coal beds are given in the stratigraphic sections of the Kenai formation on pages 69-81.

These sections show that there is certainly an enormous amount of fuel in this district. No estimates of the quantity arailable for mining are given because some factors, especially the thickness of the beds and the areal extent of the coal-bearing rocks below the Quaternary gravels, are so uncertain that any such estimates would be subject to possible correction of at least several hundred per cent. The amount of minable coal is certainly far in excess of any probable local demand that may arise within several centuries.

The geologic structure of the main coal field is simple, dips being low and faults practically absent, and is favorable to cheap mining, but the comparatively slight degree of induration of the rocks will probably be unfavorable to cheap and easy mining.

\section{CHARACTER.}

The coal of Kenai Peninsula is all lignitic. It varies in color from black to brown, is of a woody texture, and like all other lignites it checks and cracks on drying. The brown color and the more evident woody texture of the coal east of McNeil Creek give the impression that it is more lignitic, and hence of lower grade, than the coal west of this point. It is not safe to assume that such is the case, and that the easternmost and higher beds are less completely coalified than the lower beds, for the change is not gradational and can not be explained by any known difference in the character of sedimentation, by any great difference in age, or by the difference in load. The writer believes that the apparent dissimilarity is not really as great as it seems, and is essentially the result of weathering. The coal west of McNeil Creek is known chiefly from exposures near the base 
of the cliffs. (See Pl. XIX, $B$, p. 72.) These cliffs are subject to the almost continual attack of strong surf and are consequently receding rapidly. The coal-bearing beds in these cliffs are in most places overlain by glacial gravels (see Pl. XXI, $B$, p. 92), which have protected the underlying beds from deep weathering and which carry water-bearing beds, the outflow from which keeps the cliff faces continually wet and thus protects the coal. The coal east of McNeil Creek is known chiefly from outcrops high in the cliffs. The cliffs here are subject to the attack of waves less strong than those on Cook Inlet and on the lower part of Kachemak Bay, for the tidal flats here are broad and the waves reach the cliffs only at the highest water. The cliffs are therefore receding more slowly than those west of McNeil Creek. The coal beds have consequently been longer exposed to the action of weathering, whereas the less weathered beds at the base of the cliffs are at most places concealed by talus. The coal-bearing beds are, moreover, not overlain by glacial gravels and are therefore more deeply weathered.

The composition and the heating value of the coal are shown in the following table of analyses and calorimeter tests:

Analyses of Cook Inlet coals.

[First five samples collected by W. W. Atwood; analysis by F. M. Stanton, U. S. Geological Survey; last seven samples collected by R. W. Stone; analysis by W. T. Schaller, U. S. Geological Survey.]

Samples as received.

\begin{tabular}{|c|c|c|c|c|c|c|c|c|c|c|c|c|}
\hline \multirow{2}{*}{$\begin{array}{c}\text { Sam- } \\
\text { ple. } \\
\text { No. }\end{array}$} & \multicolumn{5}{|c|}{ Proximate analysis. } & \multicolumn{5}{|c|}{ Ultimate analysis. } & \multicolumn{2}{|c|}{ Calorific value. } \\
\hline & $\begin{array}{c}\text { Loss } \\
\text { on air } \\
\text { drying. }\end{array}$ & $\begin{array}{l}\text { Mois- } \\
\text { ture. }\end{array}$ & $\begin{array}{c}\text { Volatile } \\
\text { com- } \\
\text { bus- } \\
\text { tible. }\end{array}$ & $\begin{array}{c}\text { Fixed } \\
\text { carbon. }\end{array}$ & Ash. & $\begin{array}{c}\text { Sul- } \\
\text { phur. }\end{array}$ & $\begin{array}{c}\text { Hydro- } \\
\text { gen. }\end{array}$ & Carbon. & $\begin{array}{c}\text { Nitro- } \\
\text { gen. }\end{array}$ & $\begin{array}{l}\text { Oxy- } \\
\text { gen. }\end{array}$ & $\begin{array}{l}\text { Calo- } \\
\text { ries. }\end{array}$ & $\begin{array}{c}\text { British } \\
\text { thermsl } \\
\text { units. }\end{array}$ \\
\hline $\begin{array}{l}4458 . . \\
4457 . \\
4429 . \\
4426 . . \\
4432 . . \\
3 \ldots \ldots \\
4 \ldots \ldots \\
7 \ldots \ldots \\
8 \ldots \ldots \\
9 \ldots \ldots \\
10 \ldots . \\
x \ldots . .\end{array}$ & $\begin{array}{r}8.20 \\
7.00 \\
9.40 \\
19.40 \\
7.50 \\
(a) \\
(a) \\
a a \\
a \\
(a) \\
(a) \\
(a)\end{array}$ & $\begin{array}{l}19.96 \\
18.12 \\
18.59 \\
28.06 \\
19.95 \\
20.87 \\
19.26 \\
19.22 \\
18.92 \\
21.54 \\
19.29 \\
16.87\end{array}$ & $\begin{array}{l}38.73 \\
42.77 \\
36.13 \\
33.51 \\
35.88 \\
40.71 \\
43.95 \\
41.22 \\
37.62 \\
39.10 \\
40.31 \\
37.48\end{array}$ & $\begin{array}{l}32.46 \\
23.61 \\
34.92 \\
32.81 \\
29.18 \\
33.29 \\
28.74 \\
31.96 \\
28.59 \\
30.26 \\
33.11 \\
39.12\end{array}$ & $\begin{array}{r}8.85 \\
15.50 \\
10.36 \\
5.62 \\
14.99 \\
5.13 \\
8.05 \\
7.60 \\
14.87 \\
9.10 \\
7.29 \\
6.53\end{array}$ & $\begin{array}{l}0.52 \\
.43 \\
.34 \\
.19 \\
.41 \\
.36 \\
.32 \\
.38 \\
.46 \\
.34 \\
.27 \\
.39\end{array}$ & $\begin{array}{r}5.81 \\
5.51 \\
5.81 \\
6.45 \\
5.82 \\
\cdots \cdots \cdots \\
\cdots \cdots \cdots \\
\cdots \cdots \cdots\end{array}$ & $\begin{array}{r}49.53 \\
44.77 \\
49.08 \\
45.61 \\
44.55 \\
\cdots \cdots \cdots\end{array}$ & \begin{tabular}{r}
0.92 \\
.88 \\
1.14 \\
.85 \\
.97 \\
$\cdots . .$. \\
\hdashline$\ldots .$. \\
\hdashline$\ldots .$. \\
$\cdots$
\end{tabular} & $\begin{array}{l}34.37 \\
32.91 \\
33.27 \\
41.28 \\
33.26 \\
\ldots \ldots \ldots . \\
\ldots \ldots \ldots \\
\ldots \ldots \ldots \\
\ldots \ldots \ldots \\
\ldots \ldots \ldots\end{array}$ & $\begin{array}{r}4,885 \\
4,386 \\
4,749 \\
4,340 \\
4,474 \\
\cdots \ldots \ldots . \\
\cdots \ldots \ldots \ldots \\
\ldots \ldots \ldots\end{array}$ & 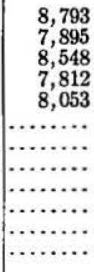 \\
\hline
\end{tabular}

4458. North shore of Port Graham.

a Not determined.

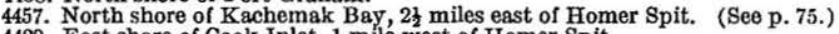

4429. East shore of Cook Inlet, 1 mile west of Homer Spit.

4426. East shore of Cook Inlet, $\frac{3}{2}$ mile west of D iamond Creek and $8 \frac{1}{2}$ miles southeast of Anchor Point. (See p. 71.)

4432. East shore of Cook Inlet, $1 \frac{1}{2}$ miles east of Troublesome Gulch and $4 \frac{1}{2}$ miles southeast of Ańchor Point.

3. Outcrop of the 2-foot 9-inch seam near the end of the railroad spur at the mine camp. (See p. 73.)

4. Mine camp, No. 3 tunnel. (See p. 73.)

7. Represents 30 inches of a $4 \frac{1}{2}$-foot bed occurring below sea level about 500 feet offshore at the point west of Coal Creek near mine camp.

8. Outcrop of the Curtis seam 400 yards west of McNeil Canyon. (See p. 77.)

9. 4-foot seam found 300 yards from the beach up MeNeil Canyon. (See p. 76.)

10. Lower 30-inch bench of a $5 \frac{1}{2}$-foot coal seam on which a tunnel was driven in Eastland Canyon. (Seep.77.) $x$. Outcrop below high tide on shore of Port Graham. 
Analyses of Cook Inlet coals-Continued.

Alr-dried samples, calculated from the table above.

\begin{tabular}{|c|c|c|c|c|c|c|c|c|c|c|c|}
\hline \multirow{2}{*}{$\begin{array}{c}\text { Sam- } \\
\text { ple } \\
\text { No. }\end{array}$} & \multicolumn{3}{|c|}{ Proximate analysis. } & \multicolumn{6}{|c|}{ Ultimate analysis. } & \multicolumn{2}{|c|}{ Calorific value. } \\
\hline & $\begin{array}{l}\text { Mois- } \\
\text { ture. }\end{array}$ & $\begin{array}{c}\text { Volatile } \\
\text { com- } \\
\text { bustible. }\end{array}$ & $\begin{array}{c}\text { Fixed } \\
\text { carbon. }\end{array}$ & Ash. & $\begin{array}{l}\text { Sul- } \\
\text { phur. }\end{array}$ & $\begin{array}{c}\text { Hydro- } \\
\text { gen. }\end{array}$ & Carbon. & $\begin{array}{l}\text { Nitro- } \\
\text { gen. }\end{array}$ & $\begin{array}{l}\text { Oxy- } \\
\text { gen. }\end{array}$ & Calories. & $\begin{array}{c}\text { British } \\
\text { thermal } \\
\text { units. }\end{array}$ \\
\hline $\begin{array}{l}4458 \ldots \\
4457 \ldots \\
4429 \ldots \\
4426 \ldots \\
4432 \ldots\end{array}$ & $\begin{array}{l}12.81 \\
11.95 \\
10.14 \\
10.74 \\
13.46\end{array}$ & $\begin{array}{l}42.19 \\
45.99 \\
39.88 \\
41.57 \\
38.79\end{array}$ & $\begin{array}{l}35.36 \\
25.39 \\
38.54 \\
40.71 \\
31.55\end{array}$ & $\begin{array}{r}9.64 \\
16.67 \\
11.43 \\
6.97 \\
16.21\end{array}$ & $\begin{array}{r}0.57 \\
.46 \\
.38 \\
.24 \\
.44\end{array}$ & $\begin{array}{l}5.34 \\
5.09 \\
5.26 \\
5.33 \\
5.39\end{array}$ & $\begin{array}{l}53.95 \\
48.14 \\
54.17 \\
56.59 \\
48.16\end{array}$ & $\begin{array}{r}1.00 \\
.95 \\
1.26 \\
1.05 \\
1.05\end{array}$ & $\begin{array}{l}29.50 \\
28.69 \\
27.49 \\
29.81 \\
28.75\end{array}$ & $\begin{array}{l}5,321 \\
4,716 \\
5,241 \\
5,384 \\
4,836\end{array}$ & $\begin{array}{l}9,578 \\
8,489 \\
9,434 \\
9,692 \\
8,706\end{array}$ \\
\hline
\end{tabular}

4458. North shore of Port Graham.

4457. North shore of Kachemak Bay, $2 \frac{1}{2}$ miles east of Homer Spit. (See p. 75.)

4429. East shore of Cook Inlet, 1 mile west of Homer Snit.

4426. East shore of Cook Inlet, $\frac{3}{4}$ mile west of Diamond Creek and $8 \frac{1}{2}$ miles southeast of Anchor Point. (See p. 71.)

4432. East shore of Cook Inlet, $\frac{3}{8}$ mile east of Troublesome Gulch and $4 \frac{1}{2}$ miles southeast of Anchor Point.

The results of steaming tests have already been published by Dall ${ }^{1}$ and by Stone. ${ }^{2}$ These analyses and tests, together with the physical character of the coal, show that it is of comparatively low fuel value and probably can not compete with the better coals available on the Pacific coast except for local use or under economic conditions or methods of utilization different from those now prevailing.

\section{MINING DEVELOPMENT.}

The earliest Alaska coal mine, and probably the oldest on the Pacific coast, was opened by the Russians in 1855 at Port Graham, where the occurrence of coal had been described by Portlock ${ }^{3}$ in 1786 . The information concerning this old mine is scanty. Petroff ${ }^{4}$ says of it:

The existence of coal in the southern portion of the Kenai Peninsula had been known for many years, and occasionally a small quantity of the mineral had been extracted for use in the Sitka shipyard and on the tugboats and small steamers of the company. The discovery of gold in California, however, gave a new impetus to this industry. Experienced miners and engineers were imported from Russia and Germany, and a large force of men was employed in opening the coal veins at English Bay, or Graham's Harbor.

The prosecution of this enterprise required a large amount of capital, which the shareholders of the Russian-American Co. were unwilling or unable to furnish, but by this time the development of California had created a demand for coal, and it was not difficult to find men willing to engage in such a venture at San Francisco. A company was formed, consisting of several American merchants of San Francisco and the RussianAmerican Co., represented by their resident agent in San Francisco, Mr. Kostrometinof. Arrangements were made for the shipment of machinery, pump and hoisting works, from the Eastern States, the Russian-American Co. furnishing the necessary capital for preliminary expenses.

${ }^{1}$ Dall, W. H., Report on coal and lignite of Alaska: U. S. Geol. Survey Seventeenth Ann. Rept., pt. 1, pp. 830-832, 1896.

${ }^{2}$ Stone, R. W., Coal fields of the Kachemak Bay region: U. S. Geol. Survey Bull. 277, pp. 70-72, 1906.

3 Portlock, Nathaniel, $\Lambda$ voyage to the northwest coast of North $A$ merica, pp. 102-110, $4^{\circ}$, London, 1789.

4 Petroff, Ivan, Report on the population, industries, and resources of Alaska: U.S. T'enth Census, vol.s, p. $115,1884$. 


\section{Dall's account ${ }^{1}$ of the mine reads as follows:}

About 1852 the Russian-American Co. began to make use of steamers, and theit: attention called to the coal described by Portlock and subsequently reported upon by Boroshin and Wossnessenski. Doroshin was a mining engineer detailed to examine the mineral resources of the colony, and under his supervision a shipload of the coal was obtained and taken to San Francisco to be tested. The RussianAmerican Co. hesitated to undertake mining operations on its own account, and, having entered into relations with certain Californian capitalists, in 1852 an establishment at Kadiak was authorized by which the American Co. was permitted to put up ice for the Californian market. After various tests.had been made, the same company was empowered, on raising the necessary capital, to open the coal mines at Port Chatham [Port Graham].

In April, 1855, the bark Cyane, Capt. Kinzie, left San Francisco for Port Chatham [Port Graham], where miners and mining machinery were landed. It is difficult at this date to obtain information in regard to these mining operations, which continued some ten years and supplied the Russians with a certain amount of coal which was used on their steamers. As better coal became available by the opening of mines in British Columbia, Oregon, and Puget Sound, the Port Chatham [Port Graham] coal became less necessary, and with the transfer of the territory to the United States the mine was finally abandoned.

\section{Bancroft's account ${ }^{2}$ reads as follows:}

Machinery was erected and run by steam power; a force of laborers was obtained in Siberia; several experienced miners were brought from Germany, and every available man in the Siberian line battalion, then stationed at Sitka, was sent to aid in the work. The prospect of furnishing the company's steamers with coal obtained in the colonies and of selling the surplus at high prices in San Francisco and elsewhere acted as a powerful incentive. In 1857 shafts had been sunk and a drift run into the vein for a distance of nearly 1,700 feet, nearly all of which was in coal. During this and the three following years over 2,700 tons were mined, the value of which was estimated at nearly 46,000 roubles, but the result was a net loss. The thickness of the vein was found to vary from nine to twelve feet, carrying 70 per cent of mineral, and its extent was practically unlimited; but the coal was found to be entirely unfit for the use of steamers, and a shipment of 500 tons forwarded to San Francisco realized only twelve and a half roubles per ton, or considerably less than cost.

The writer visited the locality in 1904 and saw the mouths of two shafts and a drift ( $\mathrm{Pl} . \mathrm{V}, B, \mathrm{p} .22)$ and the ruins of several massive $\log$ buildings. $^{3}$ One of the ruined log buildings contained scattered fire brick of American or English make and pieces of rusted machinery and was evidently a power house. Rusty axes and picks of Russian pattern which had been taken from the drift when opened the year before were shown to him, and he was told that balls and chains were found with them, suggesting the employment of convict labor. Russian residents of the neighboring town of Seldovia reported that the shaft was 180 feet deep, and passed through five beds of coal, and that the workings extended out beneath the waters of the harbor. $^{3}$ The old drift was reopened and some coal was mined for

1 Dall, W. H., Report on coal and lignite of Alaska: U. S. Geol. Survey Seventeenth Ann. Rept., pt. 1, pp. 785, 786, 1896.

2 Bancroft, H. H., History of Alaska, pp. 693, 694, 1886.

3 Stone, R. W., Coal resources of southwestern Alaska: U. S. Geol. Survey Bull. 259, p. 160, 1905. 
local use in the years 1904 to 1906 . The land on which this mine is situated was patented in 1913.

Coal has also been mined for local use at other points of Cook Inlet, especially on Kachemak Bay and at Tyonek, to supply the demand af small steamers. The methods of mining are generalky crude. No mine is usually opened, but the coal is picked up from the base of the cliffs or broken off at the outcrop by natives, who carry the pieces in their hands to a scow. The cheapness of this method has given Tyonek the interesting distinction of being the cheapest coal port in the world.

Attempts were made to develop the Kachemak Bay coal on a commercial scale many times from 1888 to 1902 , the most active operations being carried on between 1899 and 1902, when after building a wharf and 7 miles of railroad, erecting many buildings, and driving three tunnels and two slopes, the company abandoned the enterprise, being in financial difficulties.

These operations have been described by Stone ${ }^{2}$ as follows:

In 1888 the Alaska Coal Co. began what was probably the first coal mining on the north shore of Kachemak Bay. Their operations, it is said, consisted in driving a tunnel on the Bradley seam near Fritz Creek, 6 miles north of Homer. It is not known how much work was done or whether any coal was shipped. The tunnel caved in long ago.

Lieut. R. P. Schwerin, United States Navy, on behalf of New York parties, took 200 tons from Kachemak Bay in 1891. This coal was shipped to San Francisco and submitted to a series of tests, the results of which are given on page 71 [Bull. 277]. The results were not sufficiently satisfactory to warrant the development of the field under existing difficulties.

In December, 1894, the North Pacific Mining \& Transportation Co. began exploration in Eastland Canyon, about 14 miles northeast of Homer, under the supervision of M. B. Curtis. Three buildings and a short pier were erected at the mouth of the canyon, and a tramway was constructed from the pier to a tunnel driven on a coal seam half a mile up the canyon. The buildings are still standing, but the tramway, which follows the east bank of the creek, is undermined in many places. At least 650 tons of coal were taken out, lightered to the steamer Theobald, which lay at anchor in Bear Cove, and sent to San Francisco to be tested.

This company and the Alaska Coal Co. continued prospecting in Eastland and McNeil canyons from 1894 to 1897 . During this time two short tunnels were driven on a 4-foot coal seam 400 yards west of $\mathrm{McNeil}$ Canyon and 45 feet above the beach. This is called the Curtis seam. A short wharf and coal bins were built and still remain, though in a dilapidated condition. The horizontal dark bands seen in Plate XVII, $A$ [Bull. 277], represent lignite beds. The outcrop of the Curtis seam is covered by a slide above the bin and appears only at the extreme right and leit of the view. $A$ frame house at the mouth of McNeil Creek and a log cabin at the mouth of Cottonwood Creek, built by these companies, were standing in 1904, but were out of repair.

Since 1899 the Cook Inlet Coal Fields Co. has held possession of the most desirable part of the coal field on the north shore of Kachemak Bay. This is the portion which lies to the west and within 3 miles of the base of the long spit known as Coal Point.

2 Stone, R. W., Coal fields of the Kachemak Bay region: U. S. Geol. Survey Bull. 277, pp. 54-55, 1906. 
Under the management of this company a large dock was built on the east side of Coal Point, where there is protected anchorage. A 42-inch gage railroad was constructed from the dock along the spit to the mainland, where it rises to the top of the bluff about 200 feet above the beach, and ends at Coal Creek. Two shafts were started and three tunnels were driven on a $6 \frac{1}{2}$-foot coal seam which outcrops in the sea bluff between Cooper and Coal creeks. Underground work was begun in the fall of 1899 by driving the first of these shafts, which is known as the Kirsopp slope, because it was excavated under the direction of John Kirsopp, an English mining engineer. This shaft had three compartments and was carried 125 feet, when it was discovered that the slope of the shaft was so nearly parallel with the dip of the coal that it would have to be driven nearly 1,800 feet to reach the coal. In 1900 tunnel No. 1 was driven in the face of the bluff on a seam of coal $6 \frac{1}{2}$ feet thick. It proved to be very wet and was abandoned. Tunnel No. 2, on the same seam, was driven 350 feet and had to be pumped to keep it dry. Coal was brought to the mouth of the tunnel in mine cars, dumped into a skip, and hoisted over the bluff by a squareframed derrick which spilled into a railroad car standing on the spur track. At the west end of the railroad a vertical 3-compartment shaft, known as the Morgan shaft and contemporaneous with tunnel No. 1, was sunk over 25 feet, and a tunnel was

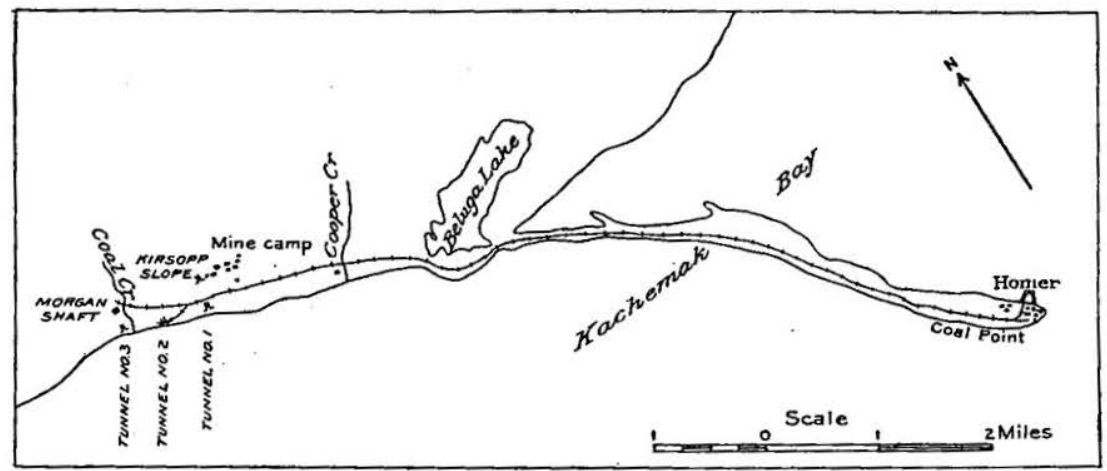

FrGURE 13.-Sketch map showing location of Cook Inlet Coal Fields Co.'s operations. (After Stone.)

started on coal in the sea bluff near Coal Creek to connect with the shaft. This third, or Ray, tunnel was driven 125 feet when work at that end of the field was discontinued and efforts were concentrated on getting out coal from tunnel No. 2. During the winter of 1901-2 the mail steamer Discovery was supplied continuously with fuel, and other vessels occasionally. All work on this property ceased in March, 1902, but the company holds possession by retaining a representative on the ground. No money or effort is being expended, however, in keeping the railroad or mine tunnels in repair. Eight buildings at the mine camp and 20 on Coal Point at Homer, which was the company's headquarters, are in good condition. Figure 13 shows the location of the development work done by this company.

\section{PLACER DEPOSITS.}

The beach sands on the east shore of Cook Inlet have at several places yielded small amounts of placer gold. The best known of these localities is at Anchor Point, where beach washing has been carried on intermittently in a small way for many years. In the summer of 1911 two men were working at this locality. They 
reported that the pay gravel lay about 2 feet below the surface, 10 inches of gravel being shoveled in and an average of one-half cent to the pan being obtained. Water for sluicing was obtained from a ditch 2 miles long. The gold is all fine.

A hydraulic plant was formerly located at Anchor Point and much money was spent in constructing ditches and buildings, but the whole undertaking proved a failure, except in that it has since furnished pipe and other material for several hydraulic plants on Turnagain Arm. It is reported that the water supply proved insufficient.

Work was also in progress in the summer of 1911 at a locality several miles north of Ninilchik and, according to report, at several other places along the shore of Cook Inlet, but the results are not known.

The gold at all the Cook Inlet beach placers is derived by wave concentration from the Quaternary gravels which in places form the cliffs. The gravels of the cliffs have apparently not been thoroughly tested by hydraulic operations, probably on account of the lack of water. The comparatively small amount and irregular distribution of the gold in the beach indicate that the cliff gravels are not uniformly gold bearing to a degree that will warrant extensive hydraulic operations without very complete preliminary testing.

Prospecting on the small streams that empty into the eastern end of Tustumena Lake has shown that their gravels carry gold in small amount. Some attempts have been made to exploit them, and for a number of years a little mining was done on Indian Creek. An elaborate hydraulic plant was taken in by way of Kasilof River and put in operation, but the result was apparently a failure and the project has been abundoned. The gold occurs in small amounts in stratified gravels, which are many hundred feet thick at this locality. (See p. 90.) The degree to which the gold has been concentrated in the bed of the creek is not known.

The bars of Kenai River and the low terrace gravels along its banks carry small amounts of gold. Dredging has been proposed at several places between Killey River and Kenai, but no operations have yet proceeded far enough to give conclusive tests.

\section{LIMESTONE.}

The crystalline limestone exposed at Gray Cliff, on the east shore of Seldovia Bay, may be of future value as blast-furnace flux or for use in agriculture. The entire promontory known as Gray Cliff is composed of massive crystalline limestone, gray to white in color and apparently fairly pure. (See p. 42.) No analyses of this limestone have been made, so it is not known whether the rock is suitable for use 
as flux. The known outcrops cover about 8 acres, in which the limestone probably averages 50 feet in depth from the surface to the level of high tide. The outcrops are on the shore close to deep sheltered water. ${ }^{1}$ If a demand for limestone of this kind should arise, the accessibility of this locality will give it an advantage over any other known place in this part of Alaska. The same limestone occurs, but in much smaller volume, about three-quarters of a mile northeast of this locality and also about 2 miles southwest of it, on the west shore of Seldovia Bay.

-The Triassic limestone of Port Graham (see pp. 55-58) occurs in beds that are probably too thin and too impure to be of commercial value. 


\section{THE CENTRAL AND NORTHERN PARTS OF KENAI PENINSULA.}

By Bertrand L. Johnson.

\section{GEOLOGY.}

\section{METAMORPHIC ROCKS.}

\section{GENERAL FEATURES.}

The metamorphic rocks of central and northern Kenai Peninsula and the area north of the head of Turnagain Arm (see Pl. III) consist of an undifferentiated series of regionally metamorphosed detrital rocks composed chiefly of alternating bands of slate and graywacke and minor amounts of interstratified quartzite, conglomerate, and limestone. This group of sedimentary beds was named the Sunrise series by Mendenhall. ${ }^{1}$ Neither its thickness nor its relations to other formations in the region examined are known. The uniformity in the appearance and composition of the beds throughout the region, the general absence of fossils, and the extensive folding and faulting render the subdivision of the group into lithologic units difficult without detailed geologic mapping. The proportions of the different rocks vary from place to place, but owing to the preponderance of the slates and graywackes in them these rocks are regarded as a slate-graywacke group.

The degree of metamorphism varies but slightly in different parts of the area, and the variation is probably due more to differences in the composition of the rocks metamorphosed and in their position on folds than to changes in the metamorphosing agencies. In most places the original grits have been changed to graywackes and the argillaceous beds have acquired a slaty cleavage. Narrow argillaceous bands that lie between graywacke beds are now in many places thoroughly cleaved or fissile, the cleavage or fissility stopping abruptly at the beds of graywacke. Shearing in carbonaceous rocks has in some placès produced small amounts of graphitic slates and has caused slight schistosity in other rocks. The present condition of this slategraywacke series appears to be the result of the dynamometamorphism of the beds under temperature and pressure like those ascribed by Van Hise to the lower part of the belt of cementation in the zone

${ }^{1}$ Mendenlall, W. C., $A$ recomaissance from Resurrection Bay to the Tamana River, Alaska, in 1895: U.S. Geol. Survey Twentieth Anu. Rept., pt. 7, pp. 305-307, 1900.

$$
4 S S 91^{\circ}-\text { Bull. } 587-15-S
$$


of katamorphism. Evidence of this action is shown in the cementation of the coarse-grained sediments, in the development of cleavage in most of the argillaceous rocks, in the absence of secondary feldspars, and in the manner of intrusion of the igneous rocks.

\section{GRAYWACKES. ${ }^{1}$}

As already noted, the proportions of the different sedimentary rocks in the slate-graywacke group vary from place to place. At some places graywackes form the major part of the rocks; at others only a few thin graywacke beds occur in a series consisting predominantly of black slate. The individual beds of graywacke range from mere lines to strata many feet thick. They are lenticular, interfingering at their edges with other beds of slate and graywacke. Along the trail from Sunrise to Hope in many places the alternating beds of slate and graywacke are very thin, and the rocks present a banded or ribboned appearance. Simillar features, as well as the sedimentary interfingering just mentioned, may be seen on rock exposures in Johnson Pass. Massive graywacke beds many feet thick are found on the divide between Lost and Porcupine creeks, along the shores of Trail Lake, along the Government road near Sunrise, and at other places.

Under certain conditions the graywackes are more resistant to degradation than the slates that are interstratified with them. Where the slate-graywacke series has been exposed to wave action along shore or where the strike of the beds has corresponded to the direction of glacial ice movement differential erosion of the two kinds of rock has left the graywackes standing in relief. In the higher altitudes, where the action of frost is great, the slates and graywackes show less difference in resistance.

The graywackes of this area are medium to fine grained, light to dark gray, massive detrital rocks, composed chiefly of angular fragments of quartz and feldspar (orthoclase and acidic plagioclases) and fragments of other minerals and rocks embedded in a fine-grained clayey matrix. The dark color of the graywackes is due to their content of carbonaceous matter. In places they contain numerous flat angular fragments of black slate or shale, some of them slightly rounded. The remarkable freshness of the feldspar grains indicates deposition where surface chemical activity was very slight. The rocks are generally somewhat calcareous, most of the calcite probably being secondary. Many of the joints are cemented by thin seams of calcite and quartz. Sulphidic mineralization of the rocks is not uncommon. One specimen of graywacke from a point near the head of Quartz Creek, taken from rock rather highly impregnated with arsenopyrite, was found on microscopic examination to be composed

${ }^{1}$ Moffit, in U. S. Geol. Survey Bull. 277, 1906, uses the term "arkose" to describe the rocks which in the present report are called "graywackes." 
principally of fragments of an andesitic rock. The weathering of these mineralized graywackes has given them a reddish or brownish color.

The graywacke beds were designated "pyroclastic diorites" by Becker, ${ }^{1}$ and they are often locally referred to as "diorite" by the prospectors, but their sedimentary origin, where it is not readily discernible in the field, is easily proved by microscopic examination of thin sections of the rock. Because of their narrow width, relatively great length, perpendicular attitude, and in some places crystalline appearance prospectors often refer to them as dikes.

Graywackes, in general, have no distinctive chemical characteristics. Their composition varies with differences in the detrital material of which they are made up, with the extent to which the component fragments have been decomposed, and with differences in the cements. But one chemical analysis ${ }^{2}$ of the graywackes of Kenai Peninsula is known. The specimen analyzed was collected by Becker from Bear Creek, a tributary of Resurrection Creek near Hope, in 1895. The analysis follows:

Analysis of graywacke from Bear Creck, Kenai Peninsula, Alaska.

[Analyst, W. F. IIillebrand.]

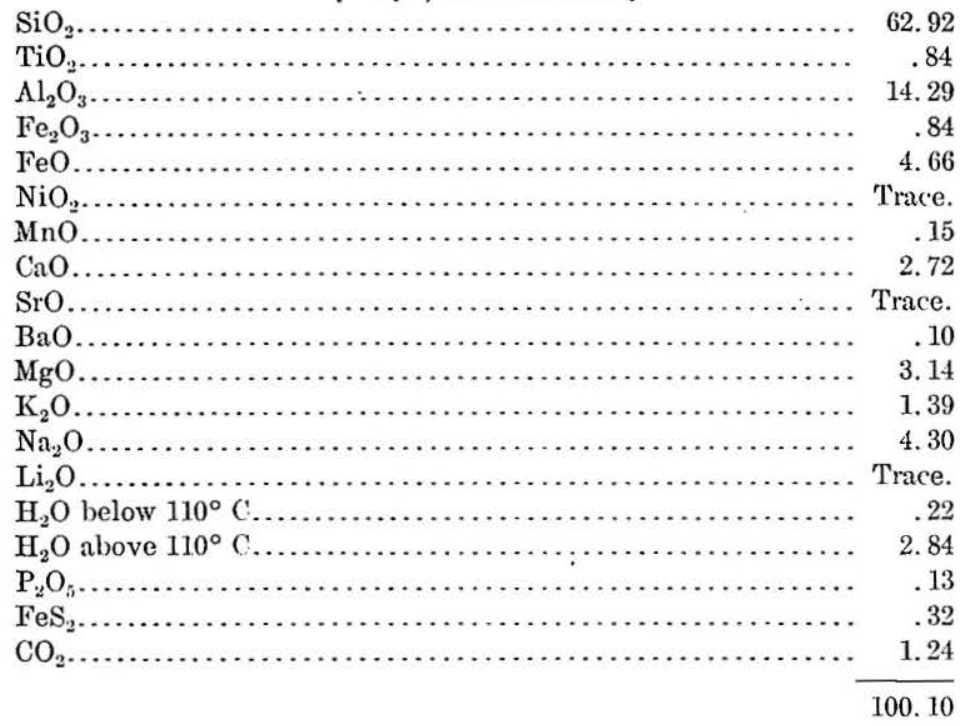

The metamorphism of the graywackes has not much changed their original character; it has only cemented the rock, developed slight schistosity in some places in the more argillaceous beds, formed hore and there a schistose graywacke, and in a few places produced a marked slaty cleavage.

${ }^{2}$ Becker, G. F., Reconnaissance of the gold fiolds of southern Alaska, with some notes on general geology: U. S. Geol. Survey Eighteenth Ann. Rept., pt. 3, pp. 43-47, 1808.

2 Idem, p. 45. 
SLATES.

The argillaceous rocks interbedded with the graywackes in this slate-graywacke series are fine-grained, dark-gray to blue-black, consolidated sediments. The dark color is due to carbonaceous matter. On Crow and Raven creeks marine fossils have been found in the slates, and fossils have also been reported in similar rocks near the tunnels of the Alaska Northern Railway.

The slates are generally fine grained and here and there include more sandy layers. The bedding is usually distinguishable. Thinbedded, fine-grained, compact, argillaceous bands, commonly without marked cleavage, are found on Devil, Juneau, Falls, Crow, and Raven creeks. All these beds are similar in lithologic appearance. The rocks of Devil Creek are markedly sonorous, ringing when hit.

Slaty cleavage is found in all stages of development, and is generally about parallel to the bedding. Where narrow alternating bands of slate and graywacke occur, however, as on the divide between Slate and Summit creeks, in the Moose Pass district, the argillaceous beds are in places thoroughly cleaved or fissile, cleavage planes crossing the bedding at a considerable angle and stopping abruptly at the beds of graywacke: Black, shiny graphitic slates occur in several places, as on Lynx and Devil creeks and between miles 12 and 14 on the Alaska Northern Railway. At these points also numerous tiny quartz-calcite veinlets, stringers, and lenses fill openings that were formed by the deformation of the beds. A peculiar birch-bark effect is noticeable in some of the slates at places where numerous parallel narrow lenticular openings, produced by secondary fracture cleavage, have been filled by quartz and calcite. Many of the slates have also been slightly impregnated by sulphides-pyrite, pyrrhotite, arsenopyrite, and chalcopyrite- which occur either in disseminated grains or in small bunches and stringers.

\section{QUARTZITES.}

Quartzite beds are found only here and there in the slate-graywacke series and form a relatively unimportant part of the Sunrise group. They are most abundant west of Resurrection Creek, along the north shore of Turnagain Arm, and in the mountains east of Resurrection Bay. Moffit ${ }^{1}$ mentions several massive quartzite beds 4 to 6 feet thick, in the vicinity of the glacier east of Seward, about 2 miles from the bay.

\section{LIMESTONES.}

A few thin-bedded fine-grained dark-gray and blue-gray sandy limestones are interstratified with the slates and graywackes of the

1 Mfomt, F. H., Gold fields of the Turnagain Arm region: U. S. Geol. Survey Bull. 277, p. 18, 1906. 
Sunrise group on Cooper, Fresno, Victor, and Devil creeks, occurring at the head of Devil Creek as fine alternating light to dark gray bands. No large limestone beds are known. It is probable that these thin-bedded limestones are more distributed than is usually believed, their occurrence among the more abundant slate and graywacke bands being easily overlooked because of their dark color and their sandy nature. These limestones, so far as now known, are not fossiliferous.

\section{CONGLOMERATES.}

Conglomerate beds form a subordinate part of the Sunrise group. They have been found on the East Fork near the point where Marion Creek crosses the Government road from Sunrise to the Alaska Northern Railway and also at a place on this road about $12 \frac{1}{2}$ miles from the railroad; on the property of the Kenai Alaska Gold Co., on Falls Creek; in the deep cut of the Nutter Dawson Mining Co., on Crow Creek; and near mile 7 and between miles 69 and 70 on the Alaska Northern Railway. Individual beds vary in thickness from 4 to 10 feet. Moffit noted a conglomerate bed 6 to 8 feet thick on Resurrection Creek and prospectors have reported that conglomerate bowlders occur on Fresno, Colorado, and Raven creeks.

The conglomerates are generally dark gray. The matrix varies from slaty to coarse grained. In some localities the conglomerates are not separated from the inclosing rocks by bedding planes, but grade irregularly, though abruptly, by diminution in the number of pebbles into graywacke. The cement is in places calcareous. The pebbles are generally well rounded and vary in size, but are mostly small, averaging less than 2 inches in diameter. They consist chiefly of argillaceous rock, but include pebbles of quartzite, limestone, quartz, and light-colored igneous material. The conglomerate bed on. Resurrection Creek, according to Moffit, is made up of rolled pebbles of granite and a few rounded fragments of quartzite in a gray argillaceous matrix.

\section{GREENSTONES AND CHERTS.}

Greenstones are reported to outcrop within the general area occupied by the rocks of the Sunrise group on Lynx Creek, and greenstone bowlders are also encountered on this and several other creeks, but the localities from which these bowlders have been derived is not known. Green and white cherts, associated with reddish, much altered basaltic rocks, occur near the junction of Mills and Stormy creeks, and gray cherts have been reported on Cripple Creck, a tributary of Resurrection Creek, near Hope. Rocks of these types are not usually regarded as belonging to the Sunrise group, and these greenstones and cherts may have come from another formation which may be infolded with or faulted in with the rocks of the Sumrise 
group. Since no exact information is available regarding their occurrence or their relations to the slates and graywackes of the Sunrise group, they are mentioned here with the other rock types included in the metamorphic rocks of Kenai Peninsula.

\section{STRUCTURE.}

The Sunrise group is a monoclinal mass of steeply dipping strata, whose attitude is undoubtedly due to repetition of the beds by close folding and faulting. Most of the beds strike a few degrees east of north, and the recorded dips range from $50^{\circ} \mathrm{E} . .^{1}$ or $50^{\circ} \mathrm{W}$. to vertical although they are generally not far from vertical. North of Turnagain Arm the general strike is east and the dip is north. In places the rocks show close folds, most of which have vertical axial planes, though on Falls Creek folds overturned toward the west were seen. Faults are numerous, but the uniform lithologic character of the rocks makes it difficult to determine the extent of the displacement. As described under the heading "Lode deposits" (p. 138), two distinct sets of fissures, trending approximately at right angles to each other, are conspicuous in this area. One set trends in general from north to a little west of north; the other set trends between east and northeast. The influence of the first set is suggested in the marked parallelism of the drainage lines, and in the strike of dike-filled fissures and of many of the gold quartz veins. The influence of the second set appears less pronounced, although many of the valleys have an easterly trend and several of the ore bodies occupy fissures that strike nearly east.

\section{AGE.}

Considerable doubt exists as to the exact age of the series of metamorphic rocks found in the central and northern parts of Kenai Peninsula and referred to as the Sunrise group.

Fossils obtained by G. C. Martin and the writer from rocks that are apparently part of the Sunrise group at the head of Crow and Raven creeks, north of Turnagain Arm, were submitted to T. W.Stanton, who made the following report on them:

These consist entirely of imprints of a small Inoceramus, which is possibly identical with the Yakutat fossil described by Ulrich as Inoceramya concentrica. There is also a closely related form in Martin's [Upper] Cretaceous collections from the Matanuska region. * * * There is no essential difference in general type between the Jurassic species of Inoceramus and some of those in the Cretaceous, hence it is impossible to make positive discriminations on the evidences of Inoceramus alone unless species of known stratigraphic range can be positively identified.

The evidence afforded by the fossils indicates a Mesozoic age for part of the rocks of the Sunrise group, but whether Jurassic or

1 All bearings given in this report are corrected for magnetic variation. 


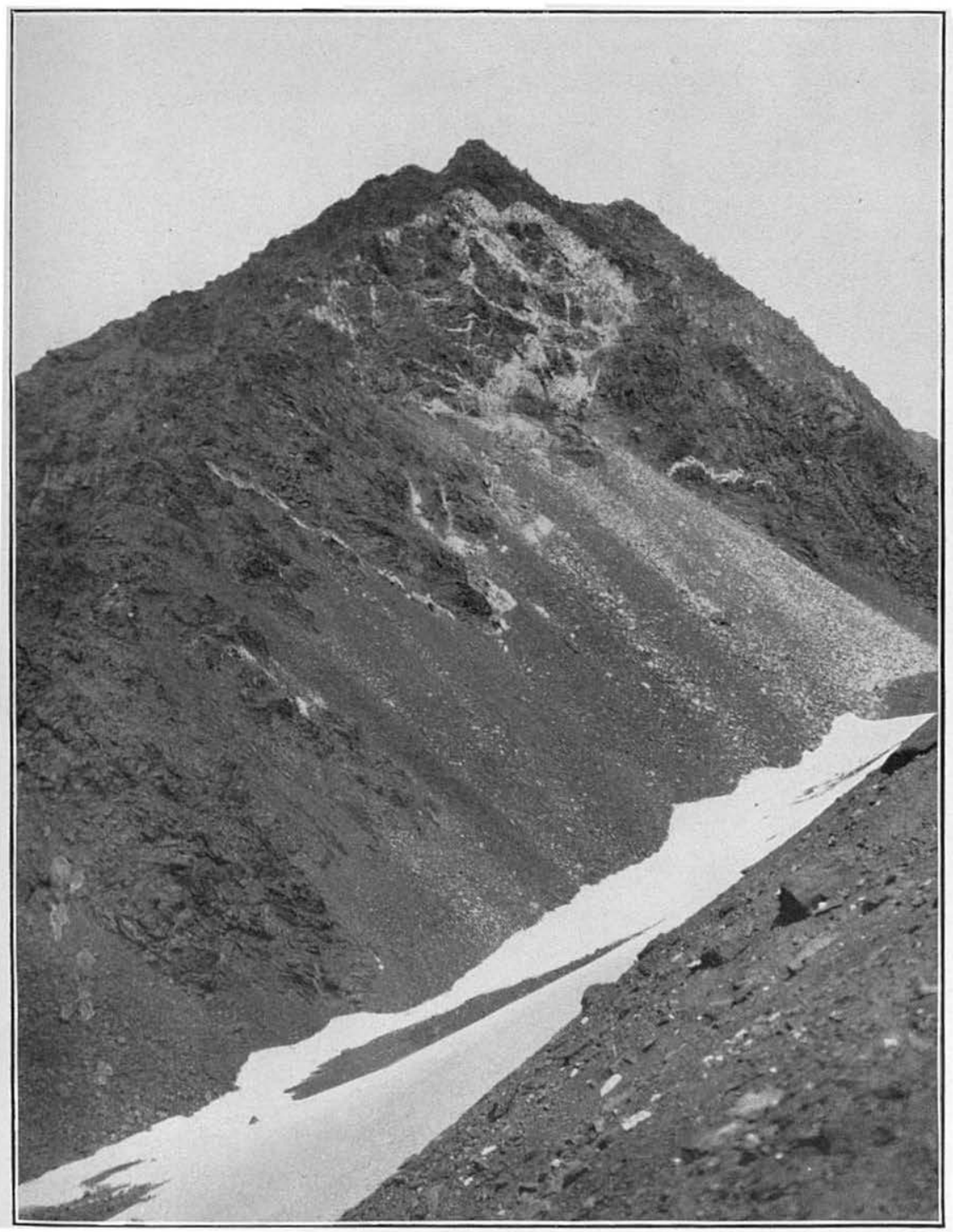

QUARTZ DIORITE INTRUSIVES IN SLATY ROCKS NEAR HEADWATERS OF CROW CREEK

Shows form of quartz diorite bosses and of the dikes branching off from the main mass. 


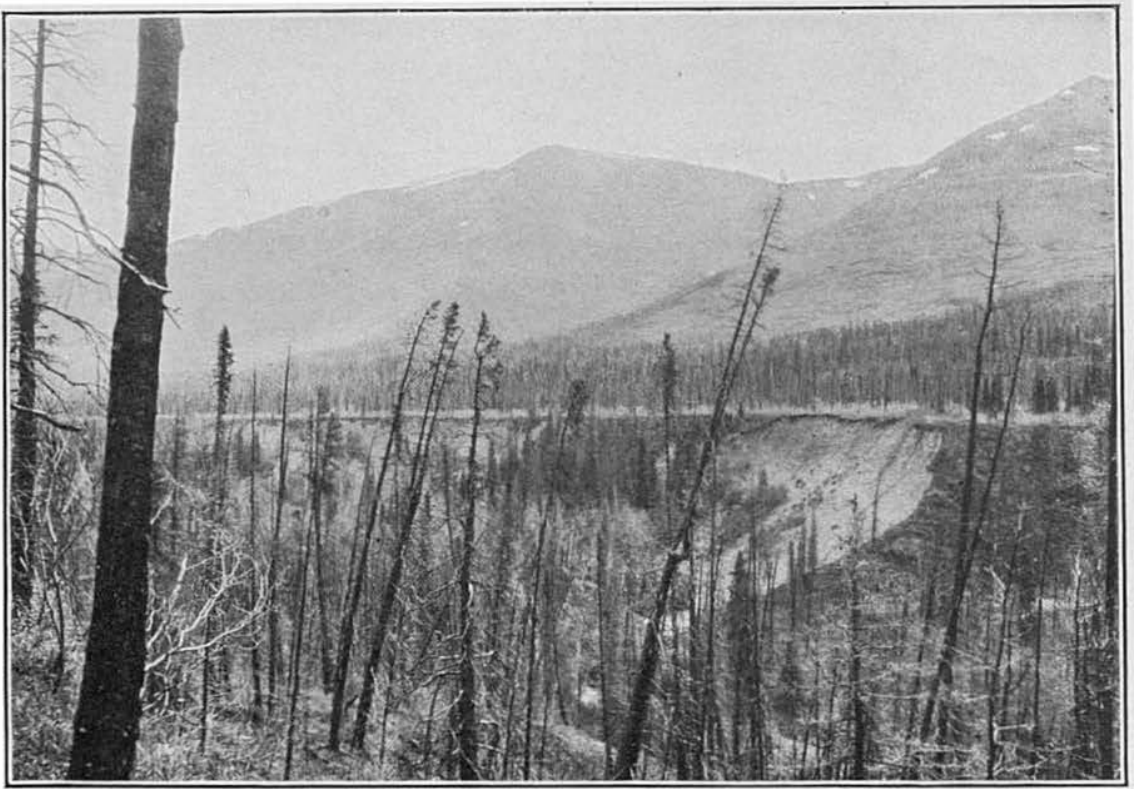

A. BENCH GRAVELS ON RESURRECTION CREEK.

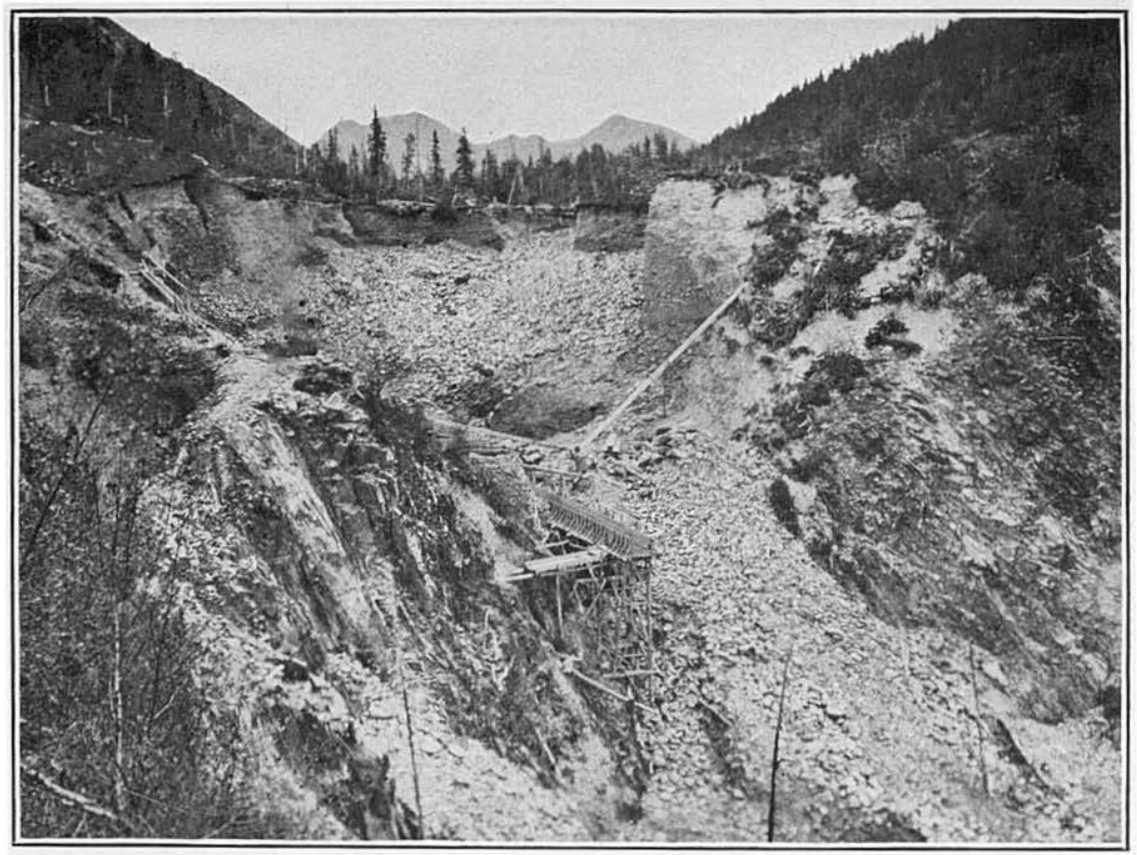

B. Old GRAVEL-FilLed ChanNel of GULCH CREeK. 
Cretaceous can not yet be determined. These Mesozoic slates and graywackes may be infolded with older formations which are nonfossiliferous or in which no fossils have yet been found.

\section{INTRUSIVE ROCKS.}

The intrusive igneous rocks of the area are far less abundant than the sedimentary rocks. These intrusive rocks are divisible into (1) fine-grained quartz diorite stocks or bosses, and (2) fine-grained dike rocks closely related to the quartz diorites. At the head of Crow Creek several small, closely grouped bosses of fine-grained, light-colored quartz diorite have intruded sediments of Jurassic or possibly Cretaceous age. Numerous light-colored dike rocks' of fine-grained to aphanitic texture occur as offshoots from these quartz diorite bosses. The manner of intrusion of these quartz diorites is well illustrated in the eastern face of one of the mountains at the head of Crow Creek. A small glacier undercutting the eastern slope has developed a nearly perpendicular rock bluff several hundred feet high, giving a complete vertical section of the upper part of one of the quartz diorite bosses. (See Pl. XXV.) This intrusion, which is probably a "cupola stock" from a more extensive mass below and one of several stocks now outcropping in the Crow Creek Pass, did not reach the surface in a molten condition. A part if the original sedimentary cover still remains as a cap over the intrusive. The pipelike form of the intrusion is well shown in the illustration, as well as the manner in which the molten mass worked its way around and upward and inclosed large blocks of the sediments. Many of these blocks are visibly suspended in the quartz diorite stock. In cross sections of other stocks in the vicinity the inclosed sediments have undergone but little contact metamorphism.

Acidic dike rocks, dioritic in composition, many of them of porphyritic texture, occur in many parts of Kenai Peninsula, as on Bear, Palmer, Porcupine, Groundhog, and Raven crecks and in the Moose Pass district (see PI. XXX, $A$ ), some of them many miles distant from known quartz diorite intrusives. The largest of these dikes, the so-called Moose Pass ledge, is several miles long and averages only 8 feet in width. It is composed of much altered, very fine grained diorite porphyry, and a description of its petrographic character will serve as a description of the rocks of this class. The rock is light colored and greenish, and owing to its extensive alteration its porphyritic character is discernible in but few hand specimens. Under the microscope these specimens show phenocrysts of plagioclase feldspars and a silicate mineral (possibly originally biotite but now completely altered to chlorite, calcite, and sericite) embedded in a fine-grained groundmass of quartz and plagioclase feldspars. 
Considerable secondary muscovite (sericite) and calcite are present, and also a small amount of chlorite, to which the greenish tinge of the rocks is probably due. Sericitization of the feldspars is well advanced.

The best evidence available as to the age of the quartz diorite and diorite porphyry intrusions is furnished at a locality on Crow Creek, where they cut folded sedimentary beds containing Jurassic or Cretaceous fossils. It appears probable that the intrusions were also pre-Tertiary.

\section{UNCONSOLIDATED DEPOSITS.}

GENERAL FEATURES.

The unconsolidated deposits of this area, consisting of glacial, fluvioglacial, and stream deposits of Quaternary age, rest unconformably upon the glaciated surface of the rocks of the Sunrise group. (See Pls. XXVI, $B$; XXXIV, $B$; XXXVI, A.) The glaciation took place in Quaternary time, a preexisting topography controlling and directing the erosive power of the ice, and the eroded material was deposited by the glaciers and glacial streams upon the glaciated bedrock surface.

All earlier unconsolidated sediments are believed to havo been removed by the glaciers during the Quaternary glaciation and reworked by the ice and by the glacial streams. The resulting débris was buried beneath the ice as ground moraine or spread out in front of the glaciers to be again worked over by the advancing ice. Deposits of any possible interglacial periods fared likewise. Only the deposits that were laid down at the time of the maximum extent of the ico sheet or during the retreat of the ice front to its present position have been preserved in place. The existing unconsolidated deposits were therefore distributed during the last great ice invasion and wero in greater part laid down during the retreat of the ice.

In an area like Kenai Peninsula, where considerable glacial activity. still exists, no sharp distinction as to time of deposition can bo mado between glacial deposits and later stream deposits. Neither can a separation be made between distinctly ice-laid deposits-those that were handled by the glaciers but whose principal features were determined by running water-and those that are strictly stream deposits. Ice and water deposits are intermixed and one class may merge into the other. The deposits have been laid down and reworked continuously by the action of water and ice from the beginning of glaciation to the present time. The glaciers carry and deposit morainic matter as they did when far more extensive, and this glacial débris is being reworked by the glacial streams as it has been reworked during all the time the ice has been present in the region. 
GLACIAL DEPOSITS.

Purely glacial deposits are not abundant. A thin mantle of till covers the overridden bedrock surfaces. Glacial till, or bowlder clay, rests on polished rock surfaces in the valley bottoms and on the lower slopes of the valley walls of many of the creeks. It consists of dense gray to bluish clay in which are embedded unassorted bowlders and pebbles of various sizes and degrees of angularity. Typical terminal moraines were observed only on Crow and Canyon creeks and in Johnson Pass. Moffit ${ }^{1}$ has described the terminal moraine in the middle valley of Crow Creek as follows:

An old terminal moraine stretches across the valley at this place, and its character has been well brought out by the cut made through it to reach the gold-bearing gravels of the basin above. This moraine is made up of angular blocks of rock, all of which are probably derived from the immediate region. Above and below are basins of stratified gravels and sands deposited by water. The debris of the moraine was apparently thrown down during a period in which the ice front was stationary, allowing the rock load to accumulate in front of the glacier, or possibly the moraine may be due to a pushing forward by the advancing ice of the loose material on its bed. After the ice retreat this moraine persisted as a dam, behind which the stream was ponded, and thus fine gravel and sand could there come to rest.

The absence of morainal deposits is probably to be attributed, in part, to the erosive power of the glacial streams, which removed the débris as soon as it was deposited by the ice and spread it over the valley floor in front of the glaciers, and, in part, to burial of the moraines beneath later fluvioglacial deposits as the glacial streams aggraded their valloys.

\section{BENCH DEPOSITS.}

Remnants of earlier fluvioglacial deposits, laid down during the retreat of the glaciers, are seen in the high bench gravels of Resurrection, Sixmile, Canyon, and other creeks. (See Pls. XXVI; XXVII, $B$; XXXIV, B.) Moffit $^{2}$ says:

Between Canyon and Quartz creeks and on Resurrection Creek they reach elevations of 1,500 to 1,600 feet above sea level. The surface of the gravels is not horizontal, but slopes gently toward the middle of the valley from either side and downstream as well. On the benches of some of these streams, notably Canyon, Juneau, and Seattle, numerous small marshy areas surrounded by spruce timber or alders mark the filled-in basins of former ponds.

[The thickness of the bench gravels] is not uniform, but depends on the surface form of the underlying rock floor. Streams have cut channels through them and in many places now flow in canyons whose walls are high banks of gravel. * * * At Sixmile Point, on Resurrection Creek, the top of the gravels is between 300 and 400 feet above the stream, or about 1,000 to 1,100 feet above sea level. Similar deposits are cut by Sixmile Creek and other streams. Near Mills Creek the high gravels have been cut into a series of sharply defined terraces from 10 to 30 feet high, extending from Canyon Creek to the western valley side. Gravels occur on the mountain sides west of

${ }^{2}$ Moffit, F. If, , Gold fields of the 'Jurnagain Arm region: V. S. (ieol. Survey 13ull, 277, p. $2 s, 1906$.

${ }^{2}$ Idem, pj). 25-2li. 
Quartz Creek on Turnagain Arm nearly 2,000 feet above tide. There are also benches in some valleys, such as that of East Creek in the Resurrection Creek basin, where the gravels reach an elevation of 3,000 feet; but these were probably deposited along the margins of glaciers that have since disappeared.

These deposits consist of washed gravels, sands, and clays. The gravels may be sandy, clayey, or ferruginous, and are made up in large part of fragments identical with the rocks of the neighboring hills. There is, however, a small percentage of granite and some basic igneous rock which was not found in place and which may have come from a source outside the valleys where it occurs. *** All the rock fragments are more or less water worn, and the smaller pieces are well rounded. Locally, also, they are strongly cemented with clay or iron oxide.

The sands contain a much greater proportion of flat scales of slate and arkose than of quartz, and sometimes show cross-bedding. At various places on different creeks sands of this nature, overlain by tough clays, carry a large amount of water. They are not firmly packed, and cave in continually when the attempt is made to sink a shaft in them.

Most of the clays are bluish or gray in color. They usually contain some gravel and are really very fine sand or rock flour-a product of grinding by glacier ice.

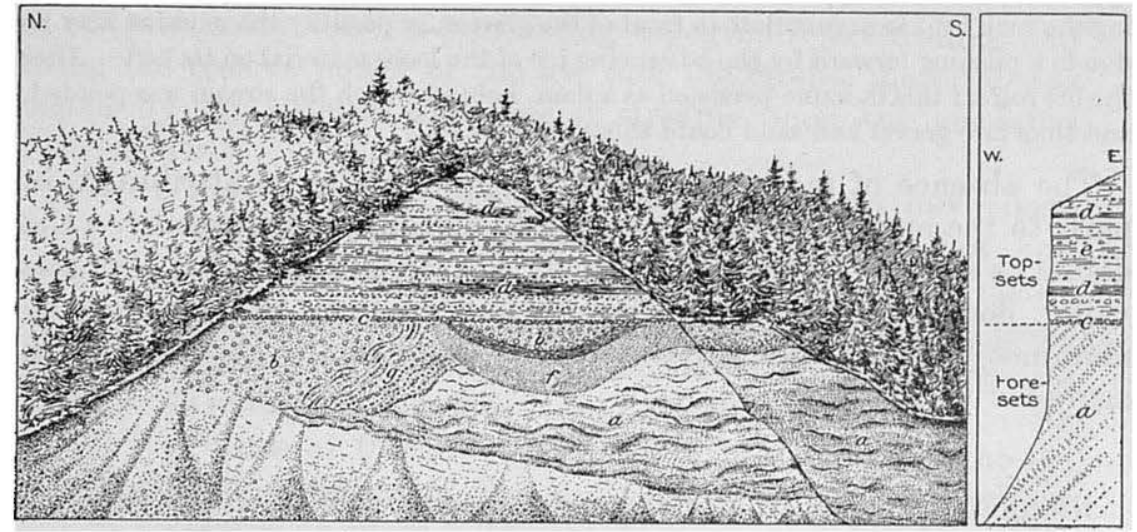

Figure 14.-Section of gravel bluff at mouth of Cooper Creek. a, Fine sand, thin bedded, layers wavy, dipping westward down face of bluff; small amount of fine, loose gravel layers; some of sand compact; $b$, no stratification visible; vertical wall; small, rounded pebbles embedded in compact, sandy clay;; $c$, unconformity; thin layer of small bowlders in coarse gravel, resting on lower beds; $d$, blackish, illdefined areas somewhat lenticular, probably due to carbonaceous matter; $e$, horizontally bedded, compact (vertical wall), clayey gravels with small pebbles; thin beds; $f$, compact fine sands; no stratification visible; $g$, irregular sands and gravels, dipping as indicated.

Lakes form y existed behind terminal moraine dams, as on Canyon Creek, where a moraine that crosses the valley a short distance above the mouth of Pass Creek dammed the waters of the tributaries upstream, forming a rather large lake which later, when an ice block occupied the basin of Lower Summit Lake, was filled with outwash débris. These sediments were afterward cut into a series of terraces by Canyon Creek as it found an outlet through the obstruction and gradually lowered its channel to its present position.

The terrace gravels in the valley of Kenai River between Kenai Lake and Russian River were deposited when the front of the Kenai River Glacier stood near the lower end of the present Kenai Lake. 


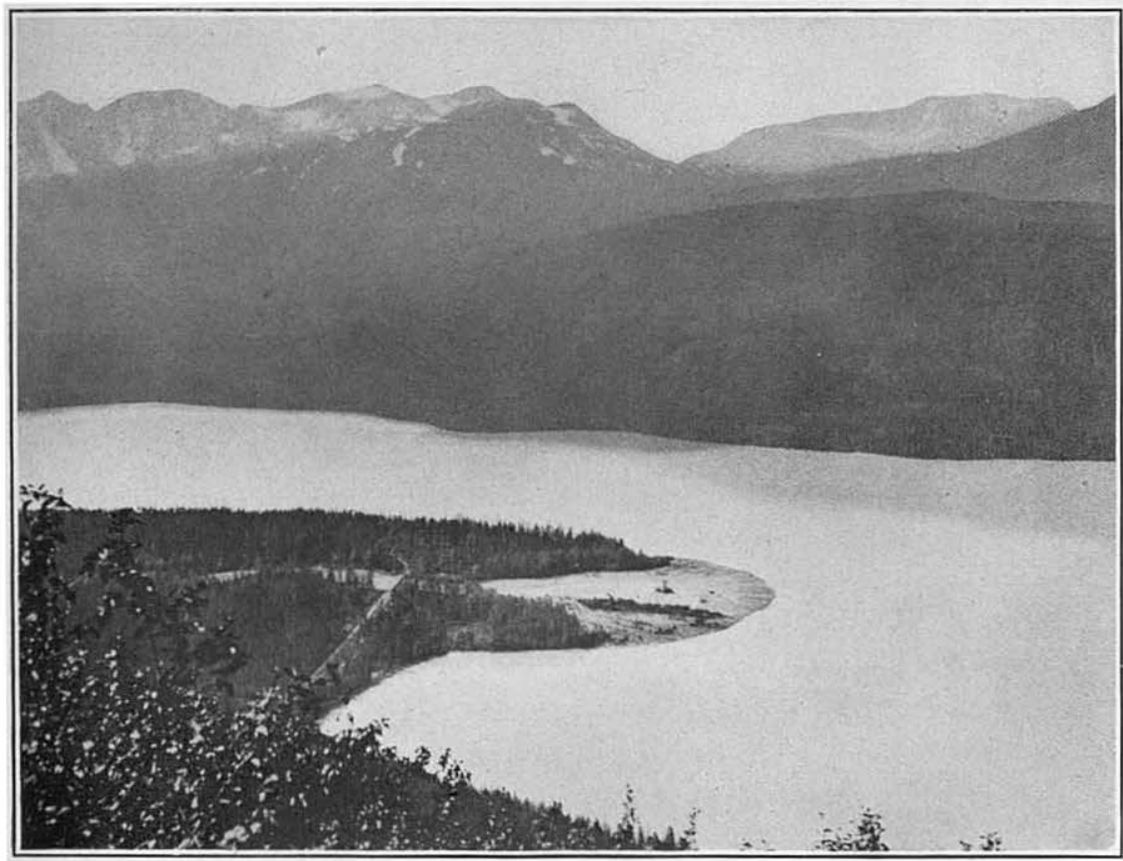

A. ALLUVIAL FAN OF VICTOR CREEK EXTENDING INTO KENAI LAKE.

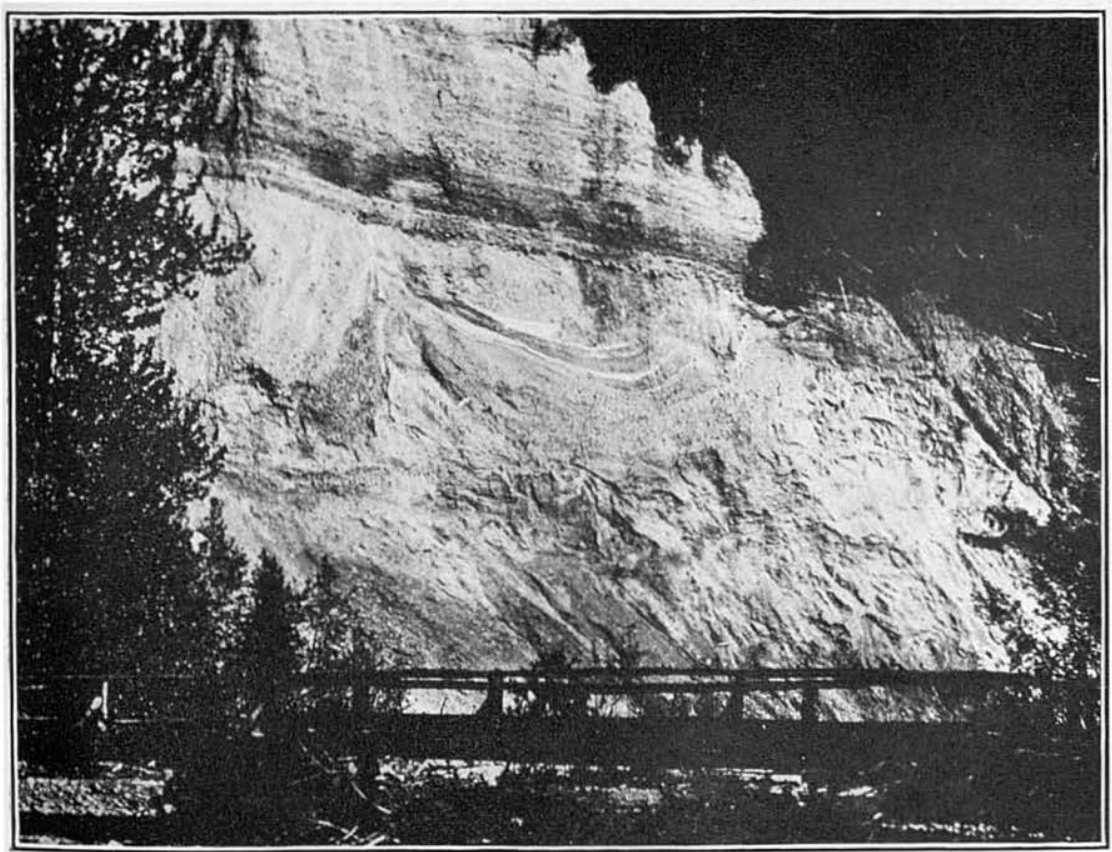

B. SECTION OF BENCH GRAVELS ON COOPER CREEK.

Photograph by A. H. Bryant. 

These gravels are in part, at least, delta deposits laid down in a former lake (see Pl. XXVII, $B$ ), although a considerable portion of them may be valley train deposits. This lake was probably formed by the glacial damming of the Kenai Valley at some point below Russian River, and was later partly filled with gravels by the Kenai River glacial stream, by Juneau and Cooper creeks, and by Russian River. At Cooper Creek recent erosion by Kenai River has cut down into these deposits to a depth of 200 feet or more, leaving the valley fill standing as high terraces flanking the river. (See Pl. XXVI, B.) A bluff at this point exposes the section shown in figure 14 .

The terraces on the lower part of Resurrection Creek (see Pl. XXVI, $B$ ) may also possibly have had a similar origin, the material forming them having been deposited in ponded waters when the big Turnagain Arm Glacier lay across the front of the creek.

\section{RECENT GRAVELS.}

Deposits whose material has been handled by the ice, but later reworked and laid down by glacial streams, may be seen in the broad gravel plains (or "valley trains") that are in process of formation in front of all of the big glaciers of the area. Glacier, Twentymile, and Portage creeks and Placer River furnish good examples of such deposits in the Turnagain Arm region. (See Pl.XXII, A.) On Resurrection and Snow rivers, near Seward, there are similar plains. The flow of the glacier-fed streams fluctuates greatly with both seasonal and daily variations in temperature. The streams are highest in midsummer, but in fall and winter they carry but little water. Their daily range in height in summer is also considerable. Their volume is lowest in the morning, but increases rapidly until late in the afternoon, when it is many times larger than it is earlier in the day. These variations of stream flow greatly affect the transportation and deposition of the detritus dumped by the glaciers. During periods of high water the streams carry large amounts of gravel, sand, and silt; at low stages their water is clear and carries but little material. As a result of the overloading of the streams during the summer their channels are constantly changing; in some places they flow in a single course, in others in an intricate network of channels. They build up bars in some places and cut them away in others, and are constantly working and reworking the material supplied by the glaciers, spreading it out over the flood plains and gradually filling up the valleys.

Glacial streams that discharge into bodies of standing water, such as Resurrection Bay, Turnagain Arm, and Kenai Lake, have formed broad flats at their mouths. The marvelous tides and bore of Turnagain Arm, comparable only to those of the Bay of Fundy on the Atlantic coast, spread the glacial silts over broad areas, and at low 
tide many miles of mud flats are exposed which at high water are completely covered as far up as the mouth of Twentymile River. Snow River is building a broad flat at the upper end of Kenai Lake, its delta being pushed from year to year farther and farther out into the lake. Smaller streams, such as Falls, Victor, and Quartz creeks, are building small delta fans out into the lake. (See Pl. XXVII, A.). Other lakes are being similarly filled, and some lakes that are now extinct were probably filled in the same way.

In a mountainous region like this these flats are about the only places available for the sites of large villages. Seward is built on the alluvial fan of a small creek near the head of Resurrection Bay (see Pl. V, A) and can find room to grow on the wide gravel flats of Resurrection River and Salmon Creek. Hope, Sunrise, and Girdwood are built on alluvial flats at the mouth of Resurrection, Sixmile, and Glacier creeks, respectively. The flats are also the most promising parts of this mountainous region for agriculture, and homesteads have been taken up on the Resurrection River flats near Seward and elsewhere on alluvial flats.

The materials deposited by the nonglacial streams in their channels include gravels, sands, and clays, which rest either on bedrock or on earlier glacial or fluvioglacial deposits. The thickness of these recent stream deposits is commonly from 2 to 10 feet, but it is in places as much as 15 or 20 feet. The deposits comprise a variety of material derived from the reworking of earlier unconsolidated deposits, already described, or from recent erosion of the bedrock, and they are usually poorly stratified.

\section{GEOLOGIC HISTORY. \\ PRE-QUATERNARY HISTORY.}

The pre-Quaternary geologic history of the central and northern parts of Kenai Peninsula may be summarized as follows: The sedimentary rocks of the Sunrise group, which include some beds of Jurassic or early Cretaceous age, were closely folded and faulted during Mesozoic time and intruded by quartz diorite stocks and diorite porphyry dikes (see PI. XXV) of the same general age and character as the Coast Range batholithic intrusives of Prince William 'Sound and southeastern Alaska. Soon after this period of igneous activity the ore deposits were formed, presumably also in Mesozoic time. No Tertiary deposits occur in this part of the peninsula, the rocks of which were probably raised above sea level during Tertiary time, and stream erosion in late Tertiary or early Quaternary time doubtless removed any beds that overlay the rocks now exposed.

QUATERNARY HISTORY.

PREGLACIAL CONDITIONS.

Up to the beginning of Quaternary glaciation the topography of the region was probably that which characterizes mountainous areas in 
which normal stream erosion has been the principal agency in shaping the surface. Well-developed drainage systems probably existed whose distribution was in general probably similar to that of the drainage "systems of to-day, and it seems reasonable to suppose that graded streams with accordant tributaries flowed in narrow, sinuous, $V$-shaped valleys, that stream gravels lay in the valley bottoms, and that a mantle of residual soil and rock waste covered the interstream areas.

GIACIAL CONDITIONS.

Beginning of glaciation and advance of the ice.-The Quaternary began with a climatic change that resulted in an annual snowfall in excess of the snow melted during the warm months and established conditions favorable to glaciation. Perennial snowdrifts were formed in the higher parts of the region. Succeeding snows added to the thickness of the deposits. The increasing weight resulted, first, in the consolidation of the snow, then in the development of the névé, which later, with additional pressure, became more compact and coherent, grading into porous ice in its lower parts. Finally, the pressure on the lower layers of the névé exceeded that under which the mass could remain quiescent on the slopes and produced downward glacial movement. Bergschrunds (dividing lines between quiescent and moving névé) appeared, cirques were formed, and rapid headwall erosion of the cirques began. Frost action, concentrated at the bergschrunds, and the abrasive power of the glaciers were the principal agents of degradation during the glacial period.

As the snow accumulated, caps of ice were formed in the higher mountainous regions, glacier tongues moved outward from the central ice masses, and the glacier fronts were pushed farther and farther down the valleys, southward into the Pacific or northward and westward toward Cook Inlet. Numerous glaciers in the high mountains east of the Alaska Northern Railway descended eastward and southward into Prince William Sound and into the Pacific and westward to unite with ice tongues that came from the southwestern ice cap, spreading out on the Cook Inlet forclands as piedmont glaciers and later merging with the broad ice sheet that flowed southward through Susitna Valley to the Pacific. Ice filled the valleys to greater and greater depths and the lower portions of the ridges between adjoining valleys were overridden. With the lowering of perpetual snow line glaciers formed in the less elevated regions, and ice streams flowed from these areas to unite with those from the higher parts of the range. The glaciation at this time was chiefly alpine, the glaciers being confined to and directed by the preglacial drainage lines.

Maximum extent of the ice:-During the maximum extent of the ice the entire central and northern parts of Kenai Peninsula were probably covered by an immense ice cap, although a few isolated 
peaks may have projected as nunataks above the level of the ice. The maximum thickness of this ice sheet is unknown, but in the valleys of some of the larger streams, such as Resurrection River, it must have been at least 4,000 or 5,000 feet.

The ice front during the maximum extent of the ice lay beyond the region examined, as the Kenai Mountain ice cap joined to the west and north the ice from the Alaska Range and on the east and south extended out into the Pacific Ocean.

Retreat of the ice.-When under climatic conditions less favorable to glaciation the ice gradually retreated and the ice cap disappeared from most of the mountainous area, mountain glaciation again prevailed, and frost action renewed its attack upon the upland areas, the headwall recession of the cirques modifying the glaciated areas and in places removing all evidences of glacial abrasion in the higher regions. The area affected by glacial abrasion and plucking decreased with the waning of the glaciers, but the process remained effective and still continues beneath the existing glaciers.

Minor fluctuations of the ice front probably occurred during the main advance and retreat of the ice, and it is possible that in Quaternary time more than one great ice advance took place, and that during the interglacial periods the ice sheet greatly diminished in size or, perhaps, disappeared entirely. In the mountainous regions of the United States and Canada there was a series of ice advances and in the continentally glaciated area of North America and Europe there were several glacial periods. Similar conditions may have prevailed in Alaska, although it is possible that in the central distributing areas, such as Kenai Peninsula must have been, the ice never left the area entirely. Sufficiently detailed studies of the glacial phenomena have not yet been made, however, to determine either the number or the extent of any major fluctuations of the ice sheet in Kenai Peninsula during Quaternary time.

A remnant of the former ice sheet caps the mountain peaks southwest of Seward. Small vestiges of the great system of ice streams that once moved seaward from the Kenai Mountains remain as the present-day glaciers (see Pls. VIII, $A$ and $B$; IX, $A$ and $B$; XXVIII, $A$ and $B$ ), whose situation, distribution, and relation to the existing drainage are shown on the topographic map (Pl. II, in pocket).

Results of glaciation.-The present topography of the region is the result of the combined action of the erosive agents of Quaternary time upon the preglacial topography. The upland features were sharpened by mountain glaciation during the ice advance, were later rounded and subdued beneath the ice cap, and were again accentuated by the mountain glaciation that followed the retreat of the ice. 


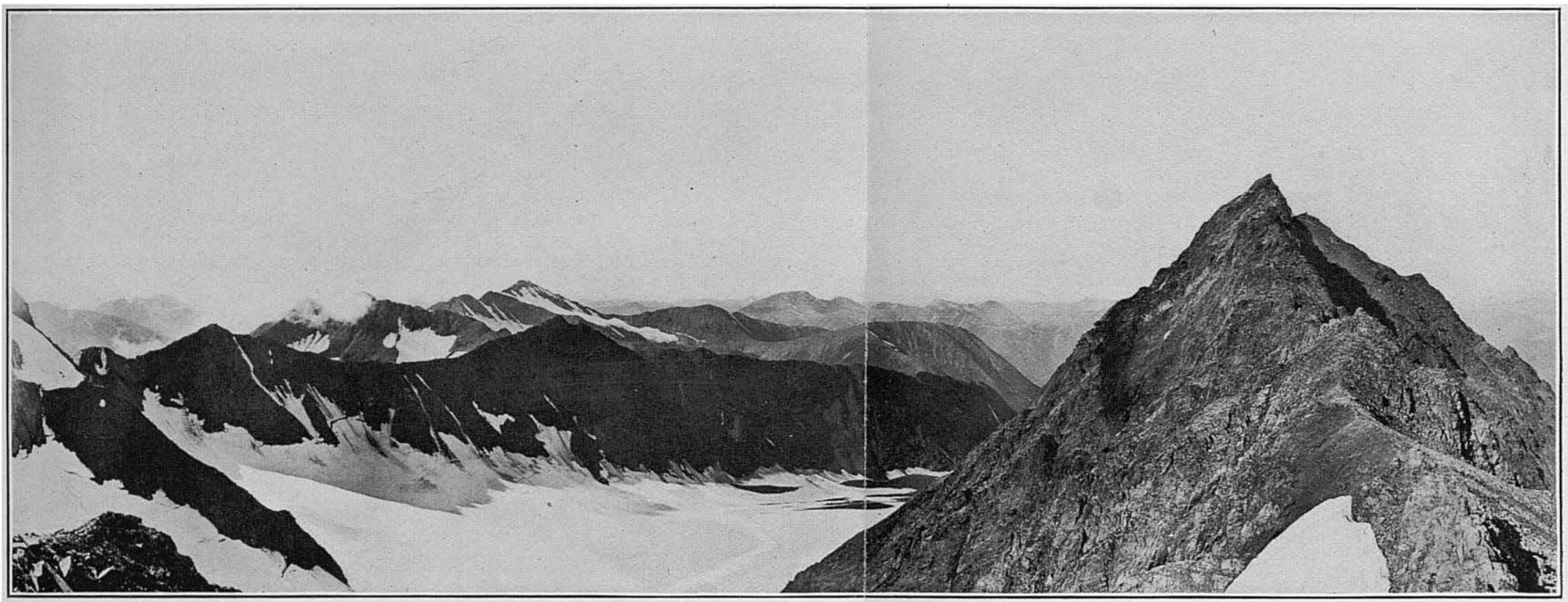

A. CIRQUES AND SMALL GLACIERS BETWEEN GRANITE CREEK AND PLACER RIVER.

View looking west from head of Granite Creek. Taken September 21, 1911.

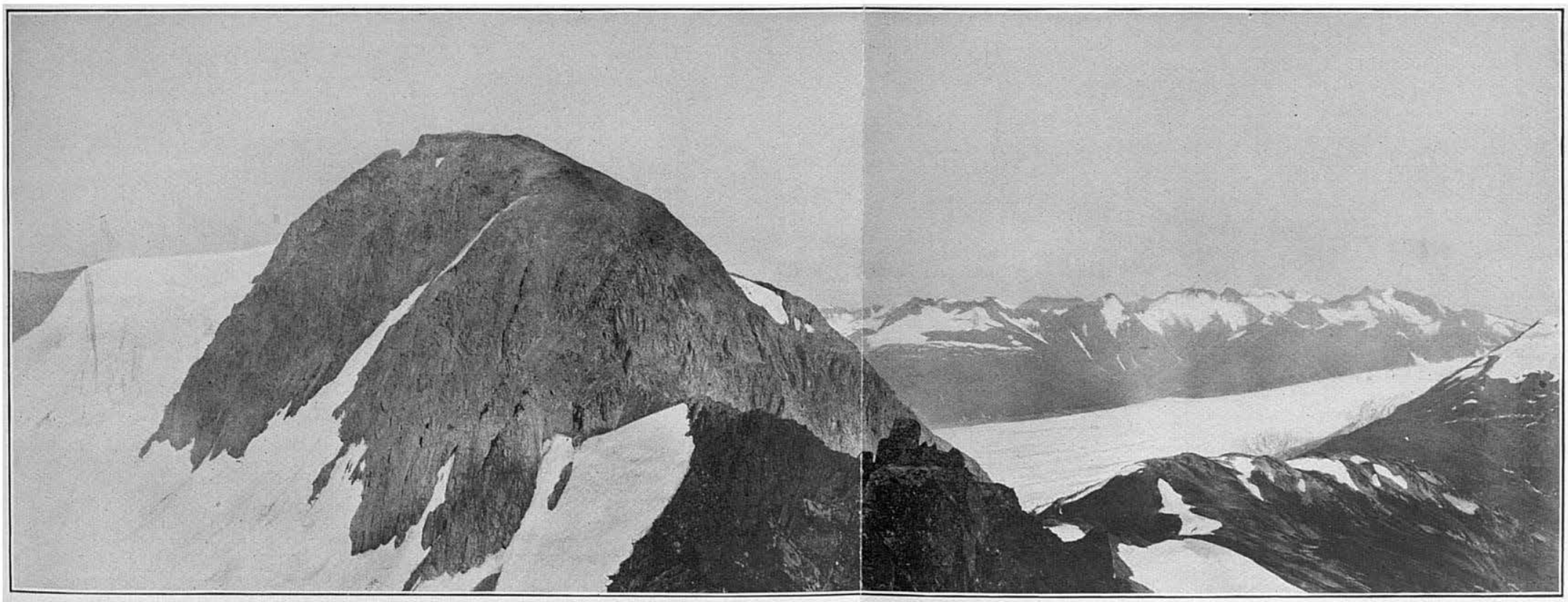

B. PEAK AT HEAD OF SOUTH FORK OF CENTER CREEK.

View looking N. $30^{\circ}$ E. Spencer Glacier at right. Photograph taken September 17, 1911. 

Evidence of glacial erosion is seen in the U-shaped cross sections of the valleys; in the overdeepening of the trunk valleys, such as Kenai River, with the development of hanging valleys from their tributaries; in the steplike valley floor of Bench and other creeks, with their alternations of flats and falls; in the truncated spurs of the main valleys; in the rounded ridges and hilltops of the western part of the area; and in numerous striated outcrops, best seen in areas recently uncovered by retreating glaciers.

The forms developed above the level of the ice during the periods of mountain glaciation preceding and following the occupation of the Kenai Mountains by ice caps present a marked contrast to those developed by abrasion and plucking beneath the glaciers. Frost action was the dominant degradational agent above the level of the ice. Where it was intensified, as at the bergschrunds of the glaciers, by the daily freezing and the thawing of the saturated rock, disintegration of the rocks and headwall erosion of the cirques proceeded with considerable speed. Complete investment of the upland area by the cirques yielded a "fretted upland," intersections of adjoining cirques yielding comb ridges, cols, and pyramidal peaks. (See Pls. XXVIII, $A$; XXIX, A.) Many of the forms developed during the advance of the ice were later overridden and rounded. (See Pl. XXIX, B.) Crow Creek Pass owes its present form to the abrasive power of an ice stream that moved through a col developed by the intersection of cirques at the heads of Raven and Crow creeks. Other passes that were similarly formed are found in this area. High-level sculpturing is still active in the higher parts of the region where glaciers remain (see Pl. XXVIII, $A$ ), and, in fact, all the characteristic features of mountain glaciation can be observed in one or another part of the Kenai Peninsula.

POSTGLACIAI EROSION.

Postglacial erosion is hardly an apt term to use in describing a region in which the glacial period is not yet ended, but it may be employed if restricted to erosion in one of the areas in that region from which the ice has retreated. Its effects are most pronounced in areas that have been longest free from ice. Disintegration is very rapid in bare rock areas above timberline in regions like the Kenai Mountains, where the daily range in temperature is great. Talus cones form at the foot of the bluffs and a thin mantle of rock waste, a result of disintegration due to frost action, covers the less steep exposed surfaces. Rock glaciers, most of them poorly developed, may be seen on Mills, Groundhog, and a few other creeks. (See Pl. XXIX, A.)

Most of the postglacial erosion, notably excepting the high-level sculpturing that accompanies mountain glaciation, has been stream 
erosion, but even in valleys that have been longest free from ice comparatively little stream erosion has taken place since the commencement of the ice retreat. As previously noted, aggradation is the principal activity characteristic of the overloaded glacial streams, whereas streams that are supplied only by melting snow and the ordinary run-off carry but little sediment and gradually cut their valleys deeper. Some streams that are interrupted by lakes, such as the lakes on some of the valley treads, exhibit both aggradation and erosion in different parts of their courses. Where the stream enters the lake it loses its coarser sediment, the lake acting as a settling pond; where it emerges it has marked eroding power, carving a narrow gorge in the rock bar or obstruction, or widening and deepening its channel in the older unconsolidated deposits below. Kenai Lake, for example, acts as a settling pond for the muddy waters of the glacier-fed Snow River, whereas the Kenai River immediately below the lake is cutting its way down through the earlier gravel deposits. Since the retreat of the ice, Cooper Creek, a tributary of Kenai River, has cut a narrow bedrock canyon through most of its course, but in its wanderings through the more easily eroded gravel filling of the overdeepened glacial channel of Kenai River it has widened its channel and developed a broad gravel-covered flat. (See Pl. XXXVI.) - At its lower end Resurrection Creek flows in a broad flat-bottomed valley which has been cut deep in the earlier gravels, remnants of which now form terraces along the valley sides. (See Pl. XXVI, B.) Narrow postglacial stream-cut rock gorges occur on Bench, Gulch, Sixmile, Canyon, Mills, Crow, Falls, and many other creeks. (See Pls. XXIX, $B$; XXXIV, $B$.)

\section{MINERAL RESOURCES.}

\section{AREA AND DEPOSITS CONSIDERED.}

The mineral resources of northern and central Kenai Peninsula include gold, copper, antimony, and silver-lead deposits. The gold deposits are by far the most valuable, the ores of other metals being of slight present commercial importance. The gold comes from both placer and lode deposits, but the placers have attracted the most attention. Interest in the gold-quartz lodes has gradually increased, however; systematic exploration has been commenced on several properties, and in 1911 and 1912 the quartz mines contributed largely to the gold production of the district.

The area covered by this report on the mineral resources lies within the third judicial division of the Territory of Alaska and includes portions of the Kenai and Knik recording districts, the recording offices of which are at Seward and Knik, respectively. Turnagain Arm divides the two districts. (See fig. 15.) 


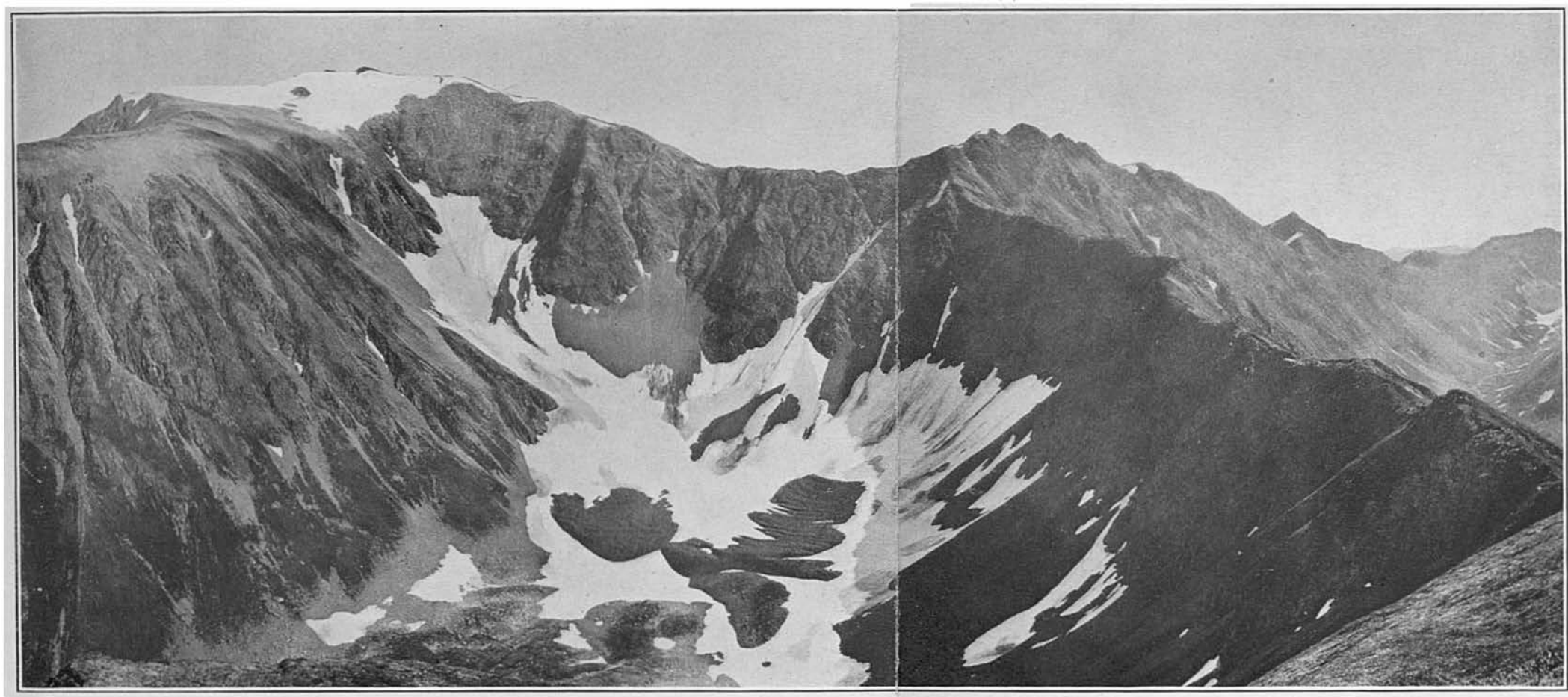

A. CIRQUE AT HEAD OF BLOCK CREEK.

View looking eastward; valley of Juneau Creek at right. Photograph taken August 29, 1911.

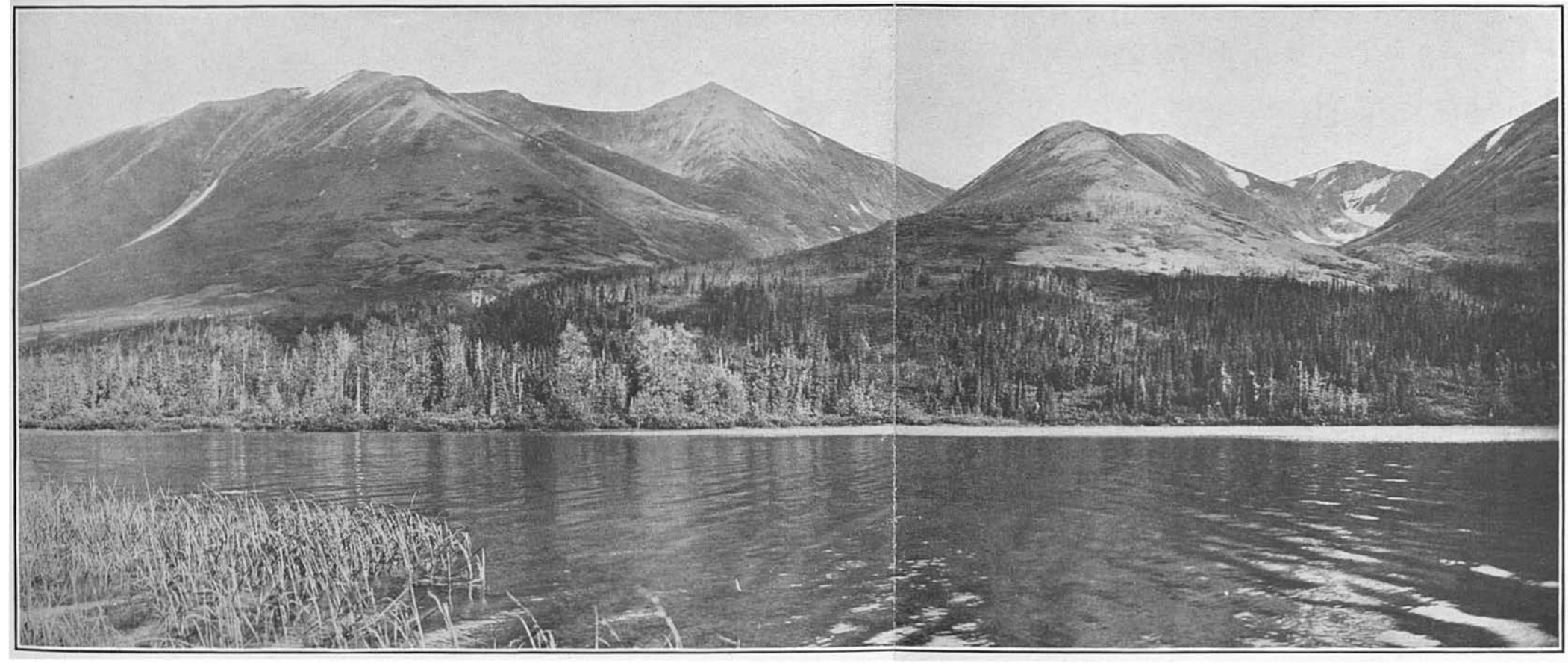

B. HANGING VALLEYS EAST OF SUMMIT LAKE. 

LODE DEPOSITS.

HISTORY.

The auriferous lodes in the Turnagain Arm region were discovered during the years of maximum activity in the development of the gold placers. Rich gold quartz float was found on Summit Creek, in the Moose Pass district, by John C. Gilpatrick in June, 1896. In 1898 quartz locations were made on Palmer, Bear, and Sawmill creeks and

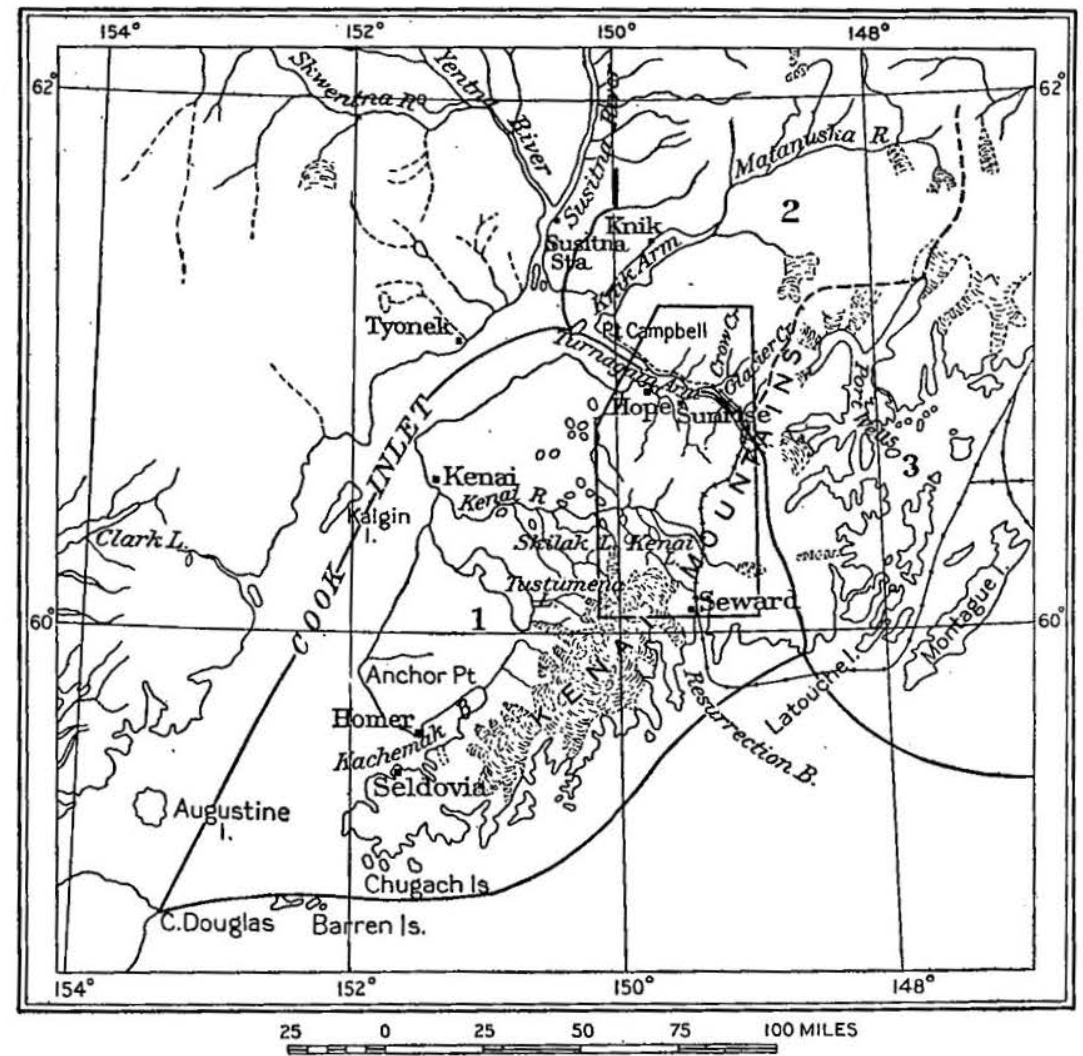

FIGURE 15.-Map showing the relation of the area described in this report to the Kenai and Knik recording districts. 1, Kenai recording district; 2, Knik recording district; 3, Valdez recording district.

some development work was done on prospects on those creeks in 1898 and 1899. In 1903 and 1904, after the settlement of Seward, gold quartz veins were discovered in the hills close to the town. The first discovery of gold-bearing quartz lodes on Falls Creek was made by F. P. Skeen and John Lechner, in 1905, on property now owned by the California-Alaska Mining Co. This property was bonded to C. D. Lane in October of that year and about 110 feet of development work was done. Between 1905 and 1907 small shipments of ore, $48891^{\circ}-$ Bull. $587-15-9$ 
averaging $\$ 35$ a ton, are reported to have been made from this property to smelters in the States. In June, 1906, J. W. and C. E. Stevenson located the Black Butte vein of the Kenai Alaska Gold Co. on Falls Creek and in August, 1906, John C. Gilpatrick made the first quartz locations in the Moose Pass district. The veins now being developed on the properties of the Seward Bonanza Gold Mines Co., near mile 21 on the Alaska Northern Railway, and of the SkeenLechner Mining Co., on Falls Creek, were located in 1907. The existence of the large mineralized dike in the Moose Pass district was not known until the later part of 1908. Many locations were made along this dike in that and the following year. On August 5, 1909, A. L. Snow and A. W. Watson bonded the Gilpatrick claims at the southern end of this dike, between Slate and Summit creeks, and did several hundred feet of development work before the refusal of the owners to extend the time limit on the second payment beyond one month caused a cessation of work and the forfeiture of the bond.

New gold lodes were discovered in 1909 on Crow Creek and Resurrection River. Arrastres were installed on the property of the California-Alaska Mining Co. on Falls Creek and were operated for a short time during that year and the next. In 1910 development work was carried on at a few properties, notably on Crow and Falls creeks, and in the Moose Pass district. During 1911 the California-Alaska Mining Co. replaced the arrastres on its property by a 2-stamp mill, and the Kenai Alaska Gold Co. erected a 5-stamp mill on the north side of the valley of Falls Creek. Both mills were in operation during a part of the summer. Development work was carried on actively at several properties and assessment work was done on many others. A large number of prospectors visited the region in 1911 and several goldbearing veins were discovered.

In 1912 stamp mills were run for a part of the season at the properties of the Primrose Mining Co., on Porcupine Creek, and the Kenai Alaska Gold Co. on Falls Creek. The mill of the California-Alaska Mining Co. on Falls Creek was run for a short time on ore from the Skeen-Lechner Mining Co.'s workings on Falls Creek. It is reported that two arrastres and a Little Giant mill were erected in the Moose Pass district and a few tons of ore crushed. A small stamp mill is also reported to have been erected on Palmer Creek. An aerial tram was erected on the Kenai Alaska Gold Co.'s property during the summer. Underground development work was carried on at the Lost Creek properties, at the Primrose Mining Co. on Porcupine Creek, at the Kenai Alaska Gold Co., and the Skeen-Lechner Mining Co. on Falls Creek, at quartz properties on Resurrection River, Grant Lake, and Crow Creek. The California-Alaska Mining Co.'s workings on Falls Creek were unwatered and sampled. Assessment work was done on several other properties. 


\section{PRODUCTION.}

The lode gold production of Kenai Peninsula previous to 1911 was small. Several hundred dollars was obtained by the use of an arrastre on Sawmill Creek about 1904. Small shipments of ore averaging $\$ 35$ a ton are reported to have been made to smelters in the United States between 1905 and 1907 from the property of the California-Alaska Mining Co. on Falls Creek. In 1909 and 1910 the arrastres of this company made a slight additional production. With the completion of the two stamp mills on Falls Creek in 1911, systematic milling operations began on the peninsula. In that year about 240 tons of ore was milled and the production was between $\$ 9,000$ and $\$ 10,000$. In 1912, after other stamp mills and arrastres had been erected, the annual production was increased to about $\$ 21,000$. The total production of lode gold to January 1, 1913, is estimated to have been about $\$ 33,000$.

\section{MINERALOGY OF THE ORE DEPOSITS.}

The mineralogy of the ore deposits of northern and central Kenai Peninsula is extremely simple, as will be evident from an examination of the accompanying table, which gives, in alphabetic order, the minerals recognized in the ores of this region. The table includes only those minerals that constitute or accompany the ore deposits, not the minerals of the wall rocks that have not been affected by the orebearing solutions.

Minerals in ore deposits of northern and central Kenai Peninsula, Alaska.

\begin{tabular}{|c|c|c|}
\hline Mineral. & Formula. & Occurrence. \\
\hline & $\mathrm{NaAlSi}_{3} \mathrm{O}_{8} \ldots \ldots$ & Occasional gangue mineral of the gold quartz ores. \\
\hline$\theta_{1}$ & $\mathrm{FeAs}$ & $\begin{array}{l}\text { Most abundant sulphide in the gold quartz ores of this district, } \\
\text { widely disseminated in altered wall rocks of veins and lodes and } \\
\text { in the mineralized dikes. }\end{array}$ \\
\hline Calcite. & $\mathrm{CaCO}_{3}$. & $\begin{array}{l}\text { Widely disseminated. Present as a gangue mineral in most of the } \\
\text { gold quartz ores. Occurs also in the altered wall rocks, impure } \\
\text { imestones, and calcareous gravwackes. }\end{array}$ \\
\hline Cerusite.. & $\mathrm{PbCO}_{3} \ldots$ & Surface oxidation product of primary galena of the ores. Not \\
\hline Chalcopyrite & CuFeS:. & $\begin{array}{l}\text { Occurs in the ores from several gold quartz properties and in the } \\
\text { copper ore on Lynx Creek. }\end{array}$ \\
\hline Chlorite.. & $\begin{array}{l}\text { Complex silicate of } \\
\text { H, Fe, Mg, and } \\
\text { Al; variable. }\end{array}$ & $\begin{array}{l}\text { Alteration product of various minerals. Found in mineralized } \\
\text { dikes, etc. Common alteration product of the ferromagnesian } \\
\text { minerals in the dikerocks; occurs rarely as a vein-forming mineral. }\end{array}$ \\
\hline Copper. & Cu................. & $\begin{array}{l}\text { Native copper nuggets found in gold placers on Lynx and of her } \\
\text { creeks, probably derived by surface alteration of copper sulphide } \\
\text { lodes. }\end{array}$ \\
\hline Galena. & Pbs.... & One of the characteristic sulphides of the gold quartz ores of the \\
\hline Gold. & Au.. & Native. The principal valuable constituent of most of the ores of \\
\hline Limoni & $\mathrm{H}_{6} \mathrm{Fe}_{4} \mathrm{O}_{9} \ldots \ldots \ldots$ & $\begin{array}{l}\text { Earthy form. Oxidation product of iron minerals in outcrops of } \\
\text { the veins. Of widespread occurrence but not abundant. }\end{array}$ \\
\hline $\begin{array}{l}\text { Magnetit } \\
\text { Malachit } \\
\text { Molybde }\end{array}$ & 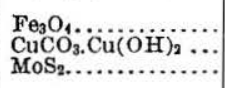 & $\begin{array}{l}\text { the veins. Of widespread occurrence but not abundant. } \\
\text { Not commontrates from gold placers as black sand. } \\
\text { In narrow quartz vein at hidation product of chalcopyrite. }\end{array}$ \\
\hline Muscovite & $\mathrm{H}_{2} \mathrm{KAl}_{3} \mathrm{Si}_{3} \mathrm{O}_{12} \ldots$ & $\begin{array}{l}\text { on Chickaloon River. } \\
\text { Occurs as variety known as sericite. Common product of the altera- } \\
\text { tion of dike rocks and the wall rocks of the veins by mineralizing }\end{array}$ \\
\hline & $\mathrm{FeS}_{2}$. & $\begin{array}{l}\text { Solutions. } \\
\text { bundant in some of the ores. Is also disseminated in altered wall } \\
\text { rocks of veins. }\end{array}$ \\
\hline
\end{tabular}


Minerals and ore deposits of northern and central Kenai Peninsula, Alaska-Continued.

\begin{tabular}{|c|c|c|}
\hline Mineral. & Formula. & Occurrence. \\
\hline Pyrolusite.... & $\mathrm{MnO}_{2} .$. & Dendritic markings on joint surfaces of igneous and sedimentary \\
\hline Pyrrhotite. & Composition varia- & Occurs in ores from several prospects. \\
\hline Quartz.. & $\mathrm{SiO}_{3} \cdot \ldots . . . . . . . . . .$. & Principal gangue mineral of the gold ores. Constituent of the igne- \\
\hline Sericite.. & See muscovite.. & Alteration product of various minerals in mineralized dikes and \\
\hline Silver.. & Ag... & Valuable constituent of gold ores and placer gold. Native silver \\
\hline Sphalerite.. & ZnS.. & One of the characteristic sulphides in the gold quartz ores of this \\
\hline Stibnite. & $\mathrm{Sb}_{2} \mathrm{~S}_{3}$. & $\begin{array}{l}\text { Occurs as stringers and disseminated particles in sheared acidic } \\
\text { dike and as needles in small quartz vein near lower end of Kenal } \\
\text { Lake. } \\
\text { Gold tellurides reported from Falls Creek and Moose Pass proper- } \\
\text { ties. Chemical tests fail to shuw their presence. }\end{array}$ \\
\hline
\end{tabular}

The relative abundance of the different minerals as well as the mineral associations in the ores of Kenai Peninsula are shown in the following table:

Relative abundance of primary ore minerals and mineral associations at mines and prospects of northern and central Kenai Perinsula, Alaska.

\begin{tabular}{|c|c|c|c|c|c|c|c|c|c|c|c|}
\hline & \multirow[b]{2}{*}{ Mines and prospects. } & \multicolumn{2}{|c|}{ Gangue. } & \multirow{2}{*}{$\begin{array}{l}\text { Visi- } \\
\text { ble } \\
\text { free } \\
\text { gold. }\end{array}$} & \multicolumn{7}{|c|}{ Sulphide-ore minerals. } \\
\hline & & Quartz. & $\begin{array}{l}\text { Cal- } \\
\text { cite. }\end{array}$ & & $\begin{array}{l}\text { Arseno- } \\
\text { pyrite. }\end{array}$ & $\begin{array}{l}\text { Ga- } \\
\text { lena. }\end{array}$ & $\begin{array}{l}\text { Sphal- } \\
\text { erite. }\end{array}$ & $\begin{array}{l}\text { Py- } \\
\text { rite. }\end{array}$ & $\begin{array}{l}\text { Pyr- } \\
\text { rho- } \\
\text { tite. }\end{array}$ & $\begin{array}{c}\text { Chal- } \\
\text { copy- } \\
\text { rite. }\end{array}$ & $\begin{array}{l}\text { Mo- } \\
\text { lyb- } \\
\text { de- } \\
\text { nite. }\end{array}$ \\
\hline 1 & $\begin{array}{l}\text { Resurrection Bay Mining } \\
\text { Co.'sprospect on Resurrec- }\end{array}$ & 0000 & ००० & $\circ$ & 00 & 。 & 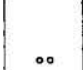 & 00 & & $\bullet$ & \\
\hline 2 & Tozier-Lane Northern Light & 0000 & & & & 。 & & & & & \\
\hline $\begin{array}{l}3 \\
4\end{array}$ & Mile Four Mining Co........... & 0000 & 0 & $\cdots \cdots$ & 000 & $\circ$ & 。 & ○ & $\circ$ & $\circ$ & $\cdots \cdots$ \\
\hline 5 & 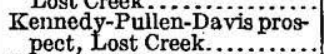 & 0000 & & & $\bullet$ & 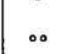 & 000 & 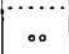 & & $\circ$ & \\
\hline 6 & $\begin{array}{l}\text { Primrose Mining Co., Porcu- } \\
\text { pine Creek............................ }\end{array}$ & 0000 & & & ○০० & $\circ$ & $\circ 0$ & $\circ$ & & 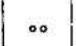 & \\
\hline 7 & 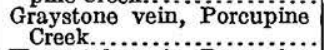 & $\therefore$ & - & & & & & & & & \\
\hline 8 & $\begin{array}{l}\text { Homestake vein, Porcupine } \\
\text { Creek........................ }\end{array}$ & $\circ$ & $\circ$ & & $\circ$ & & & $\circ$ & $\circ$ & & \\
\hline 9 & $\begin{array}{l}\text { Guimbard's prospect on Slate } \\
\text { Creek, tributary to Porcu- } \\
\text { pine Creek..................... }\end{array}$ & 0000 & & - & - & $\circ$ & & 000 & & & \\
\hline 10 & $\begin{array}{l}\text { Guimbard's prospect,3 miles } \\
\text { from Kenai Lake.......... }\end{array}$ & 0000 & $\circ$ & & 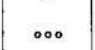 & & & $\circ$ & & & \\
\hline 11 & $\begin{array}{l}\text { Guimbard's prospect, } 1 \text { mile } \\
\text { from Kenai Lake........... }\end{array}$ & 0000 & & $\circ$ & $\bullet$ & $\cdot$ & $\circ$ & & & & \\
\hline $\begin{array}{l}12 \\
13\end{array}$ & $\begin{array}{l}\text { Porcupine Ledge } . \ldots \ldots \ldots \ldots \ldots \\
\text { Devil Club vein. . . . . } \ldots \ldots \ldots \ldots\end{array}$ & 0000 & $\because$ & $\circ$ & $\begin{array}{c}\circ \circ \\
\circ\end{array}$ & $\infty 0$ & $\infty$ & & & & \\
\hline 14 & 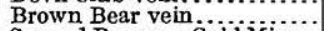 & 0000 & $\because$ & $\because+$ & 000 & 00 & $\because$ & & & $\cdots \cdots$ & \\
\hline $\begin{array}{l}15 \\
16\end{array}$ & $\begin{array}{l}\text { Seward Bonanza Gold Mines. } \\
\text { Kenai-Alaska Gold Co., Falls }\end{array}$ & 0000 & 。 & 。 & 000 & 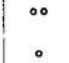 & $\bullet$ & $\because \cdots$ & & $\because \cdots$ & \\
\hline 17 & 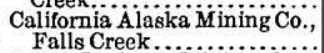 & 0000 & & - & 000 & - & $\circ$ & $\circ$ & & & \\
\hline 18 & $\begin{array}{l}\text { Skeen-Lechner Mining Co., } \\
\text { Falls Creek ....................... } \\
\text { Buster yein }\end{array}$ & $\begin{array}{l}0000 \\
0000\end{array}$ & a & 。 & $\stackrel{\circ}{\infty}$ & 0 & & & & & \\
\hline 19 & $\begin{array}{l}\text { Buster vein, Quartz Creck... } \\
\text { Kaffir vein, Quartz Creek.... }\end{array}$ & 0000 & $\because$ & & & $\cdots$ & $\because \cdots$ & $\because \cdots$ & & $\ddot{u}^{\prime} \mathrm{o}^{\prime}$ & \\
\hline 21 & $\begin{array}{l}\text { Stringer, opposite placers, } \\
\text { Quartz Creek }\end{array}$ & ○००० & & $\circ$ & & $\circ 0$ & ○ & & & & \\
\hline 22 & 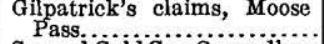 & 0000 & $\circ$ & $\circ$ & 0,0 & $\circ$ & $\circ$ & & & $\circ$ & \\
\hline 23 & 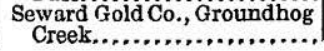 & 0000 & $\bullet$ & $\bullet$ & ००० & 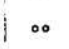 & $\infty$ & - & & & \\
\hline
\end{tabular}


Relative abundance of primary ore minerals and mineral associations at mines and prospects of northern and central Kenai Peninsula, Alaska-Continued.

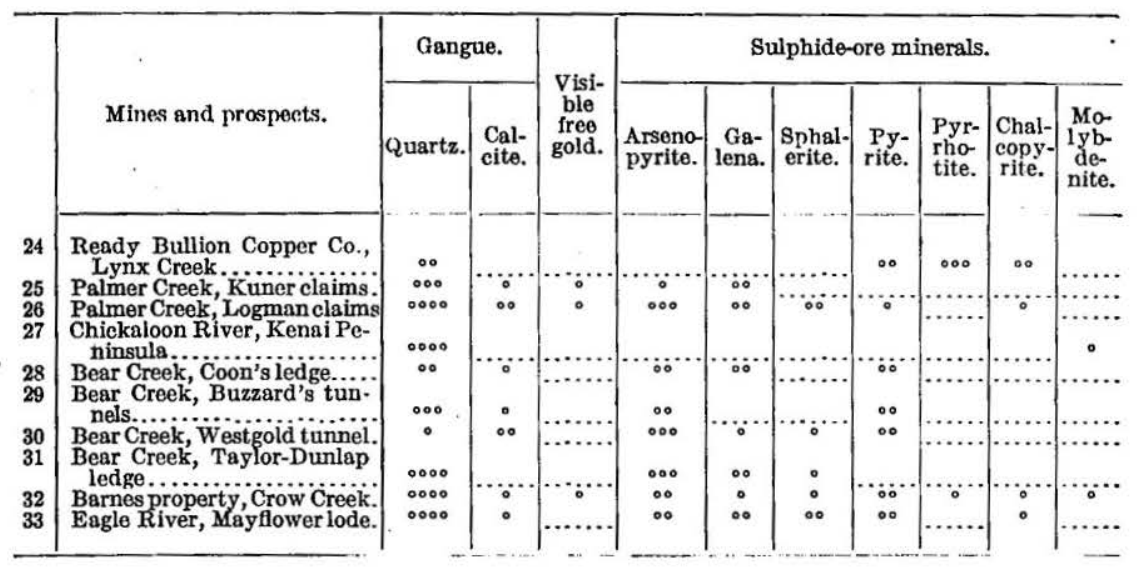

Quartz is the predominant gangue mineral, calcite being usually associated with it in very subordinate amount. The principal metallic ore minerals are arsenopyrite, galena, sphalerite, and pyrite, which are accompanied by smaller amounts of chalcopyrite and pyrrhotite. Molybdenite was noted at two localities. Free gold occurs in many of the quartz veins, most abundantly in ores that contain both galena and sphalerite, and the presence of these two minerals in the ore usually indicates a high gold content. Arsenopyrite is the most abundant sulphide, but it is not everywhere auriferous.

The list of prospects is not complete, but is believed to include most of the important properties and to be representative of the region. The prospects are considered in geographic order from Resurrection Bay northward. The circle $\left(^{\circ}\right)$ used in the table represents no definite quantitative unit, the number of circles used indicating only in a general way the relative abundance of the gangue minerals or sulphides at each prospect. The data at hand permit only the most general comparison between the different prospects. The absence of a circle in the column headed "Visible free gold" does not necessarily mean that the ore contains no free gold. It merely signifies that none was observed in the specimens examined. A like statement may be made for the other columns, but the nonoccurrence of a certain sulphide in numerous representative specimens is assumed to indicate at least the scarcity of the mineral at that prospect.

NOTES ON THE MORE IMPORTANT MINERALS OF THE ORE DEPOSITS.

Gold.-Native gold is the only mineral found in commercial quantities in this region. It occurs in veins, lodes, and placer deposits 
In the vein and lode deposits it is associated with metallic sulphides in a quartz-calcite gangue. It is mechanically included in grains of arsenopyrite, galena, and sphalerite, is intimately associated with but not included in the sulphide grains, and also occurs free in the quartz. The pyrite is probably also auriferous, wire gold having been observed in iron-stained cavities left by the oxidation of pyrite. The auriferous sulphides originally deposited along the joint cracks in many veins were later removed by oxidation and left their gold content as minute specks among the rusty decomposition products. Gold deposited on pyrite crystals was observed at the Primrose mine, on Porcupine Creek. A study of the mineral association of the gold ores of the region leads to the conclusion that the mineralizing solutions that deposited the sphalerite and galena also deposited the gold. At the Mile Four Mining Co.'s property the rich quartz stringers carry abundant sphalerite and galena and considerable arsenopyrite, while the low-grade quartz lenses in the tunnel carry only arsenopyrite, pyrite, and pyrrhotite. Knopf reports that in the Eagle River region of southeastern Alaska the association of arsenopyrite and galena is everywhere conjoined with the occurrence of gold in high values. In the Kenai Peninsula this generalization must be extended to include sphalerite. Arsenopyrite is less important in this region, for though it is invariably present in the ores the quartz veins contain many barren lenses of arsenopyrite.

Silver.-Nuggets of native silver have been found in the placers of Crow, Bear, and Palmer creeks, and the placer gold of the entire area is alloyed with a variable amount of silver. All quartz gold, as is well known, contains silver, and though native silver has not been reported from any of the lode mines of the region, assay returns show that silver occurs in widely varying amounts in the ores, the ratio of silver to gold by weight shown by assays ranging from $1: 7$ to $12: 1$.

Copper.- Small nuggets of native copper have been found in the placer gravels on several streams on Kenai Peninsula, but most abundantly on Lynx Creek, finally leading to the discovery, near the head of that creek, of a ledge carrying copper sulphides. The copper nuggets of the placers undoubtedly had their origin in lode deposits, but native copper has not been observed in any of the copper or gold lodes of the region.

Tellurides.-Gold tellurides have been reported from some of the Falls Creek and Moose Pass properties. Tests made by Grant and Higgins ${ }^{1}$ on material from the vein of the California-Alaska Mining Co. on Falls Creek failed to show the presence of any tellurium. No tellurides were seen during the examination of the district in 1911

Grant, U. S., and Higgins, D. F., Preliminary report on the mineral resources of the southern part of Kenai Peuinsula: U. S. Geol. Survey Bull. 442, pp. 171, 173, 1910. 
and tests made in the chemical laboratory of the United States Geological Survey of selected specimens of supposed telluride ore from the California-Alaska Mining Co.'s vein on Falls Creek and from the Gilpatrick property, in the Moose Pass district, showed no trace of tellurium. Though tellurides are doubtless not important metallic minerals in the gold veins of this region, yet compounds of gold and tellurium may occur in these veins in a few places in exceedingly small amounts, as they occur in similar gold quartz veins in California.

Arsenopyrite.-Arsenopyrite (FeAsS), a sulpharsenide of iron, is the most abundant metallic sulphide in the gold quartz ores of this region. It can readily be distinguished from pyrite by its silverwhite color and the garlic odor which it yields when struck with steel. It occurs in association with the other sulphides in the veins of the region and also as striated crystals in the altered country rock of the veins. At some places arsenopyrite, as well as sphalerite, galena, and pyrite, inclose native gold, but at others large masses of arsenopyrite show only a trace of gold upon assaying.

Sphaterite.-The mineral sphalerite (ZnS), zinc sulphide, commonly known as blende, zinc blende, or blackjack, is a common constituent of the gold quartz ores of Kenai Peninsula. At no place is it found in sufficient quantity to be considered as a possible zinc ore, usually occurring only in small amounts, associated with the pyrite, galena, arsenopyrite, chalcopyrite, and pyrrhotite of the ores. Sphalerite and galena are the sulphides most intimately associated with the gold. The close relation that exists between these two sulphides and the gold is well brought out in the table (p. 135) showing the association of minerals at the different gold quartz prospects.

Galena.-The sulphide of lead, galena (see p. 65), is one of the most common sulphides of the region. It occurs with the other sulphides and with gold in small scattered grains or masses in the veins. Occasionally native gold is inclosed within the grains of galena. Galena is rarely found in the altered wall rocks of the vein, and nowhere in the veins does it occur in sufficient quantity to form an ore of lead. The silver content of the ores is probably closely rolated to the galena, although the gold of the veins is alloyed with silver. The association of galena and sphalorite in the ores appears to be an indication of high values in gold.

Pyrite.-Pyrite $\left(\mathrm{FeS}_{2}\right)$, the disulphide of iron, is a primary constituent of most of the ores of the region, but is not abundant and forms no considerable masses. The pyrite generally occurs as impregnations of the wall rocks of the veins and is widely disseminated in the country rock. On Crow Creok, in the hanging wall of one of the veins, pyrite is disseminated in small specks through a very fino grained sandy argillite and occurs also in quartz-calcite 
veinlets. At the Ready Bullion mine, on Lynx Creek, it impregnates fine-grained graywackes. Calcareous graywackes impregnated with pyrite occur on Eagle River and on Raven, Quartz, Canyon, and other creeks. Graphitic slates and schists impregnated with pyrite and containing small quartz-calcite veinlets that carry a little pyrite are found at several places. Small pyrite crystals are also seen. The pyrite in some of the ores appears to be auriferous, the decomposition of an iron sulphide leaving iron-stained cavities containing abundant wire gold. Generally, however, gold is more abundant where sphalerite and galena occur.

Pyrrhotite.-Pyrrhotite, often called magnetic pyrite, a sulphide of iron containing less sulphur than pyrite, may be distinguished by its peculiar reddish-bronze color and by the fact that it is slightly attracted by a magnet. It is not abundant in the ore bodies of Kenai Peninsula but is rather widely distributed. It is associated with chalcopyrite in thin glassy quartz veinlets in slates near the quartz-dioritic intrusives at the head of Crow Creek. On the Ready Bullion Copper Co.'s claims, at the head of Lynx Creek, "chalcopyrite ore accompanied by pyrrhotite and pyrite with much quartz has been deposited along a zone of shearing."1 Pyrrhotite-impregnated diabasic greenstone bowlders are found in the gravels of Lynx Creek. Pyrrhotite occurs also in small quartz veinlets in a sandy slate between miles 13 and 14 on the Alaska Northern Railway and, in association with pyrite, impregnates graywackes and sheared black slates at several places. It is an important constituent of the ore in the Tozier prospect, on Resurrection Bay, Seward. Pyritic and pyrrhotitic impregnation of the graywacke footwall of the Kaffir ledge of Fairman \& Madson on Quartz Creek was also noted.

Chalcopyrite.-Chalcopyrite $\left(\mathrm{CuFeS}_{2}\right)$, a sulphide of copper and iron, known also as copper pyrite or yellow copper, is not a valuable constituent of the gold quartz ores, but it is the copper-bearing mineral at the Ready Bullion mine on Lynx Creek, where it occurs in association with pyrrhotite and pyrite. It is a constituent of the gold veins of the Logman property on Palmer Creek; the Barnes property, on Crow Creek; the Primrose mine, on Porcupine Creek; the Mile Four property; the Kennedy-Pullen-Davis property, on Lost Creek; the properties on Resurrection Bay near Seward; some of the prospects on Quartz Creek; the Seward Bonanza Gold prospect, near mile 20, Alaska Northern Railway; and the Mayflower ledge, on Eagle River. The chalcopyrite is rather widely distributed, and would probably be found in most of the gold quartz ore bodies of the district but is nowhere present in large quantity. Cherts carrying chalcopyrite are found near the head of Mills Creek.

\footnotetext{
1 Paige, Sidney, and Knopf, Adolph, Reconnaissance in the Matanuska and Talkeetna basins, with notes on the placers of the adjacent region: U. S. Geol. Survey Bull. 314, p. 125, 1907.
} 


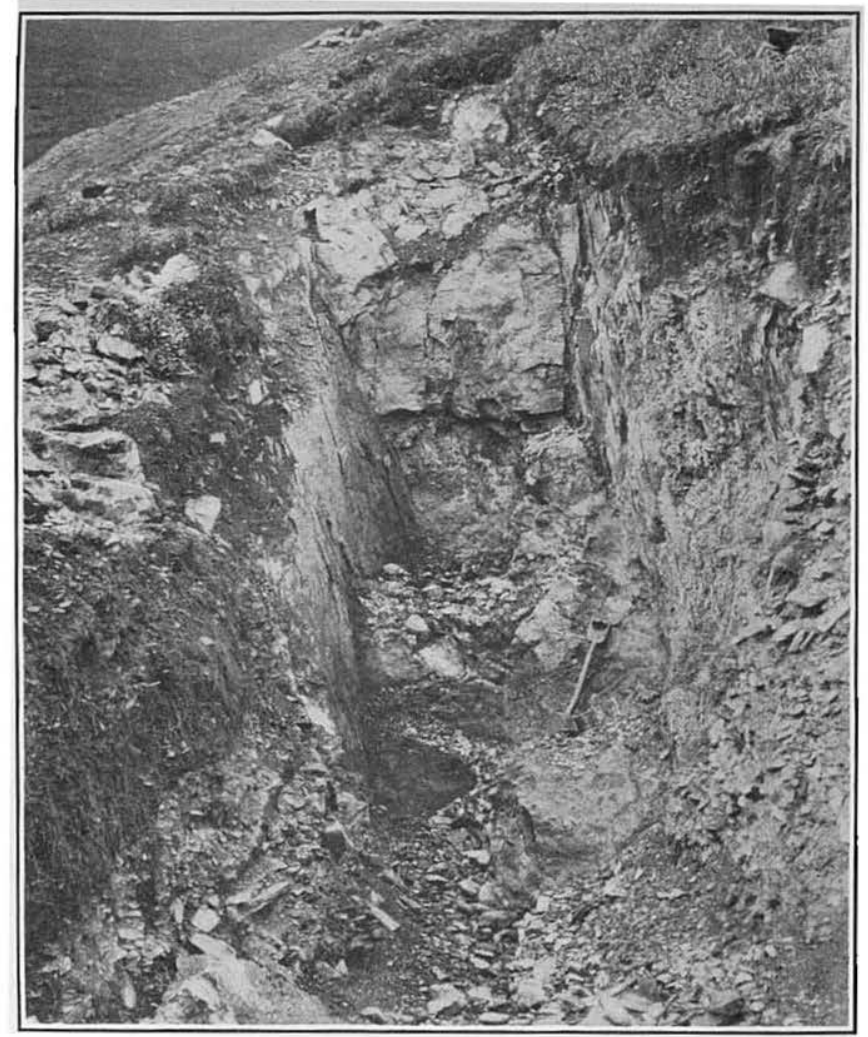

A. MINERALIZEO DIORITE PORPHYRY DIKE, FRESNO CREEK. Open cut on the Moose Pass dike. Note sheared walls, slight variation in width,
and fracturing.

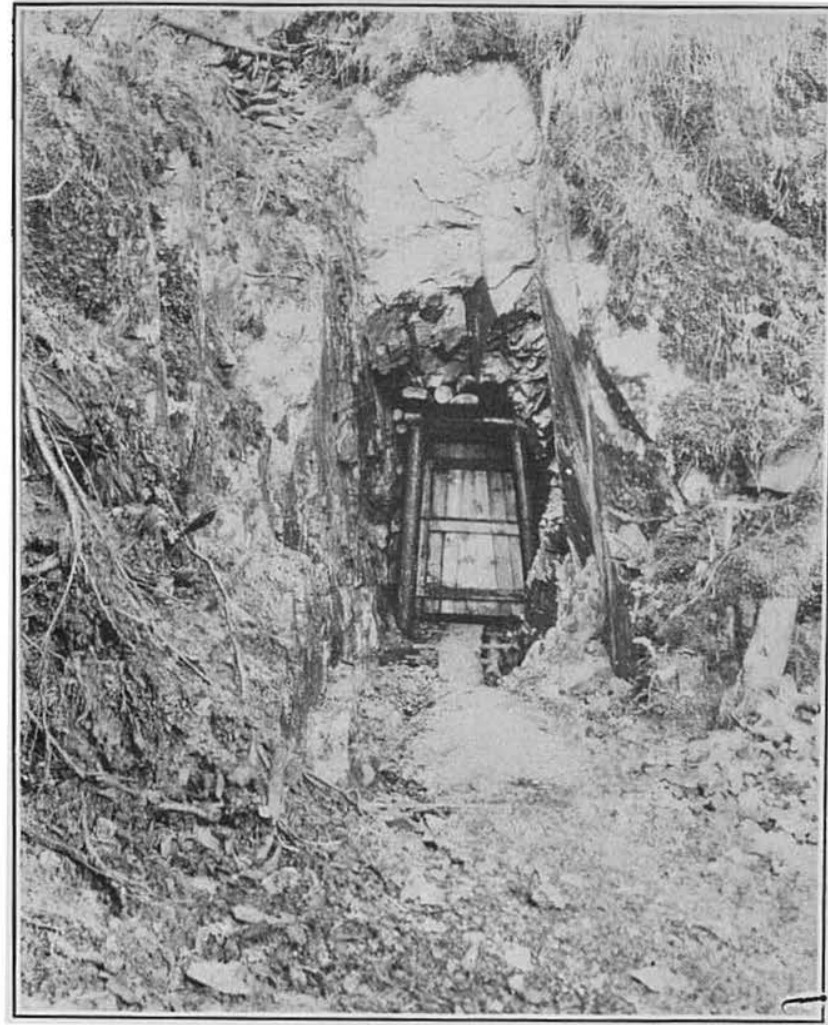

B. OUARTZ VEIN PARALLEL TO JOINT PLANES IN GRAYWACKE. Shows parallel master joints, between two of which (at the left side of the opening) is a thin quartz vein. Northern Light group near Seward. 
U. S. GEOLOGICAL SURVEY

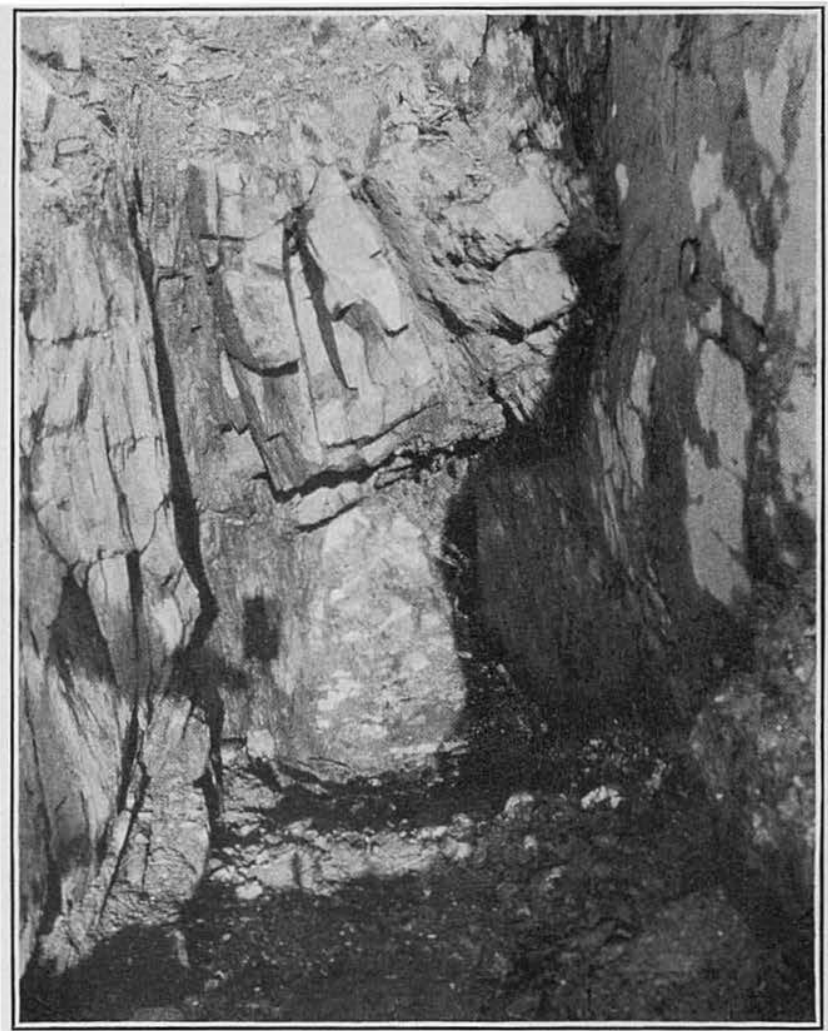

A. GOLD-BEARING QUARTZ LODE ON KENNEDY-PULLEN-DAVIS PROPERTY, LOST CREEK. Shows reticulating quartz veins cementing shattered graywacke bed along
fault planes.
BULLETIN 587 PLATE $X X X$

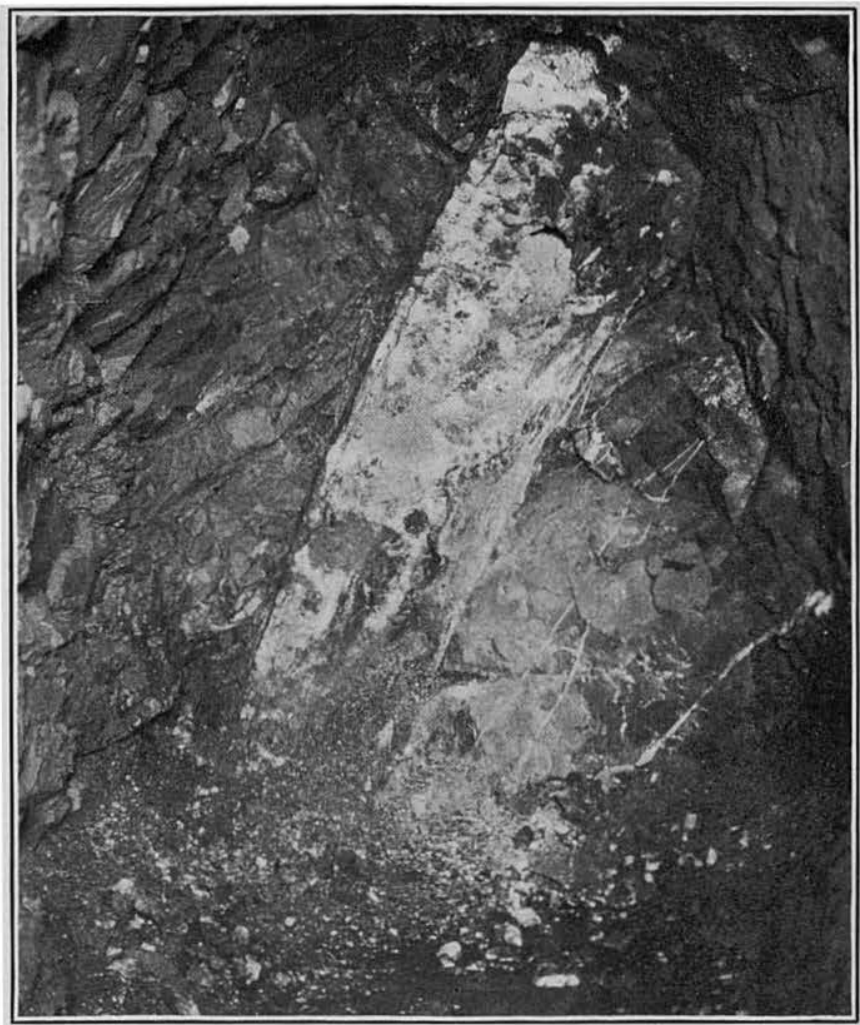

B. FISSURE VEIN IN NO. 1 TUNNEL, BARNES PROPERTY, CROW CREEK. 
Molybdenite.-Molybdenite $\left(\mathrm{MoS}_{2}\right)$, the sulphide of molybdenum, is a soft flaky mineral with a metallic luster resembling graphite, but having a bluer tinge. It is formed at high temperatures, and is generally associated with granitic igneous rocks. It is one of the rarer metallic minerals of the region, and so far as known does not occur in commercial quantities. It has been found at but two localities-in one of the tunnels on the Barnes property on Crow Creek, in a narrow quartz stringer that carried molybdenite, chalcopyrite, and pyrrhotite, and near the head of Chickaloon River, where small flakes of molybdenite occur in quartz ledges.

Quartz.-Quartz $\left(\mathrm{SiO}_{2}\right)$ is the most common gangue mineral of the ore deposits, constituting, with a little calcite and albite, 90 to 99 per cent of the ores. The quartz is generally massive, but well-terminated crystals occur at a few places in small vugs in the quartz lensas of the stringer lodes. Comb structure is also occasionally seen in these lenses. The massive vein quartz is composed of interlocking quartz grains, most of them small, associated with small amounts of calcite, albite, and metallic sulphides.

Calcite.-Calcite $\left(\mathrm{CaCO}_{3}\right)$, calcium carbonate, of ten referred to as "lime" and "carbonate of lime," is widely distributed throughout the rocks of the area. It may be easily recognized by its perfect rhombohedral cleavage, its sof tness (it is easily scratched by a knife), and by its effervescence with cold dilute hydrochloric acid. It is the cementing material of the graywackes and conglomerates at many places and fills small joint cracks in the rocks. In association with quartz it occurs in thin seams and veinlets in slates and graywackes and is an important gangue mineral in the gold veins. It is also an original constituent of the impure limestones of the region.

GOLD LODES.

TYPES OF DEPOSITS.

The gold lodes of northern Kenai Peninsula may be grouped under three general heads: (1) Veins, (2) stringer lodes, and (3) mineralized acidic dikes. The veins are the most numerous and the stringer lodes are the fewest. The acidic dikes of the region are at most places but slightly mineralized and with the exception of those of Moose Pass and Palmer Creek have received but little attention.

VEINS.

Veins are narrow tabular masses of mineral matter that occupy fissures or sets of fissures in rocks. They are usually characterized by regular and straight walls, by a fairly constant width, and by a well-defined direction of both strike and dip. (See Pls. XXX, B; XXXI, $B$; XXXII, $A$.) As a rule they cut across the stratification and cleavage of the inclosing rocks. Gold veins have been found in 
many parts of Kenai Peninsula. There are two distinct sets of veins, which stand approximately at right angles to each other. (See fig. 16.) In one set the strikes lie between north and northwest and in the other set, which comprises most of the veins of the district, they lie between east and northeast. The veins dip at angles ranging from $45^{\circ}$ to $90^{\circ}$, and some show considerable variation in dip from place to place. The dips of the veins whose trend ranges from north to northwest are about equally distributed on both sides of a vertical line; but many

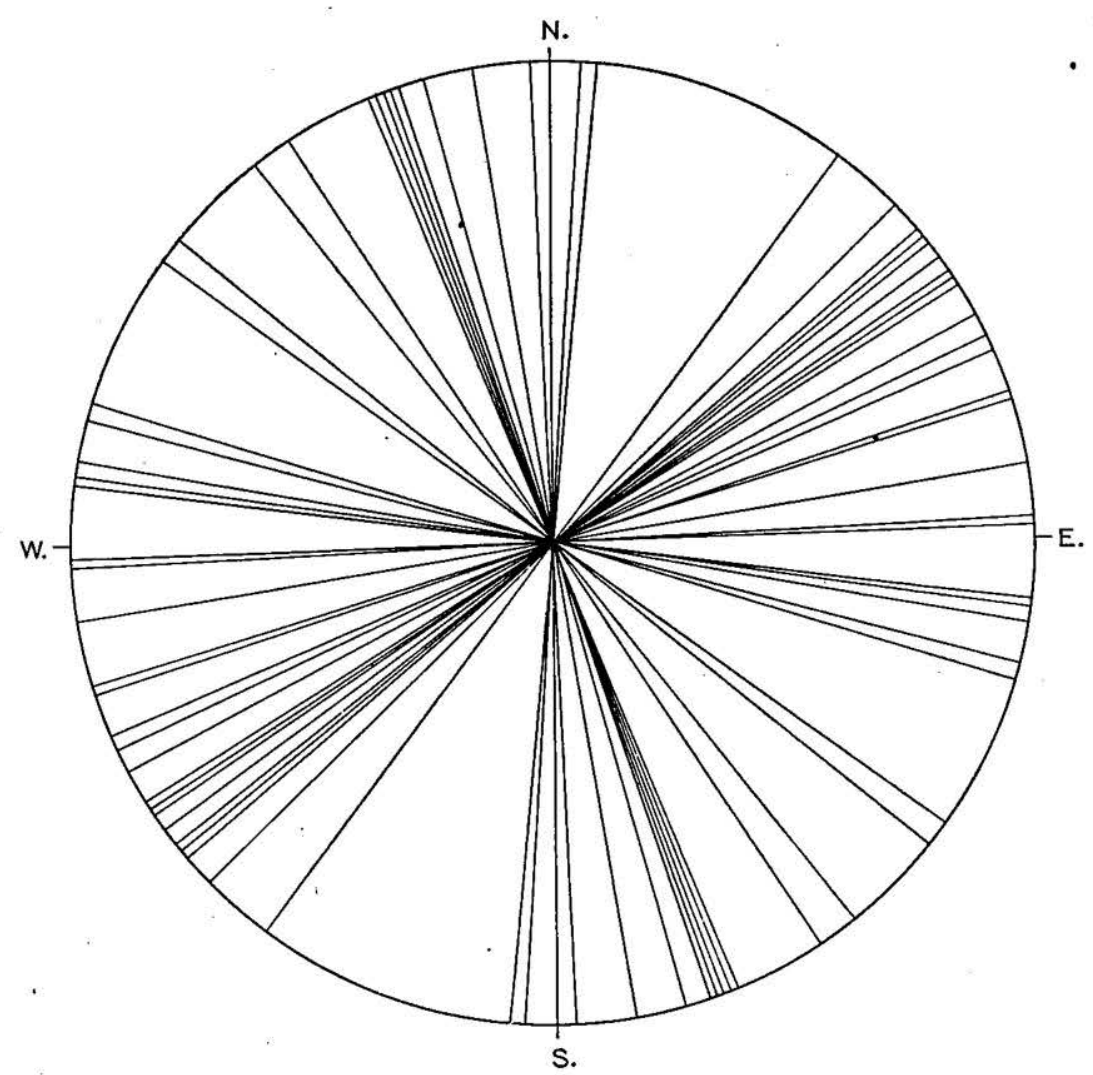

FIGURE 16.-Diagram showing strike of gold quartz veins.

of the more abundant set of veins whose trend ranges from east to northeast dip steeply toward the north, and only a few dip to the south. The diagrams (figs. 17 and 18) do not show the relative number of veins having the dips plotted, but the field records indicate that the vertical veins noted are about equal in number to all otheis combined.

Both sets of veins are, in general, ore bearing and are probably of about the same age. The latest movement appears to have been 
along the set of fractures trending east to northeast. Most of the outcrops of the ore bodies have been traced for but a few hundred feet. The veins rarely show a width of 5 feet of solid quartz, and their average thickness is probably between 2 and $2 \frac{1}{2}$ feet. There are

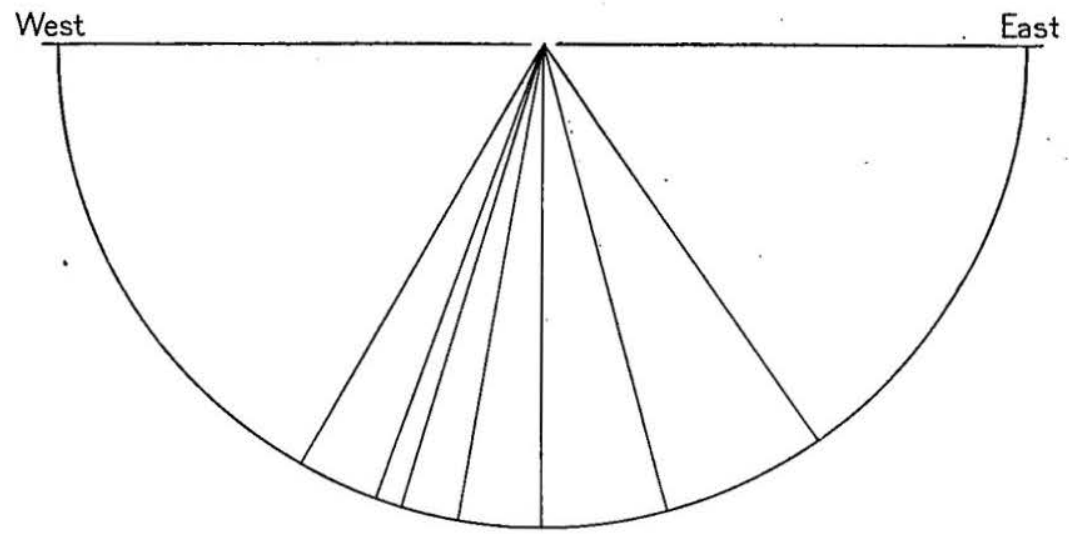

Figure 17.-Diagram showing dip of set of veins whose trend ranges from north to northwest.

many smaller veins. The mineralogic composition of the ores is simple. The gangue is quartz, with usually a little calcite. The metallic minerals are gold and the sulphides-arsenopyrite, pyrite, galena, sphalerite, chalcopyrite, pyrrhotite, and molybdenite. Arsenopyrite predominates. The ores are free milling. The gold occurs

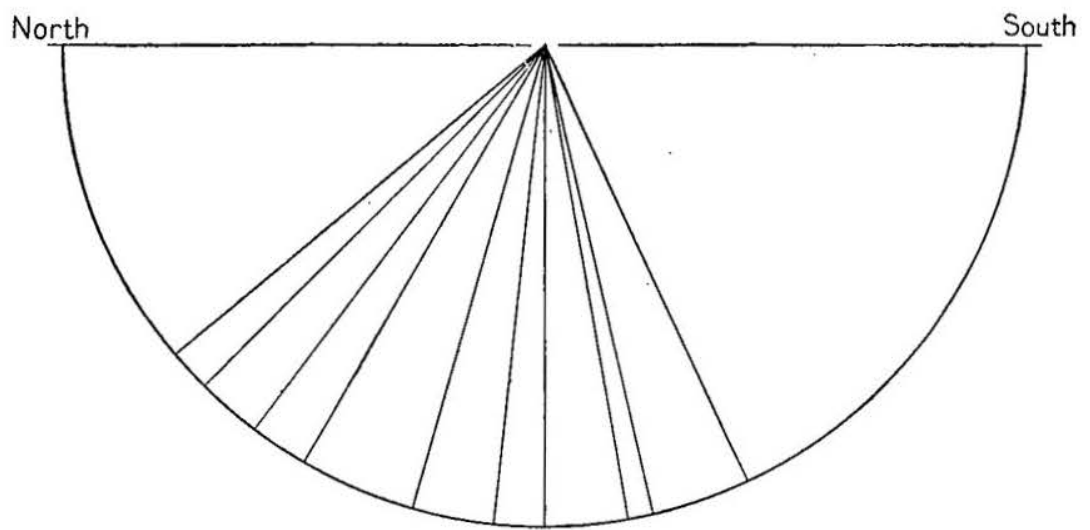

FIGURE 18.-Diagram showing dip of set of veins whose trend ranges from east to northeast.

free in the quartz and more abundantly in close association with the sulphides. It is of ten included in the grains of arsenopyrite, galena, and sphalerite. Crystals of arsenopyrite and pyrite are disseminated throughout the metasomatically altered wall rocks of the veins. 
Stringer lodes are characteristically developed in the slates and graywackes of Kenai Peninsula. The planes of stratification and cleavage and the dike contacts of that region are commonly parallel, striking a little east of north and having vertical dips. The ore bodies tend to follow the structure of the inclosing rocks both in strike and dip, but individual stringers cut across the cleavage or bedding irregularly. Most of the stringer lodes on Kenai Peninsula are in slate, the quartz veinlets occupying irregular openings along cleavage or bedding planes. In the more massive graywacke beds the rock is cut in all directions by reticulating veinlets, as in the Kennedy-Pullen-Davis lode, on the divide between Lost and Porcupine creeks, where a fractured graywacke bed is recemented by a network of quartz stringers. (See Pl. XXXI, A.)

The best known stringer lodes lie in a belt extending northward from the Mile Four property to the mouth of Porcupine Creek. Deposits of this type are also found on Palmer, Cub, Groundhog, and other creeks. The development work done on deposits of this kind in this district is small and has not yet determined either the lateral or longitudinal extent of any of the lodes, those examined having been uncovered for only short distances. The stringers are generally small, of irregular width, and comparatively short. The gangue is quartz, coarsely crystalline in some of the larger stringers and occasionally showing interlocking crystals at the center of the veins, and is usually accompanied by calcite, which occurs in very subordinate amount. The ore minerals include gold, arsenopyrite, pyrite, sphalerite, galena, chalcopyrite, and pyrrhotite. Arsenopyrite is the dominant sulphide.

As the average value of the stringer lode depends on the number and richness of the individual stringers, it is only where the stringers are rather closely spaced and well mineralized that they can be considered as possible ore bodies. Stringer lodes have proved to be of much value in southeastern Alaska, and commercially valuable deposits of this character may exist on Kenai Peninsula.

\section{MINERALIZED ACIDIC DIKES.}

The only known mineralized dikes of present economic importance are those of the Moose Pass and Palmer Creek districts. Acidic dikes occur also along Turnagain Arm and on Crow, Raven, Groundhog, Porcupine, Mile Four, Bear, and other creeks, but are so slightly mineralized that they appear to be of little economic value. Othar well-mineralized dikes, however, may yet be discovered.

A characteristic feature of the Moose Pass and Palmer Creek districts is the occurrence of several nearly parallel mineralized 
acidic dikes striking in a general north-south direction. The largest of these dikes has been traced for several miles and maintains an average width of only 8 feet. (See Pl. XXX, A.) These dikes follow closely the dominant strike lines of the district and dip nearly vertical; as do most of the sedimentary rocks. The dikes are very fine grained, much altered porphyritic rocks, light colored and greenish. Owing to the extensive alteration they have undergone their porphyritic character is discernible in few hand specimens. Under the microscope, specimens of the big Moose Pass ledge show phenocrysts of plagioclase feldspar and a silicate mineral (now completely altered to chlorite, calcite, and sericite) embedded in a fine-grained groundmass. The specimens contain considerable secondary muscovite (sericite) and calcite and also a small amount of chlorite, to which the greenish tinge of the rocks is probably due. Sericitization of the feldspars is well advanced. The unaltered rock was doubtless a very fine grained diorite porphyry.

After the dikes were formed the country rock and the dikes were fractured and slightly faulted, and the openings thus made became channels for the deposition of gold-bearing quartz. These later fissures are vertical or nearly so, and if classified by their strikes they fall into two general groups, one group striking northeastward and the other in general northwestward. Near the southern end of the Moose Pass district several promising gold quartz veins are closely associated with the dikes. North of Summit Creek the mineralized quartz appears to be confined chiefly to the fractured and mineralized dikes.

The mineralization in the dikes is poor and is irregularly distributed, barren stretches occurring at irregular intervals. Lowgrade mineralized zones of country rock of indeterminate lateral and longitudinail extent intersect the dikes, which are mineralized where the zones cross them, the erushing and fracturing of the dike rocks probably having facilitated the circulation of the mineralizing waters. The original dike rocks probably did not carry any gold. Assays on average samples from their less altered parts are reported to ranga from a trace to a little over $\$ 1$. In their more highly mineralized parts average samples are said to assay from $\$ 1.40$ to $\$ 52.80$. An average figure for the value per ton of the rock of these mineralized dikes can not be obtained without careful sampling and assaying. The length of the dikes, their probable continuity with depth, as indicated by their igneous origin, and the extent of their mineralization (which, though very irregular and in most places slight, covers a considerable area) suggest that they deserve careful consideration as possible sources of a large amount of low-grade ore. 
DETAIIED DESCRIPTIONS OF MINES AND PROSPECTS.

The more important mines and prospects are here described in detail and brief notes are given on many others. The lodes are described in geographic order from south to north, beginning with the prospects on the shores of Resurrection Bay near Seward. The accompanying geologic map (PI. III) shows the locations of the properties visited and of some prospects that were not visited but whose locations are approximately known. Bodies of gold-bearing quartz are reported by prospectors to occur on Resurrection River, in the mountain southwest of Seward, near mile 13 on the Alaska Northern Railway, and on Grant Lake, but as these lodes have not been visited they are not described.

\section{RESURRECTION BAT MINING CO.'S PROSPECT.}

The property of the Resurrection Bay Mining Co. is on the west shore of Resurrection Bay about one-third of a mile south of Seward. The developments in 1911 included four tunnels, 60, 70, 15, and 10 feet long, at elevations of $10,70,120$, and 220 feet, respectively, above sea level, and a 10-foot winze in the 70-foot tunnel. In 1912 the lower tunnel is said to have been continued to a length of 100 feet. The lower tunnel is driven in black slate. The jointing in the slates is well marked, and some of the joint cracks are occupied by thin quartz seams, the largest $1 \frac{1}{2}$ inches thick. About 45 feet from the mouth of the tunnel a few irregular masses and stringers of slightly mineralized white quartz occur in the slate country rock. The 70-foot tunnel is driven on a 3-foot sheared vertical zone in graywacke. The fractures are cemented by numerous vertical quartz stringers, the widest of which is 8 inches. The third tunnel, 15 feet long, is driven S. $52^{\circ} \mathrm{W}$. on a sheeted vertical zone in graywacke and slate. The vein has a maximum width of 3 feet. The vein matter is sheeted parallel to the walls. Calcite is exceptionally abundant. A calcite lens that is 1 foot wide in places lies along the north wall of the vein. A measured section across the vein in the face of this tunnel showed 12 inches of quartz, 5 inches of calcite, and 13 inches of graywacke carrying numerous stringers of quartz and calcite.

The metallic minerals in the ores of this prospect include arsenopyrite, sphalerite, pyrite, chalcopyrite, galena, and gold. The gangue minerals are quartz and calcite.

TOZIER-LANE NORTHERN LIGHT GROUP.

The Northern Iight Group is on the west shore of Resurrection Bay at the southern edge of the alluvial fan on which the town of Seward stands. The Northern Light claims Nos. 1, 2, 3, 4, 5, and 6 were 
located by A. C. Gould, Charles F. Hewitt, and F. J. Conner January 1, 1907. They were deeded to Herbert Tozier September 12, 1911, by the locators. In October, 1911, the developments consisted of a 40-foot tunnel that stands about 100 feet above sea level, a winze 4 feet deep, in the tunnel, a shaft 12 feet deep, in front of the tunnel mouth, and some open cuts. Work was also begun on another tunnel at a lower level. In 1912 it was reported that the lower tunnel had been driven 165 feet, and that a third tunnel, 15 feet long, had been driven on the claim to the south.

The ore deposit as developed in October, 1911, consists of several quartz veins occupying prominent, nearly parallel, joints in a large massive graywacke bed. One of these veins, which strikes N. $55^{\circ} \mathrm{W}$. and dips $81^{\circ}$.N., lies close to the left wall of the 40 -foot tunnel. This vein in the shaft in front of the tunnel shows 12 to 14 inches of solid white quartz, with free walls. Over the mouth of the tunnel the vein narrows to 3 inches. (See Pl. XXX, B.) Considerable movement along this joint has resulted in a secondary banding of the vein parallel to the walls. Just inside the mouth of the tunnel stringers of quartz extend out into the footwall of the vein, several of them following small joint cracks. About 25 feet from the mouth of the tunnel a branch vein strikes $\mathrm{N} .85^{\circ} \mathrm{W}$. off into the footwall on a joint plane. The veins are well defined until they reach the belt of slate west of the graywacke bed, where they finger out into stringers in the slate.

About 75 feet north of this tunnel vein is another vein, which strikes N. $57^{\circ}$ W., dips $85^{\circ} \mathrm{N}$., and occupies a joint in the graywacke. This vein is 10 inches wide where it is exposed in a small gulch that follows the vein. The walls are free. A third vein in this same graywacke bed has been found south of the tunnel. This vein strikes $\mathrm{N} .75^{\circ} \mathrm{W}$. and dips $85^{\circ} \mathrm{N}$. The vein is 8 to 14 inches wide and is said to be traceable about 200 feet uphill. The quartz breaks free from the walls but shows no gouge. The vein quartz is jointed parallel to the walls, 1 to 3 inch spacing appearing between the joint cracks.

An outcrop on the hillside above the 40-foot tunnel exposes lenses, stringers, and kindeys of quartz, the largest 24 inches wide, in a belt of slate lying west of the graywacke bed noted above. They strike in general N. $15^{\circ} \mathrm{E}$. Numerous parallel stringers of quartz 3 to 5 feet long, and with a maximum width of 6 inches, follow the bedding of the slate and dip vertically. The width of the slate bed is not determinate on account of timber cover. A width of about 6 feet is exposed in the outcrop.

The sulphide minerals in the ore comprise chalcopyrite, pyrrhotite, pyrite, sphalerite, galena, and arsenopyrite. Free gold is reported. The gangue of the ores is quartz. 
MILE FOUR MINING CO.

The Home ledge of the Mile Four Mining Co., discovered November 2, 1910, by Nicholas Losness, is 4 miles north of Seward and half a mile west of the track of the Alaska Northern Railway. The property is covered with timber. The developments in October, 1911, comprised a tunnel 115 feet long, driven northeastward on the lode at an elevation of 65 feet above sea level, a 23 -foot incline shaft sunk on the lode 30 feet above the tunnel, and about 75 feet of surface stripping.

The ore deposit is a stringer lode in a country rock that consists principally of black slate but includes some beds of graywacke. The strike and dip of the bedding of the slate and graywacke are not determinable from the present development. At the mouth of the tunnel the cleavage of the slate is N. $16^{\circ} \mathrm{E}$. Numerous stringers and lenses of quartz, the largest 43 inches wide, occur irregularly within the inclosing rocks. Calcite is an abundant accessory gangue mineral. The sulphide minerals of the ore include arsenopyrite, galena, sphalerite, pyrite, pyrrhotite, and chalcopyrite. The gold occurs free in the quartz and is also associated with the sulphides. Assays of $\$ 6.40$ to $\$ 1,120$ per ton have been reported, the higher assays being made on ore taken from small quartz stringers, whose principal sulphide minerals are galena, sphalerite, and arsenopyrite. Quartz lenses carrying only arsenopyrite appear to contain but little gold.

BREWER ALASKA SYNDICATE PROPERTY.

The property of the Brewer Alaska Syndicate consists of a group of claims on Lost Creek, near the upper limit of timber, at an elevation between 1,300 and 1,400 feet above sea level. The camp on the property is connected with the Alaska Northern Railway at mile $7 \frac{1}{2}$ by 4 miles of good trail. Gold quartz was first discovered on the property by J. W. Stevenson August 5, 1911, and the property has been under development since September of that year. In October, 1911, the developments comprised a tunnel 45 feet long, a little opencut work, and a trail to the property from the railroad. This trail was much improved in 1912. The underground development work, in November, 1912, is reported to consist of one long and several short tunnels, aggregating 420 feet in length, and over 300 feet of open cuts and trenches. Several buildings have been erected at the camp and a warehouse has been built where the trail leaves the railroad. A 2-stamp triple-discharge stamp mill of Joshua Hendy manufacture is reported to have been erected on the property during the winter of 1912-13. ${ }^{1}$ Twelve men were engaged in the development of the property in October, 1912.

\footnotetext{
1 Brewer, W. M., Winter work on the Kenai Peninsula: Min. and Sci. Press, vol. 106, pp. 736-737, 1913.
} 
The country rock of the ore bodies is a belt of blue-black slates, of undetermined width, which strike north and south and dip $80^{\circ} \mathrm{E}$. A few thin graywacke beds with a maximum thickness of 3 inches are interbedded with the slates. In this part of its course Lost Creek flows southward in a canyon which it has cut in this slate belt.

The ore deposits consist of irregularly distributed lodes of stringers, lenses, and kidneys of quartz in the sheared black slates. The outcrops of the lodes are in the walls of the canyon on Lost Creek. Three of the stringer lodes were examined in 1911. Stripping on the Homestake ledge showed a 33 -inch sheared zone in slate, traceable about 50 feet, containing stringers, kidneys, and lenses of iron-stained white quartz, the largest 14 inches wide and 3 to 4 feet long. The stringers are short and discontinuous. In one place the entire width of the shear was practically solid quartz; at other places there are only a few small stringers of quartz. The 45 -foot crosscut tunnel intersected this shear zone 40 feet below the outcrop and at that point the lode contained only a few small quartz stringers. On the claim below this another lode, consisting of several lenses and stringers of quartz, the largest a foot wide, occur in the black slate. A third showing, upstream from the tunnel, consisted of a few irregular stringers of quartz in slate. The stringers were 1 foot to 3 feet long, and none were over 3 inches wide. Development work in 1912 is said to have exposed several other prospects in this slate belt, some of which are reported traceable for 200 to 300 feet. One of these prospects consists of a black slate shear zone, striking a little north of east, and varying in width from $1 \frac{1}{2}$ to 4 feet. Small lenses and stringers of quartz are contained in the sheared material, the outerop of which is reported to be traceable for about 75 feet. Several of the other lodes found in 1912 are reported to be more extensive and to contain greater amounts of quartz.

The metallic minerals in the ores are arsenopyrite, galena, sphalerite, and gold. The gangue minerals are quartz and calcite.

KENNEDY-PULLEN-DAVIS PROPERTY.

The Mizpah ledge, on the Kennedy-Pullen-Davis property, outcrops on the northeast shore of the small lake at the head of Lost Creek, at an elevation of 1,800 feet. The lode was discovered and located by G. L. Kennedy September 4, 1911. The country rock consists of vertical beds of slate and graywacke, striking N. $18^{\circ}$ E.; the cleavage is approximately parallel to the bedding.

The ore deposit as exposed by a 30 -foot open cut along the lode is 3 to 5 feet wide. (See Pl. XXXI, A.) The walls, which are slate, are well defined and marked by narrow vertical zones of intense shearing. The east wall of the lode in the open cut strikes N. $2^{\circ} \mathrm{E}$. and the west $48891^{\circ}-$ Bull. $587-15-10$ 
wall strikes $\mathrm{N} .18^{\circ} \mathrm{E}$., corresponding with the strike of the country rock. The filling between the walls is principally graywacke, but some slate occurs near the east wall. The graywacke has been fractured and afterward cemented by a network of lenses and stringers of quartz, the largest 6 inches wide. In the schistose rock close to the walls these stringers stand nearly vertical and are parallel to the walls. Near the center of the lode the vertical joints are separable into two systems, one striking N. $74^{\circ} \mathrm{W}$. and the other N. $6^{\circ} \mathrm{E}$. The quartz veinlets also occupy nearly horizontal joints and fractures. The quartz forms only a small proportion of the lode material and in most of the stringers it is coarsely crystalline. Calcite also occurs in the veinlets as a gangue mineral. Gold is found free in the quartz, in association with the abundant sulphides or included in them. The sulphides are galena, sphalerite, pyrite, arsenopyrite, and chalcopyrite. Numerous small crystals of arsenopyrite and pyrite occur in the altered graywacke of the lode. Some exceedingly high assays have been reported on the vein quartz from this lode; but the average tenor of all the lode material is probably rather low.

PRIMROSE MINING CO. ${ }^{1}$

The property of the Primrose Mining Co. is on Porcupine Creek, at an elevation of about 900 feet above Kenai Lake. Porcupine Creek flows in a deep rock-cut canyon through heavily timbered hills. The veins outcrop in the canyon walls. The first discovery was made on the Bluebell claim about July 1, 1911. The veins now being developed, on the Primrose claim, were discovered about July 10, 1911, and a tunnel was driven 22 feet into the canyon wall, crosscutting the ore body, and about 20 feet of drifting was done. In June, 1912, the Primrose Mining Co. took over the Primrose claim and in July acquired the Bluebell claim. Active development work was carried on during the summer and fall of 1912, and in October the developments are reported to have comprised two adit tunnels and one incline shaft sunk to a depth of 75 feet from the inner end of the upper tunnel. The upper tunnel and drifts have a total length of 133 feet. Ten feet above the bottom of the shaft 35 feet of drift has been run along the vein. The lower crosscut tunnel, 150 feet below the outcrop of the vein, is reported to have been driven 165 feet and to lack but 60 feet of cutting the vein.

The outside improvements on the property are said to include $3 \frac{1}{2}$ miles of road from Kenai Lake to the mine, 300 feet of track connecting the mine and stamp mill, and 5 buildings, including cookhouse, bunk house, storehouse, office, and stable.

The ore-dressing equipment is reported to consist of a No. 2 Blake crusher, a Little Giant stamp mill having a capacity of $2 \frac{1}{2}$ to 3 tons

1 Data regarding developments on this property furnished by Mr. Herbert Tozier. 
per 24 hours, a concentrating table, and an overshot water wheel that furnishes power for the operation of the mill. At the conclusion of milling operations October 22, 1912, about 100 tons of ore is reported to have been milled during an actual milling time of 720 hours.

At the time this property was visited in 1911 a compact stringer lode 9 feet wide, which was crosscut in the upper tunnel, was traceable for about 125 feet along the canyon wall. Its outcrop is said to have since been traced a distance of 362 feet. Numerous parallel lenses and stringers of mineralized quartz from 1 to 15 inches wide were seen in the lode, and assays up to $\$ 100$ were reported on samples taken across the full width of some of the larger stringers. The interbedded slate and graywacke in the creek bottom strikes N. $17^{\circ}$ W. and has a vertical dip. On the canyon walls, however, surficial creep of the beds has caused an inclination of the upper part of the lode and country rock toward the creek and has resulted in a false dip of the beds away from the creek and a strike approximately parallel to the course of the canyon. The quartz stringers at the surface dip $35^{\circ}-40^{\circ} \mathrm{E}$., and at a depth of 40 feet in the incline shaft the vein is said to stand nearly vertical and to strike about N. $30^{\circ}$ E. At this depth the stringers are reported to converge into a nearly solid vein 7 feet thick with well-defined walls.

The gangue in the stringers is quartz, coarsely crystalline in some of the larger stringers and showing interlocking crystals in places at the center of the veins. Some calcite occurs with the quartz as a gangue mineral. Arsenopyrite is the most abundant sulphide and occurs in association with the other sulphides, sphalerite, chalcopyrite, galena, and pyrite. The gold occurs free in the quartz and also in intimate association with the sulphides.

LOWER PORCUPINE CREEK PROSPECTS.

Graystone ledge No.1.- The Graystone ledge No. 1 is on Porcupine Creek about half a mile above the mouth of the creek. It was located June 19, 1911, by Edw. Frederick. The ledge is a sheared acidic dike similar to those of Moose Pass, cutting black slates. The strike is approximately $\mathrm{N} .33^{\circ} \mathrm{E}$. and the dip is vertical. The dike has been fractured and recemented by quartz. No mineralization was seen.

Homestake ledge.-The Homestake ledge is on the left bank of Porcupine Creek about half a mile above the mouth of the creek. It was located June 26, 1911, by Edw. Frederick. Little development work has been done. An open cut shows a strip of sheared and crumpled slates, 6 feet wide, and a few scattered quartz stringers carrying arsenopyrite, pyrite, and pyrrhotite. The stringers are small and discontinuous. The lower part of the eut has exposed a sheared acidic dike, which forms the west wall of the lode. A maximum width of 12 inches of dike is exposed. 
Porcupine ledge.-The Porcupine ledge is on Porcupine Creek about $1 \frac{1}{2}$ miles from its mouth. The country rock includes both slates and massive graywacke. The ore body consists of a quartz vein, 6 to 9 inches wide, which strikes $\mathrm{N}$. $23^{\circ} \mathrm{E}$. and dips $80^{\circ} \mathrm{E}$. The vein has free walls, along which there is a small amount of gouge. A strip about 3 feet wide west of the vein shows a few narrow quartz stringers in slate and graywacke. Another opening on the same lead on the right bank of the creek shows a shear zone, 6 to 14 inches wide, in slates. A quartz lens, 4 inches wide and 6 feet long, lies in the sheared material, the remainder of which is filled with narrow quartz stringers, many of them lying parallel to the walls of the fissure. The metallic minerals of the ore include arsenopyrite, galena, sphalerite, pyrite, pyrrhotite, and gold. The gangue minerals are quartz and calcite.

PROSPECTS NEAR MILES 17 AND 18, ALASKa NORTHERN RAILWAY.

Lakeside claim.-The Lakeside claim is situated between miles 17 and 18 on the Alaska Northern Railway. The country rock is black slate. The ore body consists of quartz stringers, bunches, and lenses of irregular width in crumpled slate. The width of the vein varies from 4 to 10 inches, and the vein has been stripped for 30 feet; it pinches out at the southern end of the exposure. The dip is $50^{\circ} \mathrm{E}$. and the strike is approximately north. The quartz contains a small amount of arsenopyrite and pyrite, and the slate contains a little pyrite.

Brown Bear claim.-The Brown Bear claim is on the east side of the Alaska Northern tracks near the head of Kenai Lake. The outcrop of the vein is about 150 feet above the level of the lake. The country rock is black slate. The vein, which was traced about 250 feet, strikes $\mathrm{N} .12^{\circ} \mathrm{E}$. and dips $45^{\circ} \mathrm{E}$., and ranges in width from half an inch to 5 inches. No gouge was noted on the walls, but in most places the quartz breaks free. The quartz in places has a ribboned appearance. The metallic minerals of the ore include arsenopyrite, galena, sphalerite, and gold. The gangue minerals are quartz and calcite. Several feet of tunnel are reported to have been driven on this vein in 1912.

Devil Club ledge.-The Devil Club ledge is between miles 17 and 18 on the Alaska Northern Railway at an elevation of 270 feet above Kenai Lake. The country rock is slate. The only development work consists of several open cuts, exposing an ore body consisting of 2 veins lying along joint planes in slate. One of these veins, which was traced about 75 feet, strikes N. $80^{\circ} \mathrm{W}$. and has a nearly vertical dip. This vein shows 15 inches of quartz in a small open eut. The other vein, which parallels the first at a distance of about 30 feet, has a width of 4 to 8 inches and a vertical dip. Arsenopyrite was the only sulphide observed in the quartz. 
SEWARD BONANZA GOLD MINES CO.

Location.-The Seward Bonanza Gold Mines Co.'s property is on the west face of the mountain between Victor and Ptarmigan creeks. (See fig. 19.) Trails have been cut from the company's warehouse, near mile 20, on the Alaska Northern Railway, to the upper and lower tunnels on the property.

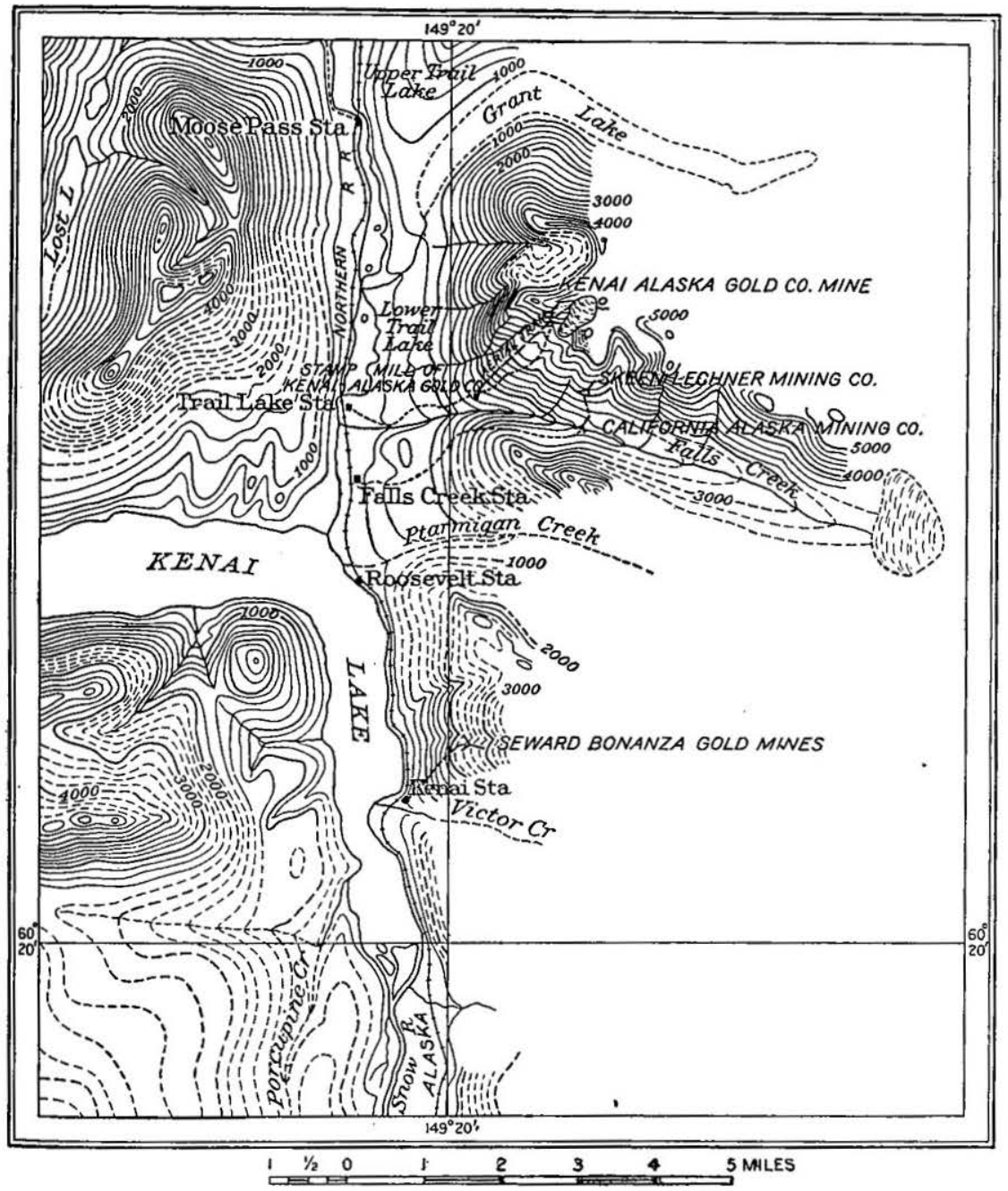

FIGURE 19.-Topographic map of the Falls Creek district.

History and development.-The vein was discovered in 1907 by C. $\mathrm{E}$. and J. W. Stevenson, but underground development was not begun on it until July, 1911, after the property had been taken over by the present owners. The underground development work on September 29, 1911, comprised a lower tunnel, driven 110 feet along the rein, at an elevation of 1,250 fect above Kenai Lake, and an upper crosscut 
tunnel, 40 feet in length, at an altitude of 5,000 feet above sea level. Developments to October, 1912, included an extension of the lower tunnel to 200 feet, the crosscutting of the vein in the upper tunnel, and about 25 feet of drifting on the vein.

Country rock and ore deposit.-The lower tunnel is being driven along a well-defined fissure vein, striking $\mathrm{N} .75^{\circ} \mathrm{W}$. and dipping $80^{\circ} \mathrm{S}$. in black slate, the cleavage of which strikes $\mathrm{N} .17^{\circ} \mathrm{W}$. (See $\mathrm{Pl}$. XXXII.) The thickness of the vein ranges from $1 \frac{1}{2}$ to 5 feet and averages $2 \frac{1}{2}$ feet. At a point 150 feet from the mouth of the tunnel it is reported to have widened to 10 feet. It outcrops along the bottom of a small gulch and has been uncovered for about 300 feet above the mouth of the tunnel. Near the upper end of this outcrop it narrows to a thickness of only a few inches. This vein is reported to have been traced eastward up the slope for the length of five claims. At an elevation of about 5,000 feet above sea level a crosscut tunnel, driven 40 feet in a northerly direction, cuts the reported continuation of this vein near its east end. The vein at this point has a width of 10 to 18 inches. The rocks near the upper workings are mostly slate, but include small amounts of graywacke and dark-gray limestone. The cleavage strikes $\mathrm{N}$. $7^{\circ} \mathrm{E}$. and dips steeply to the east at angles ranging from $55^{\circ}$ to $80^{\circ}$. The strike of the bedding appears to be about north.

Numerous parallel, approximately east-west joints that have steep dips are characteristic of this deposit. In an open cut above the upper tunnel the joints in the slate strike N. $59^{\circ} \mathrm{W}$., dip $55^{\circ} \mathrm{N}$., and carry narrow quartz veins. A few quartz lenses also occur in the slate. These parallel joints are exceedingly well developed at the open, rounded head of Stevenson Gulch, but may be seen also near the lower tunnel and at several places along the trail joining the two workings. The ore body at the lower tunnel occupies one of the larger and more persistent of these fractures, along which there was considerable movement after the quartz was deposited, as is shown by the secondary banding of the vein parallel to the walls. The joint planes in the vein are in places closely spaced, but the bands range in width from 1 inch to 18 inches. The joints appear to be closer and more abundant along the hanging wall. Sulphides have been deposited along the joint planes, and the vein is more highly mineralized where the joint planes lie close together. The quartz breaks free from the walls, which show little or no gouge. The hanging wall is better defined and freer than the footwall. Between 75 and 90 feet from the mouth of the tunnel the vein grades outward on the footwall side into a mass of shattered slate cemented by intersecting, generaliy thin, quartz stringers. These stringers are irregular in length, width, and distribution, although a few thin ones follow joint cracks in the slate. Later development work reached a point 
U. S. GEOLOGICAL SURVEY

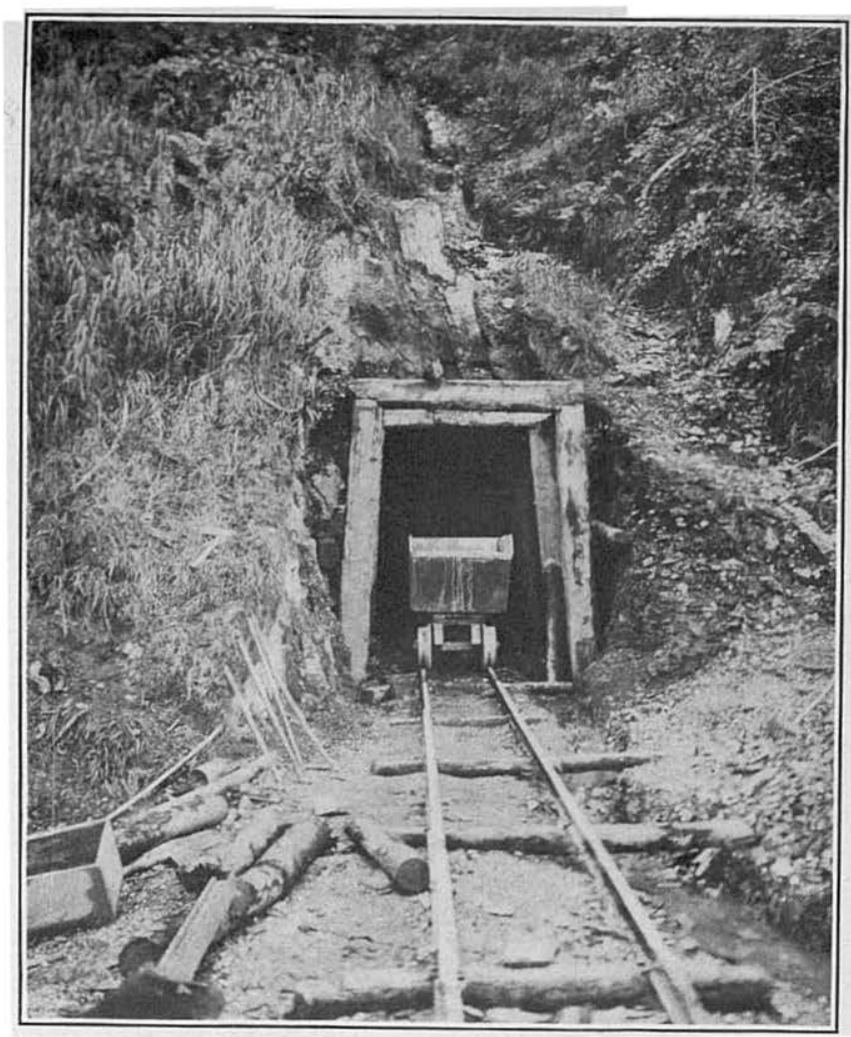

A. GOLD-BEARING QUARTZ VEIN ON PROPERTY OF SEWARD BONANZA GOLD MINES CO., NEAR MILE 20, ALASKA NORTHERN RAILWAY.
BULLETIN 587 PLATE XXXII

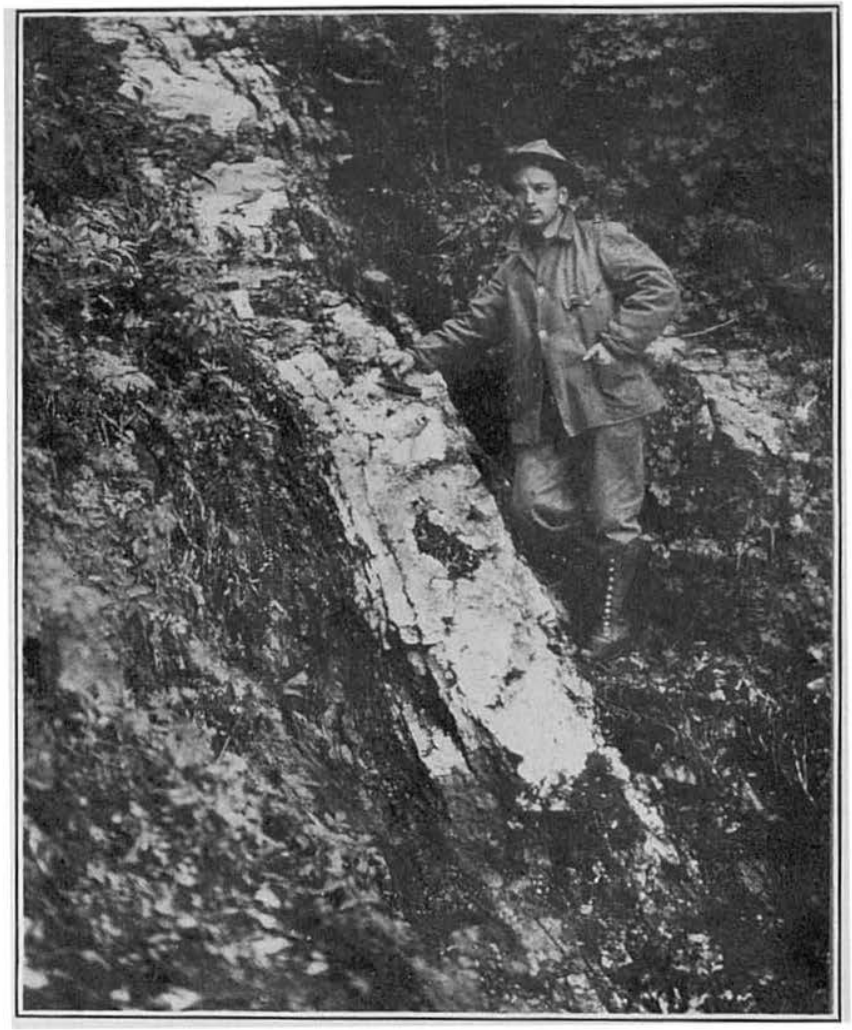

B. NEARER VIEW OF SAME VEIN. 


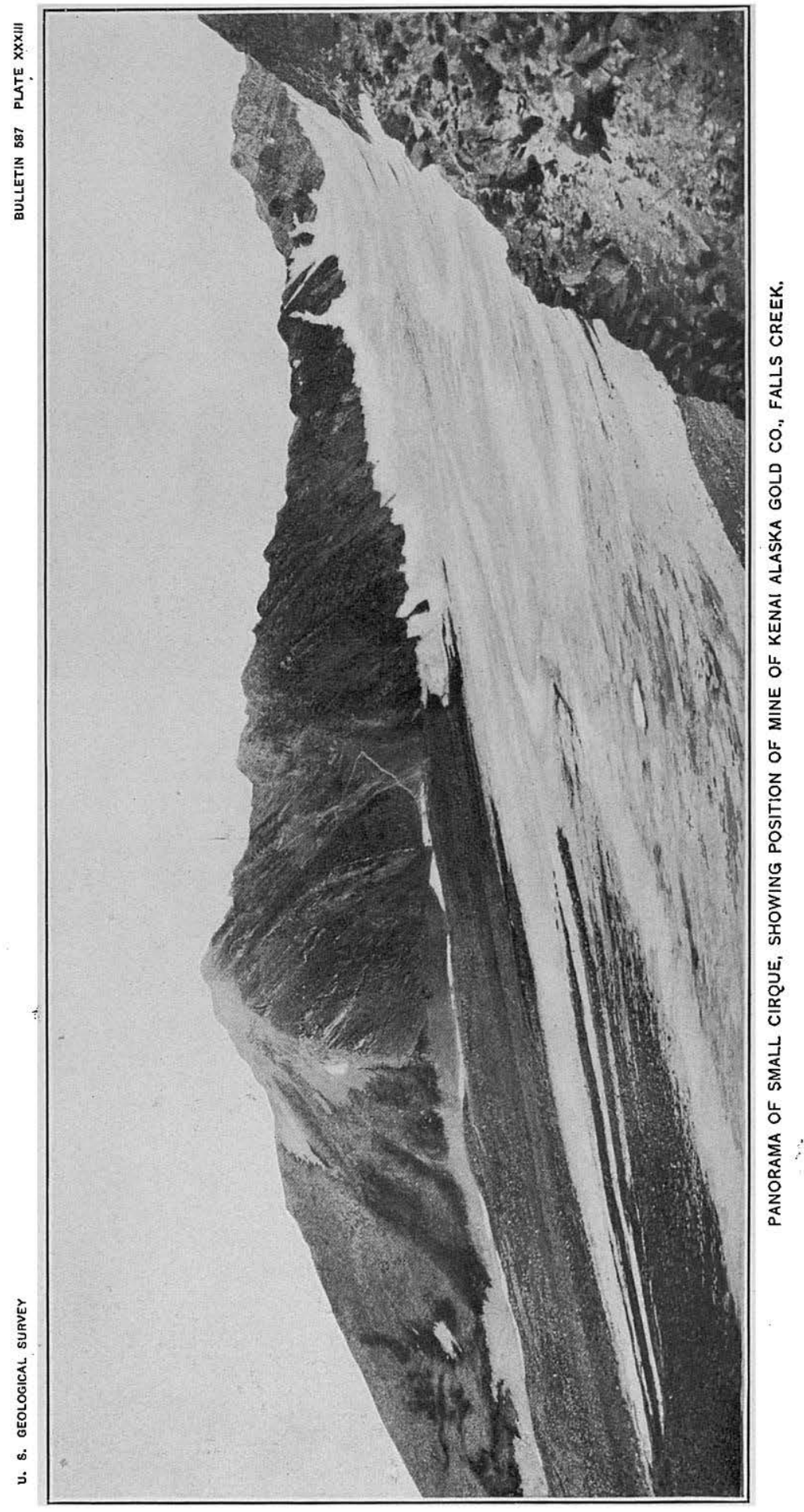


where the footwall was well defined, the vein being 16 inches wide and carrying gouge on both walls. Numerous quartz stringers occur in the adjoining country rock, in places showing parallelism with the vein.

The ore is free milling and contains abundant sulphides. Arsenopyrite, the dominant sulphide, occurs along the joint planes in the veins and as disseminated crystals in the slate. Pyrite is found principally in small stringers in the slate, with or without quartz gangue. Galena, sphalerite, and a small amount of chalcopyrite also occur in the veins. The gangue is quartz with some.calcite. The quartz is coarsely crystalline in some of the bands, but no open cavities were seen. The gold is free in the quartz. It is reported fine at the lower but coarse in the upper workings, 10-cent nuggets having been found in Stevenson Gulch. The owners figure on $\$ 20$ to $\$ 30$ a ton on the ore from this vein, although individual assays are said to run as high as $\$ 85$, and assays of ore from the vein near the upper tunnel are reported to give higher figures.

CALIFORNIA-ALASKA MINING Co.

Location.-The property of the California-Alaska Mining Co. is just above timber line at the head of the canyon on Falls Creek, 4 miles above the mouth of the creek. (See fig. 20.) The mine workings are on the north bank of the creek, the tunnel mouth being only a few feet above the creek level. The stamp mill is on the south bank, 400 feet downstream from the mine. Supplies are carried to the mine camp over a road cut through the timber on the south side of Falls Creek from the company's warehouse at mile 25 (Falls Creek station), Alaska Northern Railway.

History and development.-The first discovery of gold-bearing quartz in the Falls Creek region was made on this property by F. P. Skeen and John Lechner, July 10, 1905. The property was bonded October 4, 1905, to E. O. Ingalls, and on October 30, 1905, was assigned by him to C. D. Lane. Several tons of ore was taken out and shipped to the Tacoma smelter. After 90 feet of tunnel had been driven on the Betty claim and a winze, started 60 feet from the mouth of the tunnel, had been sunk to a depth of 20 feet, the bond was allowed to lapse, the property reverting to the original locators. No further development work was done until after the property was deeded to the present owners, the California-Alaska Mining Co., January 11,1908. The winze has since been deepened to 40 feet, and from its bottom 140 feet of drifts have been run on the vein. Flooding of the lower level stopped further development work. In 1912 the mine was unwatered and sampled but no development work was done.

Two arrastres, each 12 feet in diameter, were built in 1909 and were run for a short time. In 1910 they are reported to have been 
in operation 15 to 20 days and to have taken out about $\$ 100$. The arrastres were dismantled early in 1911 and a two-stamp mill erected. This was the first stamp mill to begin milling operations on Kenai Peninsula, the stamps dropping for the first time early in June, 1911. The mill was run intermittently during the season, and 90 tons of ore is reported to have been treated. In 1912 the mill was run for a short time on ore from the Skeen-Lechner property.

About 30 men, principally Greeks, were employed on the property in June, 1911, but this number was much decreased later in the season. Besides the erection of the stamp mill, a ditch 500 feet in length was put in and 600 feet of pipe line was laid.

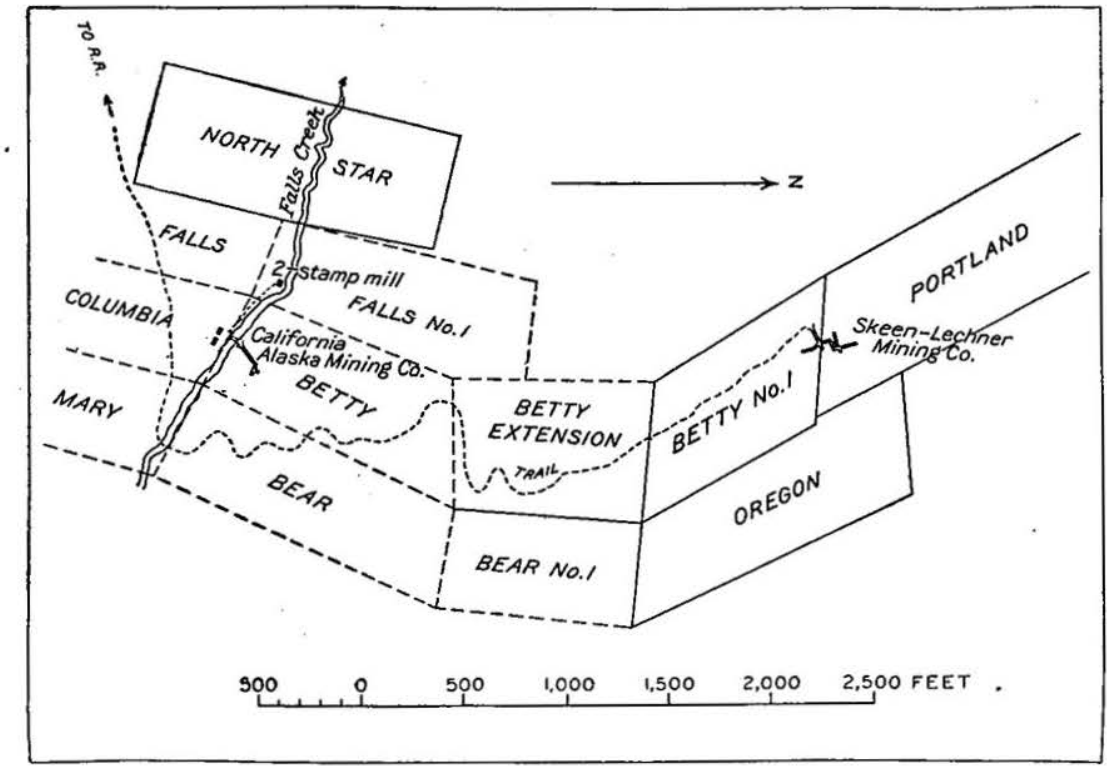

FIGURE 20.-Map showing location of workin ss of the California-Alaska Mining Co. (September, 1911), and the upper tunnel of the Skeen-Lechner Mining Co. (October, 1912), Falls Creek. (For location and development of lower tunnel of the Skeen-Lechner Mining Co. see p. 155.)

Equipment and ore treatment.-The present ore-dressing equipment consists of a Ford crusher, a stamp-driven automatic feeder, standard type, supplying ore to a two-stamp mill, and a Deister No. 2 concentrator. (See fig. 21.)

The power for the plant is furnished by a Pelton water wheel, connected by belt to the stamp mill and crusher, and operating under an 80 -foot head of water from Falls Creek.

Spruce timber for cabins and mine use is eavily obtainable from the forested area between the mine and the railroad. Two buildings, used as living quarters, and a small blacksmith shop have been erected at the mine.

Country rock.-But little of the country rock is exposed in the vicinity of the mine, the lower slopes being heavily covered except 
where bedrock has been exposed along Falls Creek by the erosive action of the stream. The rocks here consist of closely folded slate and graywacke striking a little east of north and dipping $75^{\circ} \mathrm{E}$. to $90^{\circ}$. A 12 -foot bed of graywacke, striking N. $7^{\circ}$ E. and dipping $75^{\circ}$ E., outcrops near the tunnel. This bed carries a small quantity of iron sulphides and weathers rusty. No igneous rocks are known to occur in the vicinity of the ore body.

Ore deposit.-The vein occupies a nearly vertical fissure that strikes N. $51^{\circ} \mathrm{E}$. Near the face of the tunnel the strike swings farther east and the dip changes to $75^{\circ} \mathrm{SE}$. The vein varies in width from 8 inches to 4 feet. Twenty-five feet from the mouth of the tunnel the fissure filling is 43 inches wide, mostly gouge, but carrying quartz stringers. Six feet beyond is an 18 -inch vein of quartz, which gradually widens to 46 inches, then narrows to 1 foot about 8 feet from the winze. It then widens until, directly over the winze, it is 31 inches wide, filling the entire fissure. Narrow gash quartz veins occur in the graywacke walls, which are in many places impregnated with arsenopyrite. Beyond the winze the vein fissure splits into three small fissures, 3 to 12 inches wide, and the graywacke has been shattered and recemented with numerous small quartz veins and impregnated with considerable arsenopyrite. The lower level could not be examined because the workings were flooded. The vein on this level, however, is reported to be well defined and to

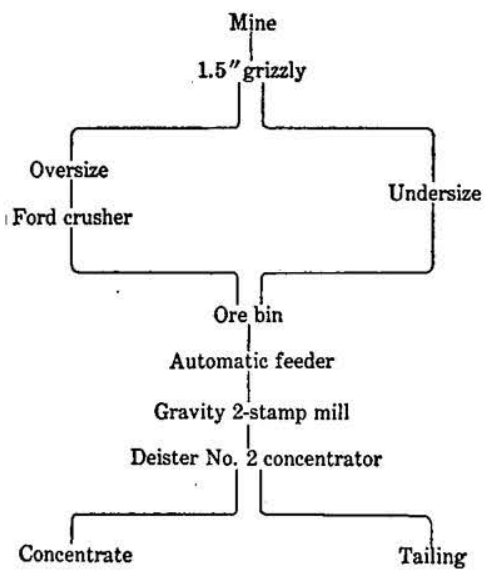

Figure 21.-Flow sheet of mill of CaliforniaAlaska Mining Co., Falls Creek.

have a width of 3 to 4 feet. (See fig. 22.)

Ore.-The vein material is quartz, massive and clear white in most parts of the main vein, although a fine-grained, dense, bluish quartz, which lies in narrow stringers in the mineralized fractured graywacke, is reported to occur also in the large vein. The marked bluish color of this quartz is due to the presence of finely disseminated sulphides. A small amount of calcite also occurs as gangue. Free gold is found in the blue quartz in close association with the fine sulphides and less abundantly in intimate association with scattered sulphide groups in the white quartz. Arsenopyrite is the principal sulphide, galena, sphalerite, and pyrite being subordinate. Numerous striated crystals of arsenopyrite are embedded in the wall rocks next to the veins and narrow quartz stringers. Gold tellurides have been reported from this ore, but tests made in the chemical laboratory 
of the Geological Survey failed to show the presence of tellurium in the specimens examined. The ore is free milling and is reported to average $\$ 30$ to $\$ 40$ gold a ton.

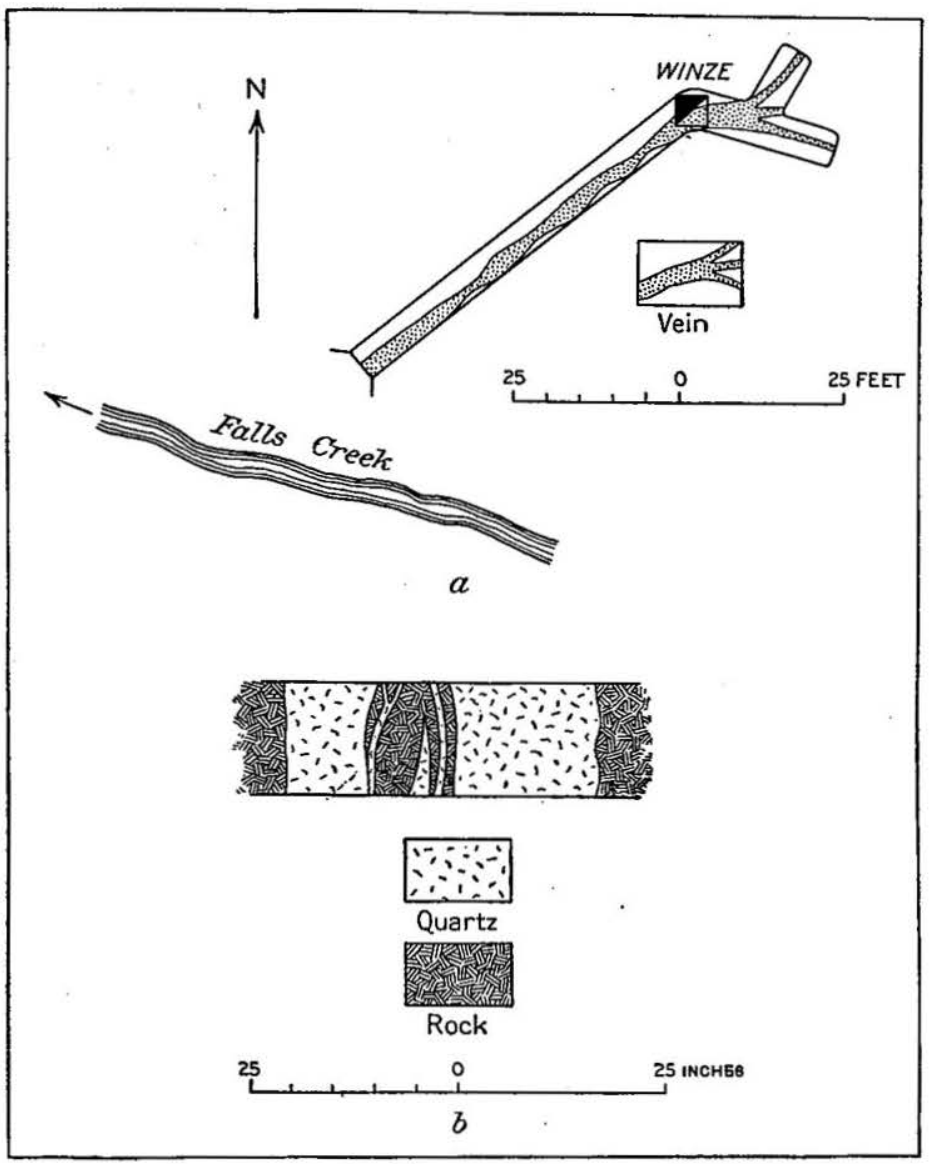

FIGURE 22.- $a$, Plan of upper level of workings of California-Alaska Mining Co., Falls Creek, September, 1911 (vein from unpublished sketch by U. S. Grant). b, Sketch of vein near entrance to tunnel (Grant).

\section{SKEEN-LECHNER MINING CO.}

Location.-The Skeen-Lechner Mining Co.'s property is at an elevation of 3,200 feet on the north side of Falls Creek, 4 miles above its junction with Trail Creek. (See fig. 19.) Supplies are brought from the railroad over the California-Alaska Mining Co.'s road to their camp and then over a trail recently laid out to the SkeenLechner Mining Co.'s camp and mine (see fig. 20), 1,000 feet above the mine of the former company.

History and development.--Two veins, one of which was discovered in 1911, are now being developed on this property. These veins are on the Portland and Betty No. 1 claims, located early in 1907 
by F. P. Skeen and L. F. Shaw, respectively. . A bond was taken on the property in May, 1910, by F. L. Ballaine and J. A. Nelson, but only a small amount of development work had been done when the property was turned over to other parties. Work was continued under the direction of Mr. Nelson. A crosscut tunnel 100 feet in length was driven, cutting the vein 90 feet from the tunnel mouth, and a drift was started northward along the vein. Work stopped when the fault offsetting the vein was reached, the bond was given up, and the property reverted to the original owners, who on September 19, 1911, deeded it to the Skeen-Lechner Mining Co. Development work was continued by this company, and on February 21, 1912, the underground workings comprised 190 feet of tunnels and 160 feet, of drifts. Late in the autumn of 1911 the second vein was uncovered near the mouth of the tunnel. (See fig. 23.) In 1912 a second tunnel was started 200 feet to the right of and 120 feet below the mouth of the upper tunnel, and the lower vein, which strikes $\mathrm{N}$. $45^{\circ}$ W. and dips $65^{\circ}$ NE., was encountered 30 feet from the mouth of the tunnel. A drift was driven 90 feet along

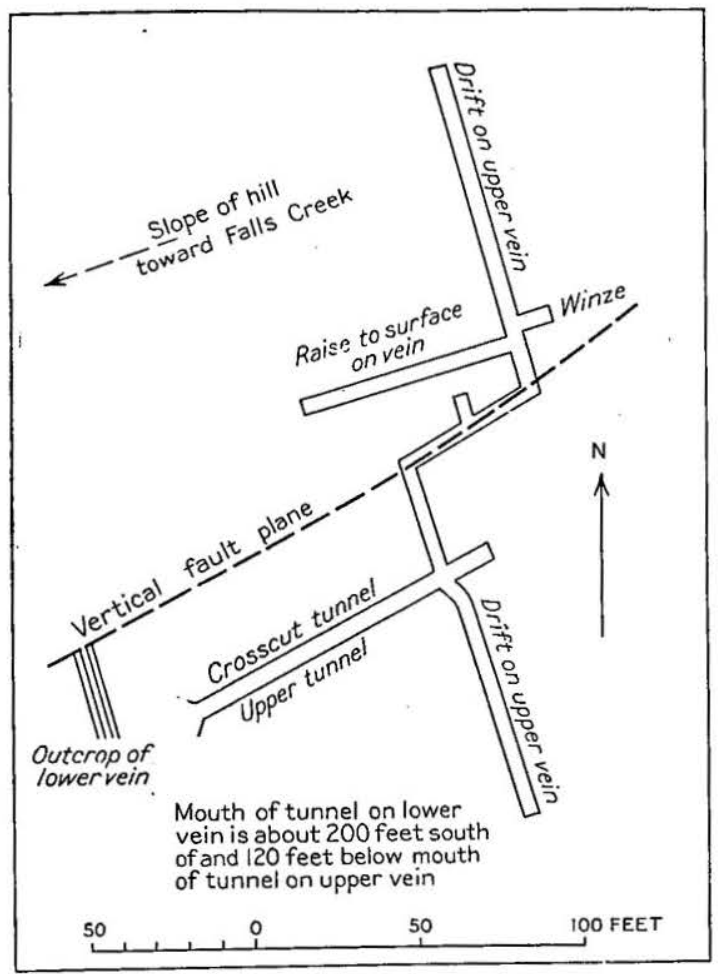

FIGURE 23.-Plan of workings on upper vein of Skeen-Lechner Mining Co.'s property, Falls Creek (October, 1912).

this vein when a fault that offset the vein was encountered, and in October, 1911, the drift had been carried 40 feet beyond this fault without picking up the continuation of the vein.

Country rock.-The country rock of the ore body is principally massive graywacke. About 20 feet west of the last open cut on the upper vein there is a graywacke-slate contact, striking N. $6^{\circ} \mathrm{E}$. and dipping $85^{\circ} \mathrm{W}$. A small amount of slate having approximately this strike occurs along the vein west of the small fault that offsets the upper vein. Bowlders of slate, graywacke, and conglomerate are found in the talus. 
Ore deposit.-Two veins have been uncovered on this property. The earlier-known (upper) vein has been opened upon the surface for 375 feet by trenches and open cuts, and the more recently found (lower) vein is reported to be traceable for 300 feet. The upper vein, occupying a fissure in the massive graywacke, strikes $\mathrm{N} .15^{\circ} \mathrm{W}$. and dips $45^{\circ} \mathrm{E}$. About midway of its present known length it is offset 40 feet on the tunnel level by a vertical fault fissure striking N. $56^{\circ} \mathrm{E}$. The sheared zone along the fault plane is 12 to 23 inches wide and is filled with crushed country rock containing fragments of vein quartz. Slickensides are visible on this included vein quartz and on the walls of the fault fissure. In the tunnel this vein is well defined, varies in width from 20 to 45 inches, and shows 1 to 4 inches of gouge on both walls. The outcrop shows much less quartz, 28 inches being the

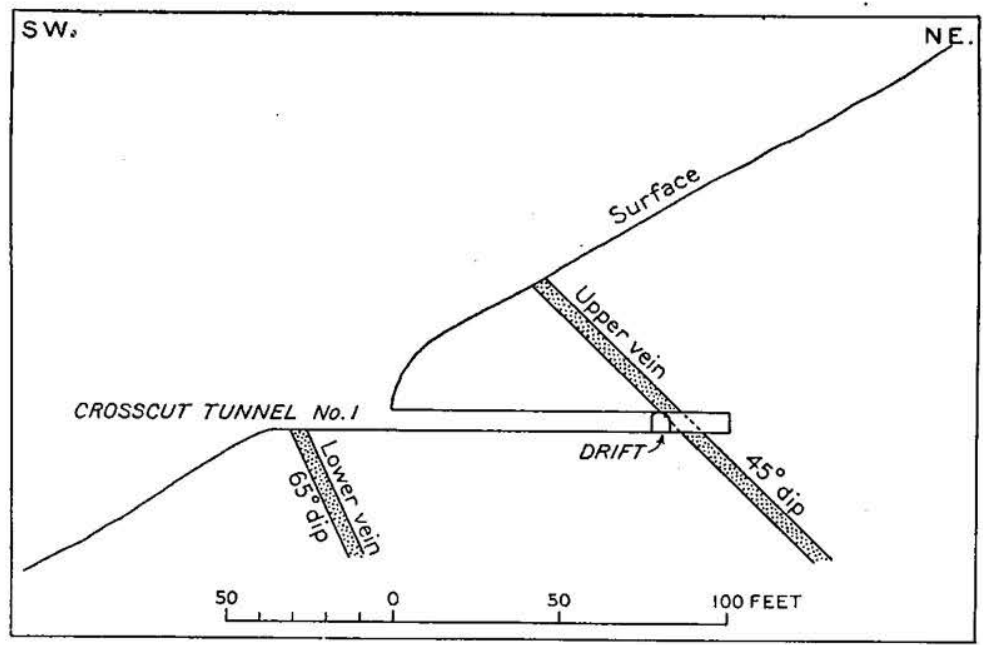

Figure 24.-Vertical section along upper tunnel of Skeen-Lechner Mining Co.'s property, Falls Creek.

maximum measurement made, and in places the fissure filling is a sheared arsenopyrite-impregnated graywacke containing only a few narrow quartz stringers. The lower vein lies about 90 feet southwest of the upper vein and has a strike of N. $45^{\circ} \mathrm{W}$. and a dip of $65^{\circ} \mathrm{NE}$. It measured 46 inches at the original discovery, near the mouth of the upper tunnel. (See fig. 24.) In the lower tunnel the width of the vein varied from 1 foot to 4 feet, averaging about 2 feet. Gouge shows on both walls.

Ore.-The fissure filling of the two veins is massive white quartz, somewhat shattered and jointed. Faint indications of secondary banding are seen in some places. Only a few small crystal-lined cavities are noticeable in the vein quartz. At the western end of the outcrop of the upper vein the quartz occurs as a network of stringers in the shattered country rock, the graywacke being considerably iron 
stained. The quartz stringers here are frozen tightly to the graywacke, and narrow rusty bands, showing the former position of iron sulphides, lie along the contact. The country rock is impregnated with iron sulphides at several places along the vein.

Sulphides are somewhat more abundant in these veins than in those of the Kenai-Alaska Gold Co., but they are not nearly so plentiful as in the vein on the adjacent property of the California-Alaska Mining Co. Native gold occurs in association with arsenopyrite and galena, and in one specimen gold was embedded in an arsenopyrite grain. The gold and sulphide appear as small grains, no large masses being observed in either vein. The ore in the upper vein is said to average over $\$ 35$ in gold to the ton, and careful sampling and assaying on the outcrop of this vein is reported to show the presence of two distinct ore shoots. Assays of $\$ 10$ to $\$ 50$ a ton are reported from the lower vein.

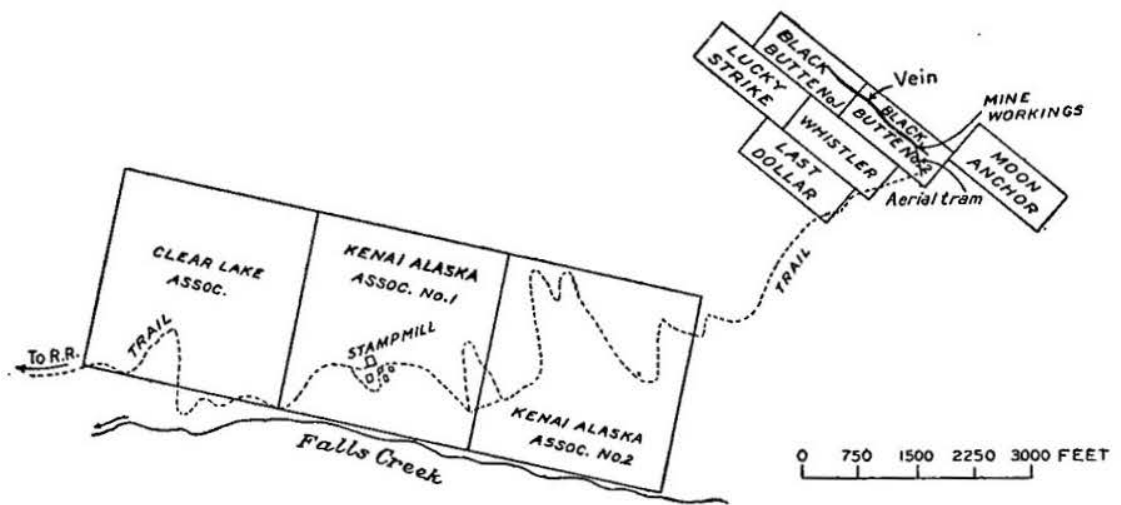

Figure 25.-Map showing claim locations of the Kenai-Alaska Gold Co., Falls Creck. From survey by Norman Wimmler, Kenai-Alaska Gold Co., Oetober, 1911.

KENAI-ALASKA GOLD CO.

Location.--The property of the Kenai-Alaska Gold Co. is on the north side of Falls Creek. The stamp mill, 2 miles east of and 1,100 fect above the company's warchouse at Trail Lake siding, near mile 26, on the Alaska Northern Railway, is close to timber line on a small tributary of Falls Creek. The mine, 2,800 feet above the mill, is in the west wall of a small cirque. The mouth of the lower tunnel is 275 feet above the surface of the small glacier in the cirque. (See fig. 19 , p. 149, and fig. 25.) $\Lambda$ road connects the warehouse, mill, and mine. (See Pl. XXXIII, p. 151.)

History and development.-The Black Butte vein was located June 16,1906 , by J. W. and C. E. Stevenson, who also located the veins on the Moon Anchor claim June 23, 1907. An option was taken on the property July 15, 1910, by T. W. Hawkins, Charles E. Brown, James R. 
Hayden, and John Adams. On December 16, 1910, the parties holding the option deeded the property to the present owners, the KenaiAlaska Gold Co., which had been incorporated under the laws of Alaska in November, 1910.

Development work, which has been confined to the Black Butte vein, began late in July, 1910. The upper and lower tunnels were driven and drifts started on the vein from each tunnel in the summer of that year. During the winter of 1910-11 the drifts on the lower level were advanced and a raise excavated connecting the two levels. On July 15, 1911, work was again started at the mine, a 630-foot aerial tram with a capacity of 5 tons per hour being built from the mouth of the lower tunnel to the lateral moraine of the glacier. Underground

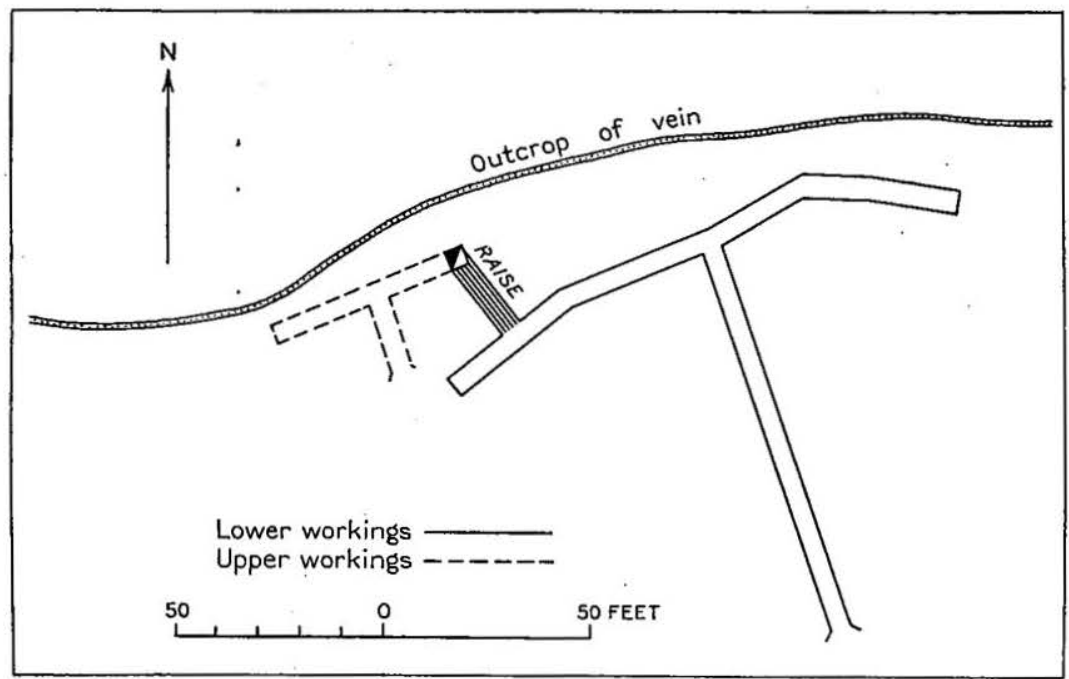

FIGURE 26.-Plan of underground workings on Black Butte vein (September, 1911).

development was actively carried on during the remainder of the season, and the extent of the workings on October 1, 1911, is shown in the accompanying diagrams (figs. 26 and 27). The development work in 1912 consisted principally in extending the levels westward, and about 200 feet of work was done. A winze was also sunk 40 feet from one of the levels.

A 5-stamp mill was erected in 1911, milling operations beginning August 24. The running time of the mill for the year was 276 hours, and 185 tons of ore was milled. Between May 15 and October 1 an average of 21 men and 2 teams were employed on the property. On October 1 the mill was closed down and the mine crew was reduced to 2 men. In 1912 an aerial tram was erected between the mill 
and the mine and was used to transport the ore to the mill. On November 3,1912, the traction cable of the tram broke, and operations were discontinued until spring.

Ore treatment.- The ore, which is sacked at the mine, is carried by a 630-foot aerial tram to the end of the road on the lateral moraine of the glacier, from which a second tramway carries it to the mill, where it passes over a 4 by 10 foot grizzly with $1 \frac{1}{2}$-inch spaces. The oversize goes to a Blake ore crusher No. 1. A Risdon Challenge ore feeder, stamp-driven type, then feeds the ore to a 5 -stamp mill (Risdon Iron Works). The stamps, each dropping 6 inches 114 times a

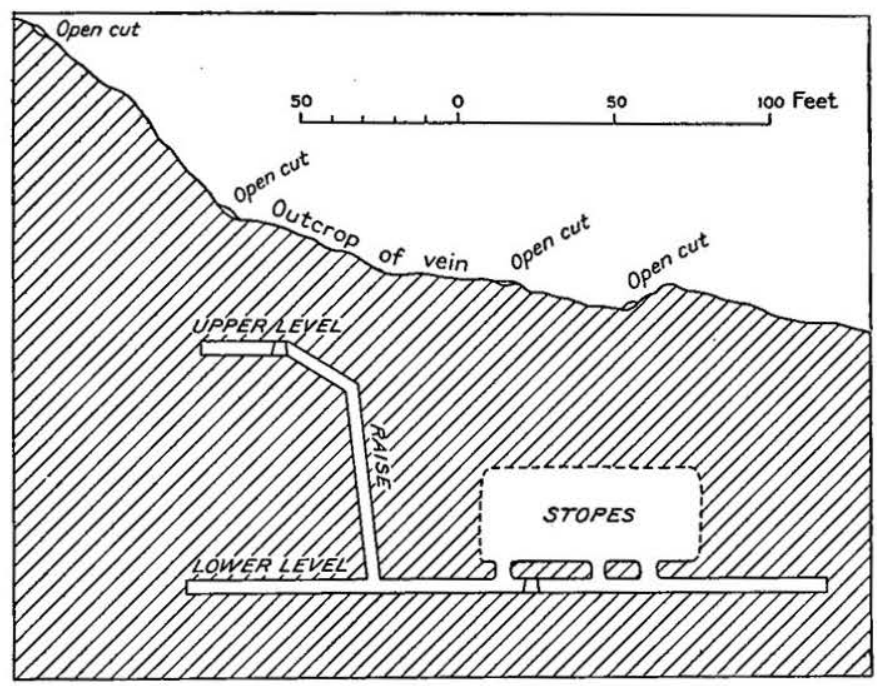

Fraure 27.-Longitudinal section of Black Butte vein showing lovels and stopes up to October 1, 1911.

minute, discharge the pulp through a 40-mesh screen. After passing over the amalgamating plates the pulp flows to a Risdon-Johnston concentrator, the concentrate from which is shipped to the Tacoma smelter. (See fig. 28.)

The power for the mill is furnished by a 25-horsepower engine, steam being generated in a 35 -horsepower wood-burning boiler. Fucl (wood) is obtained from the surrounding forest. The water supply for the power plant and mill is taken from the small creek by which the mill stands.

Country rock.--Only sedimentary rocks, slate, graywacke, and conglomerate were seen on Falls Creek, but it is reported that a basic igneous rock, greenstone, is found near the head of the creek. The slate is grayish black. The graywacke associated with the slate is a fino-grained gray to dark-gray rock, weathering much lighter than the slate. On the east wall of the cirque in which the mine is situated 
there are thin beds of graywacke, 2 to 12 inches thick, interbedded with black slate, striking $\mathrm{N} .8^{\circ} \mathrm{W}$. and dipping $70^{\circ} \mathrm{E}$. The slate predominates. Conglomerate beds are found in the cirque walls near the mine. The pebbles are small, most of them less than 2 inches in diameter, well rounded, and embedded in a slaty or siliceous matrix. The pebbles are principally of fine-grained dark-gray sedimentary rocks, but a few pebbles of acidic igneous rocks are found. The beds on the north and west walls of the cirque have been closely folded. Some of the folds show an overturning toward the west. Shearing

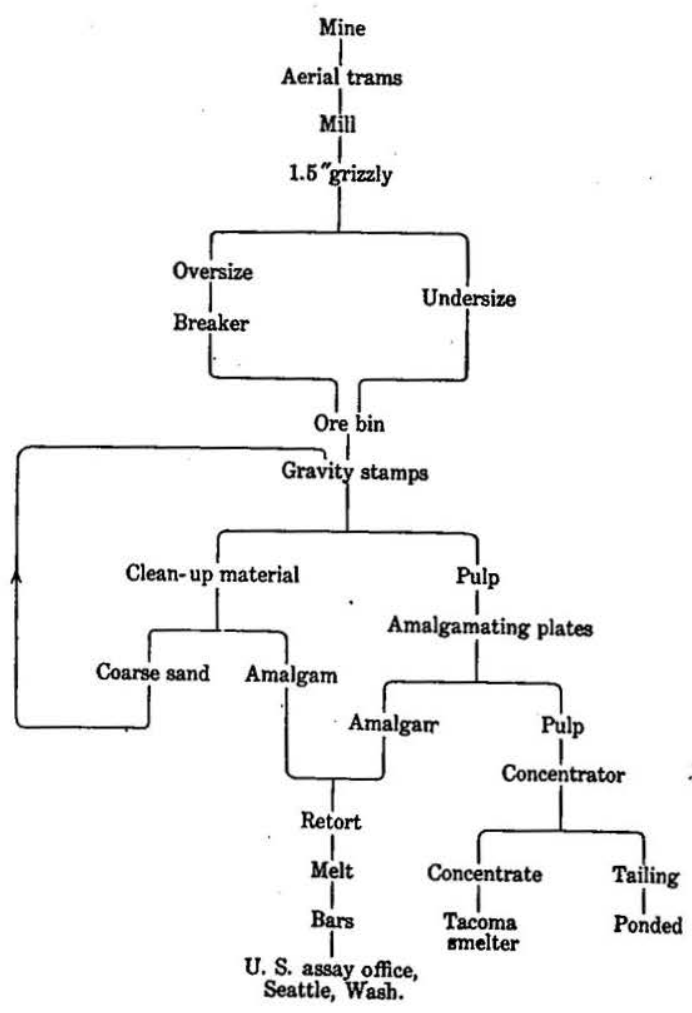

FIgURE 29.-Diagram of mill treatment of gold quartz ore from the Black Butte vein. and faulting accompanied the folding.

Ore deposit.-Threo veins have been discovered on this property, the Black Butte vein, now being developed, and two smaller veins on the Moon Anchor claim.

The Black Butte vein occupies a fissure, formed during or after the folding of the slategraywacke series. The strike of the fissure as shown by the plan of the mine workings (fig. 26 ) is slightly curved, varying from N. $50^{\circ}$ to $\mathrm{S} .83^{\circ} \mathrm{E}$. The dip ranges from $65^{\circ} \mathrm{SE}$. to $90^{\circ}$. On the surface the vein has been traced for more than 1,500 feet. The width of the fissure filling ranges

from 5 to 48 inches, the average width being from 20 to 30 inches. The fissure filling consists of crushed and decomposed country rock with numerous lenses and stringers of quartz which locally fill the entire fissure. The width of the quartz masses varies from 1 inch to 30 inches. Twenty measurements on several of the quartz lenses gave an average width of 11 inches. Larger and more continuous bodies of quartz have been found in the east end of the lower drift than in the west end, and most of the development work of 1911 was done in that part of the mine. Considerable movement has taken place along this fissure since the vein quartz 
was deposited, as is shown by the slickensided quartz surfaces within the vein, the close jointing in the quartz, and the lenticular nature of some of the quartz masses. Slickensides are also noticeable in the slate close to the veins. (See figs. 29-32.)

No development work has been done on the veins on the Moon Anchor claim and little is known regarding their size or extent. Both

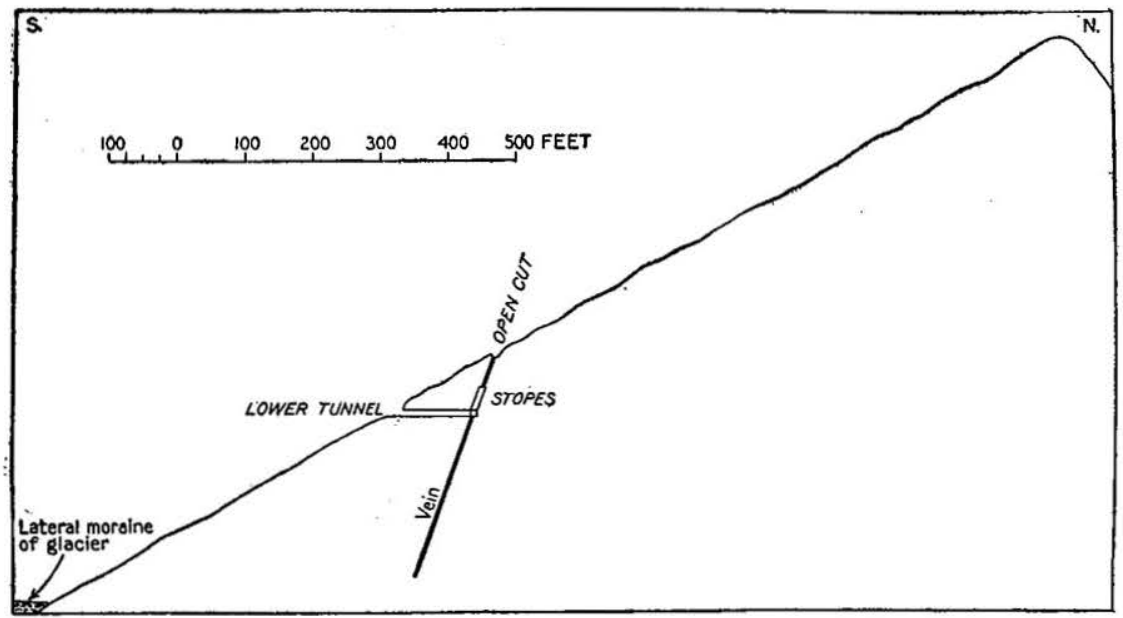

FrgURE 29.-Vertical section along lower tunnel on Black Butte No. 2 claim, showing relation of the dip of vein to the slope of hillside.

veins apparently occupy fissures, one of which strikes a little south of east and has a vertical dip. This vein is traceable about 200 feet. The width of the quartz filling of these veins varies from 1 foot to 2 feet.

Ore.-The quartz gangue, as a rule, is massive and compact. The veins on the Moon Anchor claim, however, contain a few small cavi-

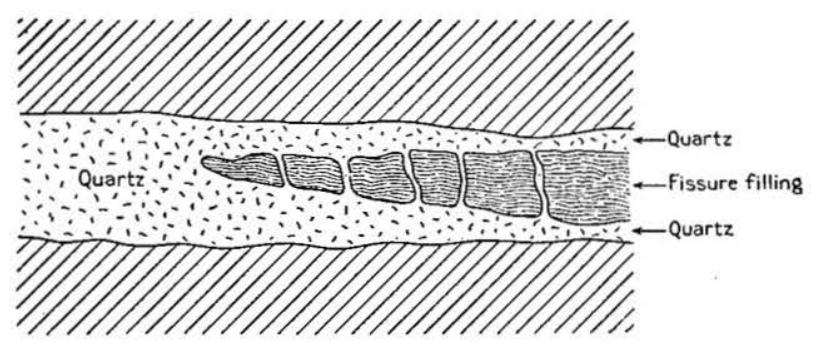

Figure 30.-Plan of portion of vein in east end of lower level of Black Butte No. 2 claim.

ties lined with well-developed quartz crystals. The vein quartz is milky-white except where discolored by decomposition products of the sulphides. Calcite occurs in the veins in small quantities. The close rhombohedral jointing of the quartz gives the ore a checked appearance.

$48891^{\circ}-$ Bull. $587-15-11$ 
The ore is free-milling. The gold is very fine and is rarely visible to the unaided eye. The sulphides, arsenopyrite, galena, and sphalerite, form less than 1 per cent of the ore. The gold is found both

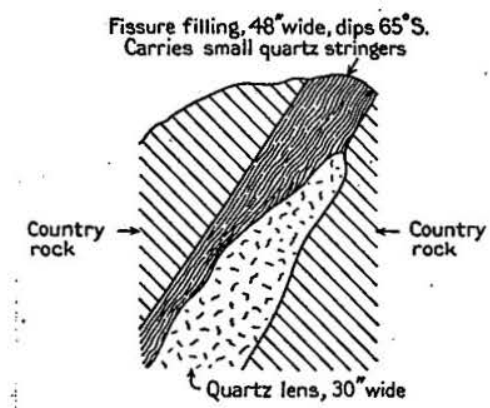

Figure 31.-Sketch illustrating occurrence of quartz in Black Butte vein. free and in close association with or included in the sulphides, which are fine and widely scattered through the quartz gangue. Many of the joint surfaces of the quartz are rusty and when cleaned show much fine gold, left by the decomposition of the goldbearing sulphides.

The vein quartz only is sacked for milling, as the country rock adjoining the vein and the fissure filling, except the quartz, are reported to be barren of gold. The gold content of the vein quartz varies. Assays as high as $\$ 84, \$ 101$, and $\$ 718$ have been obtained from different parts of the vein. An average of several assays made by the company was slightly less than

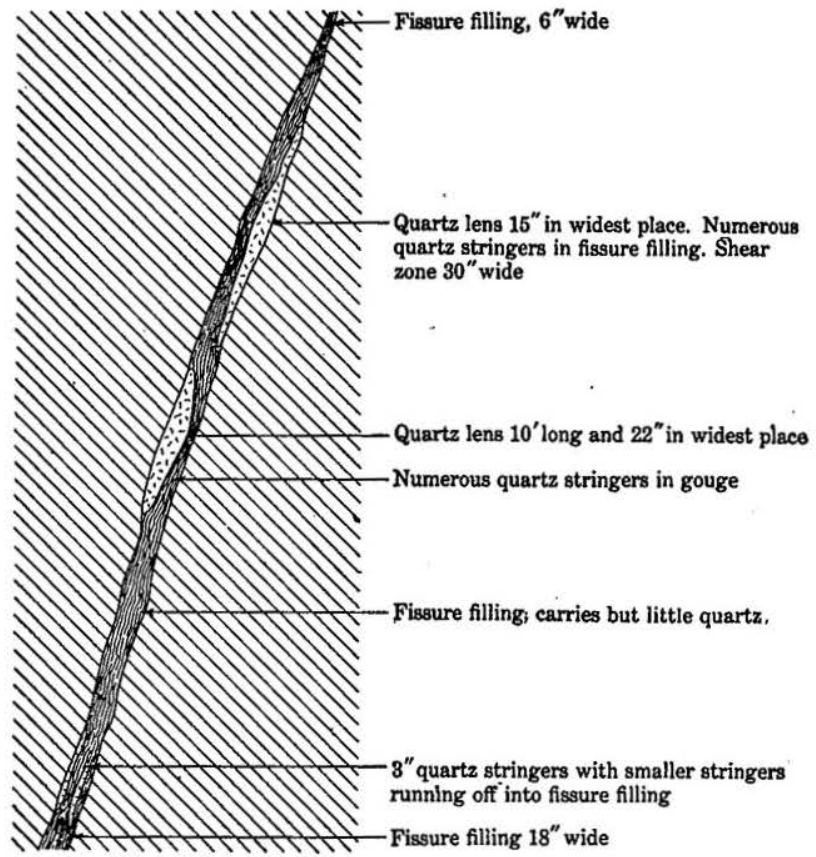

FTGURE 32.-Cross section of Black Butte vein in raise on Black Butte No. 2 claim.

$\$ 80$ a ton. This, however, included one exceptionally high assay of $\$ 718$. The results obtained at the mill in 1911 showed that the ore plated $\$ 45$ a ton. The concentrate, of which there was 0.66 ton, 
assayed more than $\$ 400$ a ton. The company estimates that 76 per cent of the gold in the ore was recovered during milling operations.

\section{FAIRMAN-MADSON PROSPECTS.}

A few quartz prospects have been located on Quartz Creek near the mouth of Devil Creek by William Fairman and John Madson. The upper prospect, known as the Kaffir ledge, is about 100 yards above the mouth of Devil Creek, on the east bank of Quartz Creek and about 40 feet above the stream. The lode was discovered in 1909 , and the development work in June, 1911, consisted of a 20-foot crosscut tunnel. and some open cuts. The only exposure of ledge when visited was in an open cut in slide rock. The ore body appears to consist of lenses of sulphide-bearing quartz, with a maximum thickness of 1 foot, in slate and graywacke. The metallic minerals present in the ores are galena, sphalerite, pyrite, chalcopyrite, and arsenopyrite. The gangue minerals are quartz and calcite. High gold values are reported in assays.

The Buster vein is on the left bank of Quartz Creek about oneeighth mile below Devil Creek. The country rock consists of sheared slates and graywackes. The vein, 16 to 18 inches wide, shows in an open cut 10 feet above the creek level. The quartz is coarsely crystalline and contains large crystals of arsenopyrite. No appreciable amount of gouge is visible on the hanging wall, and only a very little on the footwall. Small quartz stringers show in the footwall slate, which also carries a small amount of pyrite. The crushed quartz is reported to pan free gold.

The Yellow Jacket ledge is on the nose of a ridge on the left bank of Quartz Creek about a mile below Devil Creek. The vein was located June 3, 1908. The developments in June, 1911, consisted of a 35-foot crosscut tunnel, which at its inner end passed through a 44-inch quartz vein striking $\mathrm{N} .60^{\circ} \mathrm{E}$. The vein has a vertical dip. The vein on the surface is 1 foot wide and is visible for about 200 feet. It is reported to be traceable for about 1,500 feet. The highest assay reported by the owners shows $\$ 9$ gold a ton.

DEVIL CREEK PROSPECTS.

Locations have been made on an acidic dike intrusive into thinbedded slates and graywackes, at an elevation of about 4,000 feet near the head of Henry Creek, a small tributary of Devil Creek. Several open cuts have been made on the dike, which strikes N. $40^{\circ}$ E. and dips $35^{\circ} \mathrm{W}$. The dike closely resembles the Gilpatrick dike, between Slate and Summit creeks, but is a trifle narrower. It is 4 to 6 feet wide and is traceable for more than 1,000 feet. The dike has been fractured and recemented by small quartz seams. There is 
little sign of mineralization, although $\$ 4$ assays are reported from the dike. Gold-bearing quartz veins have also been reported near the head of Devil Creek, but as there was no one on the claims at the time the creek was visited no data are available regarding their location, size, or value.

IMHOFF-WEIDLICH-SAULSBURY PROSPECTS.

The claims of Imhoff, Weidlich, and Saulsbury are in the southern part of the Moose Pass district, between Slate and Boulder creeks. They were located in 1908 by Totten and Gaydon. In 1911 the development work consisted of open cuts on two claims and a trail from the owners' cabins on Quartz Creek to the prospects. The open cut on the Columbia claim at an elevation of about 3,600 feet was on a vertical sheared zone about 1 foot wide, striking N. $70^{\circ} \mathrm{E}$., in slates and graywackes. A lens of quartz with a maximum thickness of 28 inches lay along the west wall, and a mass of rusty decomposed quartz was found in the slates west of the shear during the making of the open cut. The quartz yields free gold on panning. The open cut on the Ophir claim, at an elevation of about 3,700 feet, is on a narrow shear zone that strikes N. $14^{\circ} \mathrm{W}$. and dips $70^{\circ} \mathrm{W}$. in slates and graywackes. It contains some gold-bearing quartz, one lens 12 inches wide showing on the hanging wall.

THE J. C. GILPATRICK PROPERTY.

The J. C. Gilpatrick property is near the southern end of the Moose Pass district, the claims lying across the ridge between Slate and Summit creeks. A Government road extends from mile 29 on the Alaska Northern Railway, through Moose Pass, over the low divide between Quartz and Canyon creeks, and down Canyon Creek to "the Forks." The Gilpatrick property, 15 miles from mile 29, is reached by way of this road. The underground workings, except a short tunnel on the crest of the ridge, are on the southward-facing slope of the valley of Slate Creek. A good trail extends from the Government road to the tunnels.

Gold-bearing quartz veins were first discovered on this property in August, 1906, but no development work other than assessment was done for several years. The large dike was discovered in 1908. On August 5, 1909, the property was bonded to A. L. Snow and A. W. Watson, who began work as soon as the bond was given. The development work at that time included 16 feet of tunnel on the Hattie claim and several open cuts on the dike and on the Summit and Olympia claims. Several hundred feet of development work was done by the lessees before the refusal of the owners to extend the time limit on the second payment beyond one month caused a cessation of work and the forfeiture of the bond. In 1910 the two tunnels on the dike were extended a few feet. On a claim east of these tunnels a 
200-foot tunnel was driven in the fall of 1910 by the Wanowky Gold Mines Co. on a vertical shear zone ranging in width from 3 to 30 inches and striking N. $60^{\circ} \mathrm{E}$. in slates. The underground developments on the property in 1911 are shown in the accompanying figures (figs. 33 and 34 ).

It is reported that an arrastre was erected on the property in 1912 and that a few tons of ore was then milled.

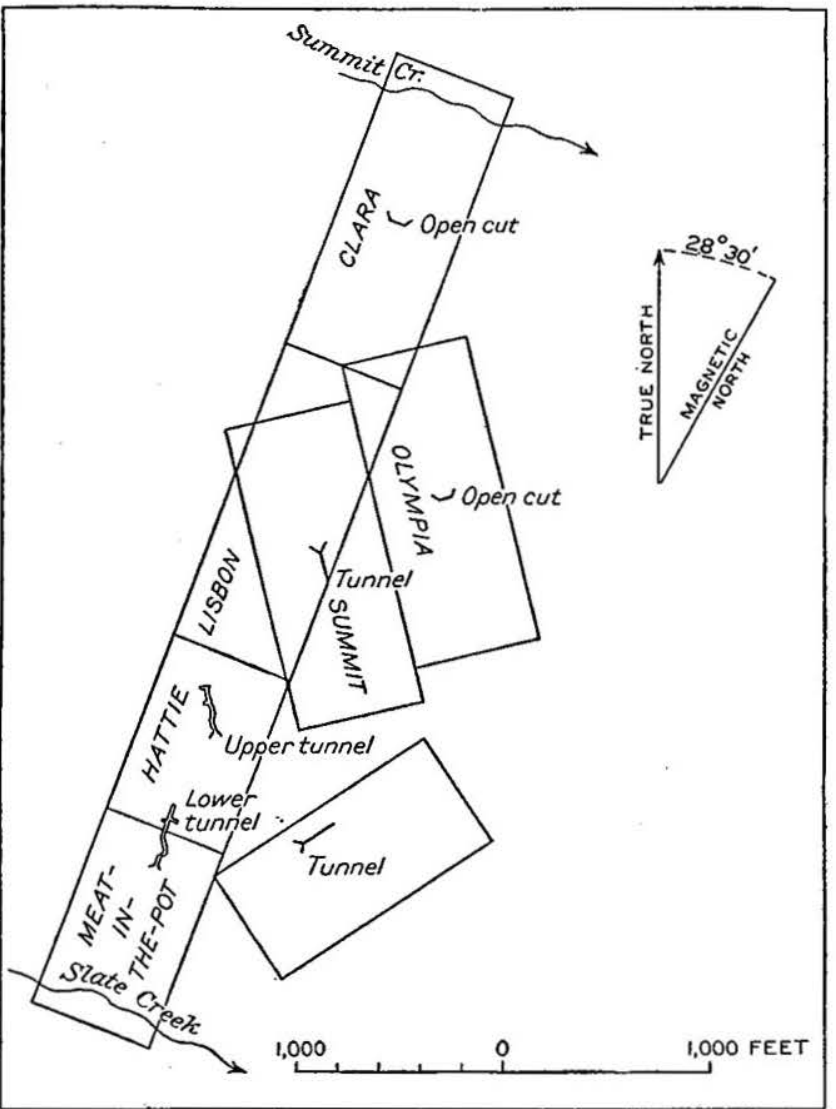

FIGURE 33.-Sketch showing looation of tunnels on the Gilpatrick claims between Slate and Summit creeks (September, 1911).

The Gilpatrick claims cover that part of the Big Moose Pass mineralized dike which lies between Slate and Summit creeks and some associated gold quartz veins. The country rock consists of interbedded slates and graywackes. The dike is a very fine grained, much altered diorite porphyry. Owing to the extensive alteration the porphyritic character is discernible in but few places. Under the microscope phenocrysts of plagioclase feldspars and a silicate (now completely altered to chlorite, calcite, and sericite) are seen embedded in a fine-grained groundmass. Considerable sericite is present, and 
also a small amount of chlorite, to which the greenish tinge of the rocks is probably due. Sericitization of the feldspars is well advanced. Small seams of calcite occur in the more altered parts of the dike, and calcite is also associated with the quartz of the veins. In places the fractured dike is cemented by irregular quartz stringers containing a little calcite. Striated crystals of arsenopyrite occur disseminated in the altered porphyry adjacent to quartz veins and stringers.

The original dike rock probably did not carry any gold. Assays on average samples from the less altered parts range from a trace to a

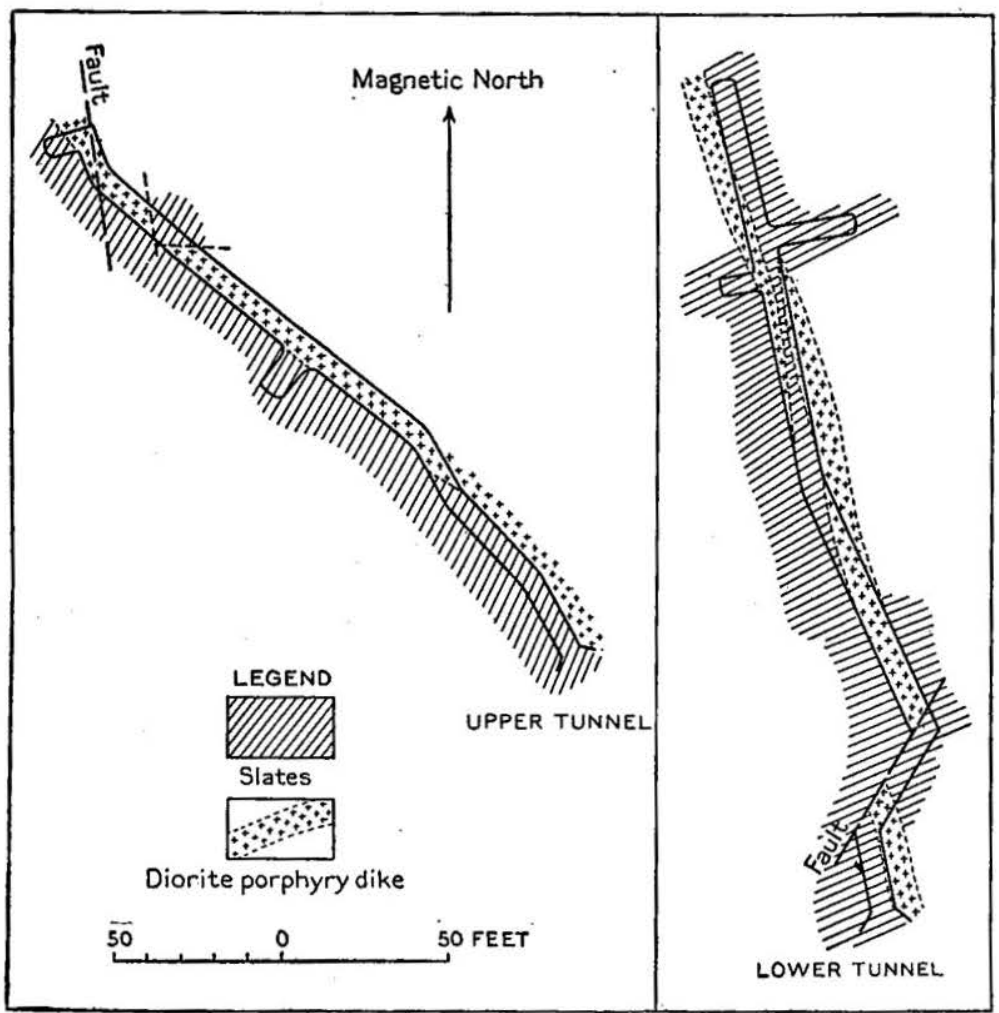

FroURE 34.-Geologic sketch plans of upper and lower tunnels on mineralized dike, Gilpatrick claim (August, 1911).

little over $\$ 1$. Higher assays are obtained in the more mineralized parts of the dike, where gold-bearing quartz cements the fractured dike rock.

A gold quartz vein follows the west wall of the dike in the upper tunnel. A crosscut to the west at the face of the tunnel shows 5 feet 2 inches of slate and quartz separated from the dike by 3 feet of slate, and small rusty quartz stringers. Within the 5 feet 2 inches are vertical veins of quartz, 7,16 , and 18 inches wide, and the slate between these veins carries numerous small quartz stringers. A crosscut to the west about 125 feet from the mouth of the tunnel 
shows a 15-inch vein of quartz in slate 12 feet west of the dike. Assays on quartz from this vein are reported to run from 80 cents to $\$ 37$.

The Summit vein, on the crest of the ridge between Slate and Summit creeks and east of the dike, lies in sheared graywacke, strikes northwest, and stands vertical. This vein has not been traced to its intersection with the dike. A tunnel (now collapsed), 117 feet in length, has been driven on this vein just below the crest on the Summit Creek side of the ridge, and the vein has been traced by several open cuts to a point on the south slope about 150 feet below the crest of the ridge. The width of the vein quartz ranges from 6 to 40 inches. Free gold is plainly visible, as are also the sulphides galena and arsenopyrite. Average assays of from $\$ 30$ to $\$ 68$ are reported from this vein.

PROSPECTS ON MINERALIZED DIKE BETWEEN SUMMIT AND COLORADO CREEKS.

Six claims have been staked along the continuation of the Gilpatrick mineralized dike between Summit and Colorado creeks. The development work consists of numerous open cuts and trails to the prospects up both Summit and Colorado creeks. The width of the dike ranges from 4 feet to 14 feet 7 inches. The dip is from $72^{\circ} \mathrm{E}$. to vertical. The dike has been shattered in many places and the fractures cemented by mineralized quartz stringers. The quartz veins appear to be confined to the dike, and the quartz stringers are more numerous in the dike than on the property to the south. The stringers reach a maximum width of 8 inches, but few are over 4 inches wide. Small calcite veins also occur, and calcite is found in the quartz veinlets. Considerable free gold is visible in some of the quartz, and arsenopyrite impregnates the dike near the quartz stringers. Average samples are reported to assay from $\$ 1.40$ to $\$ 52.80$. Average samples from five open cuts on this lead are reported by the owners to average $\$ 19$ to $\$ 20$ a ton. Comparatively unmineralized portions, however, occur in this strip, as in other parts of the dike, and these would lower the general average considerably.

PROSPECTS ON MINERALIZED DIKES BETWEEN COLORADO AND FRESNO CREEKS.

The continuation of the Gilpatrick dike crosses the crest of the Colorado Creek-Fresno Creek divide N. $18^{\circ}$ E. of the crossing of the Summit Creek-Colorado Creek ridge. On the south side of the ridge the dike is not exposed until an open cut halfway up the slope is reached. On the north side of the crest of the ridge the dike strikes $\mathrm{N}$. $30^{\circ} \mathrm{E}$. and has a dip of $80^{\circ} \mathrm{W}$. A width of 6 feet was measured on one exposure. Considerable quartz is found along the dike on the rounded hills on the south side of the valley of Fresno Creek, and it is possiblo that some well-defined veins exist. The only development work in 1911 consisted of a few open cuts, and the exposures were in most 
places poor. The metallic minerals of the ores include arsenopyrite, galena, and free gold. It is said that an arrastre was erected in 1912 on the Independence group on Fresno Creek and that a few tons of ore was milled.

Two other mineralized dikes are found on the divide between Colorado Creek and Fresno Creek west of the Gilpatrick dike. These are the Mascot and the Iron Mask dikes. The Mascot ledge outcrops at the head of the creek on a ridge between Colorado and Fox creeks. The dike strikes north and dips vertically, and is traceable for several hundred feet. At the discovery monument the dike has a width of 40 inches, and 3 feet to the east is a smaller dike 3 inches to 1 foot wide. On the spur to the north the dike has split into six distinct stringers. The Iron Mask dike outcrops on the Colorado Creek slope between the Mascot dike and the Gilpatrick dike. It is 4 feet wide at the discovery monument. The mineralization of both the Mascot and Iron Mask dikes is similar to that of the Gilpatrick dike.

PROSPECTS ON MINERALIZED DIKE NORTH OF FRESNO CREEK.

North of Fresno Creek the strike of the Gilpatrick dike changes, the width is much more variable, and the dip is more irregular. On the north side of Fresno Creek, at the foot of the hill in an open cut (see Pl. XXX, $A$ ), the dike ranges in width from 58 to 70 inches, dips $84^{\circ}$ E., and appears to strike about N. $10^{\circ} \mathrm{E}$. It is fractured and cemented with gashlike veins of quartz having a maximum width of 8 inches and is much iron stained. On the crest of the ridge the dike is 8 feet 4 inches wide and dips $43^{\circ} \mathrm{E}$., but farther north, toward Pass Creek, it is very irregular in width, at some places narrowing to less than a foot, at others pinching out. In no other place does it show the width which it has on the summit. The dike was followed to a point a mile or so south of Pass Creek. Other prospects are reported on the dike near Pass Creek. No data are available as to the gold content of the mineralized dike between Fresno and Pass creeks.

A claim was located on the north side of Pass Creek on a dike, possibly the continuation of this one, but was given up on account of the low gold assay of the dike rock.

On the divide between Pass and Frenchy creeks four claims are said to have been located by S. L. Colwell and J. C. Robertson, along a mineralized dike extending from a point on the north side of Frenchy Creek southward almost to Pass Creek. Several open cuts have been made on this dike, which is said to have a width of 12 feet on Frenchy Creek.

No exposures of the dike have been reported between Frenchy and Donaldson creeks. On Donaldson Creek two claims have been located on an acidic dike which strikes N. $30^{\circ} \mathrm{E}$. and has a vertical dip. The width of the dike ranges from 8 to $10 \frac{1}{2}$ feet. The mineral- 
ization in the open cuts here is slight; an average assay of $\$ 1.08$ is the highest reported.

\section{SEWARD GOLD CO.}

Location.-The property of the Seward Gold Co. is about 4,250 feet above sea level, on the crest of the ridge between the forks of Groundhog Creek, a tributary to Bench Creek from the west, crossing the Government road from Sunrise $10 \frac{1}{2}$ miles from mile 34 on the Alaska Northern Railway, at an elevation of 1,100 feet. A horse trail has been cut from the wagon road nearly to the prospect.

History and development.-The ore body on this property was located September 11, 1910, by R. L. Hatcher and C. A. McPherson.

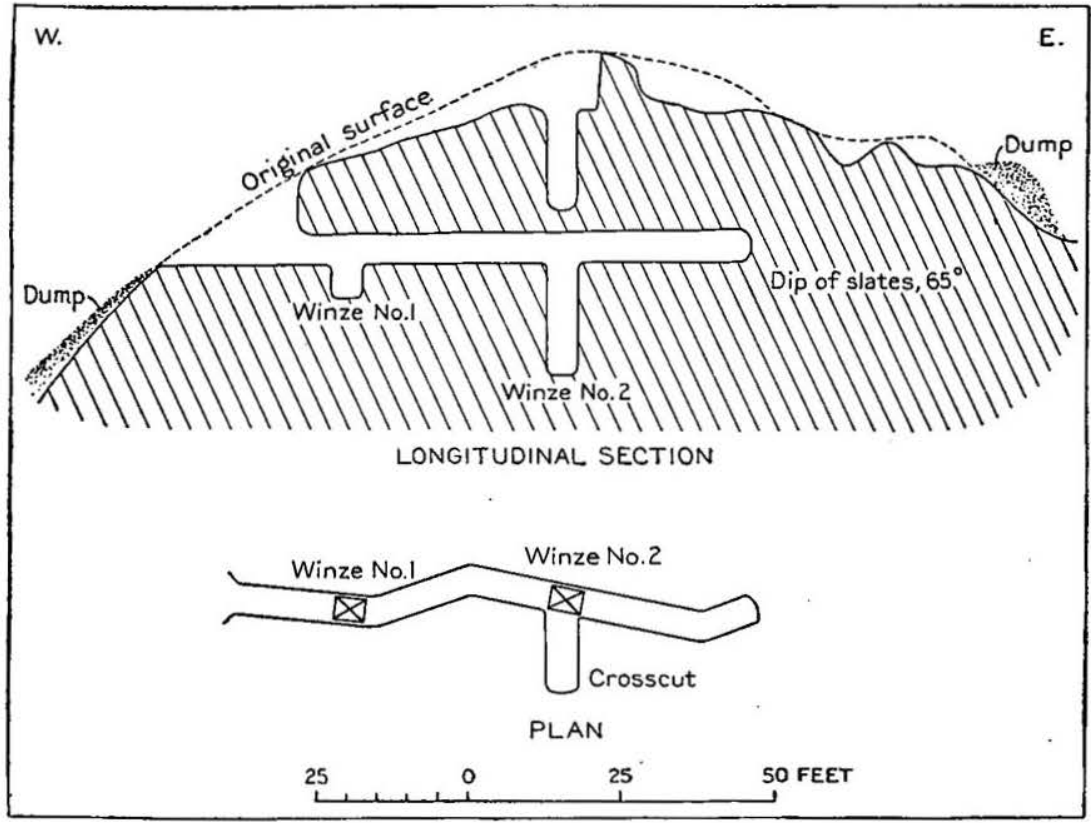

Frgure 35.-Plan and longitudinal section of workings on the Telluride No. 1 claim, Seward Gold Co., Groundhog Creek (September, 1911).

An option was taken on the property a few days after the discovery by S. I. Silverman and development work was started with four men. On October 20, 1910, the property was deeded to the Seward Gold Co. Between September 20 and the later part of November about 60 feet of tunneling was done on the vein and a winze was started. In 1911 development work was carried on early in the spring by the Seward Gold Co. and later by a party under the immediate supervision of Mr. G. A. Camphuis, of the Pacific Securities Co., to whom the writer is indebted for the accompanying maps and sketches and for considerable deseriptive data. The total development work done on the property since discovery consists of 90 feet of tumnel, 23 feet of winzes, a 12-foot crosscut, and a 15-foot shaft. (See fig. 35.) 
The development work did not appear to justify the expense of timbering the tunnel and the writer found it caved in at the time of his visit, August 9, 1911. Only assessment work was done in 1912.

Country rock.-The country rock of the ore body consists of slate and some graywacke, striking a few degrees east of north and dipping about $60^{\circ} \mathrm{E}$. The strike and dip of the cleavage correspond closely to that of the bedding. A vertical jointing near the vein strikes $\mathrm{N}$. $85^{\circ} \mathrm{E}$., the joints being irregularly spaced at intervals of a foot or more. A short distance above the workings a pale-greenish porphyry dike, 10 feet wide in places, crosses the ridge, striking $\mathrm{N} .28^{\circ} \mathrm{W}$. and dipping vertically. It shows little evidence of mineralization. About 150 feet northeast of this dike is a similar dike, whose northern end lies close to the eastern extremity of the vein as now uncovered. The outcrop of the vein has not been traced quite to the point where it should intersect this dike, nor is the dike visible on the surface north of the vein. The dike is of variable width, measuring 28 inches on the first outcrop south of the vein, but in places reaching a width of

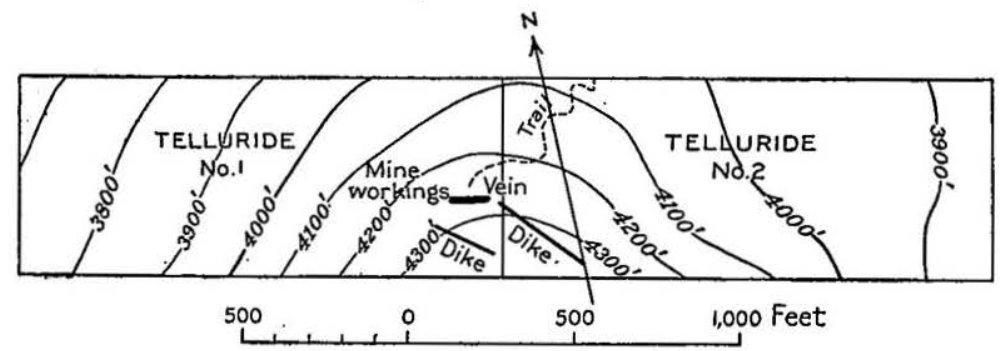

FIGURE 36.-Sketch showing relation of dikes and vein on property of Seward Gold Co., Groundhog Creek. From map by G. A. Camphuis.

at least 8 feet. It is approximately parallel to the upper dike, striking about N. $40^{\circ} \mathrm{W}$. Both dikes have been fractured and the fractures have been filled with white glassy-looking quartz, which at one place carries native gold. Arsenopyrite crystals were found in one of the dikes. (See fig. 36.)

Ore deposit. - The ore body consists of a zone of fractured slate, 5 to 6 feet wide, extending S. $80^{\circ} \mathrm{E}$. between the two dikes. It is nearly vertical, dipping steeply to the south. The vein has been traced about a hundred feet, and so far as present development work shows does not extend beyond either dike. A narrow streak of gouge lies along the hanging wall. The openings in the fractured slate have been filled with quartz, which forms a network of irregular stringers inclosing the crushed slate. Incipient jointing in the quartz and a few slickensided surfaces show that slight movements have taken place along the vein fissure since the deposition of the quartz. The vein material is more or less decomposed by surface weathering. (See fig. 37.) 
The quartz filling varies from narrow stringers to veins more than a foot in width. In many places the vein quartz, much of which is coarsely crystalline, contains drusy carities. A small quantity of calcite occurs with the quartz as a gangue mineral. The quartz carries the gold, assays of the decomposed slate from the fractured zone showing only a trace. The gold is free or occurs in close association with the sulphides, which include arsenopyrite, sphalerite, galena, and pyrite. Arsenopyrite, the most abundant sulphide, occurs also in the slate wall rock and in the dikes, its appearance in those places indicating metasomatic alteration of the country rock of the ore body by the mineralizing solutions.

PALMER CREEK PROSPECTS.

Most of the prospects on Palmer Creek are on a mineralized acidic dike, which is reported to be traceable from the Palmer Creek-Bear Creek divide north of Cœur d'Alene Gulch to the head of Palmer Creek along the east wall of the valley. A few claims have also been located on small masses of quartz and on bunches of quartz stringers in the slates and graywackes. The

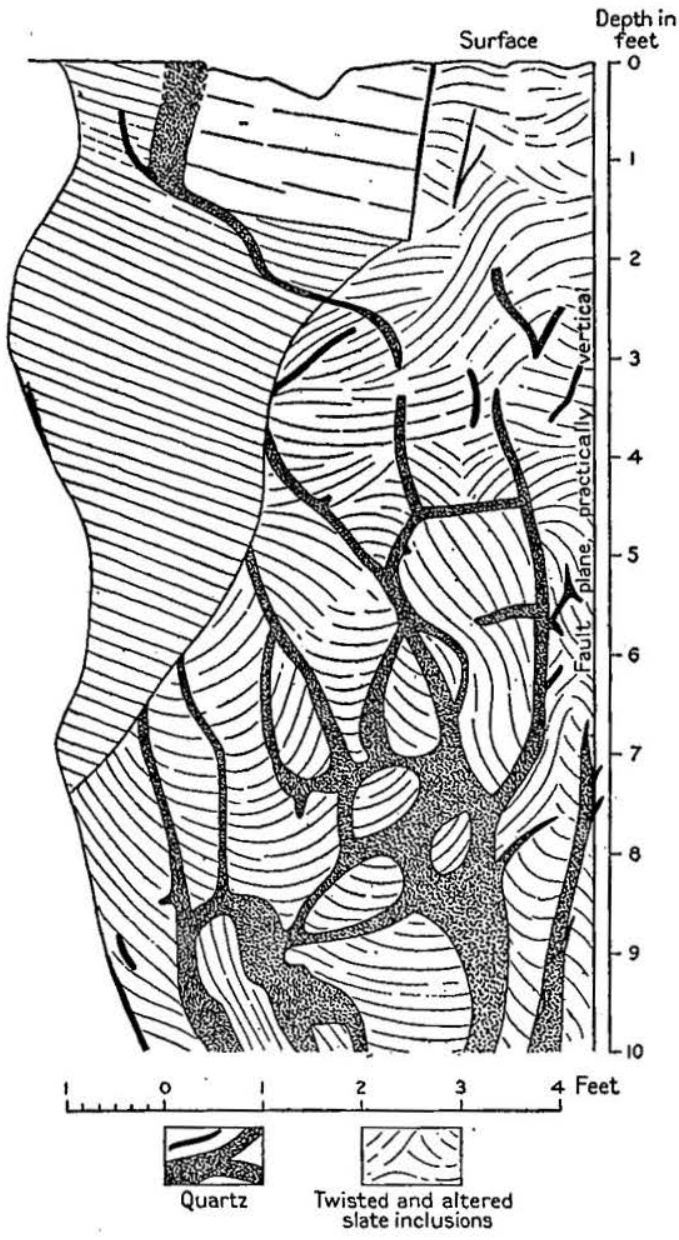

Figure 37.-Crose section of vein in shaft, Seward Gold Co., Groundhog Creek. From sketch by G. A. Camphuis.

dike was first discovered in 1898 on Cœur d'Alene Gulch by an Australian outfit, but no development work was done. Later John Hirshey and Elmer Carlson located the dike in Ptarmigan Gulch about a mile south of the original discovery and W. A. Logman relocated the dike on Cœur d'Alene Gulch. In 1911 the dike had been located for a length of 24 claims, and the development work comprised a 40-foot tunnel on Cœur d'Alene Gulch, a 50-foot tunnel 
on Ptarmigan Gulch, and several open cuts. The dike strikes about north and south and dips vertically. Its width varies from 1 foot to $6 \frac{1}{2}$ feet. It has been shattered and recemented by mineralized quartz stringers of variable width and degrees of mineralization containing the usual sulphides-arsenopyrite, galena, sphalerite, pyrite, and chalcopyrite-and free gold in a quartz-calcite gangue.

\section{BEAR CREEK PROSPECTS. ${ }^{1}$}

The known gold-bearing veins on Bear Creek occur in the midst of the broad amphitheater at the upper end of the valley. Small quartz stringers were first found in the arkoses of the stream bed and on further investigation led to the initial steps in the development now in progress. At the locality where work began the arkoses are somewhat brecciated or closely jointed, and the openings formed were filled with quartz, appearing as veins from one-half to three-quarters inch thick. Samples of the larger veins show sphalerite, galena, pyrite, and arsenopyrite, the peacock stain of copper, and a little free gold. The gangue is chiefly quartz, but contains some calcite. As the shaft was filled with water and the débris produced in enlarging the original opening, the writer did not see the veins from which these samples were taken, but was informed that the best ore was a 16-inch vein in a zone of mineralized rock 6 feet thick. No underground work other than the enlargement of the shaft had been undertaken at the end of July, 1904. This shaft has a cross section of 10 by 5 feet and a depth of 30 feet. There is a short drift at the bottom. The surface equipment consisted of a new head frame and a 4-ton boiler for operating the hoist and air compressor. A good road leads down the valley from the claims to Hope.

SAWMULL CREEK PROSPECTS.

Gold-bearing veins were discovered on Sawmill Creek very early in the development of the region and occur at three localities, which, however, are probably not entirely unrelated to one another. These are on the shore of the arm a short distance east of Slide Creek, on Slide Creek about one-half mile from the beach, and on Sawmill Creek one mile from the beach. The three lie nearly on a straight line, corresponding in direction with that of a number of fault planes observed here. At the first locality a small quartz vein in slates lies along a fault plane, striking N. $70^{\circ}$ $\mathrm{E}$. and dipping $70^{\circ} \mathrm{E}$. The rock surface of the hanging wall is smooth and highly polished. Samples of the quartz assayed $\$ 2$ in gold per ton. On Slide Creek quartz veins occur along two fault planes, the first similar to that just described, the other striking N. $50^{\circ} \mathrm{E}$. The strike of the bedding is N. $10^{\circ}-15^{\circ} \mathrm{E}$. Quartz from this locality carries a higher percentage of gold.

On Sawmill Creek the gold-bearing quartz is found along a fault zone running northeast and southwest. It is difficult to make out the structure of the slates and arkoses which are here greatly disturbed, for the fault is not a simple one, but apparently is made up of minor displacements, with no parallelism, which took place at different times. The walls are frequently striated and between them a thin gouge is usually present. An adit 60 to 70 feet long was started on a branching quartz vein having a maximum thickness of 4 feet but of very irregular dimensions. It appears to have been cut off by movements occurring after its formation, since the vein was lost and the extension of the adit did not rediscover it. The continuation, however, may possibly be found to be the quartz vein located a short distance north of the adit. This second vein is about 3 feet thick and is less disturbed than the other. It carries low gold values but no attempt has been made to extract them.

1 Moffit, F. H., Gold fields of the Turnagain Arm region: Bull. U. S. Geol. Survey 277, pp. 46-47, 1906. 
The first vein carries free gold in a quartz gangue containing arsenopyrite, pyrite, zinc blende, and galena. Crystals of arsenopyrite are also very abundant in the country rock. A small streak of rich ore, said to carry $\$ 90$ per ton, pitched steeply northeastward under the creek and could not be followed because the water broke in and stopped the work. In order to save the expense of shipping ore a small arrastre driven by water power and capable of handling two 700-pound charges a day, was erected near the adit, and with it the ore is treated. Nineteen tons of picked ore put through this arrastre yielded $\$ 500$, or a little more than $\$ 26$ per ton.

BARNES PROPERTY.

Location.-The property of the Alaska Gold Exploration \& Development Co., known locally as the Barnes property, is at the head of

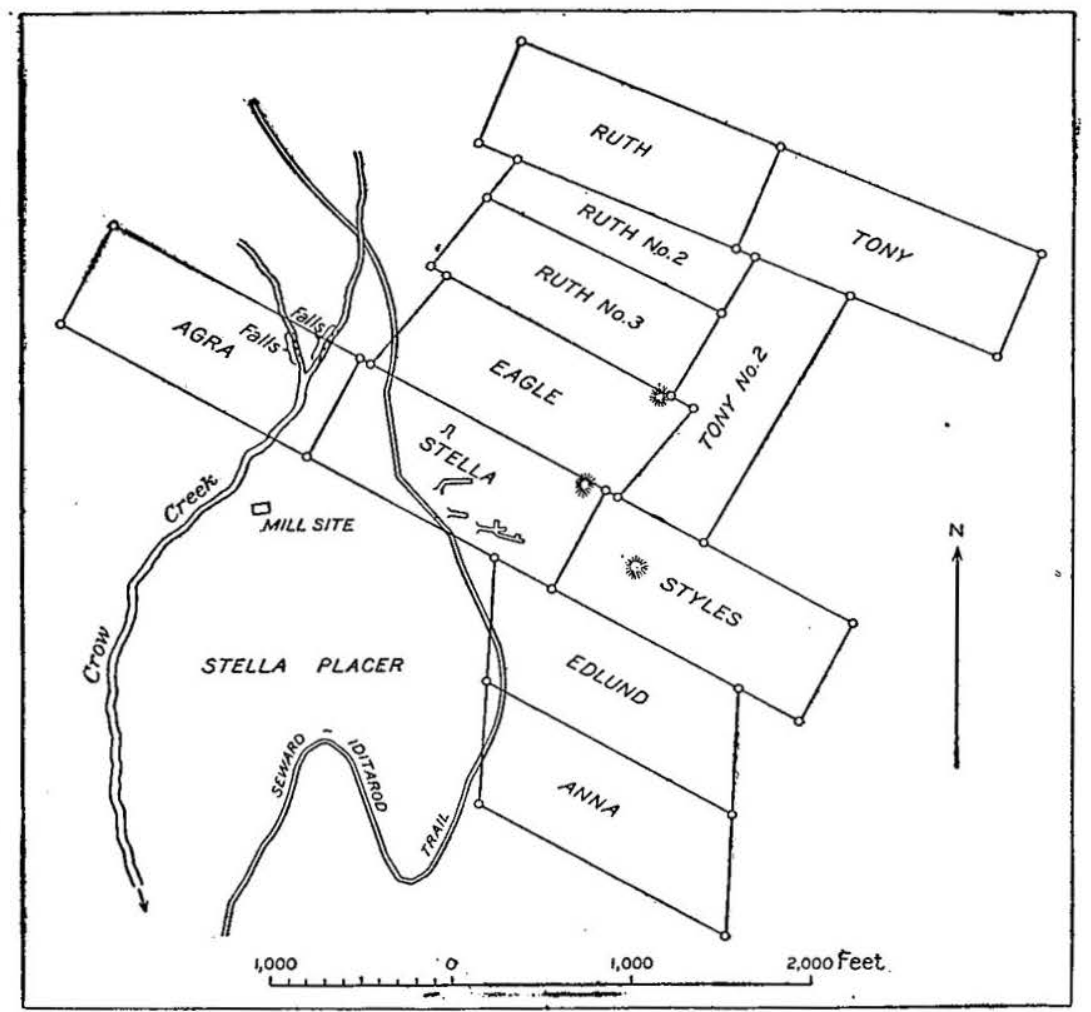

FraUre 38.-Map showing location of mine workings on the Barnes property, Crow Creek. From map by C. H. Ballard (August, 1911).

Crow Creek, 9 miles from Girdwood at the mouth of Glacier Creek. (See Pl. III.) The terminus of the Alaska Northern Railway, at Kern Creek, is 13 miles distant. The part of the Seward-Iditarod trail that lies between Kern Creek and Knik extends up Glacier and Crow creeks and passes the property. (See fig. 38.) From the Nutter-Dawson placer camp, near the lower end of Crow Creek, this trail follows the wagon road to Girdwood. During the summer boat transportation is used between Girdwood and Kern Creek. From May until October 
Seattle freight can be delivered at Girdwood by transfer at Seldovia or Knik Anchorage from the ocean steamers to the smaller boats plying on Cook Inlet and Turnagain Arm.

History and development. - Although the first discovery of goldbearing quartz on this property was made in September, 1909, by Conrad Hores, little work was done to open up the veins prior to August 1, 1910. Since that date, however, underground development has been actively carried on, all of it on the Stella claim. Three veins had already been found at the time this property was visited and a fourth was discovered on the Ruth claim late in the fall of 1911.

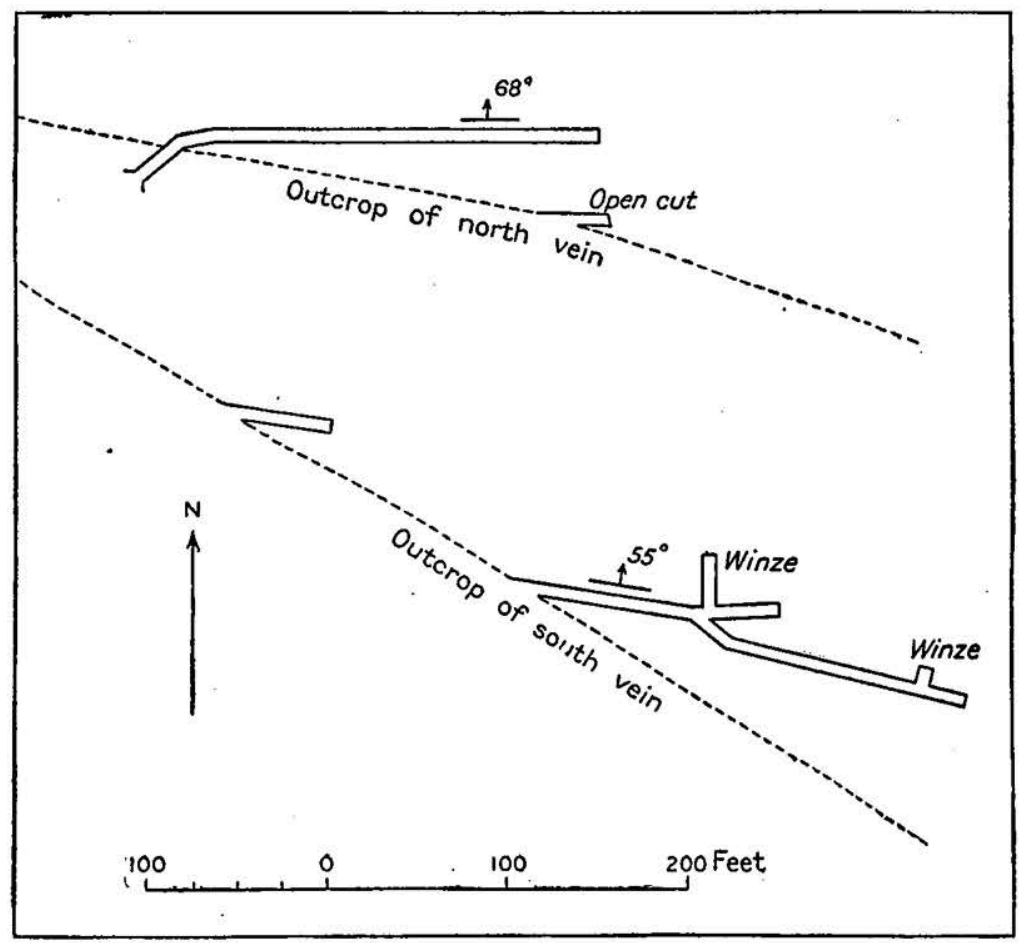

FrGURE 39.-Plan of workings on north and south veins, Stella claim, Barnes property, Crow Creek.

The developments on the Stella claim to January 1, 1912, consisted of 560 feet of adit levels, 56 feet of crosscut tunneling, 14 feet of drifts, and 52 feet of winzes, together with several open cuts on the different veins. These developments include three adit levels, two of which are on the south vein, one 100 feet vertically above the other. The upper of these two tunnels was 267 feet in length; two winzes, 42 and 10 feet in depth, have been sunk on the vein in this tunnel. The lower tunnel, started late in the fall, was only 50 feet long. On the northern vein, which is nearly parallel to this one, an adit level 243 feet in length has been driven. A 56-foot tunnel intersects the third or 
crosscutting vein on the Stella claim. (See figs. 39 and 40.) Very little work has been done on the Ruth lode. Development work on this property ceased early in the spring of 1912 .

Country rock.-The country rock of the ore deposit consists of dark slate, banded argillite, fine-grained graywacke, and conglomerate, folded and later intruded by several bosses of light-colored, finegrained granites, and fine-grained to aphanitic acidic dikes, offshoots from the granitic masses. (See Pl. XXV.) The strike and dip of the sedimentary beds vary, but in general the strike is easterly and the dip northerly. Fossils are not abundant. Imprints of a small Inoceramus of Jurassic or Cretaceous age were found during 1911 on the bedding planes of the banded argillite in bowlders on the moraines of the Crow Creek and Raven Creek glaciers and in place on the west side of the Raven Creek glacier.

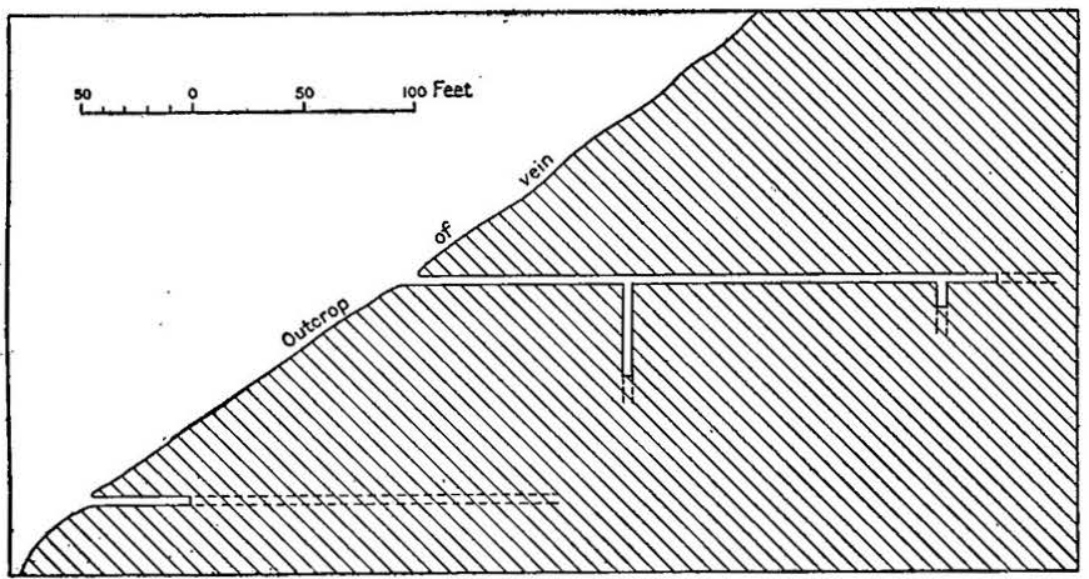

FraUre 40.-Longitudinal section along plane of south vein, Stella claim, Barnes property, Crow Creek looking north (August, 1911).

Inclusions of the banded argillite are found in some of the granite bosses, sharp contacts appearing between the igneous and sedimentary rocks. No development of contact minerals is noticeable. The angularity of the fragments of the talus, the appearance of the weathered surfaces, and the density of the rocks, as well as the reddish, rusty discoloration of the sedimentary rocks of the area, suggest considerable heat action and mineralizing activity. Faults are numerous, the displacement, however, being usually only a few feet.

Ore deposit.-The ore body on the Stella claim consists of two parallel veins, a little over 100 feet apart, striking eastward, and a third vein crossing these with a strike of $\mathrm{S} .18^{\circ} \mathrm{E}$. The southernmost of the two parallel veins strikes S. $83^{\circ} \mathrm{E}$., dips $55^{\circ} \mathrm{N}$., and varies in width from 8 to 46 inches. The northern vein varies in width from 10 inches to 3 feet, strikes N. $87^{\circ}$ E., and dips $68^{\circ}$ N. The outcrops 
of these veins have been traced only a few hundred feet. The third or crosscutting vein ranges in width from 2 to 10 inches and dips $80^{\circ} \mathrm{W}$. The vein on the Ruth claim is reported to strike eastward and to have a width of 6 to 8 inches.

Ore.-The gangue mineral of the gold veins is predominantly quartz, but it includes also some calcite. The vein quartz varies slightly in character. In some places it is coarsely crystalline and the vein contains numerous small vugs. Secondary banding parallel to the walls is noticeable in places (see Pl. XXXI, $B$ ) and sulphides have been deposited along some of the fractures. The quartz is jointed in some parts of the vein.

Arsenopyrite, pyrite, sphalerite, and galena are the principal sulphides. Chalcopyrite also occurs in small quantities. Pyrite and arsenopyrite occur as disseminated crystals in the metasomatically altered wall rock of the veins as well as in association with the other sulphides in the vein quartz. In the open cuts the galena is often altered to cerusite. The crosscut tunnel on the Stella claim passed through a small vein containing molybdenite, pyrrhotite, and chalcopyrite in a gangue of vitreous-looking quartz. Pyrrhotite and chalcopyrite also occur in narrow seams in the banded argillite near the igneous rocks.

The ores are free milling. Tests on some of the more highly mineralized ore are reported to have saved 80 per cent of the gold by amalgamation and 16.4 per cent in the concentrate. The gold is found free in the quartz and occurs also in close association with the sulphides. It is also in places included in the grains of galena and arsenopyrite. Along some of the joint planes where the auriferous iron sulphides have been oxidized, the gold is especially noticeable. Nuggets worth up to 63 cents have been found in the veins.

The ore from the two larger veins on the Stella claim is reported by the owners to average $\$ 35$ to $\$ 40$ a ton for the southern vein and $\$ 12$ a ton for the northern vein. Much higher assays have been obtained, however, in single samples. The limits of the ore shoots are not yet defined. About midway of the upper tunnel on the southern vein a stringer runs out into the hanging wall, and at this point sulphides are said to have been much more abundant and assays much higher than in other parts of the vein. Exceedingly high assays are reported from the crosscut vein on the Stella claim and from the vein on the Ruth claim. The wall rocks of none of the veins are said to carry gold.

TREASURE BOX CLAJM.

The Treasure Box quartz claim, in Crow Creek Pass, was located September 7, 1910, by James Patchell. The ore body consists of a quartz vein a foot wide, striking $\mathrm{N} .11^{\circ} \mathrm{E}$. and dipping $70^{\circ} \mathrm{E}$. The 
vein is traceable for about 50 feet. No development work had been done at the time the lode was seen and no data are available as to the gold content of the vein.

\section{COPPER LODES.}

Copper deposits occur on Kenai Peninsula only on Lynx Creek and on the east side of Resurrection Bay. The deposits on Resurrection Bay have been described in previous reports. ${ }^{1}$

Small pieces of native copper $* * *$ found with the placer gold $* * *$ in the sluice boxes on Lynx Creek *** led finally to the discovery of a ledge carrying copper sulphides, located on the mountain side at the upper end of the valley and well above the stream. Although the presence of the outcrop has been known for some time no steps toward determining its commercial value were taken till some time during 1904, when a company was raised for its exploitation. Much of the season was spent in preparation for opening the deposit and the field operations of the company did not begin until some time in August. *** An adit level, driven to strike the lode below the outcrop, had not cut it in the early part of October, but it was reported that work would be continued during the winter. ${ }^{2}$

Development work was carried on during 1905 and 1906 by the Ready Bullion Copper Co. A survey party that visited the property in September; 1906, obtained the following data: ${ }^{3}$

The country rock at this locality is a part of the graywacke-slate series composing the central and northern mass of the Kenai Mountains. The dominant cleavage at this point is $\mathrm{N} .10^{\circ} \mathrm{E}$., a direction nearly parallel with the ridge in which the copper deposit to be described occurs.

At an elevation approximating 3,000 feet a tunnel has been run 350 feet $\mathrm{S} .80^{\circ} \mathrm{W}$. into the mountain, a direction nearly at right angles to its trend. A drift from a point near the end of the tunnel was driven 150 feet to the south and 90 feet to the north, along a zone characterized by intense slickensiding or shearing in a nearly vertical direction. A short distance beyond this zone a fault dipping $35^{\circ} \mathrm{W}$. was observed. Such a dip would not interfere with the continuation of the ore in depth.

Chalcopyrite ore accompanied by pyrrhotite and pyrite with much quartz has been deposited along the zone of shearing disclosed by the drifts. Irregular masses as thick as 2 feet were observed, but their horizontal linear extension was short, the vein fluctuating between 6 inches and 2 feet in thickness. At the south end of the drift the vein was narrow, and at the north end the face did not disclose ore. It was reported that gulches cutting the mountain north and south of the tunnel showed no signs of copper. Stripping, however, had not been done.

A thousand feet below the entrance of the upper tunnel an adit is being driven to catch the ore in depth. A length of 800 feet has now been completed. A rough estimate shows that with continued vertical dip the shear zone would be reached within a distance of 2,000 feet from the mouth of the adit.

Work is reported to have been discontinued on this property late in October, 1906, about a month after the above description was

1 Grant, U. S., and Higgins, D. F., jr., Notes on geology and mineral prospects in the vicinity of Seward, Kenai Peninsula: U. S. Geol. Survey Bull. 379, pp. 98-107, 1909; Preliminary report on the mineral resources of the southern part of Kenai Peninsula: U. S. Geol. Survey Bull. 442, p. 170, 1910.

${ }^{2}$ Moffit, F. H., Gold flelds of the Turnagain Arm region: U. S. Geol. Survey Bull. 277, p. 48, 1906.

8 Paige, Sidney, and Knopf, Adolph, Reconnaissance in Matanuska and Talkeetna basins, with notes on placers of the adjacent region: U. S. Geol. Survey Bull. 314, pp. 124-125, 1907.

$48891^{\circ}-$ Bull. $587-15-12$ 
obtained, and with the exception of a short tunnel, 20 to 25 feet in length, driven in the canyon of Lynx Creek, on a ledge showing narrow stringers of chalcopyrite, no further development work has been done.

\section{SILVER LODES.}

Assays of the gold quartz ores of this region show a silver content of as much as 25 ounces to the ton, although in but few assays is the value of the silver greater than the value of the gold. Practically all quartz gold carries some silver and it is possible that the galena, an important accessory mineral in these gold quartz ores, is also silver bearing. Nuggets of native silver are found in the gold-bearing gravels of Crow, Bear, and Palmer creeks, but so far as known native silver has not been found in any of the lode deposits. Silver prospects are reported only from Eagle River and Bear Creek.

Mayflower lode, Eagle River.-The Mayflower lode, on the south side of Eagle River, at the foot of the Eagle River glacier, was discovered June 1, 1911, by J. P. Frisbie, William Murray, and M. S. McMelan. The outcrop of the ore body is well exposed on the recently glaciated surface of the massive graywacke country. The ore body consists of mineralized sheeted zones in the massive graywacke. These zones have a north-south strike, dip vertically, and have been traced about 400 feet on the south side of the river. Their continuation on the north bank is reported. They have a rusty appearance, resulting from the decomposition of the iron sulphides. Two of the zones, 50 feet apart, carry a few mineralized quartz stringers of variable width. The easternmost and widest of these sheeted zones has a width of about 50 feet, only part of which is much fractured. The largest quartz stringer observed lies near the eastern edge of this zone. It has a width of 1 to 6 inches, but in places it widens to 10 or 12 inches. The gangue of the veins is quartz with a little calcite. Small calcite veins also occur along joint planes in the graywacke. The metallic minerals of the ore deposit are galena, pyrite, sphalerite, arsenopyrite, chalcopyrite, and a little malachite. The mineral association is similar to that of the gold quartz veins of Kenai Peninsula. Galena is more abundant than in most of the gold quartz prospects, and an assay from this ledge reporting 0.05 ounce gold and 24.80 ounces silver to the ton was probably made on a specimen consisting principally of galena. No free gold was seen in any of the specimens examined.

Coon and Plowman property, Bear Creek.-The Coon and Plowman property is on the north side of Bear Creek, 1,600 feet above sea level. The ore body consists of a well-mineralized sheeted zone in slate and graywacke. This zone strikes N. $65^{\circ} \mathrm{E}$. and dips vertically. The development work consists of an open cut 7 feet wide, with a 15 -foot vertical face, in a small gulch following the shear zone. 
The entire width of the shear zone is probably not exposed by this cut. Quartz and calcite are present only in small amounts. The metallic minerals are galena, pyrite, and arsenopyrite. High silver assays are reported.

Several other prospects reported valuable chiefly for their silver content have been located within the valley of Bear Creek, but little development work has been done on them and they were not visited.

\section{ANTIMONY LODES.}

An antimony prospect is reported ${ }^{1}$ about three-fourths of a mile north of Kenai Lake and about a mile east of Quartz Creek. The country rock is slate cut by a dike 6 to 8 feet wide. Specimens from this prospect show a fine-grained, sheared, acidic dike rock containing stringers and disseminated particles of stibnite (sulphide of antimony). One specimen showed a small quartz vein that included needles of stibnite. Assays of the antimony ore are reported to show neither gold nor silver.

\section{CONCLUSIONS.}

1. Thefolded and faulted rocks of the Sunrisegroup were in Mesozoic time intruded by small quartz diorite stocks - probably subordinate or "cupola" stocks of the immense Pacific coast batholith of similar and related rocks-and by diorite porphyry dikes, offshoots from these stocks.

2. The manner of intrusion of the igneous rocks (see $\mathrm{Pl}$. XXV) and the very fine grain of the dike rocks indicate the intrusion of the magma into relatively cool rocks at a moderate depth below the earth's surface.

3 . The mineralization of the area took place subsequent to the intrusion of the igneous masses, but no gradations from dikes to quartz veins were noted nor was any direct field evidence obtained which would show that the ore bodies were extreme acid differentiation products of the igneous magma.

4. The ore deposits occupy fractures in both igneous and sedimentary rocks. There are two well-defined sets of fissures standing nearly at right angles to each other. The strike of one set trends in general from north to a little west of north; that of most of the other set lies between east and northeast. The fissures dip at angles ranging from $45^{\circ}$ to $90^{\circ}$. Both sets of fissures are in general ore bearing.

5 . The mineralogy of the ores-pyrrhotite, molybdenite, chalcopyrite, pyrite, arsenopyrite, galena, sphalerite, and gold, in a quartzcalcite-albite gangue - is characteristic of veins of deep-seated origin ${ }^{2}$

\footnotetext{
1 Grant, U. S., and Higgins, D. F., jr., Preliminary report on the mineral resources of the southern part of Kenai Peninsula, Alaska: U. S. Geol. Survey Bull. 442, p. 17s, 1910.

${ }^{2}$ Lindgren, Waldemar, The relation of ore deposition to physical conditions: Econ. Geology, vol. 2, pp. 105-127 1907.
} 
deposited by aqueous alkaline ${ }^{1}$ solutions under moderately high temperature and pressure. The metasomatic alteration of the wall rocks of the ore bodies is also that effected by heated aqueous solutions at moderate depths.

6. The temperature of the vein-forming solutions is best indicated by the present mineral composition of the ores. The gangue minerals are the most significant. Experimental research has shown that vein quartzes are formed at temperatures below $575^{\circ} \mathrm{C} . .^{2}$ Albite is classed by Lindgren and Emmons as characteristic of the deposits of the deep-vein zone, ${ }^{3}$ while calcite, as a vein mineral, is usually deposited during the last stages of hot-spring activity following igneous intrusion. Most of the sulphides in these ores are usually considered "persistent minerals" and may have been deposited under a wide range of temperature. Pyrrhotite, however, is usually referred to deposits of the deep-vein zone. ${ }^{4}$

7. The mineralization is probably best ascribed to the activities of residual mineral-bearing solutions-magmatic waters-that were forced out by the solidification of the deeper parts of the igneous magma.

8. The present known vertical range of auriferous veinfilling is about 5,000 feet, extending from about sea level in the prospects near Seward to altitudes of 4,000 to 5,000 feet on the properties of the KenaiAlaska Gold Co. and the Seward Bonanza Gold Mines Co. The deepseated origin of the ore deposits and their probable deposition from ascending thermal waters, the character of the mineralization, and the extensive vertical range of auriferous vein filling above sea level all suggest the continuity of the mineralization to depths below the limits of profitable mining, so that gold quartz veins are probably distributed through the deep-lying rocks in much the same manner and form as in the rocks that lie above sea level. The persistence of the general mineralization with depth, however, is no absolute criterion as to the persistence of mineralization in individual veins.

9. The numerous lode and placer deposits that are scattered through the mountains of the peninsula show that the mineralization is widespread, and that it is coextensive, apparently, with the area underlain by the Mesozoic and earlier rocks of the region.

10. The powerful glacial erosion of comparatively recent time has removed any secondarily enriched zones that may once have existed and has exposed the original primary sulphide ore bodies.

1 Allen, E. T., and Crenshaw, J. L., Sulphides of zinc, cadmium, and mercury; their crystalline forms and genetic conditions: $\Lambda \mathrm{m}$. Jour. Sci., 4th ser., vol. 34, pp. 341-396, 1912.

2 Wright, F. E., and Larsen, E. S., Quartz as a geologic thermometer: Am. Jour. Sci., 4th ser., vol. 27, pp. $443-447,1909$.

${ }^{3}$ Lindgren, Waldemar, The relation of ore deposition to physical conditions: Econ. Geology, vol. 2, pp. 105-127, 1907. Emmons, W. H., A genetic classification of minerals: Econ. Geology, vol. 3, pp. 611627,1908 .

4 Emmons, W. H., op. cit. Farrell, J. H., Practical field geology, p. 132, 1912. 
No marked change with increase of depth is to be expected either in the mineralogic character of the ores or in the value of the lodes as a whole. Postglacial oxidation has altered a small part of the sulphides exposed in the outcrops of some of the ore bodies, and in places has extended to depths of 200 feet or over, the depth depending on the extent of the passages open to the circulating surface waters. This oxidation has formed no secondarily enriched ore bodies, however, because of its ineompleteness and of the short time during which it has been in progress, as well as of the small percentage of sulphides in the ores and the slow rate of chemical action in high latitudes.

In conclusion it may be stated that the ore deposits of this area correspond in both age and association with most of the auriferous lodes of Alaska. ${ }^{1}$ They form, moreover, part of a Mesozoic metallogenetic province, of which gold is primarily, and copper secondarily, the characteristic metal, deposited in a petrographic province characterized by the intermediate quartz monzonite or granodiorite magmas of the great batholith of the Pacific coast, the intrusion of which in late Mesozoic times was immediately followed by intense mineralization along its borders.

\section{GOLD PLACERS.}

\section{GENERAI FEATURES.}

The formation of the gold placers is in large part an event of the Quaternary history of the region. Preglacial and glacial erosion set free the gold in the exposed parts of auriferous quartz lodes in the rocks of the Sunrise group. During the deposition of the Quaternary sediments this gold was widely distributed through them by the action of ice and water. Colors of placer gold have been found in the unconsolidated material on most if not all of the streams of central and northern Kenai Peninsula, but in few places are the deposits sufficiently rich to be of economic value under present conditions. The gold in the valleys of the streams that have cut into the gold-bearing glacial or fluvioglacial deposits and reworked them has been in many places concentrated in the present stream gravels in paying quantities. Postglncial stream erosion of auriferous bedrock may have furnished a part of the gold in the present stream gravels, from which most of the placer gold produced in Kenai Peninsula has been obtrined.

IIISTORY.

Gold was first discovered in Alaska in 1848, in the gravels of Kenai River, by P. P. Doroshin, a Russian mining engineer, who was

1 Brooks, A. H., Geologic features of Alaskan metalliferous lodes: U. S. Geol. Survey Bull. 480, pp. 43-93, 1911. 
then making an examination of the mineral resources of the district for the Russian-American Co. In 1850 and 1851 Doroshin, with a working force of 14 men, prospected the gravels of two streams entering Kenai River between Kenai and Skilak lakes and those of a third stream tributary to the latter lake. Gold was found nearly everywhere in the gravels examined but not in commercial quantities.

Nothing whatever is known of prospecting that may have been carried on between 1851 and 1884. Gold is reported to have been discovered in 1884 on Cooper Creek by Joseph Cooper, of Kachemak Bay, but no locations were made. In the Turnagain Arm region-

It is said that gold was found near Hope about the year 1888 by a man named King, and that the first claim was soon afterwards located on Resurrection Creek, 2 miles above Hope, by Charles Miller. He did not work the ground himself, but leased it to others. ${ }^{1}$

Robert Michaelsen and Neil McCush discovered gold on Sixmile Creek, opposite' Sunrise, in 1888. The Anchor Point placers were discovered by Michaelsen in March, 1889, while he was returning from a moose-hunting trip.

Gold was found on Bear Creek in 1894 by George Beady [Beede?], F. R. Walcott, and [Patrick] Riley. This stream is said to have been worked by the Russians, but if this is true such operations must have taken place later than the time of Doroshin, for he expressly states that the streams prospected by him were tributary to what is now known as Kenai River.

Gold was found on Palmer Creek by George Palmer in 1894. These discoveries naturally led to prospecting on neighboring streams, and in the following year (1895) the first stakes were driven on Mills Creek by S. J. Mills, whose name it bears. Mr. Mills at the same time staked ground at the forks of Sixmile Creek (also named by him). * * * The ground on Mills Creek was regarded with so little favcr by Mills's partner, for whom it was staked, was so far from supplies, and so difficult to reach, that no attempt was made to work it, nor was the claim recorded. Some time during the following month (July, 1895) coarse gold was found on Mills Creek by Robert Michaelsen and John Renner, old Yukon miners, who had been prospecting for quartz ledges in the mountains east of Canyon Creek without success and were returning to Hope. These two men, together with three others-Albert Brown, W. W. Price, and H. C. Pierce-staked ground on Mills Creek July 29, and formed a company known as the Polly Mining Co. Their claims included all the stream between the mouth and Juneau Creek and *** proved to be among the most valuable properties in the Turnagain field. In July, 1895 , an assembly of miners from streams in the Sixmile drainage basin formed the Sunrise mining district and elected a local recorder. This recording precinct was distinct from the older Turnagain Arm district, which included the Resurrection Creek drainage system and later the creeks north of the arm. The two precincts were afterwards united, and recently, much against the desires and convenience of those most interested, the books of the recorder were removed to Seward, where they now are. ${ }^{2}$

The first placer location on Cooper Creek was made in the fall of 1895 by C. H. Sickles, who worked for four seasons with sluice boxes

${ }^{1}$ Moffit, F. H., Gold flelds of the Turnagain Arm region: U. S. Geol. Survey Bull. 277, p. 8, 1906.

2 Jdem, pp. 8-9. 
with indifferent success on the ground later hydraulicked by the Kenai Mining \& Milling Co. Stetson Creek, a tributary of Cooper Creek, was discovered in 1895 by James Stetson and worked for two seasons quite successfully, but was finally abandoned, and has since been relocated by various prospectors. ${ }^{1}$

Other discoveries of gold were made in the Sunrise district during the same year (1895), notably that on Lynx Creek, by Fred Smith and W. P. Powers. North of the arm the first gold was found (in 1895) by F. J. Perry and Christopher Spillum, on California Creek.

The discoveries on Mills and Canyon creeks brought about during the following season (1896) the first considerable rush of prospectors to this field. Several thousand men, some state the number as high as 3,000 , are said to have landed at Tyonek en route for Turnagain Arm and Sushitna River, while a considerable number crossed by way of Portage Glacier from Prince William Sound. This was the banner year of Canyon Creek, 327 men being engaged in mining its gravels during the summer. Crow Creek, tributary to Glacier Creek, was also staked about this time, but did not produce any gold till two years later. A second rush into the Turnagain Arm field took place in 1898. This was partly an overflow from the Yukon stampede and was not entirely due to the successes on Resurrection and Sixmile creeks. ${ }^{2}$

Since 1898 placer mining has been in progress on many of the creeks of the peninsula, but chiefly on those tributary to Turnagain Arm. Practically all the placers workable at a profit by pick and shovel methods have been worked out. The lower grade auriferous gravels were exploited by hydraulic methods early in the development of the gold field, first in the Turnagain Arm region and later on the creeks in the Kenai River drainage basin. Hydraulic plants are now operating with greater or less success on creek and bench gravels, and a small dredge has been erected on Kenai River. The list of producing creeks is small and is much the same as when the region was visited by Moffit in 1904 and by Paige and Knopf in 1906 . In 1911 it included only Resurrection, Crow, Cooper, Quartz, Gulch, Mills, Canyon, Sixmile, Silvertip, Bear, and Winner creeks, and Kenai River, and many of these creeks contributed but little to the production of the district.

\section{PRODUCTION.}

No accurate estimate of the total placer-gold production of this region is possible. Most of the goldl was obtained prior to 1904, and no record is available of the annual production, except for 1895 to 1899. Moffit ${ }^{3}$ stated in 1906 that-

Since the beginning of real mining in 1895 the Turnagain Arm field has probably yielded over a million dollars, but it has been found impossible with the data at hand to give a more satisfactory estimate.

The total production of place: gold to date (1913) from Kenai Peninsula and the creeks tributary to Turnagain Arm from the north has probably been less than one and a half million dollars. 
The annual production for the years for which estimates are obtainable is shown in the following table:

Annual production of placer gold from Kenai Peninsula and the creeks tributary to Turnagain Arm from the north.

[Quantities computed from total values reported; no data available for 1900 to 1902 or 1904 to 1910.$]$

\begin{tabular}{|c|c|c|c|c|c|c|}
\hline \multirow[b]{2}{*}{ Year. } & \multicolumn{2}{|c|}{ Total. } & \multicolumn{2}{|c|}{ Gold. } & \multicolumn{2}{|c|}{ Silver. } \\
\hline & $\begin{array}{l}\text { Quantity } \\
\text { (ounces). }\end{array}$ & Value. & $\begin{array}{l}\text { Quantity } \\
\text { (fine } \\
\text { ounces). }\end{array}$ & Value. & $\begin{array}{l}\text { Quantity } \\
\text { (fine } \\
\text { ounces). }\end{array}$ & Value. \\
\hline 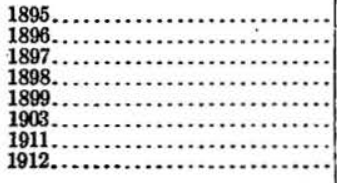 & $\begin{array}{r}2,938 \\
7,046 \\
10,288 \\
8,818 \\
8,818 \\
2,647 \\
1,538 \\
1,471\end{array}$ & $\begin{array}{r}a \quad 850,000 \\
a 120,000 \\
b 175,000 \\
b 150,000 \\
b 150,000 \\
c 45,000 \\
d 26,150 \\
25,000\end{array}$ & $\begin{array}{l}2,403 \\
5,764 \\
8,416 \\
7,213 \\
7,213 \\
2,165 \\
1,258 \\
1,203\end{array}$ & $\begin{array}{r}\$ 49,670 \\
119,150 \\
173,930 \\
149,090 \\
149,090 \\
44,750 \\
26,000 \\
24,865\end{array}$ & $\begin{array}{r}517 \\
1,240 \\
1,811 \\
1,552 \\
1,552 \\
466 \\
271 \\
259\end{array}$ & $\begin{array}{r}8330 \\
850 \\
1,070 \\
910 \\
910 \\
250 \\
150 \\
135\end{array}$ \\
\hline
\end{tabular}

a Becker, G. F., Reconnaissance of the gold flelds of southern Alaska, with some notes on general geology: U. S. Geol. Survey Eighteenth Ann. Rept., pt. 3, p. 12, 1898.

$b$ Brooks, A. H., The mining industry in 1910: U.' S. Geol. Survey Bull. 480, p. 26, 1911.

c Moffit, F. H., unpublished estimate.

d Johnson, B. t., Gold deposits of the Seward-Sunrise region, Kenai Peninsula: U. S. Geol. Survey Bull. 520 , p. 35, 1912 .

These data are shown graphically on the curve forming figure 41, which illustrates in striking manner the high production during the

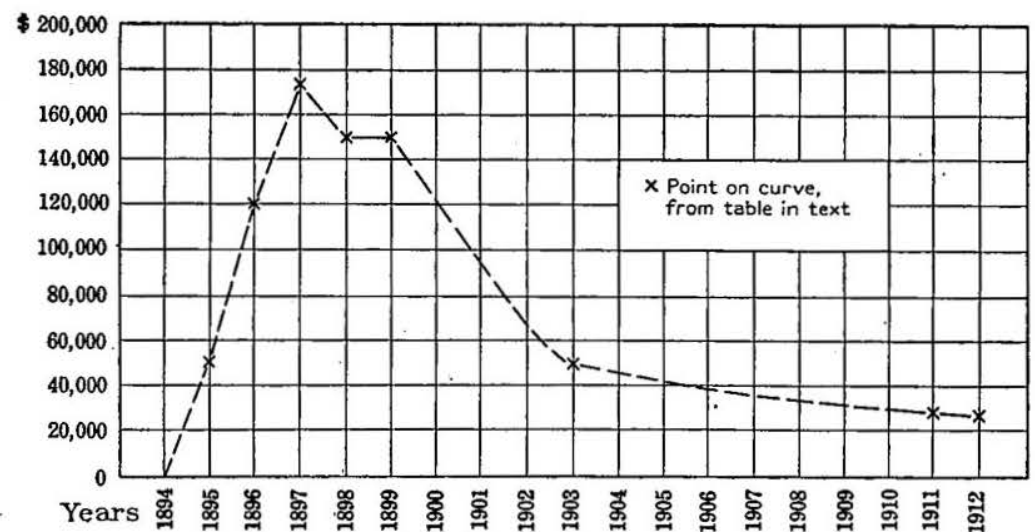

FIGURE 41.-Curve showing annual placer-gold production from Kenai Peninsula and the creeks tributary to Turnagain Arm from the north.

bonanza stage of a placer camp and the lower production later, when the rich placers are worked out and the lower-grade gravels are being treated. The maximum annual production was probably reached about 1897 .

FINENESS OF THE PLACER GOLD.

Numerous assays of the placer gold of the Kenai mining district have been made by the United States assay office at Seattle, Wash., 
and by Mr. H. E. Ellsworth, Seward, Alaska. The value of the placer gold of the region ranges from $\$ 15.86$ to $\$ 17.87$ per ounce after melting; the value before melting is slightly less. Bear and Crow creeks furnish the lower grades, the assay value per ounce of dust from these two creeks (after melting) being from $\$ 15.86$ to $\$ 15.90$. Bear Creek gold is usually taken in trade locally at $\$ 15$ per ounce. Mills and Cooper creeks and Kenai River carry the highest grade placer gold of the region. In the accompanying table a few typical assays of the placer gold are given.

Fineness of placer gold from creeks of Kenai Peninsula.

\begin{tabular}{|c|c|c|c|c|c|}
\hline \multirow{2}{*}{ Locality. } & \multicolumn{2}{|c|}{ Fineness. } & \multirow{2}{*}{$\begin{array}{c}\text { Base-metal } \\
\text { content, } \\
\text { deter- } \\
\text { mined by } \\
\text { difference. }\end{array}$} & \multirow{2}{*}{$\begin{array}{c}\text { Value per } \\
\text { ounce after } \\
\text { melting; } \\
\text { silver at } \\
\$ 0.54 \text { per } \\
\text { ounce. }\end{array}$} & \multirow[b]{2}{*}{ Assays made by- } \\
\hline & Gold. & Silver. & & & \\
\hline 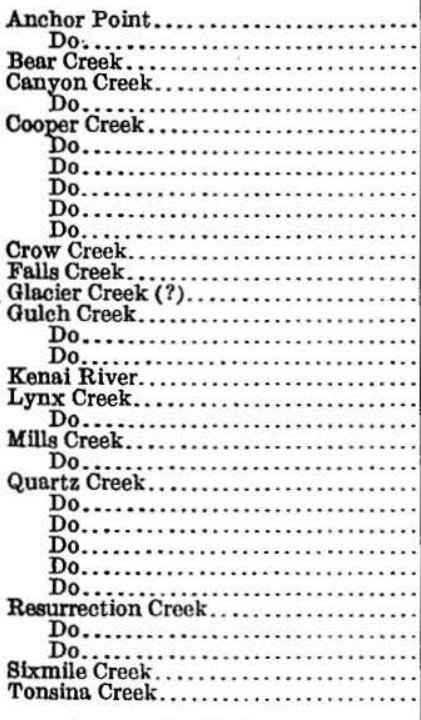 & 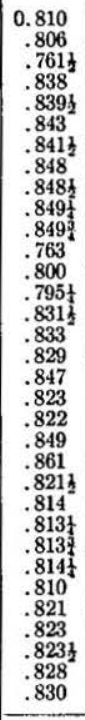 & $\begin{array}{l}a 0.184 \\
a .188 \\
.223 \\
.156 \frac{1}{2} \\
.155 \\
a .151 \\
.149 \frac{1}{2} \\
.148 \\
.147 \\
.146 \\
.145 \\
a .231 \\
a .194 \\
.198 \frac{1}{2} \\
.164 \\
a .161 \\
.165 \\
a .147 \\
a .171 \\
a .172 \\
.145 \\
.136 \\
.181 \\
.181 \\
.179 \\
.180 \\
.180 \\
a .184 \\
a .173 \\
.171 \\
.172 \frac{1}{2} \\
a .166 \\
a .164 \\
\end{array}$ & 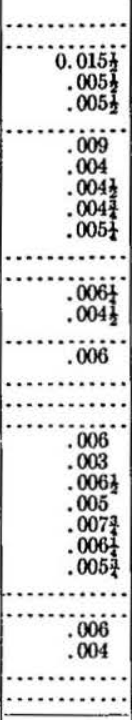 & $\begin{array}{l}\$ 16.84 \\
16.76 \\
15.86 \\
17.41 \\
17.44 \\
17.51 \\
17.48 \\
17.61 \\
17.62 \\
17.63 \\
17.64 \\
15.90 \\
16.64 \\
16.55 \\
17.28 \\
17.30 \\
17.23 \\
17.59 \\
17.10 \\
17.08 \\
17.63 \\
17.87 \\
16.89 \\
16.92 \\
16.91 \\
16.92 \\
16.93 \\
16.84 \\
17.06 \\
17.10 \\
17.12 \\
17.21 \\
17.25\end{array}$ & $\begin{array}{l}\text { H. E. Ellsworth. } \\
\text { Do. } \\
\text { U. S. assay office. } \\
\text { Do. } \\
\text { Do. } \\
\text { H. E. Ellsworth. } \\
\text { U. S. assay office. } \\
\text { Do. } \\
\text { Do. } \\
\text { Do. } \\
\text { Do. } \\
\text { H. E. Ellsworth. } \\
\text { Do. } \\
\text { U. S. assay office. } \\
\text { Do. } \\
\text { H. E. Ellsworth. } \\
\text { U. S. assay office. } \\
\text { H. E. Ellsworth. } \\
\text { Do. } \\
\text { Do. } \\
\text { U. S. assay office. } \\
\text { Do. } \\
\text { Do. } \\
\text { Do. } \\
\text { Do. } \\
\text { Do. } \\
\text { Do. } \\
\text { H. E. Ellsworth. } \\
\text { U. S. assay office. } \\
\text { Do. } \\
\text { H. E. Ellsworth. } \\
\text { Do. }\end{array}$ \\
\hline Average for district............... & .818 & .176 & .006 & 17.00 & \\
\hline
\end{tabular}

a Calculated silver fineness on average bast-metal content of 0.006 .

\section{SOURCE OF THE PIACER GOID.}

Most if not all of the placer gold of this region is undoubtedly of local origin and was probably derived from the erosion of gold veins in the slates and graywackes of the Kenai Mountains. A small part may have been brought in with material transported by glaciers coming from the north, but by far the greater part was derived from veins within the area drained by the stream in whose valley the auriferous gravels are found. Numerous gold quartz lodes are scattered through the mountainous part of the peninsula. The disin- 
tegration and decomposition of these mineralized veins set free the gold they contained, which was probably then concentrated in the gravels of preglacial streams. The present distribution and arrangement of the auriferous gravels result principally from the glacial and fluvioglacial activity of the recent past and from recent stream erosion. No preglacial gravels are known to occur in place in the part of Kenai Peninsula here under consideration. Preglacial stream deposits undoubtedly existed, but probably all of them have been removed by glacial erosion and reworked by glacial streams. As the ice retreated the shifting overloaded glacial streams laid down valley trains in which the gold was necessarily widely disseminated. Later, with a decrease in load after the disappearance of the glaciers, the streams began to cut down through the valley trains, and concentrated in the creek gravels the gold they contained. Most of the present creek placers are the product of this concentration, although some of the gold may possibly have been furnished by postglacial erosion of the lodes.

\section{PLACER-MINING METHODS.}

The future of this region as a placer-gold producer depends largely on the introduction of economical methods of handling large bodies of low-grade gravels such as are found in the bench deposits. The channel gravels yielded most of the gold in the earlier years of placer mining in the peninsula, but the richer spots were soon worked out, and the remaining creek placers have repeatedly proved unprofitable when worked by ordinary pick and shovel methods. (See Pl. XXXIV, A.) They are, moreover, in most places shallow and of small areal extent. Where most extensive, as on Cooper and Resurrection creeks, values of only 30 to 50 cents a cubic yard are reported, and methods other than shoveling into sluice boxes must be employed to obtain a profit. As the topographic conditions and abundant water supply of the region are particularly favorable to hydraulicking; most of the placer mining in recent years has been done by that method, the material worked in most places being the bench deposits. (See Pls. XXVI, $B$; XXXIV, $B$; XXXV, $B$; XXXVI, $A$; XXXVII, $B$.)

The handling of large bodies of low-grade gold-bearing gravels by methods other than those of ordinary hydraulic mining has been attempted at different times in Kenai Peninsula but thus far has not been successful. Many of the failures are to be ascribed to inadequate prospecting of the placer ground before the erection of a plant for the recovery of the gold. The failure of a Risdon 5-foot openconnected dredge on Resurrection Creek in 1905 is reported to have been due partly, at least, to numerous large bowlders in the creek gravels. A small dredge (PI. XXXV, $A$ ), differing markedly from the usual type, was erected on upper Kenai River in 1911, but appears 


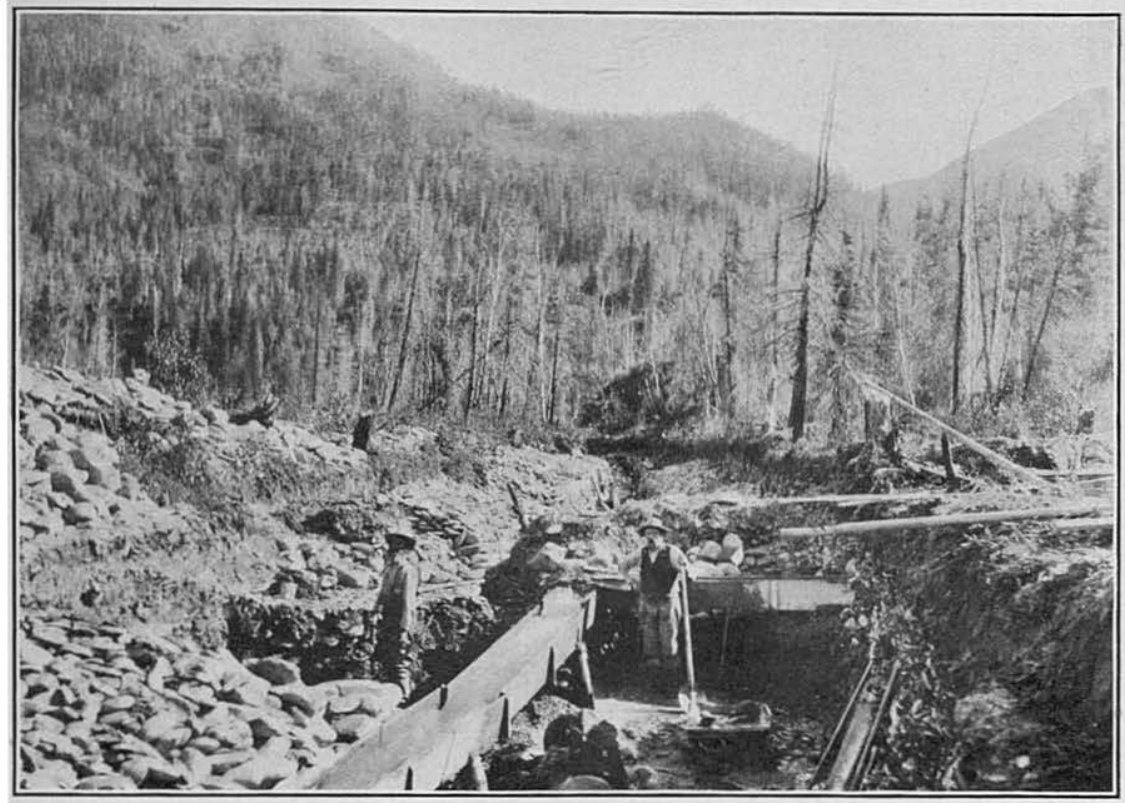

A. PICK AND SHOVEL WORK AT "THE FORKS" OF EAST FORK AND CANYON CREEK.

Photograph taken in 1904.

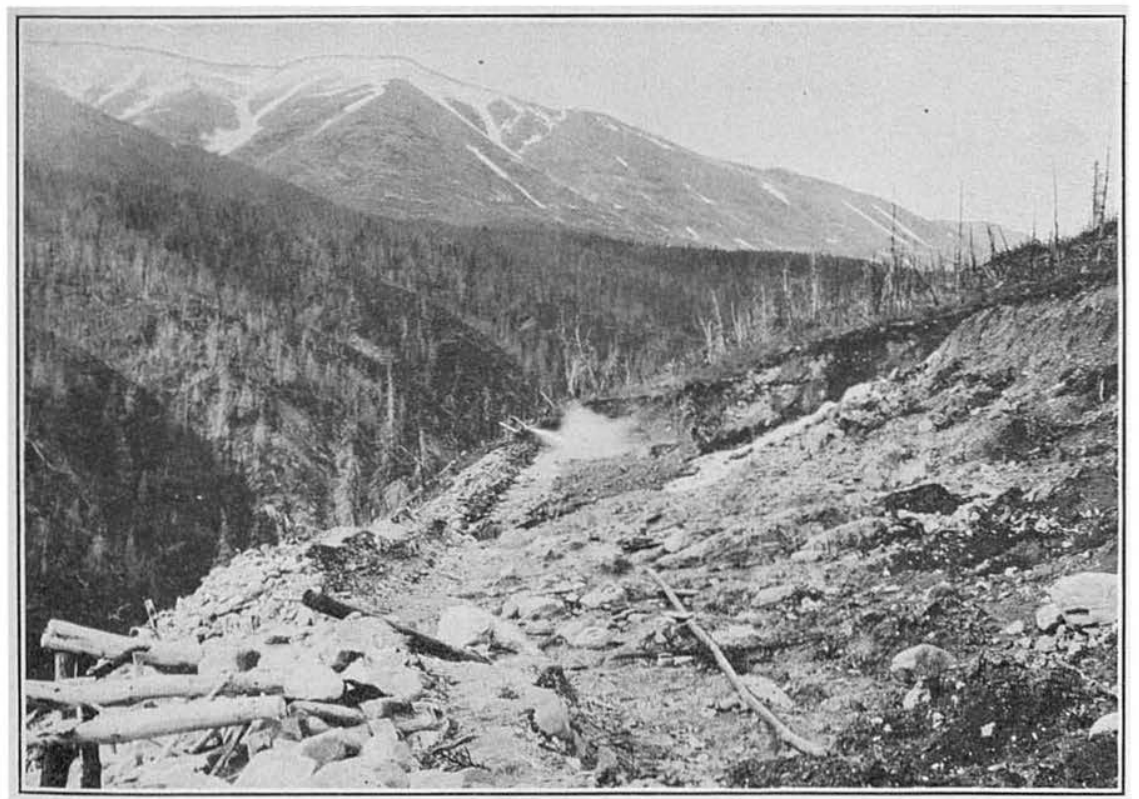

b. GRAVELS ON ROCK BENCH, CANYON CREEK.

Photograph taken in 1904. 


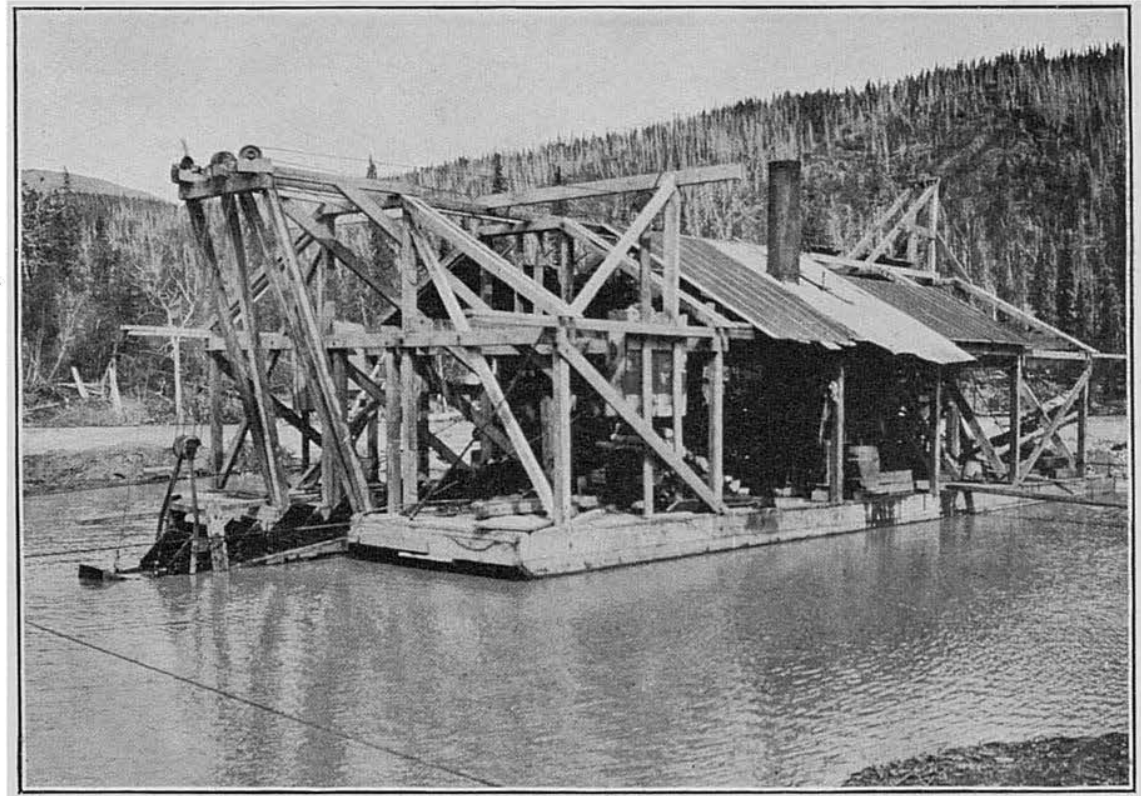

A. DREDGE ON KENAI RIVER BELOW COOPER CREEK.

Photograph by Milnor Roberts.

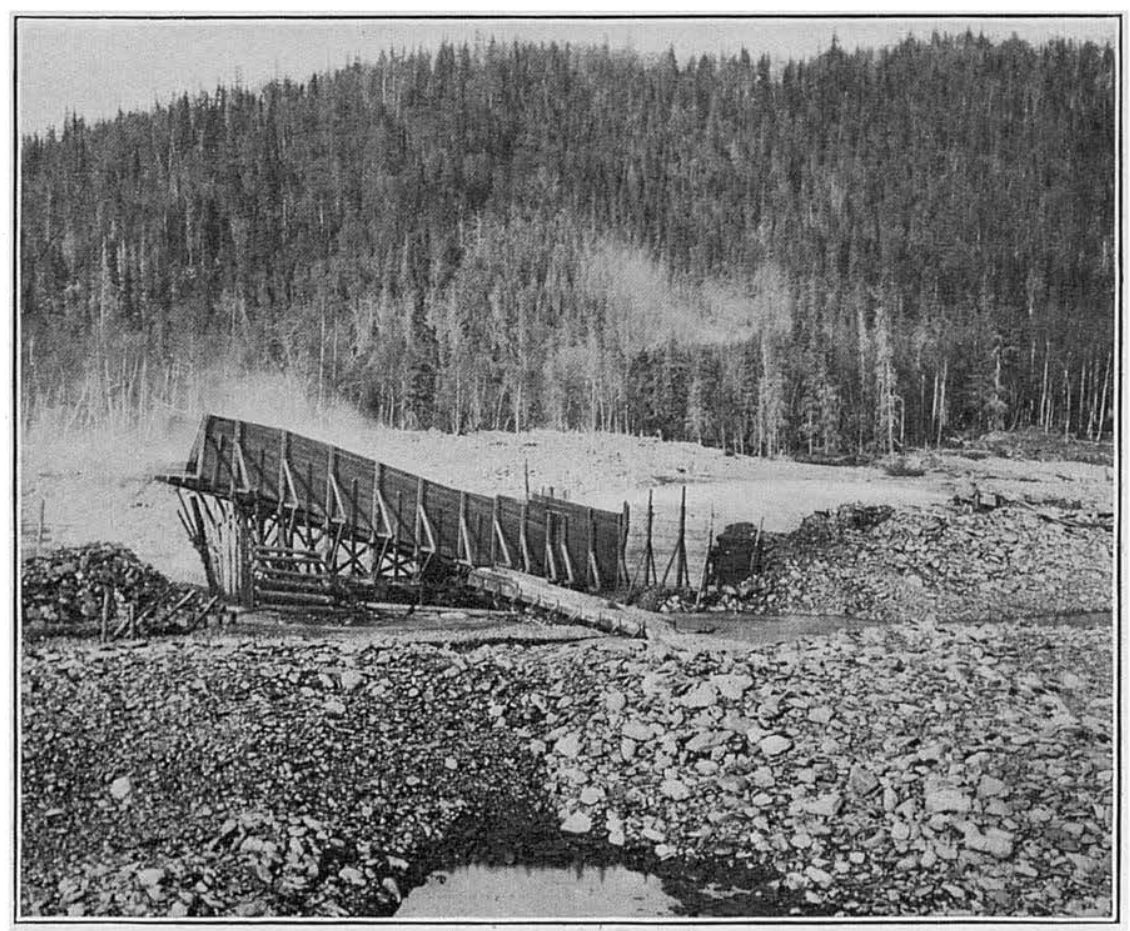

B. RUBLE ELEVATOR, COOPER CREEK.

Photograph taken in 1911 . 
so far to have failed to yield satisfactory results. Attempts to work the gold-bearing gravels on Resurrection and Sixmile creeks by hydraulic elevators were not successful. The creek gravels on Cooper Creek were hydraulicked over a Ruble elevator for several years (see Pls. XXXV, $B$; XXXVII, $B$ ), but in 1912 this method was discarded in favor of piping directly into a string of sluice boxes, a process in use with much success on the creek placers of Resurrection Creek.

\section{CLASSIFICATION.}

The placer deposits of this region may be grouped as (1) creek placers, (2) bench placers, (3) river-bar placers, (4) lake-bed placers, and (5) beach placers. The data regarding the principal characteristics of each of these classes, with examples of each and the methods at present used in working them, are tabulated here for convenience in reference.

Classification of gold placers of Kenai Peninsula and vicinity.

\begin{tabular}{|c|c|c|c|}
\hline Class. & Nature and location. & Examples. & $\begin{array}{c}\text { Method of working in } \\
1912 .\end{array}$ \\
\hline $\begin{array}{l}\text { Creek........... } \\
\text { Bench........... } \\
\text { River bar....... } \\
\text { Lake bed........ }\end{array}$ & $\begin{array}{l}\text { In, adjacent to, and at the level } \\
\text { of small streams. } \\
\text { Fluvioglacial or glacial deposits } \\
\text { in valleys but considerably } \\
\text { abovelevel of present streams; } \\
\text { usually terraced. } \\
\text { Gravel flats, in or adjacent to } \\
\text { beds of large streams. } \\
\text { Accumulations in the beds of } \\
\text { present or former lakes. } \\
\left\{\begin{array}{l}\text { Adjacent to the sea, or to large } \\
\text { bays to which waves have ac- } \\
\text { cess. }\end{array}\right.\end{array}$ & $\begin{array}{l}\text { Resurrection and Cooper } \\
\text { creeks. } \\
\text { Lynx, Crow, Canyon, Mills, } \\
\text { Sixmile, Gulch, Resurrec- } \\
\text { tion, Quartz, and Cooper } \\
\text { creeks. } \\
\text { Kenai River............... } \\
\text { Crow Creek and Bench de- } \\
\text { posits on u p per Kenai } \\
\text { River. } \\
\text { Anchor Point, Cook Inlet.... } \\
\text { Snipers Point, ·Turnagain } \\
\text { Arm. }\end{array}$ & $\begin{array}{l}\text { Hydraulicking. } \\
\text { Do. } \\
\text { Dredging. } \\
\text { Not worked. } \\
\text { R o c kers and sluice } \\
\text { boxes. } \\
\text { Not worked. }\end{array}$ \\
\hline
\end{tabular}

\section{DETAILED DESCRIPTIONS OF CREEKS.}

GENERAL FEATURES.

The general characteristics of the productive creeks have been described in considerable detail by Moffit, ${ }^{1}$ whose descriptions of several of the creeks will be quoted. Most of the data regarding placer-mining conditions previous to 1905 have also been obtained from his report:

A brief outline of the placer gold field is here presented to bring out some facts not directly evident from the map (Pl. II), while the more detailed description of individual streams will follow. For convenience the four principal drainage basins where gold-bearing gravels are exploited will be referred to by the names of the trunk streams-Resurrection, Sixmile, and Glacier creeks and Kenai River. The first three are the important streams in what may be called the Turnagain Arm field, all of whose producing creeks are inclucled in a rectangular area 25 miles from north to south and 20 miles wide.

${ }^{1}$ Molitit, F. I1., Gold flelds of the Turnagain Arm region: U. S. Geol. Survey Buil. 277, pp. $7-52,1306$. 
Resurrection Creek is the westernmost productive stream flowing into the south side of Turnagain Arm. Together with Bear Creek (which is properly a part of the same system although the two do not unite) it drains an area 21 miles long and 8 to 9 miles wide, comprising about 175 square miles. The side streams, with two or three exceptions, are short, the upper portions of the narrow valleys being above timber line. The mountains, though steep and at times covered with loose blocks and smaller débris, are much less rugged than any others seen during the season.

Sixmile Creek, which enters the arm 8 miles up from the mouth of Resurrection Creek, is formed by the union of two large branches, Canyon Creek and East Fork, and drains an area of approximately 250 square miles. The valleys of the two branches, as well as that of the trunk stream, are broad and are floored with heavy deposits of gravel. From the forks of the stream to the town of Sunrise, at its mouth, the distance is 10 miles. Mills Creek, the most important tributary, joins Canyon Creek 8 miles south of "the forks." A majority of the small streams which compose this drainage system, like those of the Resurrection Creek system, occupy steep narrow valleys, but a decided difference between the two regions is found in the character of the topography, for the smooth rounded contours of the mountains west of Resurrection Creek here give place to the rugged outlines that characterize the whole eastern portion of the peninsula.

Glacier Creek flows into the north side of Turnagain Arm 9 miles east of Sunrise. It is about 8 miles long and flows in a broad flat-bottomed valley, whose floor is covered with a heavy growth of timber. The whole drainage area comprises about 45 square miles and is a region of very rough topography. Crow Creek is the most important tributary.

Other streams flowing into the arm have been prospected with little success. Their valleys are generally narrow and steep, and it is noticeable that the great deposits of gravel, such as are seen in Resurrection and Sixmile valleys, were either never extensively developed here or have since been partly removed.

Only that part of the Kenai River drainage basin which lies above Russian River falls within the area considered in this report. The headwaters comprise Snow River and Trail Creek, glacier-fed streams rising in the mountains bordering the west side of Prince William Sound. These streams flow into Kenai Lake. Russian River joins the main stream about 6 miles below the lower end of Kenai Lake.

\section{GLACIER CREEK VALLEY.}

Glacier Creek has never been a gold producer and is therefore important at the present time only because of its tributaries. It takes its name from several small glaciers at its head and flows on the broad, gravel-covered flooir of a glaciated valley. Three tributaries, Crow, California, and Winner creeks, have yielded gold.

CROW CREEK.

Crow Creek is the largest tributary of Glacier Creek. It rises in the high mountains of the divide between this part of the Turnagain Arm drainage and Eagle River, a tributary of Knik Arm. It is 4 to 5 miles in length, heading against Raven Creek of the Eagle River drainage in a broad pass (Crow Creek Pass) about 3,550 (aneroid) feet above sea level and entering Glacier Creek from the northwest 


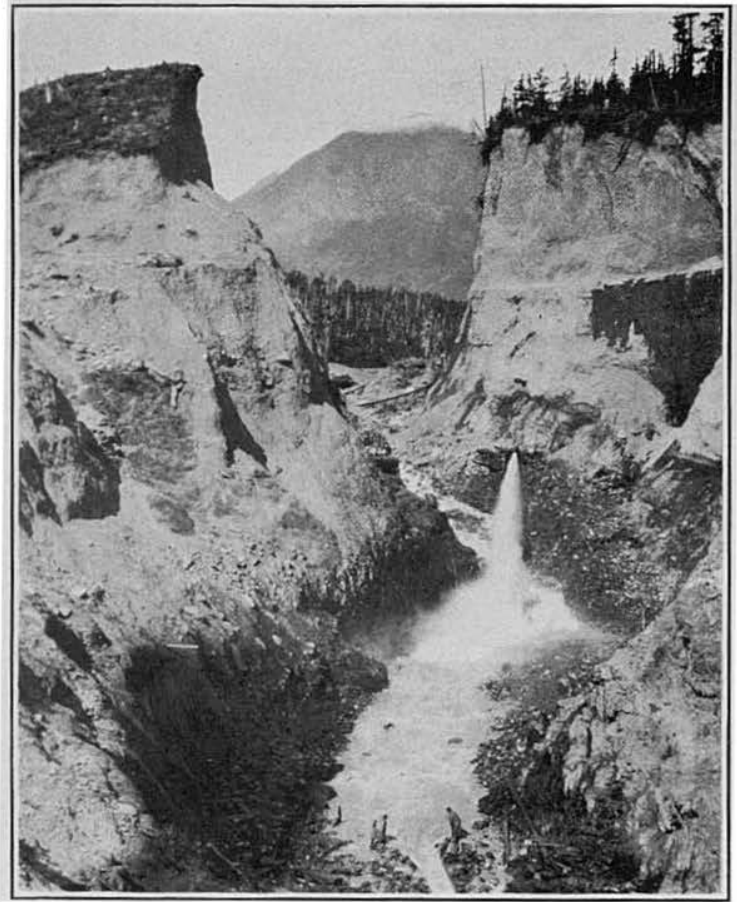

A. DEEP CUT FOLLOWING OLD CHANNEL ON NUTTERDAWSON PROPERTY, CROW CREEK.

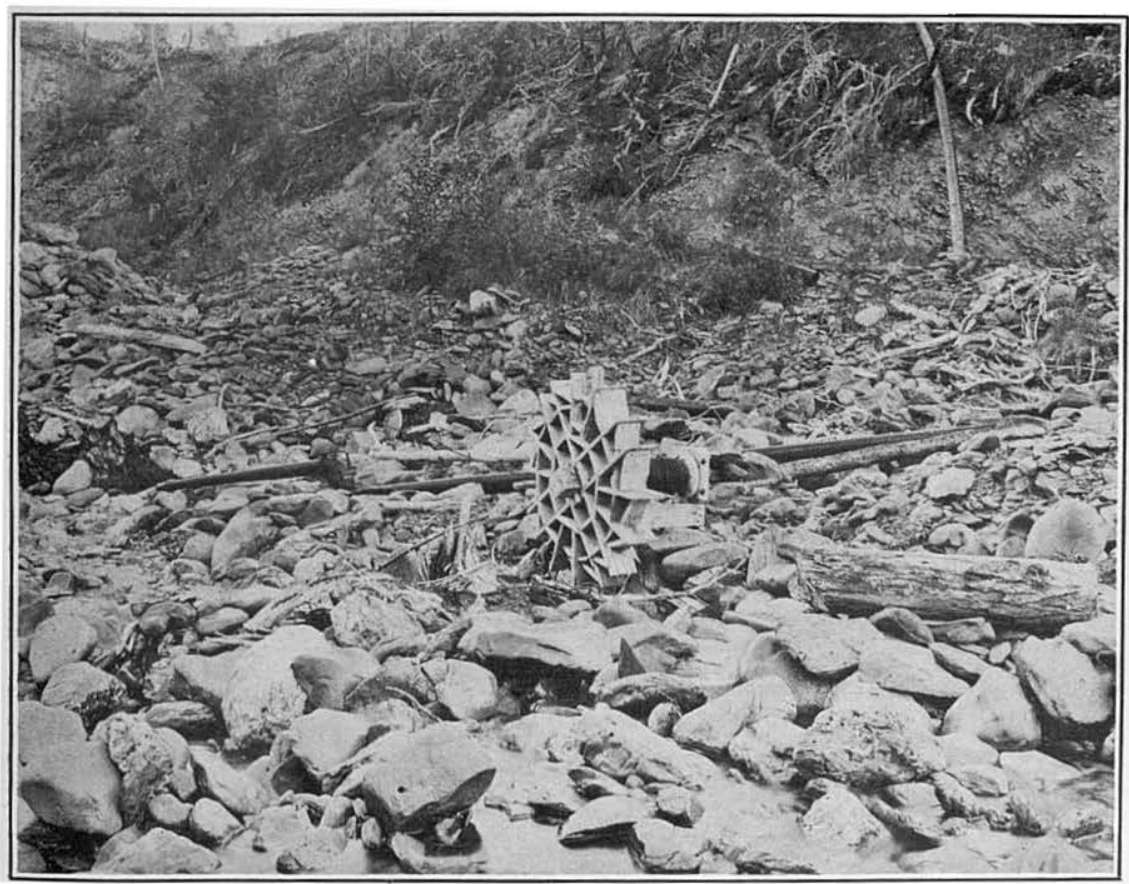

B. WHEEL RUN BY HYDRAULIC GIANT FOR HOISTING BOWLDERS WITH A DERRICK, LYNX CREEK. 


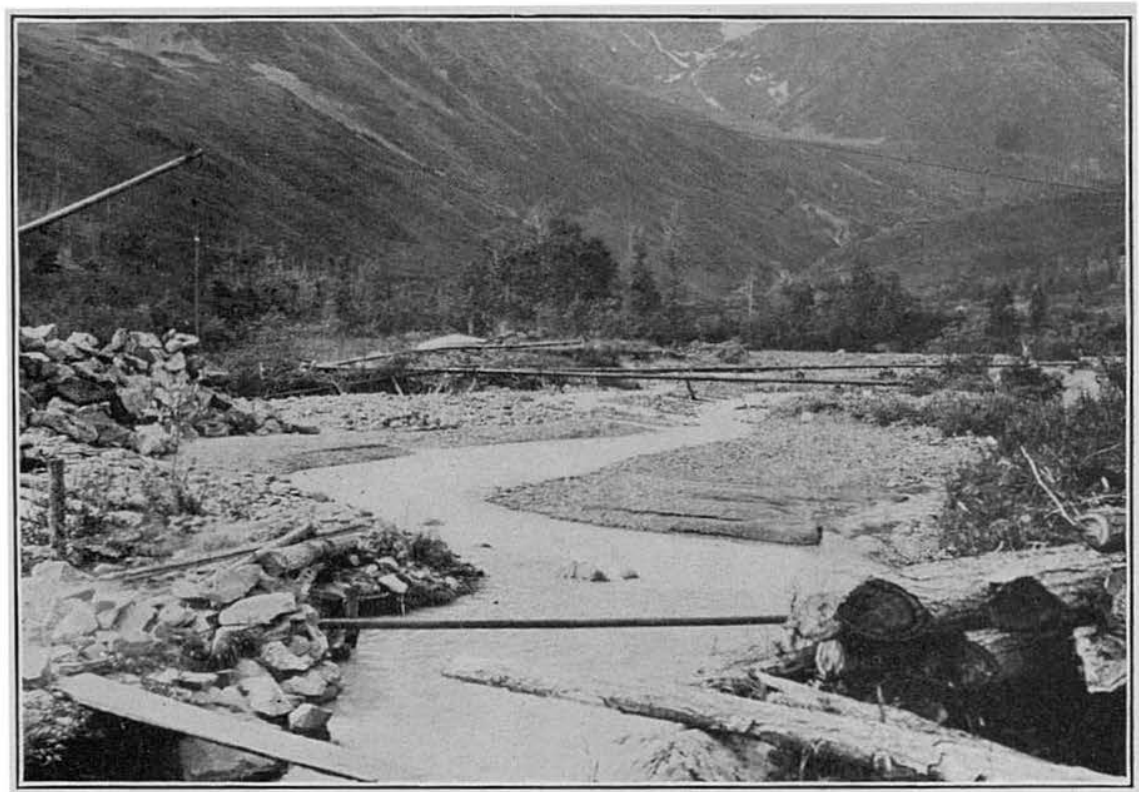

A. GRAVEL-FILLED, MORAINE-DAMMED BASIN, CROW CREEK.

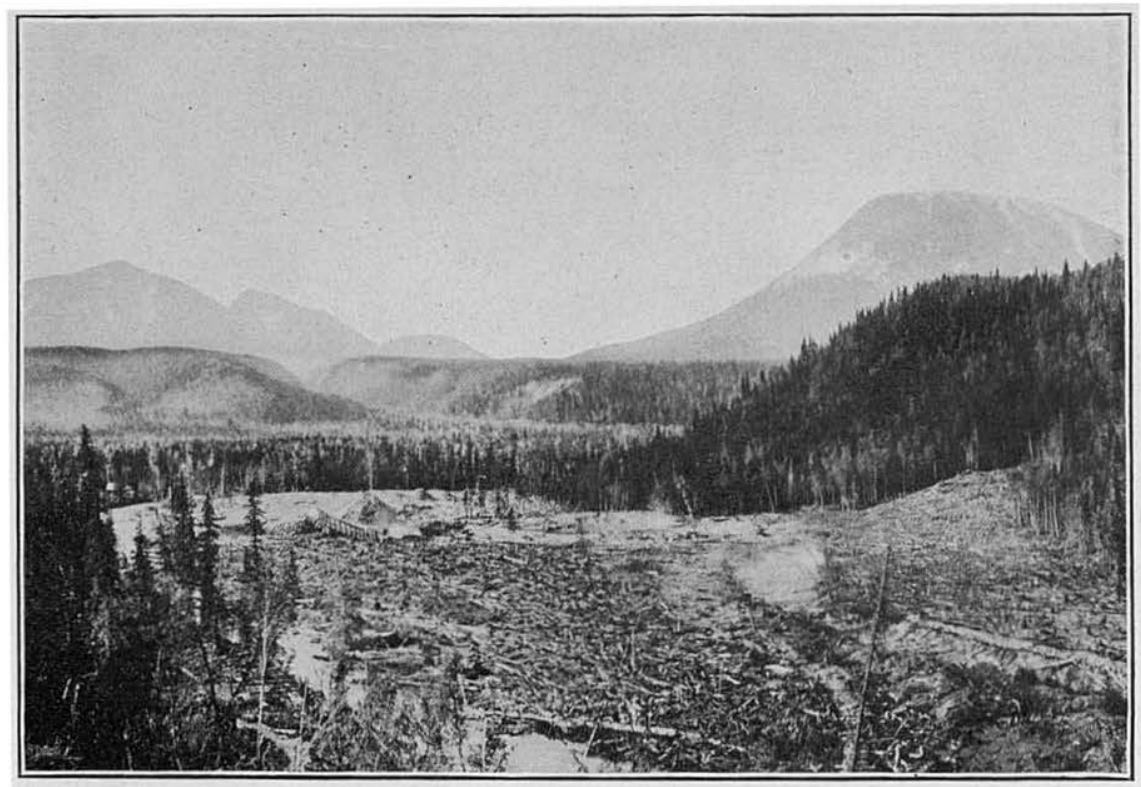

B. COOPER CREEK PLACER WORKINGS.

View looking across Kenai River and showing the canyon of Juneau Creek emerging from the gravel terraces at its mouth. Photograph taken in 1911. 


\section{at a point 5 miles from Turnagain Arm. A considerable part of its} water is derived from several small glaciers that occupy cirques in the mountains around the head of the valley. From the pass the creek flows southward in a narrow U-shaped valley, bottomed with glacial till, in which the stream has cut a small V-shaped gorge, to a point within about 3 miles of its mouth, where it swings sharply to the southeast, the valley broadening abruptly to a gravel-filled basin three-fourths of a mile long. (See Pl. XXXVII, A.) Below this basin the creek drops into a narrow gravel-walled; flat-bottomed valley, in which it flows for a considerable distance. In the last half mile of its course the stream flows through a narrow rock canyon in a series of rapids and falls to its junction with Glacier Creek.

The bedrock comprises interbedded slates, arkoses, conglomerates, and banded quartzites, striking about N. $45^{\circ} \mathrm{E}$. and cut by occasional dikes of light-colored granite.

The gravels are of three kinds-high-bench gravels, glacier deposits, and stream deposits. The first continue into the valley from Glacier Creek, and where most prominent have an elevation of nearly 1,000 feet. The top of the gravel bank east of Crow Creek at the head of the rock canyon is about 100 feet above the stream. On the west side a deep cut in the bank showed a perpendicular façe 50 feet high in rounded gravels of fairly uniform size-that is, without large bowlders and with no marks of bedding. ** * Near the middle of the rock canyon the work of the latter part of the season of 1904 disclosed the beginning of a well-developed, gravel-filled channel east of the present channel. This showed well-shingled stream gravels, and was expected to lead into the basin above the canyon. At the end of the season it had been followed in about 40 feet. The stream gravels show a large amount of material more recent than the bench gravels, consisting of angular blocks of arkose and slate, with many bowlders of light-colored granite, part of which are thought to be the product of erosion since the bench gravels were laid down. They are interbedded with finer clayey gravels and sands. A short distance above the rock canyon mining has shown that here the base of the gravels must be considerably lower than at the head of the canyon; in other words, owing to the filling of the old outlet the deposits here appear to occupy a basin. The section includes loose sand resting on bedrock, overlain by blue clay, yellow clay, gray gravels, and surface wash. A few very large bowlders are present.

Another gravel-filled basin is seen farther up the stream. About one-quarter of a mile above Crow Gulch a long curved "rock reef" extends across the valley and forms a well-marked ridge, with convex side downstream. A 60 -foot cut had to be made through this "reef" in order to sluice the ground above, and it was found to be made up of immense bowlders and angular blocks, sometimes 10 to 12 feet in diameter, thrown down in greatest confusion. Plainly it is a terminal moraine left here by the retreating glacier, which still appears in contracted form in the high valleys to the north. Behind this barrier the gravels were confined and laid down with more or less regularity. The beds may be seen abutting against the upper side of the moraine, which cuts them off from the stratified gravels below. The section disclosed in piping the ground includes fine sandy beds, separated by beds of angular wash and coarse bowlders. These beds average from 2 to 3 feet in thickness. ${ }^{1}$

Some gold has been panned from the bench gravels, but never in sufficient amount to encourage further work. The creek gravels are therefore the source of supply. Rich spots were found in the lower part of the rock canyon, and the old channel dis- 
covered last season yielded gold at the rate of 6.5 ounces per yard of gravel moved. Above the canyon the pay is irregular and is taken chiefly from the yellow clay and gray gravels. The former carries coarse gold; that from the latter is finer. Both these beds are tough and hard to pick, but the yellow gravel is the richer. In the upper part of the stream the pay is obtained almost entirely from the coarse wash, although the sandy beds carry some fine gold.

Crow Creek gold is of two distinct grades-one coarse and pale yellow in color, the other fine and bright yellow. It assays $\$ 14.80$, and with it are associated native silver, copper, and a little black sand. The largest nugget found was valued at $\$ 25.97$. $^{1}$ The conditions under which these gravels were probably laid down makes it appear that some places are decidedly more favorable for the deposition of gold than others and that consequently future developments will show the stream to be "spotted." It should be said, however, that careful prospecting in the upper basin and the results of last season's work in the lower basin above the canyon give an average of 46 and 44 cents in gold per yard of dirt moved. Most of the gold produced on Crow Creek has been taken with pick and shovel, but at present the whole of the creek is under two separate managements, both of which make use of hydraulic methods. * * * The creek carries from 3,000 to 6,000 inches of water, according to the season, and above the canyon has a grade of 2.5 per cent. The extraordinary size and quantity of bowlders is the chief difficulty to contend with in mining. ${ }^{2}$

Placer operations in recent years have been confined to the morainedammed, gravel-filled basin in the upper part of the valley and to an old buried channel at the head of the rock canyon about half a mile from the mouth of the creek. Hydraulic plants have been installed in both places.

Mining operations in 1904 near the middle of the rock canyon of the present stream disclosed an earlier well-developed, gravel-filled channel, cut in bedrock, crossed by the present channel and apparently headed toward the gravel flat at the upper end of the present rock canyon. Most of the later development work has consisted of the removal of the unconsolidated deposits that fill this channel. The property has changed hands several times. In 1911, after several seasons' work, the Nutter-Dawson Mining Co. completed a cut through the high-bench deposits from the original point of discovery of the channel in the canyon to the gravel flat at its head. (See Pl. XXXVI, $A$.) This cut, which is 1,800 feet in length and has a maximum depth of about 225 feet, follows the course of the old channel. The material filling this channel up to the level of the bedrock surface at the head of the present canyon consists chiefly of firmly cemented water-laid pebbly clays, horizontally bedded, and of a few scattered bowlders near the rim and on bedrock, along the sides and bottom of the channel. Wash gravel of variable thickness is also reported in parts of the channel. Overlying these pebbly clays is 60 feet or more of yellowish, irregularly stratified, sandy and gravelly beds. These high-level unconsolidated deposits, which extend for some dis-

\footnotetext{
1 Mendenhall reports a $\$ 50$ nugget from Crow Creek. Seo A reconnaissance from Resurrection Bay to the Tanana River, Alaska, in 1898: U. S. Geol. Survey Twentieth $\Lambda$ nn. Rept., pt. 7, p. 320, 1900.

2 Moffit, F. H., op. cit., pp. 42-43.
} 
tance up Crow Creek, have been trenched by the present stream to a considerable depth contemporaneously with the development of the rock canyon. Near the head of the present rock canyon the stream flat has an average width of 250 to 300 feet and lies about 100 feet below the top of the high-bench deposits, which here stand about 1,000 feet above sea level. The thickness of the stream-flat gravels is not known. A shaft 70 fect in depth is reported to have been sunk at the lower end of the flat without reaching bedrock. No record of the material passed through is available, but most of the section is probably similar to that exposed in the cut and must have about the same gold content, and the thickness of the present stream gravels doubtless does not exceed a few feet. The completion of the big cut has demonstrated the low gold content of those high-bench fluvioglacial deposits. Exact figures are not available, but it appears that $1 \frac{1}{2}$ cents per cubic yard would be an exceedingly liberal estimate of the gold they contain. The higher gold content of the gravels of the stream flat is due to the concentration of the gold of the bench deposits by the present stream in the development of its present channel. Moffit states that the results of mining operations in 1904 in the flat above the canyon gave an average of 44 cents in gold per cubic yard of dirt moved. No further data are available.

The recent geologic history of this deposit is probably as follows: During the general retreat of the ice following the intense glaciation of the region the Crow and Glacier creek glaciers separated. The Crow Creck glacier retreated the more rapidly because of its smaller area of ice supply, but the Glacier Creek glacier retreated sufficiently to allow the escape of the Crow Creek waters, which cut a gorge of considerable depth in the bedrock. A later advance of the Glacier Creek glacier, accompanied probably by a slight advance of the Crow Creek glacier, ponded the Crow Creek waters with a resultant deposition of their load and the filling of the gorge and of part of the valley with water-laid sediments. With the final retreat of the glaciers to their present position Crow Creck cut a now channel through the fluvioglacial deposits, deviating somewhat from its former channel and exposing the latter where the channels cross.

Water for the present hydraulic plant is taken from Crow. Creek by a ditch 5,700 feet in length, 6 feet wide at the top, 4 feet wide at the bottom, and 4 feet deep. A pipe line 3,000 feet in length, 24 inches in diameter at the intake and 15 inches at the giants, carries the water to three No. 7 Hendy giants, with 7 and 8 inch nozzles, operating under heads varying from 300 to 350 feet according to their position in the cut. The gold-saving apparatus consists of a bedrock sluice 600 feet in length, set in the bottom of the old channel, with boxes 5 feet wide by 4 feet deep placed on a grade of 9 inches to the box length. Twelve-inch cube hemlock block riffles 
are used in the boxes. Two box lengths from the lower end of the sluice two parallel 6-foot undercurrents have been installed. The tailings are dumped into the rock canyon of the present stream at the intersection of the two channels. Fifteen to twenty men were employed on the property during 1911.

About 2 miles above this plant, at the mouth of Milk Gulch, is the moraine-dammed basin previously referred to. (See Pl. XXXVII, A.) Operations at this point have been described by Moffit ${ }^{1}$ and by Paige and Knopf ${ }^{2}$ who visited these placers in 1904 and 1906, respectively. Moffit's description follows:

On the upper group of claims nearly the whole of the season of 1904 was spent in making the cut through the moraine, or "reef" as it is called. Twenty men were employed during the early part of the season, but this number was cut down when it became too dark to run a night shift. A head of 250 feet of water is used. The gravels are sent through an 8-foot race having a grade of 4.5 inches to the rod. It is said that 1,500 to 2,000 yards a day can be handled. The tailings are dumped into the stream below, but after seeing how gravels are carried down by higher water one is led to think that this practice may seriously interfere with work on the lower claims unless some measures are taken to impound at least the coarse material. This ground has been well prospected by holes and a few crosscuts, so that the management feels justified in incurring the great expense which was necessary to open the ground. The working season is several weeks shorter here than at the lower end of the stream, since the claims are above timber line and are entirely unprotected from the cold winds of the valley. ${ }^{3}$

A more detailed description of the plant is given by Paige and Knopf, ${ }^{4}$ who state that in 1906 at this plant "mining was in progress by hydraulic methods the greater part of the season. In all, about 50,000 yards of gravel were washed from two pits, with reported satisfactory results."

Assessment work only has been done in recent years.

CALIFORNIA CREEK.

This stream has cut a steep, narrow, V-shaped valley in the mountains west of Glacier Creek, which it joins 2 miles from the arm. Its bedrock comprises the same materials found on Crow Creek. The gravels are similar, also, but carry less granite and do not show in the same degree the effect of glacial action. A few thousand dollars were taken out in 1896 and 1897, but of late years nothing more than assessment work has been done. It was proposed to set up a hydraulic plant and build a sawmill last season, but for some reason the project was not carried out.

WINNER CREEK.

Winner Creek joins Glacier Creek just below the mouth of Crow Creek. Its valley, bedrock, and gravels resemble those of California Creek. Like the latter, it was worked slightly in the early days of the field, several thousand dollars in gold being

' Moffit, F. H., Gold fields of the Turnagain Arm region: U. S. Geol. Survey Bull. 277, pp. 41-43, 1906.

2 Paige, Sidney, and Knopf, Adolph, Reconnaissance in Matanuska and Talkeetna basins, with notes on placers of the adjacent region: U. S. Geol. Survey Bull. 314, pp. 121-122, 1907.

8 Moffit, F. H., op. cit., p. 43.

4 Paige, Sidney, and Knopf, Adolph, op. cit., p. 122. 
taken out in 1898 and 1899, but in the following year it produced little or nothing, and in 1904 no mining was carried on. ${ }^{1}$

In recent years Winner Creek has contributed a few hundred dollars annually to the gold production of the area.

\section{RESURRECTION CREEK VALLEY.}

\section{RESURRECTION CREEK.}

This stream, the earliest producer of the region, flows through a broad valley floored with a thick deposit of gravels, in which, throughout the greater part of its length, the waters have cut a deep, canyon-like channel. [See Pl. XXVI, A.] The portion from which gold has been taken, lying between Sixmile Point and Hope, has an average grade of 66 feet per mile, the grade of the lower 20 miles being about 100 feet per mile. Bedrock has not been reached on the majority of claims, for the stream cuts the country rock at only a few places and is working principally on gravels filling an old valley. These valley gravels are roughly stratified and have been penetrated in one place to a depth of 50 feet below the stream level without reaching solid rock. They consist largely of slates and arkoses from the neighboring hills, but contain, in addition, an uncertain percentage of material, chiefly granitic in character, foreign to the valley. ${ }^{2}$

In 1904 Moffit states that "the bench deposits have never been worked, but are known to contain fine gold. A 60 -foot bank 2 miles below Palmer Creek yielded colors from bottom to top, the best pan, about 2 cents, being taken from the upper 10 feet."'s The first bench diggings, so far as known, were begun in 1908 about 4 miles above Hope and a small amount of work has been done each year since, but the most attention has been given to the gravels of the present stream.

Placer mining is confined [1904] to the channel gravels, which, however, must be derived, in part at least, from the benches. The so-called bedrock on which pay is obtained is a gray glacial clay of variable thickness overlain by from 4 to 9 feet of stream wash containing some scattered gold. One claim on the creek yielded an average of 60 cents in gold to the cubic yard for a period of five years. This average was based on the assumption that a little over 4 yards of dirt per man per day were handled. From 4 to 5 yards is considered a good day's work.

The gold is fine and smooth, usually bright yellow in color, but at times whitish and then of lower grade. Eighteen ounces of dust sent to the assay office contained $\$ 2$ in silver. ${ }^{4}$

The fineness of the placer gold from this creek, as determined by assays made by the United States assay office in Seattle, Wash., ranges from 0.821 to 0.8235 gold and 0.171 to 0.173 silver at a point 4 miles above Hope, the value being $\$ 17.06$ to $\$ 17.12$ per ounce after melting.

Profitable mining on Resurrection Creek has been carried on entirely with pick and shovel. The method usually employed is to divert the stream into a new channel by a dam and then wash the uncovered gravels. All the material, excepting large bowlders, is sent through the boxes and the tailings are discharged into the stream below. $\Lambda$ hydraulic elevator introduced at a point 9 miles south of Hope to handle

\footnotetext{
1 Moflit, F. H., op. cit., p. $43 . \quad 2$ Idem, p. $34 . \quad{ }^{3}$ Idem, pp. 34-35. $\quad{ }^{4}$ Idem, p. 35. $48891^{\circ}-1$ inull. 587-15- 13
} 
channel gravels was not operated successfully, chiefly owing to the insufficient-water supply and many bowlders. The former difficulty can be overcome without great expense, but derricks of some kind will always be necessary to handle the large material. Bowlders 2 or 3 feet through are not uncommon, and greater ones, with diameters of 5 to 6 feet, were also noted. A dredging machine shipped to this region on one of the late boats did not reach its destination and was unloaded at Valdez, to be brought in later. It is extremely doubtful, however, if there is any locality in the Resurrection Creek valley where present dredging methods can be employed successfully, owing to the depth of the gravels and their irregularity in hoth the size of the material and the manner of its deposition. Bowlders form a large proportion of the deposits. ${ }^{1}$

A Risdon 5-foot open-connected dredge was erected in 1905 on Resurrection Creek but did not prove successful, apparently because of the shallowness of the pay gravels and the presence of numerous large bowlders.

Mining is now in progress on both creek and bench placers. Only hydraulic methods are in use, pick and shovel methods no longer paying. In 1911 the creek gravels were being worked only by the Mathison Mining Co. Their property, known as the Texas-Oklahoma Consolidation, extends from a point 4 miles above the mouth of Resurrection Creek to a point within 1,500 feet of tidewater. The stream flat here has a width of about 1,000 feet. High gravel benches flank the stream flat on both sides. Slate bedrock and rim rock outcrop in but few places, the stream not yet having removed all the unconsolidated deposits in its course. The gold-bearing creek gravels cover the stream flat to an average depth of 7 feet, resting on a false bedrock of unconsolidated fluvioglacial deposits, consisting of yellowish horizontally bedded clay containing some streaks of blue clay. The auriferous gravels are loose and stream laid and contain but little clayey sediment. Bowlders over 3 fect in diameter are not numerous, but a few are found. Bowlders of graywacke predominate, those of granite and of conglomerate being much less abundant. The gravels are reported to average between 45 and 50 cents to the cubic yard. No definite pay streak exists.

The work of 1911 was done near the upper end of the property. Sluicing was begun on May 29 and work stopped on October 8, after 127 working days, during which approximately 16,000 cubic yards of gravel is said to have been moved. An average of 7 mon were employed. Three miles of new ditch, 20 inches deep and 36 inches wide, was built, tapping Bedrock and Rimrock creeks and Gold Gulch for water supply, the water running through the ditch for the first time about September 10. Two miles of the ditch was constructed on a grade of 1 inch to the rod. Prior to the construction of this ditch the water supply had all been obtained from Bedrock Creek. About 3,000 feet of pipe line, ranging in diameter from 11 to 16 inches, is used to lead the water from the ditch to two No. 2 
Hendy ball-bearing giants with 4-inch nozzles and one No. 1 giant with a 3 -inch nozzle, all operating under 315 -foot heads.

Occasionally a $4 \frac{1}{2}$-inch nozzle is employed on one of the No. 2 giants. Two of the giants are used in the face of the workings and the third stacks the tailings from the sluice boxes. Only three 15-foot sluice boxes can be employed because of the low stream gradient. These are 3 feet in width and are set on an average grade of 9 inches to the box length. Pole riffles are used in the head box, where most of the gold is caught, and Hungarian vacuum riffles in the remaining two boxes. All the gold-bearing gravel is driven into the boxes by the giants.

Near the above plant E. E. Carson has operated a small hydraulic plant on a bench on the west side of Resurrection Creek since 1908. The gold-bearing gravels are similar to the creek gravels; they are horizontally bedded and rest on a clay bench. Water is obtained from Wildhorse Creek through a ditch $1 \frac{1}{2}$ miles in length. The present equipment is reported to consist of a No. 1 giant with a 3 -inch nozzle operating under a 60 -foot head of water. A shortage in the water supply late in the summer usually permits only a short working season on these bench gravels.

PALMER CREEK.

Palmer Greek is the largest tributary of Resurrection Creek. Its upper portion flows for 6 miles through a broad, round-bottomed valley, while its lower part occupies a steep, narrow canyon cut through rock in some places and through gravel benches in others. Mining has been carried on chiefly in the lower 1.5 miles of the stream and has been confined entirely to the channel gravels. The country rock includes interbedded slates and arkoses, whose cleavage strikes a little east of north and dips at a high angle. The arkoses are frequently very much jointed and in weathering do not break into small pieces as easily as do the slates, a fact readily seen on examining the stream wash. The gravels resemble the country rock in their composition, and were undoubtedly derived from it in large part, although there are a few granitic bowlders which may not be of local origin. There is a large proportion of angular fragments and no small percentage of coarse material, possibly 5 per cent being over 18 inches in diameter. At the surface the gravels were laid down without definite arrangement but are rudely stratified below. It is said that they yield about $\$ 1$ per yard of material handled, but it should be stated that from 30 to 40 per cent of the gold is obtained from bedrock.

Palmer Creek gold is coarse and heavy, usually much flattened, and smooth. It passes at $\$ 16$ per ounce at the local stores. In color the gold is bright yellow, but may be whitish. Pieces of native silver weighing as much as 1 pennyweight were seen, and also some black sand, which, however, is not abundant. No fine gold is saved. The claims on this stream were originally held by single individuals, but at present the whole of the lower canyon portion, 18 claims, is controlled by one company.

Two hydraulic plants were at work in 1904, employing in all about 10 men. The season was a wet one, and at the time of the writer's visit, in July, the stream was flowing not far from 3,000 inches of water, an amount sufficient for the present needs of mining. This quantity, however, is very much increased in time of high water, and may be considerably decreased during a dry season. 
The greatest difficulty met in operating these plants arises from the presence of many large bowlders, which it is necessary to move by hand at least once. They are piled in a box provided with some dumping device and hoisted from the pit by a derrick, this operation consuming about twice the amount of time spent in piping, thereby decreasing greatly the efficiency of the plant. When too large to be handled in any other way, the bowlders are reduced to convenient size with a few sticks of powder. It is the usual practice to operate the derrick with the stream from the giant rather than to use a separate line of pipe for that purpose. ${ }^{1}$

Placer operations have ceased on Palmer Creek. No active mining has been carried on in the last few years and no plants are now in operation. It is reported that work in the canyon ceased when the pay streak suddenly gave out and the operators were unable to relocate it.

BEAR CREEK.

Bear Creek is the best known stream in this part of the field. It is about 5 miles long and has a fall of nearly 500 feet to the mile. Bear Creek valley is narrower than Palmer Creek valley, and while resembling it in some ways does not have the canyon features so well developed. The country rock is a succession of arkoses ${ }^{2}$ interstratified with bluish-black slates, the beds being so thin in one or two localities as to give to the outcrops a banded structure. These beds strike N. $20^{\circ} \mathrm{E}$., or nearly at right angles to the general course of the creek, the cleavage, however, running more nearly north and south. The gravels are very irregular in distribution and are made up almost entirely of material like the country rock, but include, in addition, a few bowlders of granitic rock. In two places from 25 to 30 feet of unstratified deposits were seen. These contain a large quantity of coarse angular blocks mixed with sands and clays, the whole apparently dumped into its present position without having undergone any sorting by water. Bowlders 3 to 4 feet in diameter are plentiful. In some localities the surface wash is underlain by stratified sands and clays, which were probably deposited in small local basins, where they are sometimes found abutting against perpendicular rock faces or overlapping sloping surfaces. The hard gray clay locally underlying the surface wash and known as "glacial clay" rests on loose sands composed largely of slate particles and containing a large amount of water. It has been noticed in a few places that the rock surface above this clay is worn smooth, while below it is rough and unworn.

Bear Creek gold is lower in grade than any other from the Resurrection region. Like that from Palmer Creek, it is usually bright yellow in color, but may be whitish. Some native silver is found, and it is said that a small amount of native copper is also present. One large nugget of gold, valued at about $\$ 250$, was found. The first claim staked on the stream yielded a little more than $\$ 2,000$ the first year it was worked, but was not operated with profit in the following years. A second claim worked steadily, but in a small way, since the early days of Bear Creek's history has produced an average of $\$ 8$ a day per man.

Two hydraulic plants have been installed on Bear Creek, but only one was in operation during the season of 1904, the other being involved in lawsuits. Although there has been sufficient water in the stream for the needs of these plants the same difficulty with bowlders is encountered as on Palmer Creek. Bowlders are removed from the pit by derrick or cableway and are dumped at one side or carefully piled along the channel. It may be readily seen that the time lost in this way is great and that the cost of production is thereby very much increased. It can hardly be

1 Moffit, F. H., op. cit., pp. 35-36.

2 Moffit uses the term "arkose" to describe the rocks which in the present report are called "gray wackes," 
said that the future of the creek is bright, though with economical methods there are parts of the stream which can doubtless be worked at a profit. ${ }^{1}$

Only assessment work has been done in recent years on Bear Creek. The creek placers are reported worked out and what little mining has been done has consisted of hydraulic operations on low benches.

KENAI RIVER VALIEY.

KENAI RIVER.

The immense deposits of gravel along Kenai River afiord ground eninently suited to hydraulic mining and have been prospected at several points, in the hope of finding gravels of sufficient value to pay for working in that manner. *** All attempts, however, at hydraulicking these bench gravels have been failures.

An unsuccessful hydraulic plant was located on the north shore of Kenai River near the lower end of Jake Kenai in 1898 , but was abandoned later. * * * A second hydraulic plant is located on the high gravels south of Kenai River, about 2 miles above Iake Skilak. It was not in operation last season. The writer learned, however, that the small quantity of gold procured during the previous year all cane from a few inches of the top gravels. ${ }^{2}$

The river gravels received but little attention prior to 1910 . In that year C. D. Cunningham discovered gold in the river gravels about a mile below the mouth of Cooper Creek. After this discovery practically all the lower ground bordering the river from the lower end of Kenai Lake to Cook Inlet was staked as possible dredging ground. Little careful prospecting has yet been done. Early in 1911 ground near the mouth of Killey River was drilled to determine its suitability for dredging, and later in the season some of the claims between Skilak and Kenai lakes were prospected by shafts. In 1912 some of the ground between Cooper Creek and Russian River was prospected with an Empire drill.

Between Skilak and Kenai lakes Kenai River flows among high, rounded hills. Gravel benches flank the stream. Their upper surface is at water level at the lower end of Kenai Lake, but is high above the river in the vicinity of Cooper and Juneau creeks, where the river has cut deep into them. 'The bluff at the mouth of Cooper Creek shows that the structure of a part of these high bench deposits is that of a typical delta formed in ponded waters by a stream flowing westward, as does the present river.

In recent geologic time the trunk glacier extending down the valley now occupied by Kenai Lake and Kenai River widened and deepened the preglacial valley and impressed upon it the $U$ shape characteristic of glaciated valleys. Because of its greater size and erosive power this glacier cut the bottom of its valley considerably below the level of the valleys of its tributaries, so that Cooper and Juneau creeks were left as hanging valleys on the retreat of the ice. The delta struc- 
ture exhibited in the Cooper Creek bluff (see fig. 14,p.122) indicates the former presence of a lake of considerable size in the valley. It appears probable that the front of Kenai River glacier stood near the lower end of the present Kenai Lake during the formation of the delta. The removal of the obstruction which gave rise to the lake was followed by the cutting of the present channel through the delta deposits, a process which is still in progress. The depth to which the Kenai River glacier eroded its channel below that of its tributaries is not known, and therefore neither the thickness of the unconsolidated glacial and fluvioglacial filling nor the depth to bedrock in this part of the river's course is known, although it is probably considerable.

From the fluvioglacial character of the bench deposits it would be expected that the gold would be widely disseminated and that no definite pay streaks would occur. As to the average value per cubic yard of these bench deposits no data are at hand. It is probably exceedingly small, much too small to be worked profitably under present conditions. Panning tests in the delta bluff at the mouth of Cooper Creek failed to show any colors. These deposits are slightly auriferous, however, as is shown by the occurrence in the present stream gravels of fine flaky gold, which must have been derived, in part at least, from the concentration of the bench gravels.

Of the present river gravels that are locally considered as possible dredging ground, those in the part of the river's course between the upper and lower lakes are the result of the reworking and re-sorting of the sands and gravels of the bench deposits, as the stream cut through them down to its present level. Coarser material, derived principally from the erosion of morainic material and bedrock on the tributary streams, also occurs in the gravels of the stream flat.

The thickness of the present river gravels is unknown. Prospecting shafts reach a depth only from 4 to 8 feet before encountering water. The stream-flat gravels of the lower end of Cooper Creok have a thickness of only 8 to 10 feet, resting on a false bedrock of the delta deposit in which this portion of the creek valley is cut. The river gravels may be somewhat thicker, and probably rest on a similar false bedrock.

The low gold content of the sands and gravels of the delta underlying the present river gravels has been pointed out. In the river gravels, however, colors are obtained from the surface down without any well-defined pay streak. The value per cubic yard reported for these gravels varies considerably. The Kenai Dredging Co., whose property is about a mile below the mouth of Cooper Creek, is reported to have obtained $\$ 167$ from $9 \frac{1}{2}$ cubic yards of gravel and from 2 to 25 cents from each pan from the river bars. The results obtained from prospecting shafts 4 to 8 feet deep in the stream flat between 
the upper and lower lakes are much lower. Values of 25 and 38 cents per cubic yard were obtained in two of the shafts. Placer operations on lower Cooper Creek are reported to show an average gold content for the stream-flat gravels there of 30 to 50 cents a cubic yard. The average gold content of all material which would have to be handled in dredging operations, as reported from a considerable number of shallow shafts sunk during 1911 on the stream flats of Kenai River, was only a few cents to the cubic yard, less than the cost of dredging under more favorable conditions in California. Later drilling is reported to afford more favorable prospects.

Most of the gold in the gravels of Kenai River is very fine, light, and flaky, and has a value of about $\$ 17.58$ per ounce. Coarser gold, flat but not flaky, has been introduced into the river gravels from Cooper Creek. Active operations on the upper river have thus far been confined to the original discovery, where, during 1911, the Kenai Dredging Co. erected a small dredge, which, however, failed to save the values contained in the gravel worked. A larger dredge (see Pl. $\mathrm{XXXV}, A$ ) of the same type, in process of construction, had not been completed at the close of the season (1911), but is reported to have been in operation in 1912. Should the gravels in the upper river, after careful prospecting, warrant the installation of dredging machinery, it appears probable that dredges capable of handling rather heavy wash will be required. The further possibility that the goldbearing gravels of the present stream in this part of its course may be, and probably are, of comparatively slight thickness should not be overlooked.

COOPER CREEK.

Cooper Creek, 10 miles in length, enters Kenai River from the south 3 miles below Kenai Lake. Stetson Creek is its principal tributary. Cooper Creek, in most of its course, flows in a postglacial rock canyon cut in a broad glacial valley. Its lower half mile, however, is cut in the sands, clays, and gravels of the old fluvioglacial filling of the Kenai Valley. (See Pl. XXXVII, B.) The lower end of the stream, from the mouth of the rock canyon to Kenai River, has a drop of 48.7 feet in a distance of 2,771 feet. The grade in the lower end of the canyon is a little less than 3 per cent.

The auriferous deposits comprise both bench and creek gravels. The gold content of the delta bench gravels is low, but above the mouth of the rock canyon richer bench deposits of moraine and fluvioglacial origin, containing both coarse and fine gold, rest on the glaciated bedrock floor. The larger nuggets are very much smoothed; the largest thus far found had a value of $\$ 3.80$.

The creek gravels have been worked both in the canyon and on the flat at the lower end of the creek. The last work in the canyon was done about 1903. The gravels are said to have varied much in 
thickness and to have been richer than most of the gravel on the stream flat below. For several years active operations have been confined to the wide flat at the lower end of Cooper Creek, where the creek gravels, 8 to 10 feet thick, form a uniform layer over a false bedrock of fine sand and sandy clay, and some lenses of pebbly gravel. The surface of this bedrock is fairly even, but contains slight depressions representing temporary channels of the shifting creek as it wandered back and forth, downcutting the present flat through the old delta deposits. The creek gravels are loose and are easily handled and consist chiefly of pebbles of dark blue-black slates and graywackes with which are interspersed some conglomeratic bowlders. A few bowlders of fine grained acidic dike rocks are also found. Bowlders over 3 feet through are rare, most of them averaging $1 \frac{1}{2}$ to 2 feet. The larger bowlders appear principally in the lower part of the gravels. Considerable fine material forms a matrix for the bowlders, but it is gravelly and crumbles readily. No distinct stratification is noticeable, although most of the pebbles and bowlders are flattish or slabby and lie approximately flat. These stream-flat gravels are reported to average from 30 to 50 cents gold per cubic yard.

The gold is derived from three sources-partly from the delta deposits that flank the stream flat, partly from the auriferous glacial and fluvioglacial deposits in the glaciated valley of Cooper Creek, and probably to a slight extent by postglacial erosion, from goldbearing lodes in the bedrock of the valley. Two distinct runs of gold are reported, one a little darker than the other.

The gold is small, flat but heavy, not flaky, and has a value of about $\$ 17.60$ per ounce. Nuggets having a value of 80 cents have been found, some with quartz attached. Pyrite, arsenopyrite, and magnetite are found in the concentrates from the clean-ups. Coarser gold is reported on Stetson Creek, nuggets worth as much as $\$ 41$ having been found.

The Cooper Creek placers in 1911 and 1912 were the property of the Kenai Mining \& Milling Co., whose claims extend from Cooper Lake to Kenai River. Hydraulic operations were in progress for several years on the stream flat at the lower end of the creek. On account of the low stream gradient a Ruble elevator (see Pls. XXXV, $B$, XXXVII, $B$ ), 10 feet wide with a 48 foot body and a 12 foot extension at the lower end, had been installed in 1907 . The goldsaving attachments consisted of four sluice boxes, 12 feet long by 4 feet wide, set on a grade of 8 inches to the box length. The three lower boxes were set with steel capped wooden cross riffles 4 by 2 inches by 4 feet in size; 2 inches apart with 1-inch spaces between the steel straps, the dimensions of which were one-quarter inch by 3 inches 
by 4 feet. Water for hydraulicking is obtained from Stetson, Wildhorse, and Kickinghorse creeks by an upper ditch 4 miles long, a lower ditch $1 \frac{3}{4}$ miles long, and 1,300 feet of flume. Two No. 2 Hendy giants with 4 -inch nozzles and two No. 4 giants with 5 -inch nozzles made by a Portland firm were available, but only one giant with a 5 -inch nozzle, operating under a 200 -foot head, was in use in June, 1911. The usual mode of operation was to strip the soil down to the gravel layer and then to wash all the gravel, down to the false bedrock, over the elevator. Most of the gold was caught in the upper boxes. In 1912 the Ruble elevator was dismantled early in the spring and a better saving was made by hydraulicking directly into the sluice boxes. Three 12 -foot boxes were first tried, and two more boxes were added later.

\section{QUARTZ CREEK.}

Quartz Creek, a tributary to Kenai Lake from the north near its lower end, is about 16 miles long. In 1909 the first hydraulic plant on this creek was installed a short distance above the mouth of Devil Creek. In this part of its course Quartz Creek winds southward in a narrow, steep-sided valley cut in the bedrock floor of a broad glaciated valley. Bedrock of interbedded slates and graywackes striking $\mathrm{N} .17^{\circ} \mathrm{W}$. and dipping $60^{\circ} \mathrm{W}$. outcrops in many places in the stream course and in the valley walls. The character of the unconsolidated material covering the bedrock on the slopes is shown in the ditch that extends along the east side of the valley. This ditch is cut in a compact clayey gravel, which contains a few rounded and striated bowlders and was evidently in some places water-laid. Small gravel-covered benches lie at different elevations on the valley sides. The creek gravels are reported to have carried coarse gold and to have afforded good pay. The present operations are confined to a gravel-covered rock-cut bench, the bedrock surface of which is, at the pit, about 15 feet above the stream. The thickness of the gravel on this bench varies from 12 to 22 feet because of the unevenness of the bedrock surface. The gravels consist of fairly well rounded slate and graywacke. Large bowlders, some as much as 6 feet in diameter, are found, but most of the material is under 3 inches in diameter. An average value of 27 to 32 cents a cubic yard is reported for these gravels. The gold is coarse, pieces up to 73 cents in value haring been found, and has an assay value of about $\$ 16.90$ an ounce.

Water for hydraulicking is obtained from Quartz Creek at a point just below the mouth of Johns Creek by a ditch that is $1 \frac{1}{2}$ miles long and that has a grade of one-fourth inch to the rod. The intake is on the west bank of the creek and the ditch follows the west side of the valley to a point about half a mile below the intake, where the 
water is carried across Quartz Creek on a 160-foot flume 65 feet above the creek. The pipe line from the penstock to the giants decreases gradually in diameter from 14 inches at the penstock to 10 inches at the giants. Two No. 2 Kendall giants with No. 3 nozzles operate under heads of 95 to 120 feet. The gold-saving apparatus consists of 10 sluice boxes, set with longitudinal pole riffles, 4 poles wide and 6 feet long, 2 sets to each box. The head box was set on a grade of 14 inches to the box length, the second box on a 12-inch grade, the third on a 10-inch grade, and the remainder on a 9-inch grade. Most of the gold is caught in the first two boxes.

FAILS CREEK.

Falls Creek, a small tributary of Trail Creek between Kenai and Lower Trail lakes, has always been a grubstake creek. The gold recovered has all been taken from low benches in the canyon in the lower part of the creek and at the mouth of the canyon. The amount of gold in the canyon is reported to be small-not sufficient to pay wages on pick and shovel work. The recentness of the canyon cutting and the small amount of unconsolidated material worked over by the stream would tend to bear out this report.

The unconsolidated material in the flats along Falls Creek between Kenai and Lower Trail lakes was prospected in 1911 to determine its gold content. Twenty holes were put down with an Empire drill using a $4 \frac{1}{2}$-inch casing. The depth to bedrock as determined by the drill holes ranged from 10 to 23 feet. The material passed through is reported to be principally gravel but contains some bowlders too large for a dredge to handle. In some of the holes prospects were found all the way from surface to bedrock, but no definite pay streak was located, and as the deposit is composed partly of morainic and fluvioglacial material laid down by the former Trail Creek glacier and partly of recent outwash fan deposits of Falls Creek the gold is probably widely disseminated.

\section{SLXMILE CREEK VALIEY.}

The area of the drainage basin supplying the waters of Sixmile Creek and its branches is nearly half as large again as that of Resurrection Creek, and is much more irregular in outline. Probably the most noticeable feature of the topography in this area aside from the ruggedness of the mountains is the great development of gravel benches, which appear most prominently in the valleys of Sixmile Creek and its two branches, Canyon Creek and East Fork. This basin contains the richest gold-bearing gravels yet found in the Turnagain Arm region, and mining operations have therefore been carried on here more extensively than elsewhere.

SIXMTLE CREEK.

Sixmile Creek has not been an important gold producer. It flows through a broad, flat-bottomed valley, but has not cut deep into the valley floor, so that the canyon features seen above on Canyon Creek are not here as well developed. Some mining has 
been carried on with fairly good results in one or two cases, but on the whole without marked success. A hydraulic plant was operated for some time on gravels said to carry about 40 cents per yard, but the work proved unprofitable and was finally given up. ${ }^{1}$

Mining on Sixmile Creek, which enters Turnagain Arm at the town of Sunrise, was not carried on with any great activity during 1906, but the high benches along its course were worked by individuals with small outfits at several localities. Work in the stream gravels proper amounted to little. At the forks of Canyon Creek an attempt was made to reach bedrock by means of a hydraulic elevator. ${ }^{2}$

Placer mining on Sixmile Creek has been in recent years confined to a very few small hydraulic plants, worked by individuals, operating on high bench gravels bordering the stream and yielding only a small production.

\section{CANYON CREEK.}

Canyon Creek flows for a distance of 8 miles through a narrow canyon ranging in depth from 100 to 200 feet or more, extending from "the forks" to a point just below Mills Creek. Above Mills Creek the valley is open and the waters have not yet had an opportunity to cut deeply into the gravels.

The country rock comprises shales and arkoses whose bedding and cleavage strike parallel with the course of the stream. In some of the narrower portions of the canyon the rock walls are seen to be capped with gravel deposits, but as a rule the débris from above covers the rock faces, giving the impression that the height of the wall from the stream to the top of the bench represents the thickness of the gravels. * * * Much of the gravel is rounded and well stratified, as is well shown in the benches near "the forks." In places it is cemented by iron oxide. * * * This gravel is. locally known as "cement gravel."

The stream gravels are not stratified and the material is, in general, coarser and more angular than that of the benches. A section of gravel deposits at the flat near the mouth of Canyon Creek shows at the top from 6 to 8 feet of soil and coarse wash overlying 8 feet of sandy deposits, followed in turn by stratified clays and gravel.

The high gravels away from the channel have not been prospected, although gold is present in the high banks on the left side of Canyon (reek near "the forks," and the writer was told that a hole somewhere west of the stream showed good prospects. The only high gravels yet exploited are on the edge of the canyon, 3 miles above "the forks."

* * * Some gold is distributed through the gravel, but the greater portion comes from bedrock, which is here smooth, but shows hummock-like irregularities, due possibly to the action of ice, or, it may be, of running water. A well-defined rock channel, 40 feet wide and 12 feet deep, was uncovered by the removal of the gravels. This channel runs in a northwesterly direction, and is 150 feet above the present channel. In this channel was a bowlder weighing probably 15 tons. The gold from the bench is flaky and assays over $\$ 17$ to the ounce. The largest piece yet found there was worth about 25 cents. $^{3}$

By far the greater part of the product of Canyon Creek has come from channel gravels. The swift current prevents any uniform distribution of gold, but the eddies behind rock points and large bowlders give an opportunity for the heavy particles to find lodgment, and at such places very rich pockets have been found. The stream has therefore been a good one for "sniping;" that is, for working the richest spots in a small way with very simple appliances.

The most evenly distributed gold occurs in the gravels of the flat at the junction of Canyon Creek and East Fork. This ground lies immediately below the canyon

${ }^{1}$ Momit, F. Ir., op. cit., p. 37.

${ }^{3}$ Moflit, F. H., op. cit., pp. 3i-3s, 196)t.

2 Paige, Sidney, and Knopf, Adolph, op. cit., p. 122. 
of both Canyon Creek and East Fork, making it a sort of dumping ground for the two streams. At this place the best pay comes from the clay bedrock, but fine gold is scattered through all the gravel.

Canyon Creek gold is generally coarse, as would be expected from the nature of the channel and swift current; that from "the forks" is finer.

Mining on Canyon Creek has been carried on under difficulties, arising from the narrow channel and swift current. The more extensive operations always involve the construction of wing dams to confine the water to one side of the channel while the other side is being worked out. * * * Such operations are expensive and the results are uncertain, since in more than one instance the labor of an entire season has Feen destroyed by high water and loss of the dams. About two years ago a hydraulic plant was placed on the bench claims previously mentioned, and has met with some success. [See Pl. XXXIV, B.] A head of about 300 feet is used in sluicing. The water supply during the season of 1904 was sufficient for all needs, but there was some trouble in getting water the previous year. ${ }^{1}$

A detailed description of this plant was given by Paige and Knopf ${ }^{2}$ as it was when visited by them in 1906, a season in which 50,000 cubic yards of gravel were moved by hydraulic methods. In 1911, as in previous years, hydraulic operations were continued on these bench gravels, nearly working out the rock-cut channel referred to above by Moffit, a channel about 650 feet long, 100 feet wide, and 30 feet deep, crossing a nose in the bedrock 150 feet above the level of the present winding channel and filled with horizontally stratified water-laid gravels. Considerable work was also done on the high bench gravels near the mouth of Pass Creek. Other much smaller hydraulic plants have been worked at intervals on some of the bench gravels on Canyon Creek between the above plant and "the forks." No work has been done in the creek bed for the last three or four years.

MILLA CREEK.

Mills Creek has yielded more gold than any other stream of the Turnagain Arm field except Canyon Creek, and is probably better known than any other stream. It is nearly 5 miles long, but the important known gold-bearing gravels extend only from the mouth of the creek to the mouth of Juneau Creek, a distance of three-fourths of a mile. * * * The channel is cut principally in gravels, for the waters have not yet greatly attacked the underlying slates and arkoses.

The upper portion of Mills Creek lies in a round-bottomed valley, covered with gravels and bare of timber. High gravel benches are seen near the mouth of Juneau Creek and * * * form the north wall of the canyon below that point. Minor gravel benches are present in the upper valley. * * * The stream gravels, as far as the writer could discover, were derived from the neighboring country rock from which they differ in no way. They comprise slates and arkoses with occasional bowlders of conglomerate, consisting of rolled quartz pebbles in a fine-grained slaty cement. $^{3}$

A few dark-gray impure limestone pebbles are also found. Practically no prospecting has been done on the high bench gravels, although those of the Triangle Bench, between Juneau and Mills 
creeks, are said to show fine gold. A little hydraulic work has been done on the lower benches. Moffit reported in 1904 that-

At the mouth of Juneau Creek * * * the work of the last two seasons has shown an old channel filled with gravels, the lower portion strongly cemented with iron oxide, resting on a tough ill-smelling blue clay. * * * Part of the gold is scattered through the brownish cement gravel, but the best pay lies on top of the blue clay. All the gold is heavy and flattened, but that from the cement gravel is the finer, averaging perhaps one-eighth inch in greatest diameter. Some of the larger nuggets found on bedrock are distinctly striated, as if rubbed against or dragged over a rough surface. ${ }^{1}$

In 1904, 1905, and 1906 work was carried on in this channel with the intention of tapping bench gravels in Juneau Creek. An open cut 650 feet long, 150 feet wide, and 100 feet deep was made with a small hydraulic plant consisting of 1,400 feet of 12-inch hydraulic pipe and a No. 1 giant piping into a flume 2 feet wide and 650 feet long. This cut, which is reported to have nearly paid for itself, had uncovered but a part of the old channel when operations stopped. Only assessment work has since been done.

But little active mining has been in progress on Mills Creek during the past few years. Moffit stated in 1904 that the canyon of Mills Creek had been once worked over, but that there still remained small areas, at least, sufficiently rich to pay for sluicing. ${ }^{1} \cdot \Lambda$ small amount of work has since been done on the canyon gravels, but in 1911 the few scattered creek placers being worked were all above the mouth of Juneau Creek, whereas below Juneau Creek more attention was being given to the gravels on the low benches in the canyon. On Mills Creek, a short distance above its junction with Canyon Creek, a hydraulic outfit using two giants, a No. 1 and a No. 2, piped off a small, low bench about 15 feet above the creek level. Four men were employed during a part of the season. Operations were discontinued late in August, when the water supply from Moose Creek became insufficient for hydraulicking.

EAST FORK.

East Fork is the larger of the two branches of Sixmile Creek. It has been worked only in the lower mile of its course, between the forks and the mouth of Gulch (reek. * * * This part of the strean lies in a shallow rock-walled canyon, cut through grits and arkoses, overlain by gravels. These gravels continue through the upper valley and appear as well-formed terraces in many places. None of these have been prospected.

The stream carries a larger body of water than Canyon Creek and the difficulties in handling gravels are the same as there. Wing dams are always necessary and china pumps run by the current are used to keep the pit dry. At the time of the writer's visit no mining was being done on East Fork. ${ }^{1}$

In the spring of 1908 and 1911 a little placer mining was done on the creek gravels, wing dams and china pumps being used, until high water stopped operations. 
SILVERTIP CREEK.

Silvertip Creek has not been an important gold producer and presents no features of special interest. The entire output probably does not exceed $\$ 4,000$. A hydraulic plant installed about a mile above the point where it joins East Fork did not prove successful, and the work was abandoned. ${ }^{1}$

Numerous attempts to work the creek gravels have been made since but always with like results. In 1911 the shallow creek gravels, 3 to 4 feet deep, about half a mile above the road crossing, were worked by a small hydraulic outfit. The work was carried on for about six weeks by three men using 6 -inch hose with a $2 \frac{1}{2}$-inch nozzle under a head of 60 feet. Sluicing began June 28, and ceased in August on account of insufficient water supply. The gold is reported to be similar to that from Gulch Creek, although the nuggets found are not so large. Most of the larger nuggets had quartz attached.

GRANTTE CREEK.

Granite Creek, one of the largest tributaries of East Fork, heads against Quartz Creek, and thereby furnishes easy communication with the upper part of Turnagain Arm. Some work, more in the nature of prospecting than of mining, has been done on this stream or its tributaries for a number of years. The valley of Granite Creek below Bertha Creek is from one-quarter to one-third of a mile wide, and in many places is wet and marshy. Gravel terraces are seen here and there and the whole region presents the appearance of having been occupied by a lake or series of lakes, possibly at no distant time. A hydraulic plant, in operation for the last two years at the mouth of Bertha Creek, has been fairly successful. Here there are from 8 to 10 feet of coarse gravel and bowlders covered by 4 to 5 feet of finer wash. The gold is mostly taken from the coarse gravel, but the whole mass averages about $\$ 0.15$ to the yard. Bedrock has not yet been reached. The gold is fine, bright yellow, and fairly smooth, the largest pieces being worth about 25 cents. ${ }^{1}$

No active mining has been in progress on this creek or its tributaries for several years.

\section{GULCH CREEK.}

Gulch Creek is a small stream joining East Fork 1 mile above the mouth of Canyon Creek. Like the majority of the streams in this region its lower course is through a narrow canyon. The gravel benches, such as are seen in the larger valleys, are also present but are not so prominent. The creek gravels are made up of material like the bedrock slates and arkoses and contain many large bowlders and angular blocks, usually arkoses rather than slate. The gold production [to 1905] is about $\$ 25,000$, nearly all of which was taken from the lower part of the creek by pick and shovel work. A hydraulic plant located three-quarters of a mile above the mouth of the stream proved unprofitable, and it was in operation during the season of 1904 only long enough to complete the assessment work. ${ }^{2}$

Hydraulic operations have been carried on each year on the bench gravels near the lower end of the creek. In 1911 two hydraulic outfits were employed. The smaller of these two outfits, which was in operation the entire season, was at work on a low bench about 
20 feet above the creek level, at the junction of Guich Creek and the East Fork. The gravels, which vary from 10 to 15 feet in thickness, rest on a smooth bedrock surface. They are very compact, have a clayey cement and contain a few clayey streaks, and are roughly stratified. The pebbles and bowlders include, besides the usual slate and graywacke, an assortment of crystalline igneous rocks. The equipment consisted of an 8-inch pipe with a $2 \frac{1}{2}$-inch nozzle. Water for the piping was collected from the hillside drainage on the north side of Gulch Creek by a ditch 4,000 feet long and 2 feet wide on the bottom. In the spring sufficient water is continuously available for a full pipe head, but later the supply decreases and the water is collected in a reservoir for use as required. The gravel is piped into two lead boxes and then into a string of nine 12-foot sluice boxes, 1 foot in width, set with pole riffles. The gold recovered is flat, smooth. and medium coarse to coarse, nuggets worth $\$ 70$ having been found, At the upper plant, the Dunfranwald gold mines, a short distance above the mouth of Gulch Creek, hydraulic operations were begun on high-bench gravels early in June and discontinued about August 15. This plant was not in operation when visited. The deposit worked consisted of horizontally stratified clayey gravels, very compact in places, with beds of sandy clay, resting in an old channel cut in the interbedded slate and graywacke. (See Pl. XXVI, B.) Most of the bowlders appear to be less than a foot in diameter. No data are at hand regarding the gold content of these gravels. Water for hydraulicking is obtained from Gulch Creek by a large ditch about threefourths of a mile in length. The gold-saving apparatus consisted of a string of 11 sluice boxes with 3-foot square cross section, laid on bedrock. The two head boxes and the lowest box of all were set with steel-capped wooden cross riffles with $1 \frac{1}{2}$-inch spaces. The next eight boxes were set with block riffles, those in the first four boxes having a square and those in the remaining four boxes a circular cross section. One box length from the lower end an undercurrent 6 feet widə by 12 feet long, fitted with wooden cross riffles with -inch spaces, was inserted.

LYNX CREEK.

Lynx Creek joins East Fork 7 miles above Canyon Creek, directly opposite the mouth of Granite Creek. It is about 3 miles long and occupies a narrow valley between high rugged mountains. Deep gravel deposits are found at the mouth of Lynx Creek and continue well into the valley. ${ }^{1}$

Besides the usual slates and graywackes, bowlders of altered diabase occur in the gravels.

The gold is heavy and is associated with numerous small nuggets of native copper. Gold nuggets worth 10 to 25 cents are common, and some worth $\$ 60$ to $\$ 70$ have been found. 
Two claims furnished most of the gold up to 1904. These were practically worked out and little actual placer mining has been done since.

Owing to the low grade of the lower part of the stream the gravels there have not been exploited. To overcome this difficulty a tunnel about 500 feet long and below the level of the water at its head is being driven to divert the stream. It is the intention to place sluice boxes in the tunnel and wash all the gravel through to the valley of Bench Creek. ${ }^{1}$

At the time of Paige and Knopf's visit to the creek in $1906^{2}$ this rock-cut tunnel, 600 feet long, 6 feet high, and 5 feet wide, had been completed: The cost was estimated at $\$ 10$ per running foot. Development work was continued in the following year, and by 1911 a 3-foot flume had been constructed in the tunnel and extended 300 feet beyond the tunnel mouth out on the Bench Creek flat. This flume is fastened to bedrock in the tunnel, has a 6-inch grade at the head of the flume and a 3-inch grade at the lower end, and is riffled with round 8-inch hemlock block riffles, set on end. The extension on the Bench Creek flat consists of a forked tailrace which afforded a larger area for the distribution of the tailings. (See Pl. XXXVIII, B.) The stream flat at the head of the tunnel, about a quarter of a mile above the mouth of the creek, has a width of about 300 feet, narrowing above and below. The gravels to be worked are reported to be from 15 to 30 feet thick. A dam near the head of the flat deflects the water of Lynx Creek to two large waste ditches, several hundred feet long, on opposite sides of the flat. A sluice head of water is allowed to flow down the middle of the flat to a bedrock flume of 8 boxes discharging into the tunnel. (See Pl.XXXVIII, A.) A No. 1 giant is used to wash the gravel into these boxes and also to work the derrick that removes the bowlders from the pit. Water is obtained from two or three small creeks on the mountain side north of Lynx Creek. A little oyer 1,000 feet of pipe line feeds the No. 1 giant under a 400 -foot head. Two sizes of nozzles-11 and 3 inches-are used. Bowlders are handled by derrick moved by a stream from the giant playing on a hurdy-gurdy wheel. (See Pl. XXXVI, B.) Actual hydraulicking operations were expected to start in 1912. 


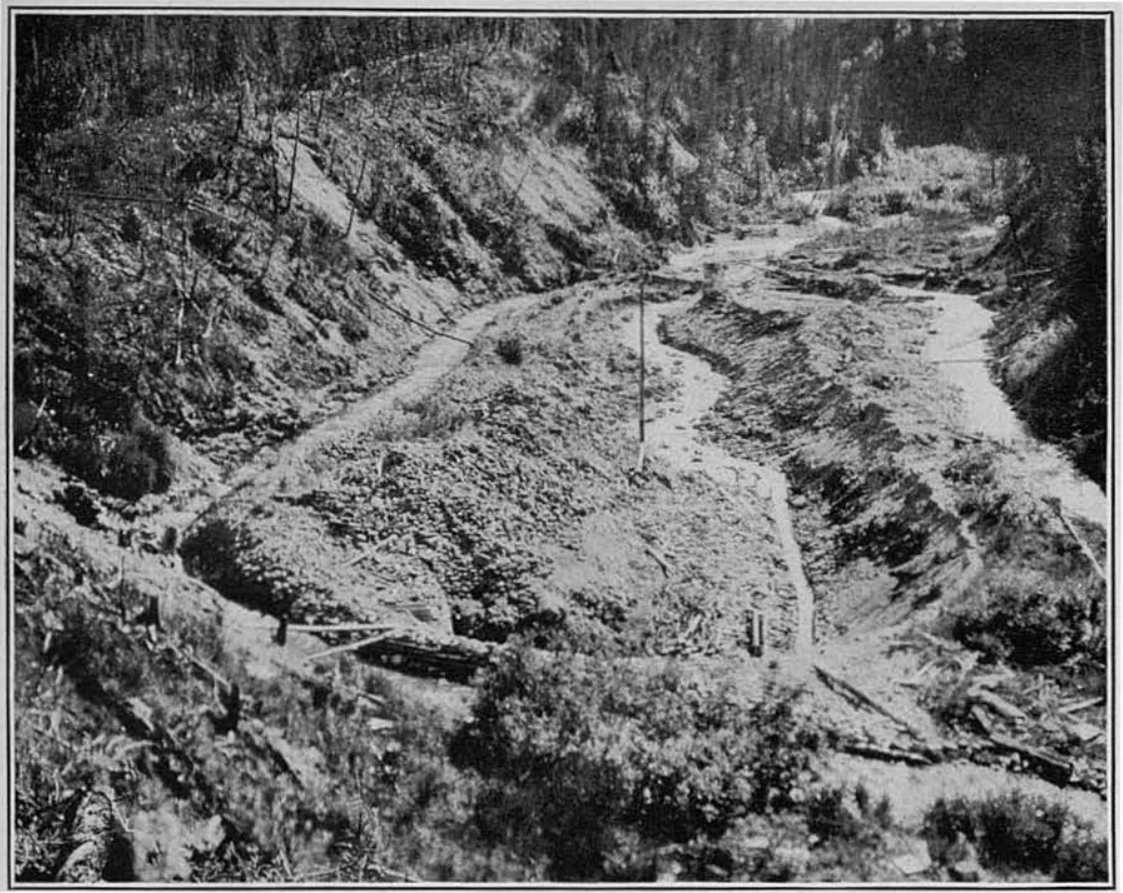

A. GRAVEL FLAT AT LOWER END OF LYNX CREEK

Shows method of handling the gravel.

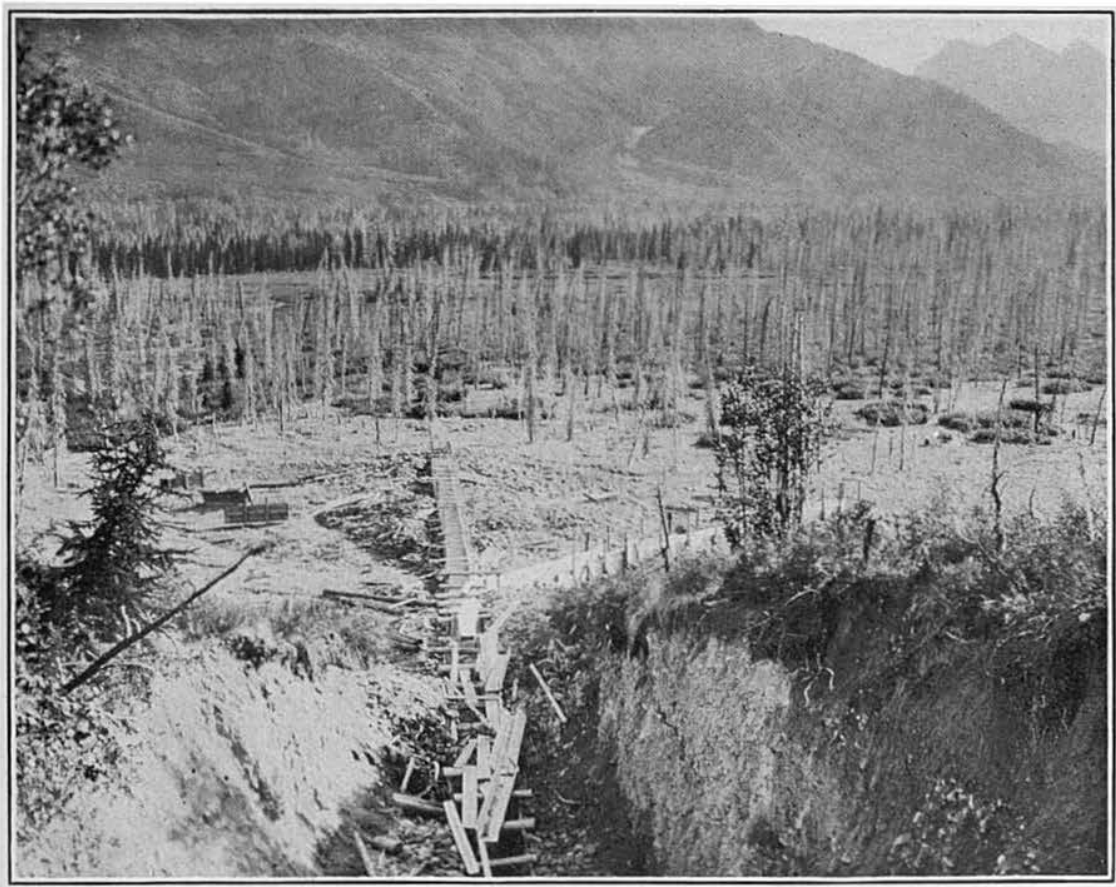

B. FORKED TAILRACE FOR SPREADING TAILINGS OVER THE BENCH CREEK FLATS AT LYNX CREEK.

Shows method of disposing of the gravel after it is brought through the tunnel from the locality shown in Plate XXXVIII, $A$, and also the character of the valley bottom and of the timber. 



\title{
THE SOUTHEASTERN COAST OF KENAT PENINSULA.
}

\author{
By U. S. Grant.
}

\section{GEOGRAPHY:}

The district here described, which includes principally the southeastern coast of Kenai Peninsula, extends from Passage Canal, on Prince William Sound, southward along the western shore of that body of water to Cape Puget, thence southwestward along the northwestern shore of Gulf of Alaska to Cape Elizabeth, and thence northward along the southeast shore of Cook Inlet to Point Bede. The extreme northern point of the district is in $60^{\circ} 48^{\prime}$ north latitude and the extreme southern point is in $59^{\circ} 6^{\prime}$ north latitude. The district is included between $147^{\circ} 57^{\prime}$ and $152^{\circ}$ west longitude.

The eastern and southern shores of Kenai Peninsula are extremely irregular in outline, having many small and large embayments, the longest of which is Resurrection Bay. The shore line-in fact, the whole region-is rocky and highly mountainous. The topographic features were produced by stream erosion and were later modified by glacier erosion, and the region has been partly submerged in the sea. Mountains near the coast rise to heights of 2,000 to 4,000 feet, and in places to more than 5,000 feet. Glaciers come to tidewater at the heads of some of the deep bays and other ice streams end at various levels above the sea. A few miles back from the shore lie extensive ice fields. (See p. 25.)

There are few settlements in this region. Seward, at the head of Resurrection Bay, is by far the most important town. It is the ocean terminus of the Alaska Northern Railway and is a starting and stopping point for travel to and from the interior of Alaska. Alexandrovsk is a native settlement on English Bay near Port Graham, close to the southeastern entrance to Cook Inlet. Port Graham, on the inlet of the same name, is a transfer point for steamers. Seldovia is a white and native village on the northeastern shore of Seldovia Bay. Alexandrovsk and Seldovia are old settloments, dating back to the Russian occupation of Alaska.

Aside from these settlements the eastern and southern coasts of Kenai Peninsula are entirely uninhabited, being visited only by a few prospectors and hunters and by roving parties of natives during the summer months. 


\section{GENERAL FEATURES OF THE GEOLOGY.}

The rocks of the southeastern coast of Kenai Peninsula (see Pl. III) can be separated into the divisions described below, which are arranged in general from northeast to southwest, the arrangement probably following closely the order of age of the different formations, the oldest being described first.

1. Highly folded slates and graywackes and small amounts of other sediments, and possibly a few contemporary igneous rocks, extend from Passage Canal, on Prince William Sound, southward and westward as far as the head of Day Harbor. They do not occur on much of the peninsula that separates Day Harbor from Resurrection Bay, but they form the main part of the coast line from Resurrection Bay southwestward to Nuka Island Passage. These rocks are of unknown age. They probably include rocks as old as the Triassic and possibly much older.

2. Greenstones form the peninsula between Resurrection Bay and Day Harbor and also Renard Island, in the mouth of Resurrection Bay. These rocks consist to a large extent of basic igneous material, of which surface flows and other associated basic surface and intrusive rocks form a very large part. Interbedded with the greenstones are smaller amounts of sediments, such as slates, graywackes, and waterdeposited tuffs.

3. Tuffs, graywackes, and slates occur in close association with the greenstones on the west shore of the peninsula between Day Harbor and Resurrection Bay, and also on some of the islands in Resurrection Bay. These rocks, together with the greenstones just described, are possibly the equivalent of the Orca group of Prince William Sound.

4. A formation consisting essentially of slates and graywackes, with which are associated small amounts of conglomerates, extends from the southern part of the west side of Nuka Island Passage southward along the coast line past Port Dick, Rocky Bay, Windy Bay, and Chugach Bay, and ends immediately north of Pearl Island, the central one of the Chugach Islands. The slates are commonly black and constitute the main part of the formation.

5. These rocks are succeeded by a series of slates, graywackes, and limestones, with which are associated considerable quantities of basic igneous rocks and some ellipsoidal greenstones. Banded black, green, and white cherts, and rarely red cherts, also occur in this formation, which extends from the west side of Nuka Island Passage southward and westward to the extreme southern point of Kenai Peninsula and thence norrthward along the bays that indent the eastern coast of Kachemak Bay.

6. The next formation in chronologic order consists of Upper Triassic limestone and stratified tuffs, with cherts, slates, limestones, and basic igneous rocks. Black slates and black limestones are 
characteristic of this formation, and the limestones carry fossils of Upper Triassic age.

7. Lower Jurassic tuffs consisting mainly of stratified tuffs with smaller amounts of other sediments and considerable quantities of contemporary basic lava flows, occupy the coast line of Kenai Peninsula from near Point Bede northward to the southern shore of Seldovia Bay. They contain a considerable fauna of Lower Jurassic age.

The several slate and graywacke formations have been much disturbed and are intricately folded and in places faulted. The unmetamorphosed rocks which carry Mesozoic fossils have also been deformed but by no means so much as the older formations.

All these formations are cut by dikes and other intrusive masses, which are described below (p. 228).

\section{DETAILS OF 'THE GEOLOGY.}

METAMORPHIC ROCKS.

\section{HIGHLY FOLDED GRAYWACKE AND SLATE EAST OF NUKA ISLAND PASSAGE.}

\section{GENERAL FEATURES.}

East of Nuka Island Passage there are beds of graywacke and slate associated with minor amounts of quartzite, conglomerate, and fine-grained black limy slate. The graywacke and slate alternate in bands of various thicknesses, but the graywacke is commonly more prominent and occurs in thicker and more massive beds, and in some localities, as along the coast from Passage Canal to Port Bainbridgo, forms most of the exposures. The slates are black to gray, commonly black, and have not generally the perfect cleavage of roofing slate. The graywackes are composed largely of angular grains of quartz and feldspar set in a finer-grained paste or matrix. The graywackes and slates that lie near granitic intrusions have become schistose by the development of numerous biotite scales, which impart to the rocks a reddish tint. At a few localities "knotenschiefer" have been developed near granite contacts.

These rocks are widely distributed on the eastern and southern shores of Kenai Peninsula. Except a few small areas that are occupiod by granite, these slates and graywackes occupy the shore line from Passage Canal, at the northeastern extremity of Kenai Peninsula, southward along the west coast of Prince William Sound to Cape Puget, from which point they extend westward to Day Harbor. They also occur on the west side of Resurrection Bay and, except in areas near Aialik Bay and Pye Islands, occupied by granite, they form the shore from Resurrection Bay southwestward to Nuka Bay and Nuka Island. A very few exposures of them are found also on the west side of Nuka Island Passage. Details of their exposure are given elsowhere. 
These rocks are intricately folded and are frequently faulted. The complexity of the folding is in places very marked, and complete details of structure in such places are difficult to determine. Areas of folding similar to those shown in figures 42 and 43 (p. 216) are common. The main axes of this folding run north or a little east of north, corresponding in general with the trend of the main axis of Kenai Peninsula. These folds are generally overturned toward the east, so that the beds on large parts of the coast show monoclinal dips at high angles toward the west. Folding in other directions has undoubtedly taken place, but its details have not been worked out, though it is obvious that the axes of many of the folds pitch north or south. In general the dip of these rocks is steeper in their more easterly exposures and becomes less steep toward the west. In general also the hardness and metamorphism of these rocks decrease slightly from east to west.

As will be shown elsewhere (pp. 220-221) these rocks include at least two unconformable series of beds, as is shown by the presence of conglomerates that include well-rounded and well-indurated pebbles of the subjacent rocks. An unconformity of this kind was noted on the west side of the east arm of Nuka Bay and is described in detail on page 220. Here a series of slates and graywackes with rather steep dips is overlain, apparently with unconformity, by another series of slates and graywackes of similar lithology. At the base of the upper series is a conglomerate containing well-rounded pebbles of slate and graywackes, which can be matched in the rocks exposed close at hand. This later series occupies most of the peninsula between the east arm of Nuka Bay and Surprise Bay and very likely occupies much of the shores of the western arms of Nuka Bay and of Nuka Island. The upper series of rocks in this vicinity is less elosely folded than the lower. The large group of graywackes and slates here mapped as a unit can be separated into at least two unconformable formations, but the details of this separation and the separate mapping of the older and the younger rocks will require more careful and thorough work than has yet been possible, so in this report no attempt has been made to separate them.

SPECIAL LOCALITIES.

PASSAGE CANAL, BLACKSTONE AND COCHRANE BAYS.

At Point Pigot, on the north side of the entrance to Passage Canal, Prince William Sound, the rocks are more quartzose than usual and resemble in hand specimens fine-grained gray quartzites. In thin section, however, they are seen to be part of the common graywackes of this vicinity, the quartz appearing in sharply angular grains. The rocks at this point strike in general north-northeast and dip eastsoutheast at an angle of $55^{\circ}$. North of Point Pigot there are a few 
small folds, 4 to 10 feet across, whose axial planes are parallel to the above strike and dip. The axes of these folds pitch $10^{\circ}-15^{\circ} \mathrm{NNE}$. Farther west on Passage Canal the strike and dip vary, but in general the strike is northeast and the dip about $70^{\circ} \mathrm{NW}$. The upper half of the canal lies almost directly parallel with the strike of the rocks, which here consist largely of graywackes, but include some slates. These graywackes are in places notably schistose, the cleavage agreeing approximately with the general strike and dip. The rocks are evidently in closely compressed folds, which have been overturned to the southeast.

A dike of fine-grained granitoid rock cuts the graywackes on the south shore of the canal near its head, and two similar dikes occur on the north shore about 2 miles west of Point Pigot. On the north side of Passage Canal is a mass of granite. ${ }^{1}$

The usual graywackes and slates occur about the shores of Blackstone Bay, Prince William Sound, and the southeast shore of this bay is essentially parallel to the strike of these rocks. They are mainly graywackes, in places schistose, and their general strike and the strike of the planes of cleavage is northeast. The rocks dip toward the northwest at varying angles, commonly about $60^{\circ}$. The folds are thus overturned to the southeast. Statements similar to the above can be made concerning Cochrane Bay and the rocks along its shores. Near the mouths of both of these bays, as well as near the mouth of Passage Canal, the dip and strike are more variable and the shore line does not so closely correspond to the strike of the rocks.

PORT NELI.IE JUAN TO PORT BAINBRIDGE.

The shores of Port Nellie Juan, Prince William Sound, contain many exposures of graywacke and slate, mainly graywacke, which is coarse grained, is usually in heavy beds, and in a number of exposures is so massive in appearance that the dip and strike can be determinod only with much difficulty or not at all. The southwestern part of Port Nellie Juan is bounded, especially on the east, by this heavy bedded graywacke, and the axis of this part of the port is approximately parallel with the strike of these beds. This upper stretch of Port Nellie Juan has probably been cut out of less resistant bedsthat is, the slates are probably more abundant here than on the shores, and this depression extends north-northeast across a low pass to Cochrane Bay and through Port Wells and College Fiord, a distance of 56 miles at sea level. This long depression is continued for an unknown distance northeastward in the valley occupied by Harvard Glacier and to an unknown distance southwestward beyond the head of Port Nellie Juan. ${ }^{2}$

1 Grant, U. S., and Higgins, D. F., Reconnaissance of the geology and mineral resoures of H'rince William Sound, Alaska: U. S. Geol. Survey Bull. 443, p. 3s, 1910.

2 Idem, p. 1ti. 
Between Port Nellie Juan and Eshamy Bay the coast line is composed of the same graywacke and slate, mainly graywacke, but was not examined in detail. The shores of the main or western part of Eshamy Bay is formed of the same rocks, but the south shore is cut by many granite dikes, which are offshoots from the Eshamy granite, a rock that lines the shores of the southeastern arm of this bay.

Granite Bay lies mostly in the Eshamy granite mass, but parts of its southern shore are composed of graywacke. Paddy and Ewan bays are also lined with graywacke and a little slate, which are altered and harder near the granite mass that lies between these two bays.

At the entrance to Jack Pot Bay is a little black and gray slate in the graywacke, striking N. $27^{\circ} \mathrm{E}$. and dipping $80^{\circ} \mathrm{W}$.; and the east shore of this bay is composed of a massive ridge of graywacke. At the head of the bay is black slate, and this easily eroded rock has probably influenced or determined the position of the bay itself, its axis being parallel to the strike of the beds. A gold-bearing quartz vein, described in another part of this report, occurs on the east side of Jack Pot Bay.

The shores of Icy Bay were not carefully examined, but the rocks where seen consist of rather massive graywacke and minor amounts of black or gray slate. The rocks on the northwest shore of this bay contain several iron-stained zones, two of which were examined and found to be beds of black slate holding ninute veinlets of pyrite.

The mountains separating the two arms of Whale Bay consist of slate and graywacke dipping about $40^{\circ}$ ENE. The small island lying on the west side of the western arm of this bay is composed of rather massive graywacke carrying a few concretionary bodies which weather brownish and probably consist mainly of curbonates of iron and lime. The dip of the rocks here is $65^{\circ} \mathrm{W}$. The promontory at the entrance to the bay, on the northwest side of this arm, shows a very large dip slope of graywacke dipping $38^{\circ} \mathrm{S} .37^{\circ} \mathrm{E}$. This slope and others in the vicinity are covered with lichens, which give a brick-red or purplish-red color to the rocky hillsides.

The northwest shore of Bainbridge Passage is composed of slate and graywacke, which about three-fourths of a mile northeast of the southwest entrance to the passage occur in rather open folds whose axes strike north-northwest.

The northern part of Port Bainbridge has many outcrops of graywacke and slate, the graywacke being more abundant and generally occurring in heavy beds. On the west shore of this port, about 3 miles north of Cape Puget, is an extensive exposure of clay slate, black to gray, and graywacke, which occurs in beds 1 to 15 feet in thickness. The strike here is N. $27^{\circ} \mathrm{E}$. and the dip is $50^{\circ} \mathrm{W}$. The graywacke contains numerous seams of quartz. The same rocks, with approximately the same dip and strike, extend southward for a mile from 
the locality above indicated and northward for 2 miles to a point where the graywacke becomes more prominent. In general slate predominates on the western shore of Port Bainbridge from Cape Puget to a point within $1 \frac{1}{2}$ miles of Bainbridge Glacier, but beyond this point graywacke is the dominant rock. Cape Puget itself, however, is made la: gely of resistant beds of graywacke.

CAPE PUGET TO DAY HARBOR.

The geology of the shore line between Cape Puget and Day Harbor has not been described. The shore is exposed to the full sweep of the waves of the Pacific, is rough and inhospitable, contains great rock cliffs, and affords few places at which a landing can be made in ordinary weather. The following notes were made in a hurried trip along this shore line on July 11, 1909:

The rocks on the eastern side of Puget Bay, near its entrance, consist of graywacke and slate, which dip $60^{\circ}-70^{\circ} \mathrm{W}$. The same rocks continue northward on the eastern shore of the bay, but the dip becomes less steep, in places as low as $20^{\circ} \mathrm{N}$. or NW., and the strike swings gradually eastward until, at the north end of the bay, where the rock is chiefly graywacke, the strike is east and the dip is $40^{\circ} \mathrm{N}$. The western shores of Puget Bay present outcrops of the same slate and graywacke. In general, these rocks occur in about equal amount on this bay and are closely interbedded, the beds varying from 1 to 40 feet in thickness. The slate is generally black, although in places it is gray. The rocks are hard, compact, and closely folded.

At Cape Junken and for about 3 miles northeastward the shore line is made of great cliffs of graywacke and slate, striking about N. $13^{\circ}$ E. and dipping $45^{\circ}-60^{\circ} \mathrm{W}$. About $2 \frac{1}{2}$ miles northeast of this cape is a marked syncline, some 300 feet across, closely compressed and overturned toward the east. The pitch of the axis of this syncline is not evident. Two miles northeast of the cape is an anticline 500 feet across, pitching $45^{\circ} \mathrm{S}$. Some idea of the intricacy of the folding and the complexity of the structure along this coast can be gained from the accompanying sketch section (fig. 43), which is about 2 miles in length and extends from the western entrance of Puget Bay southwest toward ('ape Junken. This section and another (fig. 42) were drawn from some of the exposures of less deformed rocks; many other exposures show much more complexity in structural details.

West of Cape Junken the rocks are closely folded and the accompanying sketch (fig. 42) represents the shore from this point westward for 1 mile. Interbedded with the slate and graywacke at a place $1 \frac{1}{2}$ miles northwest of Cape Junken is a layer that may be greenstone. About 3 miles northwest of Cape Junken is a bold shore showing nearly vertical heavy beds of graywacke, slate, and possiblygreenstone, in isoclinal folds. A landing was made in the bay just 
northwest of this point, but no greenstone was found either in place or as pebbles. The rock here is the usual slate and graywacke, striking N. $18^{\circ} \mathrm{E}$. and dipping $80^{\circ} \mathrm{E}$. The western shore of Johnstone Bay and the eastern shore of Whidbey Bay are composed of graywacke and slate that have a general northeasterly strike and a dip of $60^{\circ}-80^{\circ} \mathrm{NW}$. At Cape Fairfield slate is more prominent, the rocks are closely and intricately folded and faulted, and there are several closely compressed folds with axial planes parallel to the general dip and strike just given.

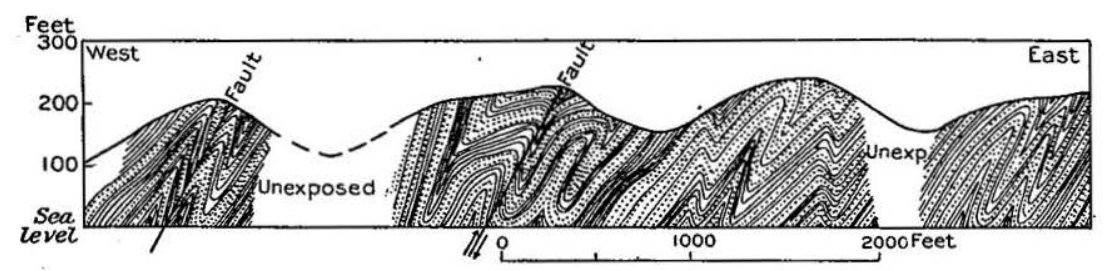

FigURE 42.-Sketch showing structure along shore westward from Cape Junken. By D. F. Higgins.

About a mile and a half northeast of Cape Mansficld the slate and graywacke are cut by a dike, probably of greenstone, about 50 feet wide, striking $\mathrm{N} .28^{\circ} \mathrm{E}$. and dipping $80^{\circ} \mathrm{W}$. On the west side of the dike small stringers run out into the slate, which here strikes $\mathrm{N} .13^{\circ}$ E. and is vertical. From this point to Cape Mansfield the rocks are mainly slate. From Cape Mansfield to Day Harbor there are many exposures of slate and graywacke, the slate being more abundant. The strike in general is northeasterly and the dip is $70^{\circ}-80^{\circ} \mathrm{NW}$. The rocks along this part of the coast are much fractured.

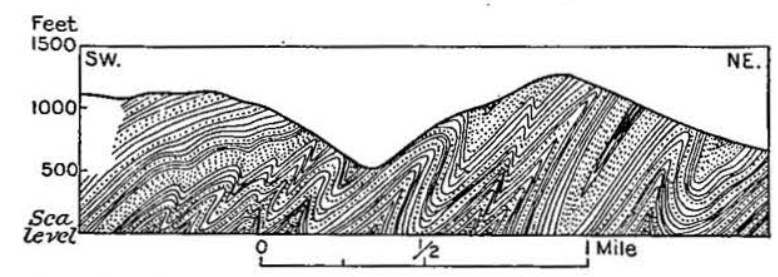

FraURE 43.-Sketch showing structure between Puget Bay and Cape Junken. By D. F. Higgins.

On the east side of Day Harbor, about 3 miles north of the entrance to the harbor, the graywackes and slates strike N. $48^{\circ}$ E. and are practically vertical. The same kind of rocks, having approximately the same dip and strike, extend northward to the north end of Day Harbor. Excelsior Glacier, at the head of this harbor, has brought down fragments of graywacke and slate, but no fragments of greenstone were seen. On the northwest shore of Day Harbor, about 4 miles from the northeast corner of the harbor and just west of a small promontory, is an exposure of slate and graywacke striking N. $33^{\circ} \mathrm{E}$. 
and dipping $80^{\circ} \mathrm{W}$. Just west of this come in the igneous rocks that are correlated with those of the Orca group, described elsewhere (p. 223). The junction of the slates and graywackes here described with the igneous rocks (greenstones) on the northwest side of Day Harbor probably lies along a fault whose downthrow is on the west or greenstone side of the fault plane.

RESURRECTION BAY.

Southwest of the wharf at Seward are exposures of graywacke, commonly coarse grained and massive, and a small amount of darkgray slate. The bedding is not distinct, but the strike is apparently north and south and the dip is about $65^{\circ} \mathrm{W}$. The same rocks continue southward nearly to Lowell Point. Rather soft, fissile, black to gray slates occur a quarter of a mile south of the base of this point. The strike of the bedding and cleavage is N. $7^{\circ} \mathrm{E}$.; the dip is $75^{\circ} \mathrm{W}$. The same rocks, with a few more resistant beds of graywacke, extend southward to Caines Head with approximately the same strike and dip. Farther south, between Caines Head and Bear Glacier, there are slates and some graywackes, having a general strike of $\mathrm{N} .16^{\circ} \mathrm{E}$. and a dip of $55^{\circ}-70^{\circ} \mathrm{W}$. The point at the east side of the bay in which this glacier lies is made of heavy beds of graywacke. The rocks along the above coast line south of Seward apparently lie in folds that are overturned to the east. These rocks closely resemble those along the coast from Cape Puget to Day Harbor. They contain a few beds that weather rusty because they contain an abundance of pyrite. The western shore of Resurrection Bay from Seward to Bear Glacier lies in general parallel to the strike of the rocks, and the headlands are formed of beds of more resistant graywacke.

South of Bear Glacier are slates and graywackes, which in general strike north or north-northeast, and dip steeply westward and eastward. The slates are in many places iron stained and the graywackes become brownish or reddish as they approach the granite. This rock comes in where the peninsula between Resurrection and Aialik bays is very narrow, about 4 miles northwest of Cheval Island, and continues southward to Cape Aialik.

The east shore of Resurrection Bay north of Thumb Cove was not examined, and it is not certain whether the rocks are the slates and graywackes now being described or the younger graywacke and slate associated with tuffs which occur south of Thumb Cove. (See p. 225.) Moffit ${ }^{1}$ states that several massive quartzite beds, 4 to 6 feet thick, are conspicuous in the vicinity of the Godwin Glacier, about 2 miles east of Resurrection Bay. The beds here lie in immense folds, which are slightly overturned toward the east.

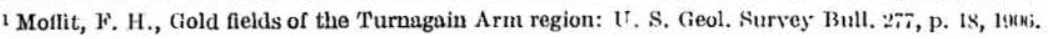


AIALIK BAY.

On the east side of Aialik Bay the southernmost exposures of these slates and graywackes occur at the north entrance to the small bay directly west of Agnes Cove, where the slates and graywackes strike N. $5^{\circ} \mathrm{E}$. and $\operatorname{dip} 70^{\circ} \mathrm{W}$. Near the northeast corner of this bay the graywacke, which occurs in beds 6 inches to 3 feet thick, and is reddish, lies in contact with granite. The strike here is N. $2^{\circ} \mathrm{E}$. and the dip is $60^{\circ} \mathrm{W}$. The shores of the bay just north of this one are made of graywacke and slate, except in three small areas at the head of the bay, where granite outcrops. From this bay northward to the head of Aialik Bay the coast line, except at two small places where granite is exposed, is made of graywacke and varying amounts of black slate. The graywacke is fine to medium grained and is gray to brownish red, the latter color being due to the development of minute flakes of biotite, which are especially abundant near the granite contacts. The general strike along this shore line is north and the dip is $65^{\circ} \mathrm{W}$. to $90^{\circ}$.

Squab Island, near the north end of Aialik Bay, is composed of graywacke and slate, much contorted and fractured, the fragments of graywacke being included in the slate, which was evidently in or near the zone of flowage when the more resistant rock was fractured. The general strike is N. $4^{\circ} \mathrm{W}$. and the dip is $80^{\circ} \mathrm{E}$. The north end of Slate Island is made of similar rocks. The west shore of Aialik Bay, opposite Slate Island, is composed of apparently much softer rocks-slate with some graywacke, which are crumbling and disintegrating under the effects of the weather. These less resistant rocks extend northward to the southwest side of the front of Aialik Glacier and can also be seen on the northwest side of this glacier about a mile from its front. The strike along the shore west of Slate Island varies from N. $15^{\circ} \mathrm{E}$. to N. $15^{\circ} \mathrm{W}$., and the dip from $70^{\circ}$ to $80^{\circ} \mathrm{W}$. near the water's edge, but higher up on the hillside the dip is considerably less. This difference in dip is probably due to hillside creep. When examined in hand specimen the rocks do not differ from the usual slate and graywacke of the district except for the fact that the slate is somewhat softer, is much fractured, and is in larger amount than the graywacke. About the center of the west side of Slate Island is the same soft, fissile, crumbling slate, with harder slate and graywacke on both sides of it. The strike here is $\mathrm{N} .15^{\circ} \mathrm{W}$. and the dip is $80^{\circ} \mathrm{W}$.

The west shore of Aialik Bay from Pedersen Glacier southward for 2 miles is composed of somewhat crumbling graywacke and slate. The end of the point at the north entrance to Holgate Arm is made of graywacke striking $\mathrm{N}$. $65^{\circ} \mathrm{W}$. and dipping $60^{\circ} \mathrm{N}$. The shores of Holgate Arm are eomposed of graywacke and slate, the graywacke rather fine grained and reddish. The general strike is north- 
northwest and the dip is $55^{\circ}-75^{\circ}$ WSW. On the north side of this arm a mile east of Holgate Glacier the graywacke holds concretionary masses of fine-grained, hard, gray siliceous rock. These masses are flattened in the plane of the bedding and are 2 to 24 inches long and 1 to 3 inches thick. They probably represent calcareous concretionary masses altered by the adjacent granite. Graywacke and slate make the shore line from Holgate Glacier southward to the head of the small bay directly west of Agnes Cove of Resurrection Bay, where granite comes to the shore. South of this point to a place opposite the north end of Harbor Island graywacke and slate outcrop on the headlands between the small bays, and granite outcrops in the bays.

HARRIS BAY TO PYE ISLANDS.

The only sedimentary rocks on the east side of Harris Bay occur in a small area at the northeast side of the front of Northwestern Glacier. On the west side of this bay, about a mile south of the glacier, is a small island composed of somewhat hardened reddish graywacke and a little slate. The strike is north and south and the dip is $70^{\circ} \mathrm{W}$. Two miles south of this island is a steep bluff of crumbling slate. The dip here at the water's edge is $70^{\circ} \mathrm{W}$., but higher up on the bluff the dip is lower $-30^{\circ}-50^{\circ} \mathrm{W}$. This change in dip is probably due to hillside creep. Between this locality and Two Arm Bay there is slate and graywacke, in places crumbling under the weather. The general strike is north and south and the dip is $60^{\circ}-75^{\circ} \mathrm{W}$. The rocks along this shore are closely folded and in places faulted, and the folds are overturned to the east.

The east shore of the eastern arm of Two Arm Bay is composed of slates and graywackes, which in general strike north-northwest and dip steeply both to the east and to the west. Here there are several noticeable anticlines and synclines, whose axes have the strike just mentioned. At the south base of the sand pit, about a mile from the north end of this arm, the graywacke contains some gray, rustyweathering, concretionary masses. About the head of this bay steep) mountains, composed apparently, except for one small mass of granite, of slates and graywackes, rise 3,000 to 4,000 feet above the sea. On the west side of this arm the strike is also approximately north-northwest and the dip is at high angles toward the west. The shores of the west arm of Two Arm Bay are composed of graywacke and slate, mainly graywacke, and toward the heal of the bay a few of the graywacke bands have been altered to "knotenschiefer." Many loose blocks of this peculiar schist are found about the head of this arm. It is probable that a large granite mass that has altered these rocks lies not far below the surface, although no outcrops of granite except three small dikes were scen in this vicinity. The bold bluft at the west entrance to Two Arm Bay, as seen from the 
boat, is of graywacke and slate, intricately folded and faulted. The structure is not fully apparent, although there are at least two large synclines and two anticlines. The general strike is north-northwest and the dip is $65^{\circ} \mathrm{W}$. The folds are overturned toward the east.

The shore between Two Arm Bay and the next bay to the southwest is composed of graywacke and black slate in the proportion of about 2 to 1 . The graywacke beds are commonly 10 to 30 feet thick. The general strike is north-northwest and the general dip is $60^{\circ} \mathrm{W}$. Here there are several folds, which are overturned toward the east, their axial planes being about horizontal. On the west side of this bay granite is overlain by the sediments. The point at the southwest side of this bay on which Black Mountain stands is composed of graywacke and slate which in general strike northeast and dip $60^{\circ} \mathrm{SE}$., although in a few places the dip is westward. This shore exhibits extensive bare dip slopes 100 to 1,000 feet in height.

NUKA BAY.

Graywacke and some slate occur on the headlands that separate the smaller bays on the east shore of the east arm of Nuka Bay, but the larger part of the shore of these small bays consists of granite. The graywacke is hard, is generally reddish, and is cut by granite dikes. In places the graywacke has been altered to "knotenschiefer." The general strike is north and the dip is toward the west at high angles.

On the east side of James Lagoon there is slate and fine to medium grained graywacke, striking north and south and dipping. $30^{\circ} \mathrm{W}$. The same rocks occur on the southwest side of this lagoon and continue southward for .a mile from McCarty Glacier. In general the strike is north-northwest and the dip is $50^{\circ}-60^{\circ} \mathrm{W}$. Still farther south (along the west shore of the east arm of Nuka Bay) for 2 miles there are exposures of crumbling black slate, beyond which graywacke and slate come in and extend southward to a small stream near which two notable rock stacks occur at the shore. At this place the strike is $\mathrm{N} .10^{\circ} \mathrm{W}$. and the dip is $75^{\circ} \mathrm{W}$. A large talus cone here contains many fragments of a conglomerate and coarse-grained massive graywacke, which also forms the matrix of the conglomerate. Many of the pebbles are composed of black slate, some of fine-grained graywacke, and a few of quartz. No exposures other than slate and graywacke occur on this small stream within a third of a mile of its mouth.

From the locality last described the graywacke and slate continue southward for 2 miles, or about 6 miles from McCarty Glacier. The general strike is a little more westward than the trend of the coast line, and the dip is $35^{\circ}-55^{\circ} \mathrm{W}$. Near this place, which is $1 \frac{1}{2}$ miles north of the point at the west entrance to the east arm of Nuka Bay, the slate and graywacke, striking N. $15^{\circ} \mathrm{W}$. and dipping $30^{\circ} \mathrm{W}$., are overlain by conglomerate. The contact between the two formations 
is exposed in an inaccessible cliff and, except for a few small faults, appears to be parallel to the bedding of the underlying slate and graywacke. The conglomerate is 25 feet thick and some of the pebbles in its lower part are 1 foot in diameter. The pebbles higher up are smaller. Above the conglomerate is slate and graywacke and about 60 feet higher is another bed of conglomerate. Near this cliff are many fragments of conglomerate, whose matrix is graywacke, and whose pebbles are commonly well rounded and from 1 to 8 inches in diameter. The most abundant pebbles are of graywacke and a grayweathering black slate which contains considerable calcite. A collection of these pebbles shows that they are composed of quartz, finegrained quartzite, fine-grained dark limy slate that weathers gray, coarser-grained dark limy slate that weathers brown, coarse and fine grained graywacke, fine-grained gray compact quartz porphyry, and fine-grained gray compact quartzless porphyry. All these pebbles, except those that are formed of igneous rocks, can be matched in exposures in this vicinity.

One-eighth of a mile south of the locality last described there are exposures of similar conglomerate lying on the slate-graywacke formation, which here strikes N. $10^{\circ} \mathrm{W}$. and dips $15^{\circ}-20^{\circ} \mathrm{W}$. The conglomerate has a similar dip and strike, and the contact between this rock and the slate and graywacke is parallel to the bedding of the lower formation except for a small distance. This conglomerate bed is 20 feet thick. Its largest pebbles lie near the center of the bed, and the pebbles are similar to those already noted. Rows of brownweathering limy concretions occur in the slate-graywacke formation.

South of the last locality to the end of the point at the west entrance to the east arm of Nuka Bay slate and graywacke occur, striking north and south and dipping $20^{\circ}-45^{\circ} \mathrm{W}$. Conglomerate and slate and graywacke occur on the end of the promontory between the east and north arms of Nuka Bay; the strike is north and the dip is $55^{\circ} \mathrm{W}$.

Along the above coast line are a few small normal strike faults, with downthrow on the west. The largest throw noted was 10 feet.

The northwest end of the island in the mouth of Surprise Bay is composed of graywacke and slate, striking N. $35^{\circ} \mathrm{W}$. and dipping $25^{\circ} \mathrm{W}$. In the cove southeast of this island is black slate, striking N. $5^{\circ} \mathrm{E}$. and dipping $75^{\circ} \mathrm{W}$. A mile northeast of this island is graywacke and slate, the graywacke forming several beds that contain pebbles of gray slate of all sizes, the largest an inch in diameter. The strike is north-northwest; the dip is $75^{\circ} \mathrm{W}$. to $75^{\circ} \mathrm{E}$.

The other shores of Surprise Bay, the shores of the north arm of Nuka Bay, the shores of Yalik Bay, and the north shore of Nuka Island Passage exhibit many exposures of graywacke and slate, the graywacke at many places carrying brown weathering limy secretions. The strike varies from N. $25^{\circ} \mathrm{E}$. to N. $25^{\circ} \mathrm{W}$., and the dips are com- 
monly westerly at angles of $10^{\circ}-75^{\circ}$. The rocks of the localities mentioned above are lithologically very similar to the slate-graywacke series farther east, but as a rule are somewhat less closely folded and somewhat less metamorphosed. The westernmost exposures of the slate and graywacke on the shores just mentioned are at the south end of the rocky knob at the front of the Yalik Glacier. Here the strike is north and south and the dip is $65^{\circ} \mathrm{W}$

The west and south sides of Nuka Island are composed of slate and graywacke, the graywacke predominating on the west side of the island and the slate on the east side. The strike is very constantly N. $5^{\circ}-15^{\circ} \mathrm{E}$., and the dip is very generally $50^{\circ}-70^{\circ} \mathrm{W}$. Easterly dips are rarely seen. The north and east sides of this island were not carefully examined, but the rocks appear to be entirely slate and graywacke except for a few small acidic dikes.

\section{AGE AND CORRELATION.}

The only fossils yet found in these rocks consist of worm tubes obtained on the shores of the small cove southeast of the island in the mouth of Surprise Bay and at the head of Yalik Bay, both forming parts of Nuka Bay. The fossils were found in beds which probably lie above the unconformity described on pages $220-221$ and have been determined by T. W. Stanton as follows:

6378 (G608). Small bay east of island at east side of entrance to middle arm of Nuka Bay. Lat. $59^{\circ} 28^{\prime} 34^{\prime \prime}$, long. $150^{\circ} 30^{\prime} 40^{\prime \prime}$.

6379 (G609). South end of beach at head of Yalik Bay, western part of Nuka Bay. Lat. $59^{\circ} 27^{\prime} 56^{\prime \prime}$, long. $150^{\circ} 40^{\prime}$.

The only species in these two lots is the obscure tube which Ulrich describes as Terebellina palachei from the Yakutat group, the age of which is still uncertain.

The writer believes that these rocks are the equivalent of at least part of the Sunrise group which was first described by Mendenhall ${ }^{1}$ from exposures seen on the shores of Passage Canal and Turnagain Arm and in the district between Seward and this arm. Moffit ${ }^{2}$ later described rocks of the same group from the interior of Kenai Peninsula, and Paige and Knopf ${ }^{3}$ found somewhat similar rocks in the valley of Knik River. Rocks of similar character and of the same age have been found on the north and west shores of Prince William Sound. ${ }^{4}$

The Orca group, as exposed on Prince William Sound and on the east shore of Resurrection Bay, contains a large thickness of slate and graywacke that are lithologically very similar to the rocks here

\footnotetext{
${ }^{1}$ Mendenhall, W. C., $\Lambda$ reconnaissance from Resurrection Bay to the Tanana River, Alaska, in 1898: U. S. Geol. Survey Twentieth Ann. Rept., pt. 7, pp. 305-397, 1900.

${ }^{2}$ Moffit, F. H., Gold fields of the Turnagain Arm region: U. S. Geol. Survey Bull. 277, pp. 17-19, 190t,

a Paige, Sidney, and Knopf, Adolph, Geologic reconnaissance in the Matanuska and Talkectna basins, Alaska: U. S. Geol. Survey Bull. 327, pp. 12-16, 1907.

4 Grant, U. S., and Higgins, D. F., Reconnaissance of the geology and mineral resources of Prince William Sound, Alaska: U. S. Geol. Survey Bull. 443, p. 24, 1910.
} 
described and to the main mass of the Sunrise group. On Prince William Sound there is believed to be an unconformity between the Orca group and the Valdez group, as this group is defined in the northeast part of the sound. A similar unconformity, marked by a conglomerate, probably exists on the west shore of Latouche Island and also on the shores of Elrington and Hoodoo islands, in the southwestern part of Prince William Sound, ${ }^{1}$ but the details of this unconformity have not yet been worked out. The Orca group is less folded and less metamorphosed than the Valdez group in its type locality, and the rocks at the southeast part of the shore of Prince William Sound, as well as those on the eastern side of Resurrection Bay, also appear to be less closely folded than the other slates in the same general vicinity. The exact relations of the Valdez, the Orca, and the Sunrise groups can not yet be determined accurately, but it seems very likely that the Valdez group, which lies unconformably beneath the Orca group, is probably of the same age and is continuous with part of the Sunrise group. The Orca group probably lies unconformably above the Valdez group and has been less folded than the Valdez. In the vicinity of Nuka Bay there is also a series of graywackes and slates which are unconformable with an older series and are less closely folded than this older series.

It would therefore appear that the rocks here described, which are believed to be the equivalent of at least part of the Sunrise group, really consist of at least two groups, which may represent parts of the Valdez and Orca groups of Prince William Sound. It is, of course, possible that more than two unconformable series are present, but the evidence for this is not conclusive.

\section{GREENSTONES OF DAY HARBOR AND RESURRECTION BAY.}

The rocks in the peninsula between Day Harbor and Resurrection Bay include both sedimentary and igneous rocks. The igneous rocks are the most abundant and the most characteristic and include abundant ellipsoidal lavas, here called ellipsoidal greenstones. These occur on both sides of the peninsula that separates Day Harbor and Resurrection Bay. On the eastern side of this peninsula there are deeper seated rocks, such as gabbros and peridotites, and in the mountains east of Thumb Cove there are other types of basic igneous rocks.

On the northwest shore of Day Harbor, about 4 miles from the northeast eorner of the harbor and just west of a small promontory, is the most westerly exposure in this vicinity of the highly folded slate and graywacke, described above, which here strike N. $33^{\circ}$ E. and $\operatorname{dip} 80^{\circ} \mathrm{W}$. Just west of this exposure is a depression running N. $38^{\circ} \mathrm{W}$., which probably marks a fault at the contact of the slaty 
rocks on the east and the igneous rocks on the west. The downthrow is probably on the west side of this fault and the amount of displacement is unknown, although it is likely to be several hundred or even a few thousand feet. On the west side of this depression is a dark, almost black altered peridotite, much broken into irregular slickensided blocks and in places sheared into a fine-grained, soft dark green schist. With the peridotite is considerable altered green to gray gabbro, in places much sheared. A few gray altered stringers that occur in the peridotite are probably parts of the gabbro and indicate that this is the later rock. The peridotite is completely altered to serpentine and iron oxide and consisted originally of olivine holding porphyritic crystals, apparently of augite. The gabbro consists essentially of augite and gray, nearly opaque, grains representing original feldspar.

The gabbro extends southwestward from the above point for about 1,000 feet to a place where there is a small amount of hardened graywacke. The gabbro here includes some streaks of pegmatite containing a little pyrrhotite and pyrite. Interrupted exposures of altered gabbro and peridotite extend southward along the shore for about half a mile from the first-mentioned exposures of these rocks. Still farther south are some contorted beds of graywacke, black slate, and soft, fine-grained green schist that probably represents a waterdeposited tuff. The general dip is here $45^{\circ} \mathrm{NNW}$. Some sheared greenstone, showing indications of original ellipsoids, occurs in connection with these sediments. Other exposures of graywacke, slate, green schist, and greenstone, all apparently interbedded, extend southward to the point on the east of a small bay opposite Anchor Cove. The general dip is about $50^{\circ} \mathrm{NE}$. The west shore of Day Harbor south of this small bay was not examined carefully, but the rocks are essentially greenstones, in places ellipsoidal, accompanied by small amounts of sediments. The end of Cape Resurrection is made of ellipsoidal greenstone.

The eastern shore of Resurrection Bay from Sunny Bay southward to Cape Resurrection affords many exposures of greenstone, which is here and there ellipsoidal; in fact, some of the exposures show very striking ellipsoidal structure. The dip is in general toward the west at angles of $20^{\circ}$ to nearly $90^{\circ}$. At one place, opposite the southern part of Renard Island, a bed of black slate, 15 feet in thickness, is interbedded with the greenstone flows.

On the northwest side of Sunny Bay black slate, in many places highly fractured, alternates with greenstone in flows interbedded with the slate. Some of these flows are ellipsoidal in structure.

The country rock for a mile northeast of Thumb Cove is greenstone, chiefly in flows, which are commonly ellipsoidal and in some places 
amygdaloidal. Here there are a few glaciers, the moraines of two of which were examined and found to contain, in addition to the common greenstone, a number of varieties of coarser-grained igneous rocks, mostly basic. At the mouth of the valley that runs northnortheastward from the northeast corner of Thumb Cove lie many bowlders of rocks similar to those in the moraines, such as mediumgrained diabase with red jasper-like veinlets, medium-grained diabase with porphyritic feldspar crystals, light-colored greenstone with quartz amygdules, coarse-grained diabase with red stains, finegrained gray granite (or aplito) in dikes in greenstone, coarse-grained diabase with large plates of augite, and medium-grained diorite with veins of diorite pegmatite.

The Orca group of Prince William Sound has been described as including a lower and an upper division, the lower consisting of basic lava flows and small amounts of sediments and the upper consisting of graywackes and slates. The rocks between Day Harbor and Resurrection Bay include two similar divisions with which they can possibly be correlated. To the lower division would belong the exposures of greenstone and other igneous rocks on the west side of Day Harbor and on the east side of Resurrection Bay from Cape Resurrection northward to Sunny Bay and still farther northward to and beyond the small glaciers that lie just east and northeast of Thumb Cove; to the upper division would belong the tuffs, graywackes, and slates described below (pp. 225-226), exposed on Renard Island and on the shore between Sunny Bay and Thumb Core, and possibly those on the coast north of this cove.

On the east the greenstones are apparently fauited against the older slates and graywackes, the greenstones being on the downthrown sido of the fault. The general strike of the rocks, both sediments and lava flows, which are considered the possible equivalent of the Orca group, is north and the general dip is toward the west. The folding of these rocks is rather close and the folds are apparently overturned slightly to the oast. Sufficient data are not at hand to permit a careful estimate of the thickness of these rocks, but the lower member is probably several thousand feet thick, and the thickness of the upper member very likely also runs into thousands of feot.

TUFFs, GRAYWACKES, AND SLATES OF RESURRECTION BAY.

These rocks occur in a belt west of the greenstones just described, outcropping on Renard Island, at the north end of Hive Island, on the east shore of Resurrection Bay between Sunny Bay and Thumb Cove, and possibly north of Thumb Cove.

Theso rocks consist mainly of slates, generally black, and graywackes, but include some quartzites and some fine-grained green $48891^{\circ}-$ Bull. $587-15-15$ 
schists which were doubtless originally water-laid tuffs. Though sediments of this character are in places interbedded with the lava flows described above (p. 223), yet they are most abundant on the west side of the peninsula between Resurrection Bay and Day Harbor, occurring west of the exposures of greenstone.

On the east side of Renard Island, just south of the long sandspit that projects northeastward, is an eastward-facing cliff consisting of black slate overlain by rather soft green and gray schistose rocks of at least two varieties. The rocks have a marked cleavage, which runs about parallel with the bedding, the strike is $\mathrm{N}$. $7^{\circ} \mathrm{W}$., and the dip is $45^{\circ} \mathrm{W}$. The gray rock is fine grained, except for small crystals of feldspar, rarely of quartz, around which the matrix of the rock seems to have flowed or to have been sheared. This rock is possibly a water-laid tuff or perhaps a sheared trachyte or andesite. Higher up in the cliff are fine-grained green schistose rocks, which are probably sheared greenstones or tuffs. At the base of the cliff, perhaps fallen from it, are fragments of coarse-grained diabasic greenstones and coarse-grained graywackes. On the northeast coast of Hive Island is a small amount of graywacke and rusty-weathering slate, apparently similar to those of Renard Island. Otherwise Hive Island is composed of granite that is probably intrusive into the sediments, but this point was not determined with certainty because of inability to land and examine the exposures.

Graywacke and a little slate occur along the coast between Sunny Bay and Thumb Cove. The general dip of these rocks is $40^{\circ}-60^{\circ}$ NNW. On the north side of Thumb Cove, just west of the main stream near the head of the cove, there are exposures of graywacke somewhat like that at Seward. The rock here is much fractured and broken and the fractures are healed by quartz veins of very fine grain, almost chalcedonic in appearance. The strike is $\mathrm{N}$. $18^{\circ} \mathrm{E}$. and the dip is $40^{\circ} \mathrm{W}$. Along the north shore of this cove, west of the locality above mentioned, graywacke and a little slate occur in several exposures, which were not closely examined. The general direction of the dip here is $20^{\circ}-50^{\circ} \mathrm{WNW}$.

The relation of the rocks on the east side of Resurrection Bay to the slaty rocks on the west side of that bay is not known. Heretofore the sediments on the east shore from Thumb Cove northward, which are here tentatively included with the rocks now being described, have been regarded as part of the Sunrise group. It is probable that this group includes at least two unconformable formations, and it is therefore possible that these tuffs, graywackes, and slates are infolded with the rocks hitherto locally described as the Sunrise group. If this is the case some of the rocks on the west shore of Resurrection Bay may also be of Orca age. 
SLIGHTLY ALTERED SLATE, GRAYWACKE, AND CONGLOMERATE.

These rocks extend (see PI. III) along the coast from the small bay west of the south end of Nuka Island to a place north of Pearl Island. They consist chiefly of slate and graywacke, but includesmall amounts of conglomerate. The slates, which are generally black, constitute the greater part of the formation.

These rocks are considerably less metamorphosed than the highly folded graywacke and slate east of Nuka Island Passage, and are consequently believed to be considerably younger. The relations of the two formations can not be clearly determined since their nearest outcrops are separated by several miles of water. These rocks are in contact, along their northern border, with the cherty slates and graywackes described below, but the precise nature of this contact is not known.

GRAYWACKE AND SLATE, WITH CHERT, LIMESTONE, AND VOLCANIC MATERIAL.

This formation occupies a large area (see Pl. III) in the southwest part of Kenai Peninsula, outcropping at the heads of all the bays from the north end of Nuka Island Passage to Koyuktolik Bay and forming the Chugach Islands. Its northward extension to the shores of Kachemak Bay has been described by Mr. Martin (pp. 44-52).

These rocks consist of slates, graywackes, and limestones, with which are associated considerable quantities of basic igneous rocks and some ellipsoidal lavas. Black, green, white, and rarely red banded cherts also make up part of the formation. It is possible that as here mapped this formation includes the equivalents of the cherts and ellipsoidal lavas of Seldovia Bay. (See pp. 52, 60.)

The formation is in contact (see Pl. III) with the slightly altered slate, graywacke, and conglomerate south of it, and also with the highly folded graywacke and slate of the coast east of Nuka Island Passage, but the nature of these contacts and the age relations of the formations are not known.

\section{UNMETAMORPHOSED SEDIMENTARY ROCKS.}

UPPER TRIASSIC LIMESTONE AND TUFF.

These rocks occur along the coast from Koyuktolik Bay to a place near PointBede (see Pl. III) and extend thence northeastward into the hills between Port Graham and Seldovia Bay. They include stratified tuffs, cherts, slates, limestones, and basic igneous rocks. The black limestones and slates are characteristic of the formation, the limestones carrying fossils (see pp. 58-59) of Upper Triassic age. The outcrops on Port Graham have been described by Mr. Martin (pp. 56-58). 
LOWER JURASSIO TUFFS.

This formation outcrops along the coast from a place near Point Bede to Seldovia Bay. (See Pl. III.) The greater part of its area is within the territory described by Mr. Martin (pp. 63-67). It consists chiefly of coarse stratified tuffs; with smaller amounts of other sediments, and with interbedded basic lavas. Some of the tuffaceous beds carry a marine Lower Jurassic fauna. (See pp. 65-66.)

\section{INTRUSIVE ROCKS.}

The intrusive igneous rocks of the district include both acidic and basic types. A few small masses of granite are intruded into the highly folded graywacke and slate of the eastern coast of Kenai Peninsula and two large granite masses are intruded into the same formation on the southern coast of the peninsula. One of these large masses of granite forms the islands in the mouth of Resurrection Bay, the end of the peninsula between Resurrection and Aialik bays, and the islands in the mouth of the Aialik Bay and the peninsula on its west side. Other small areas of granite, possibly connected with this main mass, exist in the vicinity of Aialik and Harris bays. The other large granite mass makes up Pye Islands and the peninsula immediately north of them. Small dikes of granitoid rocks cut the various slate formations and are especially abundant near the southern end of the peninsula.

Basic intrusive rocks (gabbro and diabase) occur in the vicinity of Point Bede and at the southern entrance of Dog Salmon Bay. At Red Mountain, southeast of Seldovia, and at Claim Point, on the north side of Port Chatham, there are masses of peridotite. Other basic intrusive rocks occur in small dikes and masses associated with several of the formations.

MINERAL RESOURCES.

OUTLINE.

There are no productive mines in the part of Kenai Peninsula here under discussion. Gold, copper, iron, and chromic iron have been found along the southern coast line, and development work has been done on some of the deposits. Gold prospects have been located near Resurrection, Two Arm, Windy, and Kachemak bays and near Port Dick. The prospects along the coast of the southern part of Kenai Peninsula (see Pl. III) are, so far as known, quartz veins of rather moderate size. They contain arsenopyrite and chalcopyrite, locally, with small amounts of pyrite, pyrrhotite, and sphalerite. These veins are very similar to a quartz-arsenopyrite vein found on the western part of Prince William Sound, which carries good values in gold. ${ }^{i}$

1 Grant, U. S., Gold on Prince William Sound: U. S. Gejl. Survey 13ull. 379, p. 97, 190\%. 
A little work has been done on some copper prospects near Resurrection Bay. Hematite has been found at Port Dick and chromic iron nearSeldovia and atPort Chatham. The following brief notes on these prospects are based on the investigation of 1909, except the notes on the copper deposits near Resurrection Bay, which were examined in 1908. These notes have for the most part been taken from the published reports. ${ }^{1}$ The locations of prospects described and their names, so far as learned, are shown on Plate III.

\section{GOID.}

Tho gold veins noar Soward are described elsewhere in this volume (pp. 142-143). A reported occurrence of gold-bearing quartz about 5 miles wost of Resurrection Bay, on a creek outletting to the sea near Lowell Point, has not been visited by any geologist:

TWO ARM BAY.

On the east side of the east arm of Two Arm Bay there are a few small quartz veins in the graywacke and slate, and in one place there is a zone 4 to 8 feet wide of fractured rock, the fractures being filled with quartz. J. J. Bettels reports that an assay of quartz from one of these veins showed no gold. Near the head of this arm of the bay a few granite dikes cut the graywacke and slate, and Mr. Bettels reports that an assay across one of these dikes gave $\$ 1.80$ in gold.

On the mountain at the head of the west arm of Two Arm Bay John Kusturin and Gus Johanson have staked nine claims on three quartz veins, reported to be similar veins, from 2 to $\dot{6}$ feet in thickness. One of these (No. 83 on Pl. III), on the southern flank of the mountain, was examined. The vein strikes N. $27^{\circ} \mathrm{E}$. and dips $40^{\circ} \mathrm{W}$. This vein is 71 inches thick, the upper 27 inches being quartz and rock and the rest of the vein, practically all quartz, carrying small quantities of pyrite, chalcopyrite, and graphito. Little work except some small stripping has been done on these prospects.

NUKA BAY.

On Nuka Bay Daniel Morris, James Sheridan, George W. Kuppler, and John H. Lee have staked claims at three points. One is on the flat at the west side of the front of McCarty Glacier (No. 85 on Pl.III), at the head of the eastern arm of Nuka Bay. Here are a number of pieces, the largest 5 feet in diameter, of "float" quartz carrying chalcopyrite, but no vein has been found in place. Another point is near the center of the west side of the central or northern arm of Nuka Bay. IIere the slates and graywackes are eut by three dikes

1 Grant, U. S., and Higgins, D. F., Notes on geology and mineral prospects in the vieinity of Seward, Kenai l'eninsula: 1: S. Geol. Survey Bull. 379 , pp. $96-10 \pi$, 1909. Also Preliminary report on the mineraI resources of the southern part of Kenai Peninsula: U. S. Geol. Survey Bull. 442, pp. 166-178, 1910. 
of very fine grained granite. The dikes strike N. $35^{\circ} \mathrm{W}$. and dip $80^{\circ} \mathrm{S}$. They are, reckoning from north to south, 8,25 , and 35 feet in width. The granite weathers rusty and contains disseminated pyrrhotite and pyrite.

A broken quartz vein in slates has been uncovered by the men named above near the south point of the first ridge west of the west side of McCarty Glacier (No. 86 on Pl. III). The prospect is about 300 yards from the ice as it stood in July, 1909. The vein is 4 to 5 feet wide, striking with the schistosity of the surrounding rock about north and south, and dipping steeply west. The vein contains numerous bands of shattered quartz and partings of slaty and chloritic material, indicating deformation of the rock since the vein was formed. Small amounts of pyrite and considerable rusty stain may be seen at the surface, but the vein is opened for only 2 or 3 feet.

\section{PORT DICK.}

North of the head of the western arm of Port Dick there has been considerable prospecting for gold in the last few years. Much of this work was undertaken by the Alaska Commercial Co., and later by the Port Dick Mining \& Power Co. The former company did most of its work in 1899, and the latter from 1904 to 1907 . The work done is about three-fourths of a mile north of tidewater and from 200 to 1,200 feet above the sea (No. 88 on Pl. III). Five mules, left here in the autumn of 1907 , have passed two winters without care or protection, except for the shelter of a barn, and were in good condition in August, 1909.

The country rocks about the head of the west arm of Port Dick are slates, graywackes, flints, tuffs, and greenstones. Acidic dikes, mainly of fine-grained biotite granite, are common, especially on the north side of the arm, where the country rock is largely graywacke, considerably recrystallized. The veins prospected are in the main nearly vertical quartz veins, which cut both the granite and the graywacke. The prospects examined are described below:

Some 200 feet above sea level, on the east side of the stream which flows southwestward and enters the west end of the west arm of Port Dick, is a tunnel 140 feet in length. This is carried along a vein that strikes $\mathrm{N} .54^{\circ} \mathrm{W}$. and dips $75^{\circ}-85^{\circ} \mathrm{N}$. The wall rock is hardened graywacke. The vein is 6 to 20 inches in width and has veinlets parallel to the main vein, so that there is a maximum thickness of 24 inches of quartz, the average being about 15 inches. In the quartz of the vein is a large amount of arsenopyrite and small amounts of chalcopyrite and pyrite. The arsenopyrite and quartz are so arranged as to give the vein a distinctly banded structure, and in places the arsenopyrite is 1 inch to 3 inches thick. 
About 300 feet higher than the last and 500 feet farther south is another tunnel 310 feet long. This is carried along a quartz vein that varies in direction but has a general strike of N. $64^{\circ} \mathrm{W}$. and a dip of $75^{\circ} \mathrm{N} .-80^{\circ} \mathrm{S}$. This vein branches a little, but is in general well defined and is 12 to 40 inches thick, averaging 24 inches. It is very similar to the one described above, but contains a little less arsenopyrite, carries a little pyrrhotite and sphalerite, and has small fractures filled with calcite. The wall rock is a fine-grained biotite granite.

One-third of a mile farther south and 300 feet still higher is another vein, " 6 to 12 inches thick, carrying pyrrhotite and chalcopyrite. The strike is $\mathrm{N}$. $69^{\circ} \mathrm{W}$ : and the dip is $83^{\circ} \mathrm{S}$. The wall rock is finegrained biotite granite.

Farther south and about 1,200 feet above sea level is a tunnel, 240 feet long, running N. $61^{\circ} \mathrm{E}$. The rock cut is granite and hardened graywacke. At 25 feet from the breast this tunnel cuts a quartz vein 6 to 12 inches thick. This vein strikes N. $59^{\circ} \mathrm{W}$. and dips $80^{\circ} \mathrm{N}$. and has been followed 65 feet in a branch tunnel. Aside from quartz this vein contains arsenopyrite, chalcopyrite, and pyrite.

At the water's edge on the north side of the western arm of Port Dick, near the supply house, the flints have been irregularly fractured and partly impregnated by pyrrhotite and chalcopyrite. A similar phenomenon occurs about 4 miles to the east (No. 87 on Pl. III), also at the water's edge and on the north side of the arm. A small amount of excavation has been done at each of these localities.

\section{WINDY BAY.}

About $2 \frac{1}{2}$ miles north of the west end of the western arm of Windy Bay Sanford J. Mills and A. J. Trimble have done some prospecting on several quartz veins which contain arsenopyrite, chalcopyrite, and pyrite (No. 89 on $\mathrm{Pl}$. III). These can generally be recognized at a distance by the brownish gossan that has developed on their outcrops. These veins are reported to contain gold, silver, copper, and nickel. Those examined by us were about a foot in width and contained the minerals noted above. The country rocks are graywackes, flints, limestones, tuffs, and greenstones cut by acidic dikes. In one place there is a zone, 30 to 50 feet in width, made up of reddish decaying acidic dike rock which has been much fractured by recent movements and which contains some quartz veinlets. This zone has a general north-south direction and dips $60^{\circ}-70^{\circ} \mathrm{W}$. Along both sides of the zone the rock is decayed to a limonitic clay. Several small openings have been made in this zone, especially on its sides. 


\section{PORT CHATHAM.}

About the head of Port Chatham some prospecting has been done, mainly by Thomas Rock (Nos. 90, 91, and 92 on Pl. III). The country rocks here are flints, tuffs, and graywackes, cut by granitic dikes. About 2 miles east of the head of the northeastern arm of Port Chatham, on the south side of the main valley and some 450 feet above sea level, the contact between graywacke and a fine-grained biotite granite dike has been uncovered. The dike rock is decayed and has been fractured, the fractures being healed by quartz veinlets. Along the actual contact is a clay selvage half an inch in thickness. About a quarter of a mile northeast of this prospect and 150 feet higher is an opening, 10 feet long, on a quartz vein which is 22 to 28 inches in width. The vein strikes $\mathrm{N} .19^{\circ} \mathrm{W}$. and dips $60^{\circ} \mathrm{N}$.; it carries arsenopyrite, chalcopyrite, pyrrhotite, and a little sphalerite. The country rock is a hardened graywacke. Higher up the hill to the south what appears to be the same vein has been uncovered in two places, where the width is 36 and 44 inches. Here the vein cuts a fine-grained granitic dike rock.

About a mile southwest of Cone Mountain, on the west wall of a cirque which contains a small lake, are some rusty zones crossing the tuffs and flints. At an altitude of about 2,000 feet a little work has been done on one of these zones which is 5 feet thick. These zones are fractured parts of the rock, the fractures being healed by quartz and calcite and minor quantities of sulphides.

On the coast between Port Chatham and Port Graham, about 3 miles south of Flat Islets, is a marked brown-weathering zone in tuffs, which are impregnated by pyrite. This zone is irregular and in places is 15 feet wide. No work has been done here.

\section{PORT GRAHAM.}

On Port Graham very little prospecting has been done, though a few claims have been staked. One of these is a few rods south of the steamboat wharf, one is on the north shore of the port near its east end, and another is in a gulch about 3 miles directly east of the wharf and a mile or more from tidewater. The last two claims (Nos. 94 and 95 on Pl. III) are owned by J. W. Alley, and are located on rusty-weathering fractured areas in the country rock (cherts). The fractures are filled by quartz veinlets. An assay from one of these localities is said to have shown $\$ 6$ to the ton in gold.

\section{KACHEMAK BAY.}

The prospects of the Aurora Gold Mines Co. (No. 97 on Pl. III) are about 2 miles south-southeast of the landing formerly known as Aurora, on the south side of Kachemak Bay, 12 miles northeast of Homer. 
According to notes by G. C. Martin, there are three tunnels in the canyon on the banks of the glacial stream. These tunnels extend for distances which could not be determined but which, from the amount of material on the dump, can not be great. The tunnels are driven into a fractured and probably faulted zone in graywacke not far from the contact with a 20 -foot dike of porphyry. Small amounts of disseminated pyritie could be seen in the rock lying on the dump, but this was the only visible evidence that any ore had been encouncered.

The other improvements consist of a wagon road, a telephone line from the landing to the tunnels, a trail extending for some distance farther up the bank of the stream, bridges over the glacial stream and over the head of the lagoon between the tunnels and the beach, six buildings just bclow the tunnels, and a wharf and two warehouses on the shore.

\section{COPPER.}

\section{DESCRIPTION OF PROSPECTS.}

At the water's edge on the northwest side of Day Harbor, about 4 miles southwest of the head of this bay, a small amount of work has been done on a prospect (No. 68 on Pl. III) which is along a shear zone between gabbro and peridotite. This zone is 4 feet thick and contains some gabbro pegmatite (a coarse-grained aggregate of plagioclase feldspar and augite), which carries pyrrhotite, pyrite, and possibly a small amount of chalcopyrite.

Comparatively little work has been done on the copper prospects in the vicinity of Seward, most of them having been staked recently (1908). They are all, so far as known, located east of Resurrection Bay. In the following paragraphs they are described in order from north to south, the numbers in the descriptions referring to localities on the accompanying map (PI. III).

Prospect No. 69.--This prospect is just north of the glacier at the head of Godwin River and about 2,400 feet above sea level. It was staked by L. F. Shaw, John Deubruel, and G. Bouchaert, of Seward. Little work has been done here. Specimens from the prospect are nearly solid pyrrhotite with a little chalcopyrite, and there is said to be one large bowlder here, about 700 pounds in weight, of similar ore. An 8-font vein carrying both copper and gold is also reported as occurring near this same locality.

Prospect No. 70.-This prospect, staked by W. L. Redman and Samuel Guyot, of Seward, is just south of the glacier at the head of Godwin River and about 2,700 feet above sea level. The vein here is reported to be 9 feet in wilth, and the specimens shown the writers are composed of porous, heavily iron-stained gossan carrying malachite, azurite, and chalcopyrite. No work has been done at this locality. 
Prospects Nos. 71, 72, and 73.-At these localities are the Real Thing, Copper Chief, and Iron Cap groups of claims, staked by S. E. Likes and A. H. Frazer, of Seward. There are 23 claims in these groups. At the time of visit (August, 1908) the Real Thing and the Iron Cap groups were covered with snow. Each is located at the foot of. a high cliff forming the edge of the gathering ground of a small glacier. It is reported that the magnetite in connection with the chalcopyrite at the Real Thing group extends along and up the cliff in a northwest-southeast direction for a horizontal distance of 500 to 600 feet. The lead has been traced three-quarters of a mile. The vein is reported to be as wide as 9 feet, having chalcopyrite on one side and magnetite on the other. Specimens presented by $\mathrm{Mr}$. Likes show that the magnetite is uniformly fine grained, massive, and blue-black in color. Some of it is pure, but most of it contains scattered minute grains of chalcopyrite. The contact of the main part of the chalcopyrite and the magnetite is very abrupt. The specimens show veinlets of chalcopyrite 0.03 inch wide, extending for 0.3 to 0.4 inch into the magnetite. With the chalcopyrite is pyrite in irregular patches-possibly imperfect crystals-and in elongated patches that may be veinlets. The Iron Cap lead was reported to have been traced for 4,500 feet along the glacier. Magnetite is reported to occur below, giving way to chalcopyrite and pyrite farther up the cliff.

A part of the showings of the Copper Chief group of claims was seen. The lead consists of a brecciated and sheared zone, about 6 feet wide, in partly ellipsoidal greenstone. This zone strikes N. $37^{\circ}$ W. and dips $35^{\circ} \mathrm{S}$. Pyrite, chalcopyrite, hematite, and a little epidote are distributed through the numerous quartz veinlets and through the part of the greenstone nearest the shear zone. The hematite occurs only in the quartz. The greenstone is fine grained, dense, and of a leek-green color when fresh.

Prospect No. 74.-This prospect lies south-southeast of those last described and is reached from Day Harbor. There are several claims here, staked by the Reynolds-Alaska Development Co. They are reported to carry chalcopyrite in shear zones in the greenstone.

Prospects Nos. 75 and 76.-E. F. Pitman and A. C. Gould, of Seward, have staked a group of six claims, called the Feather Bed group, running eastward from the northeast corner of Sunny Bay. At the shore a small amount of digging has been done and some pieces of float containing pyrite and a little chalcopyrite have been encountered. The chief claims of this group are about $1 \frac{1}{2}$ miles east of the shore and were not visited because they were reported to be covered with snow. These claims are said to contain a shear zone which holds four stringers of nearly pure chalcopyrite. The stringers, the largest of which are 7 inches thick, are reported to carry 14 to 19 per cent of copper. The zone strikes a little east of north and is about 
vertical. It has been traced from an elevation of about 2,500 feet up to 3,500 feet.

Prospect No. 77.-This prospect, called the Peterson claim, is at the water's edge on the east side of the north part of the south arm of Sunny Bay. The country rock is a rather fine grained, fairly fresh diabase. A tunnel, 35 feet in length, has been run along a brecciated and vertically sheeted zone, which is 5 feet in width, strikes N. $32^{\circ} \mathrm{W}$., and dips $68^{\circ} \mathrm{W}$. The cement of the breccia is composed of quartz, calcite, sphalerite, pyrite, epidote, and chalcopyrite. About 200 feet to the southwest of this tunnel is another, 35 feet long, extending along a similar brecciated zone which carries less vein material. This zone is 6 feet wide, strikes N. $12^{\circ} \mathrm{W}$., and is vertical.

Prospect No. 78.-This prospect, called the Iron Mask claim, is on the east shore of Resurrection Bay, opposite the south end of Renard Island, and was staked by H. E. Ellsworth, of Seward, and the Reynolds-Alaska Development Co. A small opening has been made here at high-tide level in a brecciated mass of greenstone. The breccia, as exposed, is 12 feet thick and has been traced for 100 feet or more along the shore. It is overlain by nonbrecciated greenstone, the junction between the two striking N. $27^{\circ} \mathrm{W}$. and dipping $20^{\circ} \mathrm{W}$. This appears to be the strike and dip of the flows at this locality. The rock of the breccia is a very fine grained diabase in fragments ranging in size from less than a fourth of an inch to a few inches. The material between the larger fragments is composed of the small fragments and a greenish cement. The original breccia, which is probably a flow breccia mixed with tuffaceous material, has been slightly broken, and the fractures have been healed by quartz and pyrite a little calcite and chalcopyrite. These minerals have also penetrated and locally replaced the original cement and some of the fragments. A very little sphalerite occurs here. Assays across this 12 -foot brecciated zone are reported to show 1.1 per cent of copper, and some small streaks carrying more chalcopyrite gave 7 to 8 per cent of copper.

Prospect No.79.-This is about a mile east-southeast of No. 10, and was staked by E. F. Pitman and A. C. Gould, of Seward. There are three claims here, called the Fairview group, running eastward from the shore. A cliff a short distance from the water shows considerable iron stain, which is not accessible. The main showings are about three-quarters of a mile east of the shore, along a cliff on the south side of a mountain which rises to an elevation of about 2,500 feet. At the base of this cliff is a brecciated zone in the greenstone somewhat similar to that described above. This zone is 8 to 10 feet in thickness, strikes N. $78^{\circ} \mathrm{E}$., and is vertical. Higher up and about 300 feet to the east is another similar zone (possibly the same one faulted a little to the north) from 8 to 10 feet in thickness. Fragments in the brec- 
cia are from 1 inch to 12 inches in diameter and consist of a medium to fine-grained diabase. This breccia seems to have been again fractured, the fractures filled, and the original cementing substance replaced, in part or wholly, by quartz, pyrite, marcasite, and chalcopyrite. Many pieces of the breccia are rounded and split in concentric layers when weathered. The cement is soft and much weathered and is now usually in the form of gossan, and the whole zone is much iron stained, although it has:not been impregnated with these sulphides through its entire thickness. At one place, in a band 6 feet thick, the cement is fairly rich in sulphides. An assay of this material is said to have given 9.8 per cent of copper. This brecciated zone has been penetrated by a tunnel, 10 feet in length, but the tunnel could not be reached at the time of the writer's examination on account of snow.

About a quarter of a mile northeast of this point, on the east side of the ridge, there are poor exposures of an irregular quartz vein, perhaps 10 feet in width, standing vertical and running approximately east and west. No work has been done here. The rock contains much quartz and is commonly free from sulphides, but locally holds pyrite and a little chalcopyrite.

Prospect No. 80.-This is on the east shore of Resurrection Bay, about half a mile from Cape Resurrection. It was staked by W. R. Lietzke, of Seward. Specimens reported to come from this place consist of quartz containing some fragments of diabase, pyrite, and a little chalcopyrite. It is probable that this prospect is in a brecciated zone similar to those at Nos. 10 and 11, described above. Mr. Lietzke also has a prospect about a mile northeast of Cape Resurrection, near the shore.

\section{SUMMARY AND CONCLUSIONS}

The copper prospects examined are on veins in basic igneous rocks, chiefly in flows of ellipsoidal greenstone. These veins occur (1) as shear zones, (2) as brecciated zones where there has boen little shearing, and (3) as brecciated zones parallel with the flows of greenstone. The first and second varieties of veins cut across the flows indiscriminately, and the third are apparently flow breccias which have been further fractured by movements due to folding. The first variety includes prospect No. 72, and probably also Nos. 71, 73, 74 , and 75 ; the second, prospect No. 9 ; and the third, prospects Nos. 78 and 79, and probably also No. 80 .

The copper-bearing mineral of these prospects is chiefly chalcopyrite, a sulphide of iron and copper, carrying, when pure, 34.5 per cent of copper. The pyrite and pyrrhotite may also carry very small amounts of copper. Locally, at or very near the surface, the chalcopyrite has altered to the carbonates, malachite and azurite. The copper in the veins has undoubtedly been derived from the surrounding greenstones probably at no great depth from the surface. 
At the time of visit (August, 1908) little development work had been done on these copper prospects, and little ore had been revealed. At none of the prospects examined (Nos. 72, 76, 77, 78, and 79) had the existence of a good thickness and a considerable extent of merchantable ore been demonstrated. Some of the prospects could not be examined for lack of time, and some because they were high up in the mountains and covered with snow, which lay on the ground much later than usual in the summer of 1908. The most encouraging statement concerning the copper veins on the east side of Resurrection Bay that can be made with the present information is that they occur in essentially the same manner and in the same kinds of rocks as the copper deposits to the east, on Prince William Sound, where there are two producing copper mines and some promising prospects.

From analogy with other copper veins of similar character elsewhere, there is no good reason to expect that ore bodies which may be found in the area under discussion will necessarily increase in size or in richness with depth. In fact, the opposite is more likely to be the case. Thus in developing a prospect it is good practice to follow the ore and not to run long crosscuts to intersect veins in depth. Under present conditions a copper prospect in this district, to afford encouragement for further work, should show a reasonable probability of the presence of several thousand tons of ore carrying at least 4 per cent of copper; or, if this metal is less in amount, sufficient values in gold or silver to offset the deficiency.

\section{IRON ORE.}

The similarity in lithology of much of Kenai Peninsula and the Lake Superior iron district is marked. In both places there are great thicknesses of graywackes and slates, as well as cherts and greenstones. The greenstones are to a considerable extent ellipsoidal in structure and are closely associated with the cherts. The cherts on Kenai Peninsula are generally gray to black in color and only here and there reddish. On a small island near the west end of Port Dick a small amount of reddish jasperoidal material and some hematite in veinlets were found in connection with these ellipsoidal greenstones. This is the only occurrence of iron ore noted in the district with the exception of chromic iron ore, which is found at Red Mountain, southeast of Seldovia, and at Port Chatham. These occurrences are described below.

\section{CHROMIC IRON ORE.}

RED MOUNTAIN.

James Linder, J. T. Ballan, and Bruce Markle have staked a number of chromic-iron claims (No. 96 on Pl. III) on Red Mountain, which is a prominent peak probably over 3,000 feet in altitude, 
lying about 7 miles southeast of the town of Seldovia. This mountain is noticeable from several positions along the coast because of its light terra-cotta color and the scarcity of vegetation on its upper slopes. The country rocks are the cherts and tuffs of possibly Triassic age, and the mountain itself is composed of a mass of finegrained peridotite of the variety dunite, a basic igneous rock composed essentially of olivine. This igneous rock occupies an approximately circular area about 2 miles in diameter. In certain places the dunite carries narrow bands of a coarser-grained rock composed of augite and olivine in varying proportions. The dunite itself contains small grains of chromite, and in places these are abundant and are segregated into bands, some of which are made up practically of chromite alone. These chromite bands range in thickness from a fraction of an inch to a foot. Most of them are 1 inch to 3 inches thick. In one place a zone of 20 feet of country rock was so well supplied with these chromite bands that about one-fifth of this thickness of 20 feet was chromite. Exposures were not sufficient to allow this zone to be traced more than a few rods. An analysis of this chromic iron ore is reported as follows:

Analysis of chromic iron ore.

[By C. E. Bogardus.]

Iron protoxide $(\mathrm{FeO})$

22.20

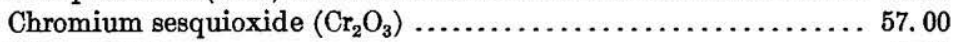

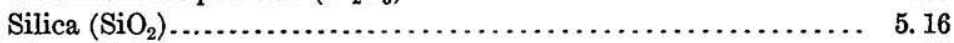

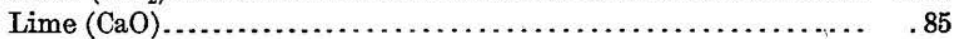

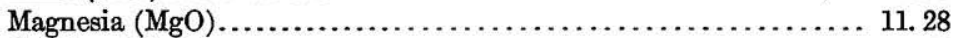

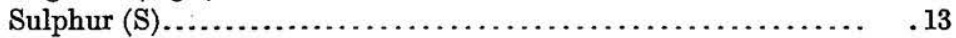

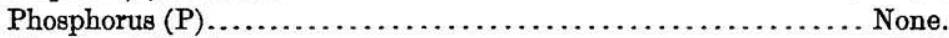

Alumina $\left(\mathrm{Al}_{2} \mathrm{O}_{3}\right) \ldots \ldots \ldots \ldots \ldots \ldots \ldots \ldots \ldots \ldots \ldots \ldots \ldots \ldots \ldots \ldots \ldots \ldots \ldots, 3.10$

99. 72

Metallic iron

Chromium

39.03

\section{PORT CHATHAM.}

The peninsula called Claim Point, on the north side of the entrance to Port Chatham, is composed of peridotite, and the same rock occurs on the mainland just north of this peninsula. On this point William and Charles Anderson have staked chromic-iron claims (No. 93, Pl. III). The mineral chromite occurs in small amounts in the peridotite and in one place on the east shore of Claim Point fairly pure chromite occurs in bands and veinlike forms on the peridotite. The veins have a general northwesterly strike and dip $50^{\circ} \mathrm{SW}$. There is 3 to 10 feet of peridotite well seamed by chromite bands, so that about a quarter of this thickness is chromite. The largest single band noted was 10 inches thick. 


\section{INDEX.}

A.

Aialik Bay, rocks on.

Alaska, central, map of.

Alaska Gold Exploration \& Development

Co. See Barnes property.

Alaska Northern Railway, construction of.. 15 prospects on ......................... 148 route and operation of............... 30,31-32 timber on, plate showing ............... 30 Alluvial fan of Victor Creek, plate showing.. 122 Anchor Point, gold placers at.............110-111 section of Quarternary deposits near..... 91 sections of the Kenai formation near 68-74, 79-82 Animals of Kenai Peninsula................ 29-30 Anticline, overturned, on shore of Seldovia Bay, plate showing.............. 98 Antimony prospects, description of.......... $\quad 179$ Arsenopyrite, mode of occurrence of......... 135 Atwood, W. W., work of .................. 19

B.

Bagley, J. W., survey by................... 19

Bancroft, H. H.; cited.................... 108

Barnes property, country rock and ore of. . 175-176 location and history of ............... 173-175

Bartlett Glacier, plate showing............. 29

Bear Creek, placer gold on......... 182, 185, 196-197 prospects on......................... 172 silver deposits on..................... 178-179

Becker, George F., cited................... 98 exploration by ....................... 16

Bench deposits, general features of ......... 120 occurrence of ....................... 121-123

Black Butte vein, character and position of. 160-161

Blackstone Bay, rocks on................. 213

Bluff Point, section of Kenai formation at... $72-73$

Bogardus, C. E., analysis of chromic iron ore by...

Bone, human, from mouth of Cottonwood Creek, age of................... 93-94

Bowlders, wheel for hoisting, plate showing.. 188 Brewer Alaska Syndicate's property, description of..................... 144-145

Brooks, A. H., preface by............... 13-20

Brown Bear claim, description of........... 148

\section{C.}

Calcite, mode of occurrence of ............. California-Alaska Mining Co.'s property, country rock and ore of........ 152-154

location and history of................ 151-152

California Creek, placer gold on.......... 183, 192

Canyon Creek, placer gold on...... 183, 185, 203-204

Cape Junken, rocks near................. 215-216

Cape Mansfield, rocks near ................ 216

Center Creek, peak at head of south fork of, plate showing................... 120

Chalcopyrite, mode of occurrence of....... 136
Page.

Character and limitations of the report....... 13-14

Chert, age and correlation of................61-63 contorted, plate showing................ $\quad 60$ distribution of....................... $\quad 60$ fauna of .............................. 61 lithology of........................... 60 occurrence of.......................... 227 on shore of Halibut Cove, plate showing. $\quad 60$ stratigraphic relations of.................. 60

Chromic iron ore, occurrence of ........... 237-238

Cirque at head of Block Creek, plate showing. 128 on Falls Creek, panorama of............ 151 Cirques near Placer River, plate showing .... 126

Claim Point, chromic iron ore on............ 238

Clam Gulch, sections of the Kenai formation near.......................... 79-82

Climate, character of .................... 26-27

Coal, analyses of......................... 106-107 beds of, in the Kenai formation........ 68-85 character of ......................... 105-107 distribution of...................... 104-105 mining of........................... 107-110

Coal Cove, Kenai formation at.............. 82

Cochrane Bay, rocks on.................. 213

Cœur d'Alene Gulch, claims in........... 171-172

Colorado Creek, prospects near............ 167-168

Conglomerates, occurrence of.............. 117, 227

Cook, Capt. James, exploration by......... 14

Cook Inlet, gold placers on.............. 110-111 section of cliff on ...................... 90 section of Kenai formation on . .......... 79-81

Cook Inlet glacier, maximum extension of... 95-96 melting back of........................ 96

Coon and Plowman property, description of. 178-179 Cooper Creek, placer gold on.182, 182-183, 185, 199-201 Ruble elevator on, plate showing ........ 187

Copper, lode deposits of. . ............... 177-178 mode of occurrence of.................... 134

Copper prospects, descriptions of......... 233-237

Correlation of formations in southern and southwestern Alaska, table showing.

Cottonwood Creek, section of Quaternary deposits at mouth of.............. 92

Cretaceous, possible occurrence of........... 34, 49 Crow Creek, gravel-filled moraine-dammed basin on, plate showing......... 189 placer gold on .............. 183, 185, 188-192

\section{D.}

Dall, William H., cited............... $87,88,108$ exploration by ........................ 16 fossils determined by ................. 87,92 Davenport, R. W., work of............... 20

Day Harbor, copper prospect near.,........ 234 rocks on ................... 216-21i , 223-225 Devil Club ledge, description of............ 148 
Devil Creek, prospects near................ 163-164

Dike, mineralized, on Fresno Creek, plate showing ..................... 136

Dikes, mineralized, character and position of .......................... 140-141 occurrence of .......................... 97-99

Diorite porphyry dike, mineralized, plate showing ..................... 136

Donaldson Creek, claims on . .............. 168-169 view at headwaters of ................. 24

Doroshin, Peter, prospecting by ........ 15, 181-182

Drainage, braided, on the alluvinl plain of Placer River, plate showing..... 93

of Kenai Peninsula.................... 24-25

Dredge on Kenai River, plate showing...... 187 E.

Eagle River, silver deposit on.............. 178

Eastland Canyon, section of coal in......... 77

Ellsworth, C. E., survey by ................. 20

Emerson, B. K., cited....................... 98-99 exploration by .......................... 16

Erosion, postglacial type of.............. 127-128 Sec also Glaciation.

Explorations, outline of ................. 14-20

\section{F.}

Fairman-Madson prospects, description of... 163

Falls Craak, placer gold on................. 202 section of Kenai formation at............ 77-78

Faults in the Kenai Mountains............ 100-103

Fissure vein on Barnes property, plate showing .......................... 137

Focht, Carl, work of ..................... 18 Folds in massive graywac':e, plate showing.. 98 in the Kenai Mountains.............. 99-103

Fossils, occurrence of...... 52, 58-59,61,65-66, 85-88 Freighting, charges for....................

Frenchy Creek, claims near............... 168 view at headwaters of.................. 24

Fresno Creek, prospects near............. 167-169

\section{G.}

Galena, mode of occurrence of............. 135

Geologic history, outline of............... 38-40 pre-Quaternary ........................ 124 Quaternary ........................ 124-128

Giflin, C. E., survey by ..................... 20

Gilbert, G. K., exploration by.............. 16

Gilpatrick, J. C., property, description of. . 164-167

Glacial deposits, general features of......... 120 occurrence of .

Glaciation, results of ................. 126-127 Glacier Creek, description of............... 188 tributaries of.......................... 188

Glaciers, action of ................. 36-37,94-97 advance of......................... 125 existing .......................... $25-26$ maximum extent of ........... 39-40,125-126 near Placer River, plate showing........ 126 retreat of ......................... 126

Godwin River, copper prospects near....... 233

Gold, lode deposits of . ................. 220-233 lode deposits of, discovery and development of ................... 129-130 mineralogy of ................. 131-137 production from.
Page.

Gold, lode deposits of, types of........... 137-141

mode of occurrence of. ................ 133-134

placer, fineness of.................... 184-185

placer deposits of....................... 110-111

classification of.................... 187

discovery and development of..... 181-183

methods of mining............... 186-187

production from.................. 183-184

source of..................... 185-186

Gold-bearing quartz vein on Kennedy-PullenDavis property, plate showing... 137

on property of Seward Bonanza Gold Mines Co., plates showing....... 150

Granite Creek, placer gold on............... 206

Grant, U. S., surveys by .................. 17-18

Gravel filling moraine-dammed basin, plate showing.........................

filling old channel of Gulch Creek, plate showing.........................

Gravel flat at lower end of Lynx Cree:z, plate showing....................... 208

Gravels, bench, character of ............ 121-123

bench, on Resurrection Cree.., plate showing...................... 119

section of, plate showing.......... 122

glacial and terrace, deposition of........ 94-97

distribution and character of........ 89-94

on roc'z bench, Canyon Creek, plate show-

ing........................... 186

recent, occurrence of .............. 123-124

Graystone ledge No. 1, description of....... 147

Graywacke, age and correlation of........ 222-223

analysis of ........................ 115

cleavage and bedding in, plate showing.. $\quad 99$

distribution of, on the southeastern coast. 211$223,225-227$

in the central and northern parts of Kenai

Peninsula, character of ........ 113-115

minor faulting in ..................... 101

occurrence of $\ldots \ldots \ldots \ldots \ldots \ldots \ldots \ldots \ldots \ldots \ldots \ldots \ldots \ldots \ldots+33-35$

of the Kachemak Bay district, age and

correlation of ................... 49

distribution of .................... $44-45$

stratigraphy and lithology of ........ 45-48

of the Kenai Valley, age and correlation

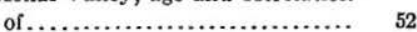

distribution of..................... 50

lithology of........................ 50-52

Greenstones, distribution of ............ 223-225

occurrence of ..................... 117-118

Gulch Creek, placer gold on........ 183, 185, 206-207

H.

Hamilton, E. G., survey by ............... 17

Harris Bay, rocks on ................... 219

Henry Creek, view at head waters of .......... $\quad 24$

Higgins, D. F., jr., surveys by ............ 17-18

IIillebrand, W. F., analysis by ............. 115

Hollick, Arthur, Correlation of the Kenai

flora......................... 88-89

fossils determined by ................. 85-87

Homer, section of Quaternary deposits near . $\quad 91$ Homer Spit, sections of the Kenai formation near........................ 68-75

Homestake ledge, description of ........... 147

Hrdlička, A., cited....................... 93 
I.

Igneous rocks. See Intrusive rocks.

Imhof-Weidlich-Saulsbury prospects, description of ...................... 164

Indian Creek, placer gold on................ 111

Industries of Kenai Peninsula............... 30-31

Intrusive rocks, occurrence of............. 36,

97-99, 119-120, 228

Intrusive rocks in slate, plate showing...... 118

Iron ore, occurrence of ................... 237-238

J.

Jacobson, R. C., work of.

John Creek, timber near showing near mouth of, plate

Johnson, B. L., survey by .................. 20 Jurassic rocks, occurrence of......... 35,63-67,228

$\mathrm{K}$.

Kachemak Bay, Kenai formation south of... 82-83 prospects on......................... 232-233 sections of the Kenai formation on north shore of ...................... $74-79$

slates and graywackes near ............ 44-49 See also Cottonwood Creek.

Kasilof River, course of .................... 25 Kenai formation on .................... 83-85

Katz, F. J., work of ....................... 19 Kenai-Alaska Gold Co.'s property, country rock and ore of................ 159-163 location and history of .............. 157-159 plate showing ......................... 151

Kenai flora, correlation of ................ \&8-89

Kenai formation, distribution of.............. $67-68$

flors and fauns of .................... 85-88

general features of .................... 68

section of, on shore of Cook Inlet, plate showing ........................

on shore of Kachemak Bay, plate showing........................ 74

sections of ........................... 68-85 with lignite beds at Bluff Point, plate showing...

near Mine Camp, plate showing.....

south of $A$ nchor Point, plate showing. with Quaternary deposits, at mouth of Cottonwood Creek, plate showing

Kenai Lake, alluvial fan extending into, plate showing ......................... .122 antimony prospect near................ 179

Kenai lowland, character of ............... 22-23 structure of......................... 102, 104 vegetrtion of ........................ 28-29

Kenai Mountains, character of.............. 22 folding and faulting in............... 99-103 vegetation of ....................... $27-28$

Kenai Peninsula, general features of...... 13, 21-40 geography of the southenstern coast of ... 209 geologic reconnaissance map of..... In pocket. relief of ............................ 22-23 rocks of the southeastern const of ...... 210-211 topographic reconnaissance map of. In pocket.

Kenai River, course of...................... 24 dredge on, plate showing .............. 187 placer gold on.......... 111, 181,183,185, 197-199 slates and graywacke; along ........... 50-52
Kennedy-Pullen-Davis property, description of .........................145-146

Kern Creek, folds in graywacke at........... 98

Kirsopp, John, jr., exploration by ........... 16

Knopf, Adolph, work of ................... 19

and Paige, Sidney, cited............... 177

Knowlton, F. H., fossils determined by ..... 87

L.

Lakeside claim, description of.............. 148

Lavas, ellipsoidal, age and correlation of..... 55

ellipsoidal, distribution of .............. 52

lithology of...................... 52-55

occurrence of ....................... 227

plate showing .................... 52

Lesquereux, Leo, fossils determined by...... $\quad 86$

Lewis, Harmon, work of................... 19-20

Lignite. Sce Coal.

Lignite bed at mouth of Cottonwood Creek, burning of.................... 92.84

Limestone, crystalline, deposits of .......... 111-112

Upper Triassic, age and correlation of.... $\quad 59$

distribution of..................... 55

fauna of .......................... 58-59

lithology of ...................... 55-58

occurrence of .................42, 43, 227

Limestones, occurrence of ........... 116-117, 227

Lodes. Sce Copper, Gold, and Silver.

Lynx Creek, copper lodes on ............ 177-178 gravel flat at lower end of, plate showing. 208 placer gold on ............... 183, 185, 207-208

\section{M.}

McNeil Creek, section of Kenai formation at.. 76-77 Martin, G. C., surveys by ........... 17, 19, 19-20 Mayflower lode, description of............. 178 Mendenhall, Walter C., exploration by ...... 16,17 Metamorphic rocks, lithology and distribution of .... 33-35,41-52,113-119, 2i1-227

Mile Four Mining Co.'s prospect, description of .......................... 144

Mills Creek, placer gold on..... 182, 183, 185, 204-205 Mine Camp, section of Kenai formation at... 73-74 Moffit, F. H., cited.............. 54-55, 91, 99, $121,121-122,172-173,177,182,183$, $187,189-190,192,193,194,195,196$, $197,202,203,204,205,206,207,208$

survey by ............................ 17

Molybdenite, mode of occurrence of......... 137 Moose Pass and vicinity, topographic map of ...................... In pocket.

N.

Northern Light claims, description of...... 142-143

Nuka Bry, gold near..................... 229-230 rocks on........................... 220-222

Nutter-Dawson property, deep cut on, plate showing....................... 188

\section{o.}

Orca series, correlation with . 34-35, 49, 222-223, 225

Ore deposits, origin of .................. 179-1s1

Osgood, W. H., cited...................... 28. 29-30 
P.

Paige, Sidney, work of. and Knopf, Adolph cited

Palache, Charles, exploration by............. 16

Palmer Creek, placer gold on........... 182,195-196 prospects on......................... 171-172

Pass Creek, claims near ...................... 168

Passage Canal, rocks on................... 212-213

Petroff, Ivan, cited....................... 107

Pick and shovel work on East Fork and Canyon Creek, plate showing........ 186

Placer River, alluvial plain of, plate showing . mountains at headwaters of, plate showing.

Placers. See Gold.

Porcupine Creek, prospects on............ 147-148

Port Bainbridge, rocks on ................ 214-215

Port Chathiam, chromic iron ore on ......... 238 minerals near........................ 232

Port Dick, gold near................... 230-231

Port Graham, gold near.................. 232 site of coal mine at, plate showing......... 22

Port Nellie Juan, rocks on ................. 213-214

Position of Kenai Peninsula............... 21-22

Power and power plants of Kenai Peninsula............................ 30-31

Precipitation, average monthly, on and near Kenai Peninsula............... 27

Primrose Mining Co.'s property, description of ........................ 146-147

Ptarmigan Gulch, claims in.............. 171-172 Puget Bay, rocks near ................... 215

Pyrite, mode of occurrence of ............. 135-136

Pyrrhotite, mode of occurrence of.

136

\section{Q.}

Quaternary deposits, occurrence of.... 36-37, 89-97 Quartz, mode of occurrence of.............. 137

Quartz Creek, antimony prospect near....... 179 mountains near, plate showing.......... 37 placer gold on.................. 183, 185, 201-202 prospects on.......................... 163

Quartz diorite intrusives, plate showing...... 118

Quartz vein parallel to joint planes, plate showing........................ 130

Quartzites, occurrence of............... 41-43,116

\section{$\mathrm{R}$.}

Recent alluvial deposits, formation of ....... $\quad 97$ Red Mountain, chromic iron ore on........ 237-238

Renard Island, rocks of . . . . . . . . . . . . . 225-226

Resurrection Bay, copper prospects east of. 233-237 rocks on ....................... 217, 223-225

timber at head of, plate showing.......... 36

Rssurrection Bay Mining Co.'s prospect, description of.................... 142

Resurrection Creek, bench gravels on, plate showing.

description of

placer gold on.................. 182, 185, 193-195

Resurrection River, alluvial plain of, plate showing

Roads and trails

Ruble elevator on Cooper Creek, plate show. ing .............................

Russians, exploration and development by . 14-15 s.

Page.

Salmon Creek, slluvial plain of, plate showing $\quad 93$ Sargent, R. H., survey by ................. 19

Sawmill Creek, prospects on ............... 172-173

Schists, age and correlation of................. 44 lithology of.............................. 41-43 occurrence of ......................... 33,41

Schrader, F. C., survey by .................. 17

Seldovia Bay, section of slaty rocks on...... $\quad .45$

Tertiary rocks near................... 83,84

Settlements of Kenai Peninsula.............. $\quad 30$

Seward, view of ........................ 22

Seward Bonanza Gold Mines Co.'s property, description of................ 149-151

Seward Gold Co.'s property, country rock and ore of ...................... 170-171

location and history of................. 169-170

Shell bed at mouth of Cottonwood Creek, origin of ..................... 92-93

Shore line of Kenai Peninsula.............. 23

Sickles, C. H., acknowledgment to........... 183

Silver, lode deposits of.................... 178-179

mode of occurrence of.................. 134

Silvertip Creek, placer gold on......... 183, 185, 206

Sixmile Creek, description of .............. 188 placer gold on ............... 182, 185, 202-203

Sixmile Creek, East Fork of, placer gold on.. 205 Skeen-Lechner Mining Co's. property, country rock and ore of ............ 155-157 location and history of................ 154-155

Slate, age and correlation of............. 222-223 cherty, cut by porphyry dike, plate showing ........................... cleavage and bedding in, plate showing.. closely folded, plate showing............. crumpled, polished surface of, plate showing...........................

distribution of, on the southeastern coast................. 211-223, 225-227

in the central and northern parts of Kenai Peninsula, character of.. 113,116

of the Kachemak Bay district, age and correlation of

49

distribution of ..................... 44-15

stratigraphy and lithology of........ 45-48

of the Kenai Valley, age and correlation of ............................... 52

distribution of ....................... 50

lithology of ....................... 50-52

Slate Creek, view at headwaters of........... 24 Slaty rocks, occurrence of................. $33-35$ Snow River summit, timber near, plate show-

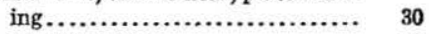
Spencer, A. C., survey by.................. 17 Spencer Glacier, mountains south of, plate showing........................ 26

plate showing ......................... 28 Sphalerite, mode of occurrence of ........... 135 Stanton, T. W., fossils determined by........ 52 , $59,65-66,67,118,222$ survey by ........................... 17 Steamship service to Kenai Peninsula ...... 31 Stetson Creek, placer gold on............... 183 Stone, R. W., cited.................. 82, 109-110 survey by........................... 17 Stringer lodes, character and position of...... 140 structure of the Kenai Peninsula........ 37, 92-104 
Page.

Summit Creek, prospects near.............. 167 Summit Lake, vegetation near, plate showing. $\quad 34$

Sunny Bay, copper prospects near......... 234-235

Sunrise group, age of................... 118-119

equivalence of................. 34,49,222-223

naming of.

T.

Tailrace, forked, on Bench Creek flats, plate showing ........................ 208

Tellurides, reported occurrence of.......... 134-135

Temperature, average monthly, on and near Kenai Peninsula................ 27

Tertiary rocks, distribution and age of ...... 67-88 occurrence of ......................... 36

Timber, map showing distribution of........ 32 near mouth of John Creek, plate showing. near Summit Lake, plate showing........ on Alaska Northern Railway, plate showing

See also Vegetation.

Tozier-Lane property, description of....... 142-143

Trail Glacier, plate showing............... 29

Transportation to and on Kenai Peninsula.. 31-32

Treasure Box claim, description of......... 176-177

Triassic rocks, occurrence of.................. 35

Triassic (?) rocks, distribution and correlation of ......................... 52-55

Triassic, Upper, rocks, divisions and distribution of.
Page.

Tuff, distribution of.................... 225-226 Lower Jurassic, age and correlation of... $\quad 67$

distribution of...................... 63

fauna of .........................65-66

lithology of.......................6.63-65

occurrence of .......................... 228 plate showing ..................... 52

Triassic, age and correlation of.......... 59 distribution of........................ 55

fauna of......................... 58-59

lithology of....................... 55-58

Tustumena Glacier, plate showing........... $\quad 28$

Two Arm Bay, gold near................. 229

rocks on ........................... 219-220

$\mathrm{V}$.

Valdez series, correlation with ... 34-35, 49,2:22-223

Valleys, hanging, east of Summit Lake, plate showing....................... 128

Vegetation, character of ................. 27-29 plate showing ................... 30,32,34, 36

Vein parallel to joint planes in graywacke, plate showing................. 136

Veins, gold, character and position of...... 137-139 W.

Weaver, C. E., work of................... 19

Wheel run by hydraulic giant for hoisting bowlders, plate showing......... 188

Windy Bay, gold near..................... 231

Winner Creek, placer gold on..... 183,185,192-193 




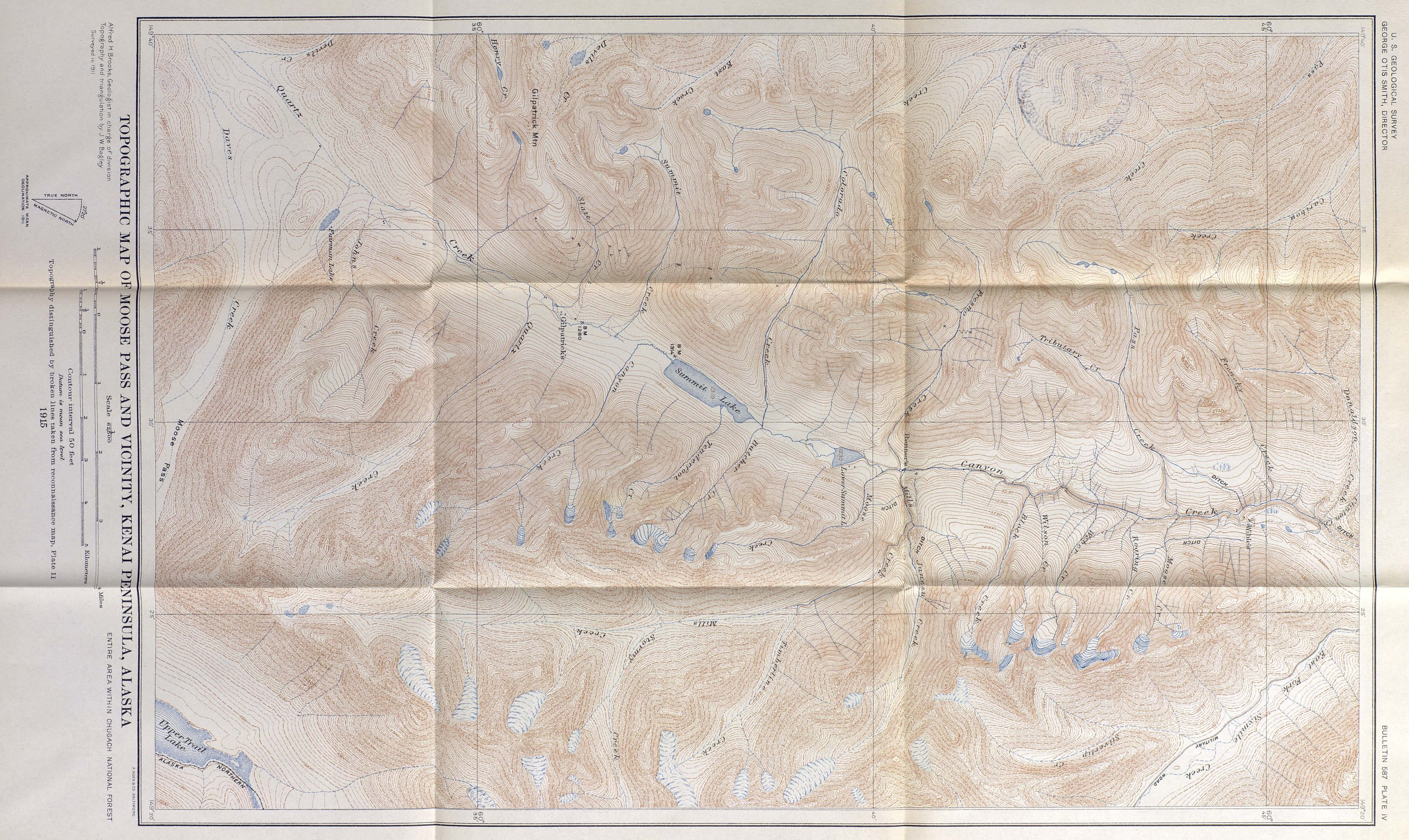


